$$
\begin{aligned}
& \text { UNIVERSIDADE DE SÃO PAULO } \\
& \text { INSTITUTO DE GEOCIÊNCIAS }
\end{aligned}
$$

\title{
GEOTERMOBAROMETRIA, GEOQUÍMICA, GEOCRONOLOGIA E EVOLUÇÃO TECTÔNICA DAS ROCHAS DA FÁCIES XISTO AZUL NAS ÁREAS DE JAMBALÓ (CAUCA) E BARRAGÁN (VALLE DEL CAUCA), COLÔMBIA
}

\author{
Andrés Bustamante Londoño
}

Orientador: Prof. Dr. Caetano Juliani

TESE DE DOUTORAMENTO

Programa de Pós-Graduação em Mineralogia e Petrologia

SÃO PAULO

2008 
BUSTAMANTE, A., 2008. Geotermobarometria, geoquímica, geocronologia e evolução tectônica das rochas da fácies xisto azul nas áreas de Jambaló (Cauca) e Barragán (Valle del Cauca), Colômbia. 179 p. Tese (Doutorado) - Instituto de Geociências, Universidade de São Paulo, São Paulo. 
“Não há assunto tão velho que não possa ser dito algo de novo sobre ele"

Fiodor Dostoievski 



\section{AGRADECIMENTOS}

Não há muitas palavras que possam expressar o imenso agradecimento que eu tenho com meu professor e amigo Dr. Caetano Juliani, quem sempre se mostrou disposto a ajudar e que proporcionou uma orientação da altíssima qualidade.

Ao projeto FAPESP 2004/10203-7: "Petrogênese, metamorfismo e evolução tectônica dos xistos azuis dos Andes na Colômbia, Equador e Chile".

À Fundación para la Promoción de la Investigación y la Tecnología del Banco de la República de Colombia pelos projetos 1.819: "Evolución geológica de los esquistos azules y rocas asociadas del área de Jambaló, Departamento de Cauca, Colombia" e 2.178: "Petrogénesis de los esquistos azules y rocas asociadas del área de Barragán, Valle del Cauca".

A CNPq e CAPES bolsas de doutorado.

Ao prof. Andrés Velásquez, diretor do Observatorio Sismológico del Suroccidente (OSSO), Colômbia; pela imensa ajuda nos contatos com o pessoal responsável pelas autorizações necessárias para visitar a área de Toribío e Jambaló, além da excelente estada que gentilmente nos ofereceu durante algumas semanas em Cali. Ao pessoal do Observatorio Sismológico del Suroccidente (OSSO), especialmente a Cristina Rosales e o Jorge Eduardo Mendoza.

Ao Senhor Guillermo Santamaria, peça fundamental nos contatos com o pessoal da U.M.A.T.A de Toribío.

$\mathrm{Na}$ cidade de Toribío, foi indispensável o atendimento e o acompanhamento nos trabalhos de campo, por isso o Senhor Diretor da U.M.A.T.A de Toribío, Efigenio Hernández merece meus mais sinceros agradecimentos. Além dele, os "animadores ambientales" e o pessoal da U.M.A.T.A de Toribío: Albeiro, Alejandra, Antonio, Astrid, Bernardo, Bertulfo, Dora, Efraín, Ferney, Jacqueline, Juan Pablo, Leyner e Lizardo; assim como a todo o pessoal dos diferentes Cabildos e os Alguaciles e Guardas Indígenas que estiveram sempre dispostos a colaborar para o tranqüilo transcorrer do trabalho de campo.

Igualmente, merecem meus agradecimentos os Senhores Governadores, em março de 2005, dos Resguardos de Tacueyó: Oscar Wilde Cuchillo; Toribío: Plinio Trochez Ascue; San Francisco: Milciades Musicue e Jambaló: Andrés Betancurt. Também gostaria agradecer aos Senhores Coordenadores do Proyecto Nasa, Nelson Lemus e do Plan Ambiental Agropecuario, Jaime Díaz. Em Jambaló, agradeço ao Senhor Diretor da U.M.A.T.A, Edgar Ramos e a Senhora Coordenadora do Plan Agro-Ambiental, Maria Eugenia Ulcue, assim como a prefeitura do referido município.

Ao geólogo Carlos Mario Echeverri Misas pela ajuda no trabalho de campo na região de Toribío e Jambaló.

Para os trabalhos de campo na região de Barragán, contei com a ajuda do Senhor Edinson Ramírez Orozco, e a Senhora Maria Antonieta "La Chilindrina" a quem expresso igualmente meus mais sinceros agradecimentos. Também contei com a ajuda da Corporación Autónoma Regional del Valle del Cauca (CVC).

A minha amiga e colega de aventuras nos terrenos de xistos azuis, Thaís Hyppolito.

A Profa. Dra. Marion B.I. Weber Scharff da Universidad Nacional de Colombia, Medellín, pelos impecáveis e apropriados aportes em diferentes tópicos, principalmente relacionados à química mineral e metamorfismo.

Ao Prof. Dr. Eric J. Essene pela continua ajuda durante o desenvolvimento deste trabalho e pela ajuda na microssonda eletrônica da University of Michigan. Igualmente ao técnico Carl Henderson do Electron Microbeam Analysis Laboratory (EMAL) da University of Michigan, nos Estados Unidos. 
Ao Prof. Dr. Martin Reich da Universidad de Chile, pela ajuda durante o período de permanência na cidade de Ann Arbor nos EUA.

Ao geólogo Pablo Castro, que perdeu dez dias de seu tempo comigo, procurando por um corpo de xistos azuis que não existe na região de Pijao, Quindio (Colômbia).

No departamento de Geologia da Universidad Eafit, agradeço o apoio das professoras Dra. Gloria Toro Villegas e MSc. Gloria Sierra Lopera e o diretor do departamento e professor MSc. Geovanny Bedoya Sanmiguel. Também os funcionários dos laboratórios de geologia Maria Isabel Acevedo e Wilton Echavarria. Com todos eles fico muito grato pela disposição de ajuda na hora de realizar o trabalho de campo e no tratamento das amostras.

Aos Professores Doutores do Instituto de Geociências Johann Hans Daniel Schorscher, Silvio Roberto Farias Vlach, Gergely Andrés Julio Szabó, Fábio Ramos Dias de Andrade, Claudio Riccomini e Romalino dos Santos Fragoso César pela amizade e a ajuda constante no transcurso da pesquisa.

Aos funcionários do Instituto de Geociências, Ana Paula Cabanal, Magali Poli Fernandes Rizzo, Marcos Monsueto, Tadeu Caggiano, Henrique Martins e Angelica Dolores de Mello Morente.

Aos profissionais do Laboratório de Laminação do Instituto de Geociências, Cláudio Hopp, Luiz Mogueira, Paulo Molinaro e Paulo Morgato, devido à rapidez e ao trabalho de alta qualidade utilizado em todas as fases desta pesquisa.

Ao pessoal das tertúlias e colóquios, às vezes proscritos, Lucas Warren, Fernanda Quaglio, Marcelo Januario (geólogo da Bale), Marlei Chamani, Carlos Henrique Grohmann, Samar dos Santos Steiner, Letícia Constantino, Luis Fernando Roldan e todos aqueles que nos acodem para dispersar suas mentes da continua e inabalável perscruta geológica no restaurant français "Franboix".

Ao Paul Duhart, amigo de varias aventuras e pela disposição em ajudar no geológico e no cotidiano.

Aos colegas Agustín Cardona, Marta Edith Velásquez e Alejandro Salazar e a minha amiga Arianna.

Ao colega Marcello Dias Fernandes.

Ao filósofo Vladimir de Oliva Mota sua esposa, a lingüista Christine Arndt e toda sua família, por serem os guias e anfitriões na linda cidade de Aracaju durante o XLIII Congresso Brasileiro de Geologia.

A minha esposa, Paula, por todo e por me agüentar e esperar por tanto tempo meus extensos trabalhos de campo e até a mudança de cosmovisión logo depois de visitar a região de Toribío e Jambaló, além da grande ajuda na parte gráfica da elaboração desta tese.

Tenho imensa gratidão com todas as pessoas que fazem da vida no Instituto de Geociências e no dia a dia uma boa razão para continuar compartilhando o devenir. 


\section{RESUMO}

Apesar da importância das rochas da fácies xisto azul para o entendimento da dinâmica das zonas de subducção no passado, pouquíssimos estudos de mapeamento, geoquímica, geotermobarometria, geocronologia e de evolução tectônica têm sido feitos em rochas desse tipo na Colômbia.

$\mathrm{Na}$ Cordilheira Central dos Andes colombianos ocorrem duas unidades rochas de alta razão $P / T$, uma delas na região de Jambaló (Departamento de Cauca) e outra na região de Barragán (Departamento de Valle de Cauca).

Na região de Jambaló destaca-se a presença de lentes de xistos azuis em uma área constituída predominantemente por rochas da fácies xisto verde. Estas rochas representam núcleos preservados dos processos retrometamórficos que afetam as rochas de alta pressão durante a exumação. Os dados de geoquímica obtidos no conjunto de rochas de Jambaló indicam uma evolução dos protolitos a partir de rochas básicas e intermediárias de arcos de ilhas e de MORB. Usando o software TWQ 1.02, foram obtidos dados $\mathrm{P}$ e $\mathrm{T}$ que mostram uma forte descompressão acompanhada por quedas relativamente pequenas na temperatura para o as rochas da fácies xisto azul. A pressão tem uma variação entre 14 e 7 kbar com uma diminuição da temperatura entre $\sim 400$ e $300{ }^{\circ} \mathrm{C}$. Para as rochas da fácies xisto verde observa-se uma descompressão $(8,2-6,6 \mathrm{kbar})$ seguida de um leve aquecimento $\left(463-500{ }^{\circ} \mathrm{C}\right)$, possivelmente devido à sua colocação junto a lascas tectônicas aquecidas em zonas de cavalgamentos. O conjunto dos dados ${ }^{40} \mathrm{Ar} /{ }^{39} \mathrm{Ar}$ mostram que o metamorfismo da fácies xisto azul de Jambaló têm idade predominante próxima de $63 \mathrm{Ma}$, com indicações de possíveis idades até mais antigas que $71 \mathrm{Ma}$, apesar do melhor intervalo situarse entre 66 e $61 \mathrm{Ma}$ (Maastritchtiano-Daniano). Isso posiciona a exumação dos xistos azuis de Jambaló no final do Cretáceo até o início do Terciário, pois considerando que foram datadas as principalmente paragonita e, subordinadamente fengita, associadas à foliação milonítica nas rochas da fácies xisto azul, a idade mínima do metamorfismo seria um pouco mais antiga e as idades obtidas representariam o evento de exumação, que tem relação direta com a geração de foliação milonítica.

Na região de Barragán é constituída por predominantemente xistos azuis e possíveis retro-eclogitos e a geoquímica caracteriza os protolitos das rochas da fácies xisto azul e anfibolito como formados em $\mathrm{N}$ MORB. Os dados de geotermobarometria obtidos para o conjunto de rochas de Barragán indicam que as amostras pertencentes à fácies anfibolito sofreram uma forte descompressão ( 15 - 9,2 kbar) seguida de um leve aumento na temperatura $\left(639-665^{\circ} \mathrm{C}\right)$ o que sugere que estas rochas tenham alcançado a fácies eclogito. As rochas da fácies xisto azul por sua parte, mostram uma leve queda na pressão (9,5 - 9,3 kbar) e uma leve queda na temperatura $\left(399-397^{\circ} \mathrm{C}\right)$, associada à transição das fácies xisto azul para xisto verde. A idade ${ }^{40} \mathrm{Ar} /{ }^{39} \mathrm{Ar}$ obtida em um metapelito associado com os xistos azuis, apresentou uma idade de $\sim 120 \mathrm{Ma}$, o que sugere que o metamorfismo na fácies xisto azul seja mais antigo (125 - $150 \mathrm{Ma})$ dependendo do modelo de geração e exumação que seja considerado.

Todo o conjunto de dados sugere duas coisas principais, a primeira que não há relação entre os xistos azuis e rochas associadas da região de Barragán e as de Jambaló e a segundo que pode ser considerado um modelo evolutivo de xistos azuis Andino, diferente aos modelos Franciscano e Alpino. 


\section{ABSTRACT}

Despite the importance of the blueschist facies rocks to unravel the dynamic of subduction zones in the past, few detailed studies including mapping, geochemistry, geothermobarometry, geochronology and tectonic evolution has been made in rock with these characteristics in Colombia.

In Central Cordillera of the Colombian Andes are found two geologic units with rocks of high P/T ratio, one of them in Jambaló area (Cauca department,) and other in Barragán area (Valle de Cauca Department).

In Jambaló area crops out several lenses of blueschists in an area that consists predominantly of greeschist facies rocks. These rocks represent preserved cores of retrometamorphic processes that affect the rocks of high pressure during exhumation. Geochemical data obtained in Jambaló rocks, indicate a trend of protholiths varying from basic to intermediate rocks in a possible islands arc and MORB settings. Using software TWQ 1.02, were obtained data of $P$ and $T$ that show a strong decompression with relatively small decrease in temperature for the blueschist facies rocks. The pressure ranges between $\sim 14$ and $7 \mathrm{kbar}$ with a decrease in temperature between 400 and $\sim 300^{\circ} \mathrm{C}$. For greenschist facies rocks of Jambaló the decompression (8.2 - 6.6 kbar) was followed by a slight temperature increasing $\left(463-500^{\circ} \mathrm{C}\right)$, possibly due to the juxtaposition with hot tectonic slabs in thrusting zones. The ${ }^{40} \mathrm{Ar}{ }^{\beta 9} \mathrm{Ar}$ data shows that the blueschist facies rocks from Jambaló rocks have predominant metamorphism age close to $63 \mathrm{Ma}$, but are also indications of possible ages older than 71 $\mathrm{Ma}$, despite the best interval is estimated between 66 and $61 \mathrm{Ma}$ (Maastritchtian-Danian), corresponding to exhumation processes of blueschist facies rocks, because the dated micas (paragonite and phengite) was crystallized during the development of the mylonitic foliation.

In Barragán area, the geochemical data indicate that the protoliths of blueschist and amphibolite facies rocks correspond to N-MORB. Geothermobarometrical data indicate that the samples of amphibolites facies were affected by strong decompression ( 15 to $9.2 \mathrm{kbar}$ ), followed by a slight increase in temperature $\left(639-665^{\circ} \mathrm{C}\right)$, which suggests that these rocks have reached eclogite facies. The blueschist facies rocks on its region, showed a slight pressure $(9.5-9.3 \mathrm{kbar})$ and a slight temperature drops $\left(399-397^{\circ} \mathrm{C}\right)$, associated with the transition from blueschist to greenschist facies rocks. Geochronology by ${ }^{40} \mathrm{Ar}{ }^{\beta 9} \mathrm{Ar}$ method, obtained in a metapelite rock associated to the blueschist facies rocks, gives an age of $120 \mathrm{Ma}$, which suggests that the metamorphism in blueschist facies is older (125-150 Ma) depending on the model of generation and exhumation considered.

The entire set of data suggests two important keys, the first that there are no relationship between blueschist and associated rocks from Barragán and Jambaló areas, and second that would be considered a model of Andean blueschist generation different to Franciscan and Alpine models. 


\section{ÍNDICE}

$\begin{array}{ll} & \text { INTRODUÇÃO } \\ 1 & \text { LOCALIZAÇÃO E ACESSOS ÀS ÁREAS DE ESTUDO } \\ 2 & \text { OBJETIVOS } \\ 3 & \text { MATERIAIS E MÉTODOS } \\ 3.1 & \text { Levantamentos bibliográficos } \\ 3.2 & \text { Levantamentos de campo e amostragem } \\ 3.3 & \text { Petrografia } \\ 3.4 & \text { Química mineral } \\ 3.5 & \text { Geotermobarometria } \\ 3.6 & \text { Geoquímica de rochas } \\ 3.7 & \text { Geocronologia Ar-Ar e K-Ar } \\ 4 & \text { SíNTESE BIBLIOGRÁFICA FUNDAMENTAL } \\ 4.1 & \text { Metamorfismo e Litotipos da Fácies Xisto Azul } \\ 4.2 & \text { Contexto Geológico e Tectônico da Cordilheira Central dos Andes Colombianos } \\ 4.3 & \text { Metamorfismo na Cordilheira Central dos Andes Colombianos }\end{array}$
Metamorfismo na Cordilheira Central dos Andes Colombianos

5.1.1 Balastrera La Luz

5.1.2 Córrego San Diego ou El Barrial

5.1.3 Mina La Manuela setor La Calera

5.2 Resguardo de Toribío

5.2.1 Córrego Vichiquí

5.3 Resguardo de San Francisco

5.3.1 Córrego Elassio

5.3.2 Córrego Río Chiquito

5.3.3 Córrego Flayó

5.3.4 Córrego La Primicia

5.3.5 Córrego Quinamayó

5.4

5.4 .1

5.4 .2

5.4 .3

5.4 .4

5.4 .5

6

Resguardo de Jambaló

Córrego El Asio

Córrego Muñoz

Córrego Cansa Bobos

Córrego Calambaz

Estrada Jambaló - San Francisco

Mica-glaucofânio xistos e glaucofânio micaxistos

$6.2 \quad$ Clorita-plagioclásio xistos 34

6.3 Mármores 39

6.4 Quartzitos milonitizados $\quad 41$

6.5 Epidositos 44

6.6 Estilpnomelano-muscovita-albita-anfibólio-quartzo xisto 46

6.7 Keratófiros $\quad 49$

6.8 Metaultramáficas $\quad 51$

6.9 Quartzo-monzonito 51

7 DESCRIÇÃO DOS PERFIS DA REGIÃO DE BARRAGÁN

7.1 Estrada Barragán - Santa Lucía 55

7.2 Estrada Barragán - Tuluá $\quad 55$

7.3 Estrada Barragán - Cumbarco $\quad 56$

8 PETROGRAFIA MICROSCÓPICA

$\begin{array}{lll}8.1 & \text { Rochas na fácies xisto azul } & 57\end{array}$

8.2 Rochas na fácies anfibolito $\quad 62$

$\begin{array}{lll}8.3 & \text { Serpentinitos } & 68\end{array}$ 
8.4 Grafita-clorita-muscovita-quartzo xistos 69

8.5 Protocataclasitos 71

8.6 Grafita-clorita-andaluzita-andesina-granada-muscovita xisto com titanita 71

9 QUÍMICA MINERAL DA REGIÃO DE JAMBALÓ

9.1 Rochas da fácies xisto azul 76

9.1.1 Anfibólio sódico $\quad 76$

9.1.2 Granada $\quad 81$

9.1.3 Mica branca $\quad 83$

9.1.4 Clorita $\quad 86$

9.1.5 Minerais do grupo do epidoto 88

9.1.6 Plagioclásio $\quad 89$

9.1.7 Carbonato $\quad 89$

$\begin{array}{lll}9.1 .8 & \text { Titanita } & 90\end{array}$

9.2 Rochas da fácies xisto verde 90

9.2.1 Anfibólio 90

9.2.2 Granada 92

9.2.3 Clorita 93

9.2.4 Mica branca 93

9.2.5 Plagioclásio $\quad 95$

9.2.6 Rutilo e titanita

9.2.7 Epidoto 96

9.2.8 Estilpnomelano 96

10 QUÍMICA MINERAL DA REGIÃO DE BARRAGÁN 97

$10.1 \quad$ Rochas da Fácies Xisto Azul $\quad 97$

10.1.1 Anfibólio sódico $\quad 97$

10.1.2 Pumpellyita $\quad 100$

$\begin{array}{ll}\text { 10.1.3 Clorita } & 101\end{array}$

10.1.4 Lawsonita 102

10.1.5 Titanita e rutilo 102

10.1.6 Carbonato 102

10.1.7 Minerais do grupo do epidoto 102

10.1.8 Mica Branca $r$

10.1.9 Plagioclásio 103

10.2 Rochas da fácies anfibolito 104

10.2.1 Anfibólio $r$

10.2.2 Granada 107

10.2.3 Plagioclásio 111

10.2.4 Minerais do grupo do epidoto 111

10.2.5 Clorita 112

10.2.6 Titanita e rutilo 112

11 GEOTERMOBAROMETRIA: Conceitos, calibrações e aplicações 113

11.1 Geotermobarômetros internamente consistentes 115

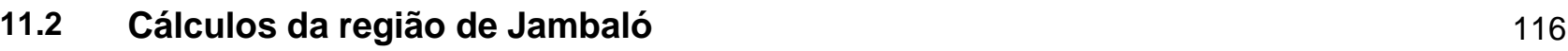

11.3 Cálculos da região de Barragán 123

12 GEOQUÍMICA DA REGIÃO DE JAMBALÓ 131

13 GEOQUÍMICA DA REGIÃO DE BARRAGÁN 144

14 GEOCRONOLOGIA ${ }^{40}$ AR/ ${ }^{39}$ AR DA REGIÃO DE JAMBALÓ

15 GEOCRONOLOGIA ${ }^{40}$ AR/ ${ }^{39}$ AR DA REGIÃO DE BARRAGÁN 160

16 DISCUSSÃO E CONCLUSÕES DO METAMORFISMO DAS ÁREAS DE ESTUDO 162

16.1 Jambaló 162

$\begin{array}{llr}16.2 & \text { Barragán } & 167\end{array}$

Referências bibliográficas $\quad 170$

1.1 Localização e vias de acesso na área de Barragán. 3 
1.2 Localização e vias de acesso na área de Jambaló.

4.1 Distribuição das áreas com rochas metamórficas na Colômbia.

4.2 Divisão da Cordilheira Central dos Andes colombianos em unidades litodêmicas.

4.3 Localização das áreas de estudo na Colômbia no contexto regional e local.

9.1 Diagramas de classificação dos anfibólios da amostra 118.

9.2 Diagramas de classificação dos anfibólios da amostra 123A.

9.3 Diagramas de classificação dos anfibólios da amostra 124.

9.4 Diagramas de classificação dos anfibólios da amostra 124J.

9.5 Diagramas de classificação dos anfibólios da amostra 125M.

9.6 Diagramas de classificação dos anfibólios da amostra 124A.

9.7 Padrão de zonamento dos principais cátions dos grãos de granada analisados na amostra 118.

9.8 Padrão de zonamento dos principais cátions dos grãos de granada analisados na amostra 124J.

9.9 Padrão de zonamento dos principais cátions dos grãos de granada analisados na amostra $121 B$.

9.10 Diagrama $\left[\left(F e_{t}+M n+T i\right)-A l^{v /}\right]$ iiiú $(M g-L i)$ de classificação das micas da amostra 118.

9.11 Diagrama $\left[\left(\mathrm{Fe}_{t}+\mathrm{Mn}+\mathrm{Ti}\right)-\mathrm{A}^{\left.l^{\prime}\right]}\right]$ iiiú $(\mathrm{Mg}-\mathrm{Li})$ de classificação das micas da amostra 123A. 84

9.12 Diagrama [ $\left.\left(F e_{t}+M n+T i\right)-A^{\left.l^{\prime l}\right]}\right]$ iiiú $(M g-L i)$ de classificação das micas da amostra 124J. 85

9.13 Diagramas de classificação da clorita de rochas da fácies xisto azul região de Jambaló. 86

9.13 (continuação).

9.14 Classificação da clorita das amostras 124l e 125H. 87

9.15 Diagramas de classificação da clorita das amostras 124H e 129A. 88

9.16 Diagramas de classificação do plagioclásio das rochas na fácies xisto azul da região de Jambaló.

9.17 Diagramas de classificação dos anfibólios da amostra 107.

9.18 Diagramas de classificação dos anfibólios da amostra 125A. 91

9.19 Diagramas representativos das substituições tschermakítica, edenítica, ferro-pargasítica e magnésio-pargasítica dos anfibólios analisados nas rochas da fácies xisto verde da região de Jambaló.

9.19 (continuação). 92

9.20 Padrão de zonamento dos principais cátions dos grãos de granada da amostra 113F. 92

9.21 Diagramas de classificação da clorita das amostras da fácies xisto verde da região de Jambaló.

10.5 Diagramas composicionais da pumpellyita de rochas da fácies xisto azul da área de Barragán. 100
10.5 (continuação).

10.6 Diagramas de classificação da clorita das amostras da facies xisto azul da região de Barragán.

10.7 Diagrama $\left[\left(\mathrm{Fe}_{t}+\mathrm{Mn}+\mathrm{Ti}\right)-\mathrm{Al}^{V l}\right]$ iiiú $(\mathrm{Mg}-\mathrm{Li})$ de classificação das micas da amostra 196D.

10.8 Classificação do plagioclásio em termos de Or-Ab-Na da amostra 199.

10.9 Diagrama de classificação dos anfibólios da amostra 187A.

10.10 Diagrama de classificação dos anfibólios da amostra 187B.

10.11 Diagrama de classificação dos anfibólios da amostra 188.

10.12 Diagrama de classificação dos anfibólios da amostra 189.

10.13 Diagrama de classificação dos anfibólios da amostra 189A.

10.14 Diagramas representativos das substituições tschermakítica, edenítica, ferro-pargasítica e magnésio-pargasítica dos anfibólios analisados nas rochas da fácies anfibolito da região de Barragán.

10.15 Padrão de zonamento dos principais cátions da granada analisada na amostra 187A.

10.16 Padrão de zonamento dos principais cátions da granada analisada na amostra 187B.

10.17 Padrão de zonamento dos principais cátions da granada analisada na amostra 188.

10.18 Padrão de zonamento dos principais cátions da granada analisada na amostra 189. 
10.19 Padrão de zonamento dos principais cátions da granada analisada na amostra 189A.

10.20 Diagrama de classificação do plagioclásio das rochas fácies anfibolito.

10.21 Classificação da clorita das rochas da fácies anfibolito da região de Barragán.

11.1 Diagramas esquemáticos $P$-T mostrando equilíbrios com inclinações $P-T$ representativas de reações utilizáveis como geotermômetros e geobarômetros.

11.2 Diagramas $P-T$ obtidos para a amostra 124l, com análises de núcleos e bordas da associação granada-paragonita-plagioclásio-glaucofânio-quartzo.

11.3 Diagrama P-T obtido para a amostra 124J, com análises de núcleos da associação granadaparagonita-plagioclásio-glaucofânio-quartzo.

11.4 Diagramas $P-T$ obtidos para a amostra 124J, com análises de núcleos e bordas da associação granada-paragonita-plagioclásio-glaucofânio-quartzo.

11.5 Diagramas $P-T$ obtidos para a amostra $125 \mathrm{H}$, com análises de núcleos e bordas da associação granada-paragonita-plagioclásio-glaucofânio-quartzo.

11.6 Diagramas P-T obtidos para a amostra 129A, com análises de núcleos e bordas da associação paragonita-plagioclásio-glaucofânio-clotita-quartzo.

11.7 Diagramas $P-T$ obtidos para a amostra 124, com análises de núcleos e bordas da associação paragonita-plagioclásio-glaucofânio-clorita-quartzo.

11.8 Diagramas $P-T$ obtidos para a amostra $113 F$, com análises de núcleos e bordas da associação granada-mica branca-albita-clorita-quartzo.

11.9 Conjunto das trajetórias das amostras individuais da região de Jambaló.

11.10 Diagrama representativo do cálculo da fração molar de $\mathrm{CO}_{2}$ das rochas na fácies anfibolito de Barragán.

11.11 Diagrama $P-T$ obtido para os núcleos dos minerais da amostra 189 da associação granadapargasita-clinozoisita-dolomita-quartzo.

11.12 Estimativa das condições $P-T$ de formação da amostra 189, com análises de núcleos e bordas da associação granada-pargasita-clinozoisita-dolomita-quartzo.

11.13 Diagramas P-T obtidos para a amostra 189A, com análises de núcleos e bordas dos minerais, da associação granada-tremolita-tschermakita-plagioclásio-quartzo.

Diagramas $P-T$ obtidos para a amostra 196D, com análises de núcleos e bordas da
associação paragonita-glaucofânio-pumpellyita-lawsonita-clinozoisita-quartzo.

11.14 Diagramas $P-T$ obtidos para a amostra 196D, com análises de núcleos e bordas da
associação paragonita-glaucofânio-pumpellyita-lawsonita-clinozoisita-quartzo.

11.15 Conjunto das trajetórias das amostras da região de Barragán. 129

12.1A Diagrama para identificação de amostras que sofreram alterações nos conteúdos de sódio e potássio devido à introdução e/ou retirada de elementos.

12.1B Diagrama de discriminação de amostras que apresentam composições compatíveis com líquidos basálticos.

12.2 Diagrama TAS (total álcalis vs sílica) para as rochas da região de Jambaló.

12.3 Diagramas de comparação de $\mathrm{Zr}$ vs $\mathrm{Ba}, \mathrm{Zr}$ vs $\mathrm{Sr}, \mathrm{Zr}$ vs $\mathrm{K}_{2} \mathrm{O}$ e $\mathrm{Zr}$ vs CaO para analise do comportamento dos elementos móveis.

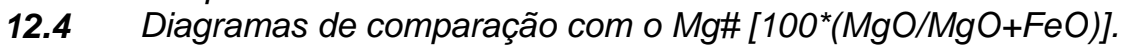

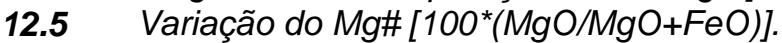

Diagrama FeO, Na2O+K2O e MgO que separa as tendências cálcio-alcalinas e tholeiíticas.

12.8 Diagramas La vs Ba (A), La vs Th (B) e La vs Nb (C).

12.9 Diagrama Ti vs $V$ de discriminação de ambiente tectônico de geração das rochas básicas.

12.10 Diagrama Hf-Th-Ta de discriminação de ambiente tectônico de geração de rochas básicas.

12.11 Diagrama $Z r$ vs $Z r / Y$ de discriminação de ambiente tectônico de geração de rochas básicas.

12.12 Diagrama $\mathrm{Nb}-\mathrm{Zr}-\mathrm{Y}$ de discriminação de ambiente tectônico de geração de rochas básicas.

12.13A Diagrama $N b / Y b$ vs $T h / Y b$.

12.13B Diagrama $\mathrm{Nb} / \mathrm{Yb}$ vs $\mathrm{TiO}_{2} / \mathrm{Yb}$.

12.14 Diagrama $Y-L a-N b$ de discriminação de basaltos em ambientes extensionais e compresionais.

12.15 Padrões multi-elementos dos metabasitos e das meta-intermediárias da região de Jambaló. 142

12.16 Padrões de elementos terras raras das amostras da região de Jambaló.

13.1A Diagrama para identificação de amostras que sofreram alterações nos conteúdos de sódio e potássio devido à introdução e/ou retirada de elementos.

13.1B Diagrama de discriminação de amostras que apresentam composições compatíveis com líquidos basálticos.

13.2 Diagrama TAS (total álcalis vs sílica) para as rochas da região de Barragán.

13.3 Diagramas de comparação de $\mathrm{Zr}$ vs $\mathrm{Ba} ; \mathrm{Sr} ; \mathrm{K}_{2} \mathrm{O}$ e $\mathrm{CaO}$.

13.4 Comparação do \#Mg [100*(MgO/MgO+FeO)] com outros óxidos. 
13.5 Comparação do \#Mg [100*(MgO/MgO+FeO $)]$ com outros elementos.

13.6 Diagrama $\mathrm{FeO}, \mathrm{Na}_{2} \mathrm{O}+\mathrm{K}_{2} \mathrm{O}$ e $\mathrm{MgO}$ que distingue as tendências cálcio-alcalinas e tholeiíticas.

13.7 Classificação das rochas metabásicas de Barragán, segundo a proposta de Winchester \& Floyd (1977).

13.8 Diagrama Ti vs $V$ de discriminação de ambiente tectônico.

13.9 Diagrama Hf-Th-Ta de discriminação de ambiente tectônico.

13.10 Diagramas $Z r$ vs $Z r / Y$ de discriminação de ambiente tectônico.

13.11 Diagrama $\mathrm{Nb}-\mathrm{Zr}-\mathrm{Y}$ de discriminação de ambiente tectônico.

13.12 Diagrama $Y-L a-N b$ de discriminação de basaltos.

13.13 Diagramas $\mathrm{Nb} / \mathrm{Yb}$ vs $\mathrm{Th} / \mathrm{Yb}$ e $\mathrm{Nb} / \mathrm{Yb}$ vs $\mathrm{TiO}_{2} / \mathrm{Yb}$.

13.14 Padrões químicos dos metabasitos na fácies xisto azul e anfibolito da região de Barragán. 153

13.15 Diagramas multi-elementares mostrando padrões de elementos terras raras das amostras da região de Barragán.

14.1 Espectro de argônio obtido para a amostra 129C.

14.2 Espectros de argônio obtidos para a paragonita da amostra 124F.

14.3 Espectros de argônio obtidos em paragonita da amostra 124G.

14.4 Espectro de argônio obtido em fengita da amostra 124J.

14.7 Espectros de argônio obtidos para a amostra 125M.

16.1 Diferentes tipos de trajetórias metamórficas de xistos azuis em zonas de subducção.

16.2 Esquema de evolução tectônica (geração e exumação) das rochas na fácies xisto azul da região de Jambaló.

16.3 Esquema de evolução tectônica (geração e exumação) das rochas de alta pressão da região de Barragán.

\section{TABELAS}

4.1 Protolitos e características dos cinturões de xistos azuis.

4.2 Mineralogia essencial das rochas das unidades da região de Jambaló.

4.3 Mineralogia essencial dos xistos glaucofânicos e eclogitos de Barragán.

6.1 Mineralogia dos principais litotipos da área de Jambaló.

6.2 Blastese dos minerais em relação às foliações metamórficas em diferentes litotipos da área de Jambaló.

8.1 Minerais presentes nos litotipos da região de Barragán.

8.2 Blastese dos minerais em relação às foliações metamórficas nos metabasitos da área de Barragán.

9.1 Intervalos de variação de $\mathrm{Fe}^{2+}$ e $\mathrm{Mg}$ em a.p.f.u. das análises classificadas no campo da picnoclorita.

10.1 Variação dos conteúdos de Si, Ca, Al e $\mathrm{Mg \#}\left(\mathrm{Mg} / \mathrm{Mg}+\mathrm{Fe}^{2+}\right)$ em a.p.f.u. na pumpellyita analisada nas rochas da fácies xisto azul da região de Barragán.

11.1 Símbolos de minerais usados nos cálculos termobarométricos da região de Jambaló.

11.2 Símbolos de minerais usados nos cálculos termobarométricos da região de Barragán.

12.1 Teores $\mathrm{SiO}_{2}$ dos metabasitos e meta-intermediárias da região de Jambaló.

14.1 Resultados ${ }^{40} \mathrm{Ar}^{3 \mathrm{y}} \mathrm{Ar}$ das amostras analisadas da região de Jambaló.

15.1 Resultados ${ }^{40} \mathrm{Ar}{ }^{34} \mathrm{Ar}$ das amostras analisadas da região de Barragán.

\section{FOTOS}

5.1 Afloramento de rochas quartzo-monzonitos com forte fraturamento no lugar conhecido como "Balastrera La Luz" no oeste do povoado de Tacueyó. No lugar existiu uma pedreira de extração do material para brita.

5.2 Aspecto típico dos afloramentos de xistos azuis (blocos) e dos clorita xistos (parede do afloramento) no Córrego San Diego ou El Barrial.

5.3 Material metaconglomerático que separa os afloramentos de metapelitos das metavulcânicas

5.4 Afloramento de xistos verdes que afloram no córrego Cansa Bobos, intensamente foliados, levemente crenulados onde os leitos mais claros são mais ricos em minerais do grupo do epidoto e os mais escuros em anfibólios.

5.5 Mica-glaucofânio xisto, com cristais prismáticos de glaucofânio (cinza-azulados) orientados na foliação e tendendo a formar arranjos radiados ou em leque, indicativos de cristalização sin- a tardi-cinemática em relação ao desenvolvimento da foliação milonítica 
Vista geral do afloramento de rochas meta-ultramáficas intensamente serpentinizadas. $O$ afloramento (131) localizado na porção central da foto apresenta-se com uma cor esverdeada produto da intensa serpentinização

6.1 Zonamento de glaucofânio com núcleo mais intensamente pleocróico que a borda 29

6.2 Zonamento de glaucofânio com núcleo menos pleocróico que a borda 29

6.3 Borda de substituição por um outro anfibólio (possível actinolita) 29

6.4 Substituição de glaucofânio por clorita nas bordas 29

6.5 Crescimento radiado de glaucofânio na escala macroscópica 29

6.6 Crescimento radiado de glaucofânio na escala microscópica 29

6.7 Foliação definida pelas micas anastomosadas 31

6.8 Desenvolvimento de textura poligonal em quartzo e contatos triplos a $\sim 120^{\circ}$

6.9 Epidoto-clinozoisita na foliação e como matriz da rocha 31

6.10 Clorita como substituição parcial de glaucofânio 31

6.11 Carbonato com lamelas de deformação 31

6.12 Plagioclásio com geminação de tipo albita 31

6.13 Minerais opacos subidioblásticos disseminados 33

6.14 Granada poiquiloblástica com bordas bem definidas 33

6.15 Estilpnomelano alongado seguindo a foliação principal da rocha 33

6.16 Albita em desequilíbrio com clorita 33

6.17 Padrão de inclusões em albita e clorita 33

6.18 Orientação das inclusões na foliação e no dobramento 33

6.19 Dobramento de albita 36

6.20 Albita definindo a textura granoblástica e a foliação da rocha 36

6.21 Banda de quartzo com extinção ondulante 36

6.22 Cristais de mica acompanhando a foliação 36

6.23 Minerais opacos orientados segundo a foliação e o dobramento 36

6.24 Epidoto-clinozoisita disseminado na rocha 36

6.25 Inclusão de zoisita em albita 37

6.26 "Bandas" de biotita que acompanham a foliação 37

6.27 Cristais prismáticos de anfibólio $\quad 37$

6.28 Glaucofânio em clorita-plagioclásio xisto 37

6.29 Granada com substituição total por clorita. Pseudomorfo 37

6.30 Granada com substituição total por clorita. Pseudomorfo 37

6.31 Epidoto-clinozoisita definindo a foliação com a mica e carbonato 40

6.32 Clorita com minerais opacos nos planos de clivagem 40

6.33 Plagioclásio fortemente deformado. Associação com mica, quartzo e minerais opacos 40

6.34 Estilpnomelano em crenulação associado à mica e clorita 40

6.35 Glaucofânio com substituição por clorita e anfibólio fibroso 40

6.36 Granada com inclusões de quartzo conservando foliação pretérita 40

6.37 Glomeroblasto de epidoto-clinozosita 45

6.38 Glomeroblasto de epidoto-clinozoisita estirado 45

6.39 Carbonato com lamelas de deformação 45

6.40 Cortes basais e longitudinais de anfibólio 45

6.41 Geminação polissintética em albita 45

6.42 Pumpellyita radiada 45

6.43 Plagioclásio com geminação de tipo albita associado com quartzo 47

6.44 Anfibólio em textura nematoblástica 47

6.45 Estilpnomelano em agregados radiados $\quad 47$

6.46 Albita como matriz $\quad 47$

$\begin{array}{lll}6.47 & \text { Albita como porfiroclastos } & 47\end{array}$

$\begin{array}{lll}6.48 & \text { nfibólio disseminado } & 47\end{array}$

6.49 Estilpnomelano subidioblástico $\quad 50$

6.50 Clorita e epidoto em veio 50

6.51 Núcleo de piroxênio (Px) em rocha ultramáfica. Associação com serpentina (Srp), clorita (Chl) e anfibólio (Amp) fibroso

6.52 Minerais opacos disseminados em rocha ultramáfica 50

6.53 Sericitização de plagioclásio $\quad 50$

6.54 Fratura de plagioclásio preenchida por carbonato 50

6.55 Textura pertítica

6.56 Quartzo com extinção ondulante 52 
6.57 Clorita como produto de substituição de biotita 52

6.58 Muscovita dobrada

6.59 Zircão idiomórfico

6.60 Zircão idiomórfico 52

7.1 Afloramento (197) de clorita-lawsonita xisto. Nele observa-se uma rocha com bandas esverdeadas que correspondem a leitos mais ricos em clorita e bandas brancas alaranjadas que contem uma mistura de quartzo e lawsonita

7.2 Afloramento de rochas ultramáficas intensamente serpentinizadas. As rochas apresentam-se intensamente fraturadas e milonitizadas. As cores verdes correspondem às maiores concentrações de serpentina e as cores marrons claras a áreas de concentração de intemperismo

7.3 Afloramento (189) de rochas da fácies anfibolito. No afloramento nota-se o intenso intemperismo superficial e a milonitização das rochas

8.1 Glaucofânio com núcleo mais intensamente pleocroico que a borda

8.2 Textura nematoblástica dobrada 58

8.3 Crenulação $S_{n+1}$ obliqua à foliação $S_{n}$ com cristalização de glaucofânio 58

8.4 Clorita (Chl) xenoblástica e subidioblástica 58

8.5 Clorita (Chl) e lawsonita (Lws) em desequilíbrio 58

8.6 Clorita (Chl) e lawsonita (Lws) em paragênese 58

8.7 Pumpellyita (Pmp) em textura nematoblástica junto ao glaucofânio (Gln) 60

8.8 Cristais subidioblásticos e idioblásticos de lawsonita (Lws) 60

8.9 Foliação Si definida pelas inclusões de titanita em lawsonita 60

8.10 Geminação lamelar em lawsonita 60

8.11 Epidoto (Ep) zonado, evidenciado na variação da cor 60

8.12 Epidoto (Ep) zonado, evidenciado na variação da birrefringência 60

8.13 Titanita disseminada e acompanhando a foliação 61

8.14 Quartzo com extinção plana 61

8.15 Mica branca (Wm) junto ao glaucofânio (Gln), epidoto e opacos 61

8.16 Pirita parcialmente oxidada 61

8.17 Grãos de plagioclásio (PI) com geminação de tipo albita 61

8.18 Calcita (Cal) xenoblástica intersticial 61

8.19 Zonamento do anfibólio 64

8.20 Exsolução de outro anfibólio na hornblenda 64

8.21 Textura simplectítica em borda de anfibólio 64

8.22 Possível anfibólio sódico (Na-Amp) em núcleo de anfibólio cálcico (Ca-Amp) 64

8.23 Granada com inclusões no núcleo e bordas límpidas 64

8.24 Plagioclásio com geminação de tipo albita 64

8.25 Plagioclásio (PI) poiquiloblástico 65

8.26 Zoisita (Zo) idioblástica 65

8.27 Titanita idioblástica 65

8.28 Titanita (Ttn) em borda de reação de rutilo (Rt) 65

8.29 Veio de escapolita (Scp) 65

$\mathbf{8 . 3 0}$ Veio de escapolita 65

8.31 Inclusão de mica em plano de clivagem de anfibólio 67

8.32 Cristais placóides de serpentina e textura mesh preservada 67

8.33 Mineral opaco xenoblástico arredondado 67

8.34 Carbonato e serpentina 67

8.35 Quartzo com contatos suturados e com extinção ondulante 67

8.36 Mica e grafita em foliação e crenulação 67

8.37 Textura lepidoblástica de clorita junto à muscovita 70

8.38 Grafita acompanhando a foliação 70

8.39 Minerais opacos porfiroblásticos 70

$\mathbf{8 . 4 0}$ "Fantasmas" de feldspato (?) 70

8.41 Textura mortar em protocataclasito 70

8.42 Textura granolepidoblástica com muscovita, clorita e quartzo 70

8.43 Quartzo com contatos suturados 72

8.44 Quartzo com contatos retos 72

8.45 Granada com concentração de minerais opacos nas bordas 72

8.46 Granada (Grt) com foliação interna $S_{i}$ inclusa em andaluzita (And) 72

8.47 Poiquiloblasto de plagioclásio 72 
8.48 Andaluzita com inclusão de granada

8.49 Borda de oxidação de limonita em clorita

8.50 Borda de oxidação de limonita em clorita

8.51 "Fitas" de grafita fortemente dobradas

8.52 Grão subidioblástico de titanita concordante com a foliação 74

8.53 Bordas de limonita e possível leucoxênio em opacos

8.54 Zonamento concêntrico em clinozoisita 74

ANEXOS

I Mapa esquemático da região de Jambaló

II Mapa esquemático da região de Barragán

III Análises de química mineral selecionadas da região de Jambaló

IV Análises de química mineral selecionadas da região de Barragán

V Análises geoquímicas completas das amostras da região de Jambaló

VI Análises geoquímicas completas das amostras da região de Barragán 


\section{INTRODUÇÃO}

Esta tese de doutoramento foi desenvolvida como parte do projeto de pesquisa Petrogênese, metamorfismo e evolução tectônica dos xistos azuis dos Andes da Colômbia, Equador e Chile (FAPESP 2004/10203-7) e visou o estudo dos xistos azuis e rochas associadas na Cordilheira Central dos Andes na Colômbia, mais especificamente aqueles das unidades dos Lawsonita-Glaucofânio Xistos e Eclogitos de Barragán (Valle del Cauca) e dos Xistos Glaucofânicos de Jambaló (Cauca). Buscou também estudar os xistos azuis do Departamento de Quindio, reportados por Núñez \& Murillo (1978), mas essas rochas não foram encontradas nas localidades descritas durante os trabalhos de campo feitos para o desenvolvimento desta tese. Outros pesquisadores (Mojica et al. 2001) realizaram trabalhos de campo em anos posteriores na região de Pijao e também não tiveram sucesso na localização desses xistos azuis, razão pela qual essa ocorrência registrada na bibliografia é desconsiderada nesta pesquisa.

A grande importância do estudo dos xistos azuis deve-se ao fato de que os cinturões metamórficos de alta pressão e baixa temperatura inequivocamente relacionam-se com zonas de subducção e de colisão entre placas litosféricas (Bowes, 1989), em especial nas zonas orogênicas mesozóicas e cenozóicas Circum-Pacíficas, no Caribe, nos Alpes e no Himalaia (Miyashiro, 1961; Ernst, 1972; Maruyama et al., 1996). A gênese e evolução dos xistos azuis comumente relacionam-se com a formação de eclogitos, rochas estas também de grande importância para o estabelecimento da evolução crustal.

Conforme discutido por Coleman (1972) e Spear (1995), os xistos azuis do tipo Franciscano têm trajetórias metamórficas e retrógradas muito próximas no campo $\mathrm{P}-\mathrm{T}$ e se caracterizam pela presença de aragonita e pela falta da sobreposição de metamorfismo da fácies xisto verde ou anfibolito, ao passo que o tipo Alpino usualmente mostra inversão da aragonita para calcita e sobreposição de metamorfismo barrowiano.

Por se associarem a limites convergentes de placas tectônicas, os estudos dos eventos metamórficos e deformacionais registrados nos xistos azuis são fundamentais para dedução do tipo da subducção e dos regimes colisionais e de exumação (Ernst, 1988; Smith et al., 1999). A evolução P-T-t e, em especial, a exumação dos xistos azuis pode ser extremamente complexa, sendo associada principalmente a eventos colisionais de naturezas diversas ou a regimes transpressivos, razão pela qual a identificação no registro geológico apresenta importantes implicações tectônicas (Draper \& Lewis, 1991; Ave-Lallemant, 1996). Conseqüentemente, a correlação de suas trajetórias P-T-t-d com dados cinemáticos, geoquímicos e geocronológicos ao longo de uma zona de subducção fóssil são ferramentas fundamentais para o entendimento da evolução geológica do evento colisional e de suas diferentes fases (Smith et al., 1999).

Apesar dos xistos azuis terem atraído grande interesse dos geocientistas nas últimas décadas, somente mais recentemente estudos geotermobarométricos e de definição das 
trajetórias $\mathrm{P}-\mathrm{T}-\mathrm{t}-\mathrm{d}$ têm sido feitos nestas rochas. Estes estudos tem se mostrado de grande importância para uma melhor compreensão dos processos geodinâmicos nos limites convergentes de placas tectônicas e da evolução térmica da Terra e dois tipos de xistos azuis, formados em diferentes regimes de subducção e exumação, sendo reconhecidos mundialmente, o Alpino e o Franciscano. A definição das trajetórias P-T-t e suas correlações com as estruturas tectônicas (d) são fundamentais para o entendimento de como o metamorfismo, o fluxo térmico e a tectônica se interrelacionam (Spear, 1995), pois essas informações auxiliam no entendimento dos processos que levam à implantação e evolução da anomalia térmica na crosta, bem como dos eventos tectônicos vinculados que causam a recomposição das isotermas e a exumação dos xistos azuis. Assim, a maior importância da definição das trajetórias P-T-t-d reside no seu uso para modelagem da evolução tectônica da crosta e, em especial, o estudo de complexos metamórficos formados em regimes de alta pressão e baixa temperatura usualmente contribui significativamente para compreensão de eventos de colisão de placas tectônicas e para as modelagens geodinâmicas (Ernst, 1972; Yardley, 1989; Spear, 1995).

A orogênese mesozóica a cenozóica nos Andes do Norte, no Equador e na Colômbia, caracteriza-se por uma série de colisões de arcos de ilhas e de plateaus oceânicos mesozóicos com a margem continental Sul-Americana, acompanhadas pela formação de diversas zonas de subducção e imbricamento de crosta oceânica, tanto na margem continental como nos domínios intra-oceânicos. Estes processos resultaram na formação de complexos ofiolíticos, de cinturões metamórficos de baixa, média e alta pressão e na amalgamação e forte interação dos diversos terrenos tectônicos (Kerr et al., 1997; 2002; Ramos, 1999; Giunta et al., 2002).

Algumas destas zonas de sutura, principalmente na Colômbia, são marcadas pela ocorrência de lascas tectônicas com rochas na fácies xisto azul, as quais apresentam idades de resfriamento variando entre 132 e $110 \mathrm{Ma}$, interpretadas por Feininger (1982) e Aspden \& McCourt (1986) como indicativas de que sua exumação deu-se no Cretáceo Inferior. Entretanto, a evolução tectono-metamórfica e as implicações tectônicas destas ocorrências de xistos azuis nos Andes do Norte não são ainda bem compreendidas (Bosch et al., 2002) e, na Colômbia, estes litotipos têm sido interpretados como relacionados a eventos de subducção, de acresção ou de colisão de uma placa oceânica vinda do noroeste, com a placa Sul-Americana (e.g. Feininger, 1980; Aspden \& McCourt, 1986; Burgois et al., 1987; Aspden et al., 1995). Entretanto, além da escassez de dados geológicos, as informações disponíveis sobre esses eventos foram coletadas em poucas ocorrências de rochas de alta pressão, o que torna as interpretações decorrentes pouco representativas, impossibilitando a caracterização dos processos tectônicos envolvidos na configuração e reestruturação meso-cenozóica dos Andes do Norte.

Nas áreas de Barragán e Jambaló, os xistos azuis estão relacionados à orogênese mesocenozóica e estudos do metamorfismo e da sua evolução P-T-t-d eram muito poucos, apesar de sua grande importância para compreensão da evolução metamórfica e tectônica dos Andes do 
Norte. Assim, os estudos feitos sobre as condições P-T dos eventos metamórficos e de se suas evoluções em relação às deformações (relações de blastese dos minerais com as foliações metamórficas), juntamente com as datações $\mathrm{Ar}-\mathrm{Ar}$ em micas brancas permitiram a determinação das idades dos eventos metamórficos associados à geração dos xistos azuis e sua correlação com os eventos orogênicos andinos. Esses dados e os estudos geoquímicos das metavulcânicas permitiram interpretar a evolução geodinâmica dominante no período de geração das associações metamórficas e dos protolitos, o que é de grande importância para melhoria dos conhecimentos sobre os regimes tectônicos da Cordilheira Central da Colômbia.

\section{LOCALIZAÇÃO E ACESSOS ÀS ÁREAS DE ESTUDO}

Os xistos azuis ocorrem no flanco ocidental da Cordilheira Central dos Andes Colombianos, nas regiões nordeste do Departamento de Cauca e nordeste do Departamento de Valle del Cauca. O acesso a Barragán pode ser feito através da rodovia que une a cidade Cali a Tuluá (Departamento de Valle del Cauca) de onde a região é alcançada por diversas estradas secundárias (Figura 1.1).

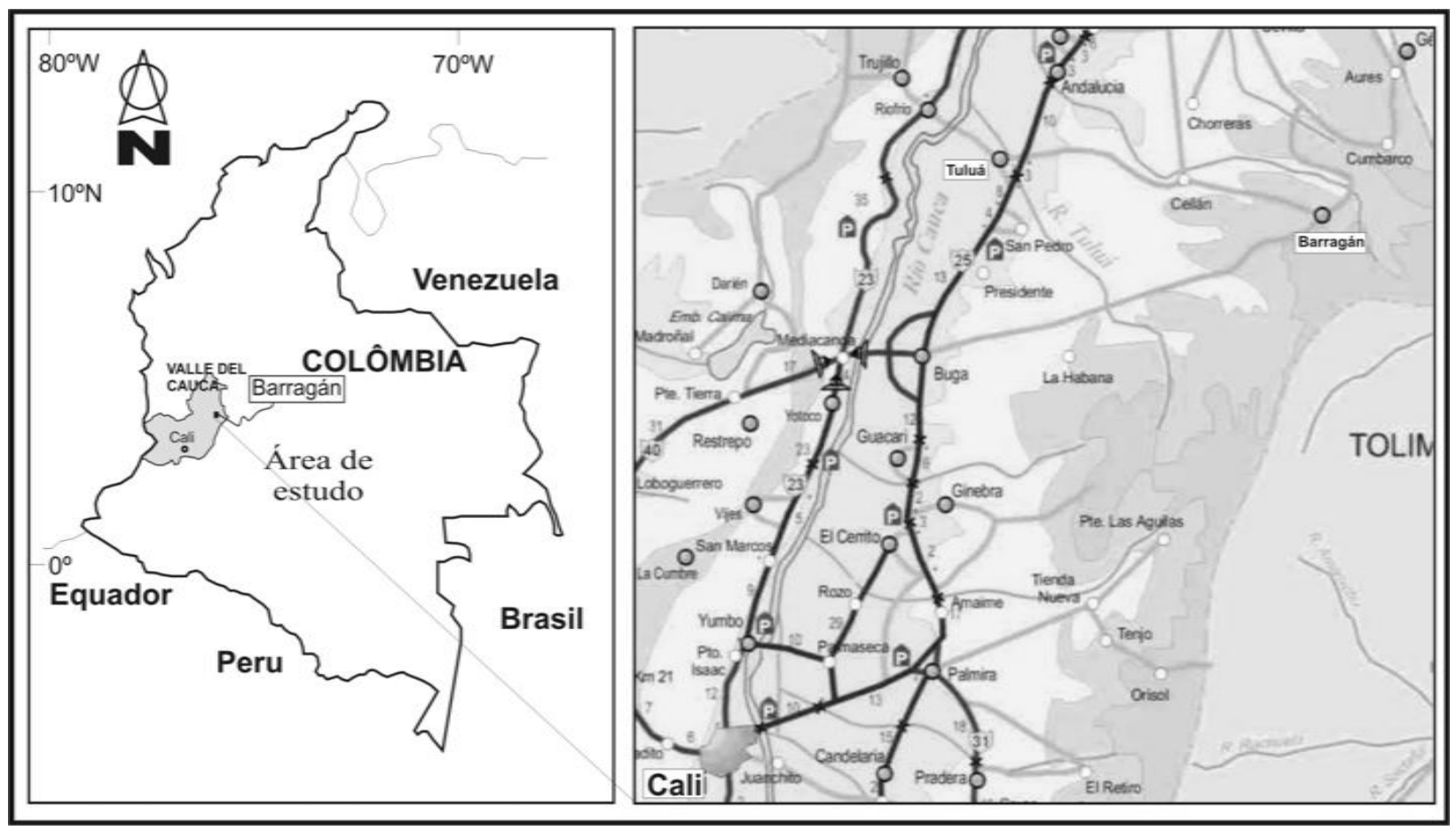

Figura 1.1. Localização e vias de acesso na área de Barragán.

O acesso à região de Jambaló pode ser feito através da rodovia que liga a cidade de Cali a Santander de Quilichao, seguindo pela via a Caloto até chegar à cidade de Toribío, no Departamento de Cauca, de onde área pode ser alcançada através de diversas estradas secundárias e trilhas (Figura 1.2). 


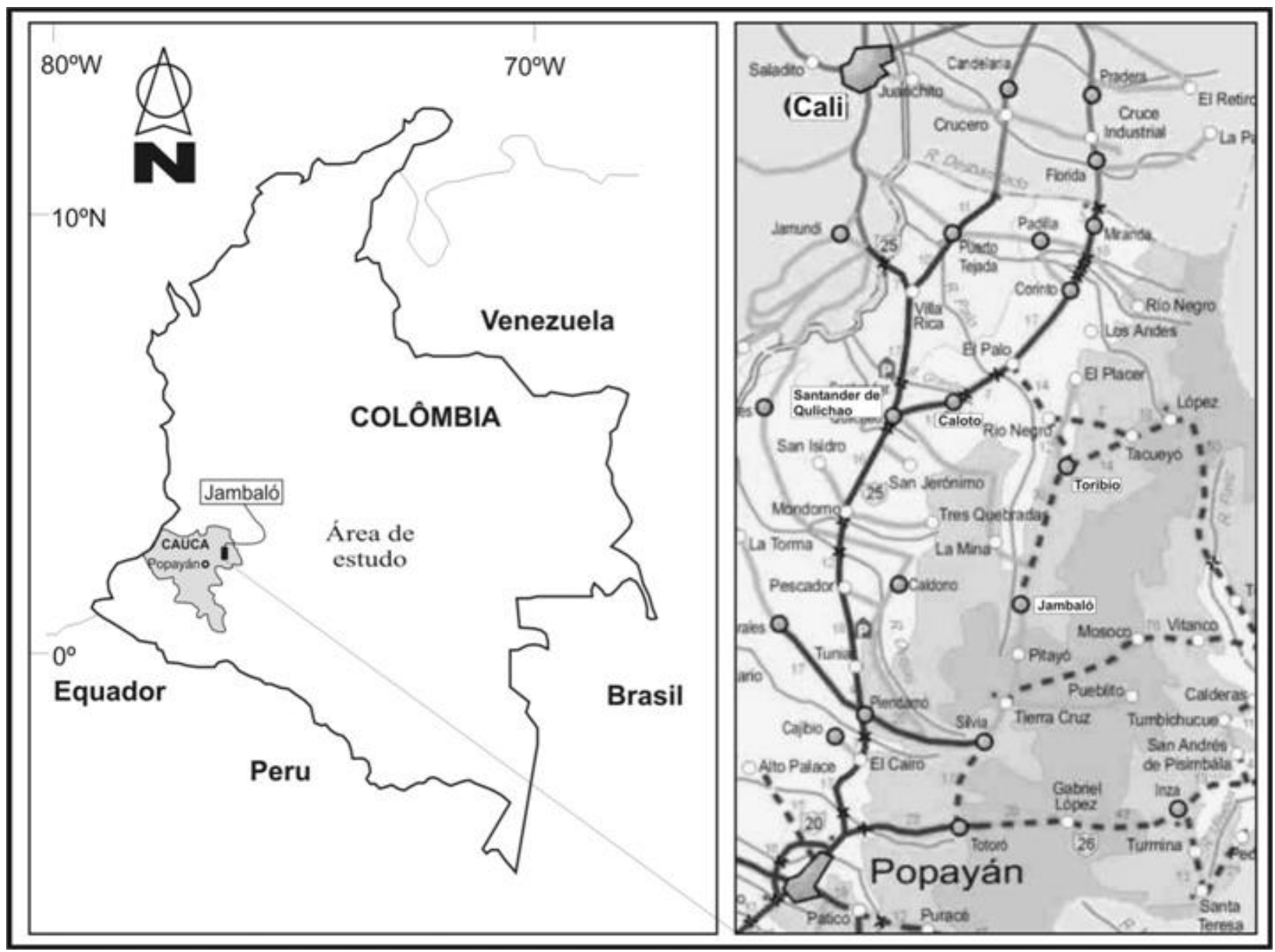

Figura 1.2. Localização e vias de acesso na área de Jambaló.

\section{OBJETIVOS}

Este doutoramento visou a caracterização petrográfica do grau metamórfico e a quantificação das condições do metamorfismo progressivo e retrógrado das rochas das áreas de Barragán e Jambaló, com ênfase para os litotipos da fácies xisto azul. Objetivou também estudar as variações temporais relativas (relações de blastese dos minerais com as foliações metamórficas) e absolutas (geocronologia), ou seja, buscou o estabelecimento das trajetórias pressão-temperatura-tempo relativo-deformação ( $\mathrm{P}-\mathrm{T}-\mathrm{t}-\mathrm{d}$ paths) e a conseqüente a modelagem da evolução geodinâmica cretácea da crosta desta porção dos Andes do Norte e sua correlação com o contexto tectônico de formação dos Andes do Norte.

Para melhor contextualização do ambiente tectônico de formação dos xistos azuis, estudou-se a geoquímica dos metabasitos, visando determinar se seus protolitos foram gerados em arcos de ilhas, plateaus ou crosta oceânica, uma vez que algumas das seqüências vulcanossedimentares da região são interpretadas como relacionadas a complexos ofiolíticos.

Com o intuito de estabelecer as idades dos eventos metamórficos foi utilizado o método de datação radiométrica $\mathrm{Ar}-\mathrm{Ar}$ em mica branca, pois a temperatura de fechamento destas varia entre 325 e $375^{\circ} \mathrm{C}$ (McDougall \& Harrison, 1999) o que na fácies xisto azul pode estar muito próximo ao 
pico metamórfico.

3 MATERIAIS E MÉTODOS

Para alcançarem-se os objetivos propostos foram utilizados os seguintes materiais e métodos:

\subsection{Levantamentos bibliográficos}

Para a elaboração da dissertação foram usados principalmente o acervo da biblioteca do IGUSP e um Trabalho de Formatura realizado por alunos da Universidad Nacional de Medellín.

Os levantamentos bibliográficos compreenderam a coleta de informações nas bases de dados fornecidas pelo Sistema Integrado de Bibliotecas da Universidade de São Paulo (SiBi/USP), consultando-se as bases de dados DEDALUS, SciELO, ERL, ProBE e Web of Science.

Estes levantamentos focaram os estudos sobre a geologia regional, tectônica, geoquímica, metamorfismo e geocronologia dos Andes do Norte, especialmente os feitos nas regiões de Jambaló e Barragán, além de estudos geotermobarométricos, notadamente quanto a calibrações de geotermômetros e geobarômetros em rochas de alta pressão. Foi também dispensada atenção a publicações sobre aplicação de geotermobarometria e sobre a evolução geológica de terrenos semelhantes aos estudados.

\subsection{Levantamentos de campo e amostragem}

Nos levantamentos em campo foram utilizadas as folhas topográficas 1:25.000 do Instituto Geográfico Agustín Codazzi (IGAC) para localização das amostras e escolha dos perfis mais apropriados, incluindo as folhas 321-III-B, 321-III-D e 343-I-B, que correspondem à faixa entre os municípios de Toribío (norte) e Jambaló (sul). Na região de Barragán foram utilizadas as folhas 262-III-A e 262-III-C.

Foi realizada apenas uma etapa de campo para cada uma das áreas, iniciada por reconhecimento regional das unidades geológicas, posteriormente, foram feitos amostragens sistemáticas mais detalhadas nas diversas unidades geológicas abrangidas nesta pesquisa.

Os trabalhos de campo no Jambaló foram realizados entre 22 de fevereiro e 27 de março de 2005, no qual foram feitos 12 perfis em córregos e, em menor proporção, em estradas. Os perfis levantados nos córregos têm em média $3 \mathrm{~km}$. O trabalho todo foi feito entre as localidades de Tacueyó ao norte e Jambaló ao sul. Neste período, foram coletadas 107 amostras de todos os litotipos presentes na região.

Os perfis foram planejados a partir da publicação de Orrego et al. (1980) e o mapa correspondente ao cuadrángulo $N-6$ publicado pela Ingeominas (1999), pois desta forma se esperaria que em todos os perfis seriam observados os corpos de xistos azuis. Considerando o 
foco do trabalho nos xistos azuis e nas rochas metamórficas associadas, foram levantados perfis nas margens orientais dos rios San Francisco e Jambaló, em função das indicações constantes nos trabalhos prévios feitos na área. É importante ressaltar que a zona é muito pobre em afloramentos e que muitas das amostras coletadas de xistos azuis foram de blocos rolados. Entretanto, diversas amostras foram também obtidas em afloramentos, apesar do forte intemperismo.

A pouca quantidade de afloramentos dificultou a obtenção de dados estruturais contínuos, mas os dados dos locais onde foram possíveis as medições foram usados para extrapolações sobre a organização dos litotipos nos perfis. Os perfis levantados nas diversas drenagens indicam que o cinturão de xistos azuis tem dimensões muito menores que o comprimento de $25 \mathrm{~km}$ estimado por Orrego et al. (1980) e Ingeominas (1999).

Entre os dias 7 a 17 de agosto de 2005 foram realizados trabalhos de campo nos arredores do povoado de Barragán, no qual foram feitos 3 perfis em estradas. Durante o trabalho foram coletadas 44 amostras de todos os litotipos peretencentes à unidade dos LawsonitaGlaucofânio Xistos de Barragán, nos quais se destacam principalmente eclogitos retrometamorfisados, metaultramáficas, metabasitos e, em menor proporção, metapelitos. Nesta zona, embora ocorram boas exposições, os contatos entre os diferentes litoitpos e as diversas unidades não puderam ser observados.

\subsection{Petrografia}

As amostras selecionadas foram preparadas na seção de laminação do IGUSP em lâminas de $30 \mu \mathrm{m}$ de espessura, com cobertura, e descritas em microscópio petrográfico de luz transmitida Zeiss Axioplan do Laboratório de Óptica do Departamento de Mineralogia e Geotectônica. Das amostras coletadas no trabalho de campo do projeto, foram confeccionadas e descritas cento e dezesseis (116) lâminas, das quais 72 pertencem à região de Jambaló e quarenta e quatro (44) a região de Barragán.

As descrições incluíram a definição da composição mineralógica, das texturas metamórficas e reliquiares, das paragêneses, das microestruturas e das relações de blastese dos minerais em relação às foliações metamórficas externas $\left(S_{e}\right)$ e internas $\left(S_{i}\right)$, o seqüenciamento dos eventos deformacionais e a preservação de minerais em domínios microestruturais. Para cada um dos litotipos foram identificados, sempre que possível, o tipo e grau metamórfico, relativamente às foliações metamórficas e aos domínios microestruturais.

As rochas alta razão P/T foram classificadas de acordo com a proposta da Subcommission on the Systematics of Metamorphic Rocks (SCMR) de Desmons \& Smulikowski (2007). Para as demais rochas metamórficas da área, foi usado o esquema de Schmid et al. (2007).

A descrição das lâminas foi acompanhada constantemente pelos textos de Spry (1969), 
Tröger (1979), Deer et al. (1992), Hibbard (1995), Passchier \& Trouw (1996), Nesse (2004) e Vernon (2005).

As fotomicrografias foram obtidas no microscópio Olympus BXP-50 e com as câmeras Olympus CAMEDIA C-5050 ZOOM e Nikon COOLPIX 8800.

\subsection{Química mineral}

Da região de Jambaló, foram feitos estudos petrográficos detalhados resultando na seleção de vinte e uma (21) amostras para obtenção das composições químicas dos minerais e sua posterior utilização em interpretações qualitativas de suas condições de formação ou cálculos geotermobarométricos. Das amostras selecionadas dezessete (17) são de rochas na fácies xisto azul ou transicionais para a fácies xisto verde, ainda com restos de anfibólio sódico, e quatro (4) de rochas da fácies xisto verde.

Para a realização das análises de química mineral da região de Barragán, foram selecionadas dez (10) amostras, sendo cinco (5) delas correspondentes aos litotipos da fácies xisto azul e outras cinco (5) da fácies anfibolito.

Para as análises das amostras da região de Jambaló em microssonda eletrônica foram confeccionadas seis (6) lâminas delgadas polidas e metalizadas com película de carbono. As análises foram feitas com a microssonda eletrônica JEOL, modelo JXA 8600 Superprobe do Departamento de Mineralogia e Geotectônica do IGUSP. Outras quinze (15) lâminas delgadas da mesma região e as de Barragán foram analisadas com a microssonda CAMECA, modelo SX-100 no Department of Geological Sciences da University of Michigan, nos Estados Unidos.

Para as análises de anfibólios, micas, estilpnomelano, clorita, granada, epidoto, clinozoisita, titanita, rutilo e carbonato, utilizou-se um feixe de elétron com diâmetro de $5 \mu \mathrm{m}$ e para o plagioclásio foi usado um feixe de $10 \mu \mathrm{m}$. Em todas as análises a corrente foi de $\sim 20,1 \mathrm{nA}$ e voltagem de $15 \mathrm{KV}$.

As composições químicas dos minerais metamórficos foram definidas em boa parte através de perfis composicionais, visando à determinação de zonamentos químicos e de suas relações de blastese com as foliações tectônicas externas e internas, para estabelecer cronologia relativa de cristalização (t). Sempre que possível, foram analisadas as inclusões de minerais e o mineral hospedeiro em contato, objetivando uma melhor determinação das condições do metamorfismo para uma determinada zona composicional do mineral.

\subsection{Geotermobarometria}

As condições de pressão e temperatura dos litotipos selecionados foram obtidas utilizandose o programa TWQ 1.02 (Berman, 1991).

Com base na petrografia detalhada das seções delgadas, foram efetuados os cálculos 
termobarométricos em amostras de cada um dos litotipos, focalizando principalmente as reações dos equilíbrios metamórficos. As análises de associações texturalmente em equilíbrio foram separadas das assembléias correspondentes a cada um dos domínios microestruturais e das cristalizadas em condições retrometamórficas. Concluída esta parte, foram avaliadas as melhores análises (melhor proporção catiônica e equilíbrios que representam) com base na qualidade e precisão para aplicação nos cálculos geotermobarométricos, usando as análises representativas dos melhores equilíbrios de cada uma das assembléias.

As informações mineralógico-estruturais obtidas pela petrografia e os dados da química mineral, utilizadas em conjunto com a geotermobarometria possibilitaram não somente a estimativa das condições de temperatura e de pressão de formação das rochas, como também a definição de suas trajetórias evolutivas no campo P-T, por meio do seqüenciamento definido pelas relações de blastese com as foliações metamórficas (tempo relativo - $t$ ).

\subsection{Geoquímica de rochas}

Nas análises geoquímicas das amostras das regiões de Jambaló e Barragán, as amostras foram selecionadas seguindo os mesmos critérios usados para a química mineral, ou seja, que foram selecionados litotipos que correspondam a principalmente a protolitos de rochas básicas. Preferencialmente foram selecionadas as amostras de metabasitos da fácies xisto azul, mas também foram analisados rochas da fácies xisto verde de Jambaló e da fácies anfibolito de região de Barragán.

Os dados geoquímicos das rochas metamórficas foram usados como indicadores da natureza e ambiente tectônico no qual elas se formaram. A interpretação dos dados baseou-se no conceito fundamental da pequena mobilidade dos elementos de HFSE (Ti, Th, Ta, $\mathrm{Zr}, \mathrm{Y}, \mathrm{Nb}, \mathrm{P}$ e $\mathrm{Hf})$, os metais transicionais ( $\mathrm{Cr}$, Ni e $\mathrm{V}$ ), os elementos terras raras (REE) e a permanência parcial de alguns elementos maiores em forma de óxidos $\left(\mathrm{SiO}_{2}, \mathrm{MgO}, \mathrm{CaO}\right.$ e $\left.\mathrm{MnO}\right)$ durante o metamorfismo e eventualmente durante alterações hidrotermais (Pearce \& Cann, 1973; Winchester \& Floyd, 1977, Beccaluva et al., 1979; Juliani \& McReath, 1993; McLenann et al., 1993). Segundo Winchester \& Max (1989), os elementos de raio iônico grande (Cs, Rb, Sr e Ba) e o $\mathrm{K}_{2} \mathrm{O}$ são potencialmente móveis nos eventos metamórficos, por esta razão sua interpretação pode resultar em erros.

A primeira etapa da preparação das amostras foi feita no Laboratório de Tratamento de Amostras (LTA) do Departamento de Mineralogia e Geotectônica do Instituto de Geociências da Universidade de São Paulo. Esta etapa compreendeu a fragmentação, trituração e pulverização em moínho de carboneto de tungstênio. Todas as amostras foram analisadas em espectrômetro de massa com plasma acoplado (ICP-MS) e pela técnica de ativação de nêutrons (INAA) no ACTIVATION LABORATORIES LTD no Canadá. Os limites de detecção para os óxidos são $\mathrm{SiO}_{2}$, 
$\mathrm{Al}_{2} \mathrm{O}_{3}, \mathrm{Fe}_{2} \mathrm{O}_{3}, \mathrm{MgO}, \mathrm{CaO}, \mathrm{Na}_{2} \mathrm{O}, \mathrm{K}_{2} \mathrm{O}, \mathrm{P}_{2} \mathrm{O}_{5}$ de $0,01 \%$ e $\mathrm{MnO}$ e $\mathrm{TiO}_{2}$ de $0,001 \%$ com perdas por ignição de $0,01 \%$. No caso dos elementos traço, estes têm variação dos limites de detecção entre 0,005 e 10000 ppm dependendo do elemento analisado.

Da área de Jambaló foram analisadas 12 amostras, das quais seis (6) correspondem a metabasitos da fácies xisto azul e seis (6) da fácies xisto verde, incluindo um epidosito e um estilpnomelano-muscovita-albita-anfibólio-quartzo xisto.

Da região de Barragán, foram analisadas 11 amostras, das quais cinco (5) correspondem a metabasitos da fácies anfibolito e seis (6) da fácies xisto azul.

\subsection{Geocronologia Ar-Ar e K-Ar}

Segundo Faure (1986), Dickin (1995), McDougall \& Harrison (1999), o potássio é um dos elementos mais abundantes da terra e tem três isótopos, dos quais $0{ }^{40} \mathrm{~K}$, que é radioativo, apresenta uma abundância de 0,01167 , quando comparado aos outros dos isótopos. $\mathrm{O}^{40} \mathrm{~K}$ decai em ${ }^{40} \mathrm{Ca} \mathrm{e}{ }^{40} \mathrm{Ar}$, sendo as constantes de decaimento para estes de $0,581 \times 10^{-10}$ anos é $4,962 \times 10^{-}$ ${ }^{10}$ anos, respectivamente.

$\mathrm{O}$ método $\mathrm{Ar}-\mathrm{Ar}$ se baseia na transformação do ${ }^{39} \mathrm{~K}$ em ${ }^{39} \mathrm{Ar}$ durante a irradiação por nêutrons em reator nuclear. Após esta irradiação o material é fundido num sistema vácuo e as abundâncias relativas dos diferentes isótopos de Ar são analisadas num espectrômetro de massa. As razões ${ }^{40} \mathrm{Ar} /{ }^{39} \mathrm{Ar}$ são proporcionais às razões ${ }^{40} \mathrm{Ar} /{ }^{40} \mathrm{~K}$ e à idade da amostra.

$\mathrm{O}$ método $\mathrm{Ar}-\mathrm{Ar}$ permite a medição direta do isótopo radiogênico e o isotópico radioativo na mesma amostra, proporcionando uma maior precisão das análises. Adicionalmente, no método Ar-Ar é possível fundir por etapas o material analisado, obtendo-se desta maneira idades aparentes ao longo de cada etapa. Estas liberações parciais de argônio permitem não somente conhecer a distribuição do gás na amostra, como também avaliar o comportamento do argônio radiogênico, possibilitando a identificação da presença de diferentes reservatórios de argônio e a existência de argônio em excesso. Com isto, é possível um maior controle do significado dos resultados geocronológicos, identificando possíveis episódios de perdas parciais de argônio, argônio em excesso, ou heterogeneidades composicionais, deixando à margem algumas incertezas do método $\mathrm{K}-\mathrm{Ar}$, que utiliza a fusão total da amostra, não permitindo o rastreamento das complexidades geológicas registradas na amostra.

$\mathrm{Na}$ interpretação dos dados $\mathrm{K}-\mathrm{Ar}$ e $\mathrm{Ar}$-Ar foi utilizado o conceito de temperatura de fechamento, que representa o momento em que a velocidade de difusão do argônio no sistema torna-se praticamente nula. As temperaturas de fechamento do anfibólio são de $450 \pm 50{ }^{\circ} \mathrm{C}$,

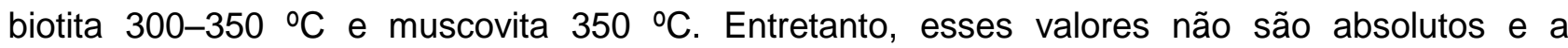
deformação, presença de fluidos, variações composicionais nas fases minerais, o tamanho da amostra e as taxas de resfriamento podem modificar significativamente este valor (Dahl, 1996; 
Villa, 1997). A muscovita, particularmente em condições de baixo grau metamórfico e na zona da diagênese, pode apresentar temperaturas de fechamento variáveis. Valores sugeridos de 100$140^{\circ} \mathrm{C}$ para a zona de diagênese-anquizona $\left(150-250^{\circ} \mathrm{C}\right)$, e $260 \pm 30^{\circ} \mathrm{C}$ para rochas no limite entre a fácies xisto verde e a sub-xisto verde que são formadas em temperaturas de $250-350{ }^{\circ} \mathrm{C}$ (Hunziker et al., 1986; Adams et al., 1999).

A interpretação das idades dentro do contexto metamórfico é condicionada pela relação entre as condições de metamorfismo (principalmente temperatura) e a temperatura de fechamento do sistema. Estudos sistemáticos em diferentes perfis contínuos de rochas metamórficas de baixo grau têm sugerido que é possível obter idades metamórficas em rochas metamorfizadas na fácies prehnita-pumpellyita, enquanto que na fácies xisto verde e condições superiores a esta as idades têm relação com o resfriamento (Adams et al., 1999; Adams \& Maas, 2004).

No caso das análises da rocha total, considera-se que o gás liberado está relacionado diretamente com as fases potássicas, tendo como possíveis inconvenientes a mescla de minerais com diferentes temperaturas de fechamento ou, em rochas de baixo grau, a preservação de heranças detríticas, como em feldspatos (Dallmayer \& Takasu, 1992; Clauer \& Chauduri, 1999). $\mathrm{Na}$ interpretação do significado da idade aplicam-se os mesmos princípios de temperatura de fechamento.

Os concentrados de minerais foram preparados com o uso de técnicas clássicas de separação, principalmente por catação manual, pois a granulação, que varia entre 0,5 e $1 \mathrm{~mm}$, e a quantidade dos minerais, simplificou o processo. Em quase todas as amostras, foram analisados dois (2) ou três (3) grãos, embora em algumas amostras foi analisado um único grão.

As análises foram feitas no Laboratório de Geocronologia de Argônio (Argon Geochronology Laboratory) da University of Michigan, nos Estados Unidos.

As análises ${ }^{40} \mathrm{Ar} /{ }^{39} \mathrm{Ar}$ foram feitas utilizando uma técnica de encapsulamento a vácuo, seguindo o procedimento descrito e discutido por Dong et al. (1995); Hall, et al. (1997) e Pettke et al., (2000). A irradiação das amostras foi realizada no reator nuclear Phoenix-Ford Memorial da University of Michigan durante 30 h, juntamente com o padrão MMHb-1 (idade = 520,4 Ma). Após a irradiação foram escolhidos dois ou três cristais de cada amostra para extração e purificação de argônio pelo método de fusão por etapas (step heating). Os isótopos Ar foram medidos com um espectrômetro de massas VG 1200S, e as análises foram realizadas utilizando um detector Daly.

Da região de Jambaló foram selecionadas e analisadas pelo método ${ }^{40} \mathrm{Ar} /{ }^{39} \mathrm{Ar}$ muscovita ou fengita ou paragonita de sete (7) amostras, das quais seis (6) são de rochas da fácies xisto azul e uma (1) da fácies xisto verde.

Da região de Barragán foi selecionada uma (1) única amostra de muscovita para a análise geocronológica $\mathrm{Ar}-\mathrm{Ar}$, correspondendo a um grafita-clorita-muscovita-quartzo xisto da fácies xisto verde, que ocorre associado a rochas da fácies xisto azul. 


\section{SÍNTESE BIBLIOGRÁFICA FUNDAMENTAL}

Uma breve revisão sobre o metamorfismo da fácies xisto azul, a evolução geológica dos Andes do Norte Colombianos no Cretáceo e a constituição geológica das áreas de Barragán e Jambaló são apresentadas a seguir:

\subsection{Metamorfismo e Litotipos da Fácies Xisto Azul}

O termo Fácies Glaucofânio Xisto foi proposto por Eskola (1939) e redefinido como Fácies Glaucofânio-Lawsonita por Fyfe \& Turner (1966). Bailey (1962) nomeou esses xistos com glaucofânio como xistos azuis e Turner (1981) cunhou o termo Fácies Xisto Azul, que mais comumente é utilizado para descrição do metamorfismo dessas rochas.

Entretanto, a exata caracterização petrográfica da fácies xisto azul tem sido objeto de controvérsias, em função da composição química variada dos seus protolitos ígneos e sedimentares. Apesar disto, há consenso sobre a típica assembléia de minerais que ocorre nos metabasitos metamorfizados em temperaturas semelhantes às da fácies xisto verde e em pressões mais altas, que são caracterizadas pela presença de glaucofânio, lawsonita, clinopiroxênio sódico ou onfacita, muscovita fengítica/fengita, pumpellyita e aragonita em paragênese com actinolita, clorita, albita, epidoto, quartzo, paragonita e estilpnomelano (Spear, 1995).

O efeito mais característico do metamorfismo de alta pressão em rochas básicas é a substituição dos anfibólios cálcicos típicos das rochas de terrenos barrowianos, pelo anfibólio sódico, com alta proporção da molécula glaucofânio, presentes em volumes importantes nos xistos azuis (Yardley, 1989). Muito embora estas rochas sejam geralmente, macroscopicamente, cinza-azuladas ou esverdeadas, elas podem apresentar cor azul-lilácea, devido a quantidades significativas de anfibólios sódicos. Ao microscópio a cor azul é usualmente observada em riebeckita e outros anfibólios sódicos ferro-férricos, como ferroglaucofânio e magnesioriebeckita, uma vez que o glaucofânio puro não apresenta cor azul (Bowes, 1989).

Os xistos azuis, por serem formados em pressões relativamente altas e a baixas temperaturas, foram considerados como gerados em zonas de subducção, onde a placa descendente é fria e alcança as pressões do manto ainda em temperaturas relativamente baixas. Uma vez que os xistos azuis ocorrem associados a zonas de subducção ativas ou em áreas de colisão continental (Ernst, 1972; Maekawa et al., 1993; Bucher \& Frey, 1994) eles foram, por algum tempo, considerados a única evidência da existência de processos de subducção antigos em terrenos metamórficos. De fato, ainda hoje, os xistos azuis tem sido uma das principais associações utilizadas para caracterização de zonas de subducção antigas.

A evolução geoquímica da crosta oceânica (incluindo componentes máficos e sedimentares) tem importante implicação para o entendimento da origem da heterogeneidade do 
manto e da geoquímica dos arcos vulcânicos basálticos. Entretanto, o conhecimento da evolução geoquímica atual da crosta oceânica subductada é baseado principalmente em evidências indiretas, tais como a composição dos arcos vulcânicos basálticos e o entendimento das propriedades geoquímicas dos elementos traço. Certos tipos de cinturões de xistos azuis são considerados como resultado da exumação de porções de crosta oceânica subductada, o que possibilita o estudo da evolução desta crosta oceânica preservada nos cinturões metamórficos com xistos azuis, que podem incluir xistos verdes e eclogitos (Lavis et al., 2005).

Os cinturões de xistos azuis podem ser classificados em dois grupos, de acordo com os protolitos, cujas principais características são resumidas na Tabela 4.1.

Tabela 4.1. Protolitos e características dos cinturões de xistos azuis (Modificado de Maruyama et al., 1996).

\begin{tabular}{|c|c|c|}
\hline Protolito & Tipo A & Tipo B \\
\hline Sedimentos marinhos de águas rasas & Plataforma de carbonatos & Calcáreos orgânicos de recife \\
\hline $\begin{array}{l}\text { Sedimentos marinhos de águas } \\
\text { profundas }\end{array}$ & Ausente & $\begin{array}{l}\text { Cherts estratificados, nódulos de } \\
\text { manganês }\end{array}$ \\
\hline Rochas ígneas & '"'Bimodal (basalto e dacito) & MORB \\
\hline Embasamento continental & $\begin{array}{l}\text { Presente (complexo granítico- } \\
\text { gnáissico) }\end{array}$ & Ausente \\
\hline Minérios & Tipo Kuroko (sulfetos maciços) & $\begin{array}{l}\text { Originados em cadeia meso- } \\
\text { oceânicas }\end{array}$ \\
\hline Depósitos de turbiditos & $\begin{array}{l}\text { Cobertura de plataforma (sedimentos } \\
\text { peraluminosos) }\end{array}$ & $\begin{array}{l}\text { Preenchimento de trincheiras } \\
\text { (grauvacas, fluxo de vulcanoclásticas } \\
\text { andesíticas) }\end{array}$ \\
\hline Pressão máxima & $45 \mathrm{kbar}$ & $12 \mathrm{kbar} \quad-m$ \\
\hline Cinturão granítico associado & Raro ou ausente & Normalmente presente \\
\hline Grau de reações retrógradas & Grande & Pequeno \\
\hline $\begin{array}{l}\text { Peridotitos regionalmente } \\
\text { metamorfisados }\end{array}$ & Granada peridotito e espinélio peridotito & $\begin{array}{l}\text { Espinélio peridotito e plagioclásio } \\
\text { peridotitos fortemente serpentinizados }\end{array}$ \\
\hline Cinturões pareados & Ausente & "'Presente \\
\hline
\end{tabular}

As rochas básicas são especialmente importantes para o entendimento do metamorfismo em altas pressões e baixas temperaturas, pois eles são mais susceptíveis a mudanças mineralógicas que os pelitos. Estas condições de alta pressão, baixa temperatura e baixo fluxo de calor são bem satisfeitas em zonas onde a subducção de crosta oceânica relativamente fria, ou de underplating de rochas supracrustais, e o espessamento da crosta continental são os processos dominantes (Bowes, 1989).

No ambiente tectônico de formação das rochas de alta pressão dois tipos principais de trajetórias metamórficas são reconhecidas nos xistos azuis (Ernst, 1972). A primeira delas, denominada Tipo Alpino, ocorre na maioria das zonas de subducção recentes, como verificado nos Alpes, Turquia, Grécia, Japão, Nova Zelândia e no norte da Ásia e China. Sua trajetória metamórfica tem sentido horário, o que faz com que os xistos azuis e os eclogitos associados sejam substituídos por xistos verdes e anfibolitos durante o retrometamorfismo. Este tipo de xisto azul é formado em zonas de subducção, nas quais ocorre descompressão aproximadamente isotermal, provocada por exumação muito rápida em regimes compressionais, à qual se associa forte erosão. Segundo Ernst (1972) isto pode ser causado pela colisão de um arco de ilhas ou por 
um fragmento de crosta continental com o continente, resultando em rápido soerguimento e denudação dos xistos azuis. Alternativamente este tipo de trajetória pode ser explicado pelo aumento de pressão causado pelo acúmulo de rochas supracrustais no prisma acrescionário de uma fossa com forte subsidência, o que faz com que haja inserção dos sedimentos sob a crosta continental, seguida pela exumação em zonas de cavalgamentos, acentuada pela presença de um bloco crustal superposto aos sedimentos durante a colisão (Platt, 1987).

O segundo tipo, chamado de Franciscano, caracteriza-se por uma trajetória retrometamórfica quase coincidente com a trajetória do metamorfismo progressivo. Esse é típico dos terrenos do Complexo Franciscano (Califórnia, EUA) e é formado em terrenos que são rapidamente resfriados durante a exumação, implicando em soerguimento crustal relativamente lento, o que possibilita a transferência da energia térmica das cunhas tectônicas de rochas de alta pressão em zonas de mélanges para as encaixantes mais frias (Cloos, 1982).

Nota-se que os diferentes tipos e modelos derivados da interpretação das trajetórias metamórficas associam-se sempre com zonas de subducção, mas sua evolução pode relacionarse com a evolução do metamorfismo de soterramento e com a colisão tectônica (segundo o modelo de Platt, 1987), com ofiolitos (Ernst, 1972) e com a exumação de eclogitos (Spear, 1995).

Especialmente na região de Jambaló, as características petrográficas dos xistos verdes e anfibolitos associados aos xistos azuis sugerem, pela presença de fengita e de relíquias de anfibólio sódico, que os xistos azuis foram retrometamorfizados em regime de maior temperatura, o que permitiria classificá-los como do Tipo Alpino. Entretanto, a presença de aragonita nos xistos azuis é indicativa de uma trajetória metamórfica do Tipo Franciscano, sugerindo que a trajetória metamórfica foi de gradiente $\mathrm{P}-\mathrm{T}$ intermediários entre os tipos Alpino e Franciscano.

\subsection{Contexto Geológico e Tectônico da Cordilheira Central dos Andes Colombianos}

A Cordilheira dos Andes é uma das mais ativas regiões de geração de crosta continental do mundo, com adições verticais de magma e acresção de domínios intra-oceânicos (Weber et al., 2002). A evolução dos Andes do Norte no Equador e na Colômbia envolveu, no final do Jurássico e início do Cretáceo, um episódio de acresção de unidades continentais e oceânicas (Litherland et al., 1993), cuja sutura está localizada no extremo ocidental da Cordilheira Oriental do Equador, a qual se estende até o noroeste da Colômbia, no flanco ocidental da Cordilheira Central (Litherland et al., 1993; Aspden et al., 1995). A Cordilheira dos Andes na Colômbia subdivide-se nas cordilheiras Oriental, Central e Ocidental, formadas por distintos eventos de acresção crustal. A Cordilheira Oriental é composta por uma espessa pilha de metassedimentos pouco deformados e de grau metamórfico muito baixo que, recobrem discordantemente o embasamento PréCambriano. A Cordilheira Ocidental é constituída por terrenos oceânicos, acrescidos à crosta continental principalmente no Cretáceo, e a Cordilheira Central é formada, em essência, pelo embasamento metamórfico, com rochas magmáticas associadas, e delgadas camadas de 
sedimentos de ocorrência local.

$\mathrm{Na}$ Cordilheira Central dos Andes Colombianos pode ainda ser reconhecido seu embasamento, formado por um complexo polimetamórfico com rochas paleozóicas e mesozóicas (Bustamante \& Juliani, 2002), afetado por intenso magmatismo granítico no Triássico (Vinasco et al., 2006) e no Mesozóico (Feininger, 1982). Depósitos vulcânicos continentais terciários e quaternários ocorrem nos dois flancos da parte sul da Cordilheira (Feininger, 1982).

Um importante sistema transcorrente dextrógiro, ativo durante o Cretáceo Superior e todo Cenozóico, conhecido como Falha Romeral (Toussaint, 1996), acompanha a Cordilheira Central em toda sua extensão na Colômbia (Figura 4.1). Esta zona de cisalhamento que separa os domínios continentais a leste e oceânicos a oeste, é interpretada como sendo o traço da antiga zona de sutura, reativada tectonicamente por transcorrências, é responsável por fatiamentos e imbricamentos tectônicos entre ambos os terrenos (Feininger, 1982).

As rochas metamórficas de alta pressão afloram entre a zona de Falhas Romeral e o embasamento paleozóico da Cordilheira Central, formado por gnaisses e xistos, situado a sudeste (Feininger, 1982). No contexto evolutivo dessa região, deve ser destacado que os gnaisses e xistos paleozóicos não foram afetados pelo metamorfismo de alta pressão (Orrego et al., 1980).

\subsection{Metamorfismo na Cordilheira Central dos Andes Colombianos}

Os Andes na Colômbia dividem-se em três cadeias de montanhas, denominadas cordilheiras Oriental, Central e Ocidental (Figura 4.1). Geologicamente pode ser dividido em dois grandes domínios, formados por diferentes terrenos tectono-estratigráficos (Restrepo \& Toussaint, 1988). O Domínio Ocidental, que inclui a Cordilheira Ocidental e a margem ocidental da Cordilheira Central, tem caráter ensimático, sendo constituído por rochas vulcanossedimentares de afinidade oceânica e por complexos ofiolíticos acrescidos à margem continental durante o Mesozóico-Cenozóico. A porção siálica é representada por dois terrenos principais, quais sejam:

a) Oriental, que corresponde ao embasamento metamórfico de alto grau Pré-Cambriano coberto por complexos metassedimentares e rochas sedimentares do Paleozóico Inferior e Superior. O conjunto foi invadido por intrusões de granitóides, acompanhados por sedimentação no Mesozóico, resultando na formação de um arco magmático continental, cuja evolução das fases de rift e de margem passiva é característica da margem ocidental das Américas (Dickinson \& Lawton, 2001). À sedimentação de margem passiva seguiu-se uma inversão tectônica, a instalação de um sistema de foreland relacionado com a orogenia andina e a acresção dos domínios oceânicos ocidentais. Este domínio tem sido considerado um terreno tectonoestratigráfico acrescido no Paleozóico (Restrepo \& Toussaint, 1988, Forero-Suárez, 1991).

b) Um terreno de afinidade continental, localizado no núcleo da Cordilheira Central, constituído predominantemente por uma série de complexos polimetamórficos com magmatismo associado, de idades variando entre o Paleozóico Médio e o Triássico. A acresção deste terreno à 


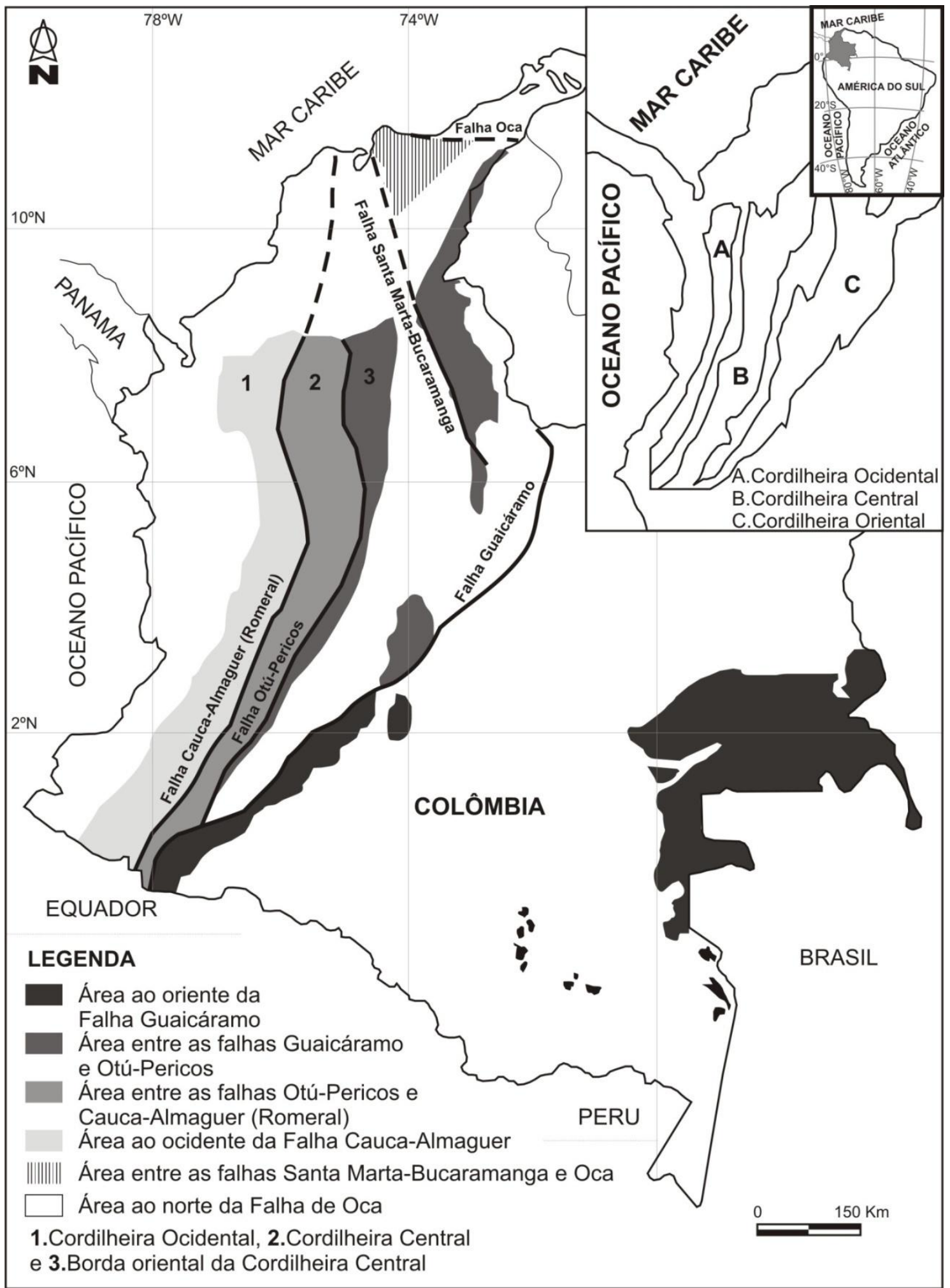

Figura 4.1. Distribuição das áreas com rochas metamórficas na Colômbia. (Modificado de Maya, 2001).

margem continental é considerada como relacionada à acresção dos outros domínios oceânicos durante o Cretáceo (Toussaint, 1996). Este terreno constitui um elemento fundamental na compreensão da evolução geológica dos Andes Norte-Ocidentais, uma vez que seu embasamento metamórfico registra a complexa história geológica ocorrida entre o Paleozóico Inferior até o Triássico, relacionada à evolução Hercínica da margem ocidental do Gondwana e à 
acresção e dispersão da Pangea (e.g. Jaillard et al., 1991; Megard et al., 1987; Noble et al., 1997; Vinasco, 2001; 2007), cuja natureza encontra-se ainda pouco compreendida. A zona de estudo insere-se no contexto geológico deste domínio.

Segundo Maya (2001), o flanco ocidental e o núcleo da Cordilheira Central são limitados pela Falha Otú-Pericos a leste e a Falha Cauca-Almaguer (Romeral) a oeste. Fazem parte desta porção tectono-estratigráfica várias unidades metamórficas do Complexo Polimetamórfico da Cordilheira Central e algumas unidades sedimentares e vulcânicas (Figura 4.1). Outros estudos baseiam-se na geocronologia, resultado de datação de amostras de várias das unidades geológicas, em sua maioria não inseridos em uma base cartográfica atualizada, feitos em áreas sem detalhamento dos processos geológicos e sem uma amostragem sistemática que permita uma correlação das idades com a evolução geológica. Com o surgimento do conceito dos eventos metamórficos superpostos na Cordilheira Central (Restrepo \& Toussaint, 1982), os pesquisadores têm revisado os modelos de evolução desta parte dos Andes e os trabalhos têm sido focados na diferenciação dos diferentes eventos tectono-metamórficos que a afetaram.

Os estudos mineralógicos mais detalhados e a aplicação dos conceitos das séries de fácies de Myashiro (1961), assim como a descoberta das características do metamorfismo do Grupo Arquia e das rochas metamórficas de média e alta pressão do flanco ocidental da Cordilheira Central, contrastantes com as rochas de baixa pressão no eixo da cordilheira, além do aumento nos dados geocronológicos, têm permitido estabelecer que as rochas metamórficas da Cordilheira Central foram afetados por vários eventos tectono-metamórficos superpostos no tempo e espaço (Restrepo \& Toussaint, 1982; Toussaint, 1993). Por isto, as rochas metamórficas da Cordilheira Central não podem ser agrupadas num único conjunto e o uso do termo Complexo Poli-metamórfico da Cordilheira Central (Restrepo \& Toussaint, 1984) é o mais adequado para referir-se a todo conjunto de rochas metamórficas que compõe a cordilheira. Segundo McCourt (1984), as rochas metamórficas da Cordilheira Central podem ser agrupadas em dois diferentes grupos: Grupo de Xistos do Leste, encontrado nas partes mais altas, que constitui o flanco oriental da cordilheira, formado pelas rochas metamórficas de baixa pressão; o Grupo de Xistos do Oeste, que compõe o flanco ocidental da Cordilheira Central e corresponde a rochas de média e alta pressão.

Segundo Maya \& González (1995), a Cordilheira Central é constituída por quatro unidades litodêmicas (Figura 4.2) separadas por falhas, cuja exposição ocorre de maneira contínua, desde os limites com Equador até os 6ํํㄹ de latitude norte.

A unidade mais ocidental é composta por rochas vulcânicas mesozóicas, mas alguns desses conjuntos definidos por Maya \& González (1995) fazem parte da Cordilheira Ocidental, razão pela qual não serão aqui descritos. Desta forma, as unidades de interesse nesta pesquisa são: 


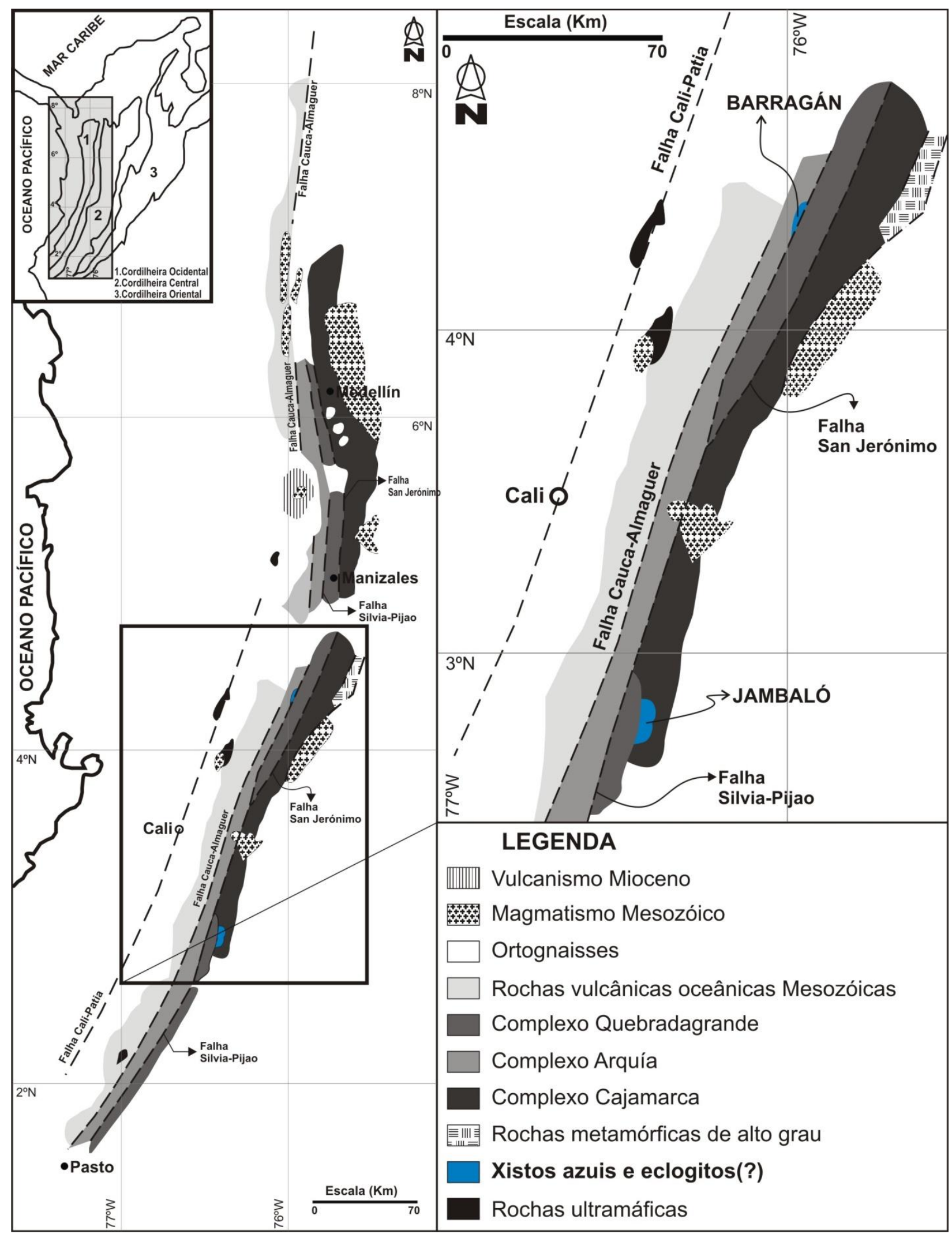

Figura 4.2. Divisão da Cordilheira Central dos Andes colombianos em unidades litodêmicas (Maya \& González, 1995).

Complexo Cajamarca (Nelson, 1957): é composto por quartzo-sericita xistos, xistos verdes, filitos e algumas camadas de mármores que afloram na seção Cajamarca Alto de La 
Línea, entre as falhas Otú-Pericos e Chapetón-Pericos e a falha Aranzazu-Manizales (Mosquera et al., 1982). Entre as cidades de Mariquita e Manizales $\left(3^{\circ} 35^{\prime} \mathrm{N}\right)$, as rochas do Cajamarca afloram desde a falha de Mulato até a falha de San Jerónimo, perto da cidade de Manizales, e encontramse parcialmente cobertas por rochas vulcânicas (Mosquera, 1978). Neste perfil as rochas do Complexo Cajamarca têm associadas rochas de alto grau metamórfico (Maya \& González, 1995). Depois dos $5^{\circ} 30^{\prime}$ de latitude norte, os quartzo-sericita xistos, actinolita xistos e quartzitos afloram somente na parte central da Cordilheira Central. Ao leste da Falha Otú, o Complexo é composto por metapelitos, rochas metamórficas de baixo grau, gnaisses, gnaisses aluminosos, hornblenda gnaisses, quartzitos, escarnitos, mármores e anfibolitos (Feininger, 1972). Ao leste da Falha Silvia-Pijao afloram as rochas metamórficas de alta razão P/T da região de Jambaló, que também se inserem no Complexo Poli-metamórfico da Cordilheira Central (Restrepo \& Toussaint, 1984), um dos objetos desta pesquisa.

Complexo Quebradagrande (Maya \& González, 1995): é dividido em duas unidades litodêmicas, uma sedimentar e outra vulcânica, que afloram entre os complexos Cajamarca e Arquia e são limitadas pelas falhas San Jerónimo a leste e Silvia-Pijao a oeste.

Complexo Arquia: localiza-se a oeste do Complexo Quebradagrande, é limitado pela Falha Silvia-Pijao a leste e pela Falha Cauca-Almaguer a oeste e é composto por rochas metassedimentares e metaígneas (Maya \& González, 1995). Este conjunto agrupa várias unidades de rochas metamórficas que incluem quartzo-sericita xistos, actinolita xistos, quartzitos e rochas metamórficas de baixo grau (Orrego et al., 1993). Rochas metamórficas com protólitos de afinidade oceânica, anfibolitos, xistos verdes, anfibólio xistos, granada anfibolitos também fazem parte deste complexo, descrito em detalhe por Restrepo \& Toussaint (1975), Toussaint \& Restrepo (1978), Mosquera (1978), Restrepo et al. (1978), González (1980), Grotjohann \& McCourt (1981), Esquivel et al. (1981), Murcia \& Cepeda (1991a; b) e Orrego \& Paris (1991). Também fazem parte do Complexo Arquia os xistos azuis e eclogitos da área de Barragán, (Orrego et al., 1980; McCourt \& Feininger, 1984).

Rochas vulcânicas oceânicas Mesozóicas: esta unidade é composta por basaltos e lavas andesíticas com doleritos, gabros e brechas vulcânicas subordinadas e com delgadas camadas de rochas vulcanoclásticas. Este conjunto apresenta um metamorfismo de baixo grau, notadamente na fácies zeólita, e em menor proporção na fácies prehnita-pumpellyita (Maya, 2001). 


\subsection{Geologia das Áreas de Estudo}

As rochas metamórficas de alta pressão e baixa temperatura (HP/LT) da Colômbia associam-se a gnaisses e xistos (Feininger, 1982). Na região de Jambaló, ocorrem três unidades geológicas principais (Figura 4.3): os Xistos Glaucofânicos de Jambaló, os Xistos Verdes de La Mina e o Anfibolito de San Antonio. A esse conjunto se associam rochas plutônicas, vulcânicas e vulcanoclásticas cretácicas e rochas sedimentares cretácicas e terciárias (Orrego et al., 1980). Os Xistos Glaucofânicos de Jambaló, os Xistos Verdes de La Mina e o Anfibolito de San Antonio, são três unidades que foram interpretadas por Orrego et al. (1980) como parte de uma seqüência ofiolítica e, ao correlacioná-las com rochas de alta pressão da Formação Raspas do Equador, Feininger (1982) propôs o seguinte modelo tectônico para a região de Jambaló: 1) Evento principal de subducção no noroeste da América do Sul, interrompido bruscamente no EoCretáceo, com formação das rochas de alta pressão, 2) Exumação dos xistos azuis a leste da Falha de Romeral, em uma faixa que pode-se estender desde o Complexo Raspas ao sul do Equador (Figura 4.3) até cerca $550 \mathrm{~km}$ a norte de Jambaló, onde as rochas cristalinas da Cordilheira Central são cobertas pelas rochas sedimentares terciárias e quaternárias no norte da Colômbia (Figura 4.3). Neste contexto, a Falha de Romeral marcaria a borda ativa entre o limite noroeste da placa Sul-Americana com a placa oceânica vinda de noroeste, pelo menos durante o início do Cretáceo.

As características mineralógicas destas rochas são apresentadas na Tabela 4.2.

Tabela 4.2. Mineralogia essencial, segundo Orrego et al. (1980), das rochas das unidades: Xistos Glaucofânicos de Jambaló (1, 2, 3, 4 e 5), Xistos Verdes de La Mina (6, 7 e 8) e Anfibolito de San Antonio (9 e 10). (1) Glaucofânio xisto, (2) clorita xisto, (3) anfibólio xisto, (4) micaxisto, (5) mármores, (6) metadiabásio e metabasalto, (7) metagabro, (8) metassedimentos, (9) metaígneas e (10) metapelitos. Na tabela: (ロ) são minerais essenciais e ( $\square$ ) acessórios

\begin{tabular}{|c|c|c|c|c|c|c|c|c|c|c|}
\hline \multirow[t]{2}{*}{ MINERAIS } & \multicolumn{10}{|c|}{ ROCHA } \\
\hline & 1 & 2 & 3 & 4 & 5 & 6 & 7 & 8 & 9 & 10 \\
\hline Glaucofânio & - & $\square$ & & & & & & & & \\
\hline Jadeíta & - & & & & & $\square$ & & & & \\
\hline Quartzo & - & - & ㅁ & ㅁ & - & - & & - & घ & ! \\
\hline Andesina & & & & & & & घ & & & \\
\hline Oligoclásio & 므 & - & 므 & 므 & 므 & & & & & \\
\hline Albita & & & & & & ! & & a & a & a \\
\hline Mica branca (fengita ?) & - & - & $\square$ & - & - & & & & & \\
\hline Calcita & - & $\square$ & - & & - & - & & & & \\
\hline Estilpnomelano & - & $\square$ & $\square$ & $\square$ & & & & & & \\
\hline Clorita & - & $\square$ & & $\square$ & 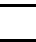 & - & ㅁ & - & & ! \\
\hline Aragonita & 므 & & 므 & & 므 & - & & & & \\
\hline Epidoto & $\bar{\square}$ & $\square$ & $\bar{\square}$ & & & & & " & - & \\
\hline Arfvedsonita (?) & - & $\square$ & - & & & & & & & \\
\hline Granada & - & & & & & & & & & \\
\hline Tremolita-actinolita & & $\square$ & 므 & & & ! & ! & & - & ! \\
\hline Titanita & ㅁ & $\square$ & $\square$ & $\square$ & & & & & & \\
\hline Grafita & 므 & $\square$ & & $\square$ & ㅁ & & & & & \\
\hline Apatita & $\square$ & $\square$ & & & $\square$ & & & & & \\
\hline Magnetita & $\square$ & & $\square$ & & $\square$ & & & & & \\
\hline Rutilo & $\square$ & $\square$ & & $\square$ & & & & & & \\
\hline Zircão & $\square$ & & & $\square$ & & & & & & \\
\hline Biotita & & & & & & & & 뜨 & - & \\
\hline Muscovita & & & & & & & & घ- & - & \\
\hline Material carbonoso & & & & & & & & $\square$ & & \\
\hline
\end{tabular}




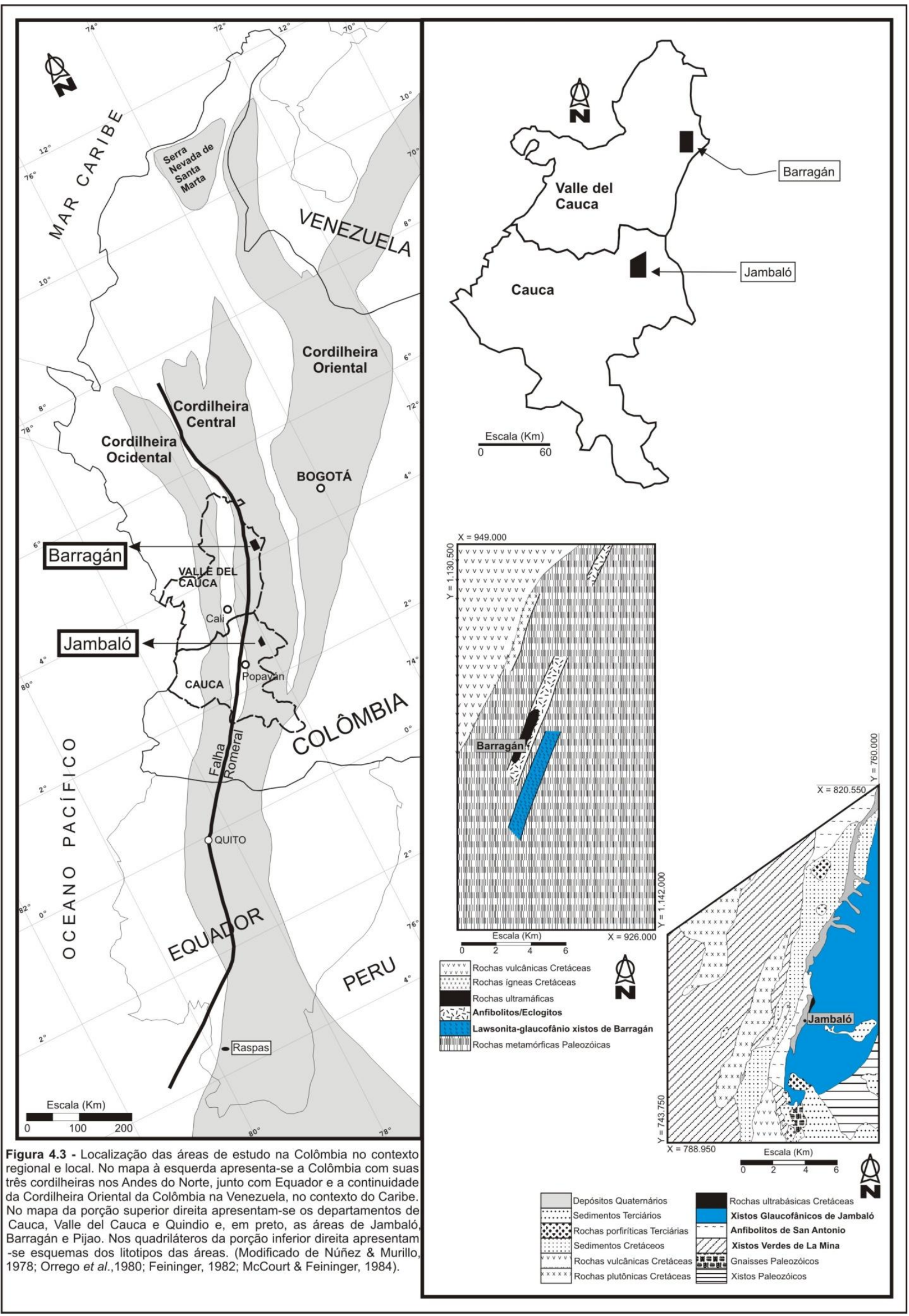


Os Lawsonita-Glaucofânio Xistos e Eclogitos de Barragán, juntamente com rochas ultramáficas intensamente serpentinizadas, constituem um cinturão descontínuo, fortemente cisalhado, inserido tectonicamente em xistos paleozóicos (McCourt \& Feininger, 1984). Os minerais que compõem estas rochas são apresentados na Tabela 4.3.

Tabela 4.3. Mineralogia essencial dos xistos glaucofânicos e eclogitos de Barragán (McCourt \& Feininger, 1984), onde (ロ) são os minerais principais.

\begin{tabular}{|c|c|c|}
\hline \multirow[b]{2}{*}{ MINERAIS } & \multicolumn{2}{|c|}{ ROCHA } \\
\hline & $\begin{array}{c}\text { Xistos } \\
\text { glaucofânicos } \\
\end{array}$ & Eclogitos \\
\hline Lawsonita & a & \\
\hline Glaucofânio & ! & \\
\hline Pumpellyita & - & \\
\hline Albita & ! & \\
\hline Sericita & - & \\
\hline Quartzo & ! & \\
\hline Onfacita & & - \\
\hline Epidoto & & I. \\
\hline Anfibólio & & - \\
\hline Clorita & & I. \\
\hline Plagioclásio (?) & & - \\
\hline
\end{tabular}

De fato, as rochas de Jambaló e Barragán, constituem, grosseiramente, um cinturão de xistos azuis e eclogitos na Cordilheira Central da Colômbia, que pode ser estendido até o Complexo Raspas, no Equador (McCourt \& Feininger, 1984). Desta forma, as rochas de alta pressão representariam remanescentes de uma zona de subducção mesozóica, com seus litotipos e vulcânicas incorporadas ao continente Sul-Americano no Cretáceo Inferior (Feininger, 1982; McCourt \& Feininger, 1984). 


\section{DESCRIÇÃO DOS PERFIS DA REGIÃO DE JAMBALÓ}

Os reconhecimentos de campo em Jambaló foram feitos nos Resguardos (áreas de reserva sob a jurisdição de autoridades indígenas) de Tacueyó, Toribío, San Francisco e Jambaló.

Os dados aqui apresentados foram obtidos a partir das descrições de afloramentos e de blocos rolados, que predominam na região. Dentre as estruturas tectônicas foram observadas e medidas somente foliações (regionais e miloníticas), geralmente de xistos de grã fina e cor cinzaesverdeada. O mapa esquemático da geologia da região de Jambaló está no Anexo I.

De norte a sul, a seguir apresenta-se a distribuição dos perfis feitos em cada um dos Resguardos:

\subsection{Resguardo de Tacueyó}

Nesta zona foram visitados os Córregos San Diego ou El Barrial e a mina La Manuela, no setor de La Calera. Ao oeste do povoado de Tacueyó, foi visitada uma pedreira abandonada de rochas ígneas félsicas conhecida na região como "Balastrera La Luz".

\subsubsection{Balastrera La Luz}

Este afloramento constitui um morro isolado onde afloram corpos maiores de rochas ígneas félsicas, dominantemente quartzo-monzonitos, fortemente fraturadas e parcialmente intemperizadas e hidrotermalizadas (Foto 5.1). Entretanto não foi possível a observação dos contatos com outros litotipos descritos na região.

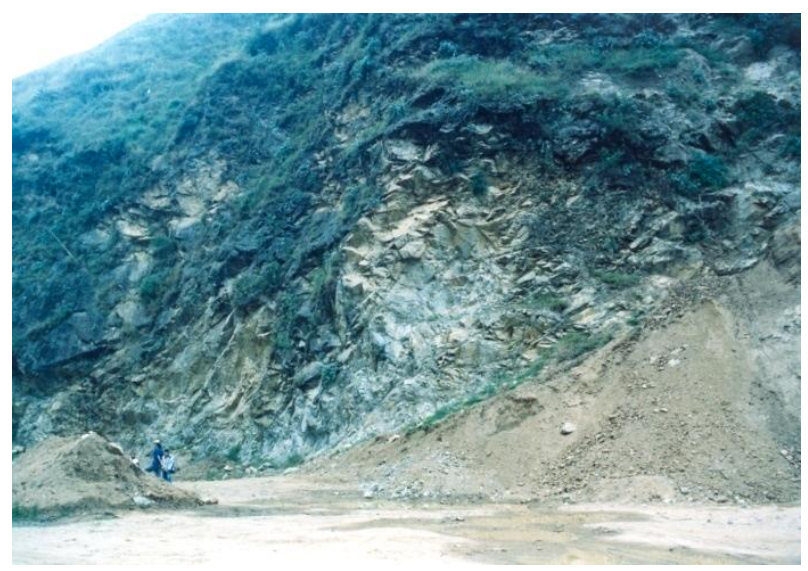

Foto 5.1. Afloramento de rochas quartzo-monzonitos com forte fraturamento, localizado em Balastrera La Luz, a oeste do povoado de Tacueyó, onde existiu uma pedreira de brita.

\subsubsection{Córrego San Diego ou El Barrial}

Neste córrego as rochas são bem foliadas, têm cor esverdeada e são representadas principalmente por clorita xistos feldspáticos finos, eventualmente com anfibólio subordinado.

Os xistos azuis foram verificados apenas como blocos rolados (Foto 5.2) em alguns trechos do perfil, o que sugere tratar-se de intercalações nos clorita xistos de no máximo poucas dezenas de metros de espessura. 
Os xistos azuis são rochas foliadas de cor cinza-escuro, compostas por anfibólio cinzaazulado e eventuais grãos de granada disseminada. Alguns cristais de pirita acompanham a mineralogia da rocha. Em dois blocos foram amostrados xistos quartzo-feldspáticos com anfibólios de cor verde-oliva, bem como blocos de filitos grafitosos cinza-escuros a negros, muito finos.

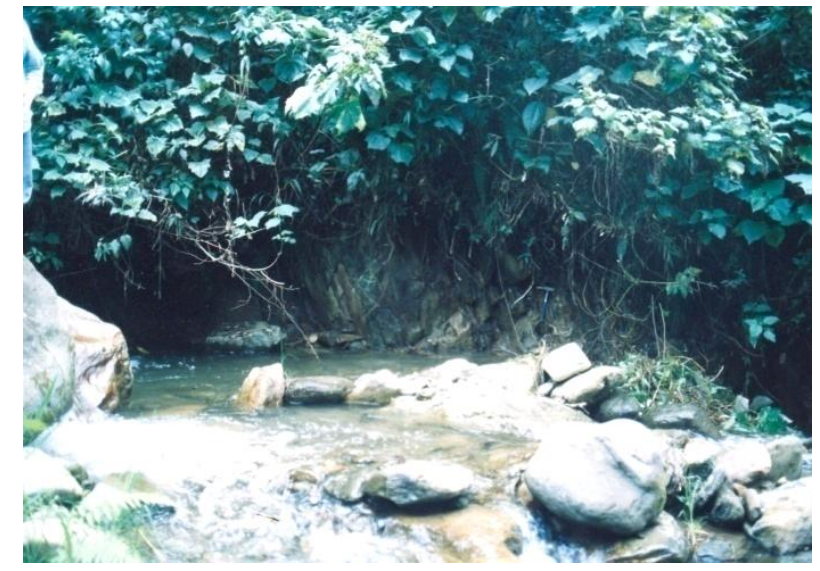

Foto 5.2. Aspecto típico dos afloramentos de xistos azuis (blocos) e dos clorita xistos (parede do afloramento) no Córrego San Diego ou El Barrial.

Todos litotipos deste perfil estão variavelmente milonitizados, apresentando uma marcada foliação e estiramento de grãos de quartzo, principalmente nos clorita xistos. A foliação neste afloramento está orientada segundo $\mathrm{N} 8^{\circ} \mathrm{W}$ e os mergulhos estão fortemente para SW. Em nenhum dos afloramentos foi possível a identificação de indicadores cinemáticos nos milonitos.

\subsubsection{Mina La Manuela setor La Calera}

Nesta região predominam mármores brancos, mas também estão presentes corpos com tons de cinza, verde ou rosa. Pequenos blocos rolados de rochas compostas por epidoto e anfibólio em arranjos radiados, mas concentrados nos planos de foliação foram também encontrados. O restante da mineralogia não pôde ser determinado a olho nú, ou mesmo com auxílio de uma lupa de mão. Uma destas amostras foi identificada como xisto azul ao microscópio. Um evento magmático básico posterior ao metamorfismo regional e tardio ao cisalhamento foi verificado pela presença de um dique de diabásio de granulação grossa, fracamente foliado, encaixado nos mármores.

Tal qual no perfil anterior, a foliação que afeta as rochas é quase sempre milonítica, com intensa transposição tectônica. O cisalhamento tem orientação $N 67^{\circ} \mathrm{E}$, com mergulho intermediário para NW.

\subsection{Resguardo de Toribío}

Nesta área, foi levantado apenas o Córrego Vichiquí. 


\subsubsection{Córrego Vichiquí}

As rochas que ali ocorrem são clorita xistos bem foliados, de cor verde e abundantes cristais de pirita disseminados. Não raramente as rochas se encontram fortemente fraturadas e, às vezes, muito intemperizadas. Em todo perfil levantado (aproximadamente $2 \mathrm{~km}$ ) as rochas não apresentam muita variação composicional ou estrutural, tanto nos blocos rolados como no único afloramento encontrado.

A estrutura mais evidente é também uma foliação milonítica intensa, orientada segundo N38르, com mergulhos fortes no sentido NW.

\subsection{Resguardo de San Francisco}

Por ser essa a zona mais central da área de ocorrência dos xistos azuis, a maioria das drenagens foi levantada, incluindo os córregos Elassio, Río Chiquito, Flayó, La Primicia e Quinamayó.

\subsubsection{Córrego Elassio}

Os afloramentos e blocos indicam que todas as rochas se encontram intensamente milonitizadas e fortemente foliadas. As rochas são cinza, com tons escuros ou esverdeados. As mais escuras são usualmente xistos muito grafitosos e quartzosos e as demais, são ricas em anfibólio. O intemperismo neste perfil é muito intenso, impossibilitando uma classificação mais precisa de todos litotipos em campo.

Por correlação com os dados obtidos no Córrego Río Chiquito, a orientação da foliação milonítica é predominantemente $\mathrm{N} 12^{\circ} \mathrm{E}$, com inclinações fortes para SE.

\subsubsection{Córrego Río Chiquito}

Neste córrego afloram quase que exclusivamente como blocos rolados, xistos grafitosos cinza-escuros de grã fina. Entretanto, alguns blocos têm tons azulados e prateados, com mica branca abundante e sua mineralogia permite identificá-los como xistos azuis.

Em um único afloramento in situ, pôde-se verificar que a foliação milonítica tem direção geral de $\mathrm{N} 12^{\circ} \mathrm{E}$, com mergulho forte para SE.

\subsubsection{Córrego Flayó}

As rochas são cinza-escuras ou esverdeadas, têm sempre granulação fina e apresentam uma marcada foliação milonítica. As rochas cinza-escuras têm maiores conteúdos de grafita, chegando mesmo a formar grafita xistos, e as esverdeadas são compostas por micas brancas e clorita, o que permite classificá-las como micaxistos com clorita milonitizados.

Também estão ocasionalmente presentes metavulcânicas ricas em epidoto, provavelmente 
derivadas de rochas básicas intensamente hidrotermalizadas.

Os litotipos em um dos afloramentos deste córrego são separados por um pequeno corpo de metaconglomerado fortemente intemperizado (Foto 5.3), indicando a existência de um nível erosivo na seqüência vulcanossedimentar.

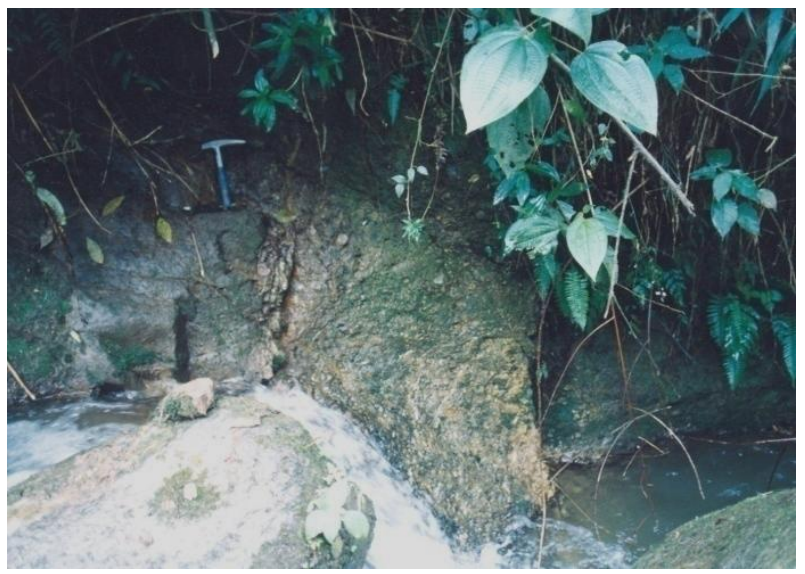

Foto 5.3. Aspecto de um pequeno corpo de metaconglomerado que separa os afloramentos de metapelitos das metavulcânicas.

Neste córrego, assim como nos Córregos La Primicia e Quinamayó do resguardo de San Francisco e no Córrego El Asio do Resguardo de Jambaló não foi possível medir a atitude da foliação milonítica pela completa ausência de afloramentos in situ.

\subsubsection{Córrego La Primicia}

Nesse córrego predominam xistos grafitosos finos, miloníticos, alguns com grafita abundante e outros com ricos em muscovita e quartzo. De modo geral as rochas são relativamente homogêneas, apresentando apenas variações na granulação.

\subsubsection{Córrego Quinamayó}

Neste córrego ocorrem xistos grafitosos finos, miloníticos semelhantes aos que afloram no Córrego La Primicia. Estão intensamente orientados por uma forte foliação milonítica e possuem cor cinza-esverdeado a cinza-escuro, sendo os primeiros ricos em anfibólio e clorita, e os demais ricos em grafita.

\subsection{Resguardo de Jambaló}

Neste resguardo foram levantados perfis nos córregos El Asio, Muñoz, Cansa Bobos e Calambaz e na estrada Jambaló-San Francisco. Também foi estudada uma lavra de rochas ultramáficas situada nas proximidades da cidade de Jambaló. 


\subsubsection{Córrego El Asio}

Predominam neste córrego xistos verdes miloníticos de cor verde-escura e grã fina, quase sempre intensamente intemperizadas para materiais argilosos.

Devido à ausência de afloramentos, não foi possível determinar-se a orientação das estruturas geológicas.

\subsubsection{Córrego Muñoz}

Neste córrego afloram rochas ultramáficas quase que totalmente serpentinizadas, cinzaescuras a pretas, de grã fina e sem uma foliação evidente. Além disso, encontram-se xistos verdes bem foliados de grã fina e xistos azuis com anfibólio azul, quartzo e mica branca.

Nesta parte da área as estruturas miloníticas estão inclinadas moderadamente no sentido NW e orientadas segundo $\mathrm{N} 30^{\circ} \mathrm{W}$.

\subsubsection{Córrego Cansa Bobos}

Predomina neste córrego xistos verdes pouco intemperizados, intensamente milonitizados e com granulação média, permitindo a identificação de anfibólio predominante e plagioclásio em menor proporção (Foto 5.4). Também ocorre um corpo de rochas ultramáficas fortemente serpentinizadas.

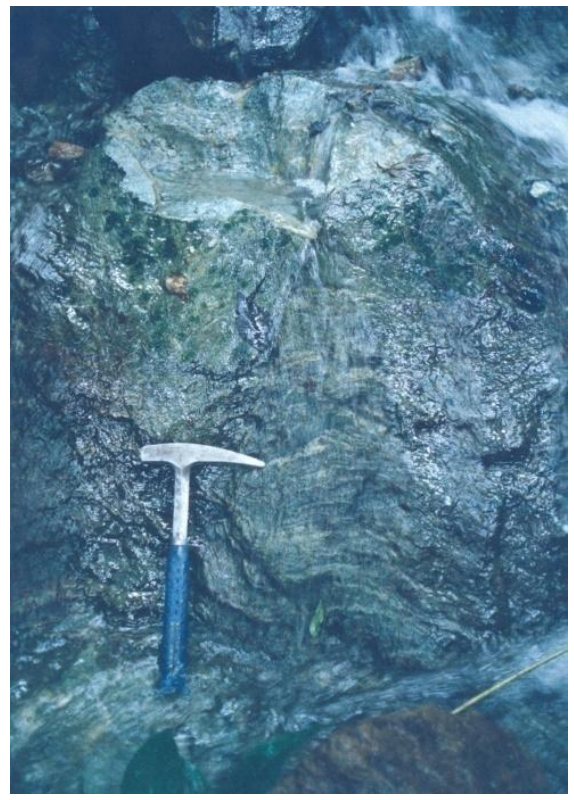

Foto 5.4. Afloramento de xistos verdes no córrego Cansa Bobos, intensamente foliados e levemente crenulados. Os leitos mais claros são mais ricos em minerais do grupo do epidoto e os mais escuros em anfibólios.

Neste córrego não foi possível medir a atitude da foliação, pois eles encontram-se muito dobrados e, usualmente, cobertos por água. 


\subsubsection{Córrego Calambaz}

Neste córrego predominam xistos azuis com uma forte foliação milonítica, compostos principalmente por anfibólio e micas e, em alguns afloramentos, estão parcialmente intemperizados. Também se ocorrem xistos verdes de cores claras intensamente milonitizados, compostos principalmente por anfibólio, clorita, micas brancas e quartzo (Foto 5.5).

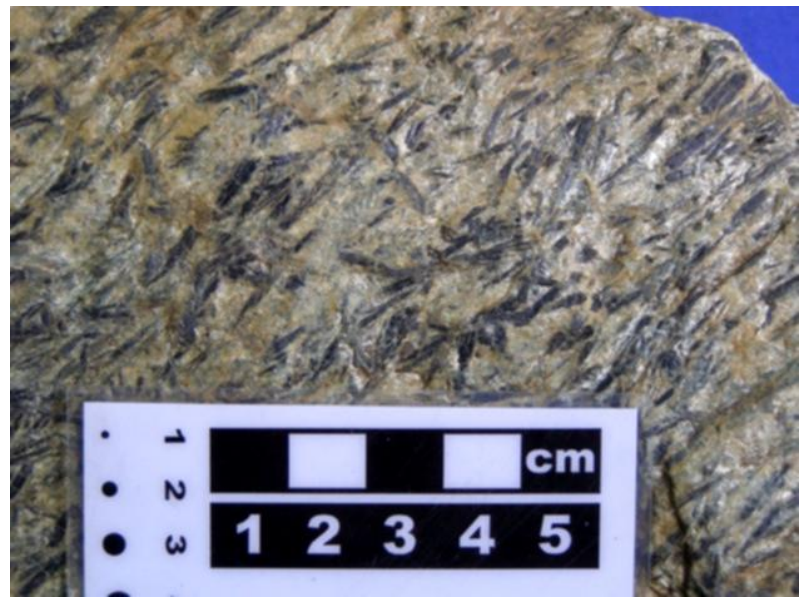

Foto 5.5. Mica-glaucofânio xisto, com cristais prismáticos de glaucofânio (cinza-azulados) orientados na foliação e tendendo a formar arranjos radiados ou em leque, indicativos de cristalização sin- a tardicinemática em relação ao desenvolvimento da foliação milonítica.

A estrutura mais evidente é também uma foliação milonítica intensa, a qual esta orientada segundo $\mathrm{N} 26^{\circ} \mathrm{E}$, com mergulhos moderados no sentido NW.

\subsubsection{Estrada Jambaló - San Francisco}

$\mathrm{Na}$ localidade do sitio La Balastrera afloram rochas ultramáficas cinza-escuras (Foto 5.6) intensamente fraturadas e fortemente serpentinizadas, especialmente em zonas fraturadas. Nesta estrada foi visitado unicamente este afloramento, pois há uma espessa cobertura vegetal assim como abundantes deslizamentos que impedem o acesso a outras ocorrências deste material.

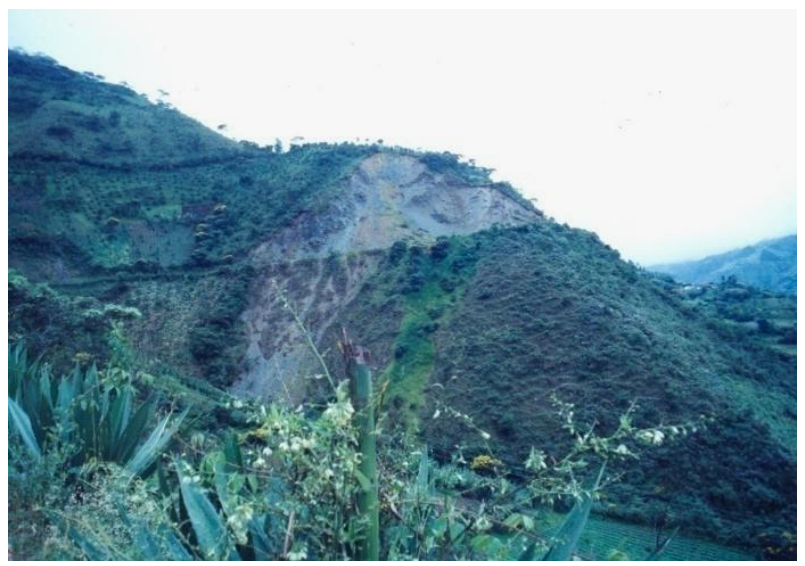

Foto 5.6. Vista geral do afloramento de rochas metaultramáficas intensamente serpentinazadas. $O$ afloramento (131), localizado na porção central da foto, apresenta-se com uma cor esverdeada, produto da intensa serpentinização da rocha ultramáfica. 


\section{PETROGRAFIA MICROSCÓPICA}

Além dos típicos xistos azuis, ocorrem na área de Jambaló outras rochas com restos de glaucofânio, mas as descrições não serão feitas em função da presença de anfibólios sódicos, sendo então feita pela classificação mineralógica-estrutural dos litotipos.

A petrografia microscópica das rochas da região de Jambaló é sumarizada a seguir:

\subsection{Mica-glaucofânio xistos e glaucofânio micaxistos}

Estes tipos de rochas são encontrados nos Córregos Calambaz e Muñoz, no Resguardo de Jambaló, e no Córrego San Diego ou El Barrial e na área de La Calera, no Resguardo de Tacueyó.

Muito embora não tenham sido encontradas rochas na fácies xisto azul em outros córregos da área, a associação litotípica permite inferir que os xistos azuis podem ter estado presentes em outros locais sob a forma de lentes preservadas pelo retrometamorfismo na fácies xisto verde, e sua ocorrência principalmente como blocos rolados deve-se à erosão dessas rochas.

Os principais componentes destas rochas são glaucofânio (30-50\%), mica branca (10-36\%), quartzo (5-12\%), epidoto e/ou clinozoisita (acessório a 30\%), clorita (acessório a 12\%) e carbonato (acessório a 5\%). O glaucofânio e a mica apresentam-se em quantidades variáveis, nas quais em algumas amostras há predomínio de glaucofânio sobre a mica e em outras ocorre o inverso. Somente na amostra 123A, o epidoto e/ou clinozoisita predomina sobre a mica, mas não sobre o glaucofânio. Como minerais acessórios (até 5\%) ocorrem plagioclásio, opacos (possivelmente pirita e ilmenita), titanita, zircão, granada e, eventualmente, rutilo, apatita e estilpnomelano.

Embora o glaucofânio na sua forma pura não apresente pleocroismo, nas descrições que se seguem é utilizado esse nome para facilitar a leitura. Assim, pleocroismo descritos nos anfibólios sódicos, que é devido ao conteúdo de Fe, indicam que o anfibólio pertence à serie glaucofânio-riebeckita.

O glaucofânio apresenta fórmula pleocróica com $X=$ incolor, $Y=$ lilás e $Z=$ azul-claro e os cristais têm tamanho variando entre 0,25 e 6,6 mm. A maioria dos cristais mais finos são subidioblásticos e os mais grossos tendem a ser xenoblásticos. Em algumas amostras que apresentam cristais prismáticos radiados, observam-se subidioblásticos e, eventualmente, idioblásticos. Há um claro zonamento óptico no anfibólio de quase todas as amostras, com núcleos mais intensamente pleocróicos que as bordas (Foto 6.1). Os núcleos mais pleocróicos contêm maior quantidade de inclusões de quartzo, opacos e, eventualmente, titanita e mica branca (Foto 6.1). Na amostra 129A, o zonamento do anfibólio é o inverso do anteriormente descrito, sendo os núcleos menos pleocróicos que as bordas (Foto 6.2). Nesse caso os núcleos 

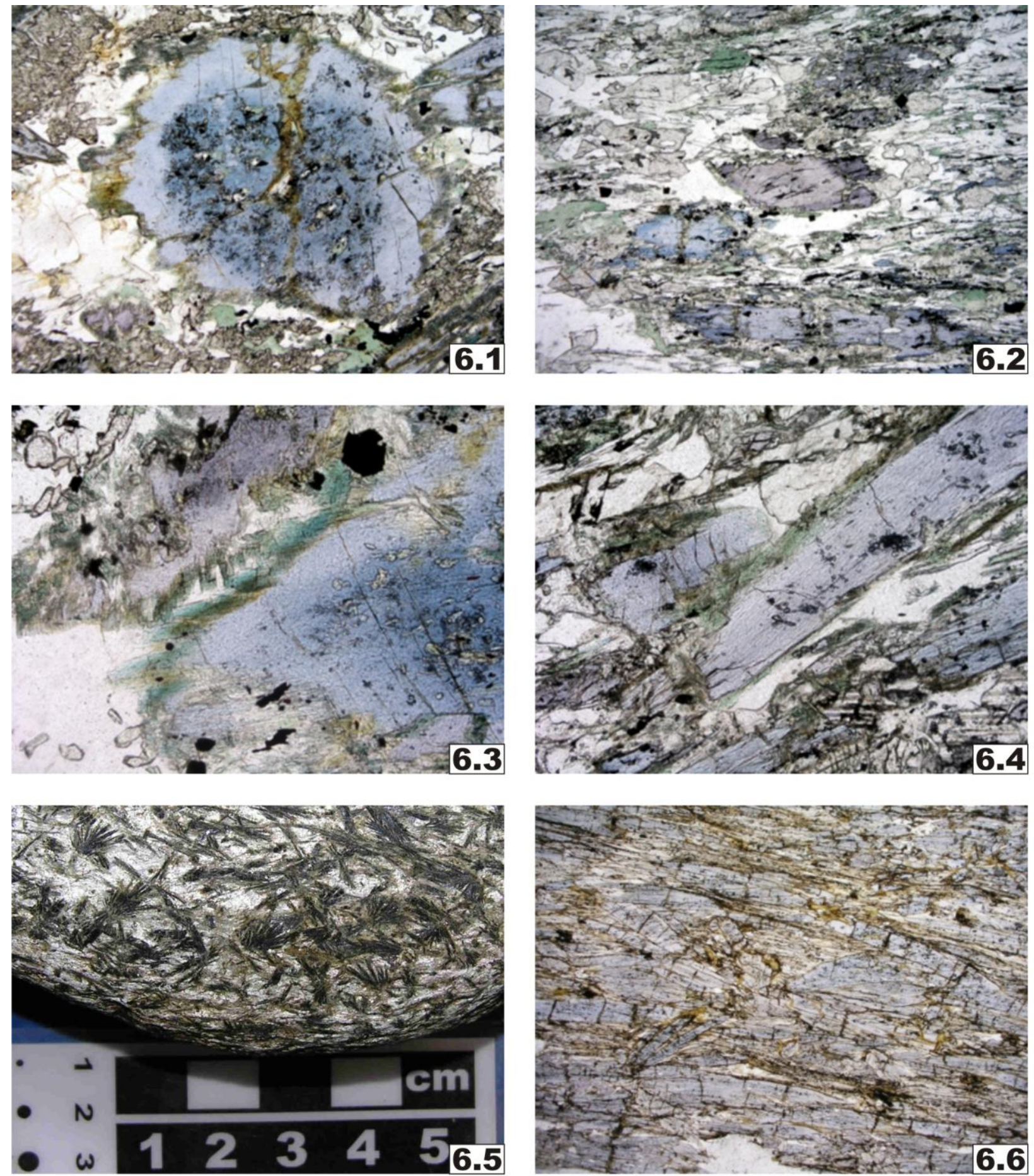

Foto 6.1. Zonamento de glaucofânio com núcleo mais intensamente pleocróico que a borda. Lado maior da foto $3,20 \mathrm{~mm}$.

Foto 6.2. Zonamento de glaucofânio com núcleo menos pleocróico que a borda. Lado maior da foto 3,20 mm.

Foto 6.3. Borda de substituição por um outro anfibólio (possível actinolita). Lado maior da foto 1,30 mm.

Foto 6.4. Substituição de glaucofânio por clorita nas bordas. Lado maior da foto $1,30 \mathrm{~mm}$.

Foto 6.5. Crescimento radiado de glaucofânio na escala macroscópica.

Foto 6.6. Crescimento radiado de glaucofânio na escala microscópica. Lado maior da foto 10,20 mm.

Todas as fotos microscópicas obtidas com polarizadores paralelos. 
também possuem uma maior quantidade de inclusões orientadas de quartzo e opacos, as quais definem uma foliação anterior. As bordas são quase que totalmente límpidas, sugerindo uma maior temperatura de cristalização, e em quase todos os cristais as bordas estão parcialmente substituídas por anfibólio verde-azulado (Foto 6.3). Esse anfibólio tem fórmula pleocróica $X=$ verde-oliva, $\mathrm{Y}=$ amarelo-claro e $\mathrm{Z}=$ verde-oliva claro, o que sugere ser actinolita. Em alguns casos observa-se substituição do anfibólio por clorita nos planos de clivagem, em fraturas e nas bordas (Foto 6.4). Os cristais apresentam inclusões de epidoto e/ou clinozoisita, opaco, zircão e, raras vezes, rutilo. A orientação do glaucofânio define uma foliação bem marcada e penetrativa que corresponde à foliação milonítica $\left(S_{n+1}=S_{m}\right)$ e, localmente, pode-se ainda observar relíquias da foliação $S_{n}$. Arranjos radiados de agregados podem ser observados a escala macroscópica (Foto 6.5) e microscópica (Foto 6.6). Em alguns cristais ocorrem sombras de pressão simétricas e assimétricas, causadas pelo cisalhamento, ou os cristais mostram-se dobrados, definindo arcos poligonais.

A mica branca forma cristais variando de 0,05 a $0,30 \mathrm{~mm}$ de comprimento, geralmente subidioblásticos e orientados na foliação $S_{n+1}$, que tem formas anastomosadas (Foto 6.7). Muitos leitos quartzosos são enriquecidos em mica e nas amostras com matriz rica em epidoto e/ou clinozoisita, os cristais de mica estão isolados. A associação da mica com o quartzo pode representar, em alguns casos, vênulas deformadas. Eventualmente ocorrem também em sombras de pressão de cristais de glaucofânio, juntamente com quartzo mais grosso, e em alguns grãos estão presentes inclusões de glaucofânio. Ópticamente esta mica parece ser representada por fengita e/ou muscovita.

O quartzo apresenta-se como cristais com granulação variando de 0,05 a $0,65 \mathrm{~mm}$, geralmente disseminados na lâmina e, em algumas porções, formando delgadas lâminas. Também ocorre incluso em carbonato, clorita e mica branca, ou em glaucofânio em sombras de pressão, como na lâmina 129A. Geralmente constitui cristais xenoblásticos com extinção ondulante, mas em algumas porções nota-se desenvolvimento de textura poligonal e, às vezes, contatos tríplices a $120^{\circ}$ (Foto 6.8).

O epidoto e/ou clinozoisita apresentam-se como cristais disseminados na rocha que variam de 0,05 a 0,20 mm de comprimento. São na sua maioria xenoblásticos, mas em algumas lâminas podem ocorrer como cristais subidioblásticos e, mais raramente, idoblásticos. Apresentam-se quase sempre orientados segundo a foliação $S_{n+1}$ ou compõem a matriz de algumas rochas, possivelmente com forte hidrotermalismo (Foto 6.9).

A clorita constitui cristais disseminados na lâmina, geralmente xenoblásticos e subidioblásticos, ou são produto da substituição parcial ou total de outros minerais, notadamente do glaucofânio (Foto 6.10), onde se concentra nas bordas, planos de clivagem e fraturas. Quando forma pseudomorfos, os cristais variam de 0,1 a $0,9 \mathrm{~mm}$ e os grãos orientam-se preferencialmente na $S_{n+1}$, mas na lâmina 124J encontram-se rosetas deste mineral, indicando cristalização em 
regime estático também.
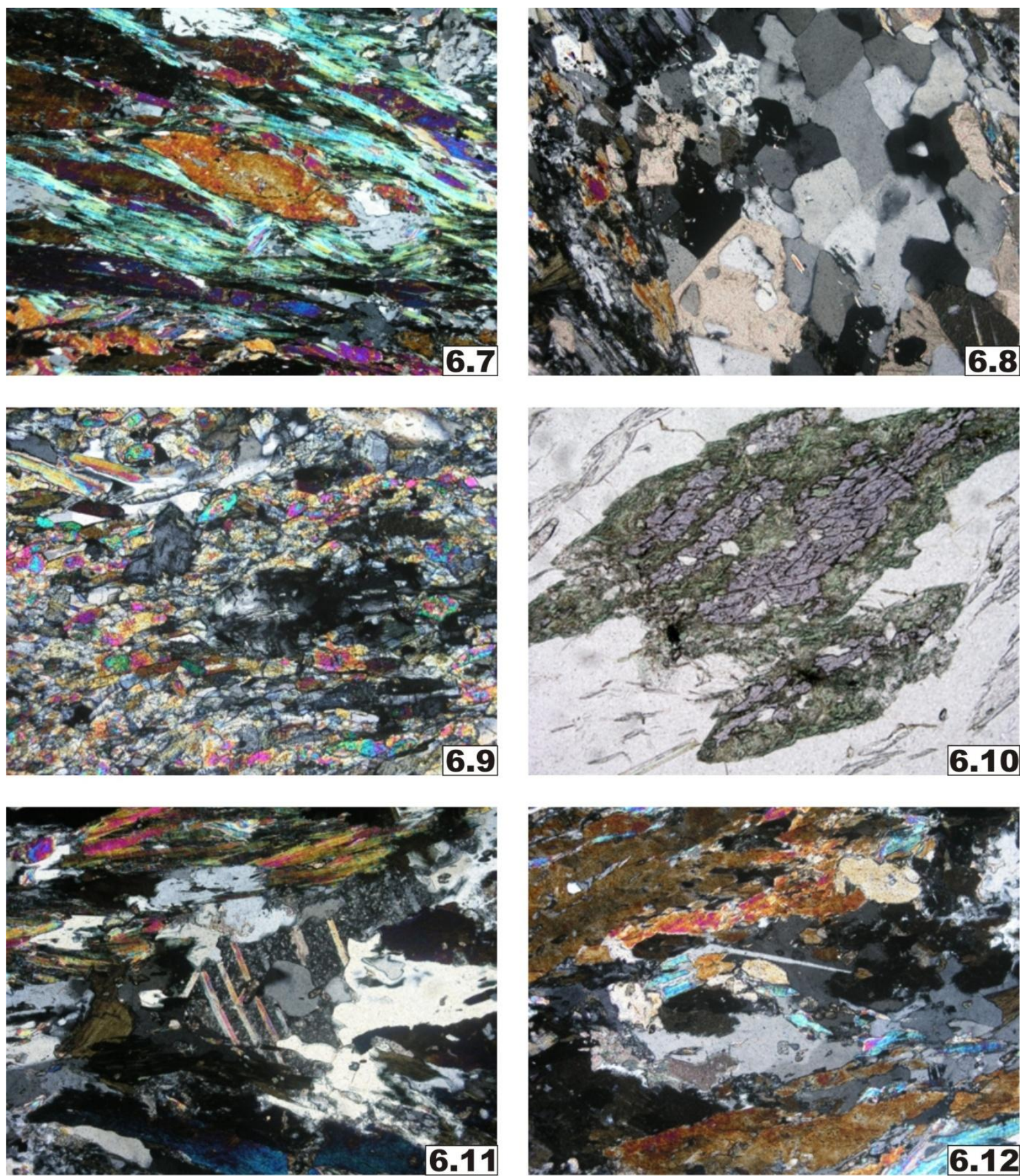

Foto 6.7. Foliação definida pelas micas anastomosadas. Lado maior da foto $3,20 \mathrm{~mm}$.

Foto 6.8. Desenvolvimento de textura poligonal em quartzo e contatos triplos a $\sim 120^{\circ}$. Lado maior da foto $1,30 \mathrm{~mm}$.

Foto 6.9. Epidoto-clinozoisita na foliação e como matriz da rocha. Lado maior da foto $1,30 \mathrm{~mm}$.

Foto 6.10. Clorita como substituição parcial de glaucofânio. Lado maior da foto $1,30 \mathrm{~mm}$.

Foto 6.11. Carbonato com lamelas de deformação. Lado maior da foto $1,30 \mathrm{~mm}$.

Foto 6.12. Plagioclásio com geminação de tipo albita. Lado maior da foto $1,30 \mathrm{~mm}$.

Foto 6.10 obtida com polarizadores paralelos e $6.7,6.8,6.9,6.11$ e 6.12 com polarizadores cruzados. 
O carbonato se apresenta como cristais que variam entre 0,2 e 0,6 mm e suas formas xenoblásticas sugerem preenchimento de cavidades, mas, em alguns grãos de glaucofânio ocorrem como inclusões. Não raramente apresentam lamelas de deformação (Foto 6.11) e, em função de seu caráter uniaxial negativo, é possível que correspondam predominantemente à calcita, mas não se descarta a possibilidade da presença de aragonita, pois alguns grãos são biaxiais. Entretanto a granulação muito fina não permite a determinação de seu sinal óptico para uma identificação segura.

Os grãos de plagioclásio em geral não ultrapassam $0,3 \mathrm{~mm}$ de comprimento, são subidioblásticos e xenoblásticos, normalmente estão associados com quartzo e sempre acompanham a foliação milonítica. Observa-se geminação de tipo albita (Foto 6.12) e albitacarlsbad, sendo sua composição fundamentalmente albita $\left(A n_{2-5}\right)$, muito embora alguns grãos apresentem composição que alcança oligoclásio $\left(\mathrm{An}_{16}\right)$.

Os minerais opacos estão disseminados por toda rocha, variando de 0,01 a 1,50 mm de diâmetro, mas podem formar, localmente, porfiroblastos. A maioria constitui cristais xenoblásticos e, subordinadamente, subidioblásticos e idioblásticos. Alguns cristais idioblásticos apresentam secções quadradas e losangulares, que sugere tratar-se de pirita e, possivelmente, magnetita (Foto 6.13). Também se encontram acumulações que formam delgadas faixas que acompanham a foliação $S_{n+1}$ e alguns grãos mais grossos apresentam sombras de pressão assimétricas, com quartzo, calcita, clorita e mica. Na amostra 123A, podem apresentar substituição por rutilo nas bordas e este, possivelmente, por leucoxênio, razão pela qual é possível que parte dos opacos presentes na rocha sejam de ilmenita ou titano-magnetita.

A titanita apresenta-se como cristais subidioblásticos e, em menor proporção, idioblásticos, com dimensões variando de 0,025 a 0,075 mm. Constituem agregados ou "fitas" que seguem a foliação. Às vezes titanita ocorre inclusa no glaucofânio, se associando preferencialmente aos planos da clivagem.

O rutilo e o zircão ocorrem como pequenos cristais disseminados pela lâmina, de máximo $0,05 \mathrm{~mm}$ de comprimento. São na sua maioria prismas alongados idioblásticos e, por vezes, ocorrem inclusos em glaucofânio.

A granada ocorre apenas nas amostras 124J e 121B, nas quais a granulação varia, respectivamente, de 0,2 a $0,4 \mathrm{~mm}$ e de 1,6 a 2,6 mm. São cristais, na sua maioria, subidioblásticos, por vezes com bordas muito bem definidas (Foto 6.14), mas quando em contato com glaucofânio, apresentam uma pequena borda substituída por clorita.

A apatita foi encontrada apenas esporadicamente nas amostras 123A e 121B. Na amostra $123 \mathrm{~A}$ os grãos têm $0,35 \mathrm{~mm}$ de comprimento e são xenoblásticos e na 121B são xenoblásticos e estão disseminados ou podem estar concentrados em porções enriquecidas em quartzo. 

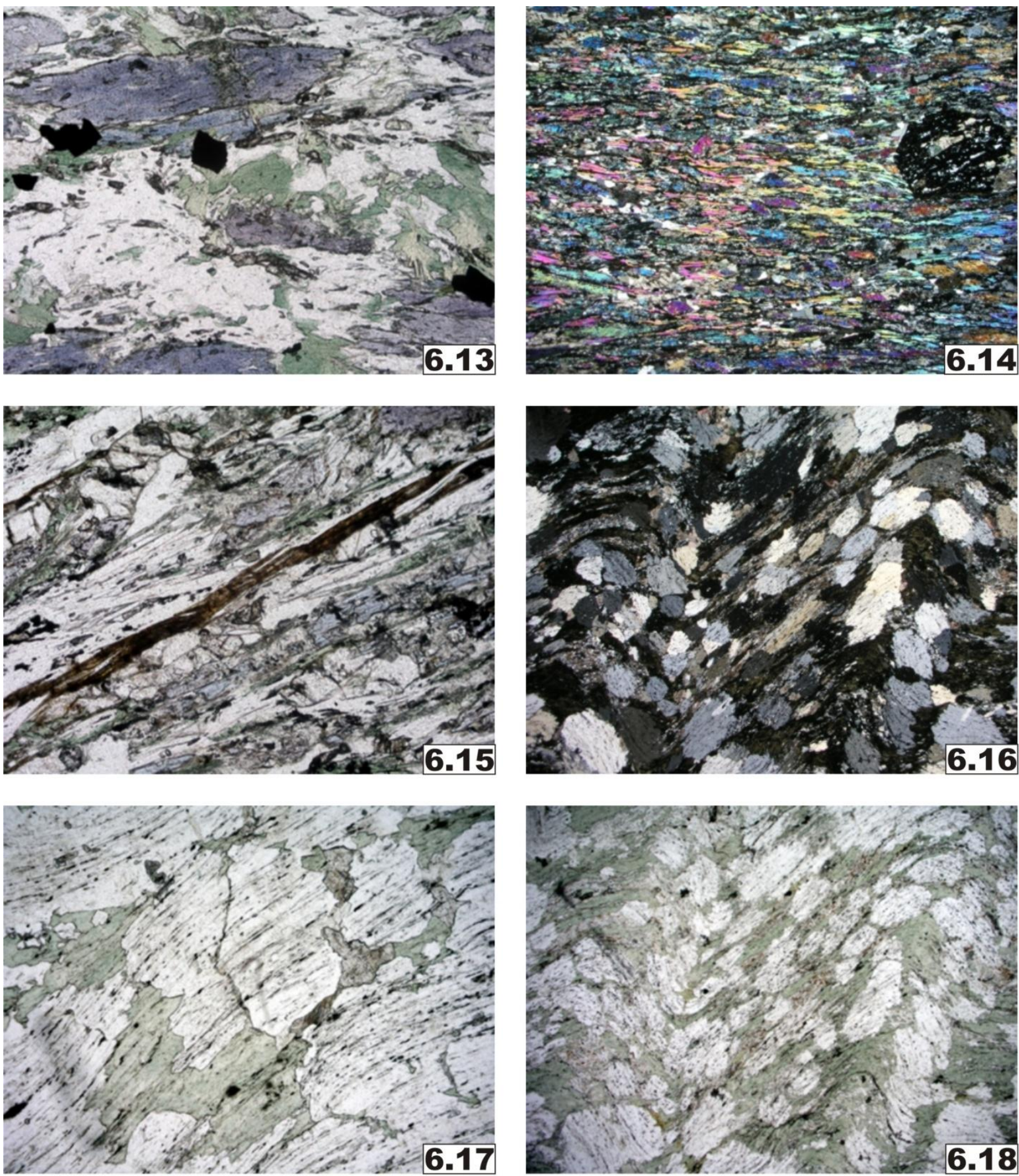

Foto 6.13. Minerais opacos subidioblásticos disseminados. Lado maior da foto $1,30 \mathrm{~mm}$.

Foto 6.14. Granada poiquiloblástica com bordas bem definidas. Lado maior da foto 10,20 mm.

Foto 6.15. Estilpnomelano alongado seguindo a foliação principal da rocha. Lado maior da foto $1,30 \mathrm{~mm}$.

Foto 6.16. Albita em desequilíbrio com clorita. Lado maior da foto $10,20 \mathrm{~mm}$.

Foto 6.17. Padrão de inclusões em albita e clorita. Lado maior da foto 3,20 mm.

Foto 6.18. Orientação das inclusões na foliação e no dobramento. Lado maior da foto 10,20 mm.

Fotos $6.13,6.15,6.17$ e 6.18 obtidas com polarizadores paralelos e 6.14 e 6.16 com polarizadores cruzados. 
Em algumas amostras, como na 121B, ocorre estilpnomelano em conteúdo máximo de $3 \%$ em volume. Geralmente se apresenta como cristais parcialmente substituídos por clorita alongados na foliação $S_{n+1}$ (Foto 6.15). Em alguns dos casos foi observado também nas bordas de cristais de glaucofânio.

Texturalmente as rochas apresentam-se lepido-nematoblásticas ou nematolepidoblásticas, dependendo da proporção de micas ou anfibólios. Textura porfiroblástica definida por anfibólios é comumente observada, sendo que alguns destes cristais são poiquiloblasticos, com inclusões de opacos, micas, carbonato, quartzo e, eventualmente, rutilo. Nas amostras com granada, o anfibólio apresenta corrosão com formas de golfo e, ocasionalmente, tem associadas sombras de pressão.

Estas rochas são classificadas como mica-glaucofânio xistos ou glaucofânio micaxistos, dependendo do predomínio de glaucofânio ou mica branca, muito embora, devido à intensa milonitização, todas poderiam ser classificadas como milonitos.

\subsection{Clorita-plagioclásio xistos}

Rochas como estas, que representam a transição da fácies xisto azul para a fácies xisto verde, foram encontradas em todos os perfis da área de estudo. São produto do metamorfismo retrógrado dos mica-glaucofânio e glaucofânio micaxistos e, tipicamente, têm relíquias de glaucofânio formando finos cristais parcialmente substituídos por anfibólio verde-claro, aparentemente uma actinolita ou clorita. Neste grupo de rochas, inserem-se também as rochas consideradas como transicionais entre as fácies xisto azul e xisto verde, que contêm glaucofânio em pequeno volume.

As rochas que compõem este grupo apresentam uma mineralogia semelhante àquelas descritas para os mica-glaucofânio xistos e glaucofânio micaxistos, diferenciando-se apenas pelos conteúdos de glaucofânio e de, possivelmente, actinolita. Nestas amostras o glaucofânio apresenta-se substituído de parcial a totalmente pelo anfibólio cálcico e/ou por clorita. Uma descrição mais detalhada deste litotipo é apresentada a seguir:

As amostras apresentam conteúdos de plagioclásio (44-68\%), clorita (8-35\%), quartzo (acessório a 17\%), mica branca (2-15\%), minerais opacos (acessório a 13\%), epidoto e/ou clinozoisita (1-8\%), zoisita (acessório a $8 \%$ ), biotita (acessório a 4\%), titanita (1-3\%), carbonato (acessório a 3\%), anfibólio (acessório a 3\%), apatita (acessório) e zircão (acessório).

Eventualmente observam-se restos de glaucofânio, como na lâmina 125M, e granada nas amostras 107B e 118A. Excepcionalmente, a amostra 124C apresenta conteúdo de anfibólio de $64 \%$ e plagioclásio de $30 \%$ em volume, sendo classificada como plagioclásio-anfibólio xisto.

O plagioclásio apresenta-se como grãos que variam de 0,2 a 2,8 mm, sempre xenoblásticos e com os contatos entre os grãos suturados ou lobados. As bordas da maioria dos 
grãos exibem texturas de desequilíbrio metamórfico, com clorita associada (Foto 6.16). Usualmente os grãos apresentam grande quantidade de inclusões, principalmente de minerais opacos (Foto 6.17) e, eventualmente, de quartzo e mica branca. Estas inclusões estão orientadas segundo a foliação $S_{n}$, assim como em estruturas dobradas que definem a foliação $S_{n+1}$ (Foto 6.18). Acompanhando as dobras, observam-se grãos de plagioclásio sem qualquer tipo de fratura, indicando que a deformação se deu pós- $S_{n}$ ou até mesmo $S_{n+1}$ e em temperatura compatível com as do regime dúctil (Foto 6.19), principalmente na lâmina 117E. Na lâmina 117A foi encontrada uma inclusão de zoisita em plagioclásio. Ocasionalmente o plagioclásio apresenta geminação polissintética e, de modo geral, arranja-se em textura granoblástica e está concentrado em leitos orientados paralelamente à foliação $S_{n+1}$ (Foto 6.20). O plagioclásio foi classificado como albita por difração de raios $X$, embora este não seja o método mais apropriado para classificar este mineral.

A clorita ocorre intersticialmente aos demais minerais (Foto 6.17) e, localmente, concentra-se em leitos concordantes à foliação milonítica. Nessas porções definem uma incipiente textura lepidoblástica. As inclusões de opacos observados na clorita mostram continuidade com as do plagioclásio, indicando que este último tem sua formação após a cristalização da clorita. A clorita neste litotipo é principalmente produto de substituição do glaucofânio, mas também é observada como um produto de cristalização a partir, possivelmente, fluidos hidrotermais, gerados após ou durante a milonitização, como indicado pela presença de rosetas deste mineral.

O quartzo concentra-se em delgados leitos ou lente orientados paralelamente à foliação e formam grãos xenoblásticos com forte extinção ondulante (Foto 6.21). Também se apresenta incluso no plagioclásio.

A mica branca foi determinada com paragonita por difração de raios X. Encontra-se em muito pouca quantidade e, geralmente, constitui agregados de pequenos grãos, por vezes intercrescidos com clorita. Alguns grãos levemente dobrados podem ser subidioblásticos e podem acompanhar a foliação $S_{n+1}$ (Foto 6.22).

Os minerais opacos apresentam-se como grãos de no máximo 0,2 mm de diâmetro, sendo a maioria deles xenoblásticos e, eventualmente, subidioblásticos. Apresentam-se tanto disseminados como orientados segundo a foliação milonítica, sendo que esta última por vezes esta dobrada (Foto 6.23). Em algumas porções das lâminas definem bandas, ou ocorrem inclusos no plagioclásio e na clorita e, eventualmente, em carbonato.

O epidoto e/ou clinozoisita constituem grãos que variam de 0,03 a $0,70 \mathrm{~mm}$, a maioria deles xenoblásticos a subidioblásticos. Em muitas das amostras estes minerais encontram-se disseminados na rocha (Foto 6.24) e na lâmina 114 ocorrem também cristais prismáticos de clinozoisita dobrados.

A zoisita apresenta-se em quantidade muito reduzida e forma cristais idioblásticos a subidioblásticos que variam de 0,05 a 0,90 mm, quase sempre inclusos em plagioclásio (Foto $6.25)$. 

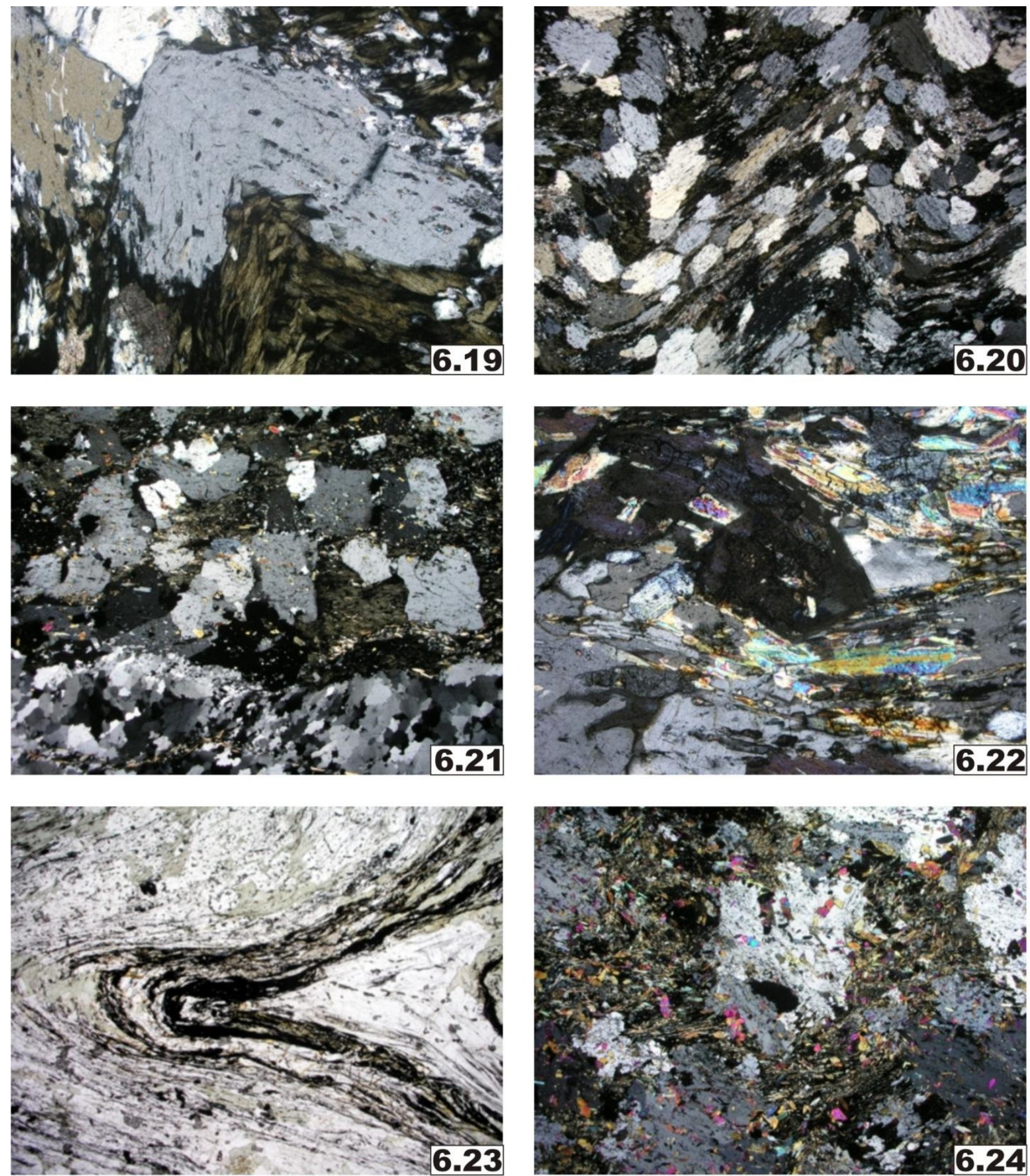

Foto 6.19. Dobramento de albita. Lado maior da foto $1,30 \mathrm{~mm}$.

Foto 6.20. Albita definindo a textura granoblástica e a foliação da rocha. Lado maior da foto $10,20 \mathrm{~mm}$.

Foto 6.21. Banda de quartzo com extinção ondulante. Lado maior da foto $10,20 \mathrm{~mm}$.

Foto 6.22. Cristais de mica acompanhando a foliação. Lado maior da foto $1,30 \mathrm{~mm}$.

Foto 6.23. Minerais opacos orientados segundo a foliação e o dobramento. Lado maior da foto $10,20 \mathrm{~mm}$.

Foto 6.24. Epidoto-clinozoisita disseminado na rocha. Lado maior da foto $10,20 \mathrm{~mm}$.

Foto $\mathbf{6 . 2 3}$ obtida com polarizadores paralelos e $\mathbf{6 . 1 9}, \mathbf{6 . 2 0}, \mathbf{6 . 2 1}, \mathbf{6 . 2 2}$ e $\mathbf{6 . 2 4}$ com polarizadores cruzados. 

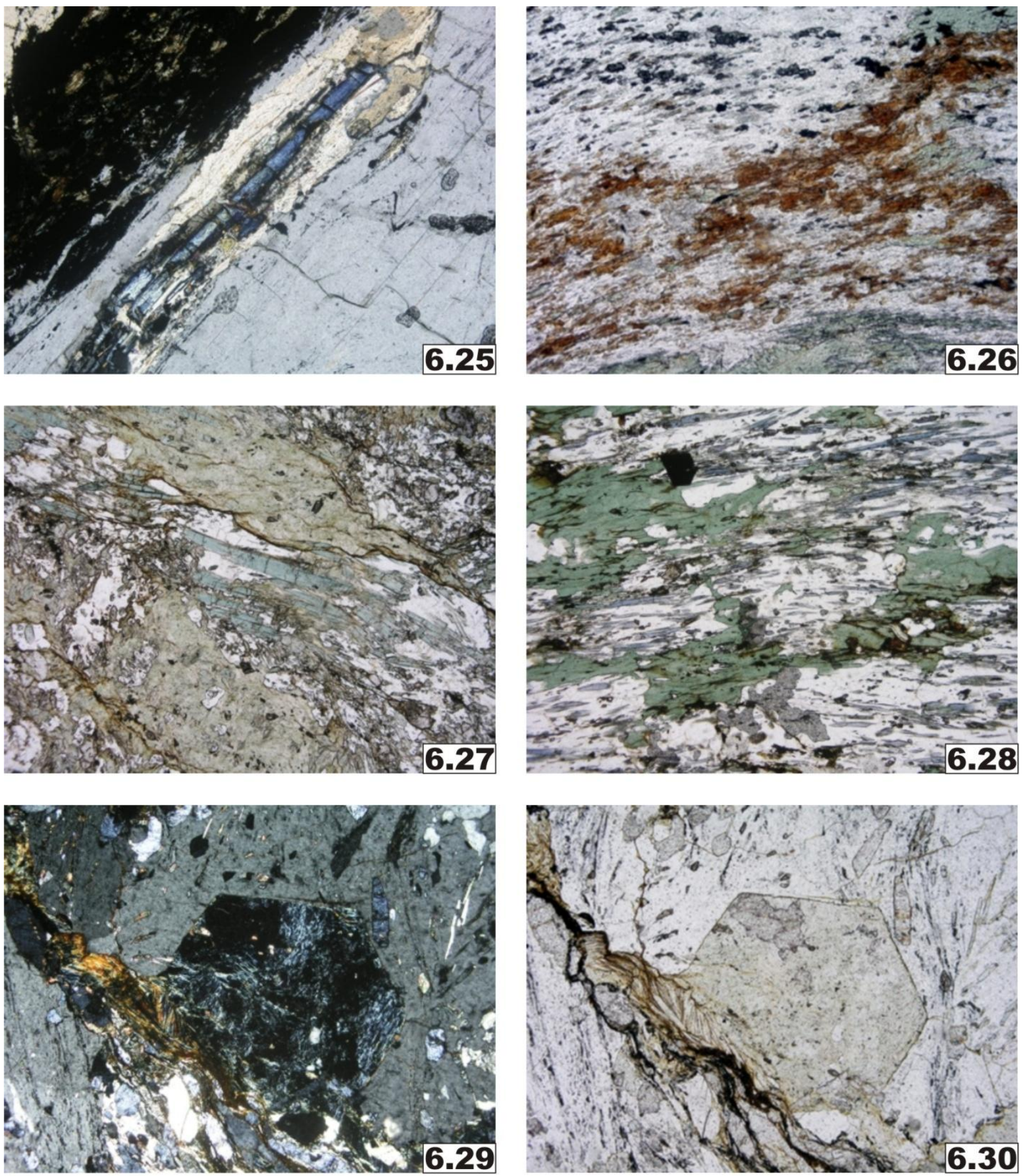

Foto 6.25. Inclusão de zoisita em albita. Lado maior da foto $1,30 \mathrm{~mm}$.

Foto 6.26. "Bandas" de biotita que acompanham a foliação. Lado maior da foto $1,30 \mathrm{~mm}$.

Foto 6.27. Cristais prismáticos de anfibólio. Lado maior da foto $3,20 \mathrm{~mm}$.

Foto 6.28. Glaucofânio em clorita-plagioclásio xisto. Lado maior da foto $3,20 \mathrm{~mm}$.

Foto 6.29. Granada com substituição total por clorita. Pseudomorfo. Lado maior da foto $1,30 \mathrm{~mm}$.

Foto 6.30. Granada com substituição total por clorita. Pseudomorfo. Lado maior da foto $1,30 \mathrm{~mm}$.

Fotos $6.26,6.27,6.28$ e 6.30 obtidas com polarizadores paralelos e 6.25 e 6.29 com polarizadores cruzados. 
A biotita agrupa-se em pequenos leitos (Foto 6.26) concordantes à foliação milonítica, ou constituem pequenos grãos xenoblásticos disseminados e/ou acumulados nas porções onde 0 quartzo é mais abundante. Quase sempre tem clorita associada.

A titanita ocorre como grãos xenoblásticos de no máximo $0,15 \mathrm{~mm}$ de comprimento, disseminados e orientados na foliação milonítica, ou como produto da substituição de grãos de opacos mais grossos, nas bordas e fraturas. Neste caso a substituição pode ser parcial ou total.

A calcita ocorre principalmente na amostra 117E, como cristais de no máximo 0,6 mm de diâmetro, xenoblásticos a subidioblásticos e, na maioria das vezes, intersticial aos grãos de plagioclásio. Alguns dos grãos apresentam inclusões de minerais opacos e clorita, ou apresentam lamelas de deformação, algumas das quais levemente dobradas.

O anfibólio (actinolita) apresenta-se em grãos de no máximo $0,4 \mathrm{~mm}$ de comprimento. Possui pleocroismo que varia de verde-amarelado a amarelo muito claro e, às vezes, constitui pequenos glomeroblastos, nos quais não se diferenciam claramente os grãos. Também se apresentam alguns cristais prismáticos (Foto 6.27) e, eventualmente, aciculares. Em alguns dos grãos é possível observar-se um fraco zonamento, no qual o núcleo apresenta pleocroismo mais forte que as bordas, mas esta característica não é comum a todos os grãos. Também apresentam substituição por clorita. Geralmente o anfibólio define a foliação e a textura nematoblástica da rocha, principalmente na lâmina 124C

A apatita apresenta-se como cristais de no máximo $0,1 \mathrm{~mm}$, idioblásticos a subidioblásticos, eventualmente com secções hexagonais ou retangulares. A maioria dos grãos encontra-se incluso no plagioclásio.

O zircão constitui finos cristais subidoblásticos e idioblásticos incluso nos grãos de plagioclásio ou disseminado na lâmina.

Glaucofânio foi encontrado unicamente na lâmina 125M (Foto 6.28). Apresenta fórmula pleocróica $X=$ incolor, $Y=$ lilás e $Z$ = azul-claro e os grãos variam de 0,05 a 0,85 mm, sendo geralmente subidioblásticos. Apresentam zonamento composicional muito fraco, com núcleos mais intensamente pleocróicos que as bordas. Nas bordas observa-se substituição por clorita, mas quando são observados em cortes basais, aparentam ser substituídos também por outro anfibólio. Poucos cristais apresentam inclusões, mas podem ser notadas algumas de minerais opacos e, mais raramente, de epidoto e/ou clinozoisita. Geralmente os cristais de glaucofânio se orientam segundo a foliação principal $S_{n+1}$ e, às vezes definindo textura nematoblástica.

Granada foi encontrada somente nas lâminas 107B e 118A, onde formam cristais de 0,1 a 0,5 mm de diâmetro, muitos deles subidioblásticos e, em muitos dos casos, mostram substituição parcial nas fraturas e nas bordas, a total, por clorita (Fotos 6.29 e 6.30), por vezes restando apenas pequenos grãos em meio a uma massa de clorita.

Texturalmente estas rochas são bem foliadas e essa foliação está também dobrada, sendo que algumas porções das rochas são tipicamente lepido-granoblásticas, devido à associação do 
plagioclásio com a clorita. Na lâmina 117A a foliação e as dobras são bem observadas em leitos de plagioclásio, minerais opacos, clorita e mica branca, mas no geral todos os minerais apresentam-se orientados segundo a foliação mais intensa da rocha $\left(S_{n+1}\right)$, que é milonítica. Essas foliações orientam o quartzo, o plagioclásio, o anfibólio, a mica e a clorita, gerando nas rochas texturas granoblástica, lepidoblástica, em menor proporção nematoblástica e a combinação de todas as texturas. A foliação milonítica destrói praticamente todas as outras foliações, mas ainda são preservados relíquias de xistosidades pretéritas, indicada por inclusões dobradas em grãos de glaucofânio e arcos poligonais mal preservados. Deformações superimpostas resultaram, comumente, em extinção ondulante no anfibólio. Também é possível observar alguns grãos de glaucofânio que não acompanham a foliação e que apresentam sombras de pressão assimétricas.

Como texturas particulares observam-se bordas de reação de clorita em anfibólio, de titanita em opacos, cristais de clorita e muscovita intercrescidos e dobrados, assim como uma marcada extinção ondulante em quartzo. Na lâmina 124C ocorre uma foliação forte e textura nematoblástica, com o anfibólio orientado segundo a $S_{n}$ dobrada, e uma $S_{n+1}$ parcialmente crenulada, sem a cristalização de novos minerais.

\subsection{Mármores}

Os mármores afloram na área de La Calera, no Resguardo de Tacueyó, onde atualmente há uma lavra ativa, e no Córrego Elassio, no Resguardo de San Francisco, onde ocorrem como blocos rolados.

Desses litotipos foi feita apenas uma lâmina da amostra 123B, que corresponde a um leito silicático no mármore, escolhido para observação de minerais com maior interesse petrogenético. Este leito é composto por carbonatos, epidoto e/ou clinozoisita, quartzo, talco, apatita, opacos, clorita, rutilo e titanita.

carbonato ocorre como grãos xenoblásticos com tamanhos que variam de 0,2 a 1,8 $\mathrm{mm}$, muito embora, em geral, a rocha seja mais equigranular (Foto 6.31). Geralmente os cristais analisados são uniaxiais negativos, mas em alguns mais deformados são biaxiais com $2 \mathrm{~V}<10^{\circ}$, características essas que podem ser devidas à deformação ou a preservação parcial de aragonita. Em algumas partes da rocha o carbonato define uma textura granoblástica, com contatos retos ou interlobados, devido à migração dos limites dos grãos durante a deformação. Em algumas das junções tríplices ocorrem cristais de quartzo mais finos e talco pode ocorrer no plano de contato entre dois grãos. Comumente apresentam lamelas de geminação.

Epidoto e/ou clinozoisita constituem grãos com tamanhos que variam entre 0,05 e 0,50 $\mathrm{mm}$, sendo, mais comumente, a clinozoisita subidioblástica e o epidoto xenoblástico. Geralmente estes minerais constituem agregados, juntamente com talco, em algumas porções da rocha, onde 
definem a foliação (Foto 6.31).
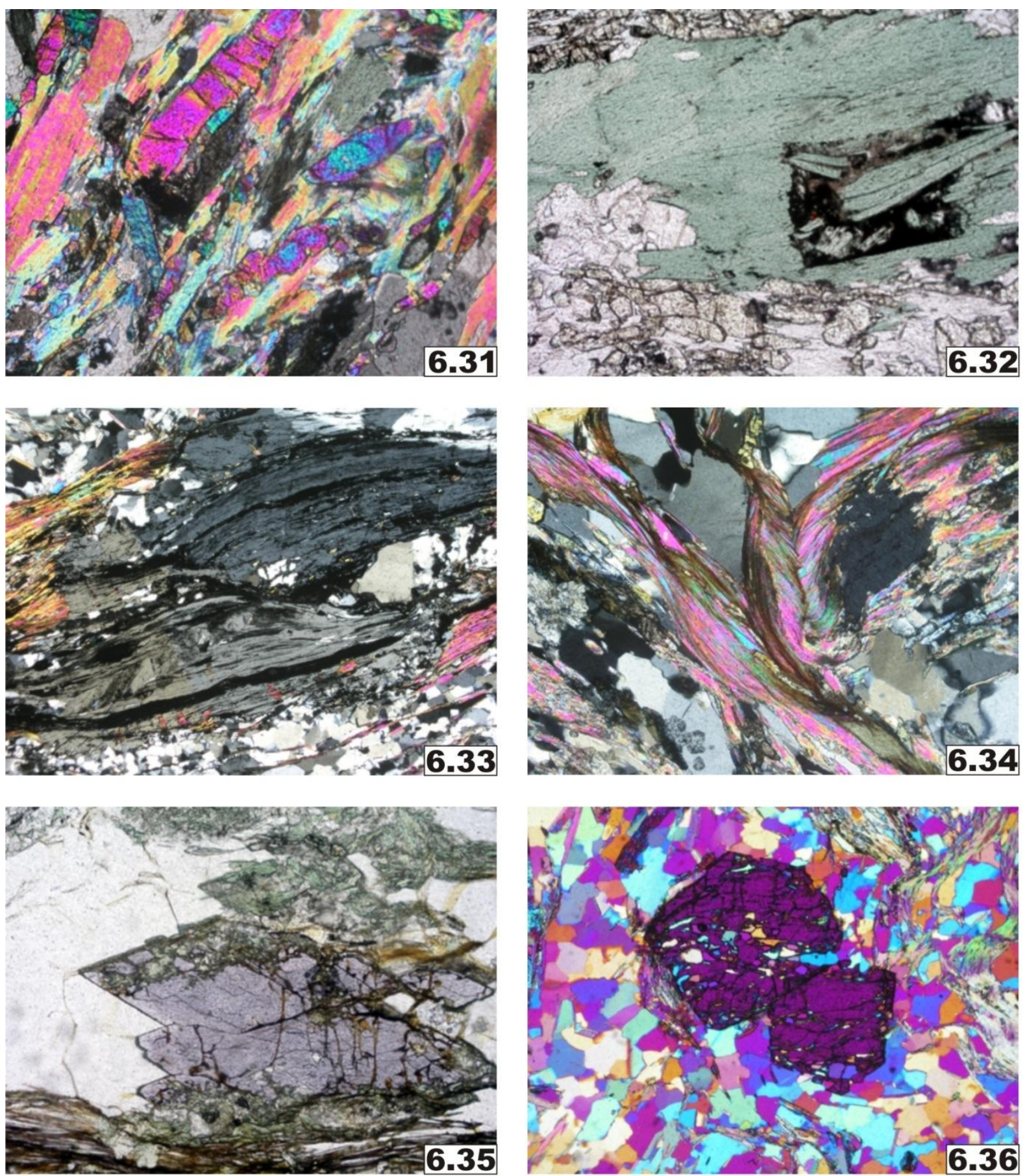

Foto 6.31. Epidoto-clinozoisita definindo a foliação com a mica e carbonato. Lado maior da foto $1,30 \mathrm{~mm}$.

Foto 6.32. Clorita com minerais opacos nos planos de clivagem. Lado maior da foto $1,30 \mathrm{~mm}$.

Foto 6.33. Plagioclásio fortemente deformado. Associação com mica, quartzo e minerais opacos. Lado maior da foto $1,30 \mathrm{~mm}$.

Foto 6.34. Estilpnomelano em crenulação associado à mica e clorita. Lado maior da foto $1,30 \mathrm{~mm}$.

Foto 6.35. Glaucofânio com substituição por clorita e anfibólio fibroso. Lado maior da foto 1,30 mm.

Foto $6.36^{\star}$. Granada com inclusões de quartzo conservando foliação pretérita. Lado maior da foto $3,20 \mathrm{~mm}$.

Fotos 6.32 e 6.35 obtidas com polarizadores paralelos e $6.31,6.33,6.34$ e 6.36 com polarizadores cruzados. *Placa $\boldsymbol{\Lambda}$. 
O quartzo forma grãos xenoblásticos com 0,1 a 1,0 mm, disseminados ou concentrados junto com o carbonato, sugerindo que a sílica foi introduzida por fluidos hidrotermais, ou seja, podem representar vênulas e veios de quartzo deformados. Também se apresenta como pequenos agregados lenticulares com textura granoblástica, ou como delgados leitos concordantes com a foliação milonítica, especialmente onde se concentram epidoto-clinozoisita e talco, o que sugere infiltração hidrotermal-metassomática. Em geral os grãos mostram-se deformados, com extinção ondulante.

O talco ocorre como cristais que variam de 0,05 e 1,00 mm, geralmente subidioblásticos e orientados na foliação, juntamente com epidoto e/ou clinozoisita (Foto 6.31) e, às vezes, quartzo. Arranjam-se em textura decussada discreta quando disseminados.

Raros grãos de apatita foram encontrados, sempre com formas arredondadas e, às vezes, xenoblásticos e disseminados pela lâmina, principalmente na porção da rocha na qual se concentram os minerais silicáticos.

A clorita distribui-se intersticialmente entre os demais minerais, mas também ocorre como pseudomorfos, possivelmente de biotita. Apresenta um pleocroismo intenso, variando de verdeescuro a incolor. Em algumas porções da rocha os cristais podem ser subidioblásticos, estarem intercrescidos com talco e conterem inclusões de quartzo e, às vezes, rutilo. Em alguns planos da clivagem apresentam-se concentrações de minerais opacos (Foto 6.32), sugerindo derivação por substituição retrometamórfica de biotita.

Os minerais opacos concentram-se nos planos da clivagem de pseudomorfos de clorita ou ocorrem como pequenas acumulações de grãos muitos finos disseminadas na lâmina (Foto 6.32).

O rutilo forma cristais de no máximo $0,1 \mathrm{~mm}$ de comprimento, possuem hábito idioblástico acicular ou prismático, por vezes em arranjos radiados, inclusos na clorita, o que indica que os fluidos retrometamórficos foram relativamente oxidantes.

A titanita apresenta-se como grãos em geral subidioblásticos que variam de 0,1 a 0,3 mm de comprimento, distribuídos nos planos da foliação milonítica e associada a leitos ricos em epidoto e/ou clinozoisita e o talco.

Texturalmente a rocha é predominantemente granoblástica nas porções compostas por carbonato e nos leitos onde se concentra talco e epidoto-clinozoisita, apresenta texturas lepidonematoblástica e nemato-lepidoblástica, dependendo do predomínio de epidoto e/ou clinozoisita ou talco. Localmente encontram-se lamelas de deformação e planos de clivagem dobrados em carbonatos e extinção ondulante do quartzo.

\subsection{Quartzitos milonitizados}

Estas rochas foram encontradas apenas no Córrego La Primicia, no Resguardo de San 
Francisco.

Amostras analisadas (118D e 118) correspondem a quartzitos micáceos com conteúdos variáveis de minerais acessórios A amostra 118D é composta por quartzo (76\%), mica branca (16\%), opacos (4\%), plagioclásio (2\%), clinozoisita (1\%) e clorita (1\%), e a 118 é constituída por quartzo $(63 \%)$, mica branca $(25 \%)$, clorita (5\%), glaucofânio (3\%), clinozoisita (2\%), zoisita $(\sim 0,6 \%)$, estilpnomelano $(\sim 0,5 \%)$, granada $(\sim 0,5 \%)$ e minerais opacos $(\sim 0,4 \%)$.

$\mathrm{Na}$ lâmina 118D o tamanho dos grãos de quartzo varia entre 0,025 e 0,750 mm e usualmente tendem a ser equigranulares. Os cristais são xenoblásticos com contatos suturados (Foto 6.33) ou interlobados e sempre apresentam extinção ondulante e alongamento paralelo à foliação milonítica. Leitos de grã mais fina ou mais grossa são separados por leitos de mica e minerais opacos. As zonas de granulação fina associam-se aos planos de cisalhamento mais intenso, onde a recristalização dos grãos foi mais forte, resultando em texturas interlobadas e de migração de limites de grãos mais evidentes.

A mica branca, possívelmente muscovita e/ou fengita, apresenta-se como cristais subidioblásticos que variam de 0,10 a $0,85 \mathrm{~mm}$, que tendem a conferir à rocha uma textura lepidoblástica local (Foto 6.33). Nas porções mais quartzosas a mica apresenta textura decussada e em algumas áreas de maior concentração notam-se ainda relíquias da foliação $S_{n}$ dobrada.

Os minerais opacos constituem pequenos grãos que acompanham a foliação nas partes onde é maior a concentração de mica e também se associam ao plagioclásio, concentrando-se nas suas bordas ou no interior dos grãos (Foto 6.33).

O plagioclásio apresenta-se como porfiroblastos xenoblásticos fortemente deformados (Foto 6.33) e estirados, paralelizados à foliação $S_{n}$, juntamente com a mica. Apresenta grande quantidade de inclusões de minerais, principalmente de opacos, que estão orientadas segundo a foliação milonítica. Em menor volume ocorrem inclusões de mica, quartzo e clinozoisita.

A clinozoisita constitui grãos subidioblásticos de no máximo $0,1 \mathrm{~mm}$ de comprimento, distribuídos nas porções onde se concentra a mica, ou ocorre como inclusões no plagioclásio e nos contatos entre os grãos de quartzo.

A clorita distribui-se de modo análogo ao verificado com a mica branca, com a qual se associa.

Texturalmente a rocha é granoblástica, com porções lepidoblásticas e lepidogranoblásticas, e foi afetada por intenso cisalhamento. Localmente a foliação está dobrada, definindo uma $S_{n+1}$.

$\mathrm{Na}$ lâmina 118 os grãos de quartzo variam de 0,1 a 1,0 mm, sendo a maioria deles xenoblásticos e com uma marcada extinção ondulante. Definem a foliação da rocha quando estirados, mas também se arranjam em texturas granoblásticas. Apresentam-se também como inclusão em glaucofânio e granada.

A mica branca ocorre como grãos subidioblásticos de 0,1 a $0,9 \mathrm{~mm}$ de comprimento, em 
arranjos que definem uma textura lepidoblástica, ou lepido-granoblástica quando em porções mais quartzosas. Em algumas partes da rocha, os cristais de mica estão dobrados, indicando a existência de uma foliação metamórfica prévia ao desenvolvimento da foliação milonítica. Também ocorre em uma crenulação $S_{n+1}$ associada à cristalização do estilpnomelano (Foto 6.34). Em algumas partes, a foliação principal esta defletida por cristais de glaucofânio e em algumas ocasiões por cristais de granada, indicando que a foliação milonítica é tardia em relação ao desenvolvimento do metamorfismo da fácies xisto azul.

A clorita encontra-se no interstício entre outros minerais e parece ser produto da substituição de outro mineral. Também substitui glaucofânio nas bordas e nos planos de clivagem dos cristais.

A clinozoisita apresenta-se em grãos xenoblásticos de no máximo $0,3 \mathrm{~mm}$ de comprimento e, por vezes, são subidioblásticos. Alguns dos grãos apresentam-se com formas arredondadas e nas porções mais micáceas acompanham a foliação, em agregados ou disseminados. Em alguns grãos de glaucofânio, a clorita o substitui parcialmente nas bordas e eventualmente a substituição e completa, restando somente pseudomorfos de clorita.

O glaucofânio apresenta fórmula pleocróica com $X=$ incolor, $Y=$ lilás e $Z$ = azul-claro. tamanho dos grãos varia de 0,01 a 2,4 mm no corte basal e de 1,0 a 1,4 mm no corte longitudinal e alguns grãos possuem inclusões de quartzo e minerais opacos. Os cristais são na sua maioria xenoblásticos, mas alguns dos cristais são subidioblásticos em cortes basais. A principal diferença do glaucofânio desta rocha com o dos xistos azuis é que nesta rocha ele não apresenta um claro zonamento. Nas bordas, fraturas e planos de clivagem observar-se substituição por clorita e anfibólio fibroso com pleocroismo verde-claro a incolor (Foto 6.35), possivelmente uma tremolitaactinolita, cuja identificação segura é muito difícil pela sua granulação muito fina. Os cristais menores podem apresentar substituição completa por clorita.

O estilpnomelano ocorre sob a forma de pequenos cristais dobrados, sempre associados com as maiores concentrações de mica (Foto 6.34).

A granada esta presente esporadicamente, sendo observados apenas alguns grãos de granulação variando de 0,2 a 1,4 mm, geralmente subidioblásticos e com inclusões de quartzo orientadas, que conservam a foliação $S_{n-1}$ pretérita da rocha (Foto 6.36). Apresentam também inclusões de epidoto e/ou clinozoisita e alguns dos porfiroblastos têm associadas sombras de pressão assimétricas e mostram-se rotacionadas, indicando que sua cristalização deu-se no evento cinemático prévio ao que gerou o glaucofânio.

A zoisita apresenta-se como cristais idioblásticos disseminados pela rocha, de no máximo $0,3 \mathrm{~mm}$ de comprimento.

Os minerais opacos são subidioblásticos, finos e estão disseminados.

Texturalmente esta amostra é granoblástica, com porções lepidoblásticas e lepidogranoblásticas. Estruturalmente pode ser identificada uma foliação mais evidente e intensa $\left(S_{n+1}\right)$ 
definida pela orientação do quartzo e das micas, e uma crenulação $\left(S_{n+2}\right)$, definida principalmente pela orientação dos cristais de mica branca. $A S_{n}$ foi identificada apenas na granada, onde apresenta um padrão de inclusões com orientação diferente ao observado na $S_{n+1}$ e $S_{n+2}$. Observam-se também bordas de reação que formaram clorita e anfibólio verde-claro em glaucofânio, pseudomorfos de clorita derivados do glaucofânio, quartzo com extinção ondulante e micas dobradas ou em textura decussada. Todos esses padrões são indicadores do intenso processo de cisalhamento que, possivelmente, tem relação com a colocação destas rochas em zonas de cavalgamento.

\subsection{Epidositos}

Este litotipo foi encontrado no Córrego San Diego ou El Barrial, no Resguardo de Tacueyó, e no Córrego Río Chiquito, no Resguardo de San Francisco.

Originalmente o termo epidosito foi aplicado para rochas caracterizadas por substituições metassomáticas dos minerais ígneos primários por associações granoblásticas (Banerjee et al., 2000). Os dados geológicos de campo e petrográficos sugerem que essas rochas são geradas na base de sistemas hidrotermais e se associam a corpos minérios de sulfetos (Richardson et al., 1987; Schiffman et al., 1987; Bettison-Varga et al., 1992; Nehlig et al., 1994).

Nesse trabalho foi utilizado o nome epidosito para as rochas com conteúdos superiores a $50 \%$ de epidoto e/ou clinozoisita, mas é importante ressaltar que as amostras não apresentam texturas blastofíticas ou blastosubofíticas, típicas dos epidositos originados por metassomatismo em fundo oceânico e zonas de black smokers.

As amostras analisadas são compostas por epidoto e/ou clinozoisita (50-63\%), carbonato (acessório a 11\%), minerais opacos (acessório a 20\%), anfibólio (acessório a 10\%), plagioclásio (10\%), clorita (7\%), quartzo (3\%), pumpellyita ( 1-5\%), mica (2\%) e zircão (acessório).

Epidoto e/ou clinozosita constituem agregados de cristais subidioblásticos e xenoblásticos, definindo uma textura glomeroblástica (Foto 6.37). Os cristais variam entre 0,05 e $0,20 \mathrm{~mm}$, mas podem ser observados cristais de até $0,75 \mathrm{~mm}$, como na lâmina 109A. Algumas porções encontram-se como agregados radiados e, especialmente na lâmina 121C, é possível observar-se que os glomeroblastos estão estirados e definem uma leve foliação (Foto 6.38).

Carbonato foi identificado apenas na lâmina 109A, onde forma massas irregulares preenchendo cavidades ou constitui, localmente, cristais subidioblásticos inclusos em epidoto e/ou clinozoisita. Algumas porções deste mineral podem apresentar lamelas de deformação (Foto 6.39).

Os minerais opacos ora definem a foliação, ora constituem grãos xenoblásticos disseminados na amostra, ora se concentram nas bordas de alguns dos glomeroblastos de epidoto e/ou clinozoisita. Observa-se ainda substituição por mineral de cor vermelha intensa nas 
bordas, possivelmente leucoxênio e limonita.
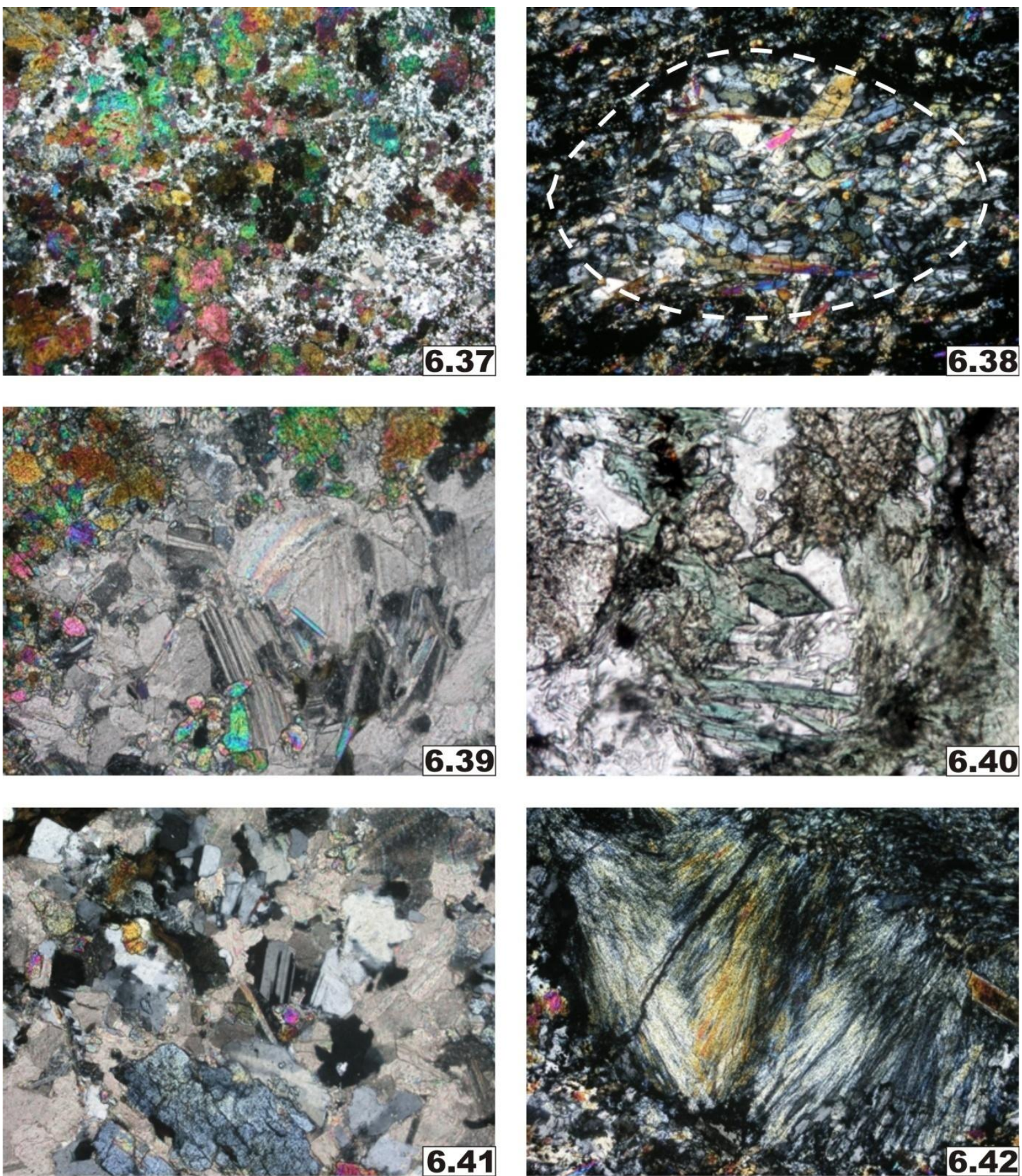

Foto 6.37. Glomeroblasto de epidoto-clinozosita. Lado maior da foto $10,20 \mathrm{~mm}$.

Foto 6.38. Glomeroblasto de epidoto-clinozoisita estirado. Lado maior da foto 1,62 mm.

Foto 6.39. Carbonato com lamelas de deformação. Lado maior da foto $1,30 \mathrm{~mm}$.

Foto 6.40. Cortes basais e longitudinais de anfibólio. Lado maior da foto $0,65 \mathrm{~mm}$.

Foto 6.41. Geminação polissintética em albita. Lado maior da foto $1,30 \mathrm{~mm}$.

Foto 6.42. Pumpellyita radiada. Lado maior da foto $1,30 \mathrm{~mm}$.

Foto 6.40 obtida com polarizadores paralelos e $6.37,6.38,6.39,6.41$ e 6.42 com polarizadores cruzados. 
O anfibólio apresenta variações na fórmula pleocróica, sendo $X=$ incolor a amarelo-claro, $\mathrm{Y}=\mathrm{Z}=$ verde muito claro a azulado e ângulo $\mathrm{C}^{\wedge} \mathrm{Z}$ de 17 a 25으, indicando trata-se, possivelmente, de hornblenda sódica. Os grãos são xenoblásticos ou subidioblásticos e, eventualmente exibem um leve zonamento, com os núcleos mais intensamente pleocróicos que as bordas. Muitos dos grãos apresentam bordas de reação, com cristalização de clorita. Os cristais estão na maioria disseminados, mas podem definir uma fraca foliação (Foto 6.40).

O plagioclásio tem conteúdo máximo de anortita de $5 \%$, os grãos, a maioria xenoblásticos, variam de 0,2 a 0,4 $\mathrm{mm}$ e raramente apresentam geminação polissintética (Foto 6.41) e, eventualmente, albita-carlsbad.

A clorita ocorre como mineral intersticial ou substituindo outros minerais, usualmente formando cristais xenoblásticos. Pode também formar algumas acumulações e alguns cristais estão dobrados segundo a fraca foliação $S_{n}$, textura essa observada principalmente na amostra $109 \mathrm{~A}$.

A pumpellyita apresenta-se disseminada e forma cristais idioblásticos aciculares de no máximo $0,15 \mathrm{~mm}$ de comprimento e, em algumas porções da lâmina, constituem agregados radiados (Foto 6.42), indicando cristalização sob regime estático.

A mica branca constitui grãos que, em geral, variam de 0,15 a 0,35 mm, mas também ocorrem alguns com até $1,5 \mathrm{~mm}$, subidioblásticos e, eventualmente, xenoblásticos. Distribui-se disseminadamente pela rocha e, às vezes, define textura decussada, quando em acumulações granoblásticas de quartzo e plagioclásio. Localmente a mica pode estar dobrada, indicando ter sido também gerada durante o desenvolvimento da foliação $S_{n}$.

O zircão ocorre como mineral acessório e forma cristais idioblásticos e subidioblásticos disseminados.

\subsection{Estilpnomelano-muscovita-albita-anfibólio-quartzo xisto}

Este tipo de xisto foi encontrado unicamente no Córrego Río Chiquito, no Resguardo de San Francisco, principalmente nos afloramentos 107 e 109. As amostras não apresentam variações notáveis na mineralogia e são compostas por quartzo (35\%), anfibólio (20\%), plagioclásio (19\%), muscovita (13\%) e estilpnomelano (7\%), além de titanita, epidoto, opacos e apatita ( $<5 \%$ da composição modal), dentre os quais predomina titanita.

O quartzo apresenta-se como pequenos cristais xenoblásticos com extinção ondulante arranjados na foliação em textura granoblástica, juntamente com plagioclásio (Foto 6.43). Encontra-se também incluso em plagioclásio

O anfibólio, possivelmente uma actinolita, apresenta fórmula pleocróica $X=$ amarelo-claro, $Y=Z$ = verde-azulado, com ângulo $C^{\wedge} Z=16^{\circ}$ e com elongação positiva. Os grãos são subidioblásticos prismáticos ou fibrosos e variam de 0,025 a 1,40 mm. Eventualmente observam- 

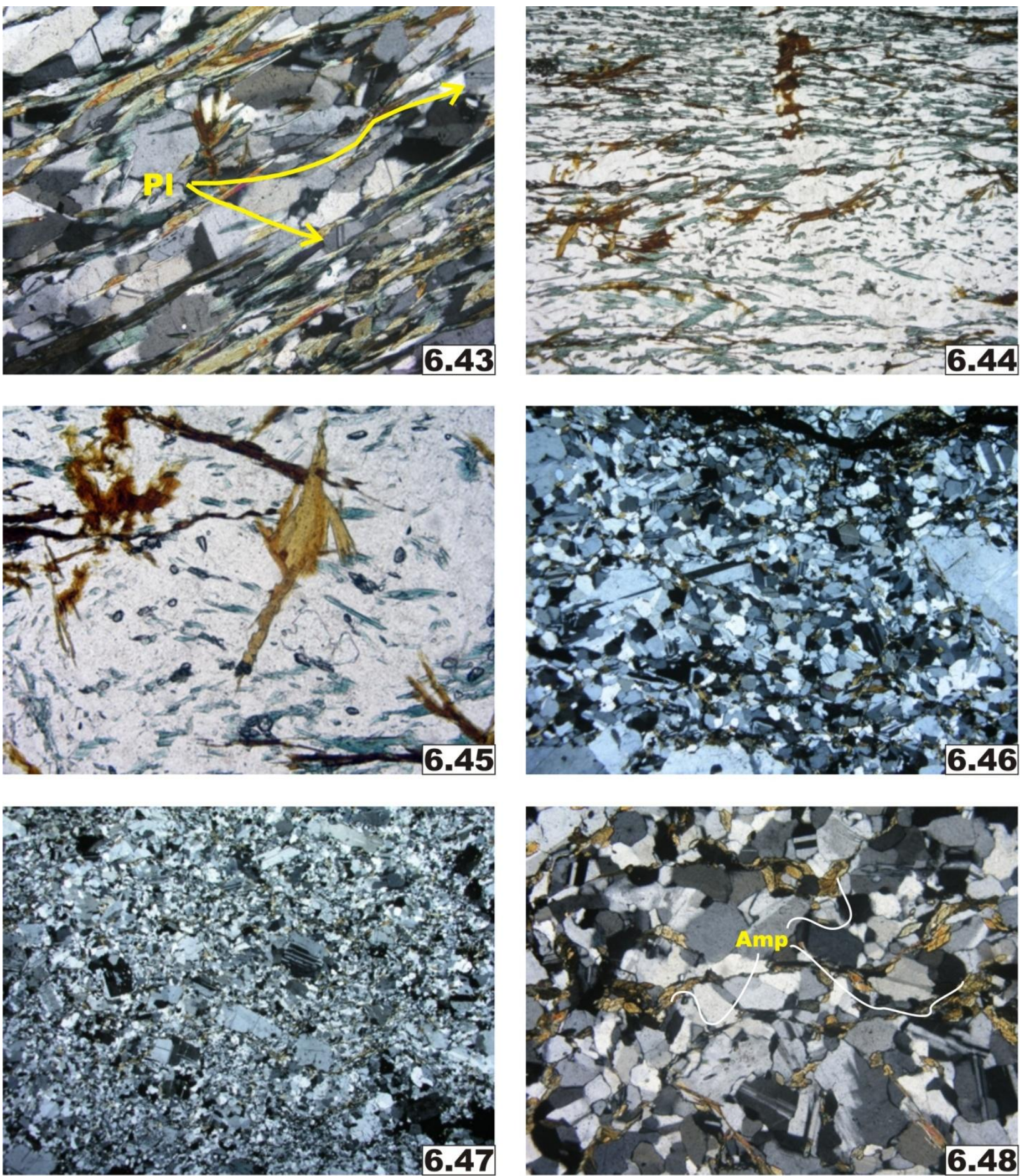

Foto 6.43. Plagioclásio com geminação de tipo albita associado com quartzo. Lado maior da foto 1,30 mm.

Foto 6.44. Anfibólio em textura nematoblástica. Lado maior da foto 3,20 mm.

Foto 6.45. Estilpnomelano em agregados radiados. Lado maior da foto $1,30 \mathrm{~mm}$.

Foto 6.46. Albita como matriz. Lado maior da foto $3,20 \mathrm{~mm}$.

Foto 6.47. Albita como porfiroclastos. Lado maior da foto $10,20 \mathrm{~mm}$.

Foto 6.48. Anfibólio disseminado. Lado maior da foto $1,30 \mathrm{~mm}$.

Fotos 6.44 e $\mathbf{6 . 4 5}$ obtidas com polarizadores paralelos e $\mathbf{6 . 4 3}, \mathbf{6 . 4 6}, \mathbf{6 . 4 7}$ e $\mathbf{6 . 4 8}$ com polarizadores cruzados. 
se alguns grãos xenoblásticos. Apresentam-se orientados definindo uma textura nematoblástica (Foto 6.44).

O plagioclásio $\left(A n_{5}\right)$ forma cristais de no máximo $0,4 \mathrm{~mm}$, sendo a maioria deles xenoblásticos e, eventualmente, subidioblásticos (Foto 6.43). Apresentam geminação do tipo albita e nos grãos não geminados observa-se uma leve insinuação de extinção concêntrica, indicativa de um fraco zonamento composicional de difícil determinação se é normal ou inverso. Alguns grãos apresentam inclusões de quartzo arredondado.

A muscovita apresenta grãos de no máximo $0,3 \mathrm{~mm}$, sendo a maioria deles subidioblásticos e arranjados em textura lepidoblástica, juntamente com o estilpnomelano. Encontra-se também disseminada na rocha, por vezes definindo textura decussada.

O estilpnomelano apresenta fórmula pleocróica $X=$ amarelo-dourado, $Y=Z=$ caféavermelhado. Os grãos têm no máximo $1,4 \mathrm{~mm}$ de comprimento, são prismáticos ou fibrosos e subidioblásticos e podem constituir agregados radiados (Foto 6.45). Orientam-se preferencialmente ao longo da foliação, onde definem uma textura lepidoblástica. Em algumas porções há substituição por clorita, concentrada principalmente nos planos da clivagem e são comuns intercrescimentos com anfibólio.

A titanita apresenta cristais que variam de 0,05 a 0,2 $\mathrm{mm}$, geralmente formando cristais com formas arredondadas ou subidioblásticas e, eventualmente, esqueléticas. Comumente se associa ao epidoto, mas de modo geral encontra-se disseminada e quando há cristais alongados, estes acompanham a foliação.

O epidoto possui pleocroismo intenso, que varia de incolor a amarelo, e forma grãos geralmente xenoblásticos de 0,1 a 0,5 mm, excepcionalmente alcançando 0,8 mm. Encontram-se disseminados pela rocha e, quando estão alongados, acompanham a foliação. Muitas das vezes se concentra nas bordas de cristais de titanita.

Os minerais opacos são pouco abundantes e constituem cristais de 0,05 a 0,50 mm, com predomínio dos maiores. A maioria deles são subidioblásticos, mas também ocorrem alguns idioblásticos, e podem estar concentrados em porções mais ricas em quartzo e plagioclásio. É possível observar-se também em alguns cristais sombras de pressão simétricas. Excepcionalmente mostram substituição de titanita e ás vezes por leucoxênio nas bordas indicando o avanço do processo de retrometamorfismo.

A apatita apresenta-se somente como pequenos cristais xenoblásticos disseminados, às vezes estirado e na foliação.

A rocha apresenta leitos de composições bem diferenciadas, com textura granoblástica, definida pelo quartzo e plagioclásio, lepidoblástica nos leitos onde se concentra muscovita e estilpnomelano, e nematoblástica onde predomina o anfibólio. Observam-se também suaves dobras que insinuam uma fraca crenulação, com cristalização incipiente de estilpnomelano nos planos. Localmente encontram-se sombras de pressão de quartzo e plagioclásio em minerais 
opacos, assim como extinção ondulante de quartzo e coronas de reação de titanita em minerais opacos.

\subsection{Keratófiros}

Este tipo de rochas é encontrado unicamente no Córrego Vichiquí, no Resguardo de Toribío.

São rochas compostas por plagioclásio (>90\%), anfibólio ( 3\%), estilpnomelano $(\sim 3 \%)$, minerais opacos ( 2\%) e clorita, epidoto e quartzo acessórios.

O plagioclásio $\left(\mathrm{An}_{5}\right)$ apresenta-se distribuído na matriz (Foto 6.46) e como porfiroclastos (Foto 6.47). Na matriz, os grãos são principalmente xenoblásticos, têm geminação do tipo albita, albita-carlsbad bem desenvolvidas, e eventualmente periclina, e alcançam no máximo 0,5 mm na maior elongação. Mais raramente ocorrem grãos sem geminação e alguns geminados estão dobrados. Os porfiroclastos variam de 1,0 a 2,2 mm e são principalmente xenoblásticos, muito embora alguns grãos subidioblásticos também estejam presentes, e mostram-se bem geminados. Parte dos cristais mais grossos apresentam incipiente substituição por clinozoisita, assim como inclusões de quartzo e anfibólio.

$\mathrm{O}$ anfibólio possui fórmula pleocróica com $\mathrm{X}=$ amarelo muito claro, $\mathrm{Y}=$ verde e $\mathrm{Z}=$ verdeazulado, com ângulo $\mathrm{C}^{\wedge} Z=18^{\circ}$ e elongação positiva sendo, portanto, identificado como hornblenda. Os cristais têm no máximo $0,15 \mathrm{~mm}$ de comprimento, são subidioblásticos e idioblásticos e, em sua maioria apresenta-se no seu corte basal na lâmina, indicado estarem bem orientados pela foliação. Os cristais distribuem-se nos interstícios entre os demais minerais e estão distribuídos aleatoriamente (Foto 6.48). Alguns cristais estão inclusos no plagioclásio.

O estilpnomelano apresenta fórmula pleocróica com $X=$ amarelo-dourado, $Y=Z$ = pardoescuro ou pardo-esverdeado. São cristais subidioblásticos que alcançam no máximo $0,5 \mathrm{~mm}$ de comprimento, (Foto 6.49), que ocorrem disseminados pela lâmina e, às vezes, formam agregados radiados de poucos cristais.

Os minerais opacos ocorrem em pequenas quantidades, geralmente constituindo agregados irregulares dispersos, às vezes envolvendo grãos ou aglomerados de grãos, principalmente de plagioclásio.

A clorita e o epidoto encontram-se apenas em vênulas hidrotermais (Foto 6.50), sendo que a clinozoisita pode eventualmente, apresentar-se como produto da substituição incipiente no plagioclásio.

O quartzo ocorre em pouca quantidade, disseminado ou incluso em alguns cristais de plagioclásio.

Texturalmente as rochas exibem evidências de recristalização, subgrãos de plagioclásio, assim como geminação dobrada, mas este litotipo não apresenta nenhuma foliação metamórfica, 

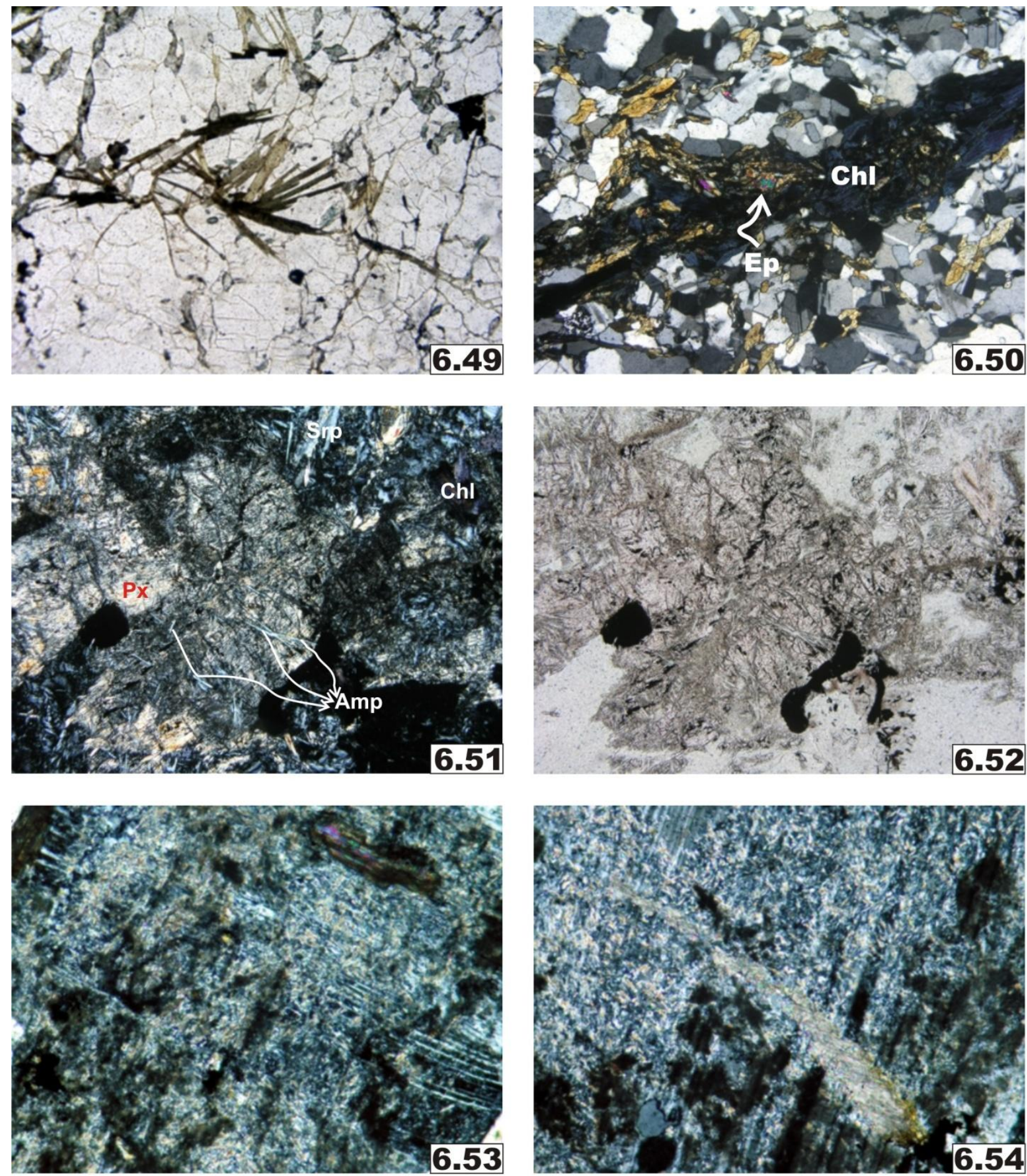

Foto 6.49. Estilpnomelano subidioblástico. Lado maior da foto $1,30 \mathrm{~mm}$.

Foto 6.50. Clorita e epidoto em veio. Lado maior da foto $1,30 \mathrm{~mm}$.

Foto 6.51. Núcleo de piroxênio (Px) em rocha ultramáfica. Associação com serpentina (Srp), clorita (Chl) e anfibólio (Amp) fibroso. Lado maior da foto $1,30 \mathrm{~mm}$.

Foto 6.52. Minerais opacos disseminados em rocha ultramáfica. Lado maior da foto 1,30 $\mathrm{mm}$.

Foto 6.53. Sericitização de plagioclásio. Lado maior da foto $1,07 \mathrm{~mm}$.

Foto 6.54. Fratura de plagioclásio preenchida por carbonato. Lado maior da foto 1,07 $\mathrm{mm}$.

Fotos $\mathbf{6 . 4 9}$ e $\mathbf{6 . 5 2}$ obtidas com polarizadores paralelos e 6.50, 6.51, $\mathbf{6 . 5 3}$ e $\mathbf{6 . 5 4}$ com polarizadores cruzados. 
o que parece indicar que a transformação do caráter cálcico da rocha deu-se em condições relativamente estáticas, sendo o principal evento sofrido o metassomático.

\subsection{Metaultramáficas}

As rochas ultramáficas são relativamente pouco freqüentes, tendo sido localizados em dois afloramentos, um perto de Jambaló e outro no Córrego Muñoz. São rochas compostas principalmente por serpentina $(70 \%)$, minerais opacos $(15 \%)$, clorita $(6 \%)$, olivina $(5 \%)$, piroxênio (3\%) e anfibólio ( 1\%).

A serpentina apresenta-se como agregados e veios fibrosos de crisotila e, por vezes placóides (Foto 6.51), de antigorita, em arranjos que definem uma textura mesh, com restos de olivina e piroxênio ígneos.

A olivina e o clinopiroxênio apresentam-se como pequenos núcleos transformados em serpentina e anfibólio respectivamente. Estes núcleos não apresentam características petrográficas que permitam uma identificação mais precisa (Foto 6.51).

O anfibólio apresenta-se como pequenos cristais, às vezes fibrosos (Foto 6.51), possivelmente produtos de substituição de piroxênio. Esta anfibólio apresenta um pleocroismo muito leve que varia de incolor para verde muito claro e um ângulo $C^{\wedge} Z=17^{\circ}$. Devido ao tamanho reduzido dos cristais não foi possível a obtenção de figuras de interferência mas, suas características ópticas sugerem tratar-se de tremolita.

A clorita apresenta-se nos interstícios entre outros minerais ou disseminada (Foto 6.51), sendo em geral os grãos xenoblásticos e, por vezes, subidioblásticos. Apresenta um pleocroismo muito leve que varia de incolor a verde muito claro. A presença deste mineral pode indicar que o protolito destas metaultramáficas tivesse na sua composição mineralógica original, um pouco de plagioclásio.

Os minerais opacos apresentam-se sob a forma de fitas na foliação, disseminados (Foto 6.52), associados à clorita e serpentina e concentrados nas bordas dos núcleos preservados de olivina.

\subsection{Quartzo-monzonito}

Embora a amostra apresente um importante evento milonítico que pode notar-se na descrição, a rocha é tratada como ígnea para ressaltar o caráter magmático e a composição ainda preservada dela. Este litotipo foi unicamente encontrado no oeste do povoado de Tacueyó e foi feita a descrição de uma lâmina (BLL) a qual é apresentada a seguir:

A rocha é composta por plagioclásio (39\%), ortoclásio (36\%), quartzo (15\%), clorita (7\%) e como minerais acessórios apresentam-se muscovita (2\%) e apatita + epidoto e/ou clinozoisita + titanita + zircão + opaco + sericita + carbonato (1\%). 

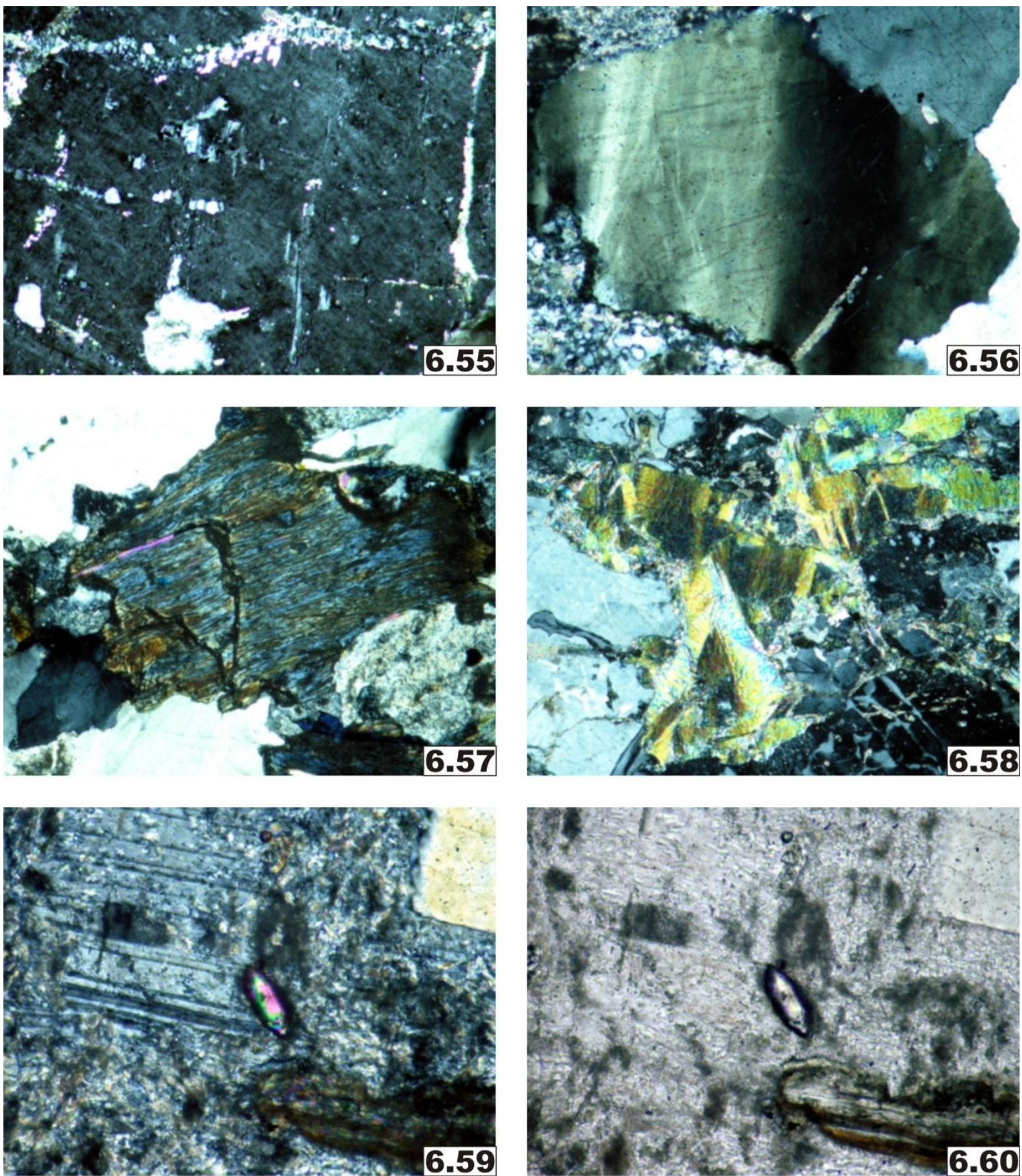

Foto 6.55. Textura pertítica. Lado maior da foto $1,07 \mathrm{~mm}$.

Foto 6.56. Quartzo com extinção ondulante. Lado maior da foto 1,07 mm.

Foto 6.57. Clorita como produto de substituição de biotita. Lado maior da foto $2,14 \mathrm{~mm}$.

Foto 6.58. Muscovita dobrada. Lado maior da foto $2,14 \mathrm{~mm}$.

Foto 6.59. Zircão idiomórfico. Lado maior da foto $0,49 \mathrm{~mm}$.

Foto 6.60. Zircão idiomórfico. Lado maior da foto $0,49 \mathrm{~mm}$.

Foto $\mathbf{6 . 6 0}$ obtida com polarizadores paralelos e $\mathbf{6 . 5 5}, \mathbf{6 . 5 6}, \mathbf{6 . 5 7}, \mathbf{6 . 5 8}$ e $\mathbf{6 . 5 9}$ com polarizadores cruzados. 
O plagioclásio $\left(A n_{20}\right)$ apresenta granulação que varia de 0,4 a $4,0 \mathrm{~mm}$, sendo os cristais xenomórficos e subidiomórficos em menor proporção. Todos os grãos, sem exceção, estão intensamente sericitizados (Foto 6.53). Inclusões de minerais opacos, titanita e apatita são comuns e muitas fraturas apresentam-se preenchidas por carbonato (Foto 6.54).

O ortoclásio constitui grãos xenomórficos que variam entre 0,8 e 2,8 mm, localmente são pertíticos (Foto 6.55) e estão parcialmente sericitizados. Alguns grãos têm inclusões de titanita e de minerais opacos.

O quartzo varia de 0,5 a $3,1 \mathrm{~mm}$, sempre é xenoblástico e exibe uma forte extinção ondulante (Foto 6.56).

A clorita ocorre como grãos usualmente subidiomórficos que variam entre 0,6 e 1,4 mm. Possivelmente é produto da substituição de biotita, pois em alguns dos grãos observam-se restos do pleocroismo típico da biotita, principalmente em alguns planos de clivagem (Foto 6.57).

A muscovita compõe grãos entre 0,6 e $1,8 \mathrm{~mm}$, predominantemente subidiomórficos e, mais raramente, xenomórficos. Alguns grãos mostram-se muito dobrados, quase formando bandas kink (Foto 6.58). A sericita é encontrada principalmente como substituição de plagioclásio e, às vezes, do ortoclásio.

O carbonato apresenta-se unicamente preenchendo fraturas do plagioclásio (Foto 6.59) e eventualmente do ortoclásio.

Apatita, epidoto e/ou clinozoisita, titanita, zircão e minerais opacos apresentam-se xenomórficos e subidiomórficos, mas o zircão também ocorre como cristais idiomórficos (Foto 6.60). A titanita apresenta leve pleocroismo que varia de tons café-escuro a claro. Nenhum destes minerais ultrapassa os $0,4 \mathrm{~mm}$ e o tamanho mínimo encontrado foi dos minerais opacos, os quais chegam a medir $0,05 \mathrm{~mm}$.

Em termos gerais, este litotipo apresenta-se holocristalino, inequigranular seriado, fanerítico e hipidiomórfico. Localmente observam-se texturas pertíticas que podem ser reliquiares do protolito.

Um resumo da mineralogia das rochas de Jambaló é apresentado na Tabela 6.1. 
Tabela 6.1. Mineralogia dos principais litotipos da área de Jambaló, onde 1 = Mica-glaucofânio ou glaucofânio micaxistos, 2 = Clorita-plagioclásio xistos (xistos verdes), 3 = Mármores, $\mathbf{4}$ = Quartzitos milonitizados, $\mathbf{5}$ = Epidositos, $\mathbf{6}=$ Estilpnomelano-muscovita-albita-anfibólio-quartzo xisto, $\mathbf{7}=$ Keratófiros, $\boldsymbol{8}$ = Metaultramáficas, 9 = Quartzo-monzonito. Proporção dos minerais: ○ Essencial, • Subordinado ( $<5 \%)$, albita ou oligoclásio, ${ }^{\complement}$ glaucofânio, só presente na lâmina $125 \mathrm{M} e^{\ddagger}$ granada só presente nas amostras $107 B$ e 118 .

\begin{tabular}{|c|c|c|c|c|c|c|c|c|c|}
\hline Mineral & 1 & 2 & 3 & 4 & 5 & 6 & 7 & 8 & 9 \\
\hline Glaucofânio & o & $\bullet^{4}$ & & $\bullet$ & & & & & \\
\hline Tremolita & & & & & & & & $\bullet$ & \\
\hline Actinolita & 0 & $\circ \bullet$ & & & & o & & & \\
\hline Hornblenda & & & & & 0 & & $\bullet$ & & \\
\hline Plagioclásio* & $\bullet$ & 0 & & $\bullet$ & $\circ \bullet$ & 0 & o & & \\
\hline Mica branca & o & $\circ \bullet$ & $\bullet$ & 0 & $\bullet$ & & & & \\
\hline Muscovita & & & & & & $\circ$ & & & $\bullet$ \\
\hline Biotita & & $\bullet$ & & & & & & & \\
\hline Quartzo & 0 & $\circ \bullet$ & $\bullet$ & 0 & $\bullet$ & o & $\bullet$ & & 0 \\
\hline Epidoto e/ou Clinozoisita & $\circ \bullet$ & $\circ \bullet$ & $\bullet$ & $\bullet$ & 0 & $\bullet$ & $\bullet$ & & $\bullet$ \\
\hline Zoisita & & $\circ \bullet$ & & $\bullet$ & & & & & \\
\hline Clorita & $\circ \bullet$ & $\circ$ & $\bullet$ & $\circ \bullet$ & $\circ$ & 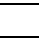 & $\bullet$ & $\bullet$ & 0 \\
\hline Carbonato & $\circ \bullet$ & $\bullet$ & 0 & & $\circ \bullet$ & 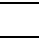 & & & $\bullet$ \\
\hline Titanita & $\bullet$ & $\bullet$ & $\bullet$ & & & $\bullet$ & & & $\bullet$ \\
\hline Rutilo & $\bullet$ & & $\bullet$ & & & & & & \\
\hline Zircão & $\bullet$ & $\bullet$ & & & $\bullet$ & & & & $\bullet$ \\
\hline Granada & $\bullet$ & $e^{t}$ & & $\bullet$ & & & & & \\
\hline Apatita & $\bullet$ & $\bullet$ & $\bullet$ & & & $\bullet$ & & & $\bullet$ \\
\hline Estilpnomelano & $\bullet$ & & & $\bullet$ & & 0 & $\bullet$ & & \\
\hline Pumpellyita & & & & & $\bullet$ & & & & \\
\hline Opacos & $\bullet$ & $\circ \bullet$ & $\bullet$ & $\bullet$ & $\circ \bullet$ & $\bullet$ & $\bullet$ & $\bullet$ & $\bullet$ \\
\hline Olivina & & & & & & & & 0 & \\
\hline Piroxênio & & & & & & & & 0 & \\
\hline Serpentina & & & & & & & & $\bullet$ & \\
\hline Ortoclásio & & & & & & & & & o \\
\hline
\end{tabular}

Um resumo da blastese dos minerais das rochas da área de Jambaló, em relação ao desenvolvimento das foliações metamórficas pode ser observado na Tabela 6.2.

Tabela 6.2. Blastese dos minerais em relação às foliações metamórficas em diferentes litotipos da área de Jambaló, onde $X A=$ xisto azul, $X V=x i s t o$ verde, Anf = anfibolito, Prh-Pmp = prehnita-pumpellyita, * albita ou oligoclásio.

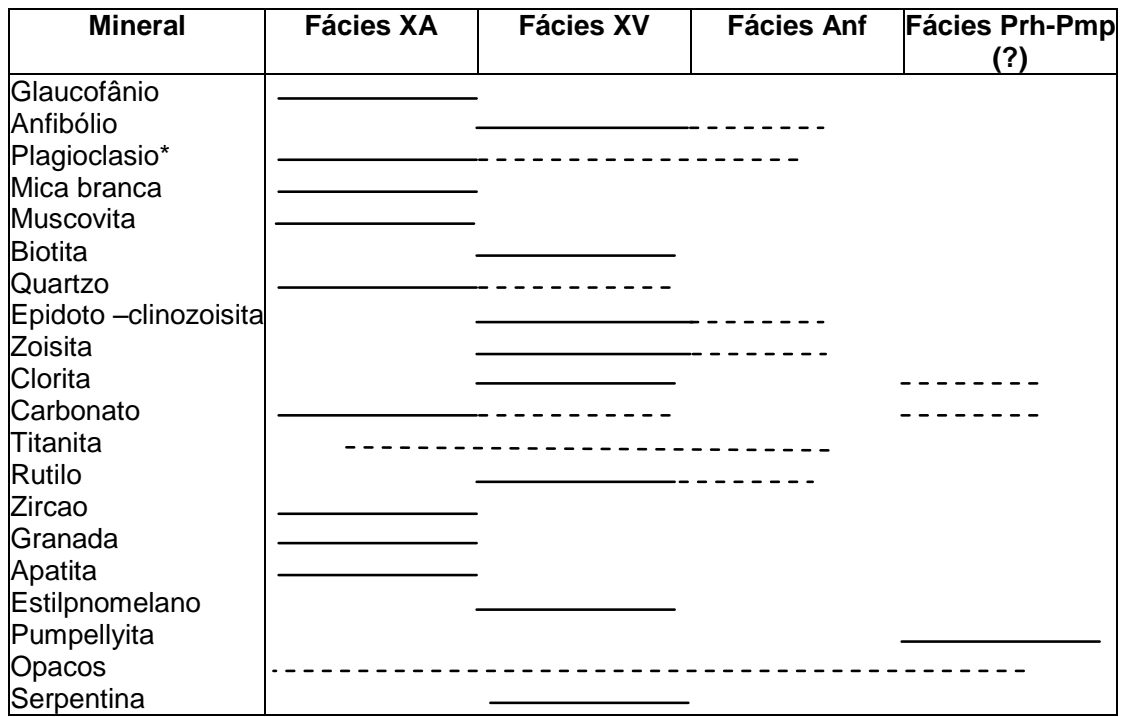




\section{DESCRIÇÃO DOS PERFIS DA REGIÃO DE BARRAGÁN}

Considerando o povoado de Barragán como o centro da área de trabalho. Os perfis foram concentrados em três estradas que saem do povoado ao sul, norte e noroeste e o mapa esquemático da geologia da região de Barragán está no Anexo Il e as descrições a seguir:

\subsection{Estrada Barragán - Santa Lucía}

Neste perfil são observados principalmente metabasitos e metapelitos.

Dentre os metabasitos predominam epidoto-glaucofânio xistos e clorita-lawsonita xistos. Os primeiros são azul-acinzentados e têm granulação muito fina e os demais são verdes, com lâminas brancas com maior concentração de lawsonita (Foto 7.1). Estes dois litotipos estão sempre intemperizados para materiais marrons, formando uma crosta ao redor da às amostras, mas são comuns núcleos de rochas frescas.

As relações estruturais entre os dois litotipos não puderam ser esclarecidas, pois os afloramentos são de um ou de outro litotipo, sem que haja continuidade ou contato entre ambos.

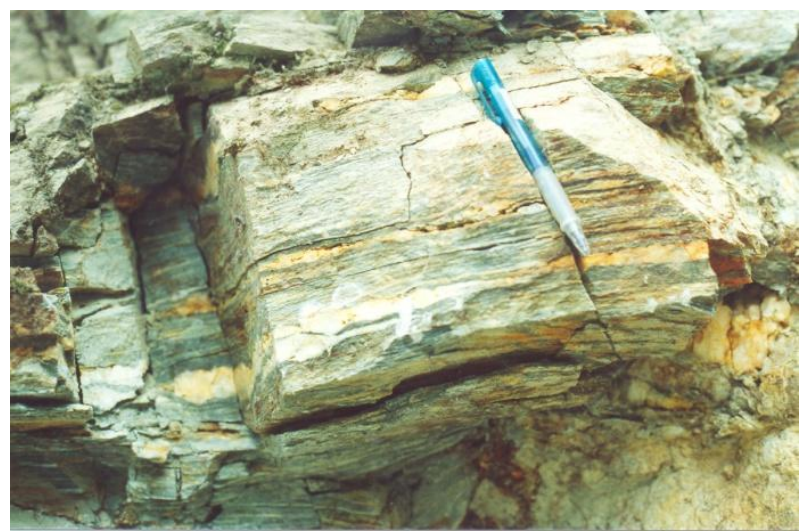

Foto 7.1. Afloramento (197) de clorita-lawsonita xisto. Nele observa-se uma rocha com bandas verdes mais ricas em clorita e bandas brancas a alaranjadas, constituídas por quartzo e lawsonita predominantes.

Apesar de irregulares, os planos da foliação tende a orientar-se preferencialmente ao redor de $\mathrm{N} 87^{\circ} \mathrm{W}$, com mergulho aproximado de $20^{\circ} \mathrm{SW}$.

Os metapelitos possuem cor cinza-escuro e são compostos principalmente por mica, grafita e quartzo. Intercalados ocorrem metassedimentos micáceos cinza-claros, mais quartzosos que os anteriores. Estas rochas apresentam-se orientadas segundo E-W com mergulhos até $40^{\circ} \mathrm{S}$.

\subsection{Estrada Barragán - Tuluá}

Nesta estrada encontram-se principalmente rochas ultramáficas intensamente serpentinizadas (Foto 7.2) e xistos metapelíticos compostos por mica, quartzo e, eventualmente, grafita. 
A relação estrutural entre estas duas unidades não pode ser determinada, pois os dois litotipos afloram nos topos de morros separados por pequenos vales. Ambos litotipos estão variavelmente intemperizados, mas corpos de rochas ultramáficas miloníticas frescas, orientadas segundo N55트 e com mergulho forte para SE estão ocasionalmente presentes. Em nenhum dos afloramentos foi possível a identificação de indicadores cinemáticos.

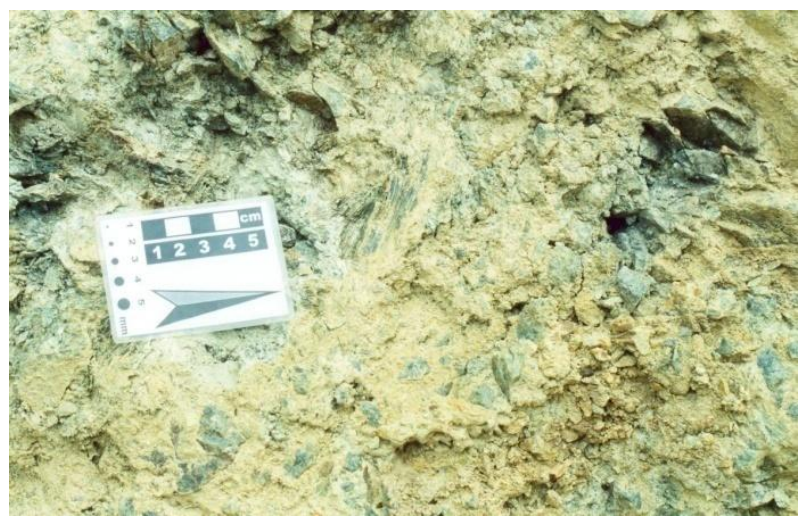

Foto 7.2. Afloramento de rochas ultramáficas intensamente serpentinizadas. As rochas apresentam-se intensamente fraturadas e milonitizadas. As cores verdes correspondem às maiores concentrações de serpentina e as cores marrons-claras a áreas mais intensamente intemperizaas.

\subsection{Estrada Barragán - Cumbarco}

Neste perfil encontram-se principalmente por retro-eclogitos cinza-escuros, por vezes azulados, compostos principalmente por granada e anfibólio (McCourt \& Feininger, 1984; González, 1997). Também estão presentes metassedimentos cinza-escuros constituídos essencialmente por grafita, quartzo e micas, assim como xistos verdes com anfibólio e clorita predominantes. Estes dois litotipos estão variavelmente intemperizados e fraturados (Foto 7.3) e uma grande quantidade de veios de quartzo irregulares, sem nenhuma orientação preferencial, cortam as rochas. Neste perfil a foliação das rochas esta orientada preferencialmente segundo $\mathrm{N} 80^{\circ} \mathrm{E}$, com mergulhos fortes para SE.

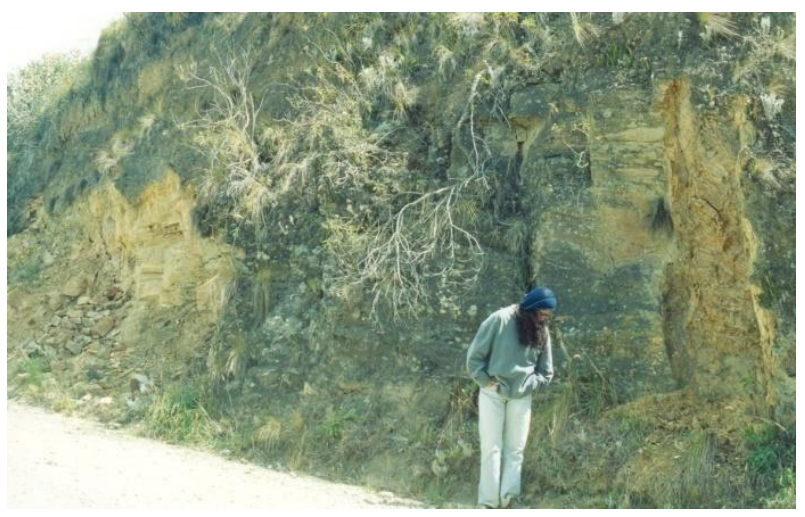

Foto 7.3. Afloramento (189) de rochas da fácies anfibolito. No afloramento nota-se o intenso intemperismo superficial e a milonitização das rochas. 


\section{PETROGRAFIA MICROSCÓPICA}

Da região de Barragán foram analisadas lâminas de metabasitos, meta-ultramáficas serpentinizadas, serpentinitos, grafita-clorita-muscovita-quartzo xistos, protocataclasitos e grafitaclorita-andaluzita-andesina-granada-muscovita xisto com titanita.

Os metabasitos foram agrupados em dois conjuntos, um deles incluindo os litotipos da fácies xisto azul e o outro da fácies anfibolito, descritos a seguir:

\subsection{Rochas na fácies xisto azul}

Esses litotipos ocorrem principalmente na estrada Barragán-Santa Lucia e são compostos por anfibólio (22-50\%), clorita (15-31\%), pumpellyita (14-35\%), lawsonita (acessório-10\%), epidoto e/ou clinozoisita (acessório-31\%), titanita (5-10\%), quartzo (1-4\%), mica branca (1-3\%), minerais opacos (2-4\%), plagioclásio (1-4\%) e calcita ( 1\%).

O anfibólio é representado exclusivamente pelo glaucofânio, que apresenta fórmula pleocróica segundo $X=$ incolor, $Y=Z=$ azul-claro e um ângulo $C^{\wedge} Z=11^{\circ}$. A sua granulação varia de 0,1 a 0,45 mm, os cristais são subidioblásticos, eventualmente xenoblásticos e comumente apresentam inclusões finas de titanita. Em algumas das amostras o glaucofânio apresenta-se zonado, com núcleo mais intensamente pleocróico que a borda (Foto 8.1). As bordas de alguns cristais apresentam-se substituídas por finos cristais de um mineral pleocróico esverdeado, possivelmente outro anfibólio, além de clorita.

Em termos gerais o anfibólio define a textura nematoblástica, sendo que a foliação melhor desenvolvida $\left(S_{n}\right)$ eventualmente encontra-se dobrada (Foto 8.2). Na lâmina MC27 Alguns foram observados arcos poligonais e uma crenulação $\left(S_{n+1}\right)$ oblíqua pouco desenvolvida, com glaucofânio associado (Foto 8.3), indicando que o início da exumação deu-se ainda na fácies xisto azul. Na amostra 197 o glaucofânio encontra-se somente nas porções de maior concentração de quartzo enquanto nas porções com menor quantidade de quartzo apresenta-se clorita e eventualmente lawsonita.

A clorita ocorre como pequenos cristais disseminado pela lâmina, de no máximo $0,2 \mathrm{~mm}$ de comprimento, com pleocroismo amarelo a verde e formas xenoblásticas, mais raramente subidioblásticas (Foto 8.4). Às vezes este mineral é observado nas bordas dos anfibólios e, comumente, apresenta inclusões de titanita. Junto ao glaucofânio arranjam-se em textura lepidonematoblástica, muitas vezes encontrando-se dobrada. Em algumas amostras associa-se à lawsonita, definindo uma textura nemato-lepidoblástica, como na amostra 197A. Em outros casos encontra-se em desequilíbrio (Foto 8.5), ou em paragênese com a lawsonita (Foto 8.6). 

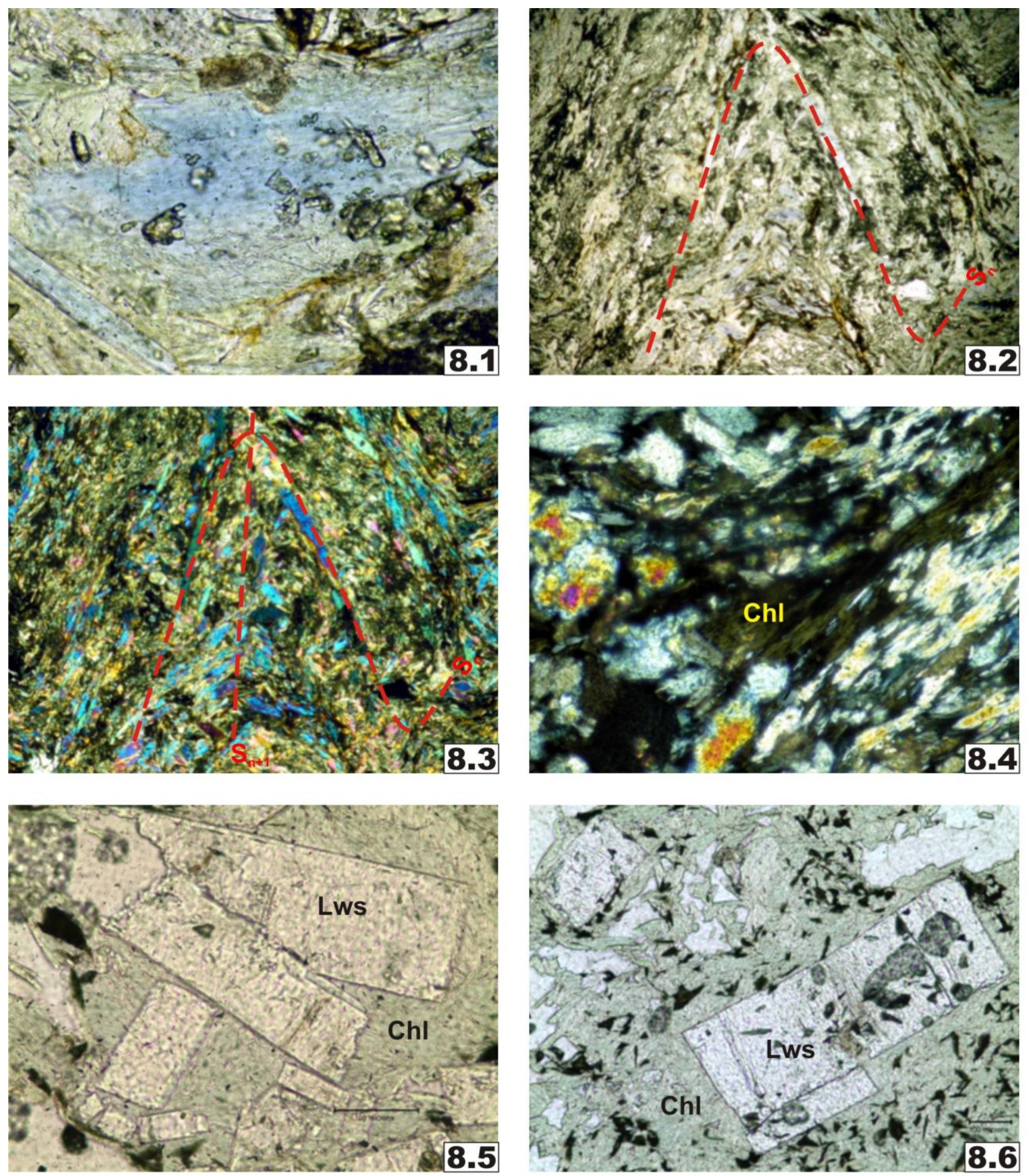

Foto 8.1. Glaucofânio com núcleo mais intensamente pleocróico que a borda. Lado maior da foto $0,65 \mathrm{~mm}$.

Foto 8.2. Textura nematoblástica dobrada. Lado maior da foto $2,14 \mathrm{~mm}$.

Foto 8.3. Crenulação $S_{n+1}$ obliqua à foliação $S_{n}$ com cristalização de glaucofânio. Lado maior da foto 2,14 $\mathrm{mm}$.

Foto 8.4. Clorita (Chl) xenoblástica e subidioblástica. Lado maior da foto $0,49 \mathrm{~mm}$.

Foto 8.5. Clorita (Chl) e lawsonita (Lws) em desequilíbrio. Lado maior da foto 0,63 mm.

Foto 8.6. Clorita (Chl) e lawsonita (Lws) em paragênese. Lado maior da foto 1,30 mm.

Fotos 8.1, 8.2, 8.5 e $\mathbf{8 . 6}$ obtidas com polarizadores paralelos e $\mathbf{8 . 3}$ e $\mathbf{8 . 4}$ com polarizadores cruzados. 
A pumpellyita está presente apenas em algumas das amostras dos afloramentos 196 e 199. Os cristais variam de 0,1 a $0,4 \mathrm{~mm}$ e são, na maioria dos casos, subidioblásticos e, eventualmente, idioblásticos. Em quase todas as amostras o mineral encontra-se em arranjos orientados, definindo a textura nematoblástica (Foto 8.7), juntamente com o glaucofânio, mas na amostra MC27 distribui-se aleatoriamente em algumas porções. O pleocroismo varia de incolor a verde-pálido e, às vezes, o mineral apresenta inclusões de titanita.

Da mesma forma que a pumpellyita, a lawsonita de distribuição generalizada, ocorrendo principalmente nas amostras do afloramento 197. Os cristais têm dimensões variando entre 0,04 e 0,50 mm sendo mais comumente subidioblásticos e mais raramente, idioblásticos (Foto 8.8). Apresentam um leve pleocroismo em tons de azul muito claro e incolor. Normalmente a lawsonita está orientada e, juntamente com a clorita, definem uma textura nemato-lepidoblástica, localmente dobrada, ou encontram-se disseminados. Os cristais podem apresentar bordas de reação gerando clorita e em alguns dos cristais é clara a presença de uma foliação $S_{i}$ (Foto 8.9) dobrada e paralela com a $S_{e}$, indicando cristalização pós-cinemática. Geminação lamelar (Foto 8.10) é observada em alguns cristais.

Epidoto e/ou clinozoisita estão presentes na maioria das amostras da fácies xisto azul e em algumas amostras apresentam um pleocroismo que varia de incolor a amarelo-claro ou zonamentos na cor e no pleocroismo, mais intenso nos núcleos que nas bordas (Fotos 8.11 e 8.12). Os grãos são xenoblásticos, às vezes subidioblástico e sua granulação varia de 0,05 e 0,20 $\mathrm{mm}$. Inclusões de quartzo são comuns e, no geral, este mineral ocorre ora disseminado ora acompanhando a foliação $S_{n}$, definindo a textura nematoblástica, juntamente com glaucofânio e/ou pumpellyita.

A titanita se apresenta em grãos que variam de 0,03 a $0,10 \mathrm{~mm}$ de comprimento, são subidioblásticos e, menos comumente xenoblásticos a idioblásticos. Geralmente distribuem-se disseminadamente e orientados na foliação (Foto 8.13), ou como inclusões, principalmente em lawsonita, clorita, glaucofânio e pumpellyita.

O quartzo é acessório, sendo que as maiores concentrações ( 10\%) são observadas nas amostras com lawsonita. Os grãos não ultrapassam 0,1 mm, são sempre xenoblásticos e exibem extinção ondulante ou, eventualmente, reta (Foto 8.14). Em algumas porções da lâmina constituem agregados com textura poligonal.

A mica branca não é comum nas rochas da fácies xisto azul, mas quando presente os grãos variam entre 0,05 e $0,120 \mathrm{~mm}$, sendo xenoblásticos e subidioblásticos (Foto 8.15). Quase sempre se apresenta disseminado e somente em partes da lâmina MC27 acompanha a foliação e define uma fraca textura lepidoblástica. 

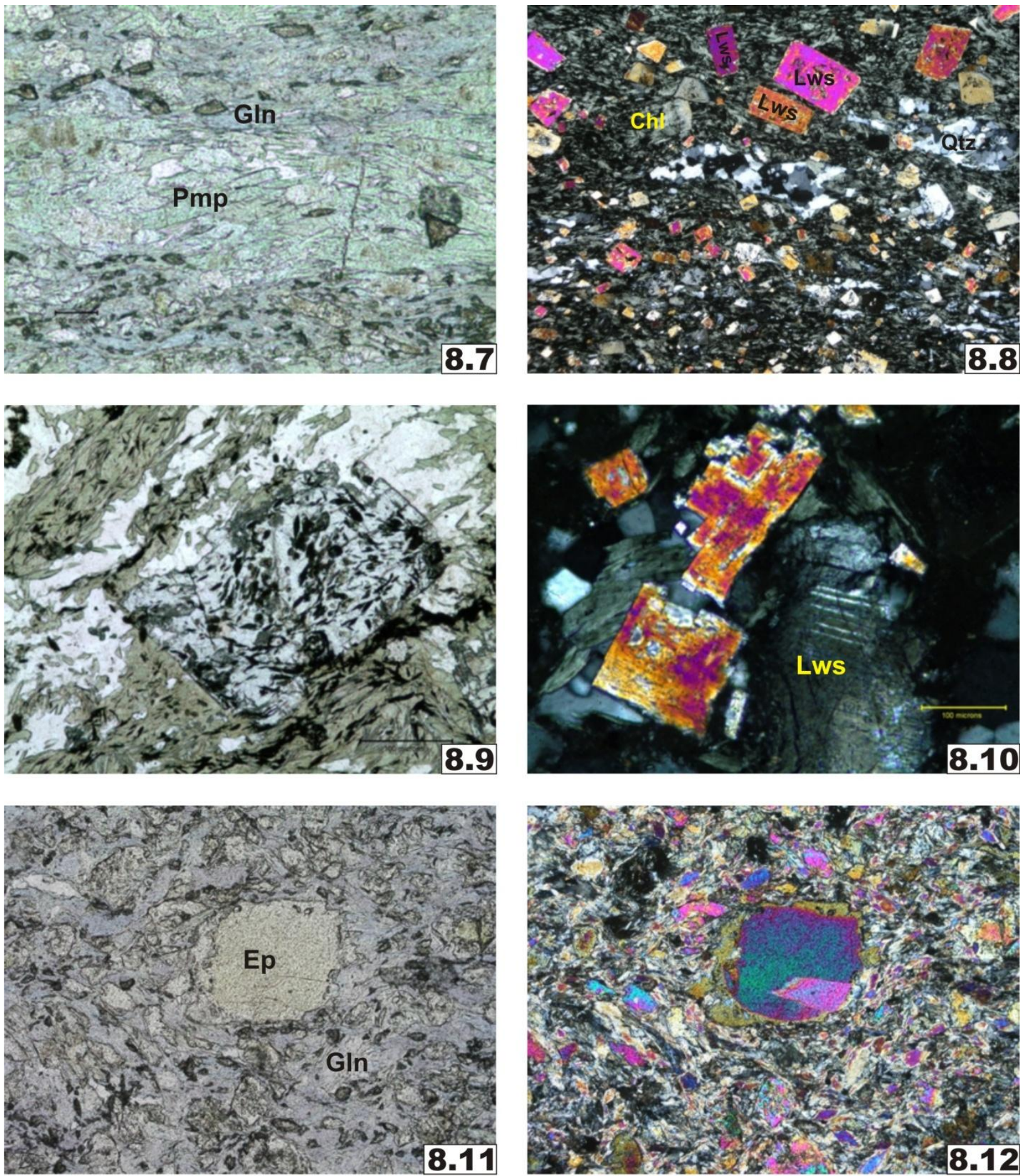

Foto 8.7. Pumpellyita (Pmp) em textura nematoblástica junto ao glaucofânio (Gln). Lado maior da foto $1,30 \mathrm{~mm}$.

Foto 8.8. Cristais subidioblásticos e idioblásticos de lawsonita (Lws). Lado maior da foto 3,20 mm.

Foto 8.9. Foliação $S_{i}$ definida pelas inclusões de titanita em lawsonita. Lado maior da foto $2,60 \mathrm{~mm}$.

Foto 8.10. Geminação lamelar em lawsonita. Lado maior da foto $0,65 \mathrm{~mm}$.

Foto 8.11. Epidoto (Ep) zonado, evidenciado na variação da cor. Lado maior da foto 1,30 mm.

Foto 8.12. Epidoto (Ep) zonado, evidenciado na variação da birrefringência. Lado maior da foto $1,30 \mathrm{~mm}$.

Fotos 8.7, 8.9 e $\mathbf{8 . 1 1}$ obtidas com polarizadores paralelos e 8.8, 8.10 e 8.12 com polarizadores cruzados. 

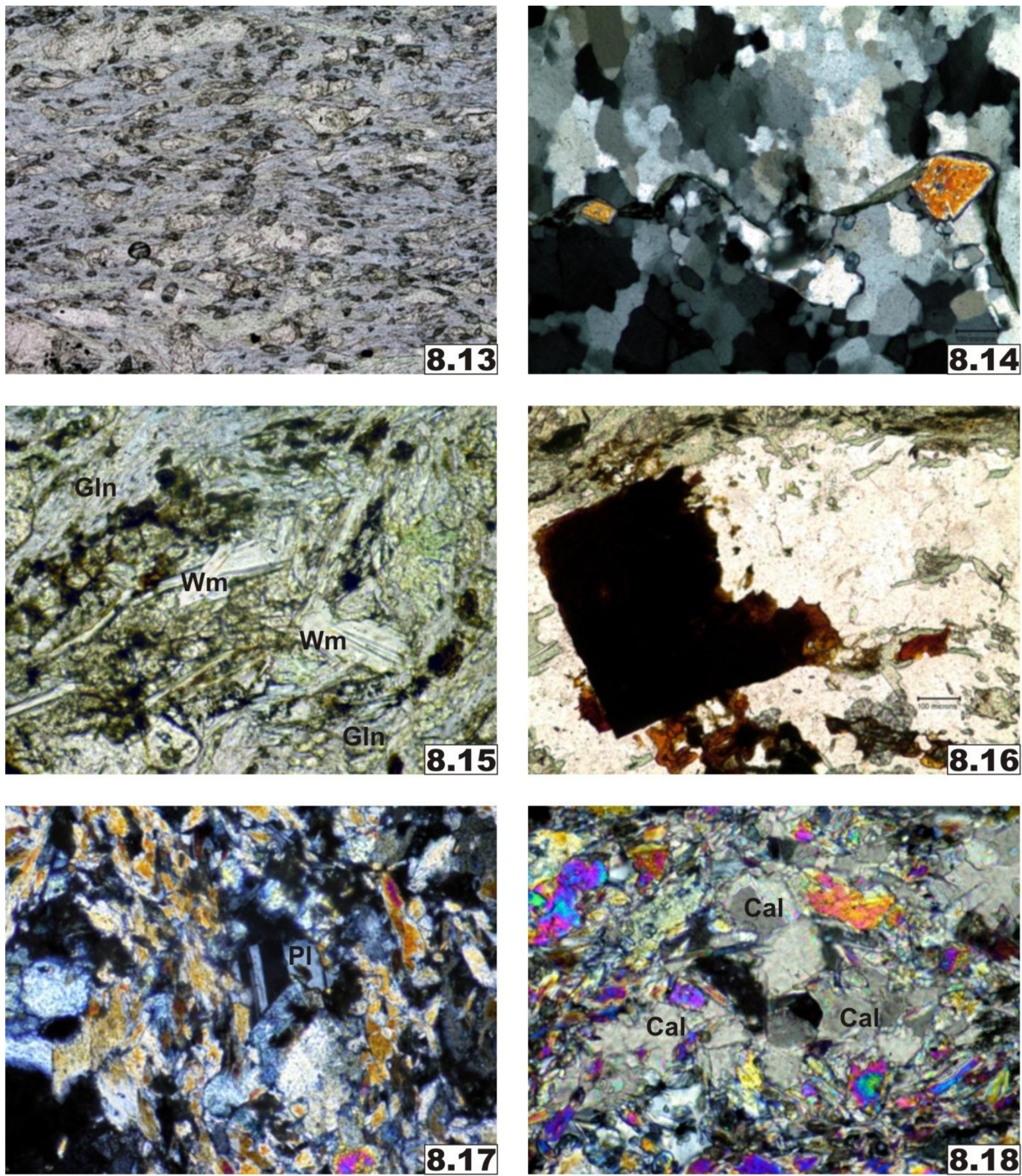

Foto 8.13. Titanita disseminada e acompanhando a foliação. Lado maior da foto $1,30 \mathrm{~mm}$.

Foto 8.14. Quartzo com extinção plana. Lado maior da foto $1,30 \mathrm{~mm}$.

Foto 8.15. Mica branca (Wm) junto ao glaucofânio (Gln), epidoto e opacos. Lado maior da foto $0,49 \mathrm{~mm}$.

Foto 8.16. Pirita parcialmente oxidada. Lado maior da foto $0,65 \mathrm{~mm}$.

Foto 8.17. Grãos de plagioclásio (PI) com geminação de tipo albita. Lado maior da foto $0,49 \mathrm{~mm}$.

Foto 8.18. Calcita (Cal) xenoblástica intersticial. Lado maior da foto $0,49 \mathrm{~mm}$.

Fotos $\mathbf{8 . 1 3}$, $\mathbf{8 . 1 5}$ e $\mathbf{8 . 1 6}$ obtidas com polarizadores paralelos e $\mathbf{8 . 1 4}$, $\mathbf{8 . 1 7}$ e $\mathbf{8 . 1 8}$ com polarizadores cruzados. 
Os minerais opacos ocorrem disseminados e são representados predominantemente pela ilmenita, magnetita e pirita (Foto 8.16), que formam cristais subidioblásticos e idioblásticos que alcançam até $0,5 \mathrm{~mm}$. Freqüentemente a ilmenita foi parcialmente substituída por leucoxênio e, comumente, a magnetita e a pirita mostram-se intemperizados para hidróxidos de ferro.

O plagioclásio $\left(\sim \mathrm{An}_{10}\right)$ se encontra unicamente nas amostras 196D, 196E e MC27. Os grãos variam de 0,05 a 0,150 mm e são, na maioria dos casos, subidioblásticos ou xenoblásticos. Normalmente apresenta-se disseminados na rocha, mas na amostra MC27 observa-se num pequeno veio de plagioclásio, indicando a existência de metassomatismo sódico. Alguns dos grãos apresentam zonamento concêntrico, indicando variações na no teor de anortita, mas devido às suas formas e à ausência de geminação, não foi possível determinar-se se o zonamento é normal ou inverso. Eventualmente observam-se grãos com geminação polissintética (Foto 8.17) e são comuns pequenas inclusões globulares de quartzo.

Calcita foi observada unicamente na amostra 196A, formando pequenos cristais xenoblásticos disseminados ou intersticiais que não ultrapassam os $0,1 \mathrm{~mm}$ de comprimento (Foto 8.18). Apresenta, mais raramente, geminação lamelar.

Em termos gerais, estes litotipos apresentam textura nematoblástica definindo a foliação $\mathrm{S}_{\mathrm{n}}$, com eventuais variações a lepido-granoblástica, quando o glaucofânio e a pumpellyita associam-se à clorita. A foliação $S_{n}$ pode estar dobrada, raramente definindo uma foliação $S_{n+1}$. Localmente observam-se alguns arcos poligonais em glaucofânio, indicando que as a temperatura manteve-se relativamente estável após a deformação. Estes arcos podem eventualmente representar pequenas dobras intrafoliais que definem uma $S_{n-1}$.

As rochas deste grupo são genericamente classificadas como pumpellyita-clorita-epidotoglaucofânio xistos, glaucofânio-clorita-pumpellyita xistos e, mais raramente, como lawsonita-clorita xistos.

\subsection{Rochas na fácies anfibolito}

Este litotipo ocorre principalmente na Estrada Barragán-Cumbarco. Além das rochas da fácies anfibolito, diversos autores (e.g. McCourt \& Feininger, 1984; González, 1997) têm sugerido a presença de rochas da fácies eclogito na região de Barragán, mas no presente trabalho foram encontrados poucos afloramentos de rochas que respaldem essas citações.

Os anfibolitos são compostos por anfibólio (42-65\%), granada (8-20\%), plagioclásio (7$11 \%)$, zoisita (10-14\%), epidoto e/ou clinozoisita (5-12\%), titanita (3-10\%), quartzo (1-6\%), rutilo (1-2\%), clorita ( 1\%), mica ( 1\%) e escapolita (3\%), esse somente em veios na amostra 188. Apatita foi identificada em quantidades muito reduzidas na lâmina 187B. Rochas que apresentam zoisita não possuem epidoto e/ou clinozoisita e vice-versa. 
O anfibólio apresenta uma fórmula pleocróica segundo $X=$ amarelo-esverdeado, $Y=$ verde e $Z$ = verde-azulado e um ângulo $C^{\wedge} Z=24^{\circ}$, correspondendo petrograficamente a uma hornblenda. O tamanho dos grãos varia entre 0,1 e 2,5 mm e são subidioblásticos, muito embora não faltem cristais xenoblásticos. Às vezes observam-se zonamentos dados por núcleos menos intensamente pleocróicos que as bordas (Foto 8.19) e, geralmente, esse mineral arranja-se numa textura nematoblástica que define a foliação $S_{n}$, que é dominante nessas rochas. Na lâmina 187 foi observada localmente substituição da hornblenda (Foto 8.20) por, possivelmente, actinolita, de difícil caracterização óptica, em função das dimensões reduzidas dos cristais. Na lâmina 188 ocorre localmente anfibólio fibroso, que pode concentrar-se na borda de cristais de granada, formando uma textura simplectítica (Foto 8.21), possivelmente indicando que se trata de um retroeclogito, mas esta feição não e comum no conjunto de rochas desta unidade. Nessa lâmina os anfibólios podem apresentar núcleos mais azulados no anfibólio (Foto 8.22), indicando composições mais sódicas, sugerindo uma possível passagem da fácies xisto azul de alta temperatura, para a fácies anfibolito e com tendência final à fácies epidoto anfibolito.

A granada forma porfiroblastos subidioblásticos e xenoblásticos com diâmetros variando entre 0,3 e 1,9 mm, com inclusões de epidoto e/ou clinozoisita e quartzo. Os porfiroblastos às vezes exibem com sombras de pressão simétricas e assimétricas, nas quais cristalizou-se quartzo, plagioclásio, clorita e anfibólio, indicando que, pelo menos em parte, são anteriores à foliação $S_{n}$. Bordas geradas por cristalização acretiva são observadas em algumas das amostras, possivelmente relacionável ao evento de desenvolvimento da $S_{n+1}$. Às vezes a granada apresenta núcleo ricos em inclusões e bordas mais límpidas (Foto 8.23), zonamento esse que pode ser indicativo de um aumento da temperatura durante a cristalização do mineral. Comumente nota-se substituição das bordas da granada por plagioclásio, indicativo de um evento descompressivo, juntamente com epidoto e/ou clinozoisita e clorita. A clorita cristaliza-se também nas fraturas, indicando retrometamorfismo na fácies xisto verde. Na amostra 187B observam-se cristais esqueléticos de granada, bem como cristais deformados e fragmentados, sendo esta uma granada pré- $S_{\mathrm{n}}$ e na amostra 188 os cristais estão muito fraturados e mostram com uma corona simplectito com anfibólio, epidoto, plagioclásio e quartzo, indicando que possivelmente algumas das amostras analisadas correspondam a retro-eclogitos.

O plagioclásio $\left(\mathrm{An}_{12-22}\right)$ apresenta-se como grãos xenoblásticos com entre 0,5 a 2,8 mm de comprimento, comumente apresentam zonamento concêntrico normal e mais raramente apresentam geminação do tipo albita (Foto 8.24). Os grãos são geralmente poiquiloblásticos (Foto 8.25), com inclusões de anfibólio, granada, epidoto-clinozoisita, titanita, quartzo e clorita, sendo que o plagioclásio é tardio em relação à foliação, o que possivelmente sugere que este litotipo corresponda a retro-eclogitos. Os cristais orientam-se concordantemente à foliação $S_{n}$. Em algumas amostras, associada com anfibólio, faz parte de coronas simplectíticas em granada, notadamente na lâmina 188. 

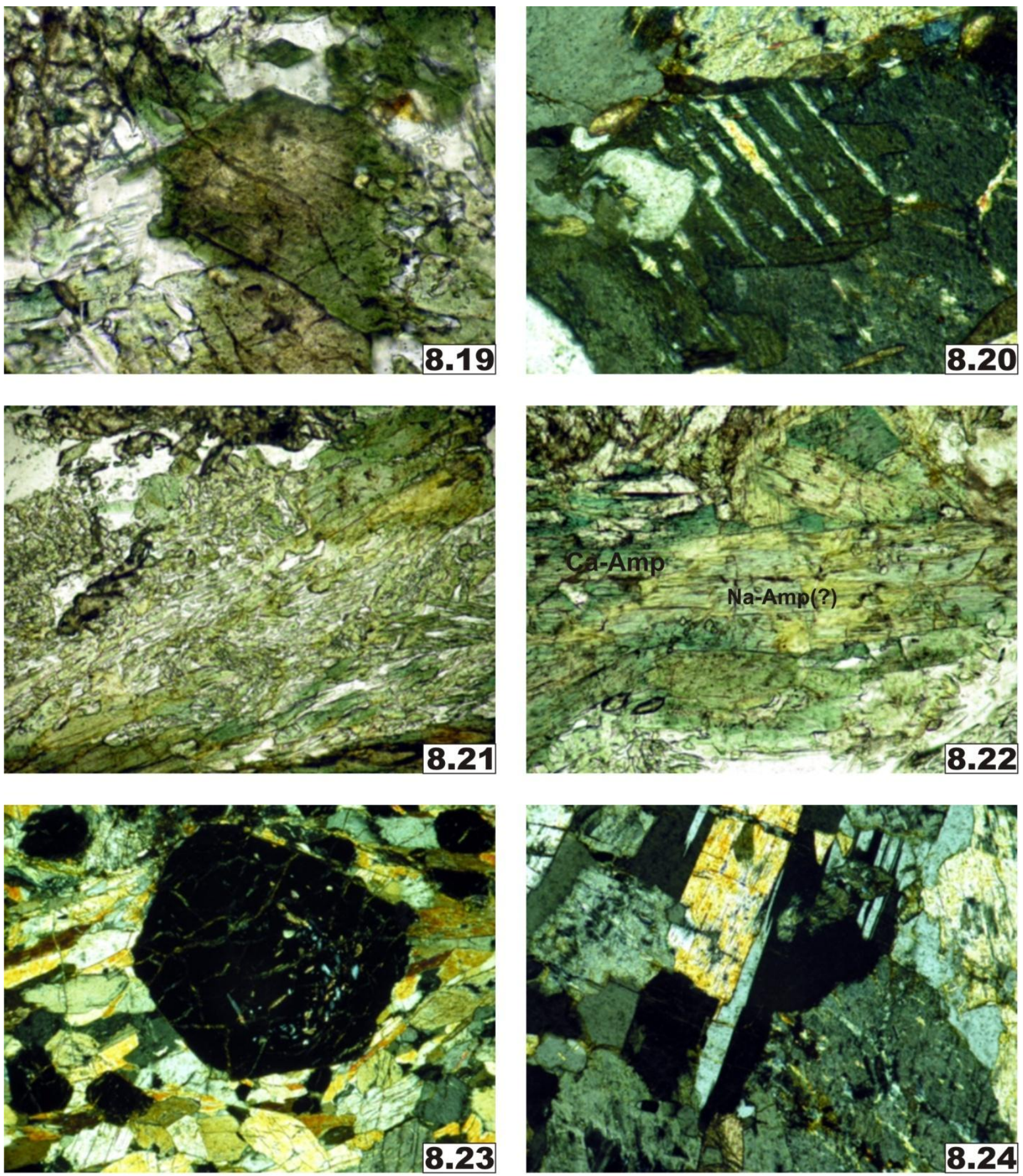

Foto 8.19. Zonamento do anfibólio. Lado maior da foto $0,49 \mathrm{~mm}$.

Foto 8.20. Exsolução de outro anfibólio na hornblenda. Lado maior da foto $0,49 \mathrm{~mm}$.

Foto 8.21. Textura simplectítica em borda de anfibólio. Lado maior da foto 1,07 mm.

Foto 8.22. Possível anfibólio sódico (Na-Amp) em núcleo de anfibólio cálcico (Ca-Amp). Lado maior da foto $1,07 \mathrm{~mm}$

Foto 8.23. Granada com inclusões no núcleo e bordas límpidas. Lado maior da foto 2,14 mm.

Foto 8.24. Plagioclásio com geminação de tipo albita. Lado maior da foto $1,07 \mathrm{~mm}$.

Fotos $\mathbf{8 . 1 9}$, 8.21 e $\mathbf{8 . 2 2}$ obtidas com polarizadores paralelos e $\mathbf{8 . 2 0}$, 8.23 ,e 8.24 com polarizadores cruzados. 

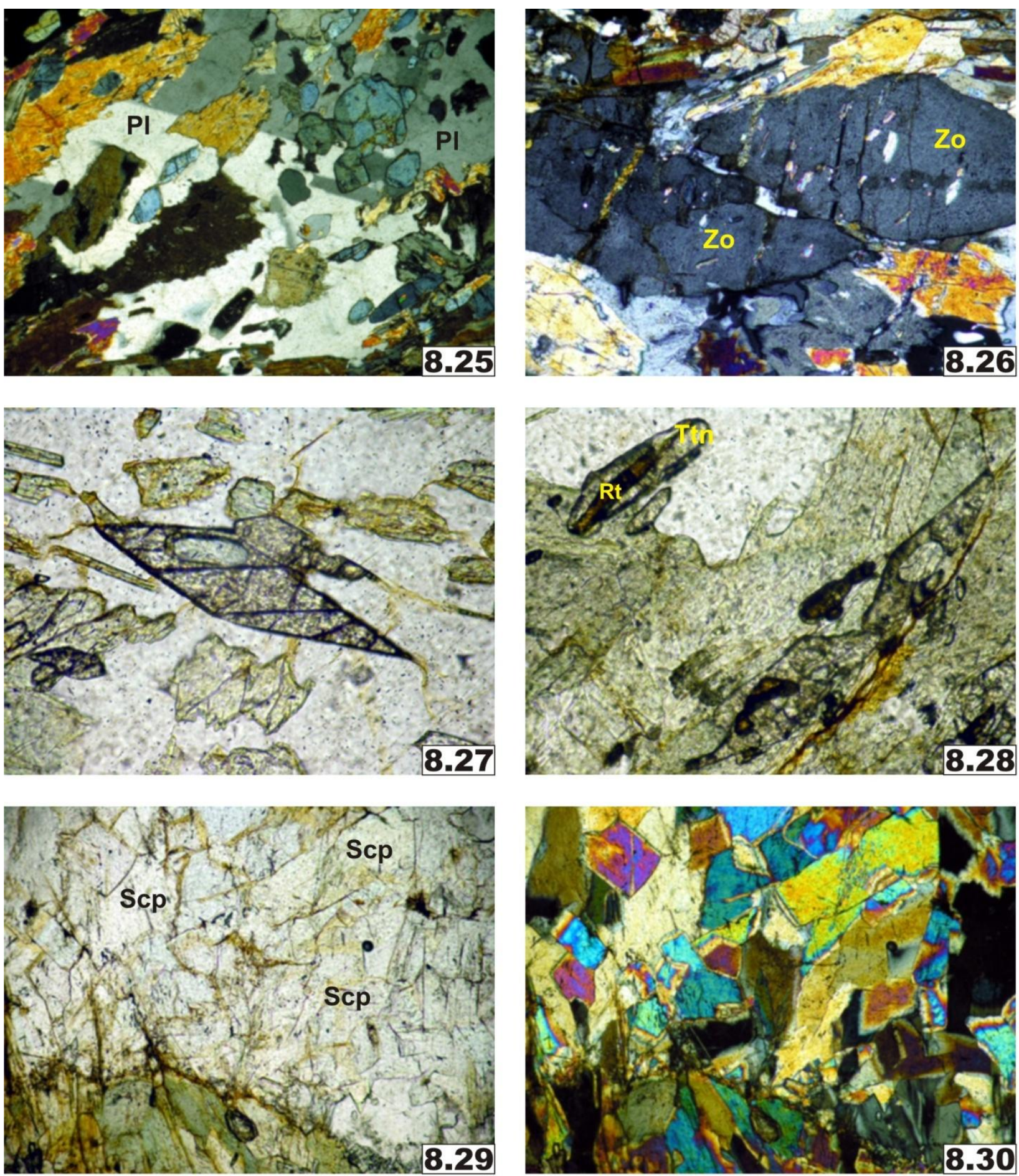

Foto 8.25. Plagioclásio (PI) poiquiloblástico. Lado maior da foto $2,14 \mathrm{~mm}$.

Foto 8.26. Zoisita (Zo) idioblástica. Lado maior da foto $1,07 \mathrm{~mm}$.

Foto 8.27. Titanita idioblástica. Lado maior da foto $0,49 \mathrm{~mm}$.

Foto 8.28. Titanita (Ttn) em borda de reação de rutilo (Rt). Lado maior da foto $0,49 \mathrm{~mm}$.

Foto 8.29. Veio de escapolita (Scp). Lado maior da foto $1,07 \mathrm{~mm}$.

Foto 8.30. Veio de escapolita. Lado maior da foto $1,07 \mathrm{~mm}$.

Fotos $\mathbf{8 . 2 7}, \mathbf{8 . 2 8}$ e $\mathbf{8 . 2 9}$ obtidas com polarizadores paralelos e $\mathbf{8 . 2 5}$, $\mathbf{8 . 2 6}$ e $\mathbf{8 . 3 0}$ com polarizadores cruzados. 
A zoisita apresenta-se como cristais subidioblásticos ou idioblásticos variando entre 0,1 e 3,0 mm de comprimento, possuem inclusões de titanita e estão levemente fraturados (Foto 8.26). Ocorrem disseminados ou concentrados junto ao anfibólio, na textura nematoblástica.

Epidoto e/ou clinozoisita são observados na maioria das amostras analisadas, nunca coexistindo com zoisita. Forma cristais subidioblásticos e xenoblásticos com 0,1 a 0,7 mm de comprimento e alguns grãos parece indicar zonamento composicional, dado pela variação da birrefringência no núcleo e na borda. Geralmente esses se encontram disseminados ou concentrados nas sombras de pressão da granada. $O$ epidoto e a clinozoisita apresentam contatos retos com a granada e com o anfibólio, mas foram também observados alguns casos nos quais os contatos são serrilhados. Pelas relações texturais observadas, os minerais do grupo do epidoto parecem estar indicando terem sido cristalizados tardiamente.

A titanita apresenta-se com um pleocroismo leve que varia em tons de café claro e escuro, em tamanhos que variam entre 0,05 e 0,55 mm sendo esta xenoblástica, subidioblástica e idioblástica (Foto 8.27). Este mineral encontra-se também como finos cristais inclusos em anfibólio e plagioclásio ou é produto da substituição do rutilo (Foto 8.28). Embora a titanita ocorra disseminada nas lâminas, esta sempre está orientada segundo a foliação $S_{n}$.

O quartzo encontra-se como grãos xenoblásticos com dimensões que variam entre 0,15 e 0,6 mm, usualmente com extinção ondulante e, mais raramente, reta. Apresenta-se disseminado ou como finos cristais inclusos na granada, plagioclásio e, eventualmente, nas coronas simplectíticas da granada.

A escapolita está presente unicamente na amostra 188, onde forma veios que cortam a foliação principal $S_{n}$ (Fotos 8.29 e 8.30), constituídos por grãos xenoblásticos e subidioblásticos que variam entre 0,05 e $0,8 \mathrm{~mm}$. A escapolita foi classificada, em função da sua birrefringência, como possuindo um conteúdo de marialita ao redor $30 \%$.

O rutilo é representado por pequenos grãos xenoblásticos e subidioblásticos que variam entre 0,03 e 0,25 mm de comprimento. Encontra-se disseminado e, eventualmente, com os grãos orientados segundo a foliação $S_{n}$ e são comuns pequenos cristais com borda de titanita (Foto 8.28).

A clorita apresenta um leve pleocroismo que varia em tons de verde-claro e amarelo, constitui cristais geralmente xenoblásticos e, menos freqüentemente subidioblásticos, com tamanhos variando entre 0,1 e 0,6 mm. Encontra-se geralmente disseminada, mas também ocorre associada nas coronas simplectíticas da granada, sendo que esta clorita faz parte do evento retrometamórfico que afetou as rochas.

A mica apresenta-se como pequenos grãos que variam entre 0,1 e 0,3 mm, sempre xenoblásticos. Encontra-se disseminada e também inclusa em plagioclásio e anfibólio (Foto 8.31). 

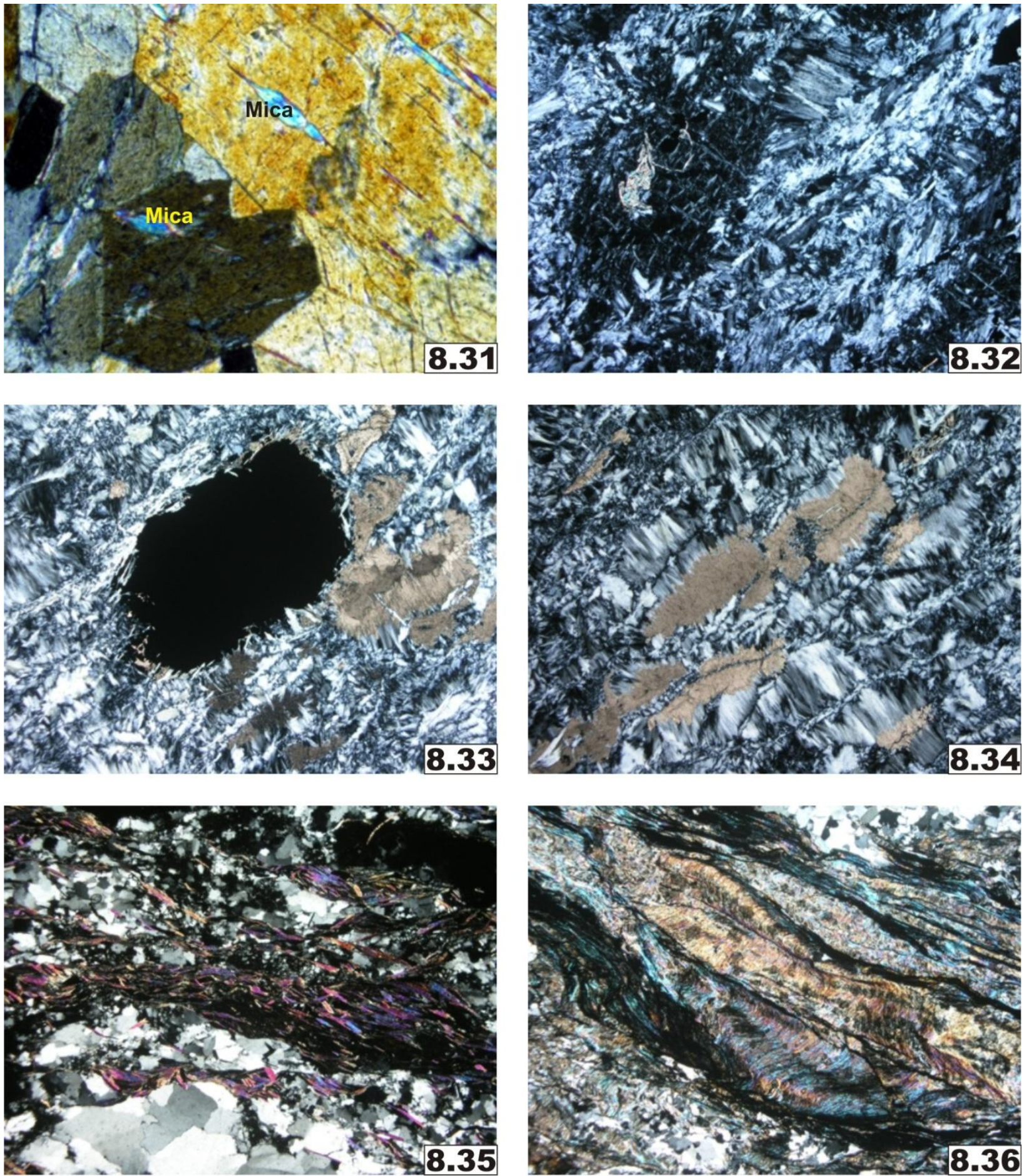

Foto 8.31. Inclusão de mica em plano de clivagem de anfibólio. Lado maior da foto 0,49 $\mathrm{mm}$.

Foto 8.32. Cristais placóides de serpentina e textura mesh preservada. Lado maior da foto $3,20 \mathrm{~mm}$.

Foto 8.33. Mineral opaco xenoblástico arredondado. Lado maior da foto $3,20 \mathrm{~mm}$.

Foto 8.34. Carbonato e serpentina. Lado maior da foto $3,20 \mathrm{~mm}$.

Foto 8.35. Quartzo com contatos suturados e com extinção ondulante. Lado maior da foto 3,20 mm.

Foto 8.36. Mica e grafita em foliação e crenulação. Lado maior da foto $3,20 \mathrm{~mm}$.

Todas as fotos obtidas com polarizadores cruzados. 
Texturalmente estes litotipos apresentam textura nematoblástica definida pela orientação do anfibólio e, eventualmente, acompanhada por minerais do grupo do epidoto. Também é comum observar-se textura porfiroblástica definida pela granada e, às vezes, encontra-se plagioclásio poiquiloblástico. A textura nematoblástica define uma $S_{n}$ e uma segunda foliação, definida também pelo anfibólio, marca a $S_{n+1}$. Durante o desenvolvimento dessa foliação também ocorreu cristalização acretiva na borda de alguns grãos de granada.

As rochas deste grupo podem ser classificadas como epidoto-oligoclásio-granadahornblenda xistos ou oligoclásio-epidoto-granada-anfibólio xistos, dependendo das concentrações de oligoclásio, epidoto, clinozoisita e zoisita. Muiro embora os minerais do grupo de epidoto estejam presentes em todas as amostras, a associação hornblenda + oligoclásio é típica da fácies anfibolito.

\subsection{Serpentinitos}

Estas rochas ocorrem principalmente na estrada Barragán-Tuluá e são compostas por serpentina (94-99\%) e minerais opacos (1-6\%). Carbonato ( 5\%) foi encontrado apenas nas amostras 184C e 184D e ortopiroxênio ( 5\%) unicamente na lâmina 184.

A serpentina apresenta um tamanho de grão que varia de 0,4 a 1,0 $\mathrm{mm}$ e os cristais são subidioblásticos e placóides (Foto 8.32), indicando serem possivelmente antigorita. Eventualmente, definem textura lepidoblástica orientada na foliação $S_{n}$ mas também podem formar agregados com arranjos radiados e, localmente observar-se textura mesh preservada (Foto 8.32).

Os minerais opacos apresentam-se em grãos menores de $2,0 \mathrm{~mm}$, geralmente xenoblásticos e arredondados, os quais estão disseminados na lâmina (Foto 8.33).

O ortopiroxênio apresenta-se em grãos de no máximo $1,2 \mathrm{~mm}$, são xenoblásticos e possuem grande quantidade de inclusões de minerais opacos. Em geral estão disseminados na lâmina e podem estar completamente substituídos por serpentina, restando apenas pseudomorfos, às vezes com pequenos restos do mineral nos núcleos, onde observa-se somente a sua clivagem.

A calcita constitui agregados, juntamente com a serpentina, e geralmente encontra-se disseminada na lâmina toda (Foto 8.34). Eventualmente apresenta lamelas de deformação.

Especialmente na lâmina 184A observa-se textura lepidoblástica bem definida, dada pela orientação da serpentina. A presença de piroxênio numa das amostras sugere que os protólitos destes serpentinitos correspondam a peridotitos ou harzburgitos. 


\subsection{Grafita-clorita-muscovita-quartzo xistos}

Este litotipo ocorre principalmente na estrada Barragán-Santa Lucia. São rochas compostas por quartzo (40-55\%), muscovita (20-30\%), clorita (15-25\%), grafita (5-12\%) e como minerais subordinados encontram-se opacos (subordinado a $5 \%$ ), albita $(<3 \%)$ e apatita $(<1)$.

O quartzo apresenta-se em grãos menores de $0,7 \mathrm{~mm}$, todos xenoblásticos, que definem localmente uma textura granoblástica em mosaico, com grãos em contatos de $120^{\circ}$, com contatos suturados e com extinção ondulante (Foto 8.35).

A muscovita constitui grãos de no máximo $0,4 \mathrm{~mm}$ de comprimento, geralmente xenoblásticos e, mais raramente subidioblásticos, definido uma textura lepidoblástica (Foto 8.36). Também se cristalizou em sombras de pressão de minerais opacos, como na amostra 187C, e alguns grãos mostram-se dobrados formando kink bands, com cristais com extinção fortemente ondulante.

A clorita apresenta pleocroismo leve, que varia em tons de verde muito claro a incolor, e ocorre como cristais com dimensões inferiores $0,4 \mathrm{~mm}$, xenoblásticos e, eventualmente, subidioblásticos. Juntamente com a muscovita definem uma textura lepidoblástica (Foto 8.37).

A grafita apresenta-se como agregados formando delgadas lâminas que se estendem ao longo da amostra e sempre acompanhando a foliação milonitica (Foto 8.38).

Os minerais opacos estão presentes como grãos disseminados que variam de 0,5 a 2,7 mm, mas na lâmina 187C constituem porfiroblastos (Foto 8.39). Usualmente são subidioblásticos, exceto na amostra 187C, onde formam cristais idioblásticos. Comumente têm inclusões de mica e quartzo e estão parcialmente intemperizados. As formas sugerem ser o mineral a pirita.

A albita constitui grãos xenoblásticos de 1,0 a 1,5 mm e, em algumas amostras, podem constituir porfiroblastos. Embora o zonamento não seja muito claro, vários grãos apresentam extinção concêntrica e, mais raramente observam-se inclusões de mica.

A apatita ocorre como grãos menores de $0,2 \mathrm{~mm}$, arredondados e disseminados nas amostras.

Numa destas amostras (185) foram observados agregados de argilo-minerais com formas formas retangulares e losangulares "fantasmas" (Foto 8.40), sugerindo serem feldspatos intemperizados.

Estes xistos apresentam uma forte foliação definida principalmente pelos minerais micáceos e a grafita. O quartzo geralmente forma bandas paralelas à foliação, mas também se apresenta como veios delgados, formados por cristais de granulação fina formando arranjos grano-lepidoblástico e lepido-granoblástico. O quartzo também esta presente em sombras de pressão dos minerais opacos, principalmente na amostra 187C. Na maioria das amostras também é possível observar uma crenulação com cristalização de muscovita e grafita associada (Foto 8.36). Eventualmente muscovita ocorre nas sombras de pressão. 

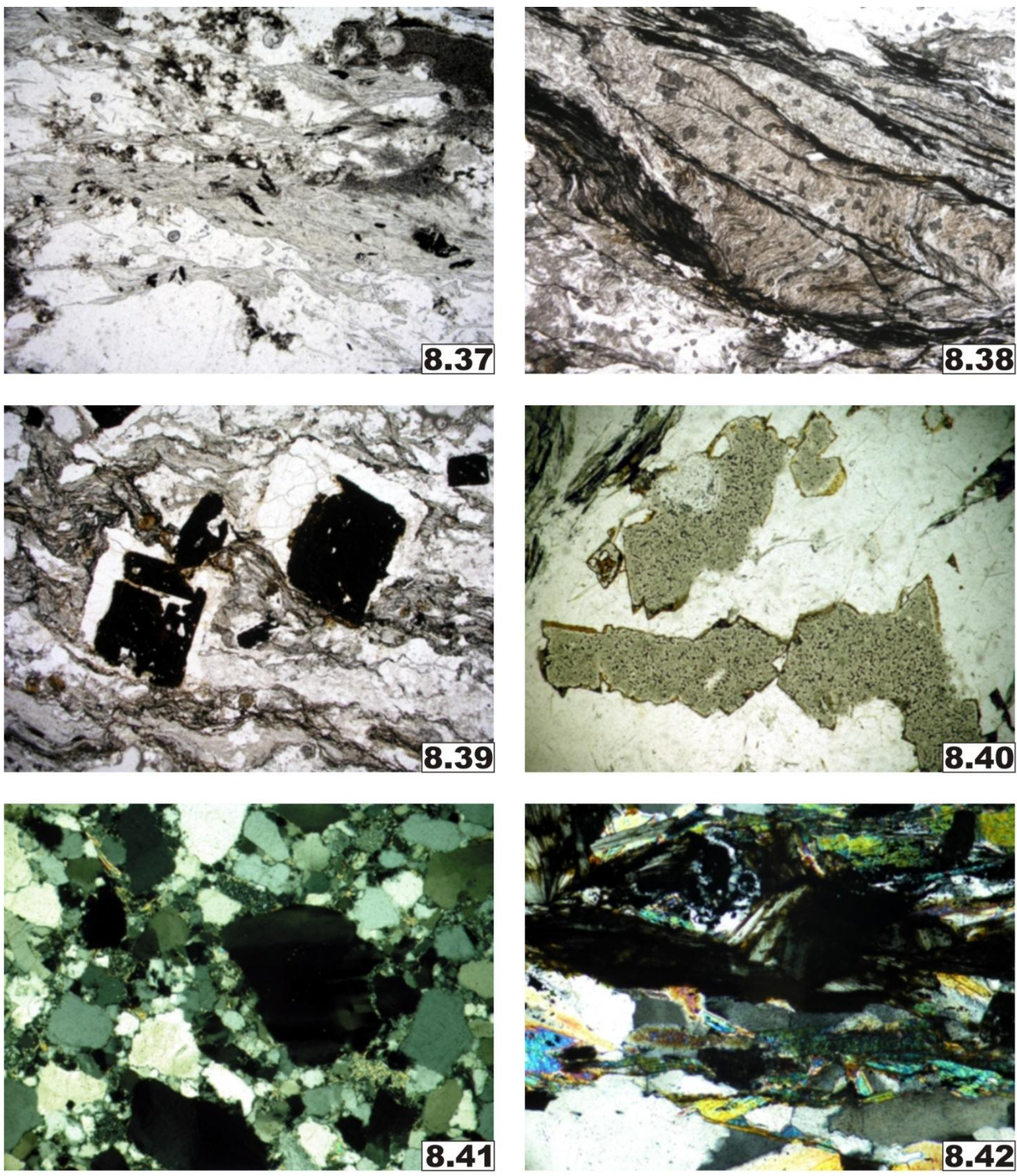

Foto 8.37. Textura lepidoblástica de clorita junto a muscovita. Lado maior da foto $3,20 \mathrm{~mm}$.

Foto 8.38. Grafita acompanhando a foliação. Lado maior da foto $3,20 \mathrm{~mm}$.

Foto 8.39. Minerais opacos porfiroblásticos. Lado maior da foto $10,20 \mathrm{~mm}$.

Foto 8.40. "Fantasmas" de feldspato(?). Lado maior da foto $2,14 \mathrm{~mm}$.

Foto 8.41. Textura mortar em protocataclasito. Lado maior da foto $2,14 \mathrm{~mm}$.

Foto 8.42. Textura granolepidoblástica com muscovita, clorita e quartzo. Lado maior da foto 1,07 mm.

Fotos $\mathbf{8 . 3 7}, \mathbf{8 . 3 8}, \mathbf{8 . 3 9}$ e $\mathbf{8 . 4 0}$ obtidas com polarizadores paralelos e $\mathbf{8 . 4 1}$ e $\mathbf{8 . 4 2}$ com polarizadores cruzados. 


\subsection{Protocataclasitos}

Este litotipo encontra-se na estrada Barragán-Santa Lucia, sendo rochas com uma mineralogia monótona, compostas principalmente por quartzo (90-95\%) e minerais opacos (4$6 \%)$. Como acessórios ocorrem muscovita $(2-4 \%)$ zircão $(\sim 1 \%)$ e turmalina $(<1 \%)$.

O quartzo apresenta-se como porfiroclastos de 0,3 a $2,1 \mathrm{~mm}$ ou dispersos na matriz, em grãos que alcançam $0,1 \mathrm{~mm}$ de diâmetro. Os cristais são xenoblásticos, apresentam forte extinção ondulante e, esporadicamente, definem textura mortar (Foto 8.41).

Minerais opacos ocorrem em grãos disseminados, de no máximo $0,1 \mathrm{~mm}$, xenoblásticos e com uma cor de oxidação avermelhada.

A muscovita ou sericita apresenta-se em grãos disseminados de no máximo $0,1 \mathrm{~mm}$, xenoblásticos e, eventualmente, subidioblásticos.

O zircão ocorre em grãos que dificilmente alcançam os $0,1 \mathrm{~mm}$, sendo todos eles subidioblásticos e sempre disseminados nas rochas.

A turmalina é observada em pequenos cristais xenoblásticos disseminados, de no máximo $0,05 \mathrm{~mm}$.

Estas rochas apresentam comumente típica estrutura cataclástica e textura mortar mas, localmente restam porções com textura granoblástica inequigranular seriada.

\subsection{Grafita-clorita-andaluzita-andesina-granada-muscovita xisto com titanita}

Somente uma amostra desse litotipo foi encontrado, também no perfil Barragán-Santa Lucia. É composto por quartzo (27\%), muscovita (25\%), granada (17\%), plagioclásio (12\%), andaluzita (9\%), clorita (7\%), grafita (6\%), titanita (4\%), e minerais opacos $(2 \%)$.

A muscovita constitui grãos com tamanhos entre 0,1 e 1,0 mm, principalmente xenoblásticos, mas também ocorrem alguns subidioblásticos. Juntamente com a clorita definem a foliação $S_{n}$, assim como a textura lepidoblástica (Foto 8.42), mas pode também ocorrer como cristais inclusos em titanita e plagioclásio. Quando associada ao quartzo define texturas lepidogranoblástica ou granolepidoblástica, dependendo do predomínio de micas ou quartzo, respectivamente.

O quartzo apresenta-se com uma variação granulométrica de 0,1 a 0,6 mm, com cristais sempre xenoblásticos em textura poligonal, com contatos retos ou suturados (Fotos 8.43 e 8.44) em leitos onde está mais concentrado. Quando associado às maiores concentrações de micas os cristais são granulares.

A granada constitui cristais que variam entre 0,1 e 1,2 $\mathrm{mm}$, predominantemente subidioblásticos e xenoblásticos, com poucas inclusões de quartzo e com minerais opacos concentrados nas bordas (Foto 8.45). Eventualmente formam finos porfiroblastos, geralmente 

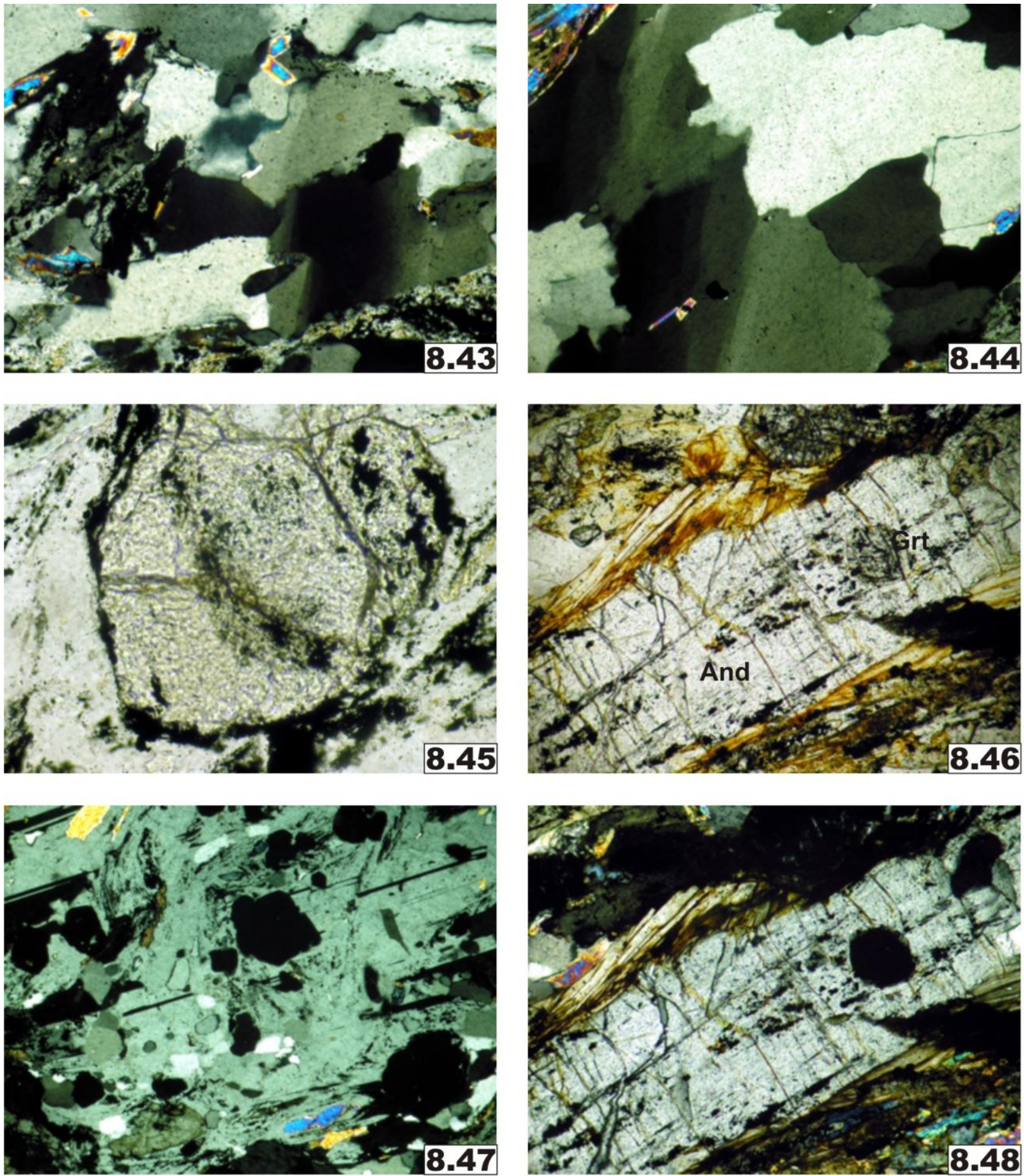

Foto 8.43. Quartzo com contatos suturados. Lado maior da foto $0,49 \mathrm{~mm}$.

Foto 8.44. Quartzo com contatos retos. Lado maior da foto $1,07 \mathrm{~mm}$.

Foto 8.45. Granada com concentração de minerais opacos nas bordas. Lado maior da foto $0,49 \mathrm{~mm}$.

Foto 8.46. Granada (Grt) com foliação interna $S_{i}$ inclusa em andaluzita (And). Lado maior da foto 1,07 mm.

Foto 8.47. Poiquiloblasto de plagioclásio. Lado maior da foto 2,14 mm.

Foto 8.48. Andaluzita com inclusão de granada. Lado maior da foto $1,07 \mathrm{~mm}$.

Fotos $\mathbf{8 . 4 5}$ e $\mathbf{8 . 4 6}$ obtidas com polarizadores paralelos e $\mathbf{8 . 4 3}, \mathbf{8 . 4 4}, \mathbf{8 . 4 7}$ e $\mathbf{8 . 4 8}$ com polarizadores cruzados. 
muito fraturados, e às vezes ocorrem como inclusão em plagioclásio e andaluzita. Apresenta localmente uma foliação interna $S_{i}$ definida pelo arranjo dos minerais opacos (Foto 8.46).

O plagioclásio $\left(\mathrm{An}_{33}\right)$ ocorre como grãos xenoblásticos que variam entre 0,3 e 3,2 mm, geralmente poiquiloblásticos e com inclusões de granada, quartzo, andaluzita, minerais opacos e mica (Foto 8.47). Apresenta geminação de tipo albita e periclina.

Os cristais de andaluzita variam de 0,1 a $2,8 \mathrm{~mm}$ de comprimento, sendo predominantemente subidioblásticos, mas grãos xenoblásticos e idioblásticos ocorrem subordinadamente. Inclusões de minerais opacos, quartzo e granada (Foto 8.48) são comuns em muitos dos grãos. Localmente a andaluzita forma agregados orientados, definindo textura nematoblástica, mas geralmente encontra-se disseminada na lâmina.

A clorita apresenta-se um fraco pleocroismo em tons de verde muito claro e constitui grãos subidioblásticos e xenoblásticos com 0,1 a 0,6 mm de comprimento, sempre acompanhados por minerais opacos, sugerindo, pelo menos em parte, formação a partir do retrometamorfismo de biotita. Apresenta-se disseminada ou agrupada, juntamente com muscovita, definindo textura lepidoblástica. Comumente apresenta bordas de oxidação, possivelmente de limonita (Fotos 8.49 e 8.50).

A grafita apresenta-se concentrada em delgadas lâminas orientadas na foliação ou também fortemente dobradas (Foto 8.51). Comumente tem quartzo associado, mas também ocorre incluso dos demais minerais da rocha.

A titanita tem um pleocroismo que varia em tons de café-claro e escuro, variando entre 0,2 e $0,8 \mathrm{~mm}$ de comprimento e forma grãos subidioblásticos e xenoblásticos (Foto 8.52). Possui inclusões de mica e quartzo e apresenta-se disseminado, mas quase sempre acompanhando a foliação principal $S_{n}$.

Os minerais opacos são xenoblásticos, estão disseminados pela rocha ou ocorrem inclusos nos demais minerais ou acumulados nas bordas de cristais de granada e de andaluzita. Comumente têm bordas de titanita e, possivelmente, leucoxênio (Foto 8.53), sugerindo serem ilmenita. Outros cristais, quase sempre parcialmente limonitizados, sugerem serem sulfetos.

Finos cristais idioblásticos (máximo 0,05 mm) de clinozoisita são observados disseminados. Às vezes os cristais apresentam zonamento concêntrico, observado pela variação da birrefringência (Foto 8.54).

Estas rochas variam texturalmente de lepidoblástica, definida pela clorita e muscovita,a granoblástica nas porções mais quartzosas e nematoblástica quando mais rica em andaluzita. Localmente o plagioclásio pode conferir à rocha texturas poiquiloblásticas. Em termos gerais, a rocha apresenta uma foliação principal $S_{n}$ e uma $S_{n+1}$ fracamente desenvolvimento, dada pela orientação da clorita. 

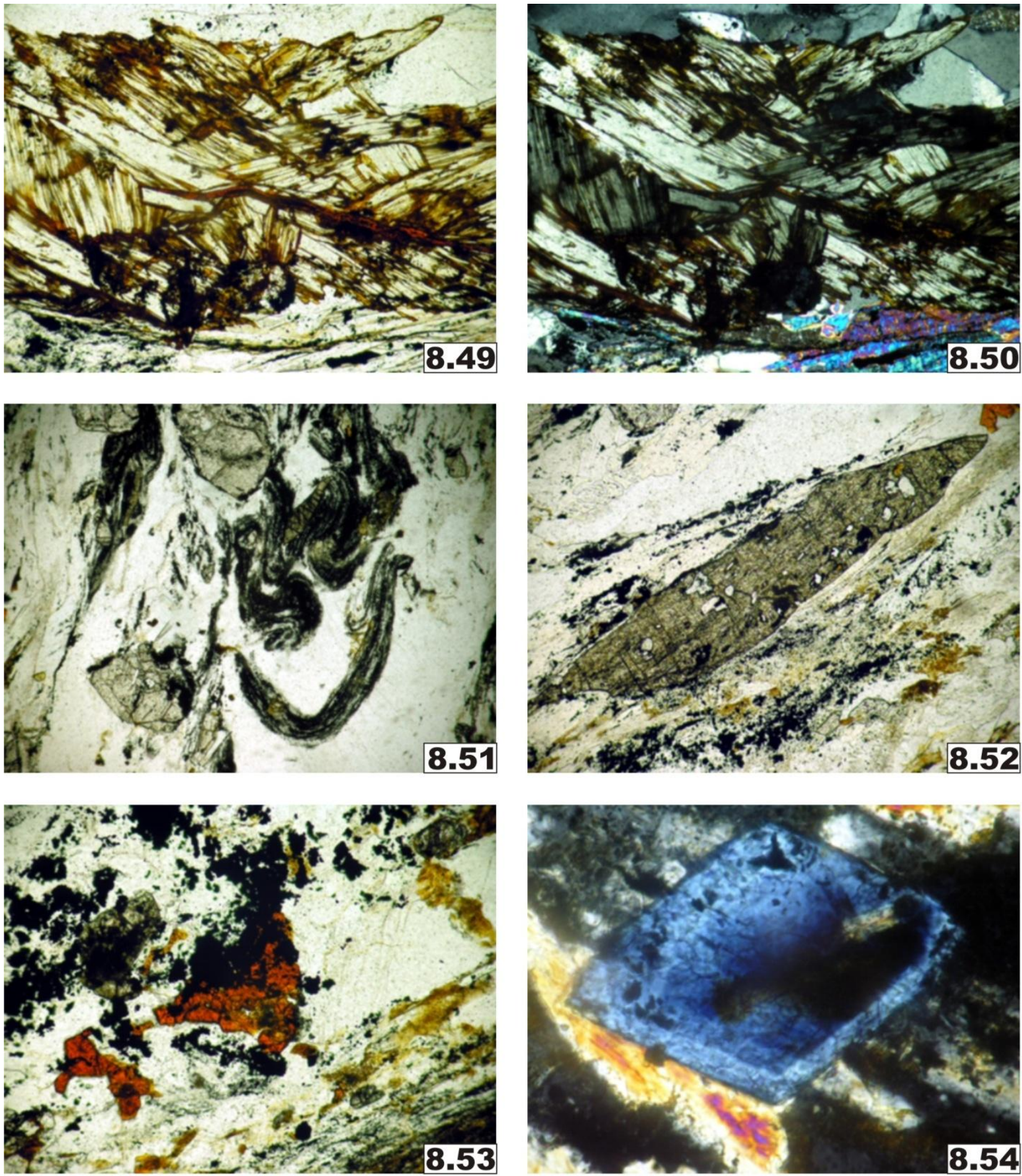

Foto 8.49. Borda de oxidação de limonita em clorita. Lado maior da foto $1,07 \mathrm{~mm}$.

Foto 8.50. Borda de oxidação de limonita em clorita. Lado maior da foto $1,07 \mathrm{~mm}$.

Foto 8.51. "Fitas" de grafita fortemente dobradas. Lado maior da foto $2,14 \mathrm{~mm}$.

Foto 8.52. Grão subidioblástico de titanita concordante com a foliação. Lado maior da foto 1,07 mm.

Foto 8.53. Bordas de limonita e possível leucoxênio em opacos. Lado maior da foto 1,07 mm.

Foto 8.54. Zonamento concêntrico em clinozoisita. Lado maior da foto $0,21 \mathrm{~mm}$.

Fotos 8.49, 8.51, 8.52 e $\mathbf{8 . 5 3}$ obtidas com polarizadores paralelos e $\mathbf{8 . 5 0}$ e 8.54 com polarizadores cruzados. 
$\mathrm{Na}$ Tabela 8.1 é apresentado um resumo dos minerais presentes em cada um dos litotipos analisados da área de Barragán.

Tabela 8.1. Minerais presentes nos litotipos da região de Barragán, onde $1=$ rochas na fácies xisto azul, 2 = rochas na fácies anfibolito, $\mathbf{3}=$ serpentinitos, $\mathbf{4}=$ grafita-clorita-muscovita-quartzo xistos, $\mathbf{5}=$ protocataclasitos, $\mathbf{6}$ = grafita-clorita-andaluzita-andesina-granada-muscovita xisto com titanita, onde 0 mineral essencial, • mineral subordinado $(<5 \%)$ e $\bullet$ o minerais que variam de subordinado a essencial.

\begin{tabular}{|c|c|c|c|c|c|c|}
\hline Mineral & 1 & 2 & 3 & 4 & 5 & 6 \\
\hline Anfibólio sódico & $\circ$ & & & & & \\
\hline Anfibólio cálcico & & 0 & & & & \\
\hline Granada & & o & & & & O \\
\hline Clorita & $\circ$ & $\bullet$ & & $\circ$ & & \\
\hline Pumpellyita & 0 & & & & & \\
\hline Lawsonita & $\bullet \circ$ & & & & & \\
\hline Epidoto/clinozoisita & $\bullet \circ$ & 0 & & & & $\bullet$ \\
\hline Zoisita & & 0 & & & & \\
\hline Titanita & o & $\bullet$ & & & & $\bullet$ \\
\hline Rutilo & & $\bullet$ & & & & \\
\hline Quartzo & $\bullet$ & $\bullet \circ$ & & o & o & o \\
\hline Mica branca & $\bullet$ & $\bullet$ & & 0 & $\bullet$ & o \\
\hline Opacos & $\bullet$ & $\bullet$ & $\bullet$ & $\bullet \circ$ & $\bullet \circ$ & $\bullet$ \\
\hline Plagioclásio & $\bullet$ & o & & $\bullet$ & & o \\
\hline Carbonato & $\bullet$ & & $\bullet$ & & & \\
\hline Escapolita & & $\bullet$ & & & & \\
\hline Apatita & & $\bullet$ & & $\bullet$ & & \\
\hline Serpentina & & & 0 & & & \\
\hline Piroxênio & & & $\bullet$ & & & \\
\hline Grafita & & & & $\circ$ & & $\mathrm{O}$ \\
\hline Zircão & & & & & $\bullet$ & \\
\hline Turmalina & & & & & $\bullet$ & \\
\hline Andaluzita & & & & & & $\circ$ \\
\hline
\end{tabular}

As relações de blastese dos minerais observados e descritos nos litotipos de protolito básico da região de Barragán são apresentadas na Tabela 8.2.

Tabela 8.2. Blastese dos minerais em relação às foliações metamórficas nos metabasitos da área de Barragán, onde $X A=x i s t o$ azul, $X V=$ xisto verde e $A n f=$ anfibolito.

\begin{tabular}{|c|c|c|c|}
\hline \multirow{2}{*}{\begin{tabular}{|l|} 
Mineral \\
Anfibólio sódico \\
\end{tabular}} & Facies XA & Facies XV & Facies Anf \\
\hline & & & \\
\hline $\begin{array}{l}\text { Anfibólio cálcico } \\
\text { Granada }\end{array}$ & & & \\
\hline Clorita & & & \\
\hline Pumpellyita & & & \\
\hline Epidoto/clinozoisita & & & ( \\
\hline Zoisita & & & \\
\hline Titanita & & & \\
\hline Rutilo & & & \\
\hline Quartzo & & & \\
\hline $\begin{array}{l}\text { Mica branca } \\
\text { Opacos }\end{array}$ & & & \\
\hline $\begin{array}{l}\text { Upacos } \\
\text { Plagioclásio }\end{array}$ & & & \\
\hline Carbonato & & & \\
\hline Escapolita & & & 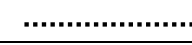 \\
\hline
\end{tabular}




\section{QUÍMICA MINERAL DA REGIÃO DE JAMBALÓ}

Para determinação da composição química dos minerais da região de Jambaló foram selecionadas principalmente as amostras de rochas da fácies xisto azul, mas rochas fácies xisto verde também tiveram seus minerais analisados. Dentre as rochas da fácies xisto azul foram feitas análises principalmente em anfibólio sódico, mica branca, clorita e minerais do grupo do epidoto, mas alguns minerais acessórios, como plagioclásio, granada, titanita, rutilo e carbonato foram também analisados. Nas rochas da fácies xisto verde foram analisados principalmente anfibólio cálcico, clorita, granada, plagioclásio, mica e minerais do grupo do epidoto. Dos minerais subordinados foi analisado unicamente o estilpnomelano. As análises selecionadas da química mineral encontram-se no Anexo III.

\subsection{Rochas da fácies xisto azul}

As características químicas dos minerais das rochas da fácies xisto azul são apresentadas a seguir:

\subsubsection{Anfibólio sódico}

$\mathrm{Na}$ amostra 118 os anfibólios analisados entram no campo dos alcalinos (Figura 9.1) segundo a divisão de Leake et al. (1997, 2004). Segundo a classificação de Miyashiro (1957) os anfibólios alcalinos pertencem ao campo do glaucofânio (Figura 9.1).
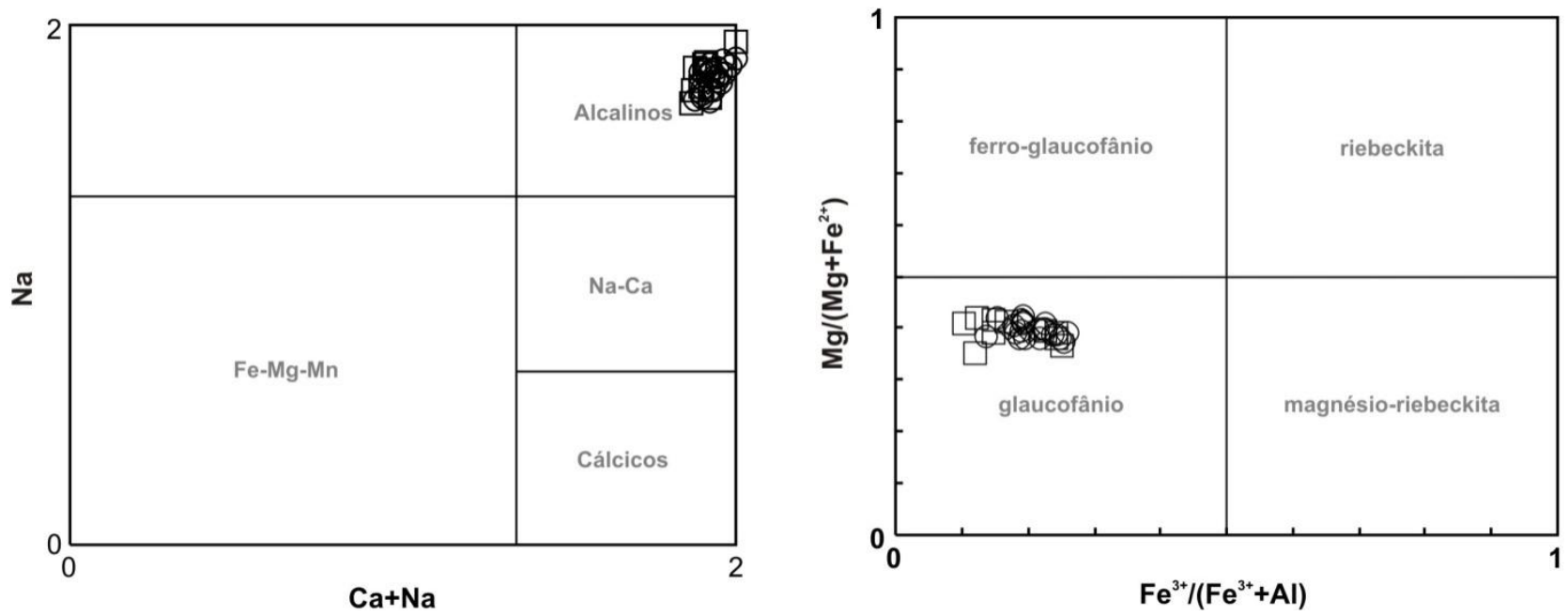

Borda $\bigcirc$ Intermediário $\diamond$ Núcleo

Figura 9.1. À esquerda é apresentado o diagrama de classificação dos anfibólios da amostra 118 nos quatro grupos principais segundo Leake et al. (1997, 2004), indicando serem todos anfibólios alcalinos. No diagrama da direita pode ser observado que anfibólio sódico tem composição de glaucofânio, segundo a classificação de Miyashiro (1957).

Nestas análises nota-se que o zonamento observado na petrografia apresenta uma variação do núcleo para a borda dos grãos glaucofânio em direção ao campo do ferro-glaucofânio. Nas análises obtidas para a amostra 118, apresentam-se conteúdos de $\mathrm{Na}$ e $\mathrm{Ca}$ relativamente 
homogêneos. Para as bordas foram obtidos conteúdos de Na que variam entre 1,72 e 1,97 a.p.f.u. e de Ca variando entre 0,05 e 0,21 a.p.f.u. Nos pontos intermediários os valores de Na estão no intervalo de 1,73 - 1,88 a.p.f.u. e o Ca 0,07 - 0,22 a.p.f.u. No caso das análises de núcleos, os valores de $\mathrm{Na}$ variam entre 1,79 e 1,84 a.p.f.u. e o Ca entre 0,10 e 0,14 a.p.f.u.

$\mathrm{Na}$ amostra 123A a maior parte dos anfibólios entram no campo dos alcalinos (Figura 9.2A) segundo a classificação de Leake et al. (1997, 2004). Dentro dos anfibólios alcalinos, usando a proposta de Miyashiro (1957), estes correspondem ao campo do glaucofânio na sua maioria, com alguns pontos no campo da magnésio-riebeckita (Figura 9.2B).
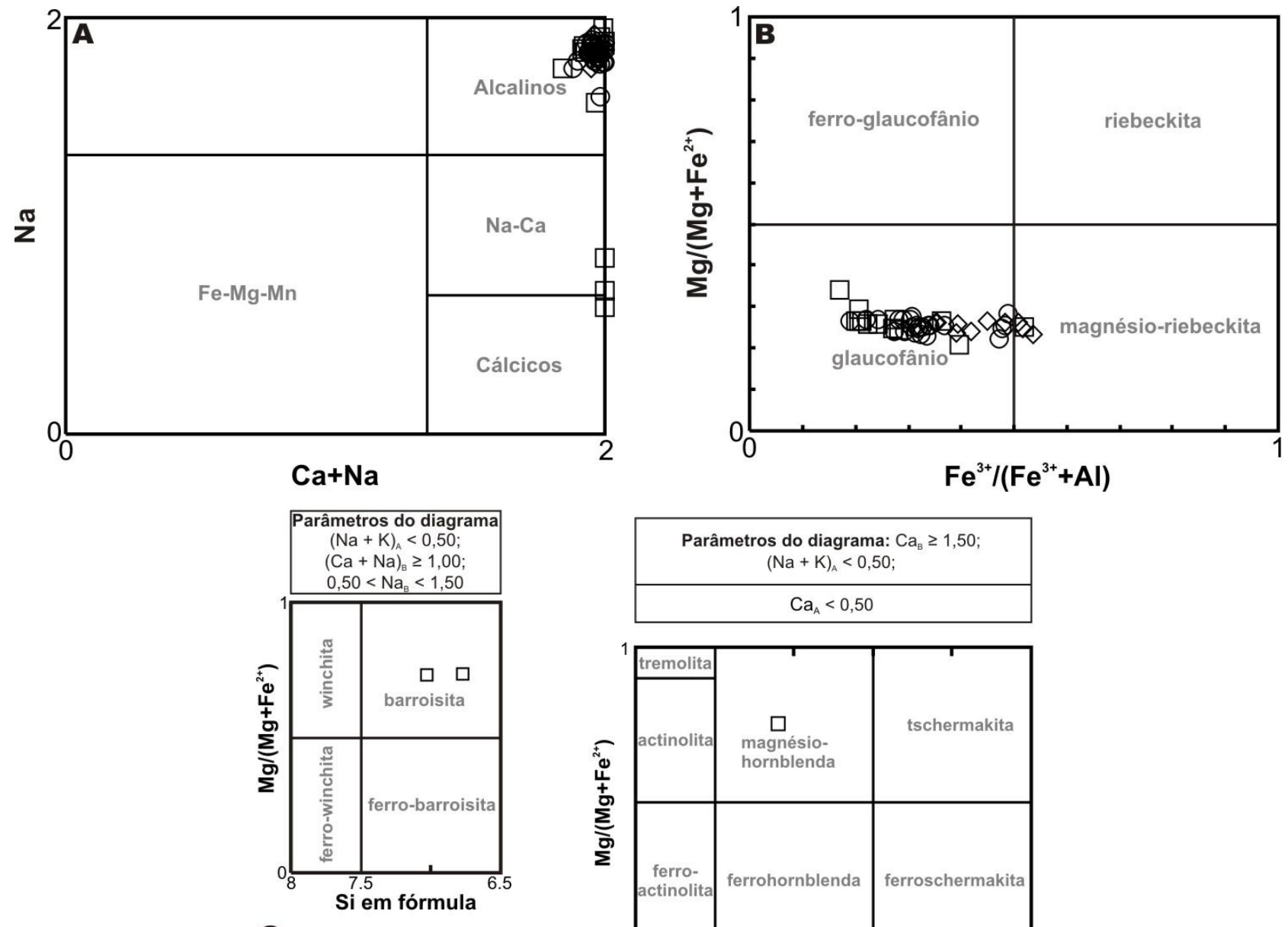

$$
\text { c }
$$

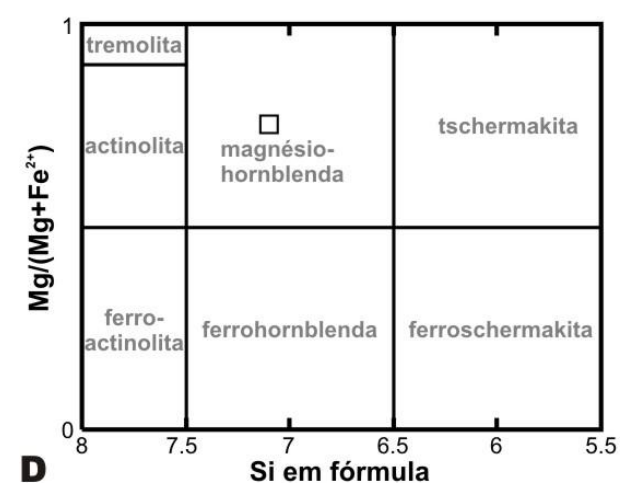

Borda $\bigcirc$ Intermediário $\diamond$ Núcleo

Figura 9.2. Diagramas de classificação dos anfibólios da amostra 123A nos quatro grupos principais (A) segundo Leake et al. (1997, 2004), indicando serem a maioria anfibólios alcalinos. No diagrama (B) pode ser observada a composição do anfibólio sódico no campo do glaucofânio e alguns no campo da magnésioriebeckita, segundo a definição de Miyashiro (1957). Em (C) indica-se que as análises de borda plotam no campo da barroisita e em (D) no campo da magnésio-hornblenda.

Um par de pontos de borda tem composição que adentra no campo dos anfibólios sódicocálcicos (Figura 9.2C), que corresponde à barroisita, segundo a classificação de Leake et al. (1997). Um único ponto de borda é de anfibólio cálcico, correspondendo a magnésio-hornblenda 
(Figura 9.2D) segundo o esquema de classificação de Leake et al. (1997). Este zonamento confirma o observado na petrografia, no qual os núcleos mais intensamente pleocróicos correspondem às fases mais sódicas que passam para anfibólios sódico-cálcicos e depois para anfibólios cálcicos nas bordas.

Os conteúdos de $\mathrm{Na}$ e $\mathrm{Ca}$ obtidos para os anfibólios da amostra 123A também refletem o zonamento observado na petrografia. Assim para os pontos de borda apresentam-se os intervalos de variação mais amplos, sendo que o $\mathrm{Na}$ varia entre 0,76 e 1,96 a.p.f.u. e o Ca varia entre 0,07 e 1,42 a.p.f.u. Nas análises realizadas em pontos intermediárias apresentam conteúdos de $\mathrm{Na}$ que variam entre 1,64 e 1,91 a.p.f.u. e o Ca varia entre 0,06 e 0,37 a.p.f.u. No caso dos núcleos a variação obtida apresenta os menores intervalos, sendo que o $\mathrm{Na}$ varia entre 1,79 e 1,95 a.p.f.u. e o Ca varia entre 0,05 e 0,20 a.p.f.u.

$\mathrm{Na}$ amostra 124 foram obtidos poucos pontos dos anfibólios. Estes correspondem em sua totalidade aos alcalinos (Figura 9.3) segundo a proposta de classificação de Leake et al. (1997). Segundo a classificação de Miyashiro (1957) os anfibólios correspondem a glaucofânio com uma tendência evolutiva ao campo do ferro-glaucofânio (Figura 9.3).
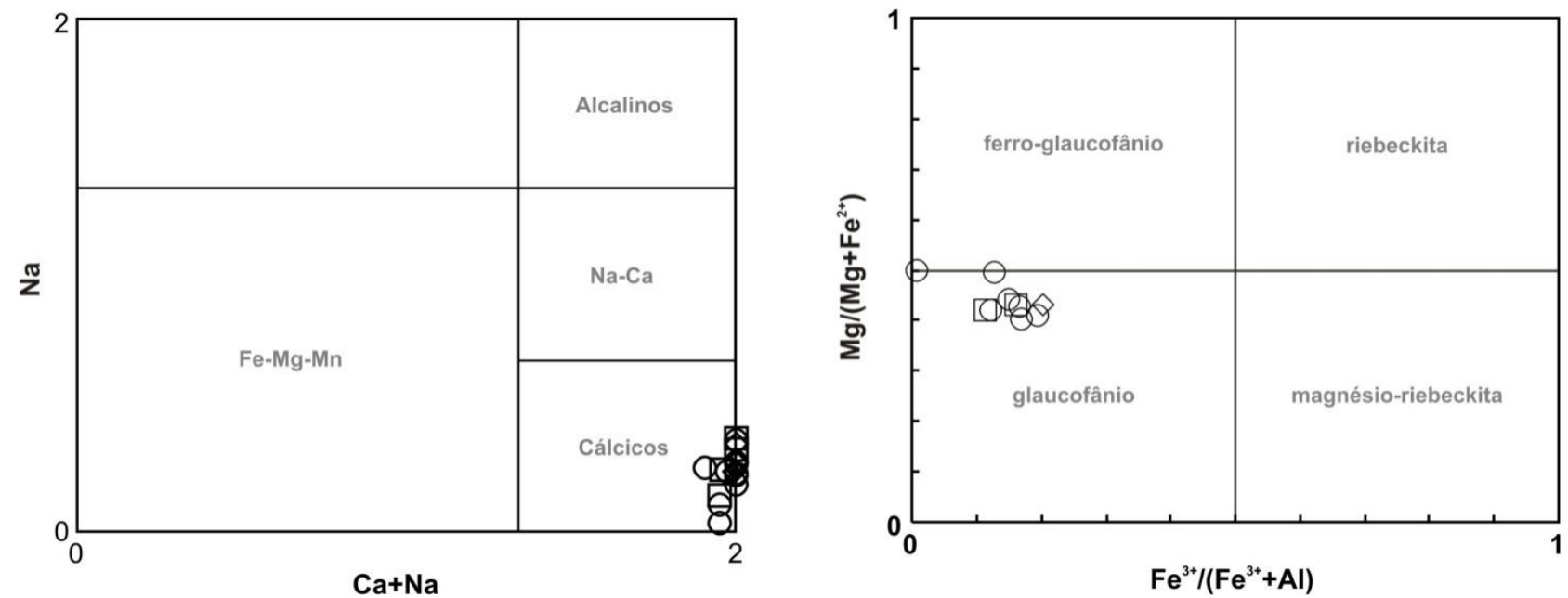

Borda $\bigcirc$ Intermediário $\diamond$ Núcleo

Figura 9.3. À esquerda é apresentado o diagrama de classificação dos anfibólios da amostra 124 nos quatro grupos principais segundo Leake et al. (1997, 2004), indicando serem todos anfibólios alcalinos. No diagrama da direita pode ser observada a composição de glaucofânio e ferro-glaucofânio, conforme definido por Miyashiro (1957).

Nesta amostra os conteúdos de $\mathrm{Na}$ dos pontos de borda apresenta uma variação no intervalo entre 1,78 e 1,89 a.p.f.u. e de $\mathrm{Ca}$ entre 0,08 e 0,13 a.p.f.u. No caso dos pontos intermediários obtidos nesta amostra, os valores de $\mathrm{Na}$ estão entre 1,82 e 1,94 a.p.f.u. e o Ca apresentam um intervalo amplo de variação entre 0,04 e 0,26 a.p.f.u. No núcleo do grão dessa amostra foi analisado apenas um ponto, que indicou conteúdo de $\mathrm{Na}$ de 1,78 a.p.f.u. e de Ca de 0,16 a.p.f.u.

$\mathrm{Na}$ amostra 124J os anfibólios plotam todos dentro do campo dos alcalinos (Figura 9.4) 
segundo a classificação de Leake et al. (1997). Já no diagrama de Miyashiro (1957) para a série glaucofânio-riebeckita, os anfibólios desta amostra estão todos no campo do glaucofânio, com uma tendência de evolução para o ferro-glaucofânio (Figura 9.4).
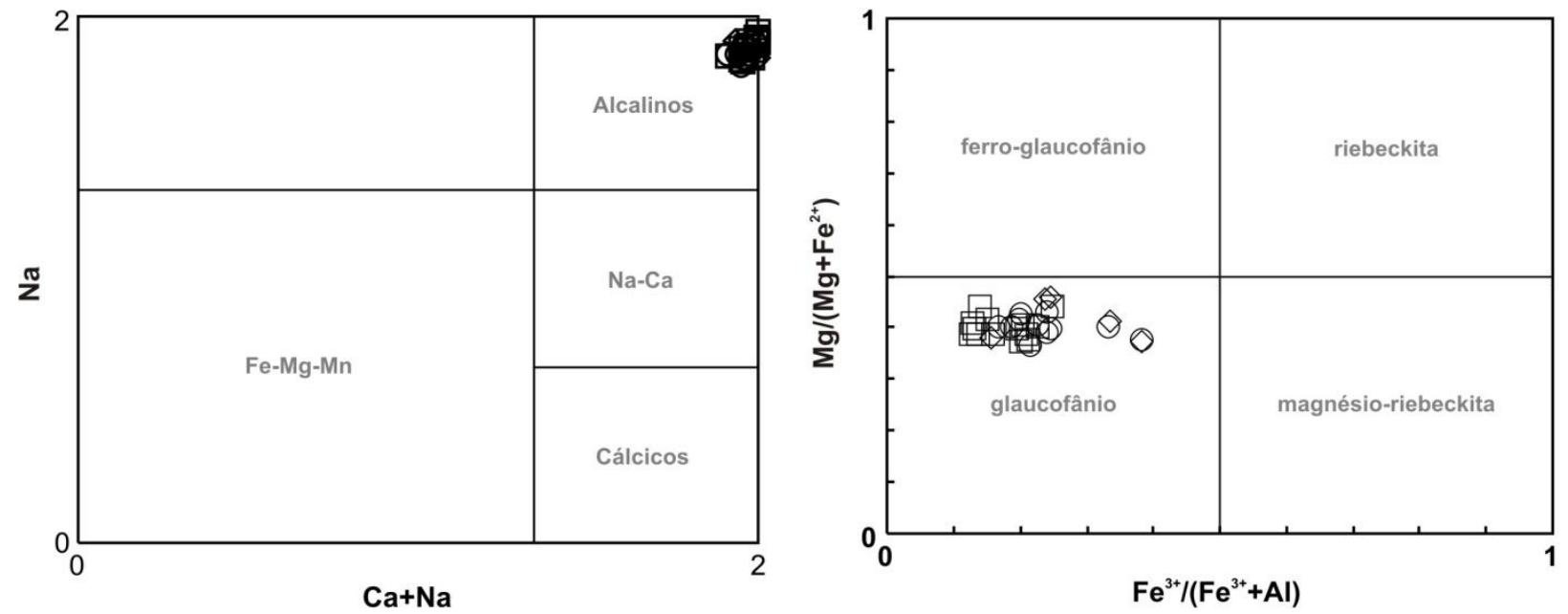

Borda $\bigcirc$ Intermediário $\diamond$ Núcleo

Figura 9.4. À esquerda é apresentado o diagrama de classificação dos anfibólios da amostra 124J nos quatro grupos principais segundo Leake et al. (1997, 2004), indicando serem todos anfibólios alcalinos. No diagrama da direita pode ser observada a composição do anfibólio sódico no campo da série glaucofânioriebeckita (Miyashiro, 1957), evidenciando sua composição de glaucofânio, com uma leve tendência ao campo do ferro-glaucofânio.

O Na e Ca dos anfibólios analisados na amostra 124J apresentam um pequeno intervalo de variação. Nas análises de borda os conteúdos de $\mathrm{Na}$ variam entre 1,84 e 1,97 a.p.f.u. e o Ca varia entre 0,06 e 0,14 a.p.f.u. Para as análises em pontos intermediários o intervalo de variação do $\mathrm{Na}$ esta entre 1,85 e 1,92 a.p.f.u. e o Ca varia entre 0,06 e 0,14 a.p.f.u. Já no núcleo a variação de $\mathrm{Na}$ encontra-se entre 1,87 e 1,92 a.p.f.u. e o Ca entre 0,03 e 0,16 a.p.f.u.

A amostra 125M apresenta a maior parte dos anfibólios dentro do campo dos alcalinos (Figura 9.5) segundo a proposta de Leake et al. (1997). Dentro do esquema de classificação de Miyashiro (1957) os anfibólios correspondem ao grupo de glaucofânio (Figura 9.5) e um par de análises de bordas do mineral adentram no campo da winchita (Figura 9.5), de acordo com a classificação de Leake et al. (1997). Embora as análises obtidas no anfibólio desta amostra não apresentem um padrão de evolução muito claro, o fato de ter composições mais sódico-cálcicas nas bordas sugere que o anfibólio tem uma transformação proveniente dos anfibólios cálcicos.

Nesta amostra, os conteúdos de $\mathrm{Na}$ e $\mathrm{Ca}$ encontrados apresentam um intervalo de variação relativamente amplo quando analisados os pontos obtidos nas bordas do mineral. No caso do $\mathrm{Na}$, este varia entre 1,28 e 1,95 a.p.f.u. e o Ca entre 0,03 e 0,76 a.p.f.u. Nas análises correspondentes dos pontos intermediários o Na varia entre 1,85 e 1,92 a.p.f.u. e o Ca entre 0,11 e 0,14. Nos núcleos os valores de Na estão entre 1,84 e 1,94 a.p.f.u. e o Ca entre 0,07 e 0,016 a.p.f.u. 

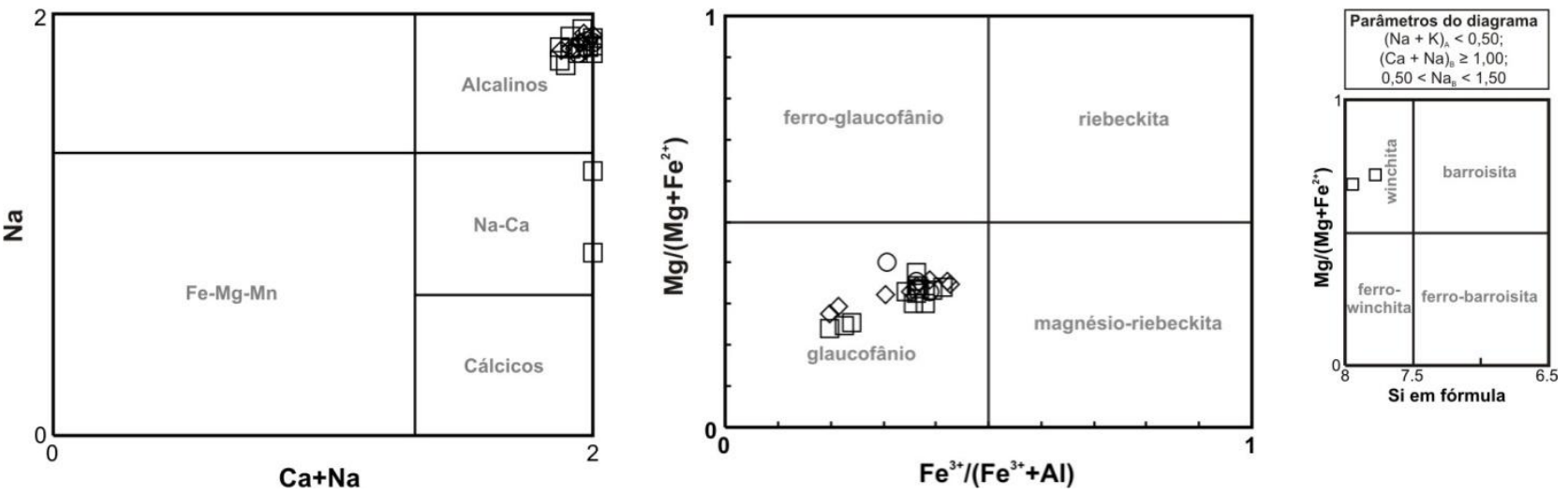

Borda $\bigcirc$ Intermediário $\diamond$ Núcleo

Figura 9.5. Diagramas de classificação dos anfibólios da amostra $125 \mathrm{M}$ nos quatro grupos principais (esquerda) segundo Leake et al. (1997, 2004), indicando serem a maioria anfibólios alcalinos. No diagrama central pode ser observada a composição do anfibólio sódico no campo do glaucofânio, segundo o esquema de Miyashiro (1957). No diagrama de classificação dos anfibólios sódico-cálcicos (direita) apresenta-se as análises de borda no campo da winchita segundo o esquema de Leake et al. (1997).

$\mathrm{Na}$ amostra 129A todos os anfibólios analisados entram no campo dos alcalinos (Figura 9.6) segundo a divisão de Leake et al. (1997) e no diagrama de classificação de Miyashiro (1957) estão no campo do glaucofânio e alguns pontos na transição para ferro-glaucofânio (Figura 9.6).

Esta amostra apresenta os conteúdos mais altos de $\mathrm{Na}$ e os mais baixos de $\mathrm{Ca}$ nas bordas do mineral de todo o conjunto de anfibólios das rochas da fácies xisto azul. Essa variação pode ser o reflexo do zonamento observado na petrografia, no qual há um núcleo menos intensamente pleocróico que as bordas. Nesta amostra, a evolução do anfibólio varia no sentido da composição da riebeckita e da magnésio-riebeckita.
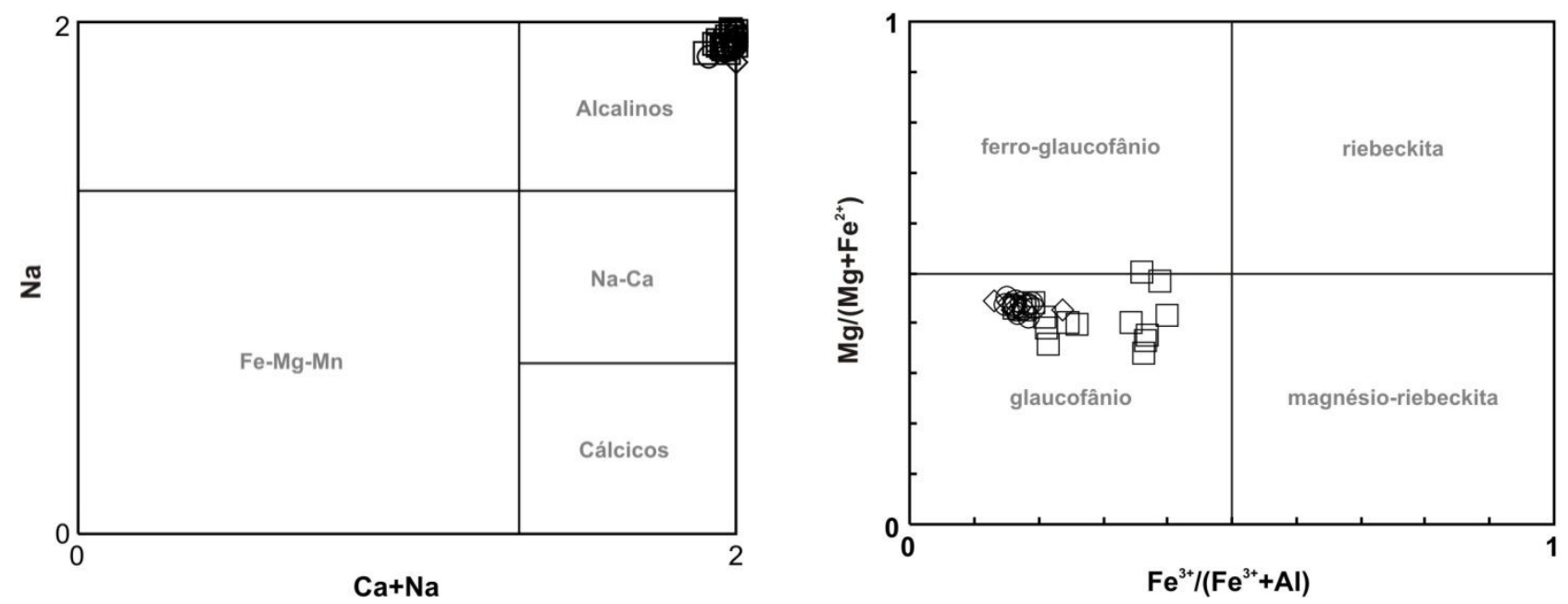

Borda O Intermediário $\diamond$ Núcleo

Figura 9.6. À esquerda é apresentado o diagrama de classificação dos anfibólios da amostra 124A nos quatro grupos principais segundo Leake et al. (1997, 2004), indicando serem todos anfibólios alcalinos. No diagrama da direita pode ser observada a composição do anfibólio sódico no campo da série glaucofânioriebeckita (Miyashiro, 1957), evidenciando sua composição de glaucofânio, com uma leve tendência ao campo do ferro-glaucofânio.

As análises feitas na borda do mineral têm conteúdos de $\mathrm{Na}$ variando entre 1,89 e 2,04 
a.p.f.u. e o Ca apresenta-se entre 0,01 e 0,10 a.p.f.u. Para as análises intermediárias o $\mathrm{Na}$ varia entre 1,88 e 2,01 a.p.f.u. e o Ca entre 0,04 e 0,10 a.p.f.u. Nos núcleos têm teores de Na entre 1,89 e 1,93 a.p.f.u. e de Ca entre 0,07 e 0,16 a.p.f.u.

\subsubsection{Granada}

Das amostras da fácies xisto azul da região de Jambaló foi analisada a granada de três (3) delas.

$\mathrm{Na}$ amostra 118, foram analisados três (3) cristais, sendo que, os pontos obtidos estão distribuídos segundo borda-núcleo-borda. Em termos gerais, a granada apresenta um marcado zonamento em dois dos cristais analisados (Figura 9.7), mas no terceiro não é muito pronunciado (Figura 9.7). Os conteúdos de $\mathrm{Fe}^{2+}$ da granada aumentam do núcleo para borda e o mesmo comportamento, embora não tão fortemente marcado, ocorre com o $\mathrm{Mg}$ e com o $\mathrm{Ca}$. Um comportamento inverso é observado para o $\mathrm{Mn}$. Estas variações sugerem substituições complexas entre os diferentes componentes da granada, possivelmente como resultado de aumentos na temperatura do metamorfismo que afetou o conjunto, e como conseqüência da transição da fácies xisto azul para xisto verde.
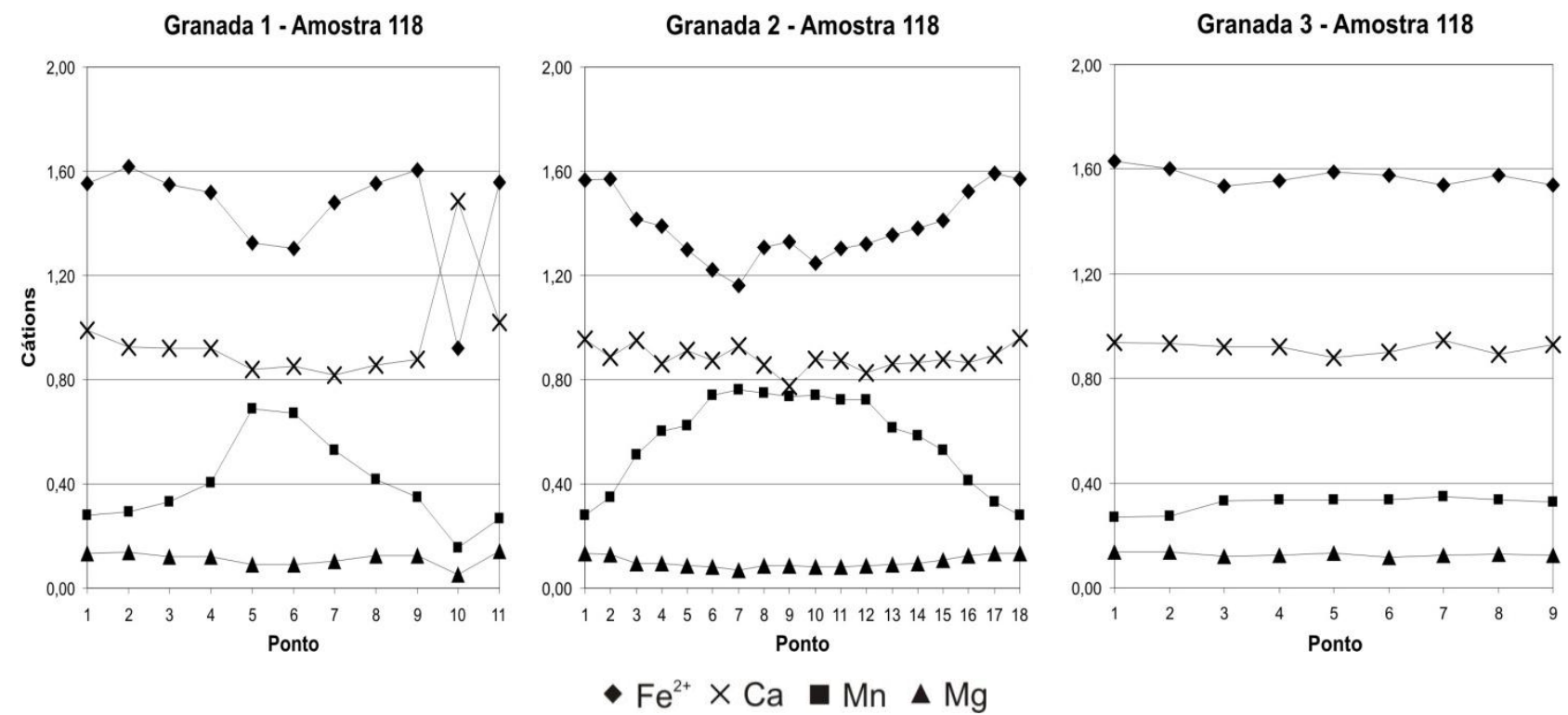

Figura 9.7. Padrão de zonamento dos principais cátions dos grãos de granada analisados na amostra 118. Os diagramas representam os pontos obtidos em perfis borda-núcleo-borda. Nota-se o forte zonamento nos diagramas da esquerda e central e o zonamento mais levemente definido no diagrama da direita.

A variação dos principais componentes da granada desta amostra podem ser expressos em termos de almandina (Alm) + grossularia (Grs) + piropo (Pyp) + espessartita (Sps) da seguinte forma: $\operatorname{Alm}_{39,76-54,80} \mathrm{Grs}_{26,45-34,14} \mathrm{Pyp}_{2,38-4,70} \mathrm{Sps}_{7,82-26,00}$.

Nos pontos analisados em dois (2) cristais da amostra 124J observam-se padrões de zonamentos semelhantes aos encontrados na amostra 118, mas não tão bem definidos. Destaca- 
se, entretanto, o comportamento inverso entre $\circ \mathrm{Mn}$ e $\circ \mathrm{Fe}^{2+}$ causado pelo aumento da temperatura de núcleo para a borda o metamorfismo progressivo. Nesta amostra as variações nos conteúdos de $\mathrm{Fe}^{2+}, \mathrm{Mg}$, Ca e Mn (Figura 9.8) mostram intervalos de variação pequenos quando comparados com o observado na amostra 118. Neste caso, unicamente o conteúdo de Mn apresenta uma distribuição heterogênea e um amplo intervalo de variação de núcleo para borda. Os principais componentes da granada analisada para esta amostra podem expressar-se assim: Alm $_{32,00-41,98} \operatorname{Grs}_{26,06-31,46} \operatorname{Pyp}_{1,61-2,64} \operatorname{Sps}_{24,67-39,77}$.
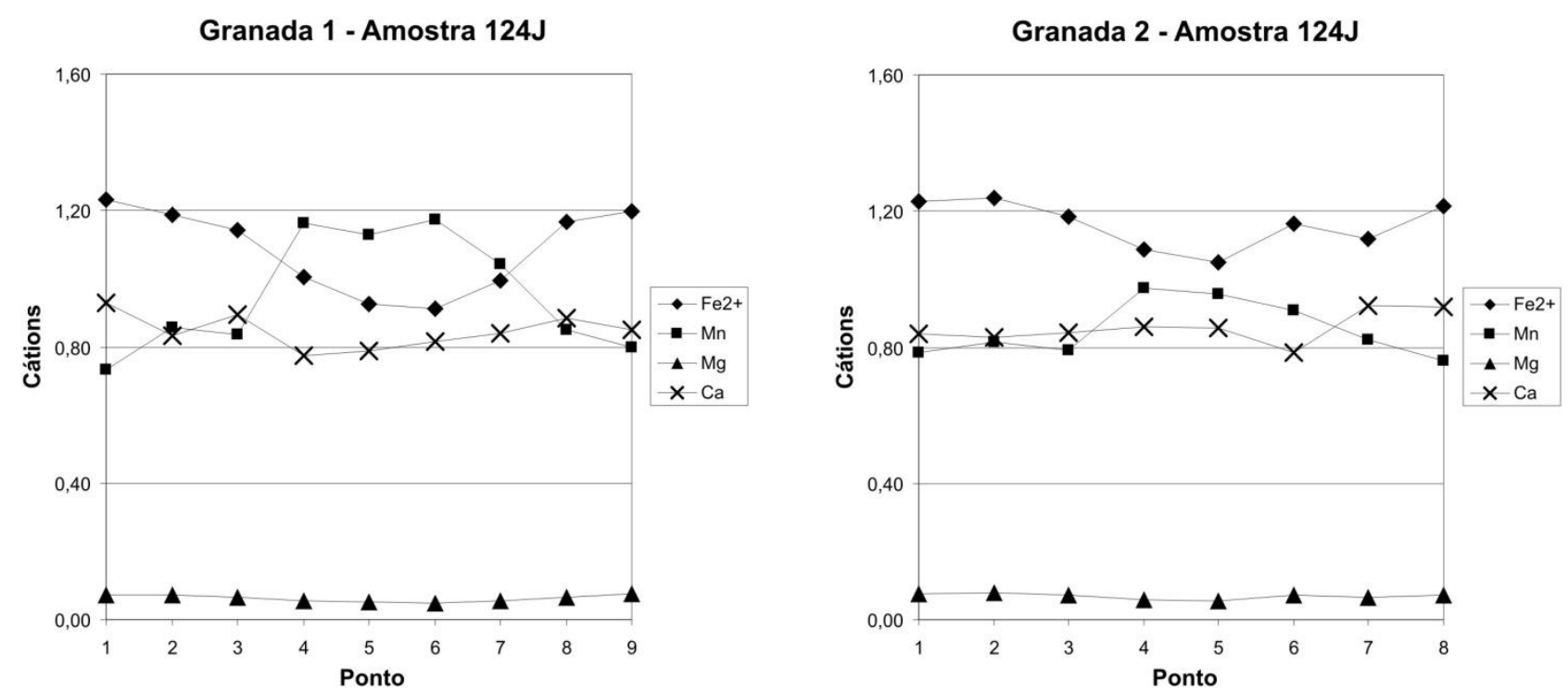

Figura 9.8. Padrão de zonamento dos principais cátions dos grãos de granada analisados na amostra 124J. Os diagramas representam os pontos obtidos em perfis borda-núcleo-borda.

Dois perfis obtidos em grãos de granada da amostra 121B encontraram-se padrões semelhantes com os da amostra 124J. Nos perfis borda-núcleo-borda (Figura 9.9) observa-se uma distribuição dos principais cátions da granada nos quais se destacam os comportamentos oposto do $\mathrm{Mn}$ e do $\mathrm{Fe}^{2+}$, com os núcleos mais enriquecidos em ferro. $\mathrm{O} \mathrm{Mg}$ apresenta-se mais empobrecido nos núcleos que nas bordas, mas os pontos intermediários são os que apresentam os mais altos conteúdos deste elemento. No caso do Ca a distribuição é irregular, mas mesmo assim é possível notar-se menores conteúdos no núcleo do que nas bordas, com pontos de muito baixo conteúdo do elemento comparado com os demais obtidos tanto nas bordas quanto nos intermediários.

A variação dos principais componentes dos grãos de granada analisados nesta amostra pode ser expressa da seguinte forma: $\operatorname{Alm}_{42,56-60,68} \mathrm{Grs}_{21,30-32,22} \operatorname{Pyp}_{2,03-4,18} \mathrm{Sps}_{5,38-29,31}$. 

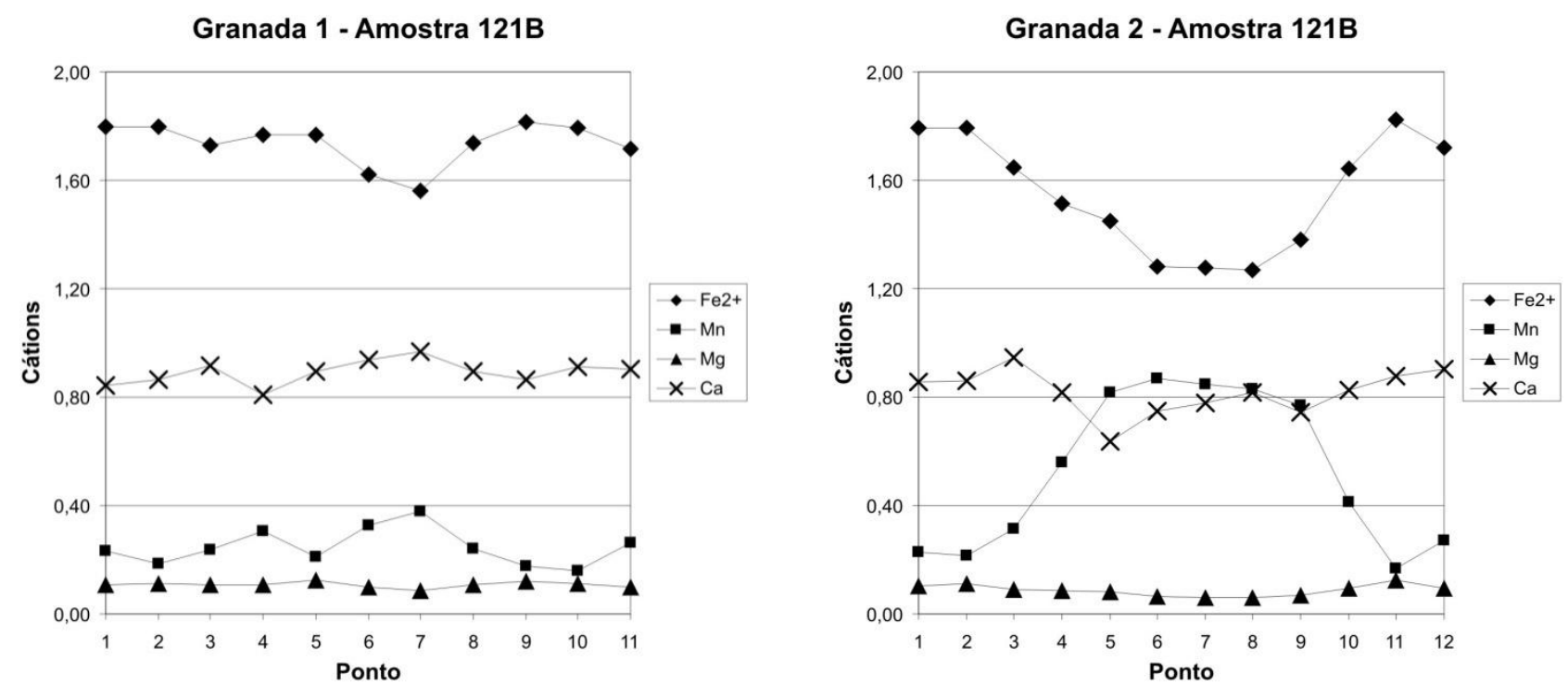

Figura 9.9. Padrão de zonamento dos principais cátions dos grãos de granada analisados na amostra 121B. Os diagramas representam os pontos obtidos em perfis borda-núcleo-borda.

\subsubsection{Mica branca}

Devido à granulação, não foi possível a obtenção de perfis composicionais nos cristais de micas.

A mica é encontrada nos diferentes litotipos sendo que sempre se encontra subidioblástico e definindo a foliação principal $S_{n}$. As amostras analisadas foram a 118, 121B, 123A, 124J e 129A. Em todas elas a composição das micas é variável e em algumas delas nota-se a coexistência de fengita e paragonita, como e o caso das amostras 118, 123A e 124J. Nas outras amostras ocorre unicamente paragonita.

$\mathrm{Na}$ amostra 118 a mica corresponde ao campo da fengita (Figura 9.10) segundo a classificação de Tischendorf (1997). Nota-se ainda que alguns pontos têm composição próxima à da muscovita.

Nesta amostra os conteúdos de Si da fengita variam entre 3,17 e 3,24 para cada 11(O) por unidade de fórmula. O K varia entre 0,44 e 0,86 a.p.f.u. e o $\mathrm{Na}$ entre 0,04 e 0,06 a.p.f.u.

$\mathrm{Na}$ amostra 118 a fengita coexiste com paragonita. Esta última apresenta valores de Si entre 2,92 e 3,07 para cada $11(\mathrm{O})$ por unidade de fórmula. O Na varia entre 0,47 e 0,77 e o $\mathrm{K}$ entre 0,04 e 0,06 a.p.f.u. 


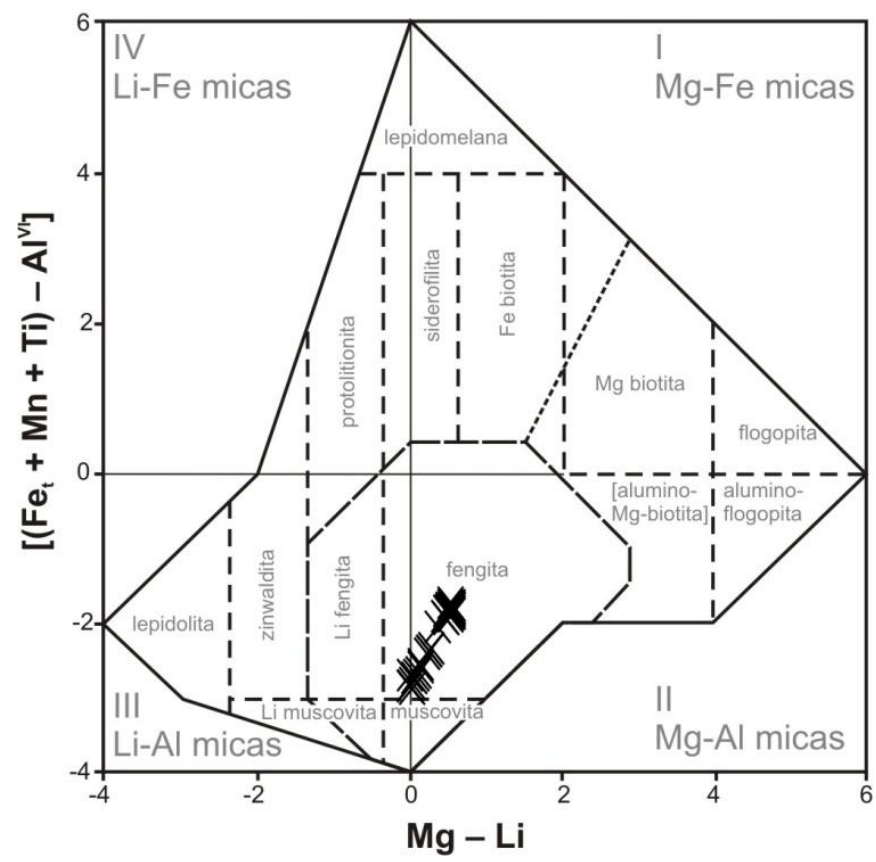

Figura 9.10. Diagrama $\left[\left(F e_{t}+M n+T i\right)-A l^{V l}\right]$ vs $(M g-L i)$ de classificação das micas segundo Tischendorf (1997,) no qual verifica-se a composição predominantemente fengítica da mica branca da amostra 118.

Para a amostra 123A a esta classificada no campo da fengita (Figura 9.11) segundo a proposta de classificação de Tischendorf (1997). Nesta amostra notam-se também variações para a composição da muscovita.

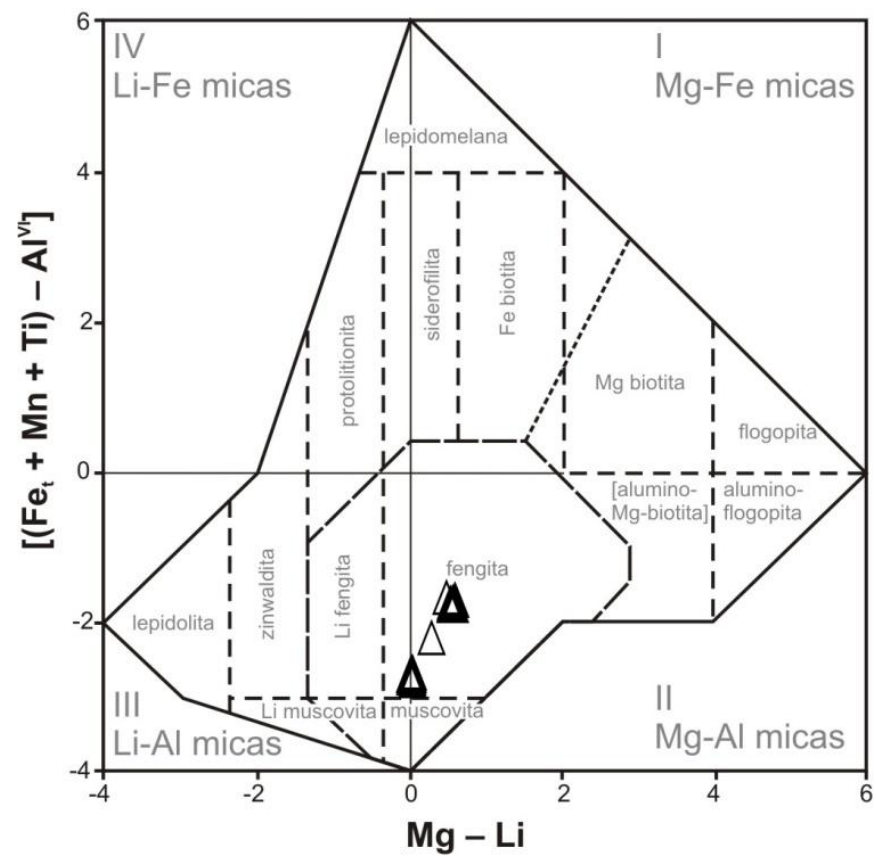

Figura 9.11. Diagrama $\left[\left(F e_{t}+M n+T i\right)-A l^{V l}\right]$ vs $(M g-L i)$ de classificação das micas segundo Tischendorf (1997) no qual se apresenta a composição dos grãos de mica branca analisados na amostra 123A, que correspondem predominantemente à fengita.

Nesta amostra o intervalo de variação do Si da fengita está entre 3,17 e 3,77 para cada 11 (O) por unidade de fórmula. No caso do K apresenta-se uma variação entre 0,52 e 0,84 a.p.f.u. e o Na varia entre 0,01 e 0,07 a.p.f.u. 
A amostra 123A também tem paragonita coexistindo com a fengita, com teores de $\mathrm{Si}$ variando entre 2,90 e 2,98 para cada $11(\mathrm{O})$ por unidade de fórmula. O Na varia entre 0,79 e 0,91 a.p.f.u. e o K apresenta um intervalo de variação entre 0,05 e 0,08 a.p.f.u.

$\mathrm{Na}$ amostra 124J as micas analisadas correspondem à fengita, com gradação para a muscovita (Figura 9.12), segundo a classificação de Tischendorf (1997).

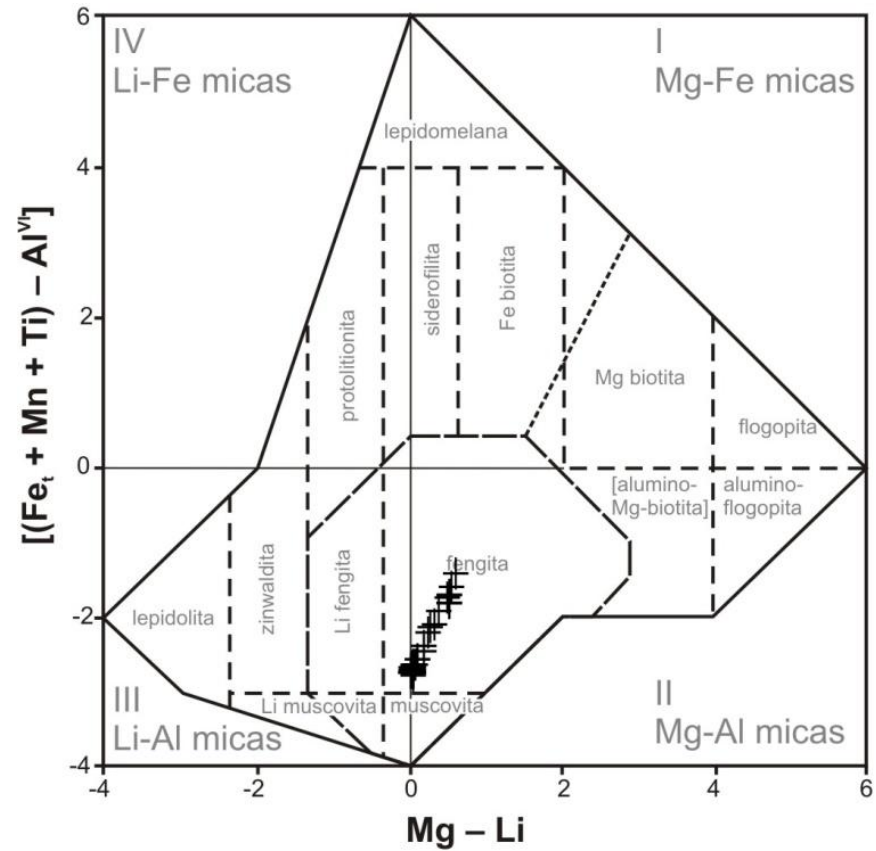

Figura 9.12. Diagrama $\left[\left(F e_{t}+M n+T i\right)-A l^{V l}\right]$ vs $(M g-L i)$ de classificação das micas segundo Tischendorf (1997) no qual se apresenta a composição dos grãos de mica branca analisados na amostra 124J, que são predominantemente fengita.

Nesta amostra os valores de Si da fengita estão no intervalo entre 3,01 e 3,23 para cada 11(O) por unidade de fórmula. O K apresenta uma variação entre 0,53 e 0,82 a.p.f.u. e o $\mathrm{Na}$ entre 0,06 e 0,08 a.p.f.u.

Tal qual observado nas outras duas amostras, há também coexistência de fengita e paragonita, essa com Si variando entre 2,87 e 2,98 para cada 11(O) por unidade de fórmula. O Na apresenta uma variação entre 0,64 e 0,93 a.p.f.u. e o $\mathrm{K}$ apresenta valores entre 0,03 e 0,07 a.p.f.u.

A amostra 121B unicamente apresenta paragonita, embora alguns dados obtidos parecessem indicar a presença de fengita, mas devido ao fechamento de pouca qualidade não foram considerados para a descrição. Os valores de Si da paragonita variam entre 2,88 e 2,91 para cada $11(\mathrm{O})$ por unidade de fórmula. O Na está no intervalo entre 0,64 e 0,86 a.p.f.u e o $\mathrm{K}$ entre 0,02 e 0,07 a.p.f.u. 
A amostra 129A também apresenta unicamente paragonita. Neste caso os valores de $\mathrm{Si}$ estão entre 2,87 e 3,02 para cada 11(O) por unidade de fórmula. Os valores de $\mathrm{Na}$ oscilam entre 0,86 e 0,98 a.p.f.u. e o $\mathrm{K}$ varia entre 0,03 e 0,07 a.p.f.u.

Do conjunto de micas analisadas em todas as amostras nota-se que certa uniformidade composicional entre as diferentes micas, tanto na fengita quanto na paragonita. Os intervalos de variação, principalmente no $\mathrm{K}$ no caso da fengita e $\mathrm{Na}$ no caso da paragonita são relativamente amplos, o que sugere possíveis zonamentos químicos, hipótese esta que reforçada pela variação composicional para o campo da muscovita. Os valores de Si a fengita correspondem a valores típicos de metabasitos da fácies xisto azul, segundo Okay (1980) e El Shazly (1994), mas são consideravelmente mais baixos que o verificado por Sorensen (1986).

\subsubsection{Clorita}

As análises feitas em clorita não representam perfis composicionais, pois eles foram obtidos apenas para caracterizar a fase mineral. Normalmente a clorita é produto do retrometamorfismo nas rochas estudadas, estando comumente concentrada nas bordas ou como produto de substituição em planos de clivagem e fraturas de anfibólios sódicos. A composição da clorita é apresentada nos diagramas da Figura 9.13, no qual se pode observar que a maior parte dos grãos das amostras da fácies xisto azul corresponde à picnoclorita, segundo o esquema de classificação de Hey (1954).
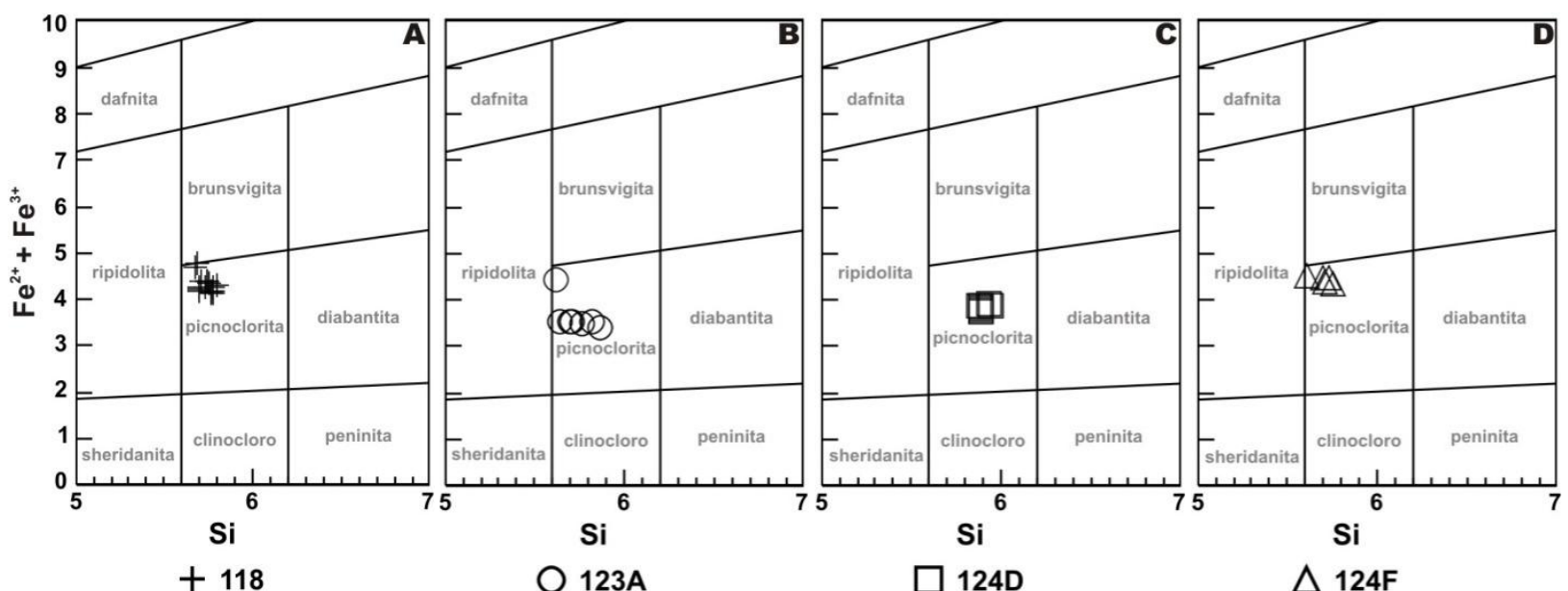

Figura 9.13. Diagramas de classificação da clorita de rochas da fácies xisto azul região de Jambaló, segundo o diagrama de Hey (1954), nos quais se pode notar a composição de picnoclorita. Amostras: (A) 118, (B) 123A, (C) 124D e (D) 124F. 

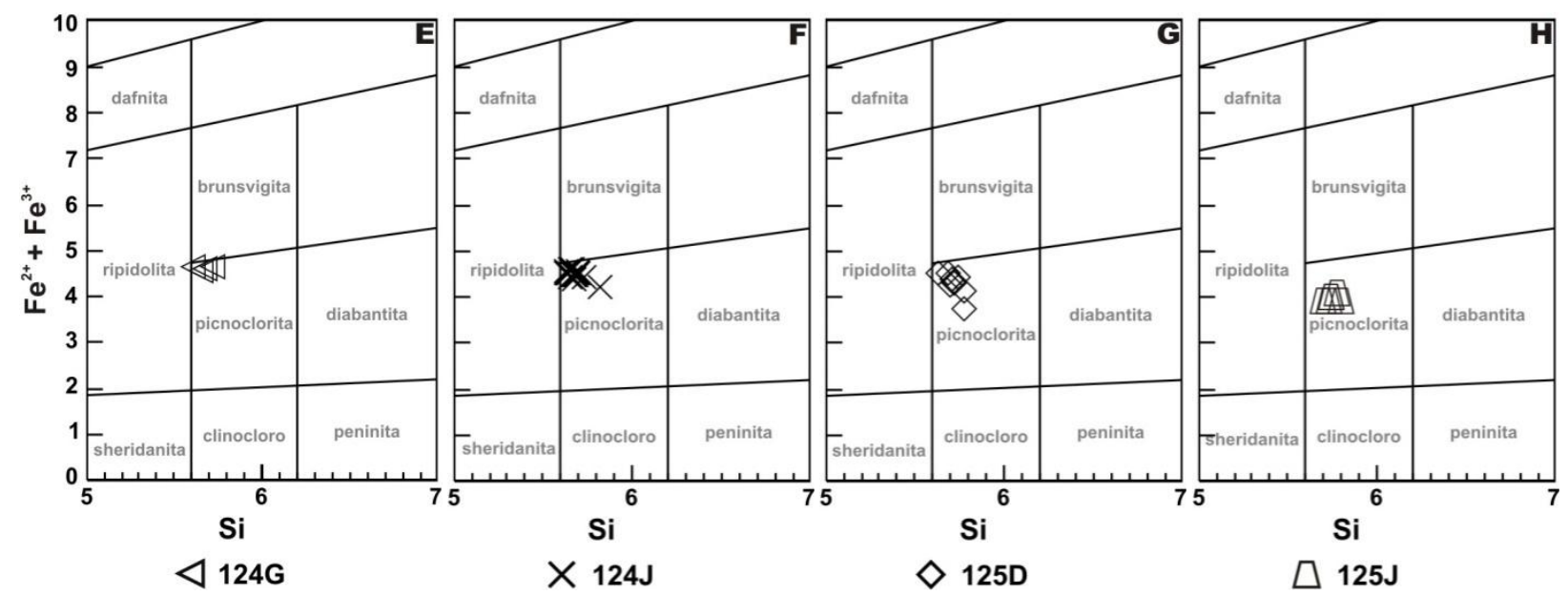

Figura 9.13 (continuação). Diagramas de classificação da clorita de rochas da fácies xisto azul região de Jambaló, segundo o diagrama de Hey (1954), nos quais pode-se notar a composição de picnoclorita. Amostras: (E) 124G, (F) 124J, (G) 124D e (H) 125J.

Os intervalos de variação de $\mathrm{Fe}^{2+}$ e $\mathrm{Mg}$ das análises de picnoclorita são apresentadas na Tabela 9.1.

Tabela 9.1. Intervalos de variação de $\mathrm{Fe}^{2+}$ e $\mathrm{Mg}$ em a.p.f.u. das análises classificadas no campo da picnoclorita segundo a proposta de Hey (1954).

\begin{tabular}{|c|c|c|c|c|c|c|c|c|}
\hline & 118 & 123A & 124D & 124F & 124G & 124J & 125D & 125J \\
\hline $\mathrm{Fe}^{2+}$ & $4,00-4,63$ & $3,28-3,43$ & $3,64-3,79$ & $4,21-4,36$ & $4,40-4,53$ & $4,08-4,46$ & $3,61-4,35$ & $3,79-3,96$ \\
\hline $\mathrm{Mg}$ & $4,80-5,26$ & $5,98-6,16$ & $5,53-5,71$ & $4,91-5,11$ & $4,78-5,00$ & $5,01-5,22$ & $4,95-5,48$ & $5,30-5,48$ \\
\hline
\end{tabular}

A clorita das amostras 124I e 125H têm composição de brunsvigita (Figura 9.14), segundo o esquema de classificação de Hey (1954).
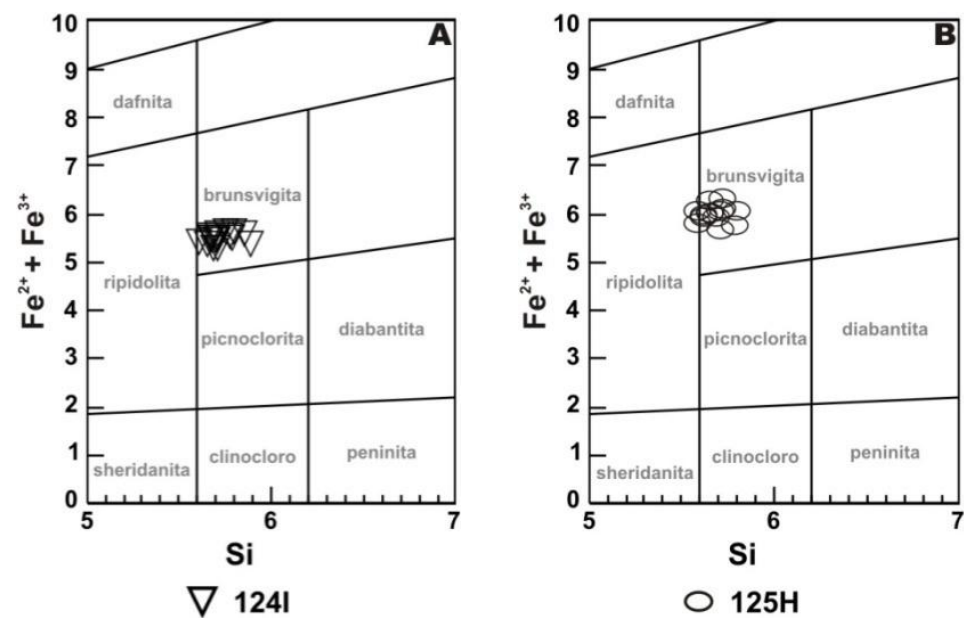

Figura 9.14. Classificação da clorita das amostras (A) $124 \mathrm{l}$ e (B) $125 \mathrm{H}$ (rochas da fácies xisto azul da região de Jambaló), evidenciando composições de brunsvigita com variações para ripidiolita no diagrama de segundo Hey (1954).

$\mathrm{Na}$ amostra 124H a composição da clorita corresponde à picnoclorita, com algumas análises de brunsvigita e de diabantita (Figura 9.15). Na amostra 129A a composição predominante é de picnoclorita, com variações para ripidolita (Figura 9.15), segundo a proposta de classificação de Hey (1954). 

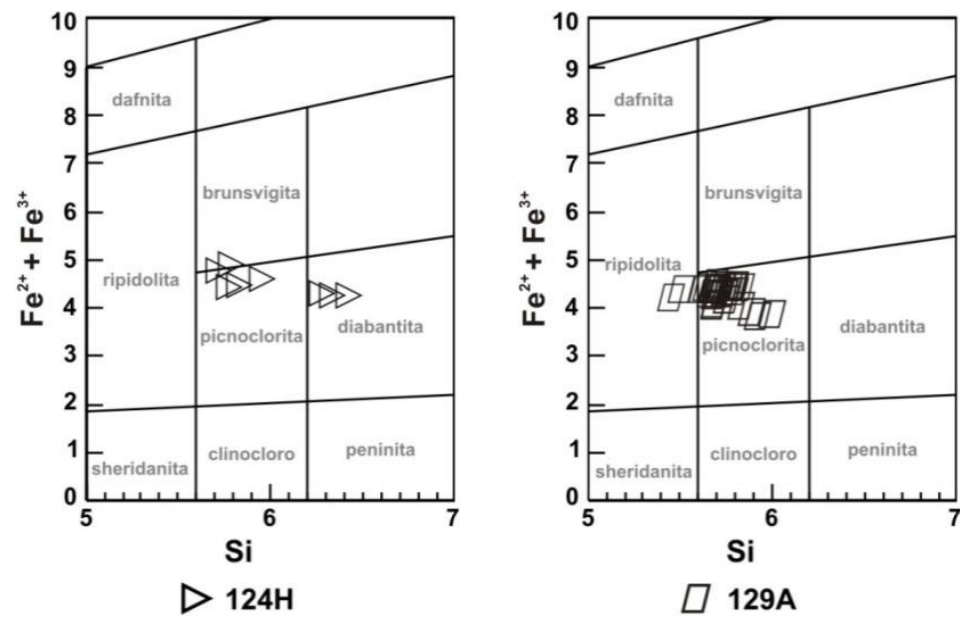

Figura 9.15. Diagramas de classificação da clorita das amostras $124 \mathrm{H}$ e 129A, indicando composições predominantes de picnoclorita, com variações para brunsvigita (124H) ou ripidiolita e diabantita (129A., segundo o diagrama de segundo Hey (1954)

Os valores de $\mathrm{Fe}^{2+}(5,19$ - 5,44 a.p.f.u.) da clorira da amostra 124 l são menores que os da amostra $125 \mathrm{H}$ (5,48 - 6,10 a.p.f.u.) e os valores de $\mathrm{Mg}$ da amostra $124 \mathrm{I}$ (3,82 - 4,13 a.p.f.u.) são mais elevados do que os valores de $\mathrm{Mg}$ (2,67 - 3,43 a.p.f.u.) da amostra $125 \mathrm{H}$, sendo que em ambas a clorita foi classificadas como brunsvigita, segundo o esquema de Hey (1954).

A amostra $124 \mathrm{H}$, que tem análises classificados como picnoclorita e diabantita, os valores de $\mathrm{Fe}^{2+}$ variam entre 4,12 e 4,75 a.p.f.u. e o $\mathrm{Mg}$ entre 4,22 - 4,91 a.p.f.u. $\mathrm{Na}$ amostra 129A que tem análises no campo da picnoclorita e alguns no da ripidolita os valores de $\mathrm{Fe}^{2+}$ variam entre 3,69 e 4,25 a.p.f.u. e $\mathrm{Mg}$ entre 5,06 e 6,11 a.p.f.u.

\subsubsection{Minerais do grupo do epidoto}

A Comissão de Novos Minerais e Nomes de Minerais (Commission on New Minerals and Mineral Names -CNMMN-) recomenda fortemente os critérios ópticos para a diferenciação dos minerais do grupo do epidoto. Embora os testes ópticos (e.g. determinação de sinal óptico, orientação óptica e pleocroismo) sejam úteis para a identificação preliminar das espécies, a mesma comissão recomenda o uso de análises de microssonda eletrônica para classificação do mineral (Armbruster et al. 2006).

Os minerais deste grupo foram normalizados considerando 12,5 (O).

Embora seja comum encontrar na petrografia epidoto e clinozoisita, as análises foram feitas em epidoto para as amostras 124, 125D e 125J. Na amostra 124H foi analisada clinozoisita.

Os valores de $\mathrm{Fe}^{3+}$ encontrados na amostra 124 variam entre 0,64 e 0,84 a.p.f.u. e o $\mathrm{Mn}^{3+}$ varia entre 0 e 0,02 a.p.f.u. Para a amostra 125D os conteúdos de $\mathrm{Fe}^{3+}$ variam entre 0,82 e 0,94 a.p.f.u., enquanto o $\mathrm{Mn}^{3+}$ varia entre 0,01 e 0,03 a.p.f.u. $\mathrm{Na}$ amostra $125 \mathrm{~J}$ os valores de $\mathrm{Fe}^{3+}$ variam entre 0,56 e 0,77 a.p.f.u. e o $\mathrm{Mn}^{3+}$ varia entre 0,03 e 0,07 a.p.f.u.

Aa clinozoisita da amostra $124 \mathrm{H}$ tem $\mathrm{Fe}^{3+}$ variando entre 0,44 e 0,70 a.p.f.u. e $\mathrm{Mn}^{3+}$ entre 0,02 e 0,03 a.p.f.u. 


\subsubsection{Plagioclásio}

Poucas análises deste mineral foram feitas nas amostras da fácies xisto azul da região e Jambaló, devido a um incipiente processo de sericitização concentrado no núcleo dos grãos e em porções intermediárias do plagioclásio nestas amostras. Todos os pontos obtidos correspondem a albita quase pura (Figura 9.16), mas com alguns dos pontos intermediários sugere-se que o zonamento observado na petrografia de algumas amostras seja de caráter normal.

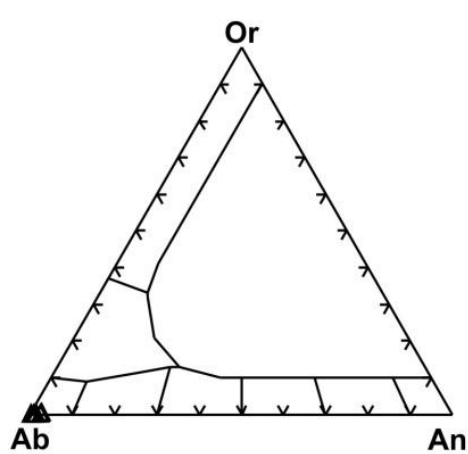

$\triangle 124$ I

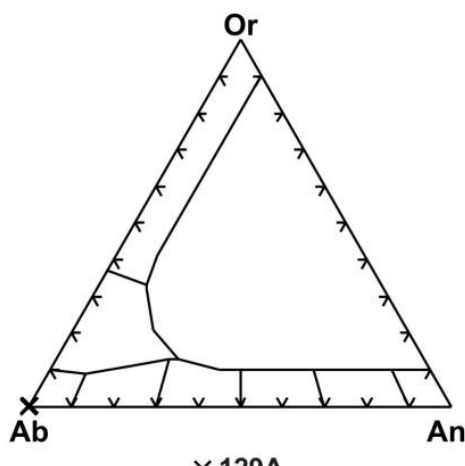

$\times 129 \mathrm{~A}$

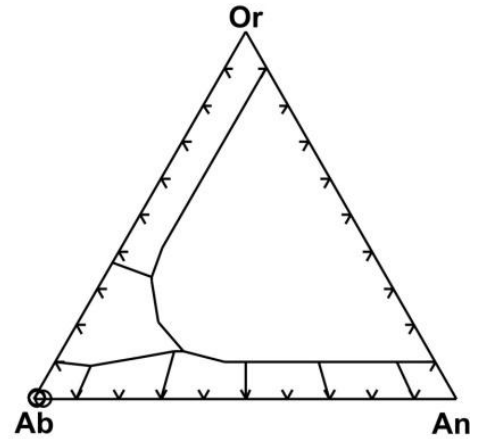

$0124 \mathrm{~J}$

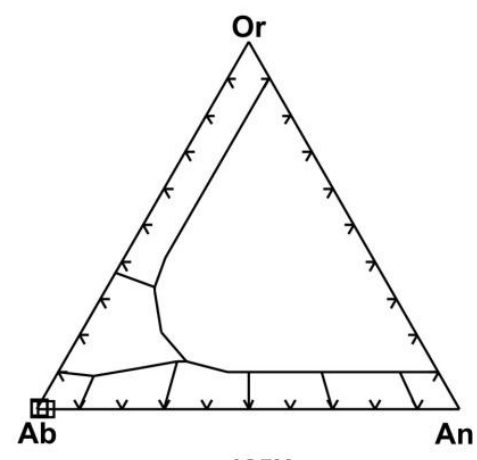

$\square 125 \mathrm{H}$

Figura 9.16. Diagramas de classificação do plagioclásio das rochas na fácies xisto azul da região de Jambaló, onde Or = ortoclásio, $A b=$ albita e $A n=$ anortita.

Para a amostra 124I o conteúdo de anortita obtido varia segundo $A n_{0,4-2,6}$, enquanto na amostra 124J este conteúdo é $A n_{0,5-2,2}$; na amostra 129A os valores de variação de são $A n_{0,1-0,2} \mathrm{e}$ na amostra $125 \mathrm{H}$ varia segundo $\mathrm{Na}_{0,2-0,4}$. Em algumas das amostras obtiveram-se valores para 0 núcleo com conteúdos de anortita próximos de $\mathrm{An}_{12}$, mas devido ao fechamento de baixa qualidade não são apresentados na Figura 9.16.

\subsubsection{Carbonato}

O carbonato foi analisado nas amostras 121B e 124F, em pequenos cristais xenoblásticos disseminados ou intersticiais. Das análises de química mineral, observa-se carbonato de cálcio puro. Estas informações junto com os dados petrográficos permitem confirmar que se trata de calcita. 


\subsubsection{Titanita}

As análises de química mineral feitas em diferentes grãos de titanita das amostras 121B, 124D, 124F, 124G, 124I, 125C, 125D, 125H e 125J. Em todos os casos apresenta-se como uma fase pura.

\subsection{Rochas da fácies xisto verde}

As características químicas dos minerais das rochas desta fácies são apresentadas a seguir:

\subsubsection{Anfibólio}

$\mathrm{Na}$ amostra 107 as análises de anfibólios concentram-se principalmente no campo do sódico-cálcicos (Figura 9.17) com alguns dos pontos com composições de anfibólios cálcicos (Figura 9.17), segundo a divisão proposta por Leake et al. (1997). A composição é de barroisita com gradação para winchita e, internamente, observam-se composições de winchita mais pobre em Si (Figura 9.17). Algumas análises de anfibólios cálcicos têm composição de actinolita e uma análise é de magnésio-hornblenda. Estas transições entre os diferentes grupos de anfibólios sugerem zonamentos composicional e substituições do anfibólio e podem indicar que a rocha sofreu metamorfismo em pressões mais elevadas, cristalizando anfibólios mais ricos em $\mathrm{Na}$, evoluindo até formar anfibólios mais cálcicos com a queda na pressão.
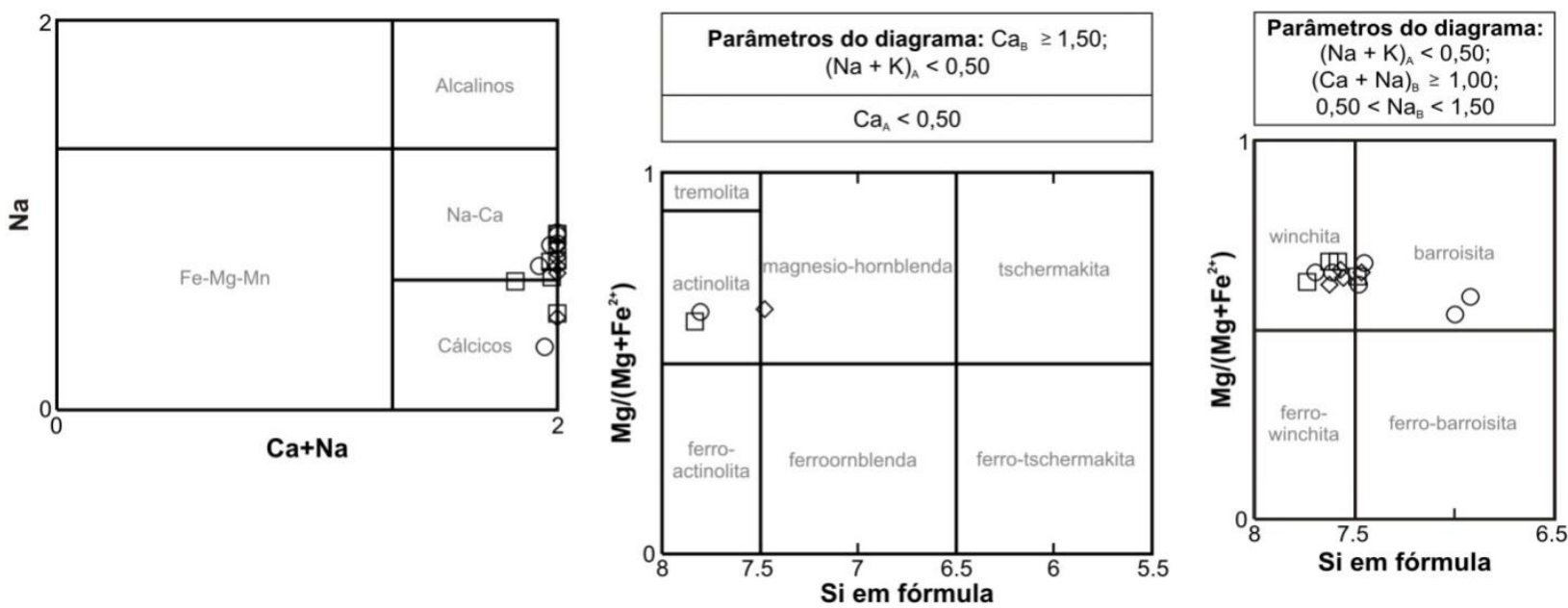

Borda $\bigcirc$ Intermediário $\diamond$ Núcleo

Figura 9.17. Diagramas de classificação dos anfibólios da amostra 107 nos quatro grupos principais (esquerda), dos anfibólios cálcicos (centro) e dos anfibólios sódico-cálcicos (direita). Todos os diagramas segundo Leake et al. (1997). No diagrama da esquerda nota-se que as algumas das análises plotam na borda porque o sítio $A$ está totalmente preenchido.

Nas análises de anfibólio da amostra 107 os conteúdos de Ca nas bordas variam entre 1,10 e 1,58 a.p.f.u. e de $\mathrm{Na}$ entre 0,51 e 0,91 a.p.f.u. Para os pontos obtidos nas porções 
intermediárias o Ca varia entre 1,09 e 1,63 a.p.f.u. e o Na entre 0,32 e 1,19 a.p.f.u. Nas análises feitas nas bordas, os conteúdos de Ca variam entre 1,16 e 1,53 a.p.f.u. e do Na entre 0,53 e 0,88 a.p.f.u. Essas variações do $\mathrm{Na}$ em intervalos relativamente amplos de variação são também indicativos do zonamento nos diagramas de classificação apresentados na Figura 9.17.

$\mathrm{Na}$ amostra 125A os anfibólios são todos cálcicos, têm composição de actinolita (Figura 9.18) e mostram uma tendência de enriquecimento em sílica nos núcleos relativamente às bordas. Os conteúdos de Ca nas análises de borda variam entre 1,64 e 1,81 a.p.f.u. e de Na entre 0,15 e 0,47 a.p.f.u. As partes intermediárias têm Ca no intervalo entre 1,64 e 1,91 a.p.f.u. e o Na entre 0,04 e 0,32 a.p.f.u. Os núcleos apresentam conteúdos de Ca entre 1,65 e 1,76 a.p.f.u. e Na entre 0,24 e 0,49 a.p.f.u.
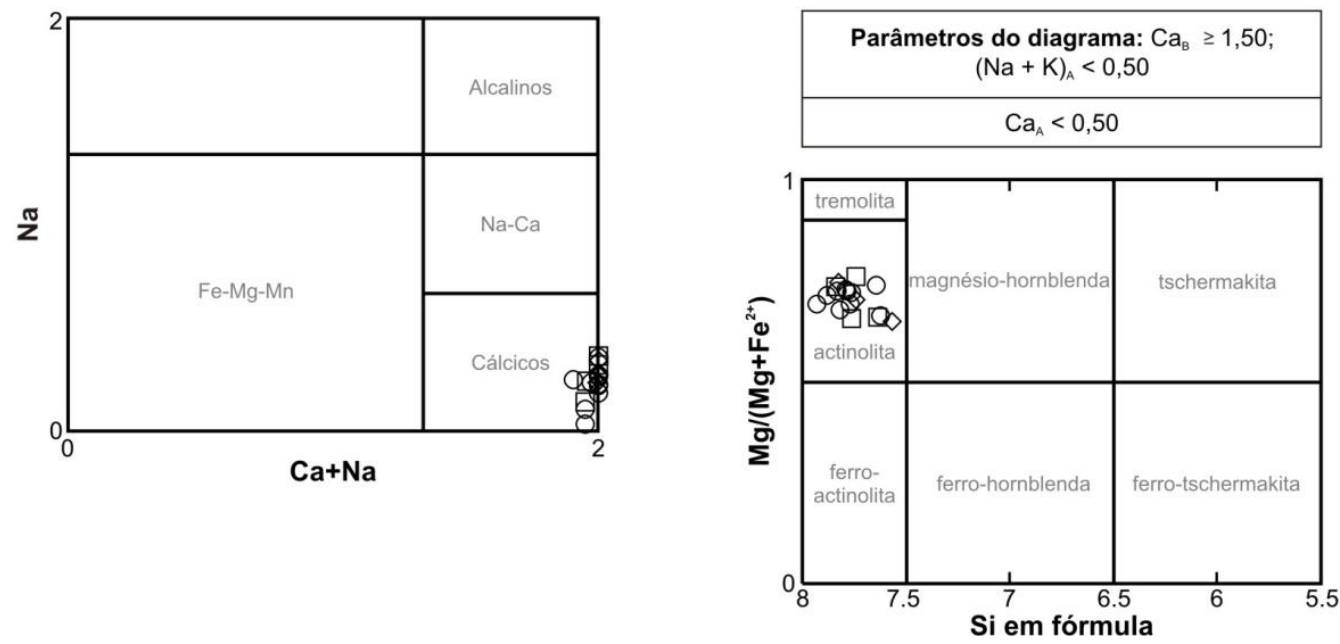

Borda $\bigcirc$ Intermediário $\diamond$ Núcleo

Figura 9.18. Diagramas de classificação dos anfibólios da amostra 125A nos quatro grupos principais (esquerda) e dos anfibólios cálcicos (direita). Os dois diagramas segundo Leake et al. (1997).

Em todas as amostras da fácies xisto verde da região de Jambaló pode-se avaliar a existência de substituição tschermakítica (Figura 9.19 A) predominante nos anfibólios, com alguma contribuição da substituição edenítica (Figura 9.19 B).
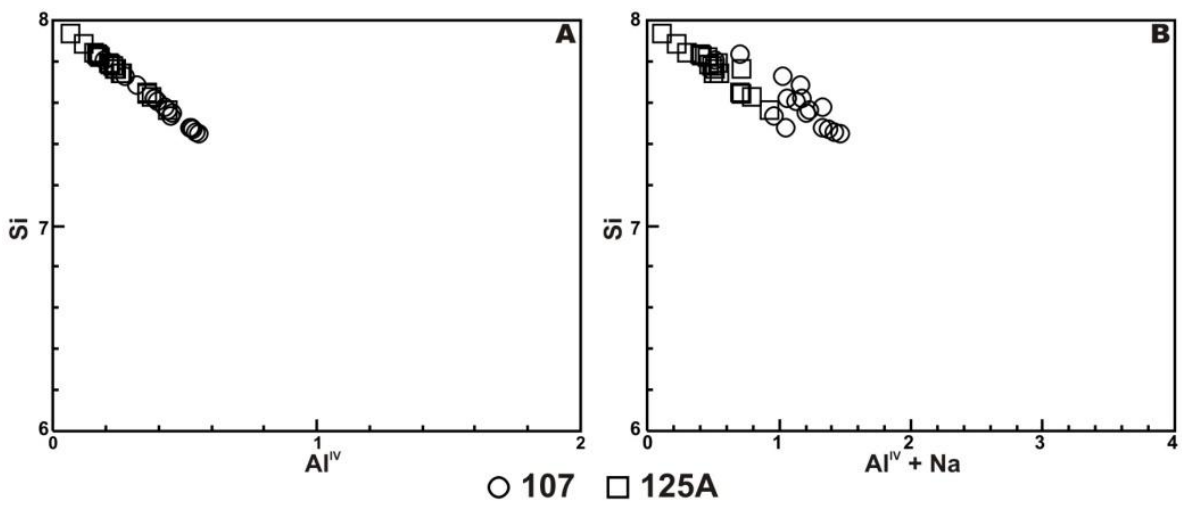

Figura 9.19. Diagramas representativos das substituições tschermakítica $(\boldsymbol{A})$ e edenítica dos anfibólios analisados nas rochas da fácies xisto verde da região de Jambaló. 

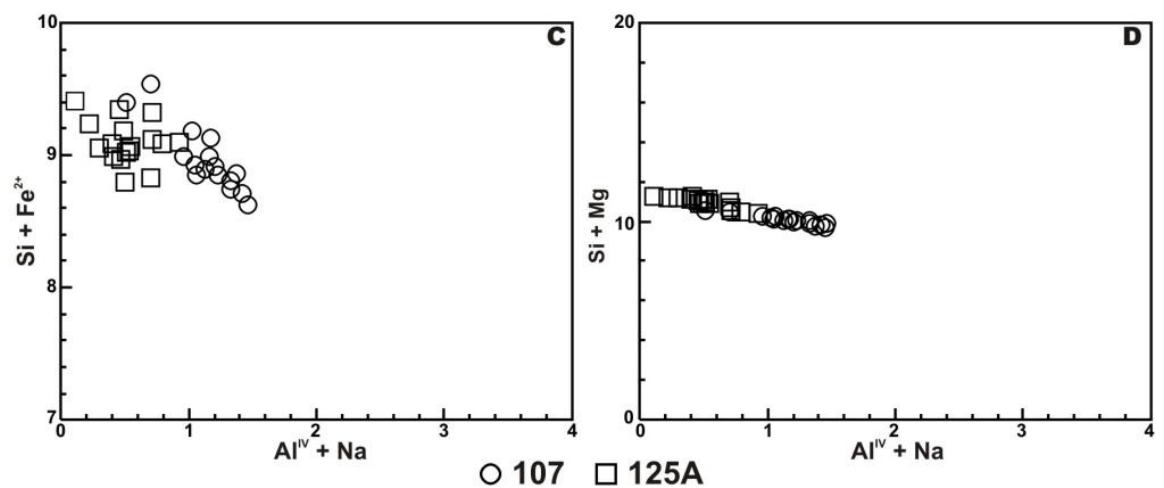

Figura 9.19 (continuação). Diagramas representativos das substituições ferro-pargasítica (C) e magnésiopargasítica $(\boldsymbol{D})$ dos anfibólios analisados nas rochas da fácies xisto verde da região de Jambaló.

As variações composicionais dos anfibólios também sugerem substituição magnésiopargasítica (Figura 9.19 D) e, menos intensamente, ferro-pargasítica (Figura 9.19 C).

\subsubsection{Granada}

A granada foi analisada unicamente numa amostra desta fácies, pois esse mineral apresenta-se fortemente substituído, não permitindo a obtenção de perfis composicionais. $\mathrm{Na}$ amostra 113F os perfis de zonamento são bem definidos, mesmo que as variações nos valores mínimos e máximos dos conteúdos de $\mathrm{Fe}^{2+}, \mathrm{Mg}$, $\mathrm{Ca}$ e $\mathrm{Mn}$ não sejam muito fortes. Na Figura 9.20 nota-se que os conteúdos de $\mathrm{Fe}^{2+}$ e $\mathrm{Ca}$ aumentam do núcleo para borda e o conteúdo de $\mathrm{Mn}$ diminui do núcleo para borda. O conteúdo de $\mathrm{Mg}$ apresenta um comportamento relativamente homogêneo nos perfis, mas notam-se pequenas diminuições nas bordas quando comparadas com os núcleos.
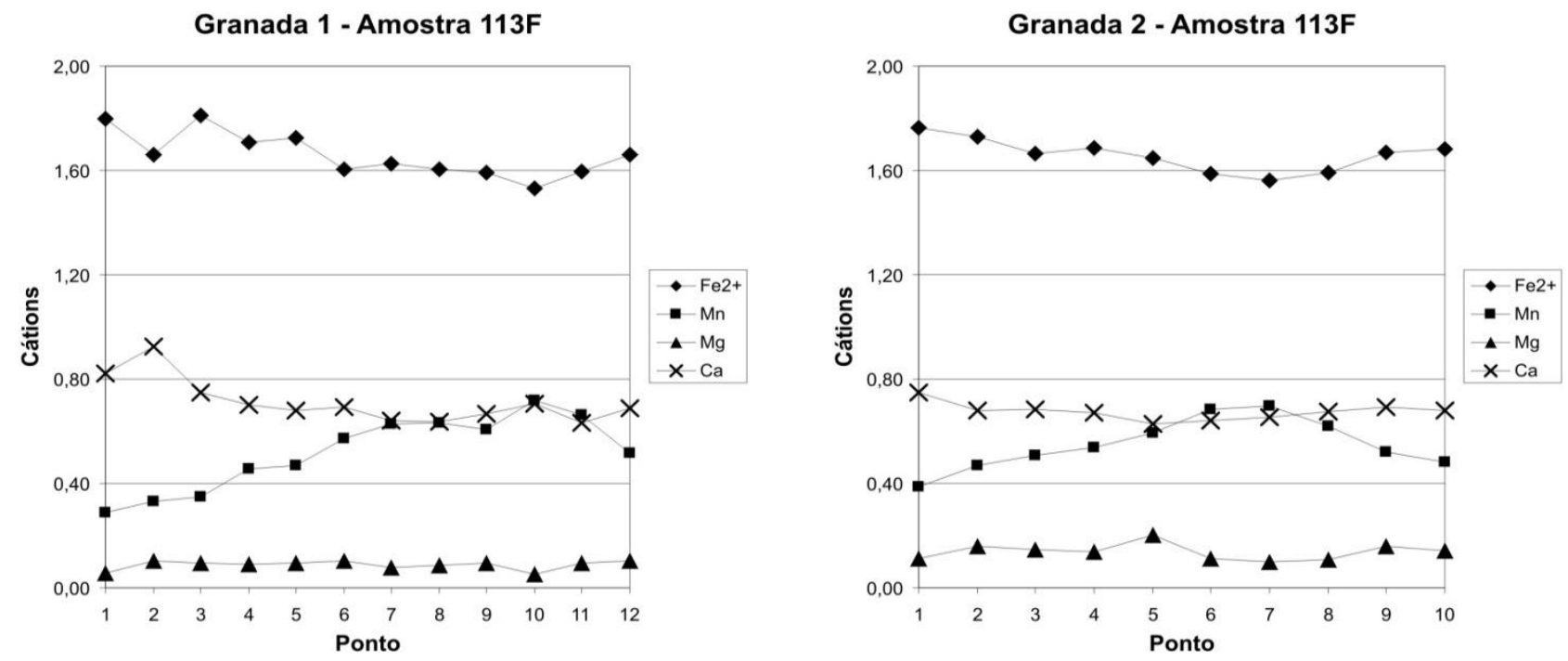

Figura 9.20. Padrão de zonamento dos principais cátions dos grãos de granada da amostra 113F. Os diagramas representam os pontos obtidos em perfis borda-núcleo-borda. 
Embora os conteúdos dos principais componentes da granada apresentem-se semelhantes, o conteúdo de $\mathrm{Fe}^{2+}$ é muito maior que o dos cristais de granada das amostras da fácies xisto azul. Isso pode ser interpretado como devido ao aumento da temperatura sofrido pelas rochas na transição da fácies xisto azul para xisto verde.

A variação dos principais componentes da granada dessa amostra pode ser expressa em termos de almandina (Alm) + grossularia (Grs) + piropo (Pyp) + espessartita (Sps) da seguinte forma: $\mathrm{Alm}_{50,94-58,53} \mathrm{Grs}_{21,14-30,65} \mathrm{Pyp}_{1,75-5,24} \mathrm{Sps}_{10,93-23,82}$.

\subsubsection{Clorita}

A clorita foi analisada nas amostras 107C, 108, 113F e 125A e, geralmente, não puderam ser feitos perfis composicionais. Essas amostras apresentam uma heterogeneidade composicional semelhante ao observado nas amostras da fácies xisto azul, mas há uma maior concentração nos campos composicionais da brunsvigita e da picnoclorita (Figura 9.21A, B, C e D), como poucos dados do campo da picnoclorita e da ripidolita.

$\mathrm{Na}$ amostra 113F os conteúdos de $\mathrm{Fe}^{2+}$ variam entre 5,50 e 5,71 a.p.f.u. e o Mg entre 3,31 e 3,64 a.p.f.u. Para a amostra $107 \mathrm{C}$ os valores de $\mathrm{Fe}^{2+}$ variam entre 4,73 e 5,07 a.p.f.u. e o $\mathrm{Mg}$ entre 3,96 e 4,68 a.p.f.u. Já na amostra 108 os valores de $\mathrm{Fe}^{2+}$ estão no intervalo entre 4,00 e 4,63 a.p.f.u. e o $\mathrm{Mg}$ entre 4,80 e 5,44 a.p.f.u. Na amostra 125A a variação do Fe ${ }^{2+}$ está entre 3,98 e 4,17 a.p.f.u. e o Mg entre 4,73 e 5,11 a.p.f.u.

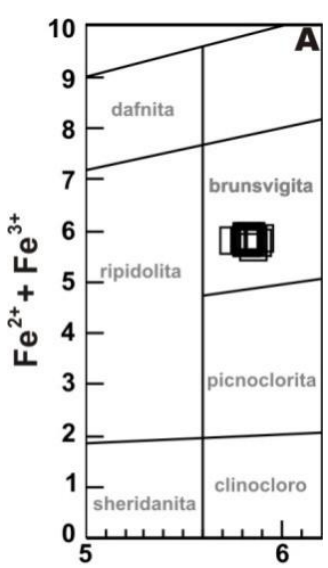

$\mathrm{Si}$

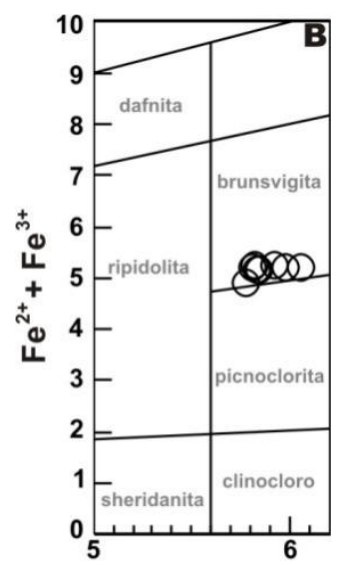

$\mathrm{Si}$

○ $107 \mathrm{C}$

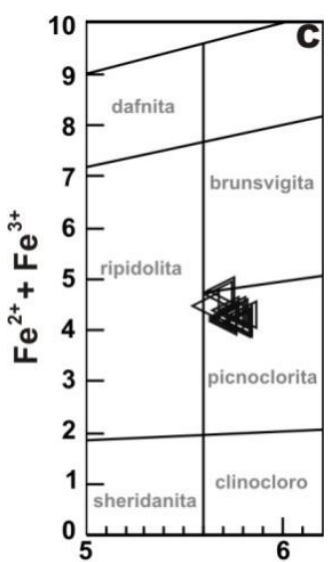

$\mathrm{Si}$

$\triangleleft 108$

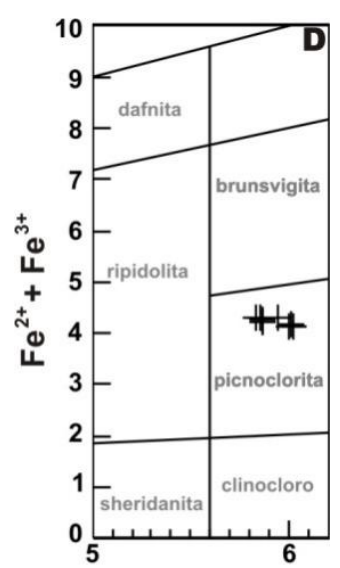

$\mathrm{Si}$

$+125 \mathrm{~A}$

Figura 9.21. Diagramas de classificação da clorita segundo Hey (1954). Nas figuras observa-se que os pontos estão concentrados no campo da brunsvigita nas amostras $113 \mathrm{~F}(\boldsymbol{A})$ e $107 \mathrm{C}(\boldsymbol{B})$ e no campo da picnoclorita nas amostras 108 (C) e 125A (D).

\subsubsection{Mica branca}

A mica branca foi analisada nas amostras 107, 107C e 113F. Em nenhum dos casos foram obtidos perfis composicionais. 
Na amostra 107 as análises correspondem a fengita (Figura 9.22), segundo a classificação de Tischendorf (1997). A fengita da amostra 107 apresenta conteúdos de Si no intervalo entre 3,20 e 3,25 a.p.f.u., de K entre 0,77 e 0,90 a.p.f.u. e de $\mathrm{Na}$ entre 0,03 e 0,07 a.p.f.u.

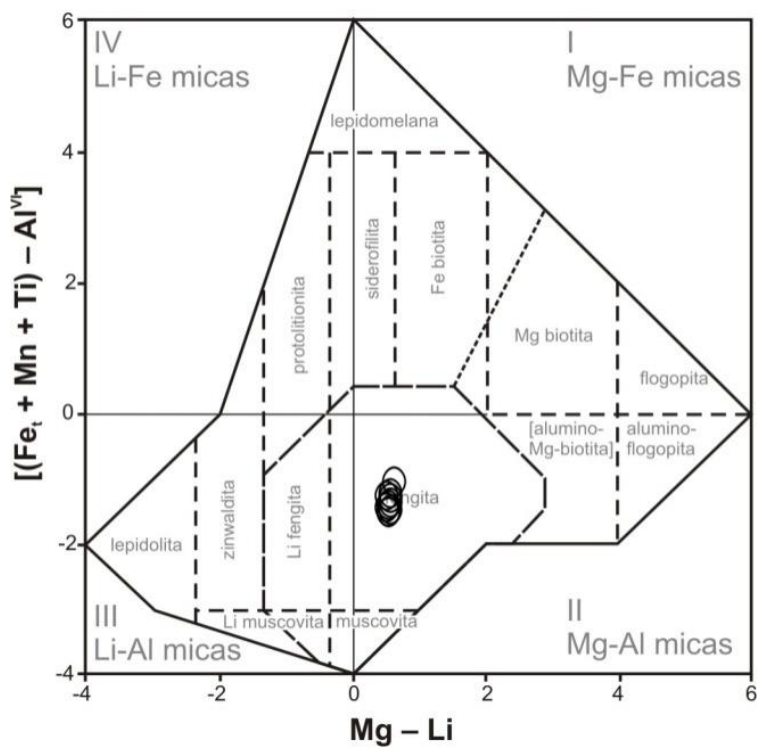

Figura 9.22. Diagrama $\left[\left(F e_{t}+M n+T i\right)-A l^{V l}\right]$ vs $(M g-L i)$ de classificação das micas segundo Tischendorf (1997), no qual se apresenta a composição dos grãos de mica branca da amostra 107, que têm composição predominantemente fengítica.

As análises obtidas da amostra 107C correspondem à fengita (Figura 9.23) segundo o esquema de classificação proposto por Tischendorf (1997). Os teores de Si obtidos variam entre 3,22 e 3,30 a.p.f.u., de K entre 0,58 e 0,85 a.p.f.u. e de $\mathrm{Na}$ entre 0,01 e 0,06 a.p.f.u.

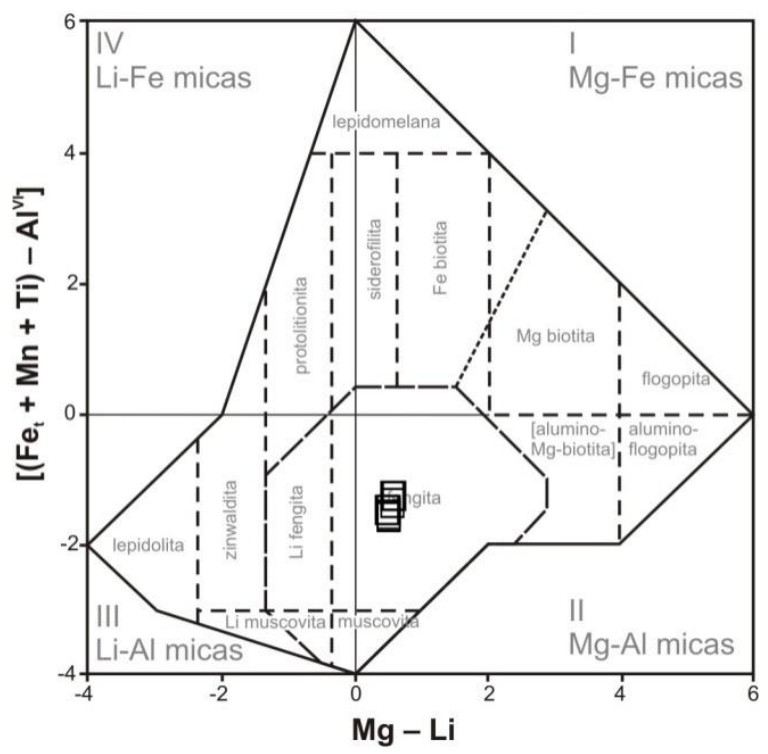

Figura 9.23. Diagrama $\left[\left(\mathrm{Fe}_{t}+\mathrm{Mn}+\mathrm{Ti}\right)-\mathrm{Al} \mathrm{l}^{V l}\right]$ vs $(\mathrm{Mg}-\mathrm{Li})$ de classificação das micas segundo Tischendorf (1997) no qual se apresenta a composição dos grãos de mica branca analisados na amostra 107C, que têm composição predominantemente fengítica. 
Para amostra 113F a mica branca foi igualmente classificada como fengita (Figura 9.24) de acordo com o esquema de Tischendorf (1997). Os teores de Si variam entre 3,18 e 3,28 a.p.f.u., os de $\mathrm{K}$ entre 0,84 e 0,89 a.p.f.u. e os de $\mathrm{Na}$ entre 0,01 e 0,08 a.p.f.u.

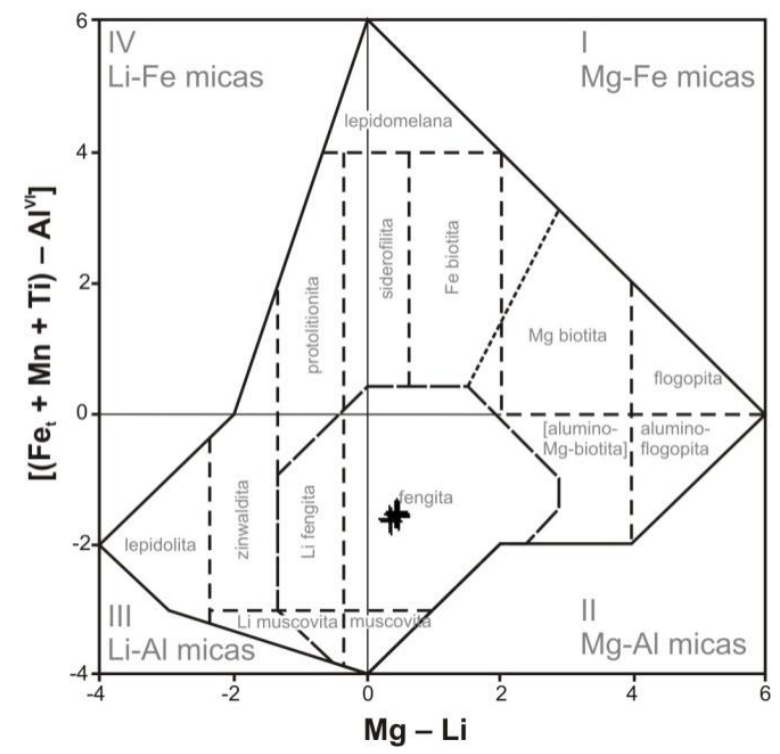

Figura 9.24. Diagrama $\left[\left(F e_{t}+M n+T i\right)-A l^{V l}\right]$ vs $(M g-L i)$ de classificação das micas segundo Tischendorf (1997), no qual se apresenta a composição dos grãos de mica branca da amostra 113F, que mostram a composição predominantemente fengítica.

\subsubsection{Plagioclásio}

O plagioclásio foi analisado somente na amostra 113F. A composição é de albita essencialmente pura (Figura 9.25), com conteúdos de anortita que variam entre $\mathrm{An}_{0,1-1,3}$.

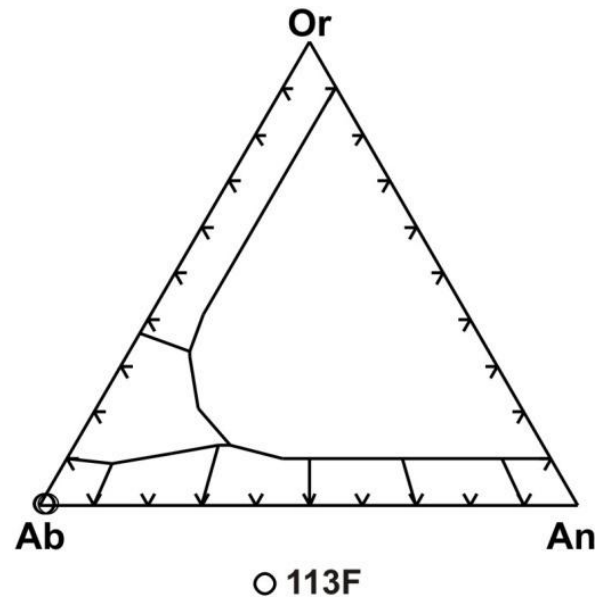

Figura 9.25. Diagrama de classificação do plagioclásio da amostra $113 F$ no qual se observam todas as análises concentradas no campo da albita. Or = ortoclásio, $A b=$ albita e $A n=$ anortita.

\subsubsection{Rutilo e titanita}

O rutilo é um mineral comumente encontrado nas amostras, tanto da fácies xisto azul como da fácies xisto verde. Às vezes apresenta-se uma relação de reação de ilmenita-rutilo-titanita, na 
qual o rutilo constitui um anel intermediário ao redor da ilmenita que, por sua vez, é envolvido pela titanita. Mesmo assim, pelo reduzido tamanho dos cristais, foi possível obter dados analíticos de apenas uma amostra da fácies xisto verde (113F). Nas análises observa-se que corresponde a uma fase pura. A titanita foi unicamente analisada na amostra $107 \mathrm{C}$ e igualmente corresponde a um mineral em essência puro.

\subsubsection{Epidoto}

Foi obtido um perfil de epidoto na amostra 113F o qual apresenta conteúdos de $\mathrm{Fe}^{3+}$ nas bordas que variam entre 0,61 e 0,63 a.p.f.u. e $\mathrm{Mn}^{3+}$ sem variação (0,01 a.p.f.u.). Nos pontos intermediários o $\mathrm{Fe}^{3+}$ varia entre 0,60 e 0,61 e o $\mathrm{Mn}^{3+}$ varia entre 0 e 0,01 a.p.f.u. Para os núcleos o conteúdo de $\mathrm{Fe}^{3+}$ varia entre 0,65 e 0,68 e o $\mathrm{Mn}^{3+}$ sem variação (0,02 a.p.f.u.). Estes sugerem um leve zonamento com empobrecimento dos conteúdos de $\mathrm{Fe}^{3+}$ do núcleo para a borda.

$\mathrm{Na}$ amostra 125A os dados obtidos não correspondem a perfil composicional. Neste caso o $\mathrm{Fe}^{3+}$ varia entre 0,39 e 042 a.p.f.u. e o $\mathrm{Mn}^{3+}$ entre 0,01 e 0,02 a.p.f.u.

\subsubsection{Estilpnomelano}

As composições dos grãos analisados da amostra 107 apresentam-se relativamente homogêneas, pois os conteúdos de $\mathrm{Fe}^{2+}$ variam entre 3,46 e 3,66 a.p.f.u. o $\mathrm{Mg}$ entre 1,89 e 2,02 a.p.f.u. e o $\mathrm{Mn}$ entre 0,14 e 0,18 a.p.f.u. 


\section{QUÍMICA MINERAL DA REGIÃO DE BARRAGÁN}

Nas rochas da fácies xisto azul foram analisados principalmente anfibólio sódico, pumpellyita, lawsonita, clorita, titanita, rutilo, epidoto, mica, plagioclásio e carbonato. Nas rochas da fácies anfibolito foram analisados essencialmente granada, anfibólio cálcico, titanita, plagioclásio, minerais do grupo do epidoto, clorita e rutilo. Todas as análises da química mineral encontram-se no Anexo IV.

\subsection{Rochas da Fácies Xisto Azul}

As características químicas dos minerais das rochas dessa fácies são apresentadas a seguir:

\subsubsection{Anfibólio sódico}

Os anfibólios analisados foram calculados assumindo 22(O).

Todos os anfibólios da amostra 196 são alcalinos (Figura 10.1), segundo o diagrama de Leake et al. (1997; 2004), e no diagrama de Miyashiro (1957) os anfibólios sódicos são caracterizados como glaucofânio (Figura 10.1). Mesmo com zonamento óptico observado na petrografia, as poucas análises obtidas na amostra 196 não permitem determinar precisamente os motivos desse zonamento, mas nota-se uma fraca tendência de empobrecimento em $\mathrm{Mg}$ e Fe das porções de núcleo e intermediárias para as bordas.

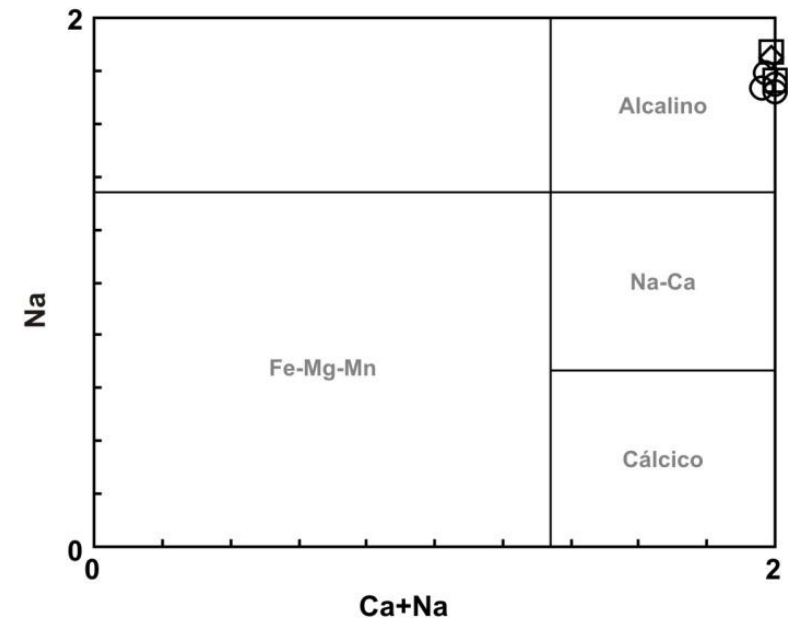

Borda $\bigcirc$ Intermediário $\diamond$ Núcleo

Figura 10.1. À esquerda é apresentado o diagrama de classificação dos anfibólios da amostra 196 nos quatro grupos principais segundo Leake et al. (1997, 2004), indicando serem todos anfibólios alcalinos. No diagrama da direita pode ser observada a composição do anfibólio sódico no campo da série glaucofânioriebeckita (Miyashiro, 1957), evidenciando sua composição de glaucofânio.

Os anfibólios da amostra 196 têm conteúdos de Na nas bordas variando entre 1,80 e 1,88 a.p.f.u.; nas partes intermediárias entre 1,74 e 1,81 a.p.f.u. e nos núcleos ao redor de 1,86 a.p.f.u. 
O Ca varia entre 0,12 e 0,24 a.p.f.u. nas bordas, 0,18 e 0,28 a.p.f.u. nas porções intermediárias e no núcleo o valor é 0,14 a.p.f.u.

$\mathrm{Na}$ amostra 196D os anfibólios plotam no campo dos alcalinos (Figura 10.2) segundo Leake et al. (1997, 2004) e no diagrama de Miyashiro (1957) as análises correspondem a glaucofânio (Figura 10.2), sem uma clara tendência evolutiva quando comparadas as análises borda-intermediário-núcleo.
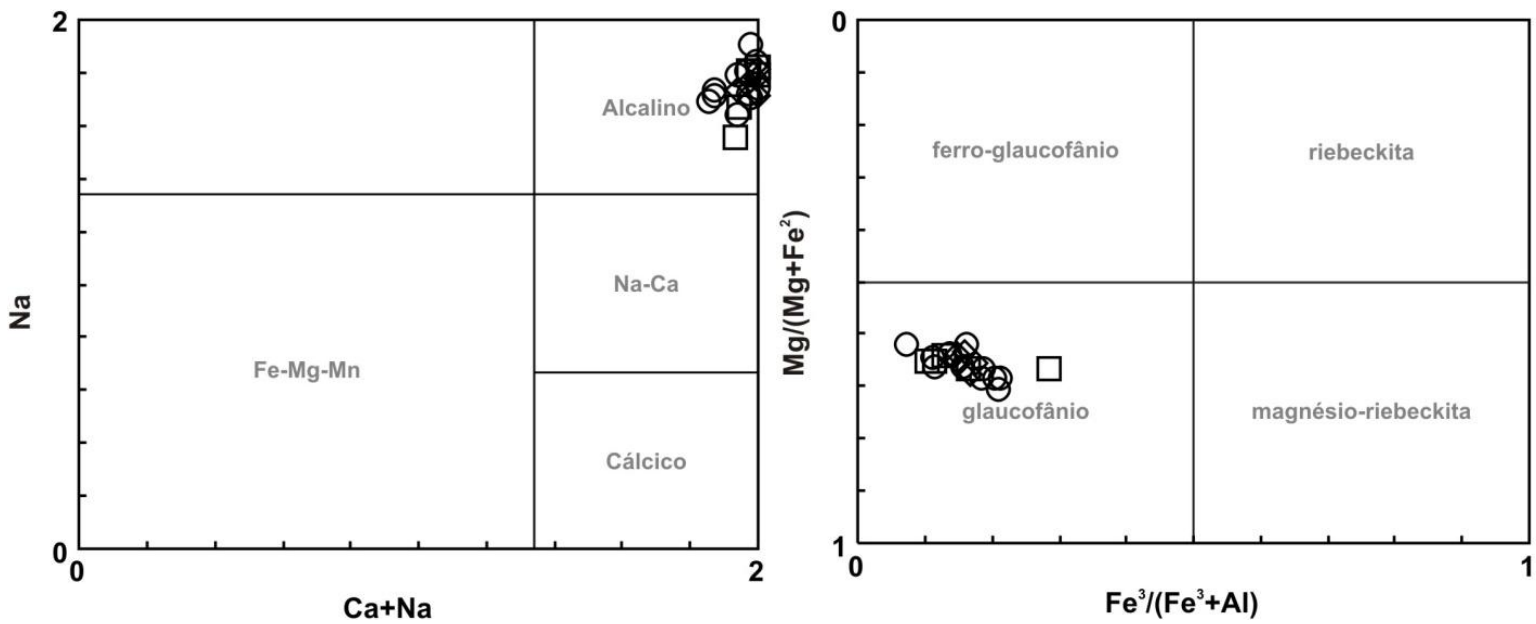

Borda O Intermediário $\diamond$ Núcleo

Figura 10.2. À esquerda é apresentado o diagrama de classificação dos anfibólios da amostra 196D nos quatro grupos principais segundo Leake et al. (1997, 2004), indicando serem todos anfibólios alcalinos. No diagrama da direita pode ser observada a composição do anfibólio sódico no campo da série glaucofânioriebeckita (Miyashiro, 1957), evidenciando sua composição de glaucofânio.

$\mathrm{Na}$ amostra 196D os valores de $\mathrm{Na}$ encontrados nas análises de borda variam entre 1,91 e 1,57; nos pontos intermediários entre 1,65 e 1,85 a.p.f.u. e nos núcleos entre 1,74 e 1,84 a.p.f.u. 0 $\mathrm{Ca}$ nas bordas dos anfibólios tem concentrações entre 0,16 e 0.39 a.p.f.u.; nos pontos intermediários varia entre 0,14 e 0,30 a.p.f.u.e nos núcleos entre 0,19 e 0,29 a.p.f.u.

A amostra de xisto azul 197 tem também glaucofânio (Figura 10.3), com \# Mg um pouco mais elevado relativamente à amostra 196, e com variações nos teores de sódio, com uma única análise situada no limite com o campo dos anfibólios sódico-cálcicos. Nota-se, apesar da sobreposição das análises, uma tendência de evolução para ferro-glaucofânio do núcleo para as bordas do mineral.

$\mathrm{Na}$ amostra 197 os conteúdos de $\mathrm{Na}$ os anfibólios variam entre 1,83 e 1,96 a.p.f.u. nas bordas dos cristais, entre 1,66 e 1,97 a.p.f.u. nas partes intermediárias e entre 1,41 e 1,98 a.p.f.u. Os conteúdos de Ca apresentam variação nas bordas entre 0,09 e 0.14 a.p.f.u., nas porções intermediárias entre 0,07 e 0,23 a.p.f.u. e nos núcleos entre 0,04 e 0,21 a.p.f.u. Uma análise apenas mostrou um alto teor de $\mathrm{Ca}(0,61)$, o que posiciona composicionalmente o anfibólio no limite dos campos dos anfibólios alcalinos e dos sódico-cálcicos. Apesar do intervalo de variação de $\mathrm{Na}$ seja de quase $~ 0,50$ a.p.f.u., não há um claro padrão de zonamento dos cristais de 
anfibólio. Entretanto, pode-se deduzir que os núcleos são mais sódicos que as bordas, o pode sugerir um evento de descompressão.
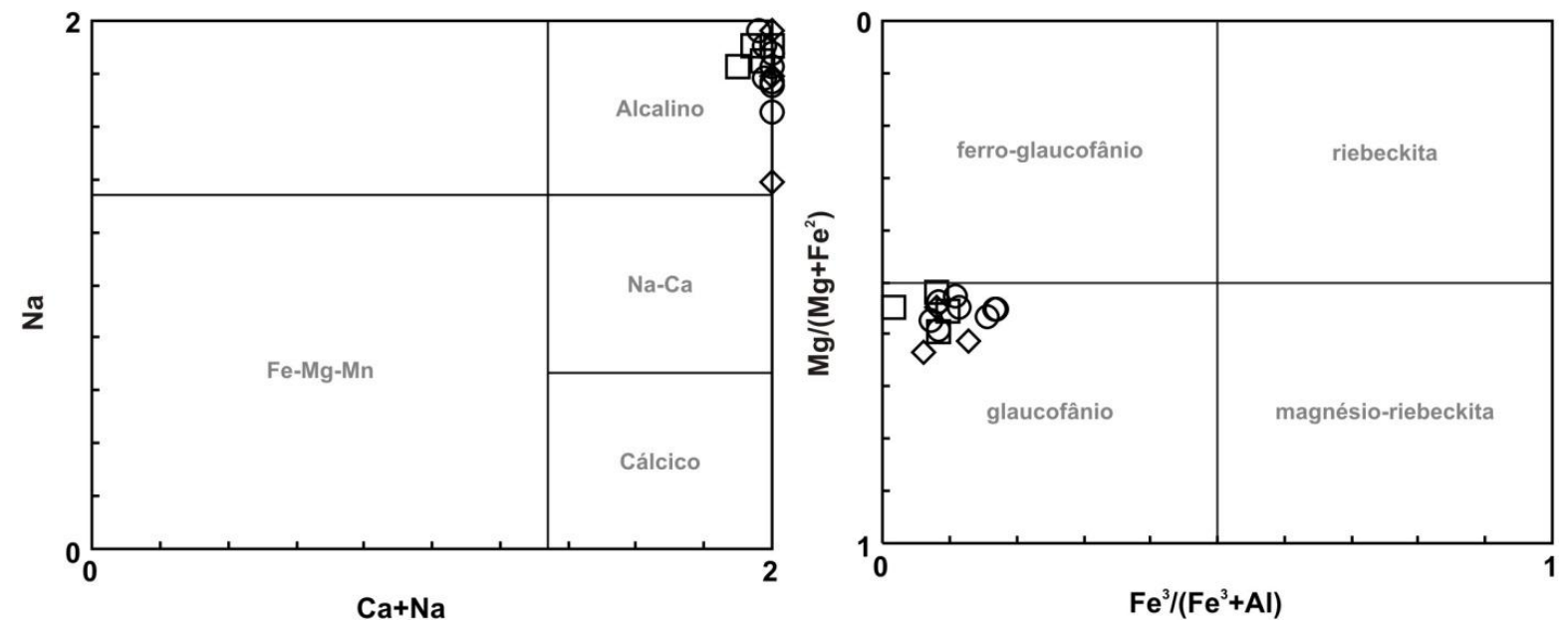

Borda $\bigcirc$ Intermediário $\diamond$ Núcleo

Figura 10.3. À esquerda é apresentado o diagrama de classificação dos anfibólios da amostra 197 nos quatro grupos principais segundo Leake et al. (1997, 2004), indicando serem todos anfibólios alcalinos. No diagrama da direita pode ser observada a composição do anfibólio sódico no campo da série glaucofânioriebeckita (Miyashiro, 1957), evidenciando sua composição de glaucofânio com a tendência para ferroglaucofânio nas bordas.

A última amostra deste conjunto de fácies xisto azul, corresponde à 199. Da mesma forma que nas outras analisadas encaixam na área dos anfibólios alcalinos (Figura 10.4), exceto uma análise, que se posiciona no limite dos campos dos anfibólios alcalinos e sódico-cálcicos. Mesmo assim, foi identificado apenas glaucofânio (Figura 10.4), segundo o diagrama de Miyashiro (1957). Nessa amostra não há um claro zonamento núcleo-borda, apesar da variação na razão $\mathrm{Fe}^{3+} /\left(\mathrm{Fe}^{3+}+\mathrm{Al}\right)$.

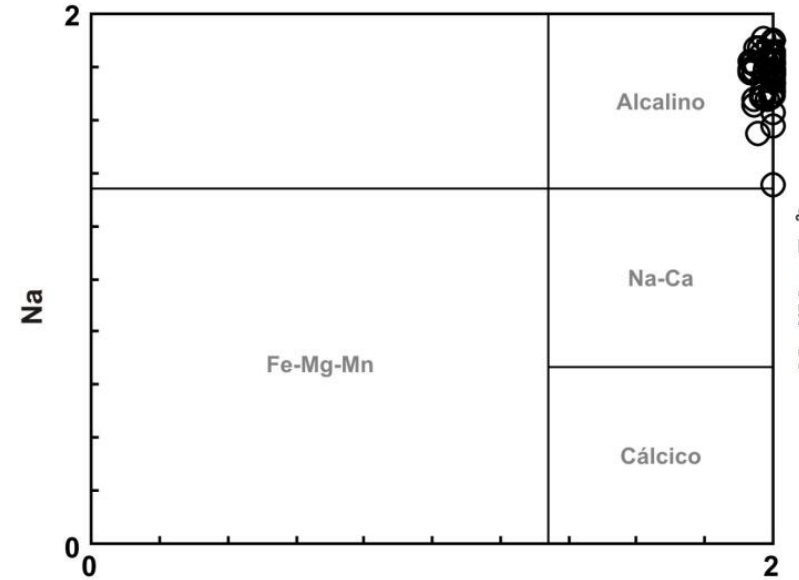

$\mathrm{Ca}+\mathrm{Na}$

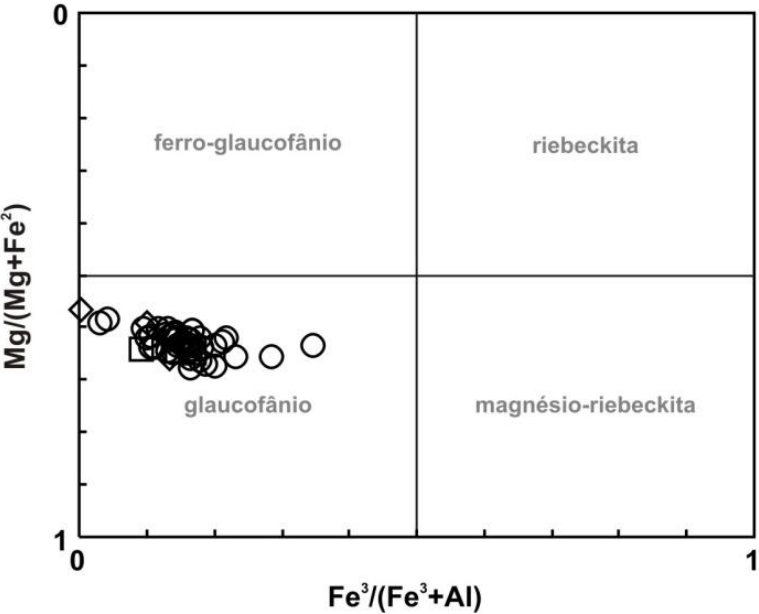

$\mathrm{Fe}^{3} /\left(\mathrm{Fe}^{3}+\mathrm{Al}\right)$

Borda $\bigcirc$ Intermediário $\diamond$ Núcleo

Figura 10.4. À esquerda é apresentado o diagrama de classificação dos anfibólios da amostra 199 nos quatro grupos principais, segundo Leake et al. (1997, 2004), indicando serem todos anfibólios alcalinos. No diagrama da direita pode ser observada a composição galucofânica do anfibólio sódico no campo da série glaucofânio-riebeckita (Miyashiro, 1957). 
Os conteúdos de $\mathrm{Na}$ obtidos nas análises nas bordas dos grãos apresentam uma variação entre 1, 72 e 1,87 a.p.f.u., nas porções intermediárias entre 0,13 e 0,26 a.p.f.u. e nos núcleos entre 1,77 e 1,92 a.p.f.u. O Ca varia, respectivamente nas bordas, partes intermediárias e núcleos, de 0,13 a 0,26, 0,13 a0,30 e 0,16 a 0,26 a.p.f.u. Uma análise feita no núcleo de um cristal apresentou um alto teor de $\mathrm{Ca}$ (0,65 a.p.f.u.), resultando num anfibólio com composição situada no limite entre os anfibólios alcalinos e os sódico-cálcicos.

\subsubsection{Pumpellyita}

A distribuição catiônica foi feita segundo a fórmula ideal $W_{4} X_{2} Y_{4} Z_{6} O_{21}(O H)_{7}$ de Coombs et al. (1976), onde $\mathrm{W}=\mathrm{Ca}, \mathrm{X}=\mathrm{Mg}, \mathrm{Y}=\mathrm{Al}$ e $\mathrm{Z}=\mathrm{Si}$ e desconsidera a presença de água na fórmula. Os conteúdos de $\mathrm{Fe}^{3+}$ foram calculados pelo método de Cortesogno et al. (1984), o qual assume 16 cátions por $24,5(0)$ anidro.

O intervalos de variação dos conteúdos de $\mathrm{Si}, \mathrm{Ca}, \mathrm{Al}$ e $\mathrm{Mg} / \mathrm{Mg}+\mathrm{Fe}^{2+}$ obtidos para cada uma das amostras são apresentados na Tabela 10.1. Da tabela nota-se que em todas as amostras analisadas, os conteúdos de $\mathrm{Si}, \mathrm{Ca}, \mathrm{Al}, \mathrm{Mg} / \mathrm{Mg}+\mathrm{Fe}^{2+}$ apresentam teores relativamente homogêneos, o que permite caracterizar a pumpellyita como uma fase relativamente pura.

Tabela 10.1. Variação dos conteúdos de Si, Ca, Al e $M g \#\left(M g / M g+F e^{2+}\right)$ em a.p.f.u. na pumpellyita analisada nas rochas da fácies xisto azul da região de Barragán.

\begin{tabular}{lccccccccc}
\hline Cátion & $\mathbf{1 9 6}$ & 196D & $\mathbf{1 9 7}$ & $\mathbf{1 9 9}$ & Cátion & $\mathbf{1 9 6}$ & $\mathbf{1 9 6 D}$ & $\mathbf{1 9 7}$ & 199 \\
$\mathrm{Si}$ & $6,00-6,08$ & $6,00-6,07$ & $6,00-6,10$ & $6,00-6,04$ & $\mathrm{Al}$ & $4,75-4,88$ & $4,73-4,82$ & $4,77-4,93$ & $4,66-4,84$ \\
$\mathrm{Ca}$ & $3,70-3,84$ & $3,75-3,94$ & $3,69-3,84$ & $3,85-4,00$ & $\mathrm{Mg \#}$ & $0,70-0,83$ & $0,70-0,80$ & $0,65-0,77$ & $0,78-0,90$ \\
\hline
\end{tabular}

Em termos gerais, a pumpellyita analisada apresenta substituições moderadas de $\mathrm{Al}_{2} \mathrm{O}_{3}$ por $\mathrm{FeO}$ pouca por $\mathrm{MgO}$. Na Figura 10.5 apresentam diagrama $\mathrm{Al}_{2} \mathrm{O}_{3}-\mathrm{FeO}-\mathrm{MgO}$ da pumpellyita das diferentes amostras da região de Barragán, nos quais nota-se que a sua composição não apresenta variação composicional significativa.
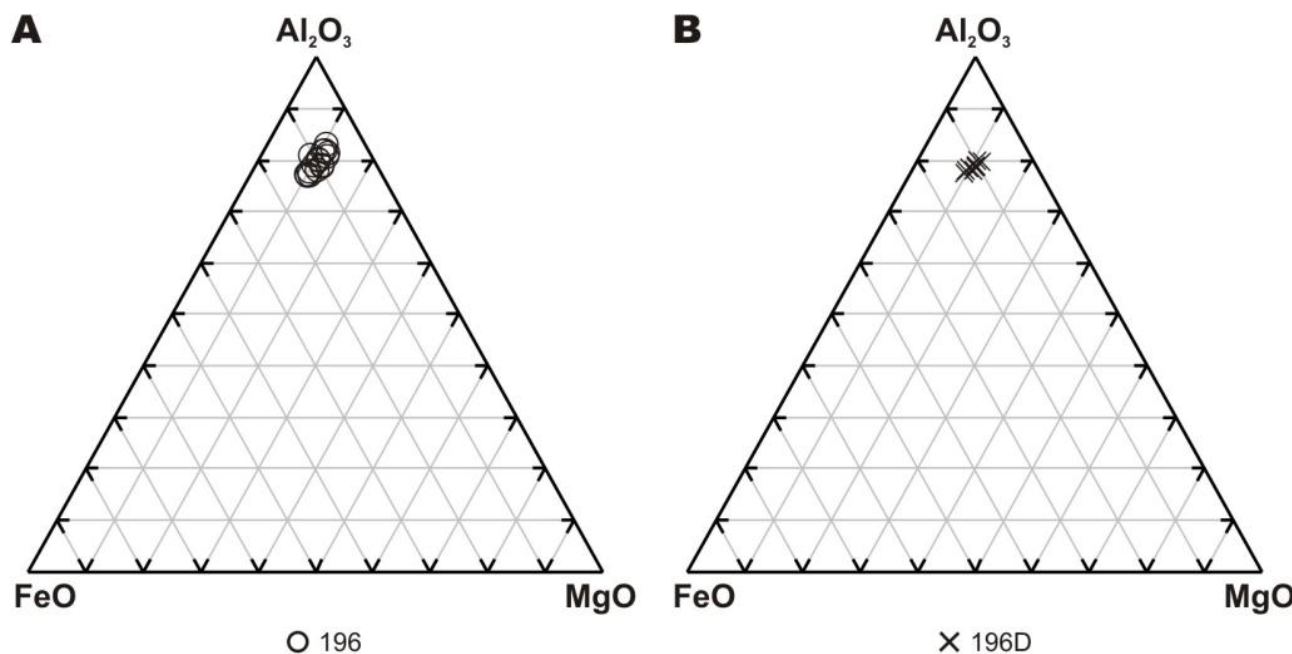

Figura 10.5. Diagramas composicionais da pumpellyita de rochas da fácies xisto azul da área de Barragán, indicando a leve substituição de Al por Fe e a pouca influência do magnésio na substituição. A. Amostra 196 e B. Amostra 196D. 


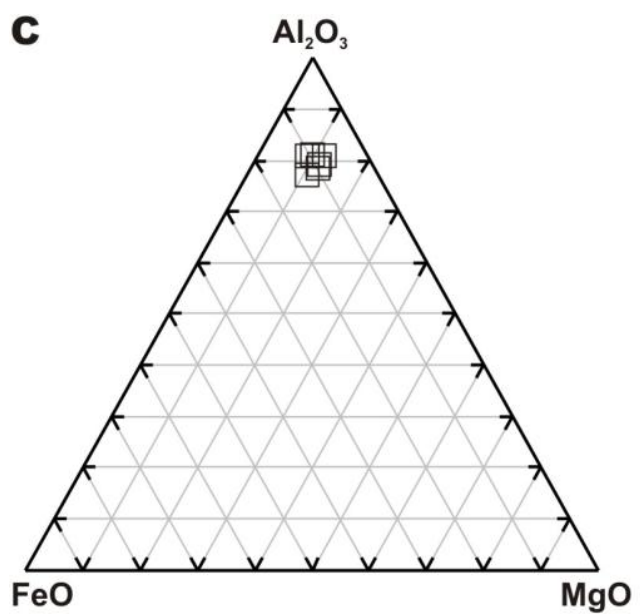

$\square 197$

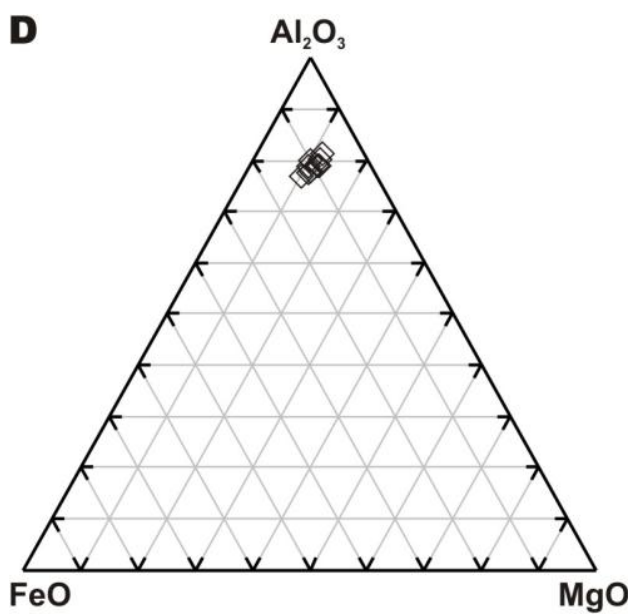

$\diamond 199$

Figura 10.5 (continuação). Diagramas composicionais da pumpellyita de rochas da fácies xisto azul da área de Barragán, indicando a leve substituição de Al por Fe e a pouca influência do magnésio na substituição. C. Amostra 197 e D. Amostra 199.

\subsubsection{Clorita}

As análises feitas nas amostras da fácies xisto azul indicam que a composição da clorita varia entre as diferentes amostras. Devido ao reduzido tamanho dos grãos de clorita não foi possível a obtenção de perfis composicionais.

$\mathrm{Na}$ amostra 196D, segundo a classificação de Hey (1954), está presente somente picnoclorita relativamente homogênea (Figura 10.6A); na 197 predomina picnoclorita, mas há variações para ripidolita (Figura 10.6B), e na 197A a composição tende a se concentrar no limite entre os campos da picnoclorita e da ripidolita, com apenas uma análise de clorita mais rica em Si (Figura 10.6C).

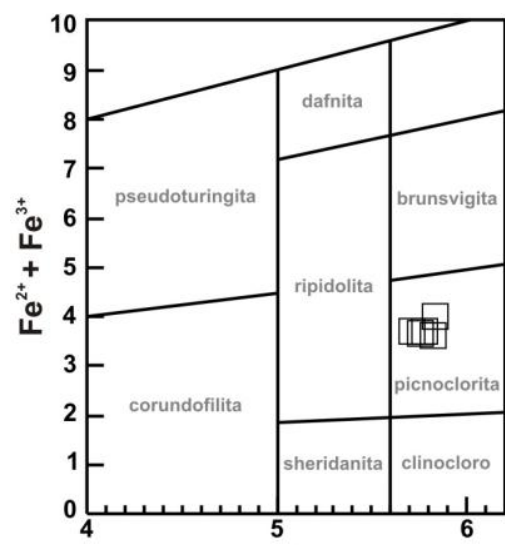

A

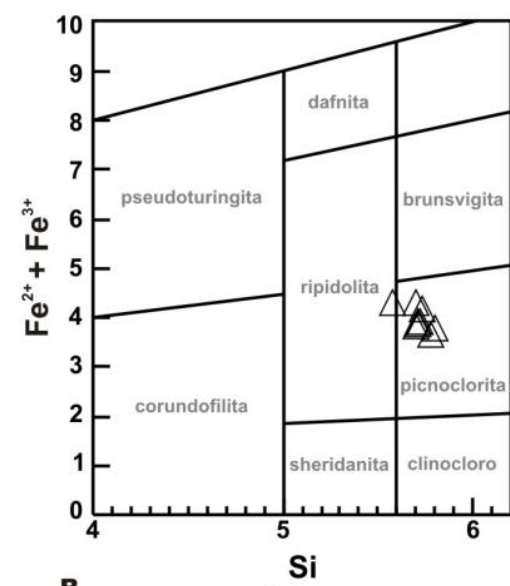

$\mathrm{Si}$

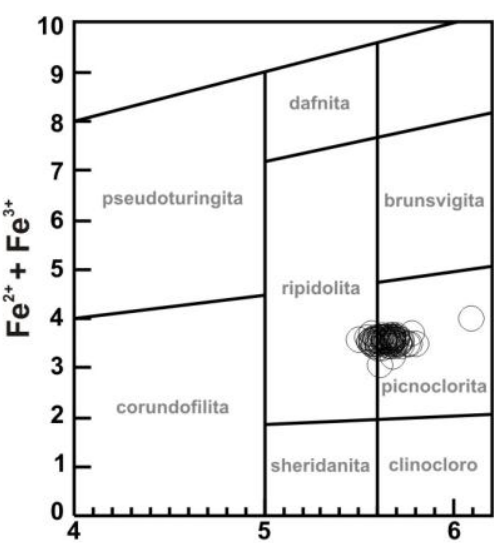

C
Si

197A

Figura 10.6. Diagramas de classificação da clorita, segundo Hey (1954), nos quais observa-se que a maioria das análises correspondem a picnoclorita, com variações composicionais subordinadas para ripidolita.

Apesar das diferenças composicionais nas amostras, há certa homogeneidade nos valores de Mg da clorita de cada uma das amostras. As amostras 196D, 197A e 197 mostram, 
respectivamente, variação de 5,37 a 6,03 , de 5,51 a 6,04 e de 5,06 a 5,54 a.p.f.u., enquanto o $\mathrm{Fe}^{2+}$ varia entre 3,69 e 3,99, 3,04 e 3,84 e 3,65 e 4,33 a.p.f.u. Essas variações nos conteúdos de $\mathrm{Fe}^{2+}$ e Mg são, possivelmente, conseqüência de variações na temperatura durante o retrometamorfismo.

\subsubsection{Lawsonita}

A lawsonita, presente somente nas amostras 197 e 197A, é uma fase quase pura, exceto por possíveis pequenas impurezas de Ti, com 0,01 a 0,02 a.p.f.u. na amostra 197 e 0,01 a 0,4 a.p.f.u. na amostra 197A. O um conteúdo de Fe é muito baixo, variando entre 0,01 e 0,02 a.p.f.u.

\subsubsection{Titanita e rutilo}

As análises de química mineral feitas em diferentes grãos de titanita das amostras 196, 196D, 197A e 199 indicam que o mineral é bastante puro. O rutilo, analisado apenas na amostra 197A, é também uma fase relativamente pura.

\subsubsection{Carbonato}

Pequenos cristais de carbonato xenoblásticos, disseminados ou intersticiais, da amostra 196D foram analisados, revelando ser carbonato de cálcio puro, o que, aliado com os dados ópticos, indicam ser calcita.

\subsubsection{Minerais do grupo do epidoto}

Foi analisado apenas clinozoisita das amostras 196 e 196D e 199 e os conteúdos de $\mathrm{Fe}^{3+}$ variam, respectivamente, de 0,40 a 0,53, de 0,50 a 0,73 e de 0,55-0,81 a.p.f.u., enquanto o $\mathrm{Mn}^{3+}$ está abaixo do limite de detecção ( 0.01 a.p.f.u.) nas duas primeiras amostras e situa-se entre 0,01 e 0,04 a.p.f.u. na amostra 199.

\subsubsection{Mica Branca}

Mica branca foi analisada somente na amostra 196D e sua composição corresponde à da fengita (Figura 10.7), segundo a classificação de Tischendorf (1997). Devido às dimensões dos grãos, não puderam ser obtidos perfis composicionais. 


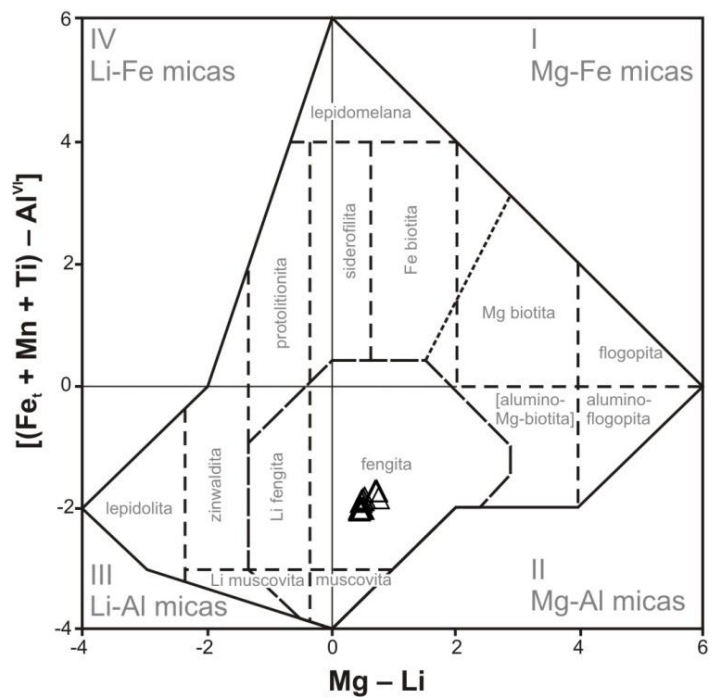

Figura 10.7. Diagrama $\left[\left(F e_{t}+M n+T i\right)-A l^{V l}\right]$ vs $(M g-L i)$ de classificação das micas, segundo Tischendorf (1997), no qual pode-se observar que a mica branca da amostra 196D de xisto azul da região de Barragán é representada pela fengita.

A fengita apresenta conteúdos de Si no intervalo 3,00 e 3,20 para cada 11(O) por unidade de fórmula. Esses valores são típicos de muitas metabásicas na fácies xisto azul (e.g. Okay, 1980; El Shazly, 1994), mas são consideravelmente mais baixos que outras regiões, como exemplificado por Sorensen (1986).

\subsubsection{Plagioclásio}

Embora tenha sido encontrado plagioclásio em várias amostras da fácies xisto azul, esse mineral foi analisado unicamente na amostra 199, mas não foi possível a obtenção de perfis composicionais, até mesmo porque se trata de albita pura (Figura 10.8).

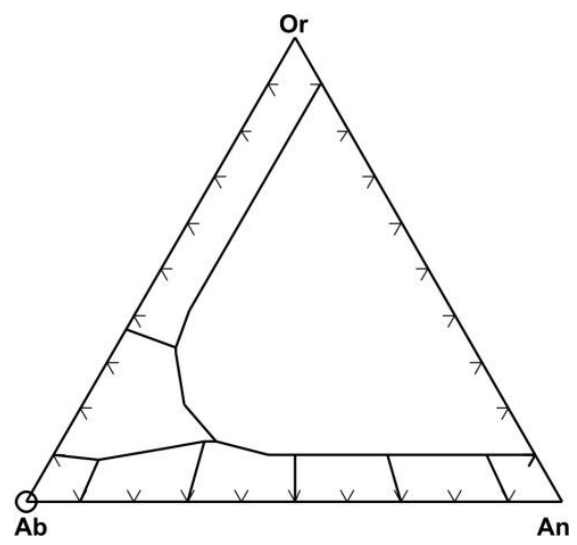

Figura 10.8. Classificação do plagioclásio em termos de Or-Ab-An da amostra 199, no qual se observa a composição de albita pura em todas as análises.

Entretanto, foram observados zonamentos composicionais na petrografia que não puderam ser identificados nos poucos pontos analisados. 


\subsection{Rochas da fácies anfibolito}

A química mineral das rochas da fácies anfibolito é apresentada a seguir:

\subsubsection{Anfibólio}

$\mathrm{Na}$ amostra 187A as análises obtidas indicam que o anfibólio é usualmente cálcico (magnésio-hornblenda), mas há ainda relíquias de anfibólio sódicos-cálcicos (barroisita) (Figura 10.9), segundo a classificação de Leake et al. (1997). A barroisita foi identificada tanto no núcleo como na borda de cristais de magnésio-hornblenda, indicando a evolução do anfibólio de composições mais alcalinas para as mais cálcicas durante o retrometamorfismo, o que sugere que as rochas tenham experimentado pressões mais altas antes de alcançar o equilíbrio na fácies anfibolito.
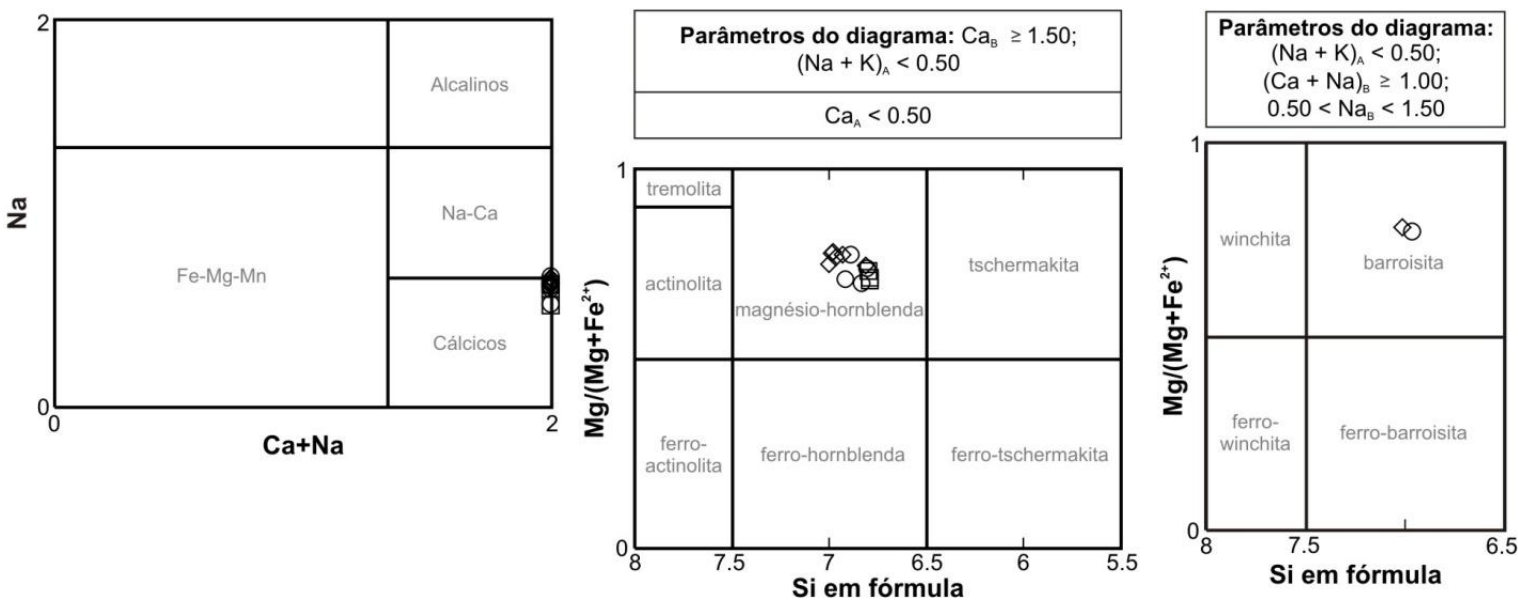

Borda $\bigcirc$ Intermediário $\diamond$ Núcleo

Figura 10.9. Diagrama de classificação dos anfibólios da amostra 187A nos quatro grupos principais (esquerda), dos anfibólios cálcicos (centro) e dos anfibólios sódico-cálcicos (direita), segundo Leake et al. (1997), indicando composições de magnesio-hornblenda, com duas análises correspondentes a barroisita.

$\mathrm{Na}$ amostra 187B todo anfibólio é magnésio-hornblenda (Figura 10.10). Não se nota nenhuma tendência de evolução núcleo-borda, pois as variações composicionais se sobrepõem.
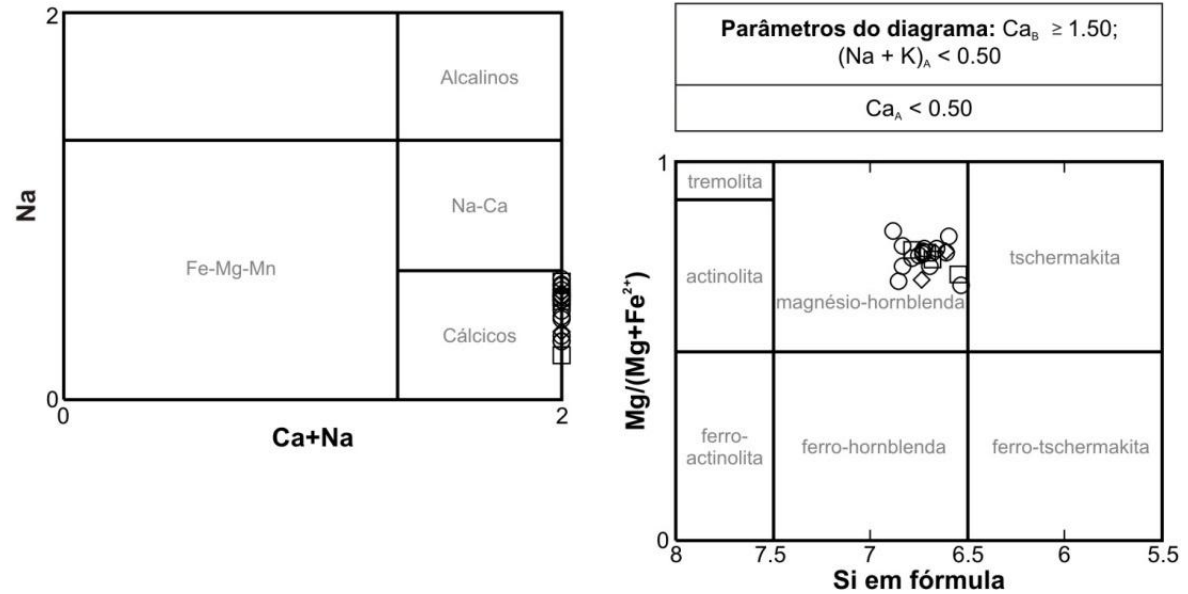

Borda $\bigcirc$ Intermediário $\diamond$ Núcleo

Figura 10.10. Diagrama de classificação dos anfibólios da amostra $187 \mathrm{~B}$ nos quatro grupos principais (esquerda) e dos anfibólios cálcicos (direita), indicando composições de magnésio-hornblenda. 
$\mathrm{Na}$ amostra 188 os anfibólios também são magnésio-hornblenda (Figura 10.11) e mostram grãos com composições distintas, mas tendência evolutiva semelhante em direção ao campo da actinolita, reflexo do retrometamorfismo.
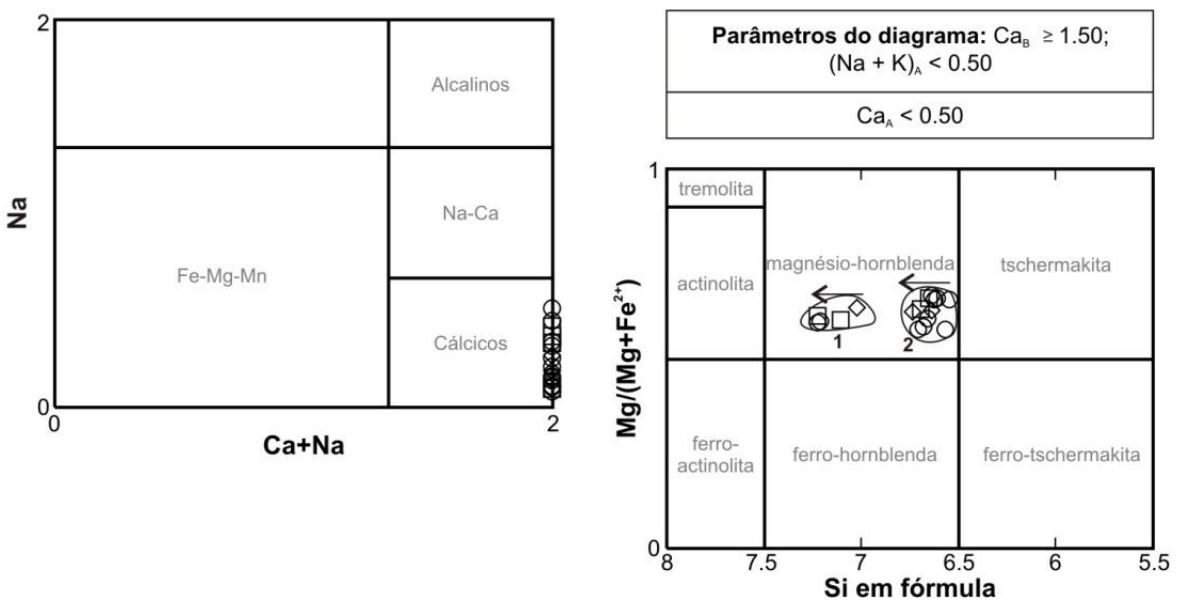

Borda $\bigcirc$ Intermediário $\diamond$ Núcleo

Figura 10.11. Diagrama de classificação dos anfibólios da amostra 188 nos quatro grupos principais (esquerda) e dos anfibólios cálcicos (direita), indicando composições de magnésio-hornblenda, com tendência evolutiva para actinolita. Os numeros 1 e 2 correspondem a grãos diferentes e as setas indicam a tendência evolutiva.

Com as análises obtidas para a amostra 189, encontrou-se que os anfibólios pertencem ao grupo dos cálcicos (Figura 10.12), mas são também verificadas relíquias de anfibólio sódicocálcico (Figura 10.12), segundo a classificação de Leake et al. (1997), identificados como magnésio-hornblenda e barroisita. Estas análises sugerem uma evolução de um anfibólio de mais alta pressão e mais enriquecido em Na no núcleo com uma tendência evolutiva para anfibólios de cálcico nas bordas. Já a magnésio-hornblenda mostra uma tendência evolutiva para ferrohornblenda, possivelmente devido a variações na temperatura.
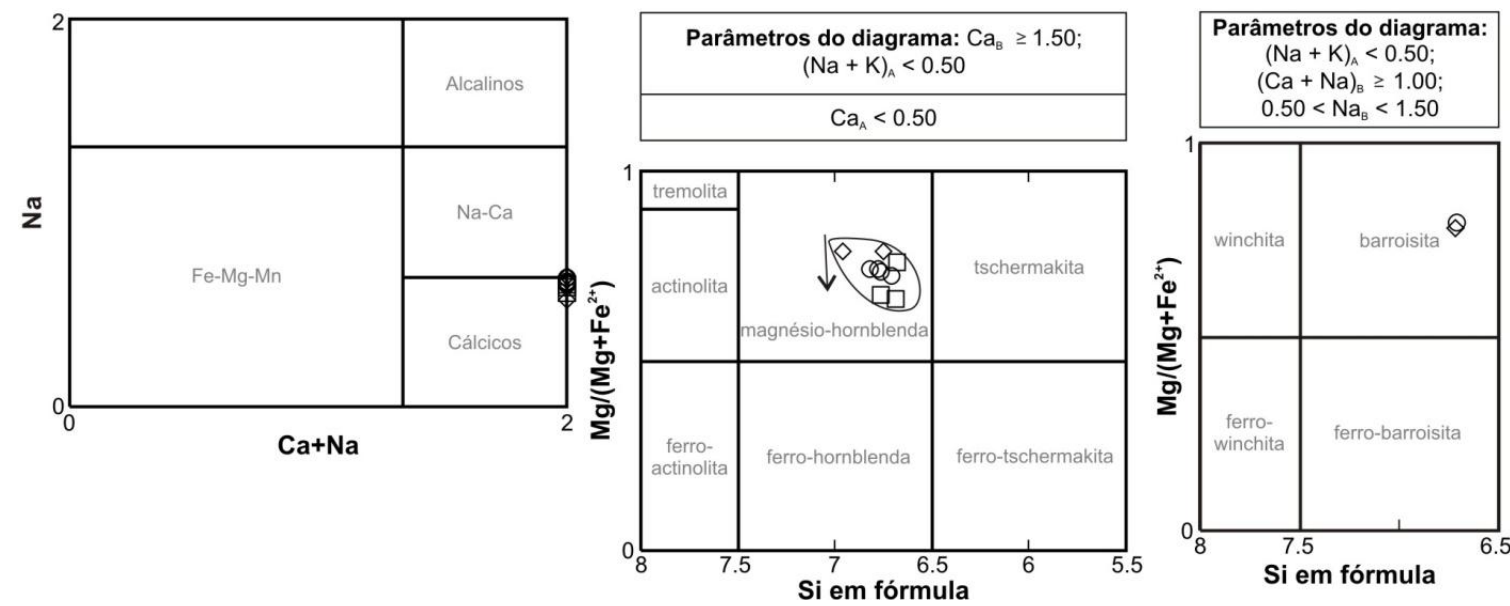

Borda $\bigcirc$ Intermediário $\diamond$ Núcleo

Figura 10.12. Diagrama de classificação dos anfibólios da amostra 189 nos quatro grupos principais (esquerda), dos anfibólios cálcicos (centro) e dos anfibólios sódico-cálcicos (direita), indicando composições de magnésio-hornblenda e barroisita. A seta no diagrama central indica a possível tendência evolutiva da magnésio-hornblenda para ferro-hornblenda. 
$\mathrm{Na}$ amostra 189A os anfibólios estão todos igualmente dentro do grupo dos cálcicos (Figura 10.13), com composições de magnésio-hornblenda, segundo a classificação proposta por Leake et al. (1997). Embora não haja uma clara tendência de evolução do anfibólio nesta amostra, há uma leve indicação de variação composicional semelhante à verificada no anfibólio da amostra anterior, com gradação para o campo da ferro-hornblenda.
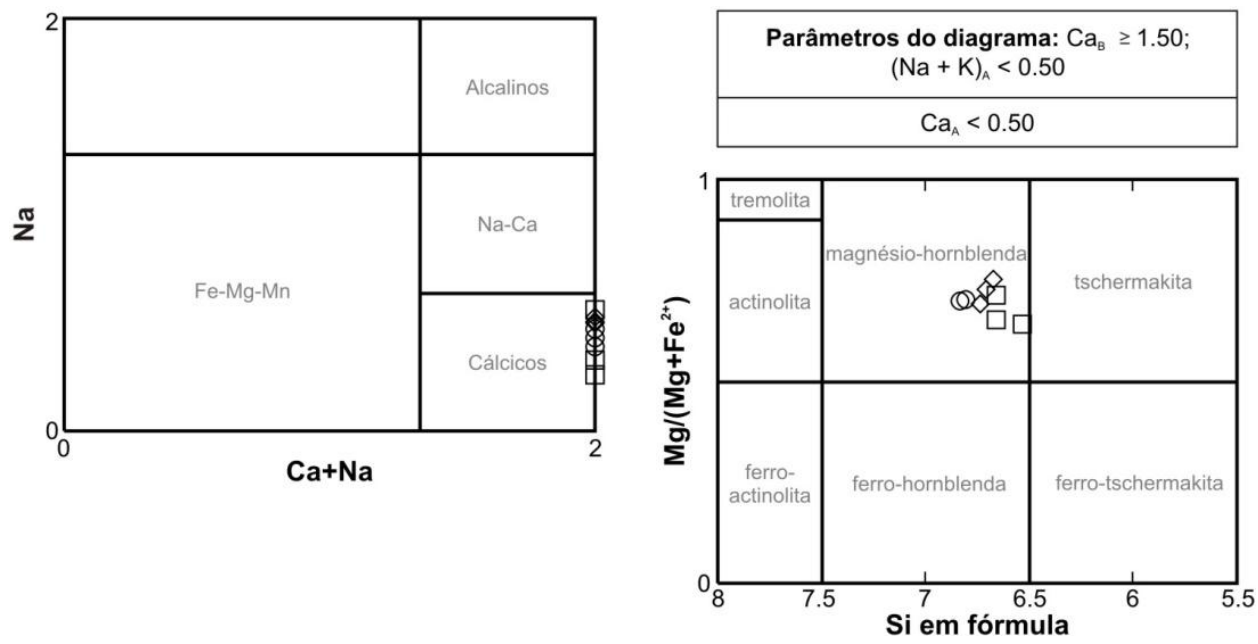

Borda $\bigcirc$ Intermediário $\diamond$ Núcleo

Figura 10.13. Diagrama de classificação dos anfibólios da amostra $189 \mathrm{~A}$ nos quatro grupos principais (esquerda) e dos anfibólios cálcicos (direita), nos quais se notam as composições de magnésio-hornblenda.

De modo geral, todos os anfibólios aqui analisados são magnésio-hornblenda e mostram relíquias de anfibólios mais sódicos, cristalizados sob regimes de alta pressão. Os anfibólios cálcicos comumente apresentam linearidade entre as substituições tschermakítica e edenítica o que caracteriza a substituição pargasítica (Spear, 1995). Em todas as amostras da fácies anfibolito da região de Barragán pode-se verificar a existência de substituição tschermakítica (Figura 10.14A) predominante nos anfibólios, com algo de contribuição da substituição edenítica (Figura 10.14B). O conjunto de anfibólios analisados também sugere uma substituição magnésiopargasítica (Figura 10.14C) e em menor proporção a ferro-pargasítica (Figura 10.14D). Principalmente a substituição tschermakítica e magnésio-pargasítica podem ser consideradas como o enriquecimento de $\mathrm{Mg}$ em detrimento do $\mathrm{Na}$ nos anfibólios cálcicos, como foi notado nas figuras apresentadas para os anfibólios analisados da região de Barragán. 

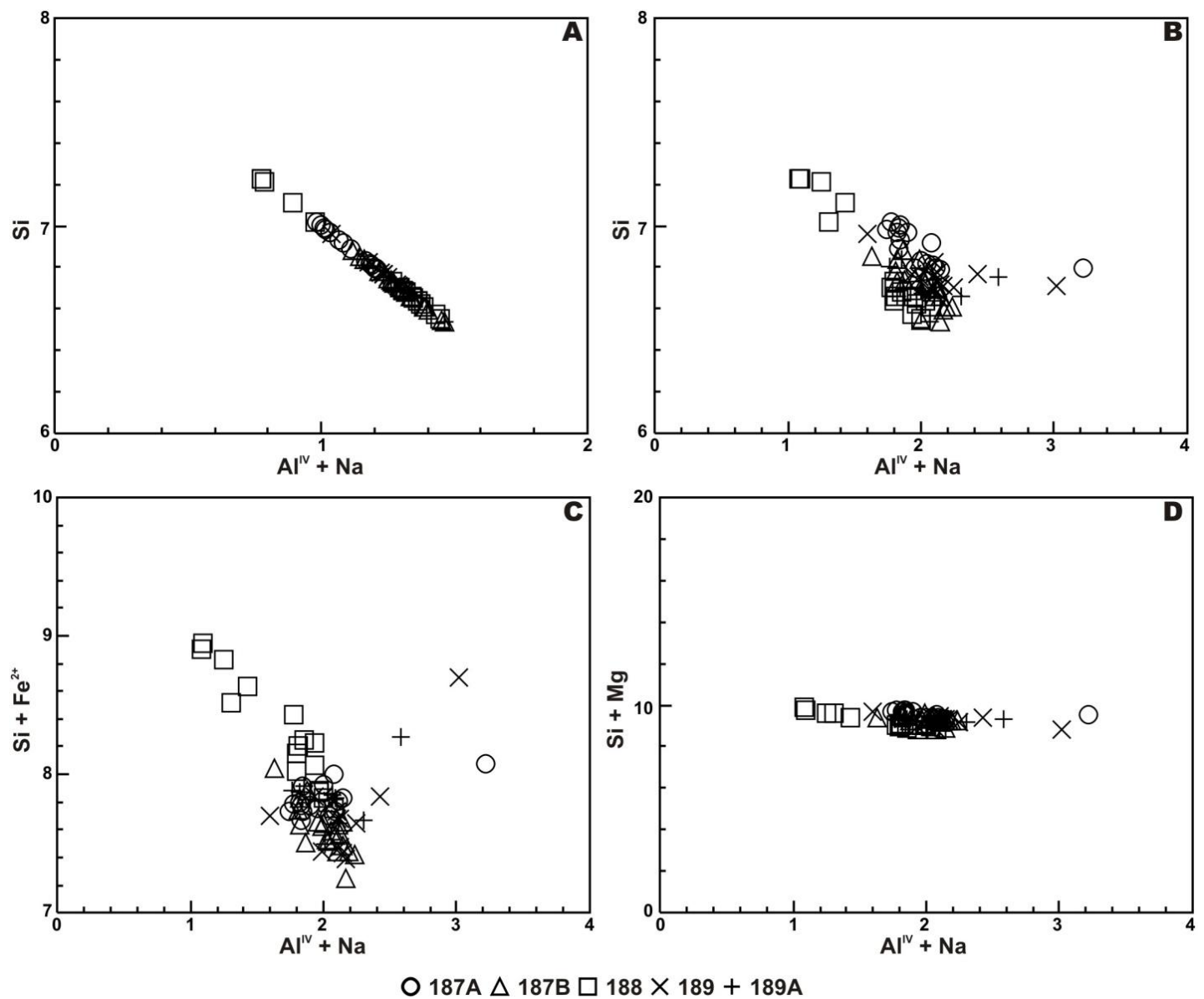

Figura 10.14. Diagramas representativos das substituições tschermakítica (A), edenítica (B), ferropargasítica (C) e magnésio-pargasítica (D) dos anfibólios analisados nas rochas da fácies anfibolito da região de Barragán.

\subsubsection{Granada}

Um perfil composicional feito em um grão de granada da amostra 187A apresenta um padrão de zonamento do $\mathrm{Mg}$ e do $\mathrm{Mn}$ muito marcado. O Mg apresenta-se empobrecido no núcleo e enriquecido na borda, de modo inverso ao que ocorre com o $\mathrm{Mn}$. O Ca mostra uma distribuição relativamente uniforme, mas com pequenos aumentos na borda comparado com o núcleo, e o $\mathrm{Fe}^{2+}$ tem uma variação relativamente irregular, com dois picos de aumento nos pontos intermediários, mas pode-se notar um certo enriquecimento no núcleo e borda empobrecida (Figura 10.15).

A variação da composição da granada, expressa em termos de almandina (Alm) + grossularia (Grs) + piropo (Pyp) + espessartita (Sps) é: Alm $_{49,32-54,75} \operatorname{Grs}_{28,32-31,95} \operatorname{Pyp}_{7,82-13,43} \mathrm{Sps}_{8,55-8,55}$. 


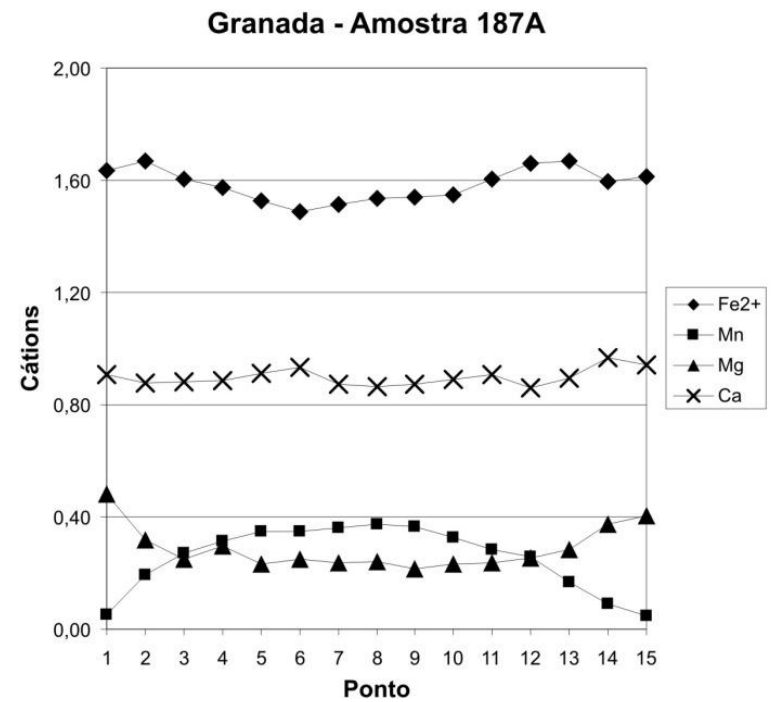

Figura 10.15. Padrão de zonamento dos principais cátions da granada analisada na amostra 187A. 0 diagrama representa os pontos obtidos num perfil borda-núcleo-borda.

$\mathrm{Na}$ amostra 187B foi analisado um único grão de granada. Esse apresenta um padrão de zonamento (Figura 10.16) diferente do observado na amostra 187A, pois o Ca apresenta uma borda mais pobre do que a outra, provavelmente devido à fase em contato ou nas proximidades, mas, de modo geral os teores das bordas são menores que os do núcleo. O Mg, apresenta um padrão inverso ao observado para o $\mathrm{Ca}$, sendo que o núcleo é mais empobrecido do que as bordas, mas com uma borda mas rica em $\mathrm{Mg}$ do que a outra. O Mn apresenta um perfil de zonamento relativamente plano, mas com leves insinuações de um núcleo, mas enriquecido que as bordas. $\mathrm{O} \mathrm{Fe}^{2+}$ apresenta irregularidade na sua distribuição, pois se observa um núcleo, mas enriquecido que as bordas, mas com leves aumentos e quedas no conteúdo deste cátion nos pontos intermediários.

A variação da composição dos principais componentes da granada da amostra 187B e pode ser expressada da seguinte forma: $\operatorname{Alm}_{52,71-57,17} \operatorname{Grs}_{29,77-32,10} \operatorname{Pyp}_{8,00-13,56} \mathrm{Sps}_{1,18-5,90}$

Granada - Amostra 187B

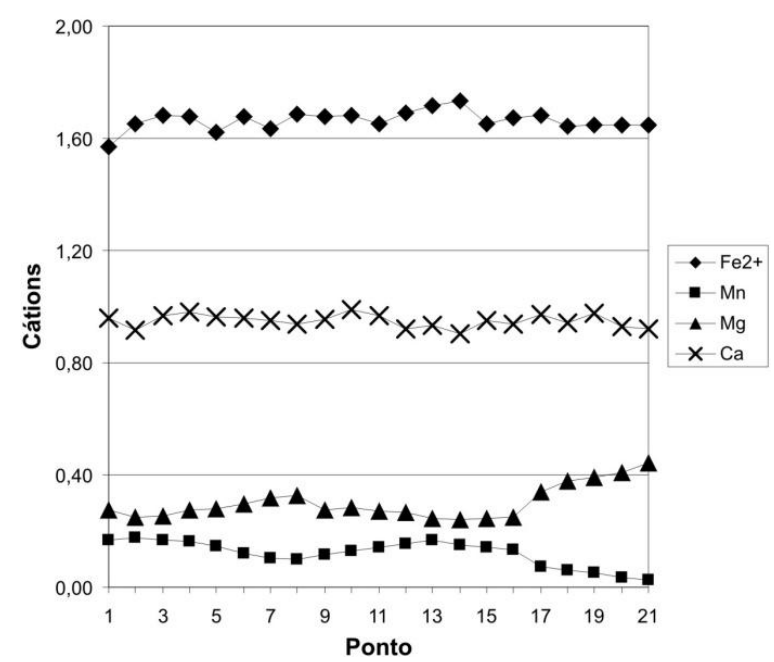

Figura 10.16. Padrão de zonamento dos principais cátions da granada analisada na amostra 187B. O diagrama representa os pontos obtidos num perfil borda-núcleo-borda. 
$\mathrm{Na}$ amostra 188 o perfil feito em um único grão mostra uma complexa distribuição dos principais cátions (Figura 10.17). O Mn está enriquecido no núcleo, seguem-se pontos intermediários mais empobrecidos até chegar a bordas novamente enriquecidas. $\mathrm{O}$ Mg apresenta um comportamento totalmente oposto ao $\mathrm{Mn}$, sendo que o núcleo apresenta-se mais empobrecido que os pontos intermediários e as bordas estão igualmente empobrecidas. O Ca apresenta um padrão de distribuição mais irregular, mas com o núcleo mais enriquecido seguido de pontos intermediários nos quais há uma queda no conteúdo deste elemento e antes de chegar à borda empobrecida. $\mathrm{O} \mathrm{Fe}{ }^{2+}$ apresenta um comportamento oposto ao observado para o $\mathrm{Ca}$, pois nota-se um núcleo mais empobrecido seguido de pontos intermediários mais enriquecidos e uma das bordas mais enriquecida e outra mais empobrecida que o núcleo. A variação dos principais componentes da granada analisada na amostra 188 pode expressar-se da seguinte forma: Alm $_{54,74-60,44} \operatorname{Grs}_{28,762-33,57} \operatorname{Pyp}_{4,84-11,15}$ Sps $_{1,07-8,98}$.

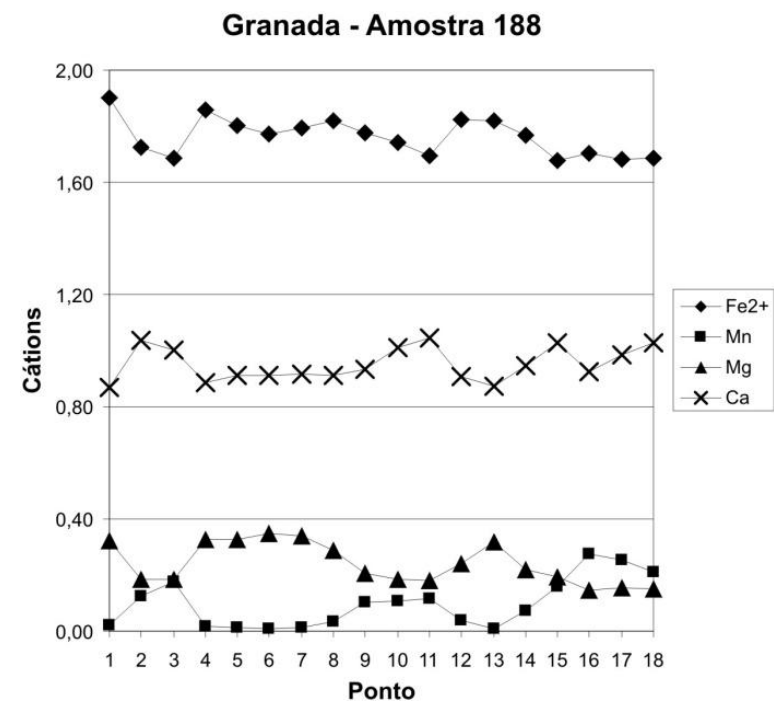

Figura 10.17. Padrão de zonamento dos principais cátions da granada analisada na amostra 188. 0 diagrama representa os pontos obtidos num perfil borda-núcleo-borda.

$\mathrm{Na}$ amostra 189 o perfil obtido em um grão de granada apresenta um zonamento relativamente irregular (Figura 10.18), onde o Mg apresenta um núcleo mais enriquecido que os pontos intermediários e que as bordas. O Mn apresenta um comportamento inverso ao do $\mathrm{Mg}$, sendo que o núcleo apresenta-se mais empobrecido, seguido de pontos intermediários mais enriquecidos e finalizando nas bordas mais pobres. O Ca apresenta um padrão de distribuição relativamente homogêneo, com uma leve tendência de empobrecimento nas bordas. Já para o caso do $\mathrm{Fe}^{2+}$ apresenta-se certa irregularidade na sua distribuição, sendo o núcleo o mais empobrecido seguido de um aumento, uma diminuição, um posterior aumento até uma nova redução no seu conteúdo nas bordas. As variações dos principais componentes da granada nesta amostra se expressa da seguinte forma: $\operatorname{Alm}_{44,83-52,02} \operatorname{Grs}_{30,18-32,14} \mathrm{Pyp}_{6,12-11,96} \mathrm{Sps}_{5,32-14,36}$. 


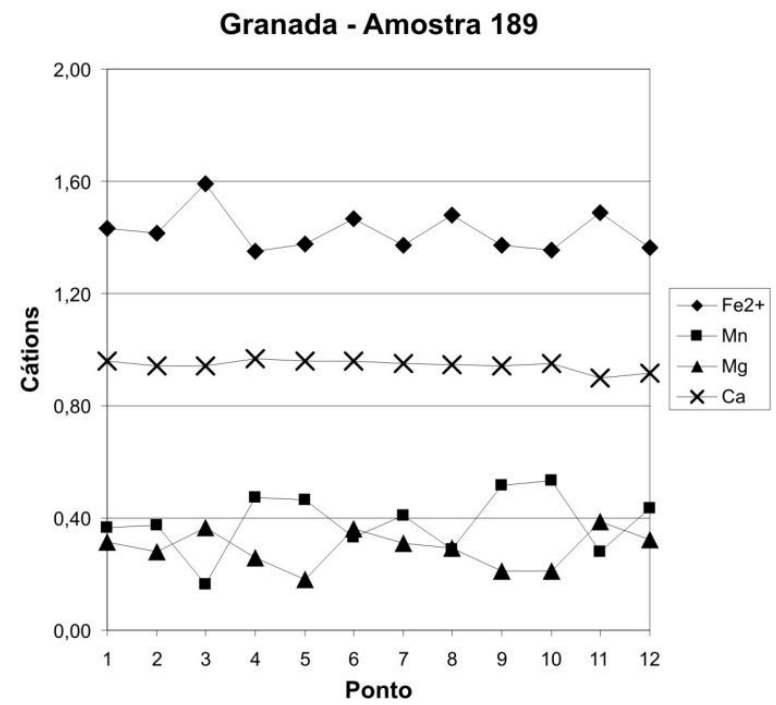

Figura 10.18. Padrão de zonamento dos principais cátions da granada analisada na amostra 189. 0 diagrama representa os pontos obtidos num perfil borda-núcleo-borda.

$\mathrm{Na}$ amostra 189A, foi também feito um perfil composicional em um grão de granada (Figura 10.19).

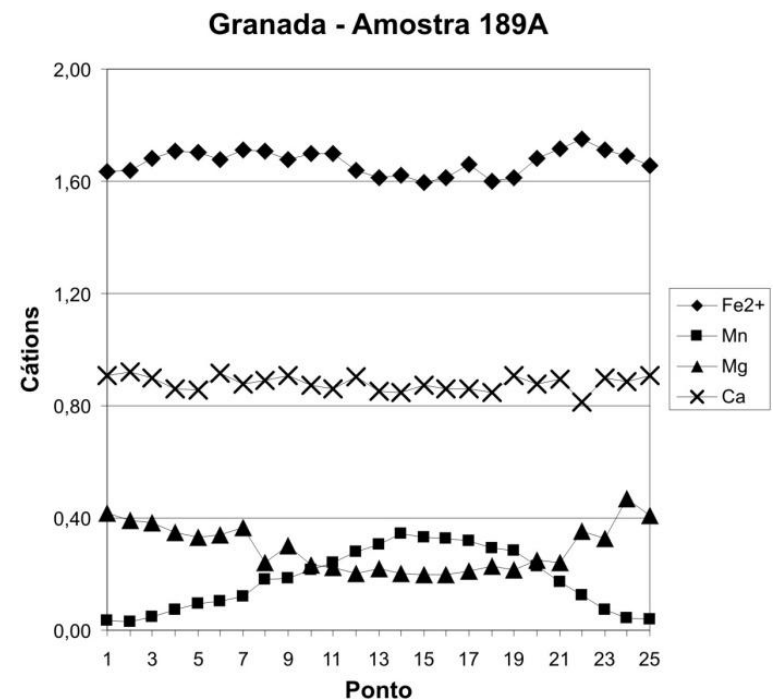

Figura 10.19. Padrão de zonamento dos principais cátions da granada analisada na amostra $189 \mathrm{~A}$. 0 diagrama representa os pontos obtidos num perfil borda-núcleo-borda.

Esta amostra apresenta um padrão de zonamento com conteúdos Mn mais altos no núcleo do que nas bordas. O Mg apresenta uma distribuição com o núcleo mais empobrecido que as bordas. No caso do $\mathrm{Ca}$, este se apresenta distribuição relativamente homogênea, tendo somente alguns pontos intermediários mais empobrecidos que as bordas estão levemente mais enriquecidas que o núcleo. O $\mathrm{Fe}^{2+}$ está mais empobrecido no núcleo que alguns pontos intermediários, os quais são por sua vez, mas enriquecidos que as bordas. A variação dos principais componentes da granada analisada na amostra 189 se expressa da seguinte forma: Alm $_{53,22-57,65} \operatorname{Grs}_{26,72-30,38} \operatorname{Pyp}_{6,64-13,62}$ Sps $_{1,12-11,35}$. 


\subsubsection{Plagioclásio}

Poucas análises foram feitas neste mineral nas amostras da fácies anfibolito da região de Barragán. Estas análises estão representadas na Figura 10.20.
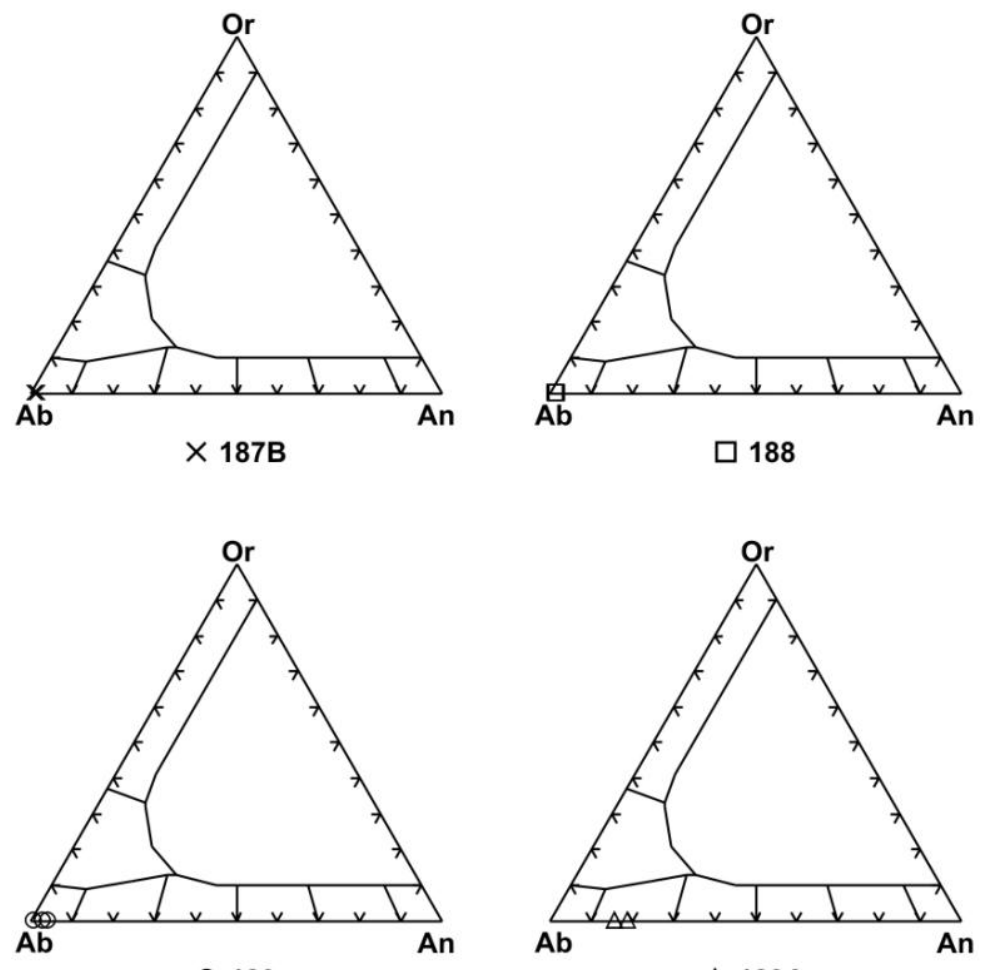

О 189

$\triangle 189 \mathrm{~A}$

Figura 10.20. Diagrama de classificação do plagioclásio das rochas fácies anfibolito, onde Or = ortoclásio, $A b=$ albita e $A n=$ anortita.

A maior parte dos cristais está afetada por sericitização incipiente, o que não permitiu a obtenção de dados analíticos precisos do plagioclásio. Isso também impossibilitou a identificação de variações composicionais em perfis para determinação do zonamento observado na petrografia. Somente na amostra 189A foi possível analisar o núcleo do mineral, no qual se notam conteúdos de anortita que variam entre $A n_{15,5-18,8}$. Os demais pontos obtidos nas bordas dos grãos correspondem a albita quase pura, o que permite sugerir que o zonamento observado na petrografia e normal. A variação dos conteúdos de anortita na amostra 187B está no intervalo entre $A n_{0,9-1,7}$; na amostra 188 varia entre $A n_{1,2-1,4}$ e na 189 entre $A n_{0,5-4,1}$.

\subsubsection{Minerais do grupo do epidoto}

Foi analisada a clinozoisita das amostras 187A, 189, 189A e 188 e zoisita na 187B.

A clinozoisita possui teores de $\mathrm{Fe}^{3+}$ entre 0,10 e 0,16 a.p.f.u. na amostra $187 \mathrm{~A}$; de $0,10 \mathrm{e}$ 0,15 a.p.f.u. na 189 , de 0,11 e 0,13 a.p.f.u. na $189 \mathrm{~A}$ e de 0,39 e 0,52 a.p.f.u. na 188 , indicando uma relativa homogeneidade composicional. $\mathrm{O} \mathrm{Mn}^{3+}$ somente apresenta-se detectável na amostra 187A ( 0,01 a.p.f.u.). 
A zoisita tem teor de $\mathrm{Fe}^{3+} 0,10$ a 0,46 a.p.f.u. e de $\mathrm{Mn}^{3+}$ no limite de detecção $(\sim 0,01$ a.p.f.u.).

\subsubsection{Clorita}

A clorita das amostras da fácies anfibolito da região de Barragán é sempre produto do retrometamorfismo e foi analisada apenas pontualmente. Todas as análises indicam composição da ripidolita, com gradação para picnoclorita e a brunsvigita (Figura 10.21) nas amostras 189 e 189A, segundo a classificação proposta por Hey (1954).
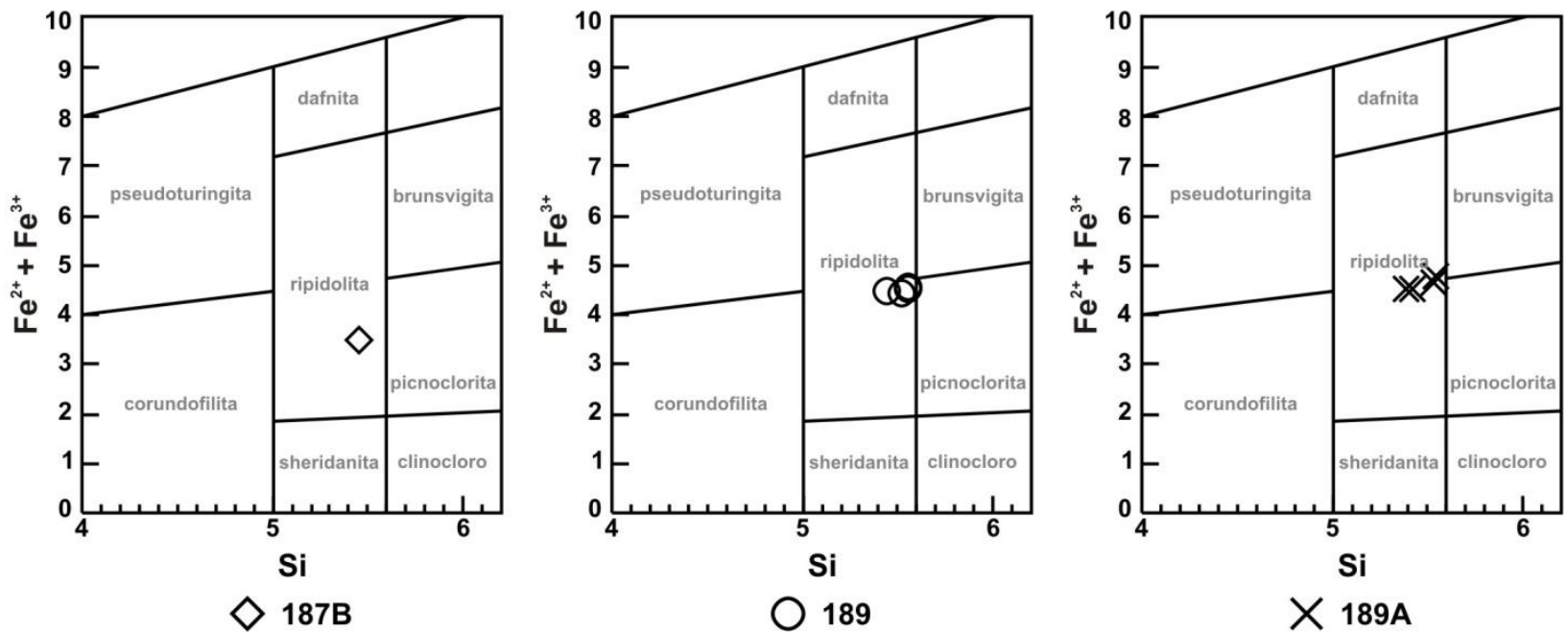

Figura 10.21. Classificação da clorita, segundo Hey (1954), das rochas da fácies anfibolito da região de Barragán.

Os conteúdos de $\mathrm{Fe}^{2+}$ e $\mathrm{Mg}$ são relativamente homogêneos para as amostras 189 e 189A, enquanto a amostra 187B apresenta valores de $\mathrm{Fe}^{2+}$ mais baixos e $\mathrm{Mg}$ mais altos quando comparado com as anteriores. No caso da amostra 189 , o $\mathrm{Fe}^{2+}$ varia entre 4,44 e 4,57 a.p.f.u. e o $\mathrm{Mg}$ entre 4,56 e 4,68 a.p.f.u. A amostra 189A apresenta valores de $\mathrm{Fe}^{2+}$ entre 4,52 e 4,58 a.p.f.u. e $\mathrm{Mg}$ entre 4,20 e 4,63\%. Na amostra 187B somente foi obtido uma análise, pois os grãos geralmente apresentam finas inclusões de minerais opacos e as análises não se mostraram de boa qualidade. Nessa análise o $\mathrm{Fe}^{2+}$ compõe 3,48 a.p.f.u. e o $\mathrm{Mg}$ 5,78 a.p.f.u.

\subsubsection{Titanita e rutilo}

A titanita foi analisada nas amostras 187A, 187B, 188, 189 e 189A. Em todos os casos apresenta-se como uma fase essencialmente pura. $O$ rutilo foi analisado unicamente na amostra 187 e não apresenta impurezas na sua composição. 


\section{GEOTERMOBAROMETRIA: Conceitos, calibrações e aplicações}

Geotermobarometria é o nome dado aos cálculos da pressão e da temperatura de formação dos minerais, obtidos a partir de uma constante de equilíbrio (Spear, 1989). Esta técnica pode ser aplicada às paragêneses ígneas, mas seu uso é mais generalizado no estudo das rochas metamórficas. As calibrações dos geotermômetros e geobarômetros são feitas de dois modos: o primeiro deles é o experimental, no qual as calibrações dependem das medidas em laboratório da constante de equilíbrio de uma determinada reação em função da temperatura e a pressão em experimentos, sob condições químicas controladas. No segundo, conhecido como calibrações empíricas, as medidas dependem da constante de equilíbrio em associações que ocorrem naturalmente, das quais, a temperatura e a pressão do equilíbrio são inferidas a partir de outros dados, como as paragêneses minerais ou dados de isótopos estáveis (Spear, 1989).

A hipótese fundamental na aplicação de alguma relação de equilíbrio é que as fases envolvidas estejam em equilíbrio. A confirmação dessa condição é difícil e, conseqüentemente, resulta na maior fonte de erros na aplicação dos geotermobarômetros, uma vez que, sempre é possível provar que as fases não estão em equilíbrio, mas é impossível provar se uma associação está em equilíbrio termodinâmico (Spear, 1989).

O fundamento da geotermobarometria baseia-se no fato de que a constante de equilíbrio de uma determinada reação, representada na equação (1), pode ser determinada pela medida da composição química dos minerais coexistentes aplicadas a modelos de atividade, desde que, as propriedades calorimétricas das substâncias sejam conhecidas. Uma constante de equilíbrio simples definiria uma linha em um diagrama $\mathrm{P}-\mathrm{T}$ e, como os equilíbrios de end-members ou de diferentes minerais em paragênese apresentam-se como reações com diferentes taxas de inclinação nos diagramas P-T, a intersecção de dois equilíbrios pode ser usada para a estimativa das condições de pressão e temperatura do equilíbrio das reações e, portanto, da formação e/ou reequilíbrio dos minerais das rochas.

$0=\Delta \mathrm{H}\left(\mathrm{T}_{\mathrm{R}}, \mathrm{P}_{\mathrm{R}}\right)+\int \Delta \mathrm{C}_{\mathrm{P}} \mathrm{dT}-\mathrm{T}\left(\Delta \mathrm{S}\left(\mathrm{T}_{\mathrm{R}}, \mathrm{P}_{\mathrm{R}}\right)\right)+\int\left(\left(\Delta \mathrm{C}_{\mathrm{P}} / \mathrm{T}\right) \mathrm{dT}\right)+\Delta \mathrm{V}_{\mathrm{S}}(\mathrm{P}-1)+\mathrm{RT} \operatorname{lnK}_{\text {eq }}$

onde:

$\Delta \mathrm{H}=$ Entalpia, $T_{R}=$ Temperatura de referência, $P_{R}=$ Pressão de referência, $\Delta C_{P}=$ Capacidade de troca de calor da reação, $\mathrm{T}=$ Temperatura, $\Delta \mathrm{S}=$ Entropia, $\Delta \mathrm{V}_{\mathrm{S}}=$ Mudança de volume dos sólidos, $\mathrm{P}=$ Pressão, $\mathrm{R}=$ Constante dos gases, $\mathrm{K}_{\mathrm{eq}}=$ Constante de equilíbrio.

Como geotermômetros são utilizados os equilíbrios pouco dependentes da pressão e como geobarômetros os equilíbrios que são relativamente insensíveis à temperatura.

Uma avaliação dos equilíbrios que podem ser utilizados na geotermometria e geobarometria pode ser feita examinando a dependência da pressão e da temperatura da constante de equilíbrio apresentada nas duas equações seguintes:

$0=\left[\mathrm{RlnK}_{\mathrm{eq}}-\left(\Delta \mathrm{S}\left(\mathrm{T}_{\mathrm{R}}, \mathrm{P}_{\mathrm{R}}\right)+\int\left(\Delta \mathrm{C}_{\mathrm{P}} / \mathrm{T}\right) \mathrm{dT}\right)\right] \mathrm{dT}+\Delta \mathrm{V}_{\mathrm{S}} \mathrm{dP}+\mathrm{RlnK}_{\mathrm{eq}}$ 
$0=\frac{\left(\Delta \mathrm{H}\left(\mathrm{T}_{\mathrm{R}}, \mathrm{P}_{\mathrm{R}}\right)+\int \Delta \mathrm{C}_{\mathrm{P}} \mathrm{dT}+\Delta \mathrm{V}_{\mathrm{S}}(\mathrm{P}-1)\right)}{\mathrm{T}} \mathrm{dT}+\Delta \mathrm{V}_{\mathrm{S}} \mathrm{dP}+\mathrm{RT} \mathrm{Tln} \mathrm{K}_{\mathrm{eq}}$

Iniciando com a derivada total da lei de ação de massa obtém-se:

$\mathrm{dP} / \mathrm{dT}(\mathrm{dP} / \mathrm{dT})_{\ln \mathrm{K}_{\text {eq }}}=\frac{\operatorname{Rln} \mathrm{K}_{\mathrm{eq}}-\Delta \mathrm{S}\left(\mathrm{T}_{\mathrm{R}}, \mathrm{P}_{\mathrm{R}}\right)-\int\left(\left(\Delta \mathrm{C}_{\mathrm{P}} / \mathrm{T}\right) \mathrm{dT}\right)}{\Delta \mathrm{V}}=\frac{\left(\Delta \mathrm{H}\left(\mathrm{T}_{\mathrm{R}}, \mathrm{P}_{\mathrm{R}}\right)+\int \Delta \mathrm{C}_{\mathrm{P}} \mathrm{dT}+\Delta \mathrm{V}_{\mathrm{S}}(\mathrm{P}-1)\right)}{\mathrm{T} \Delta \mathrm{V}}$

$\left(\mathrm{dlnK}_{\mathrm{eq}} / \mathrm{dT}\right)_{\mathrm{P}}=\frac{\mathrm{Rln} \mathrm{K}_{\mathrm{eq}}-\Delta \mathrm{S}\left(\mathrm{T}_{\mathrm{R}}, \mathrm{P}_{\mathrm{R}}\right)-\int\left(\left(\Delta \mathrm{C}_{\mathrm{P}} / \mathrm{T}\right) \mathrm{dT}\right)}{\mathrm{RT}}=\frac{\left(\Delta \mathrm{H}\left(\mathrm{T}_{\mathrm{R}}, \mathrm{P}_{\mathrm{R}}\right)+\int \Delta \mathrm{C}_{\mathrm{P}} \mathrm{dT}+\Delta \mathrm{V}_{\mathrm{S}}(\mathrm{P}-1)\right)}{\mathrm{RT}^{2}}$

$\left(\mathrm{dlnK}_{\mathrm{eq}} / \mathrm{dP}\right)_{\mathrm{T}}=\frac{\Delta \mathrm{V}_{\mathrm{S}}}{\mathrm{RT}}$

Da equação 4, a inclinação de uma isopleta de $\mathrm{K}_{\text {eq }}$ resulta numa função da entropia e no volume de uma reação. Geralmente um equilíbrio com grande $\Delta S$ é relacionado a fortes inclinações de $\mathrm{RInK}_{\text {eq }}$ e um equilíbrio com grande $\Delta \mathrm{V}$ tem inclinações suaves. A dependência da pressão e da temperatura da constante de equilíbrio é tão importante como a inclinação da curva P-T para as determinações precisas da pressão e da temperatura. Como se pode deduzir das equações 5 e 6 , um grande $\Delta \mathrm{H}$ é necessário para uma alta dependência da temperatura e um grande $\Delta V$ é exigido para uma forte dependência da pressão, como pode ser visto na Figura 11.1.

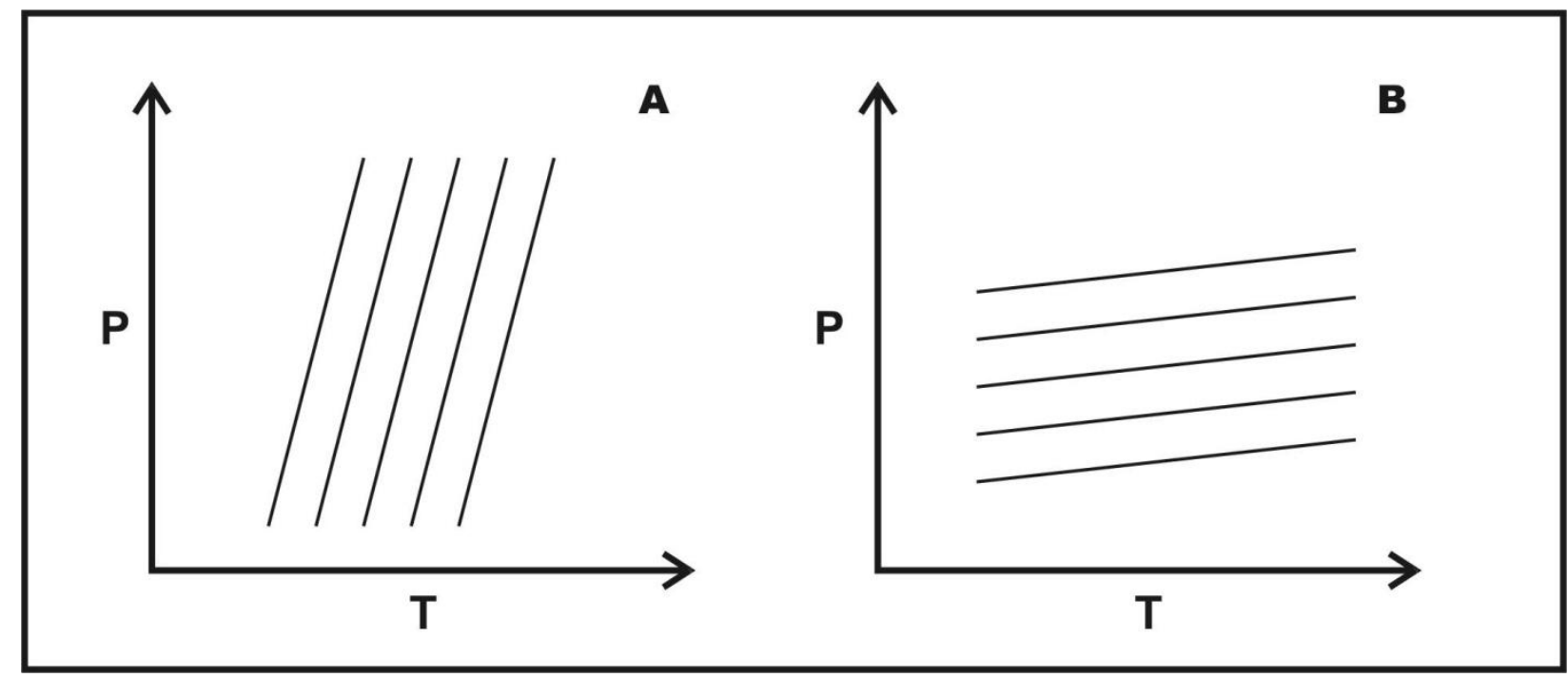

Figura 11.1. Diagramas esquemáticos $P$ - $T$ mostrando equilíbrios com inclinações $P-T$ representativas de reações utilizáveis como geotermômetros $(\boldsymbol{A})$ e geobarômetros $(\boldsymbol{B})$, segundo Spear (1989).

Segundo Spear (1989; 1993), as reações usadas como geotermômetros são as de troca catiônica (exchange reactions) e com base em solvus e como geobarômetros são usadas reações de transferência de cátions entre uma determinada assembléia de minerais (net transfer).

As reações de troca catiônica são utilizadas num grande número de geotermômetros, sendo os principais para rochas metamórficas os que envolvem a troca de Fe e Mg entre silicatos 
coexistentes. As reações de troca geralmente apresentam um pequeno $\Delta \mathrm{V}$ com um moderado $\Delta \mathrm{S}$ e $\Delta \mathrm{H}$ de forma que a isopleta da $\mathrm{K}_{\text {eq }}$ tem uma inclinação relativamente forte. A constante de equilíbrio para as reações de troca catiônica geralmente pode ser simplificada como uma relação de troca catiônica em uma fase dividida pela mesma relação na segunda fase (Spear, 1989). Esta formulação é definida como o coeficiente de distribuição $\left(K_{D}\right)$. Assim, por exemplo, o coeficiente de distribuição para a troca de $\mathrm{Fe}$ e $\mathrm{Mg}$ entre as fases A e B é definida como $K_{D}=\frac{(\mathrm{Fe} / \mathrm{Mg})_{A}}{(\mathrm{Fe} / \mathrm{Mg})_{B}}(\mathrm{Spear}$, 1989).

No caso dos geotermômetros de solvus, várias calibrações têm como base a distribuição dos elementos através do solvus. Em muitos casos a frase "geotermometria solvus" é um nome equivocado porque o termo "solvus" restringe-se a fases isoestruturais e vários dos denominados "geotermômetros solvus" atualmente envolvem duas fases que não são isoestruturais, devendo, portanto, serem mais corretamente chamados geotermômetros de troca catiônica (Spear, 1989; 1993).

As reações de transferência de cátions entre uma determinada assembléia de minerais (net transfer equilibria) são excelentes geobarômetros, pois elas têm grandes variações de volume o que significa que são reações que causam produção e consumo das fases sendo, conseqüentemente, a constante de equilíbrio sensível às variações da pressão (Spear, 1989; 1993)

\subsection{Geotermobarômetros internamente consistentes}

A aplicação prática da termobarometria, entretanto, resulta em consideráveis incertezas, não apenas devido à dificuldade na definição e na identificação de minerais em equilíbrio termodinâmico, como também pelos diferentes dados termodinâmicos, variados modelos de atividade das fases e diversos modelos para estabelecimento das constantes de equilíbrio que têm sido utilizados na definição das calibrações dos geotermômetros e geobarômetros (Spear, 1993). Por esse motivo diversos autores começaram a utilizar um conjunto de termômetros e barômetros internamente consistentes como uma forma de obter estimações de pressão e temperatura mais coerentes (e.g. Powell \& Holland, 1985, 1988; De Capitani \& Brown, 1987; Berman, 1988, 1991; Brown et al., 1988, 1989; Connolly, 1990; Castelli, et al., 1997). O conjunto de calibrações internamente consistentes utiliza os mesmos dados termodinâmicos e modelos de atividade para todas as fases ou foram calibrados usando o mesmo conjunto de dados empíricos (Spear, 1993). A consistência interna entre os conjuntos de calibrações assegura o grau no qual uma amostra está equilibrada. A consistência interna tem a tendência de eliminar, ou pelo menos identificar calibrações com grandes erros sistemáticos porque tem a tendência a permanecer visíveis (Spear, 1993). Essa técnica tem sido denominada como geotermobarometria com bancos de dados termodinâmicos internamente consistentes. 
Neste trabalho foram usados os geotermobarômetros internamente consistentes apresentados no TWQ 1.02 (Berman, 1988, 1990)

\subsection{Cálculos da região de Jambaló}

Os cálculos geotermobarométricos foram feitos com o software TWQ 1.02 (Berman, 1988, 1991), por ser esse o único do conjunto que inclui os anfibólios. Esses cálculos possibilitam a determinação da pressão com uma precisão de $\pm 1 \mathrm{kbar}$ e da temperatura de $\pm 50^{\circ} \mathrm{C}$.

As amostras para esses cálculos foram selecionadas em função da presença de granada, anfibólio e plagioclásio, que resultam em cálculos mai precisos, e as análises químicas dos minerais encontram-se no anexo III.

As estimativas $\mathrm{P}-\mathrm{T}$ foram feitas em minerais em paragênese ou em associações de minerais em um mesmo domínio microestrutural, buscando assim uma maior probabilidade de equilíbrio termodinâmico e uma maior coerência nos cálculos das condições de $P$ e $T$ responsáveis pela formação das diferentes rochas.

Os símbolos de minerais usados para os cálculos termobarométricos da região de Jambaló estão na Tabela 11.1.

Tabela 11.1. Símbolos de minerais usados nos cálculos termobarométricos da região de Jambaló, segundo Kretz (1983) e Spear (1993).

\begin{tabular}{llllllllll}
\hline Ab & albita & Chl & clorita & Grs & grossulária & Pg & paragonita & Qtz & quartzo \\
Alm & almandina & Czo & clinozoisita & Jd & jadeita & Pmp & pumpellyita & Rt & rutilo \\
An & anortita & Dol & dolomita & Lws & lawsonita & Prg & pargasita & Tr & tremolita \\
Cal & calcita & Gln & glaucofânio & Ms & muscovita & Prp & piropo & Ts & tschermakita \\
\hline
\end{tabular}

Os cálculos geotermobarométricos foram feitos com as análises dos minerais de seis das amostras procurando sempre a presença de granada com mica, plagioclásio e glaucofânio.

Dentre as amostras selecionadas as 124I, 124J, 125H e 129A são da fácies xisto azul, a 124 é uma amostra da transição entre as fácies xisto azul e xisto verde e a 113F é da fácies xisto verde.

A amostra 124I apresenta uma forte foliação milonítica, com porções mais ricas em glaucofânio e outras nas quais este mineral esta quase totalmente ausente. Texturalmente a rocha é nematoblástica, com variações a nemato-lepidoblástica, em função do conteúdo de mica branca, e o quartzo e a albita eventualmente definem uma textura granoblástica. Nesta amostra foram feitas análises de granada, paragonita, albita e glaucofânio, mas nos cálculos termobarométricos foi usada a associação granada-paragonita-albita, que registrada as pressões e temperaturas máximas alcançadas pelo sistema. As estimativas da fração molar de $\mathrm{CO}_{2}$ indicam um fluido formado praticamente somente por $\mathrm{H}_{2} \mathrm{O}\left(\mathrm{XCO}_{2}=0,01\right)$. A atividade da paragonita na mica branca foi estimada para esses cálculos em 0,08 . Os resultados obtidos mostram pressões que variam entre 14,1 e 6,7 kbar e temperaturas entre 502 e $382^{\circ} \mathrm{C}$ (Figura 11.2). Nota-se claramente uma forte descompressão acompanhada por queda na temperatura, em concordância com o 
evidenciado pela petrografia, que mostra geração de anfibólios sódico-cálcicos e cálcicos substituindo as bordas do anfibólio sódico.
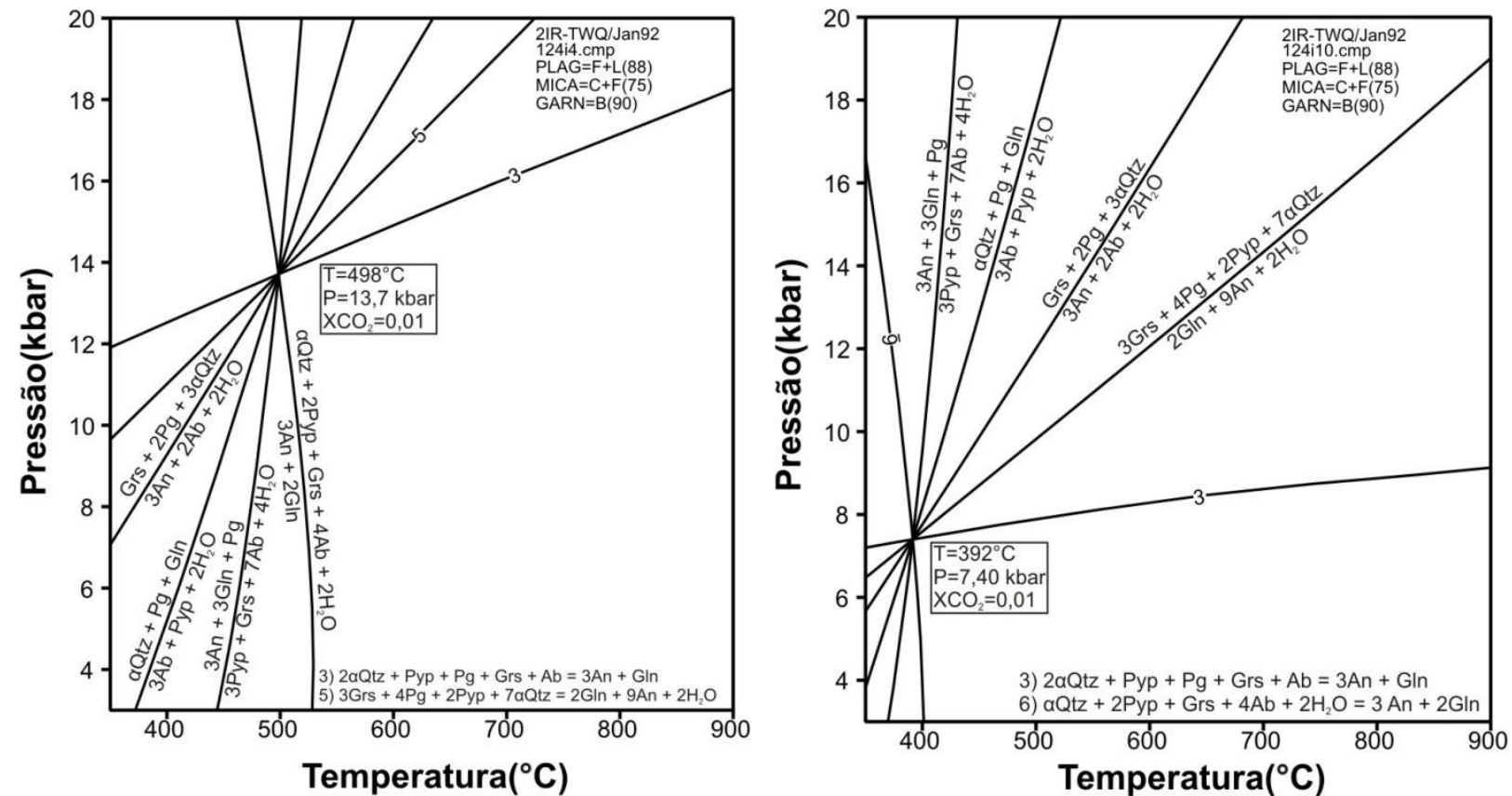

Figura 11.2. Diagramas $P-T$ obtidos para a amostra 124l, com análises de núcleos (esquerda) e bordas (direita) da associação granada-paragonita-plagioclásio-glaucofânio-quartzo, mostrando uma forte descompressão $(13,7-7,4 \mathrm{~kb})$ e uma queda na temperatura por encima de $100^{\circ} \mathrm{C}\left(498-392^{\circ} \mathrm{C}\right)$. Diagramas calculados com $a_{P g}$ na mica branca $=0,08$.

A amostra 124J também apresenta uma intensa foliação milonítica e uma textura nematolepidoblástica. Eventuais poiquiloblastos de granada estão disseminados na amostra, sendo que neles observam-se inclusões de quartzo, epidoto/clinozoisita e, mais raramente, zircão. O glaucofânio apresenta-se zonados, com núcleos mais intensamente pleocróicos que as bordas, e substituição por anfibólios sódico-cálcicos e cálcicos, principalmente nas bordas. Nesta amostra foram feitas análises em granada, mica branca, glaucofânio e plagioclásio e nos cálculos termobarométricos foi usada a mesma associação. A XCO $X_{2}$ foi estimada em 0,028 e a atividade da paragonita na mica branca $a_{\mathrm{Pg}}=0,7$. Os cálculos termobarométricos resultaram em pressão muito alta, alcançando $16,9 \mathrm{kbar}$, a uma temperatura de $497^{\circ} \mathrm{C}$ (Figura 11.3), o que é um resultado com valores muito altos, possivelmente resultado da presença de paragonita junto a granada com alto conteúdo de Ca e glaucofânio. 


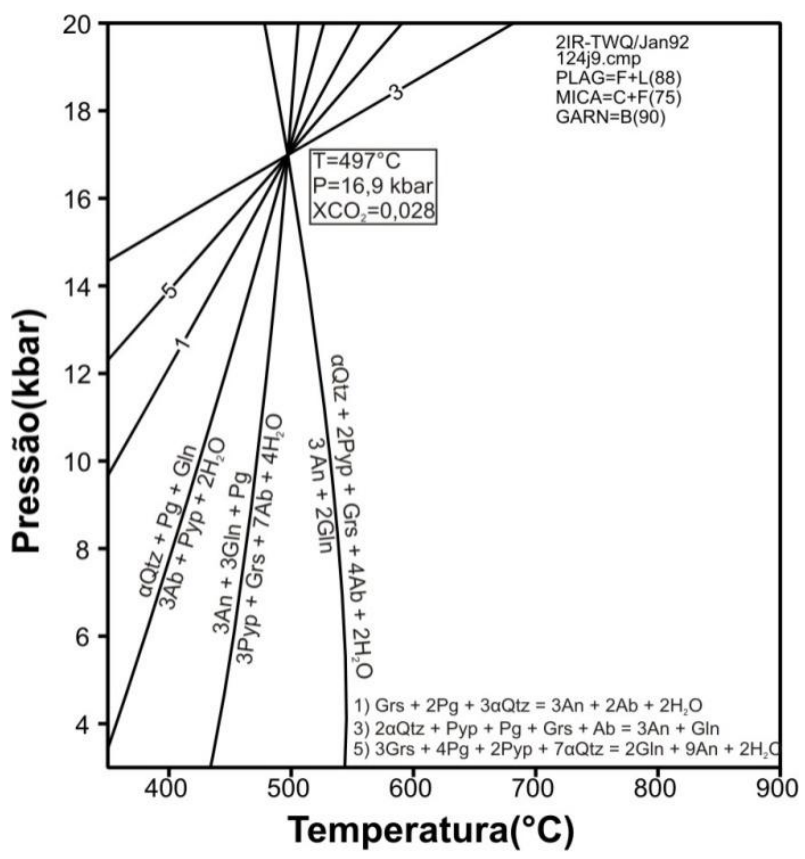

Figura 11.3. Diagrama P-T obtido para a amostra 124J, com análises de núcleos da associação granadaparagonita-plagioclásio-glaucofânio-quartzo, mostrando uma pressao alta (16,9 kb) e uma temperatura de $497^{\circ} \mathrm{C}$. Diagramas calculados com $a_{P g}$ na mica branca $=0,7$.

Outros cálculos feitos com os minerais da amostra 124J mostram a pressão entre 13,9 e 7,4 kbar e temperatura entre 454 e $371^{\circ} \mathrm{C}$ (Figura 11.4). Esses cálculos são coerentes com os da amostra 124 l que, mesmo sendo amostras do mesmo afloramento e com valores relativamente altos, indica que as transições dos anfibólios sódicos para sódico-cálcicos e para cálcicos na bordas, são produto de um evento de forte descompressão relacionado à exumação dos xistoas azuis durante o desenvolvimento da foliação milonítica.
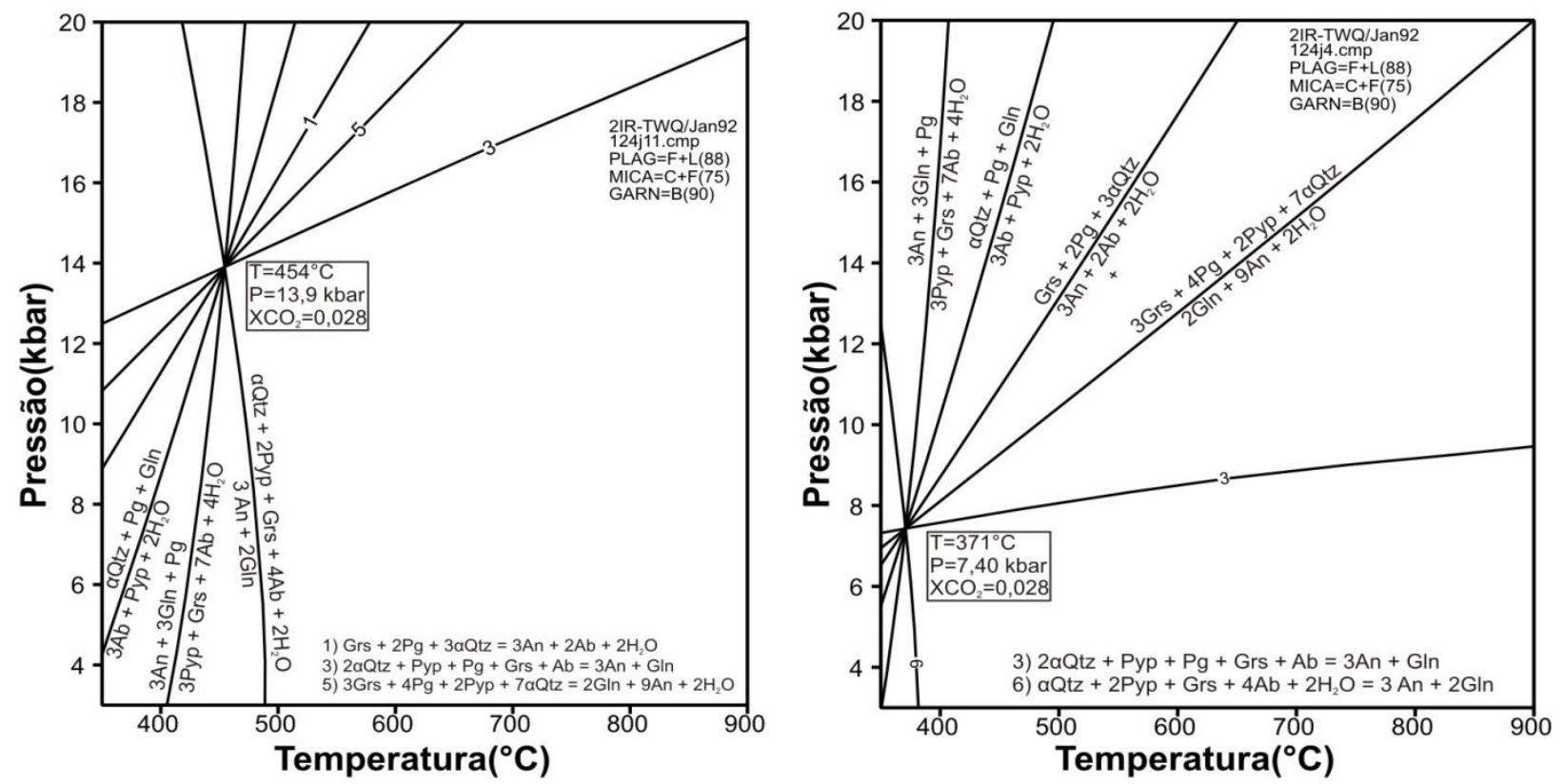

Figura 11.4. Diagramas $P-T$ obtidos para a amostra 124J, com análises de núcleos (esquerda) e bordas (direita) da associação granada-paragonita-plagioclásio-glaucofânio-quartzo, mostrando uma forte descompressão $(13,9-7,4 \mathrm{~kb})$ e uma queda na temperatura de quase $100^{\circ} \mathrm{C}\left(454-371^{\circ} \mathrm{C}\right)$. Diagramas calculados com $a_{P g}$ na mica branca $=0,7$. 
A amostra $125 \mathrm{H}$ apresenta além da foliação milonítica, uma cristalização radiada de glaucofânio, indicando a existência de um período de cessamento ou redução da deformação na zona de cisalhamento, ainda sob condições metamórficas de alta pressão. Alguns porfiroblastos de granada associados foram cristalizados durante a geração da foliação milonítica.

Da mesma forma que nas amostras anteriores, as análises foram concentradas em granada, mica branca, plagioclásio e glaucofânio, utilizando as estimativas de $\mathrm{XCO}_{2}=0,05$ e de atividade de paragonita na mica branca de $a_{\mathrm{pg}}=0,01$. Esta amostra apresenta também uma forte queda na pressão do núcleo (13,7 a 7,4 kbar) para as bordas dos cristais, mas com pequenas variações na temperatura $\left(535\right.$ a $\left.511^{\circ} \mathrm{C}\right)$ (Figura 11.5), sugerindo que a cristalização estática de glaucofâno pode estar associada à colocação de corpos ígneos na zona de cisalhamento durante a exumação.
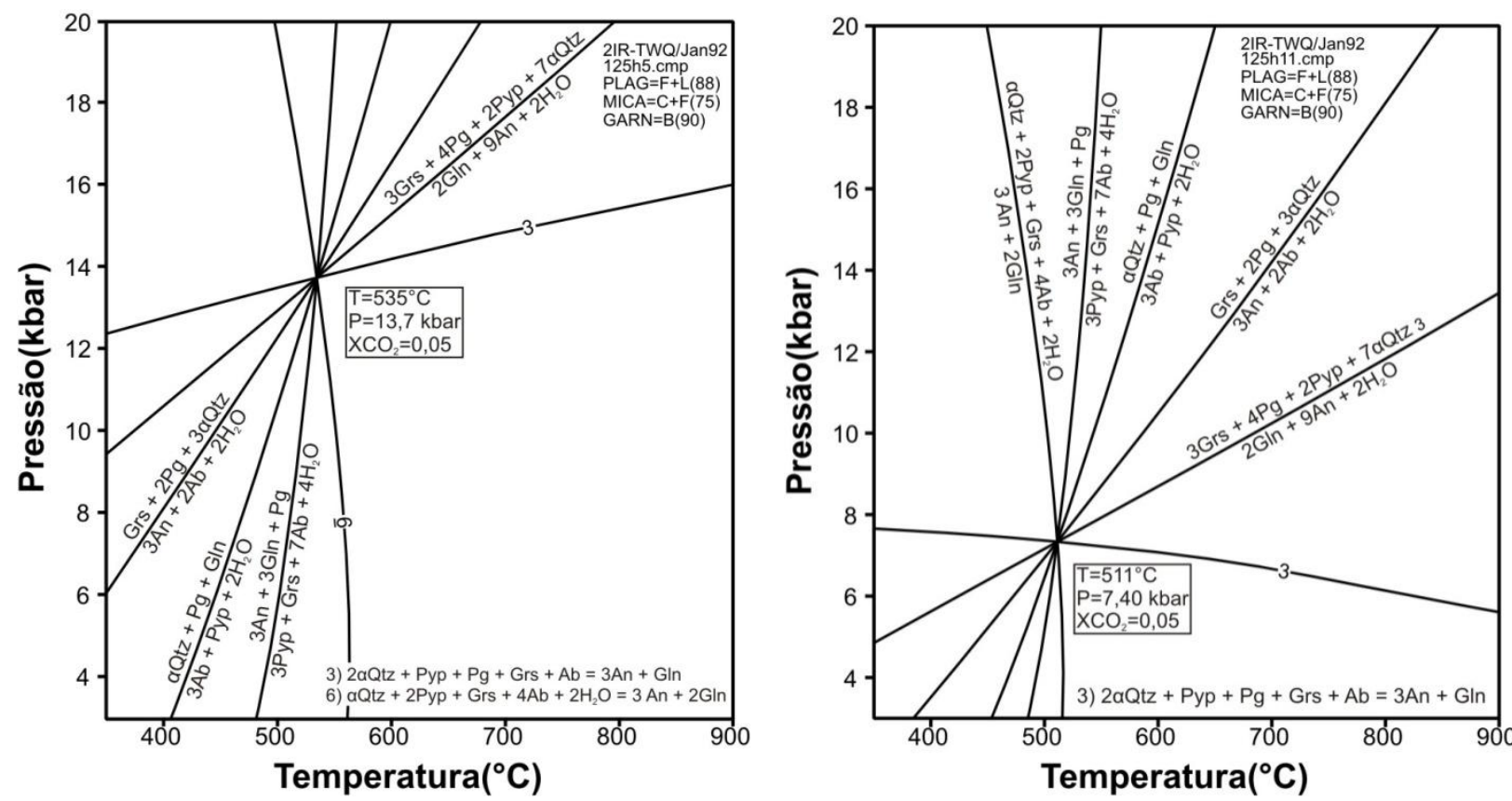

Figura 11.5. Diagramas $P-T$ obtidos para a amostra $125 \mathrm{H}$, com análises de núcleos (esquerda) e bordas (direita) da associação granada-paragonita-plagioclásio-glaucofânio-quartzo, mostrando uma forte descompressão $(13,7-7,4 \mathrm{~kb})$ e uma pequena queda na temperatura $\left(535-511^{\circ} \mathrm{C}\right)$. Diagramas calculados com $a_{P g}$ na mica branca $=0,01$.

$\mathrm{Na}$ amostra 129A as análises de química mineral foram concentradas no glaucofânio, mica branca, clorita e plagioclásio. Mesmo com a ausência de granada, que dificulta os cálculos termobarométricos, a presença da clorita permitiu a obtenção de bons equilíbrios. Os cálculos feitos com $\mathrm{XCO}_{2}=0,1$ e atividade da pargonita em mica branca $a_{\mathrm{Pg}}=0,03$, mostram equilíbrio, sendo que não há muita variação quando analisados os núcleos e as bordas dos minerais, que resultaram, respectivamente, em $9,9 \mathrm{kbar}$ e $416^{\circ} \mathrm{C}$ e $9,2 \mathrm{kbar}$ e $369^{\circ} \mathrm{C}$ (Figura 11.6). A clorita nesta amostra pertence à associação de minerais retrometamórficos e formou-se principalmente a expensas do glaucofânio, sugerindo um reequilíbrio entre a fácies xisto azul e xisto verde e, como conseqüência da perda da herança química de mais alta pressão dos minerais, pode haver certo equilíbrio da borda do glaucofânio em contato com a clorita que o substitui. 

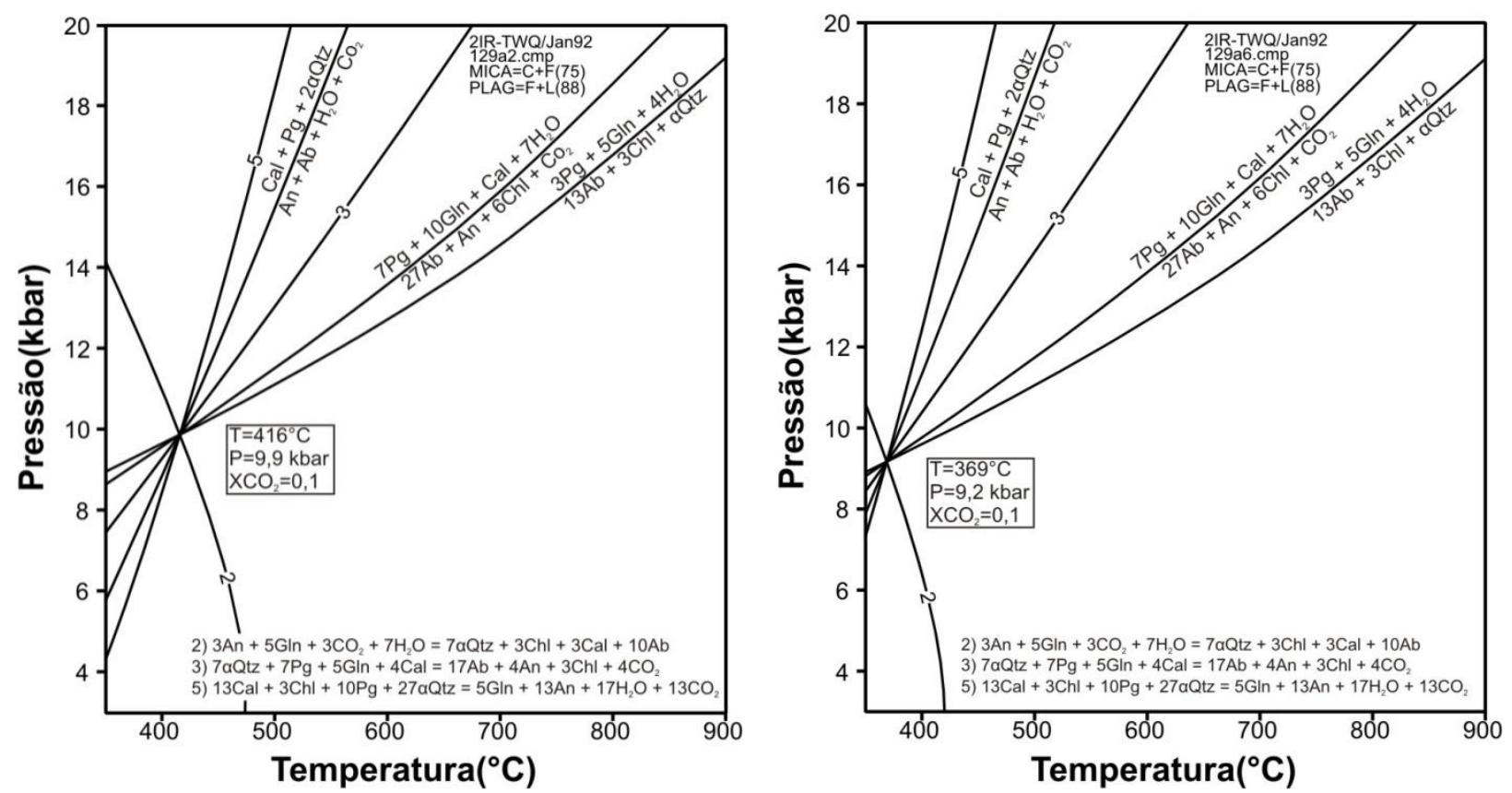

Figura 11.6. Diagramas $P-T$ obtidos para a amostra 129A, com análises de núcleos (esquerda) e bordas (direita) da associação paragonita-plagioclásio-glaucofânio-clotita-quartzo, mostrando uma pequena descompressão $(9,9-9,2 \mathrm{~kb})$ e uma queda pequena na temperatura $\left(416-369^{\circ} \mathrm{C}\right)$. Diagramas calculados com $a_{P g}$ na mica branca $=0,03$.

A amostra 124, que corresponde à transicional da fácies xisto azul para a fácies xisto verde, apresenta textura nemato-lepidoblástica, com uma forte foliação milonítica $S_{n+1}$. Na amostra há domínios com concentração de glaucofânio, localmente porfiroblástico, sempre parcialmente substituídos por anfibólio sódico-cálcico e com bordas de anfibólio cálcico, e domínios onde praticamente não ocorre glaucofânio, enriquecida em clorita e com porfiroblastos de albita com uma foliação interna, definida pelo arranjo dos minerais opacos paralelamente à foliação externa.

Nessa amostra as análises foram concentradas no glaucofânio, mica branca, albita e clorita e, embora existam dois diferentes domínios mineralógicos. Os cálculos feitos em associações de núcleos apresentam mais altas pressões e temperaturas que as associações de bordas, utilizando-se $\mathrm{XCO}_{2}=0,01$ e atividade da pargonita em mica branca $a_{\mathrm{pg}}=0,07$, resultaram em pressões variando entre 7,5 e 6,2 kbar e temperaturas entre 458 e $424^{\circ} \mathrm{C}$ (Figura 11.7). 

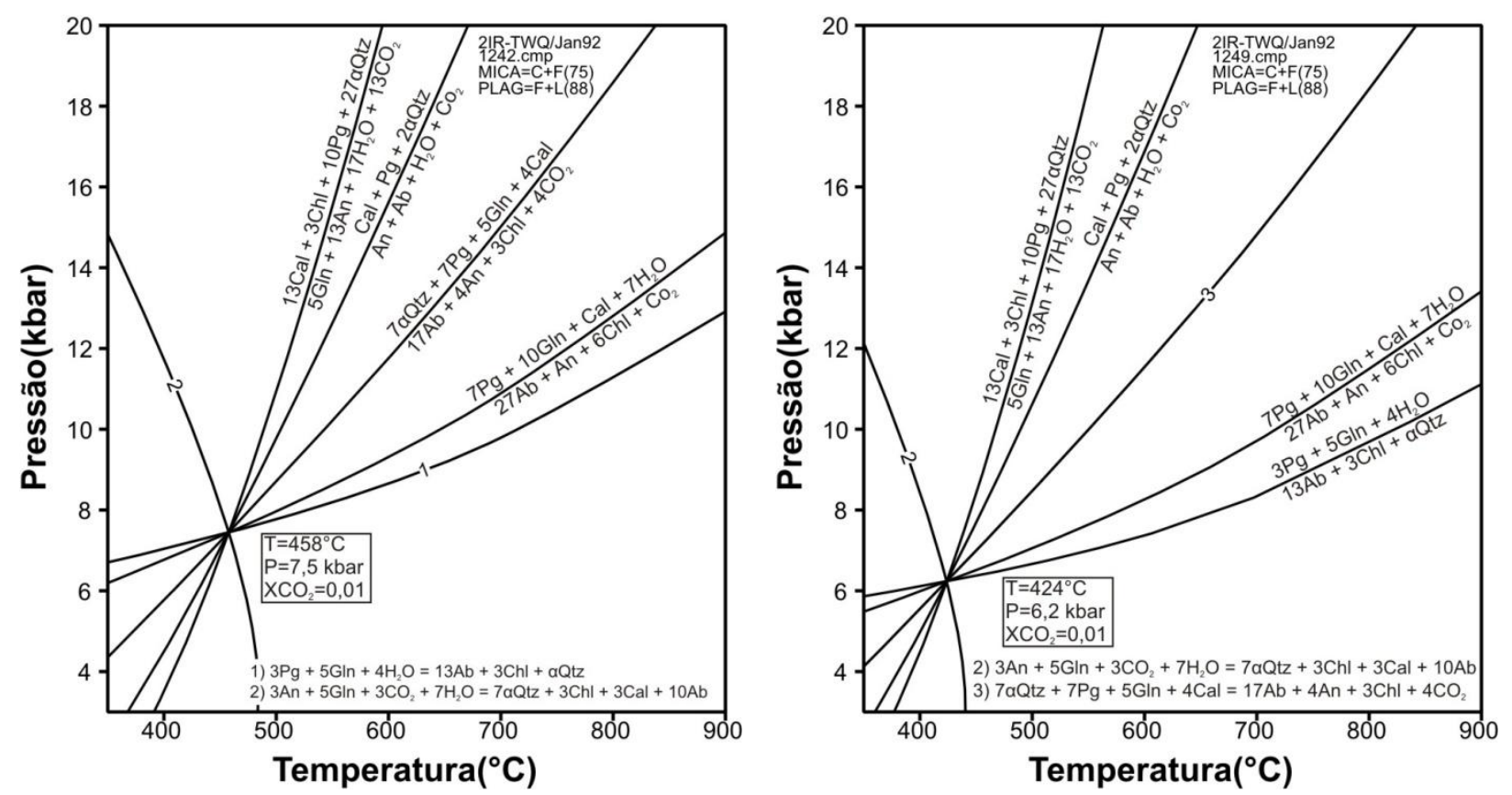

Figura 11.7. Diagramas $P-T$ obtidos para a amostra 124, com análises de núcleos (esquerda) e bordas (direita) da associação paragonita-plagioclásio-glaucofânio-clorita-quartzo, mostrando uma descompressão $(9,9-9,2 \mathrm{~kb})$ e uma queda pequena na temperatura $\left(458-424^{\circ} \mathrm{C}\right)$. Diagramas calculados com $a_{P g}$ na mica branca $=0,01$.

A amostra 113F corresponde à fácies xisto verde. A rocha apresenta uma textura nematolepidoblástica que define uma foliação milonítica $S_{n}$. $O$ anfibólio apresenta um leve zonamento, com núcleos mais intensamente pleocróicos que as bordas. Granada ocorre disseminada e em pouquíssima quantidade, sendo geralmente límpida, muito embora alguns dos grãos apresentem pequenas inclusões de quartzo e minerais opacos.

Nesta amostra, as análises foram concentradas na granada, anfibólio, plagioclásio e mica. Os resultados obtidos, considerando-se as estimas de $\mathrm{XCO}_{2}=0,01$ e atividade da paragonita na mica branca $a_{\mathrm{Pg}}=0,03$, indicam núcleos formados em mais altas pressões e menores temperaturas que as bordas com, respectivamente, $8,2 \mathrm{kbar}$ e $463^{\circ} \mathrm{C}$ e $6,6 \mathrm{kbar}$ e $500^{\circ} \mathrm{C}$ (Figura 11.8). 

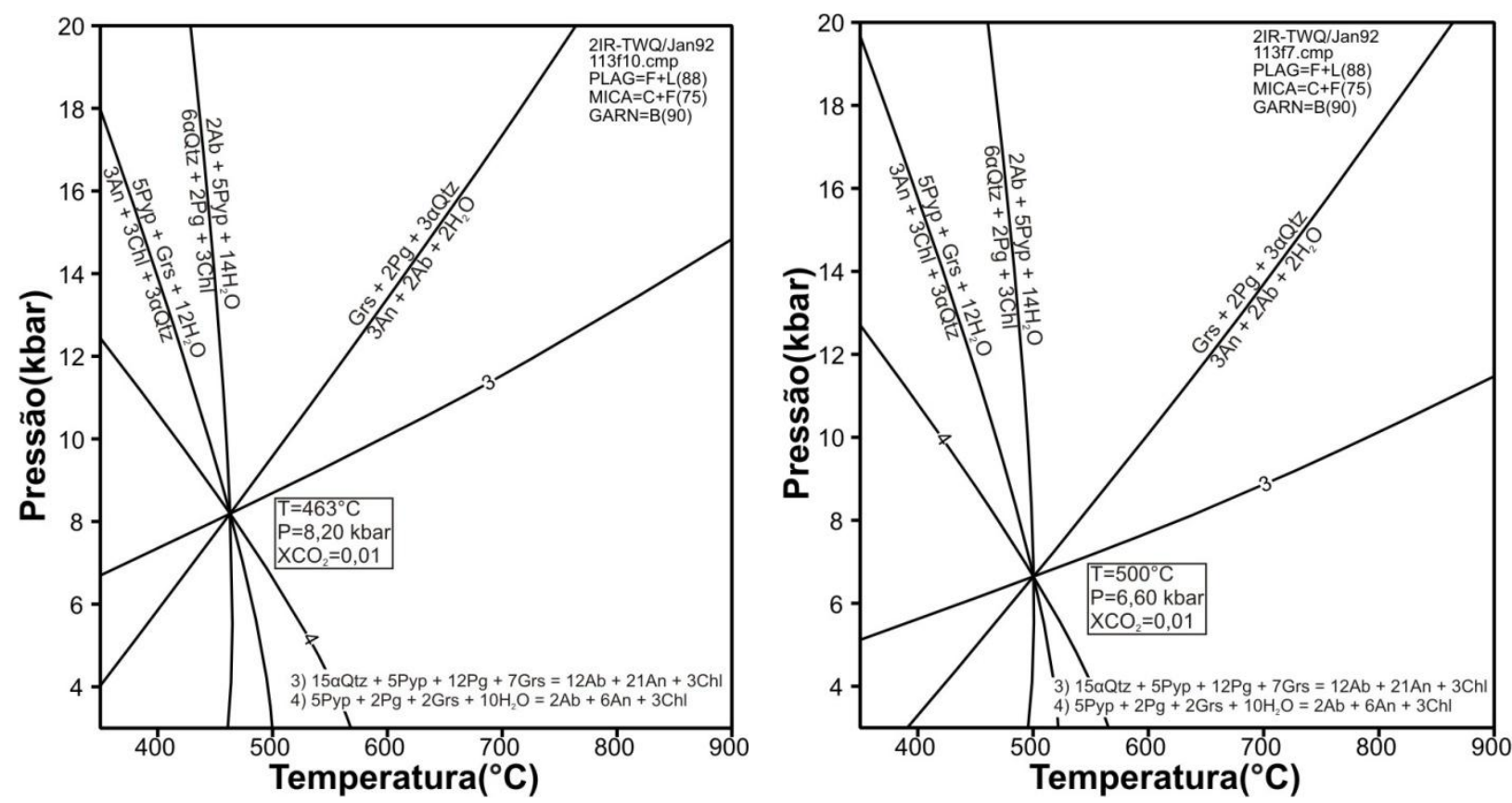

Figura 11.8. Diagramas $P-T$ obtidos para a amostra 113F, com análises de núcleos (esquerda) e bordas (direita) da associação granada-mica branca-albita-clorita-quartzo, mostrando uma descompressão (8,2 $6,5 \mathrm{~kb})$ e um aumento pequeno da temperatura $\left(463-500^{\circ} \mathrm{C}\right)$. Diagramas calculados com $a_{P g}$ na mica branca $=0,01$.

O conjunto dos dados, juntamente com as trajetórias retrometamórficas das amostras individuais (Figura 11.9) indicam que os xistos azuis de Jambaló foram formados em pressões relativamente altas e sofreram inicialmente uma forte descompressão aproximadamente isotérmica, a qual pode ser associada à sua exumação causada numa zona de cavalgamento, o que propiciou a formação da foliação milonítica registrada nas rochas. Nota-se também que xistos azuis de níveis crustais semelhantes foram formados em temperaturas variáveis, com $\sim 80^{\circ} \mathrm{C}$ de diferença, indicando fortes anomalias e heterogeneidades das isotermas na crosta, em especial na amostra $125 \mathrm{H}$, que apresenta a maior temperatura na formação inicial dos minerais.

A maior pressão encontrada na amostra, apesar de ser exagerada por causa das paragêneses, principalmente pelo alto conteúdo de $\mathrm{Na}$ no glaucofânio e $\mathrm{Ca}$ na granada, mostra uma tendência evolutiva coerente com as demais amostras.

A parte final da evolução das rochas mostra-se mais complexa, sendo observados três padrões.

O primeiro deles, definido pelas amostras $124 \mathrm{I}$ e $124 \mathrm{~J}$ e pela rocha transicional entre as fácies xisto azul e xisto verde, exibe uma trajetória de exumação acompanhada por resfriamento, típica de terrenos Franciscanos. A segunda, definida pela amostra $125 \mathrm{H}$, inicia-se em temperaturas mais altas e sofre relativamente pouca queda na temperatura, culminando sua evolução com a evolução dos xistos verdes, que tem por sua vez sua evolução final marcada pelo aumento da temperatura.

Essas trajetórias poderiam ser indicativas de uma exumação mais lenta, propiciando a recomposição das isotermas, mas a proximidade das amostras (Figura 11.9), a despeito das 
descontinuidades introduzidas pelo cisalhamento, são muito próximas e sugere que o aquecimento pode ser devido à intrusão de rochas ígneas, ou à introdução de uma lasca mantélica mais aquecida nos xistos azuis, durante a exumação.

Por fim, a trajetória definida pela amostra 129A, evidencia um forte resfriamento, acompanhado por uma taxa de descompressão menor que as demais rochas. A posição da amostra sugere que esses xistos azuis foram colocados tectonicamente sobre as rochas ultramáficas, estando, potencialmente, originalmente num nível crustal mais raso e, por estarem sobre as ultramáficas que podem ter aquecido os xistos durante da exumação, podem ter sido resfriados mais eficientemente que as rochas mais profundas.

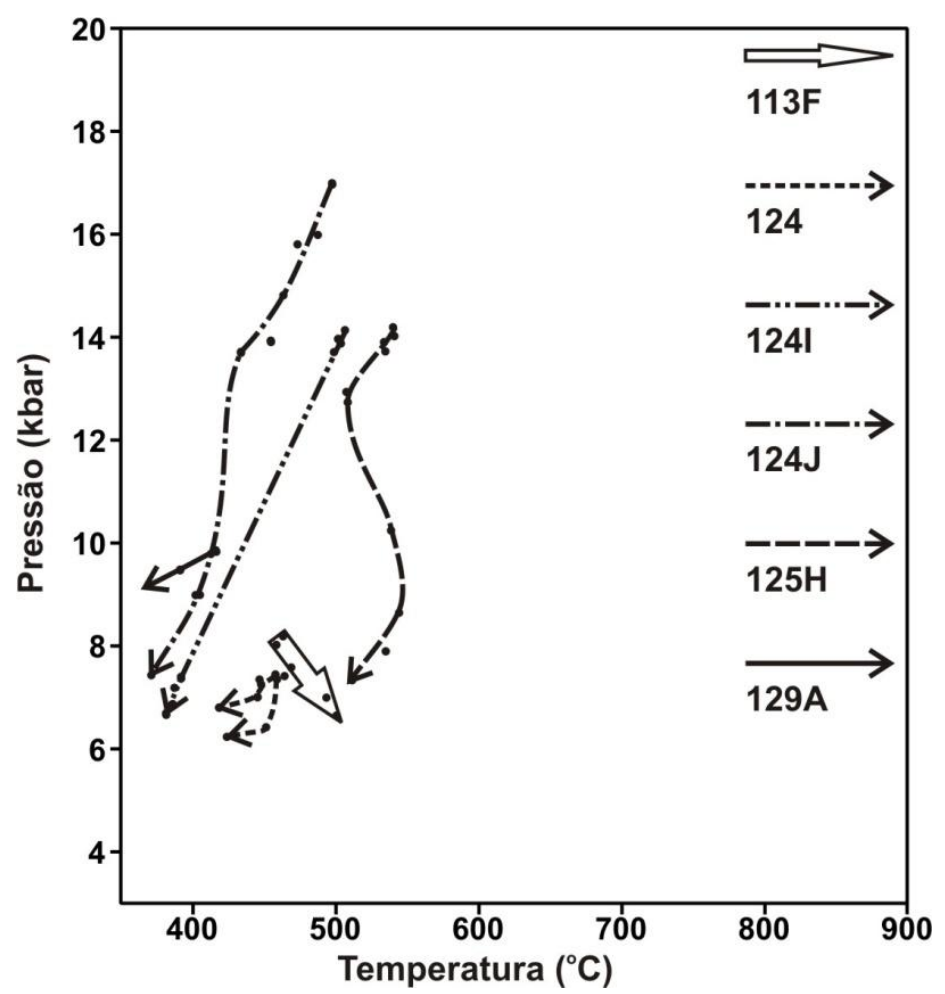

Figura 11.9. Conjunto das trajetórias das amostras individuais da região de Jambaló no qual se observa que as amostras 124l, 124J, 125H apresentam uma forte descompressão. A amostra 129A apresenta uma pequena queda na pressão acompanhada de uma queda forte na temperatura. A amostra 124 apresenta um padrão similar ao da 129A, mas com uma queda menor de temperatura e a amostra $113 \mathrm{~F}$ apresenta queda na pressão com aumento na temperatura. No diagrama os pontos indicam a interseção de alguns dos equilíbrios obtidos nas amostras.

\subsection{Cálculos da região de Barragán}

Os cálculos geotermobarométricos foram feitos com o software TWQ 1.02 (Berman, 1988, 1991), por ser esse o único do conjunto que inclui os anfibólios. Esses cálculos possibilitam a determinação da pressão com uma precisão de \pm 1 kbar e da temperatura de $\pm 50{ }^{\circ} \mathrm{C}$.

As amostras para esses cálculos foram selecionadas em função da presença de granada, anfibólio e plagioclásio, que resultam em cálculos mai precisos, e as análises químicas dos minerais encontram-se no Anexo IV. 
As estimativas $\mathrm{P}-\mathrm{T}$ foram feitas em minerais em paragênese ou em associações de minerais em um mesmo domínio microestrutural, buscando assim uma maior probabilidade de equilíbrio termodinâmico e uma maior coerência nos cálculos das condições de $\mathrm{P}$ e T responsáveis pela formação das diferentes rochas.

Os símbolos de minerais usados para os cálculos termobarométricos da região de Barragán estão na Tabela 11.2.

Tabela 11.2. Símbolos de minerais usados nos cálculos termobarométricos da região de Barragán, segundo Kretz (1983) e Spear (1993).

\begin{tabular}{llllllllll}
\hline Ab & albita & Chl & clorita & Grs & grossulária & Pg & paragonita & Qtz & quartzo \\
Alm & almandina & Czo & clinozoisita & Jd & jadeita & Pmp & pumpellyita & Rt & rutilo \\
An & anortita & Dol & dolomita & Lws & lawsonita & Prg & pargasita & Tr & tremolita \\
Cal & calcita & Gln & glaucofânio & Ms & muscovita & Prp & piropo & Ts & tschermakita \\
\hline
\end{tabular}

Duas amostras (189 e 189A) região de Barragán foram selecionadas para os cálculos termobarométricos, ambas da fácies anfibolito.

A amostra 189 apresenta uma textura nematoblástica que define a foliação principal da rocha e, eventualmente os grãos de anfibólio mostram um pleocroismo mais acentuado no núcleo. Mais raramente observa-se nos núcleo dos cristais um pleocroismo azul-claro, característico de anfibólios sódicos. Entretanto, as análises em microssonda eletrônica não confirmaram a presença de minerais da serie glaucofânio-riebeckita, tendo sido observados apenas uma analise de núcleo e outra intermediária no campo da barroisita e os demais pontos no campo da magnésio-hornblenda. A granada apresenta-se sempre fraturada e com inclusões de minerais opacos e quartzo. Algumas vezes concentra-se plagioclásio nas bordas da granada, sempre de composição próxima da albita pura. Clinozoisita acompanha a textura nematoblástica e a foliação principal $\mathrm{S}_{\mathrm{n}+1}$.

Devido à presença de calcita e/ou dolomita na amostra 189, foi calculada a fração molar de $\mathrm{CO}_{2}$. Neste caso foi fixada a pressão em $10 \mathrm{kbar}$ e simplificou-se o sistema da mesma forma que foi feito com o cálculo dos equilíbrios da associação granada-anfibólio. A fração molar de $\mathrm{CO}_{2}$ nesta pressão está perto de 0,92 , mas com a variação da pressão pode diminuir até 0,90 . Na Figura 11.10, apresenta-se o calculo feito para a fração molar de $\mathrm{CO}_{2}$ desta amostra. Embora as reações a dolomita possam representar a devolatilização para formação de anfibólios, que comumente ocorre em BIFs e paranfibolitos, pode também ser um componente importante de rochas em fácies anfibolito e eclogito com protolito ígneo (Zhang et al. 2003). 


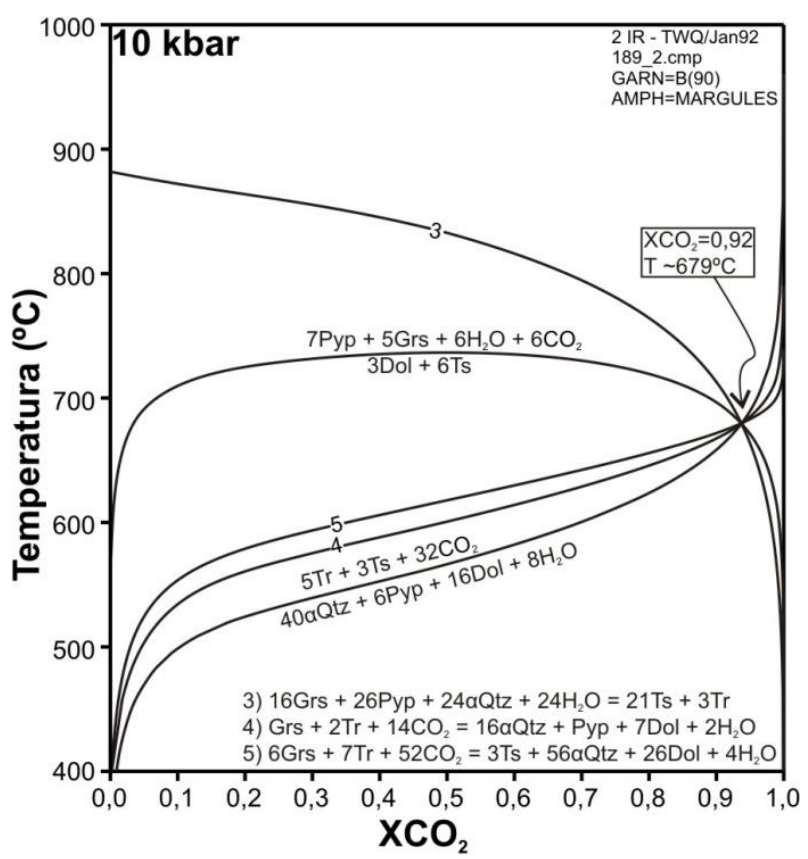

Figura 11.10. Diagrama representativo do cálculo da fração molar de $\mathrm{CO}_{2}$ das rochas na fácies anfibolito de Barragán, em $P=10 \mathrm{kbar}$ usando a associação granada-anfibólio-dolomita-quartzo da amostra 189, indicando equilíbrio em $679^{\circ} \mathrm{C}$ a $\mathrm{XCO}_{2}$ de 0,94 .

Um dos cálculos obtidos com análises de núcleos da associação granada-anfibólio, amostra 189 mostrou a pressão mais alta do conjunto de rochas da fácies anfibolito, indicando a possibilidade das rochas desta região terem alcançado a fácies eclogito. A pressão obtida para o ponto alcançou os $15 \mathrm{kbar}$ e uma temperatura de $639^{\circ} \mathrm{C}$ (Figura 11.11).

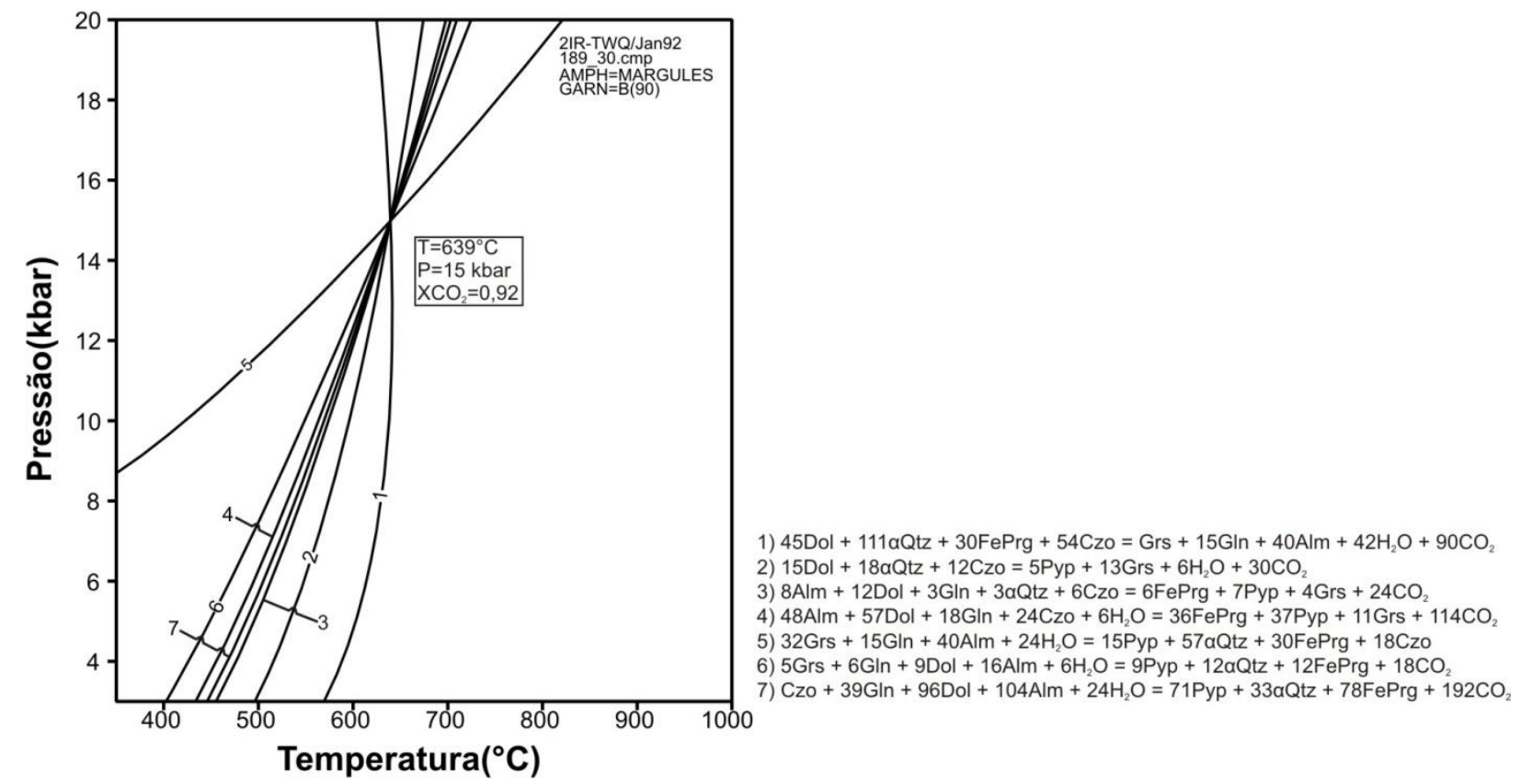

Figura 11.11. Diagrama $P-T$ obtido para os núcleos dos minerais da amostra 189 da associação granadapargasita-clinozoisita-dolomita-quartzo, o qual apresenta a pressão mais alta do conjunto de rochas da fácies anfibolito da região de Barragán.

Utilizando-se as composições dos núcleos e bordas da granada e do anfibólio foram obtidas temperaturas entre 634 e $665^{\circ} \mathrm{C}$ e pressões entre 14,3 e 9,2 kbar respectivamente (Figura 
11.12), indicando que a rocha sofreu uma descompressão isotérmica quando do desenvolvimento da foliação $S_{n+1}$.

Esses dados indicam que as rochas da unidade provavelmente alcançaram à fácies eclogito, quando houve a cristalização de anfibólio pargasítico em paragênese com granada rica em piropo. Posteriormente essas rochas sofreram uma forte descompressão aproximadamente isotérmica, com leve aquecimento, sugerindo uma a possível presença de intrusões sin- a tardicisalhamento que não têm sido encontrados na região.
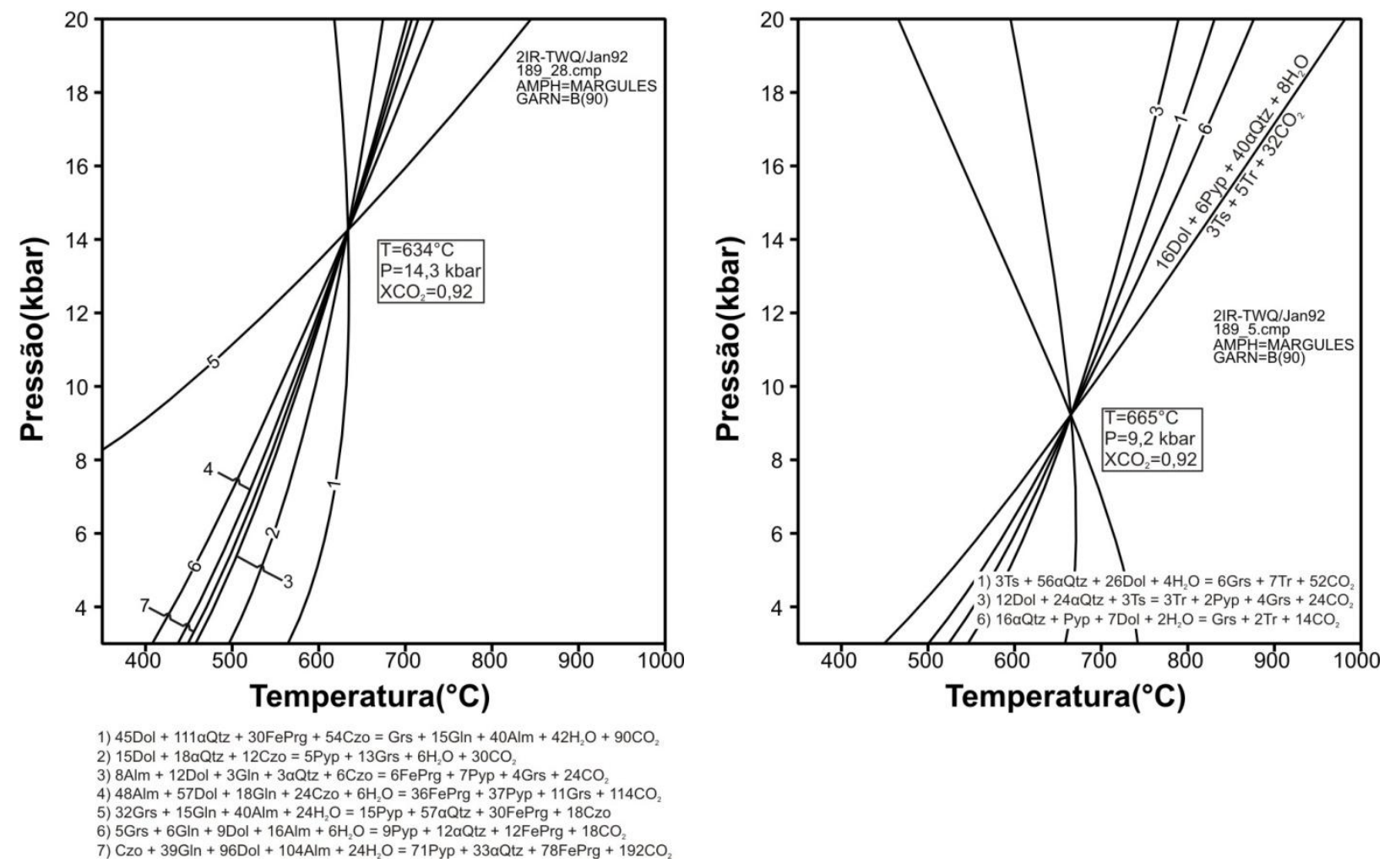

Figura 11.12. Estimativa das condições $P-T$ de formação da amostra 189, com análises de núcleos (esquerda) e bordas (direita) da associação granada-pargasita-clinozoisita-dolomita-quartzo.

A amostra 189A também apresenta textura nematoblástica orientada segundo a foliação milonítica da rocha. Esta textura é normalmente acompanhada por cristais subidioblásticos prismáticos de clinozoisita. Em algumas porções da rocha o anfibólio mostra bordas mais pleocróicas do que o núcleo e, tal qual a amostra 189, alguns grãos podem apresentar o núcleo com pleocroismo azul-claro, embora nesta amostra esses núcleos não tenham sido analisados. $\mathrm{A}$ granada apresenta-se porfiroblástica, por vezes poiquiloblástica, sempre fraturada e com inclusões de quartzo, opacos e, às vezes, de plagioclásio. Plagioclásio, sempre de composição próxima da albita pura, mas com baixos conteúdos de anortita, substitui as bordas da granada. A milonitização nesta amostra, embora presente, não é muito forte.

Nesta amostra, as análises de química mineral foram concentradas na granada, anfibólio e plagioclásio. $\mathrm{A} \mathrm{XCO}_{2}$ para essa amostra, estimada a $10 \mathrm{kbar}$ foi de 0,80 . Os cálculos dos equilíbrios obtidos para a amostra 189A mostram-se semelhantes aos da amostra 189, sendo que 
os núcleos dos minerais resultam em pressões um pouco mais elevadas e temperaturas um pouco menores, quando comparados com as composições das bordas. Assim, foram obtidas, respectivamente para núcleos e bordas, pressões variando de 14 e 13 kbar e temperatura de 632 e $640^{\circ} \mathrm{C}$ (Figura 11.13). Considerando-se que essa rocha foi pouco afetada pela foliação milonítica, essas condições P-T podem ser interpretadas como sendo do evento metamórfico que antecedeu a exumação e a foliação milonítica que chega a formar rochas de baixo grau metamórfico. Esses resultados são coerentes com os obtidos para os núcleos dos minerais da amostra 189 e são indicativos do pico metamórfico que afetou essas rochas, situado na transição da fácies anfibolito para a fácies eclogito e, mais provavelmente, tendo alcançado até a fácies eclogito.
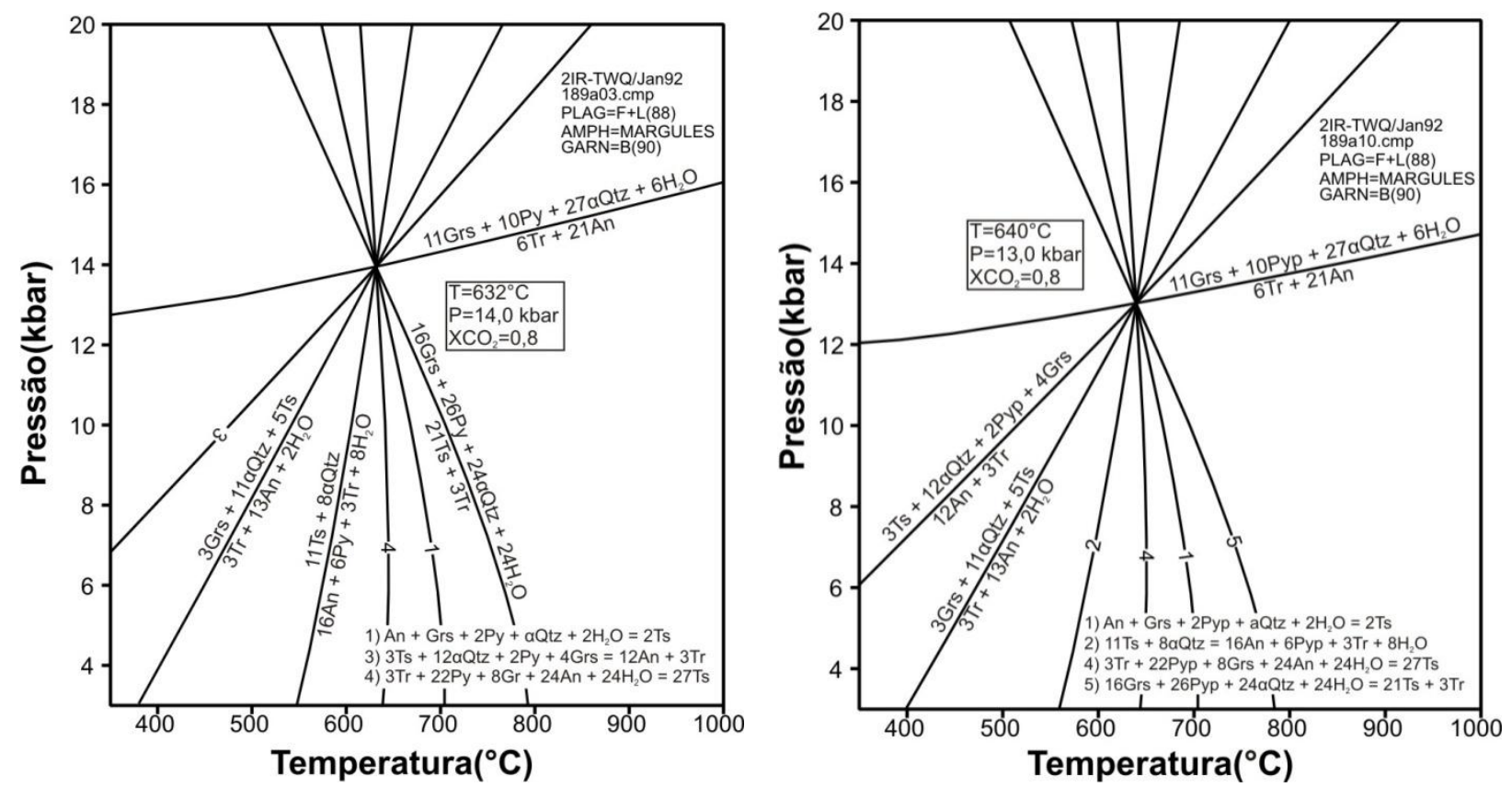

Figura 11.13. Diagramas $P-T$ obtidos para a amostra 189A, com análises de núcleos (esquerda) e bordas (direita) dos minerais, da associação granada-tremolita-tschermakita-plagioclásio-quartzo.

As paragêneses das rochas da fácies xisto azul de Barragán, pela ausência da granada, não são as mais apropriadas para estimativas termobarométricas com base em bancos de dados termodinâmicos internamente consistentes (Rubatto, 2002).

Apenas a amostra 196D foi usada para cálculos termobarométricos utilizando o programa TWQ 1.02, por se a única na qual foram obtidos dados de química mineral em todas as fases. $A$ amostra apresenta textura nematoblástica definida pelos cristais de glaucofânio, pumpellyita e clinozoisita e, em algumas partes, a textura predominante e nemato-lepidoblástica, devido à maior abundância de mica branca e clorita. Localmente ocorrem finos cristais de lawsonita disseminados.

Nesta amostra as análises de química mineral foram concentradas em mica branca, glaucofânio, pumpellyita, lawsonita e clinozoisita e essa mesma associação foi utilizada para a estimativa de pressão e temperatura de geração da rocha. 
Os resultados dos cálculos termobarométricos evidenciam bons equilíbrios e praticamente não há diferenças nas condições $\mathrm{P}-\mathrm{T}$ dos núcleos para as bordas, que são, respectivamente, de 9,5 kbar e $399^{\circ} \mathrm{C}$ e 9,3 kbar e $397^{\circ} \mathrm{C}$ (Figura 11.14 ).
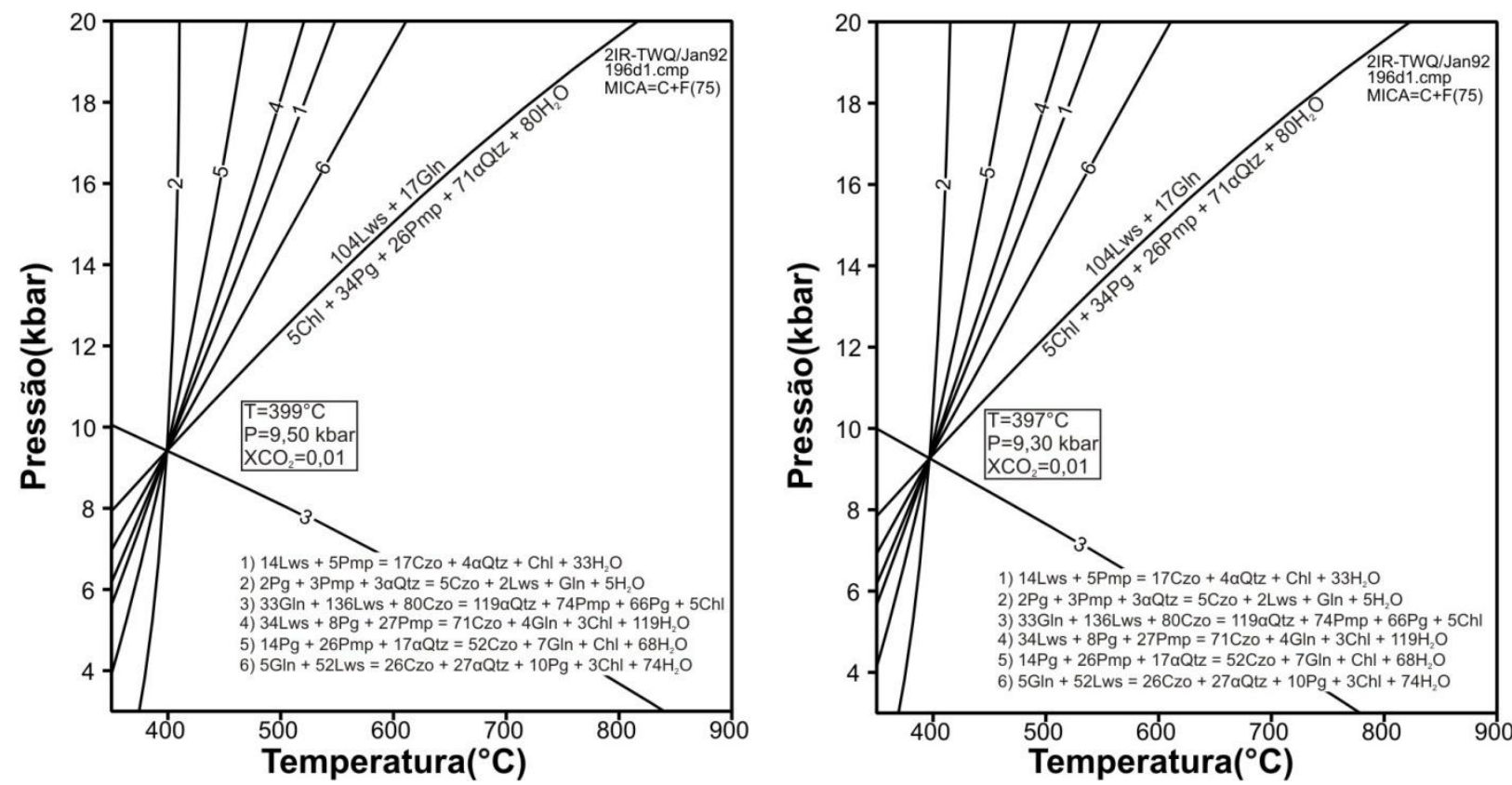

Figura 11.14. Diagramas P-T obtidos para a amostra 196D, com análises de núcleos (esquerda) e bordas (direita) da associação paragonita-glaucofânio-pumpellyita-lawsonita-clinozoisita-quartzo.

A pressão e a temperatura de formação dos xistos azuis podem também ser estimadas pelas reações que resultaram na cristalização dos minerais, deduzidas pela petrografia, em comparação com estimativas feitas por outros autores em rochas semelhantes de outros lugares.

Assim, para as rochas com lawsonita, clorita e abundante titanita, pode-se inferir que se o rutilo inicialmente estava em excesso em relação à titanita e o ferro presente na clorita poderia reagir com a titanita e com o rutilo, resultando na cristalização de lawsonita, restando titanita como inclusões, e rutilo + ilmenita na matriz (Shau et al., 1991; Fitzherbert et al., 2003). Essas associações e texturas foram observadas nas amostras do afloramento 197, especialmente na amostra 197A, o que permite inferir, segundo os autores citados, que essas rochas se formaram em pressões próximas de $8 \mathrm{kbar}$ e temperaturas da ordem de $300^{\circ} \mathrm{C}$.

A associação de lawsonita com glaucofânio, clorita, calcita/aragonita e pumpellyita é considerada como formada em pressões litostáticas entre 6,5 e 8 kbar, em altas pressões de fluidos, a temperaturas no intervalo entre 200 e $300^{\circ} \mathrm{C}$ (Deer et al., 1986). Além disso, a reação envolvendo lawsonita e glaucofânio apresentada adiante, teve seu intervalo de P-T definido por Deer et al. (1986) ao redor de $5-7 \mathrm{kbar}$ e $250-400^{\circ} \mathrm{C}$.

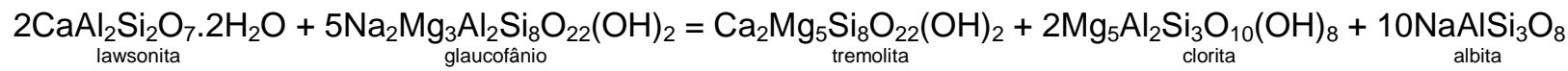

Segundo Shau et al. (1991), a seguinte reação caracteriza a transição da fácies xisto azul para o xisto verde: 
$\underset{\text { lawsonita }}{4 \mathrm{CaAl}_{2} \mathrm{Si}_{2} \mathrm{O}_{7}(\mathrm{OH})_{2}} \cdot \mathrm{H}_{2} \mathrm{O}+\underset{\text { albita }}{\mathrm{NaAlSi}_{3} \mathrm{O}_{8}}=\underset{\substack{\text { clinozoisita } \\ \text { paragonita }}}{2 \mathrm{Ca}_{2} \mathrm{Al}_{3} \mathrm{Si}_{3} \mathrm{O}_{12}}(\mathrm{OH})+\underset{\text { quartzo }}{\mathrm{NaAl}_{3} \mathrm{Si}_{3} \mathrm{O}_{10}}(\mathrm{OH})_{2}+\underset{\mathrm{SiO}_{2}}{6 \mathrm{H}_{2} \mathrm{O}}$

Essa reação processa-se a $\sim 9$ kbar e $\sim 350^{\circ} \mathrm{C}$, ou a pressões ainda menores sob baixas pressões parciais de $\mathrm{H}_{2} \mathrm{O}$.

Considerando as reações apresentadas, e comparando com a mineralogia observada para o conjunto de rochas da fácies xisto azul da região de Barragán, sugere-se que o metamorfismo desta fácies observado na área tenha um registro que varia de $\sim 9 \mathrm{kbar}$ e $\sim 350^{\circ} \mathrm{C}$ e $\sim 5 \mathrm{kbar}$ e $250^{\circ} \mathrm{C}$.

A trajetória metamórfica registrada nas rochas da fácies anfibolito indica uma forte descompressão e leve aquecimento durante a exumação de, possivelmente, eclogitos ou rochas transicionais entre as fácies eclogito e anfibolito alto (Figura 11.15).

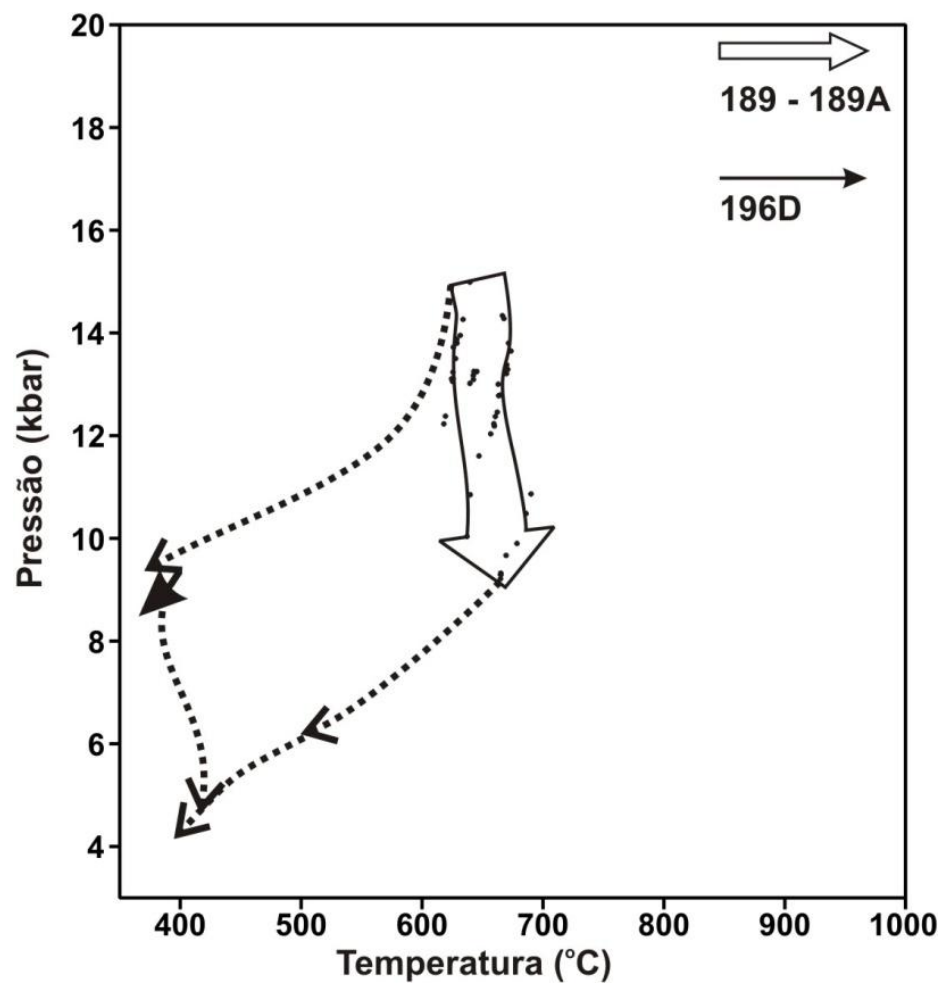

Figura 11.15. Conjunto das trajetórias das amostras da região de Barragán no qual se observa uma descompressão forte com aumentos leves na temperatura nas rochas da fácies anfibolito (189 - 189A) e uma leve descompressão e queda na temperatura na amostra 196D. No diagrama os pontos indicam a interseção de alguns dos equilíbrios obtidos nas amostras e as setas pontilhadas representam trajetórias tentativas.

Essa exumação está associada ao desenvolvimento da zona de cisalhamento impressa nas rochas como a foliação $S_{n+1}$. O xisto azul estudado tem as composições de núcleo e de borda dos minerais muito semelhantes, mas mesmo assim, uma leve descompressão e um leve resfriamento podem ter afetado essas rochas, sugerindo uma trajetória semelhante à das rochas da fácies anfibolito. Essas trajetórias podem ser interpretadas como devidas à exumação de rochas de alta pressão estratificadas, com eclogitos em níveis mais profundos, capeados por xistos azuis, desenvolvidos em uma seqüência vulcano-sedimentar oceânica, com basaltos do tipo 
MORB. As evidências petrográficas indicam que as paragêneses da fácies xisto azul e anfibolito foram retrometamorfisadas até a fácies xisto verde com cristalização principalmente de anfibólio cálcico e clorita como tentativamente indicado na Figura 11.15. Nesse contexto, os serpentinitos situados a oeste das rochas da fácies anfibolito poderiam representar lascas tectônicas do manto, arrancadas durante o evento de exumação das rochas de alta pressão. 


\section{GEOQUÍMICA DA REGIÃO DE JAMBALÓ}

As rochas de composição básica normalmente refletem as características químicas da fonte mantélica onde foram geradas e essas características, juntamente com o grau de fusão parcial original, resultam em assinaturas geoquímicas que podem ser usadas para definir o ambiente tectônico magma primário foi gerado (Pearce, 1982; Sun \& McDonough, 1989; Wilson, 1989).

O estudo do quimismo dos metabasitos, em analogia às rochas básicas, é comumente utilizado na definição da natureza dos magmas, bem como do ambiente tectônico no qual eles se formaram. Essa aplicação para rochas metamórficas fundamenta-se na pequena mobilidade dos elementos de HFSE (Ti, Th, Ta, $\mathrm{Zr}$, Y, Nb, P e Hf), dos metais transicionais ( $\mathrm{Cr}$, $\mathrm{Ni}$ e $\mathrm{V}$ ), das terras raras ( $\mathrm{REE}$ ) e de alguns elementos maiores sob a forma de óxidos $\left(\mathrm{SiO}_{2}, \mathrm{MgO}, \mathrm{CaO}\right.$ e $\mathrm{MnO}$ ) durante a maioria dos eventos metamórficos e, eventualmente, durante alterações hidrotermais de fundo oceânico e associadas a eventos ígneos (Pearce \& Cann, 1973; Winchester \& Floyd, 1977, Beccaluva et al., 1979; Juliani \& McReath, 1993; McLenann et al., 1993). Inversamente, segundo Winchester \& Max (1989), os elementos de raio iônico grande ( $\mathrm{Cs}$, $\mathrm{Rb}$, $\mathrm{Sr}$ e Ba) e o K são potencialmente móveis nos eventos metamórficos, razão pela qual o seu uso em diagramas discriminantes pode resultar em erros interpretativos.

Foi também analisado um epidosito e uma amostra de estilpnomelano-muscovita-albitaanfibólio-quartzo xisto. A primeira dessas rochas, mesmo que possa ter tido um protolito ígneo ou vulcanoclástico básico a intermediário, foi profundamente afetada por alteração hidrotermal, razão pela qual essa não será considerada na análise dos protolitos e do ambiente tectônico de formação. O mesmo se aplica para o estilpnomelano-muscovita-albita-anfibólio-quartzo xisto que representa, possivelmente, um metassedimento com contribuição de tufos máficos e/ou de precipitados químicos associado às rochas vulcânicas/vulcanoclásticas.

As rochas derivadas de protolitos ígneos ou vulcanoclásticos mostram teores de $\mathrm{SiO}_{2}$ variando de 49 a 59\% (Tabela 12.1) indicando, a despeito de possíveis alterações no quimismo introduzidas por hidrotermalismo e metassomatismo pré- a pós-metamórfico, composições básicas relativamente evoluídas a típicas rochas intermediárias. Essa associação distingue-se dos metabasitos de Barragán, que são predominantemente pouco evoluídos e não chegam a constituir típicas rochas intermediárias. As análises químicas completas encontram-se no Anexo V.

Tabela 12.1. Teores $\mathrm{SiO}_{2}$ dos metabasitos e meta-intermediárias da região de Jambaló.

\begin{tabular}{|c|c|c|c|c|c|c|c|}
\hline Amostra & Fácies & $\mathrm{SiO}_{2}$ & Tipo de rocha & Amostra & Fácies & $\mathrm{SiO}_{2}$ & Tipo de rocha \\
\hline $107^{\star}$ & Xisto verde & 59,27 & Metapelito & 121C & Xisto azul & 50,94 & Metabásica \\
\hline $107 A$ & Xisto verde & 49,06 & Metabásica & $123 A$ & Xisto azul & 50,42 & Metabásica \\
\hline 107B & Xisto verde & 58,12 & Meta-intermediária & & Xisto azul & 56,90 & Meta-intermediária \\
\hline $109 A^{* \star}$ & Xisto verde & 38,27 & Epidosito & 124J & Xisto azul & 52,01 & Meta-intermediária \\
\hline 114 & Xisto verde & 55,16 & Meta-intermediária & $125 M$ & Xisto azul & 56,33 & Meta-intermediária \\
\hline 121B & Xisto azul & 51,74 & Metabásica & $129 A$ & Xisto azul & 51,42 & Metabásica \\
\hline
\end{tabular}

* 107 estilpnomelano-muscovita-albita-anfibólio-quartzo xisto e ** 109A epidosito. 
O diagrama de Miyashiro (1975) discrimina as amostras que sofreram alterações no conteúdo de sódio e potássio e, da região de Jambaló, nota-se que somente dois metabasitos tiveram sua composição química modificada por alteração hidrotermal (Figura 12.1A).

A identificação dos protolitos é dificultada pela falta de texturas e estruturas dos protolitos das rochas metamorfisadas, tais como estruturas vulcanoclásticas, cumuláticas, de assimilação, etc. Assim, para que as rochas possam ser classificadas em diagramas petrogenéticos, é necessário verificar se as suas composições correspondem a líquidos basálticos. Isso pode ser feito por meio do diagrama de Pearce (1982), modificado por Juliani \& McReath (1993), que permite que rochas com a composição de líquidos basálticos de diversos ambientes tectônicos modernos possam ser identificadas (Figura 12.1B). Nesse caso, não se notam efeitos significativos de cristalização parcial ou de cúmulus, permitindo que todas as rochas possam ser utilizadas nos diagramas classificatórios e de identificação de ambiente tectônico.
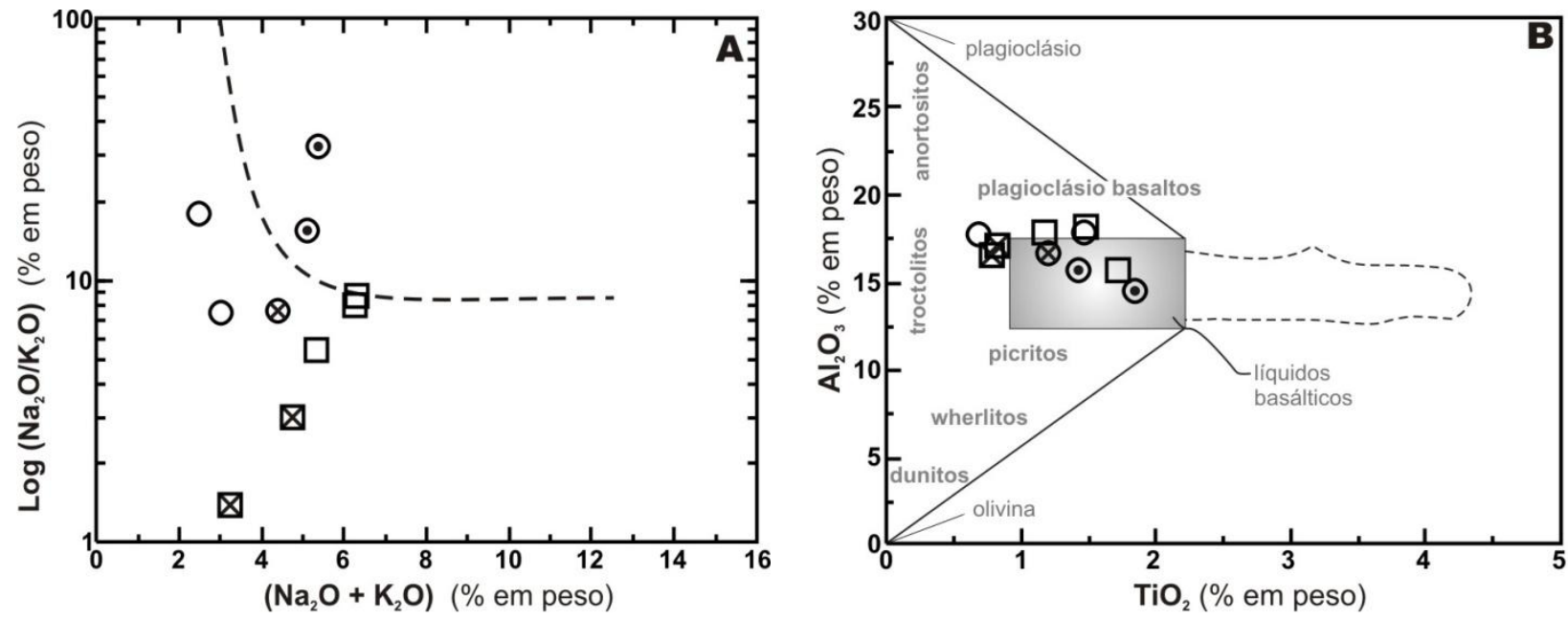

$\bigcirc$ Metabasitos (FXA) $\otimes$ Metabasito (FXV) $\odot$ Metabasitos (FXA - A)

$\square$ Meta-intermediárias (FXA) $\bigotimes$ Meta-intermediárias (FXV)

Figura 12.1. (A) diagrama para identificação de amostras que sofreram alterações nos conteúdos de sódio e potássio devido à introdução e/ou retirada de elementos, representadas acima da curva tracejada (Miyashiro 1975), e (B) diagrama de discriminação de amostras que apresentam composições compatíveis com líquidos basálticos, segundo Pearce (1982), modificado por Juliani \& McReath (1993). FXA = rochas da fácies xisto azul; $F X V=$ da fácies xisto verde e $F X A-A=$ da fácies xisto azul com alterações nos conteúdos de sódio e potássio.

O diagrama TAS (total álcalis vs silica) para classificação de rochas vulcânicas (Figura 12.2) proposto por LeMaitre et al. (2002) mostra que as rochas da região de Jambaló têm composições básicas e intermediárias, correspondendo a uma série que varia de basaltos a andesitos. Nota-se que as amostras nas quais foram identificadas como afetadas por alteração hidrotermal estão plotadas acima da tendência evolutiva citada, juntamente com outras rochas que plotam nas proximidades do limite entre os campos da Figura 12.1A. Isso pode ser indicativo de alterações hidrotermais importantes em ambiente oceânico ou durante o metamorfismo, em especial, durante o cisalhamento. Alternativamente, essas rochas poderiam representar outra seqüência vulcânica, com basaltos alcalinos, traquibasaltos e traquiandesito basáltico, o que 
parece ser menos provável, em função da associação das rochas em campo.

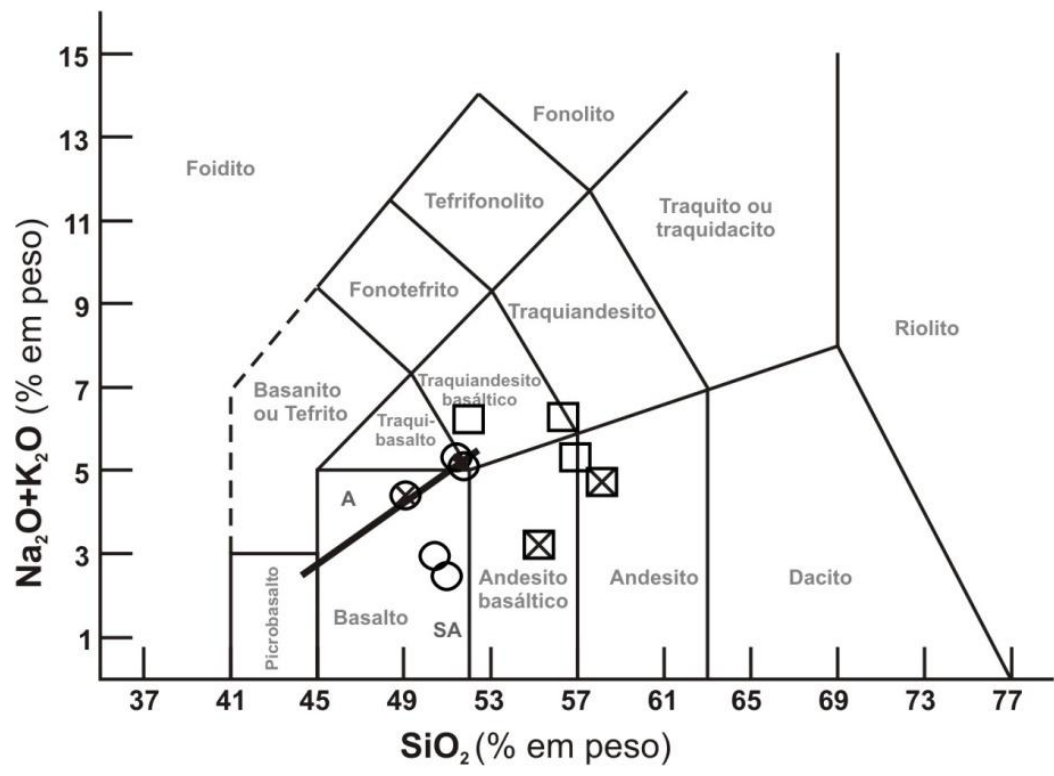

Metabasitos (FXA) $\otimes$ Metabasito (FXV) ○ Metabasitos (FXA - A)

$\square$ Meta-intermediárias (FXA) $\bigotimes$ Meta-intermediárias (FXV)

Figura 12.2. Diagrama TAS (total álcalis vs sílica), segundo LeMaitre et al. (2002) para as rochas da região de Jambaló, no qual todas as análises apresentam-se dispersas segundo sejam de protolitos básicos ou intermediários. No campo do basalto, a linha divide as rochas entre alcalinas (A) e subalcalinas (SA) segundo Irvine \& Baragar (1971). Neste caso, as amostras que tem alteração nos conteúdos de sódio e potássio estão sobre da linha divide as rochas entre alcalinas e subalcalinas. FXA = rochas da fácies xisto azul; $F X V=$ da fácies xisto verde e FXA - $A=$ da fácies xisto azul com alterações nos conteúdos de sódio e potássio.

Nos diagramas da Figura 12.3 pode-se notar que o $\mathrm{CaO}$ e o $\mathrm{Sr}$ exibem correlações negativas com o $\mathrm{Zr}$, que podem ser atribuídas a diferenciações magmáticas que resultaram na formação de protolitos intermediários a partir de magmas básicos. O Ba mostra também correlação negativa, o que sugere que a seqüência vulcano-sedimentar desenvolveu-se num ambiente com importantes atividades exalativas ou, alternativamente, que o elemento foi introduzido em eventos pós-magmáticos, em especial durante o cisalhamento que ocasionou 0 retrometamorfismo das rochas da fácies xisto azul. Nota-se também que $\circ \mathrm{K}_{2} \mathrm{O}$, quando considerado o conjunto das amostras, não define tendências evolutivas, observando-se uma forte dispersão, indicativa de grande mobilidade do elemento. Entretanto, quando são considerados apenas os xistos azuis (metabasitos e meta-intermediárias), apesar da dispersão, pode-se notar ainda certa tendência que poderia ser indicativa de cristalização fracionada. Por outro lado, os xistos verdes estão fortemente dispersos, sugerindo que a introdução do potássio deu-se principalmente durante o desenvolvimento das zonas de cisalhamento responsáveis pela exumação dos xistos azuis. 

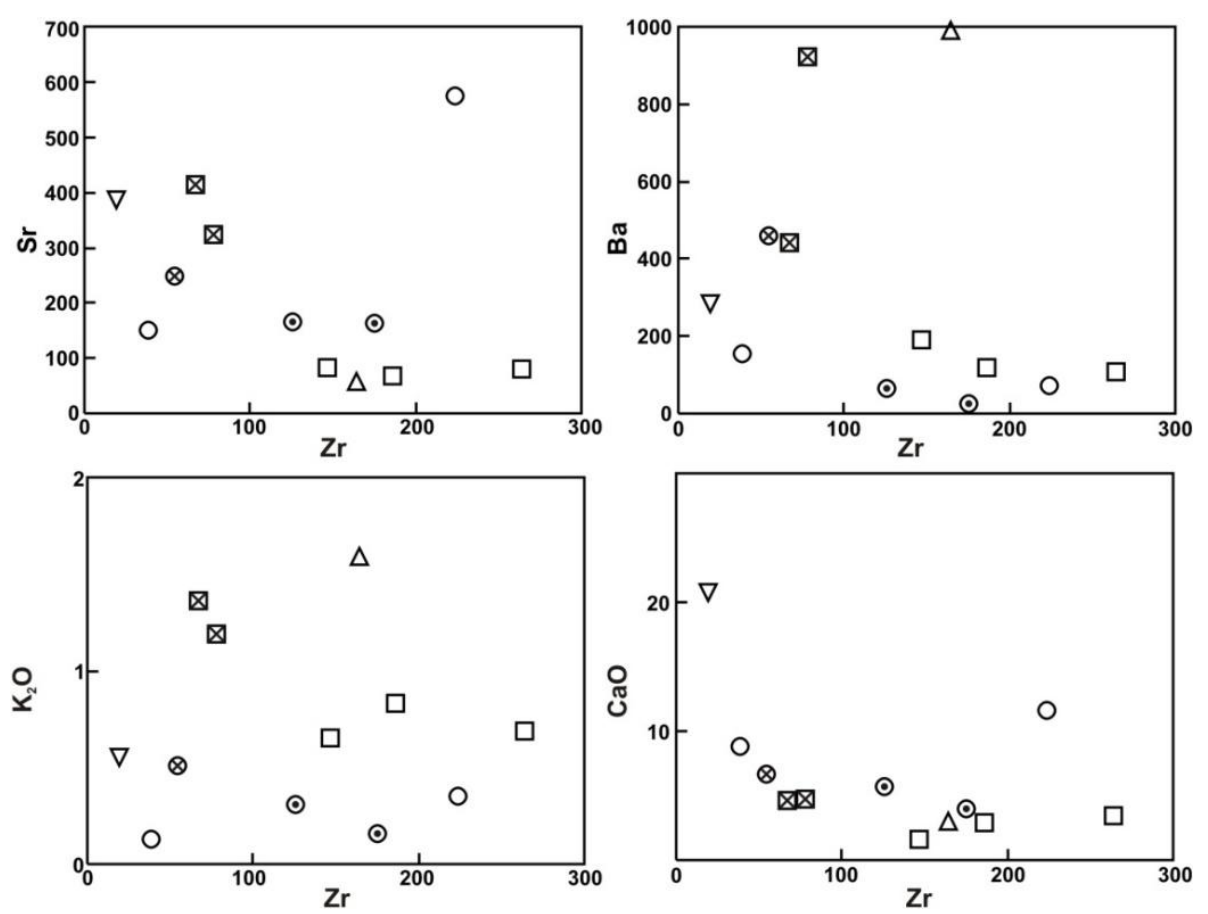

$\bigcirc$ Metabasitos (FXA) $\otimes$ Metabasito (FXV) $\odot$ Metabasitos (FXA - A)

$\square$ Meta-intermediárias (FXA) $\bigotimes$ Meta-intermediárias (FXV)

$\Delta$ Estilpnomelano-muscovita-albita-anfibólio-quartzo xisto $\nabla$ Epidosito

Figura 12.3. Diagramas de comparação de $\mathrm{Zr}$ vs $\mathrm{Ba}, \mathrm{Zr}$ vs $\mathrm{Sr}, \mathrm{Zr}$ vs $\mathrm{K}_{2} \mathrm{O}$ e $\mathrm{Zr}$ vs CaO para analise do comportamento dos elementos móveis. Nos diagramas observa-se que o $\mathrm{Sr}$, Ba e Ca apresentam uma correlação negativa, enquanto o $K_{2} \mathrm{O}$ aparentemente não apresenta nenhuma correlação devido a sua dispersão. $F X A=$ rochas da fácies xisto azul; $F X V=d a$ fácies xisto verde e $F X A-A=d a$ fácies xisto azul com alterações nos conteúdos de sódio e potássio.

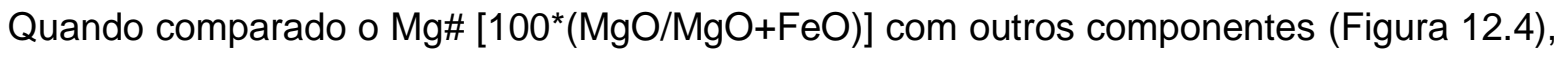
não é clara a existência de uma correlação positiva ou negativa, devido principalmente ao reduzido número de análises. Mesmo assim, analisando-se mais detalhadamente o diagrama nota-se que $0 \mathrm{TiO}_{2}, \mathrm{CaO}, \mathrm{K}_{2} \mathrm{O}$ e $\mathrm{P}_{2} \mathrm{O}_{5}$ apresentam correlações levemente negativas, principalmente quando são analisados os metabasitos e as meta-intermediárias separadamente. A dispersão das rochas da fácies e da fácies xisto verde é maior, em parte devido a pouca quantidade de análises, mas, mais provavelmente, devido a alterações hidrotermais durante o cisalhamento. $\mathrm{O} \mathrm{Al}_{2} \mathrm{O}_{3}$ e $\circ \mathrm{Na}_{2} \mathrm{O}$ mostram uma leve tendência de correlação positiva para 0 primeiro e mais fortemente insinuada no segundo caso, que podem ser atribuídas a processos de diferenciação magmática ou fusão parcial na formação de rochas mais evoluídas. As rochas da fácies xisto verde distinguem-se das tendências das rochas da fácies xisto azul, o que pode ser devido às alterações hidrotermais. $\mathrm{O} \quad \mathrm{MnO}$ e $\quad \mathrm{Fe}_{2} \mathrm{O}_{3}$ não apresentam tendências de enriquecimento ou empobrecimento. 

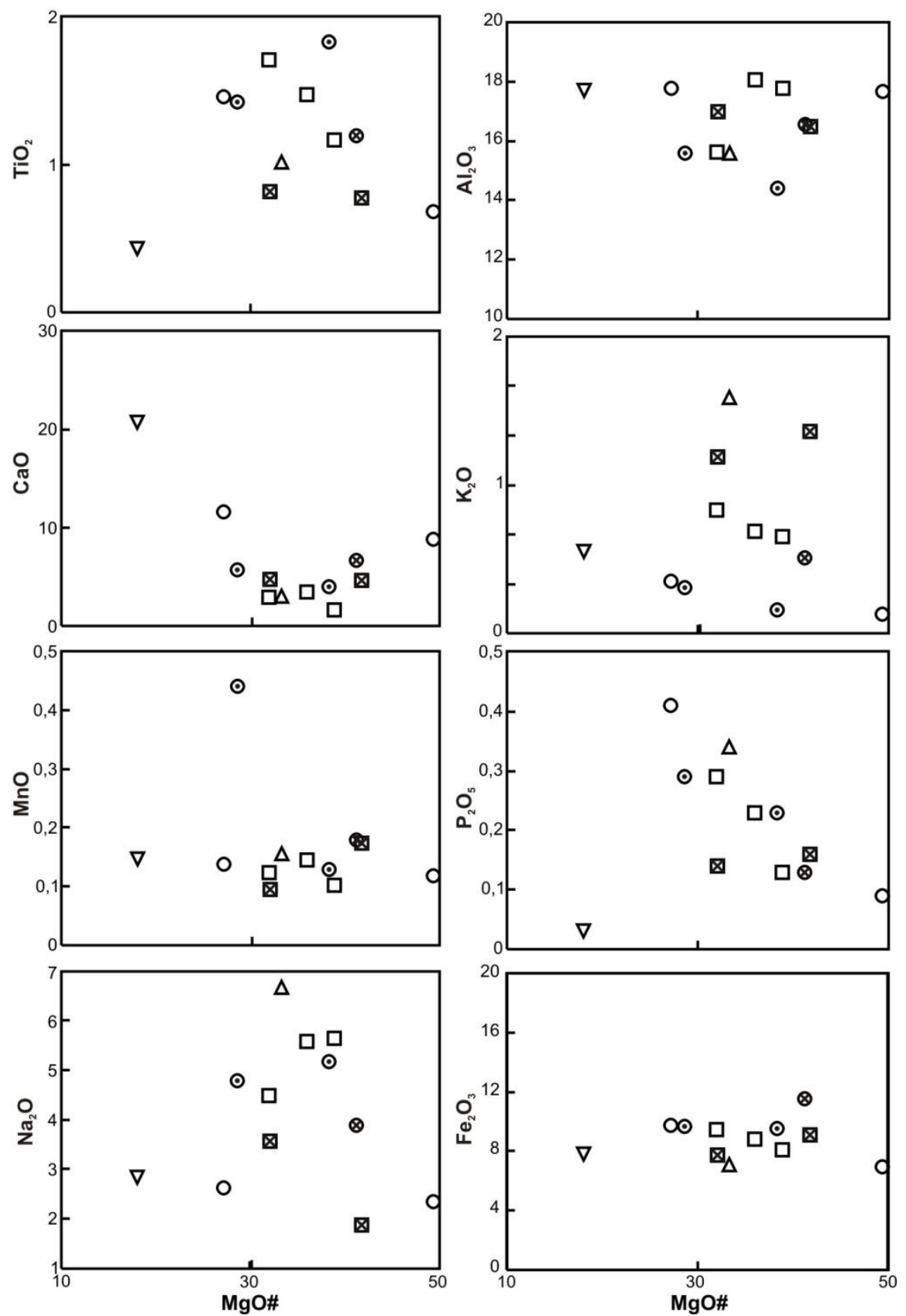

Metabasitos (FXA) $\otimes$ Metabasito (FXV) ○ Metabasitos (FXA - A)

$\square$ Meta-intermediárias (FXA) $\triangle$ Meta-intermediárias (FXV)

$\Delta$ Estilpnomelano-muscovita-albita-anfibólio-quartzo xisto $\nabla$ Epidosito

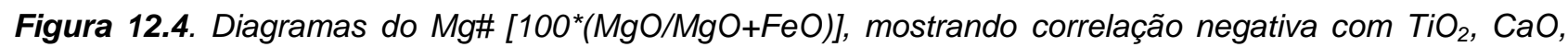
$\mathrm{K}_{2} \mathrm{O}$ e $\mathrm{P}_{2} \mathrm{O}_{5}$, positiva com $\mathrm{Al}_{2} \mathrm{O}_{3}$ e o $\mathrm{Na}_{2} \mathrm{O}$ e sem variações para o $\mathrm{MnO}$ e o $\mathrm{Fe}_{2} \mathrm{O}_{3}$. $\mathrm{FXA}=$ rochas da fácies xisto azul; $F X V=$ da fácies xisto verde e FXA - $A=$ da fácies xisto azul com alterações nos conteúdos de sódio e potássio.

$\mathrm{O}$ \#Mg aparentemente mostra uma mobilidade menor e, quando comparada com as variações dos teores de Co, $\mathrm{Zr}$ e $\mathrm{Cr}$, exibem correlações indicativas de diferenciação magmática por cristalização fracionada ou por fusão parcial (Figura 12.5). Das amostras analisadas, várias tem conteúdo de $\mathrm{Cr}$ abaixo do limite de detecção e, por esse motivo, não foram plotadas. O V, Sc e Zn exibem correlação positiva mas com tendências distintas para as metabásicas e as metaintermediárias e o Cu mostra dispersão das análises. O conteúdo de Ni de várias amostras com 
30 ppm e outras estão no limite de detecção, não definindo qualquer correlação.
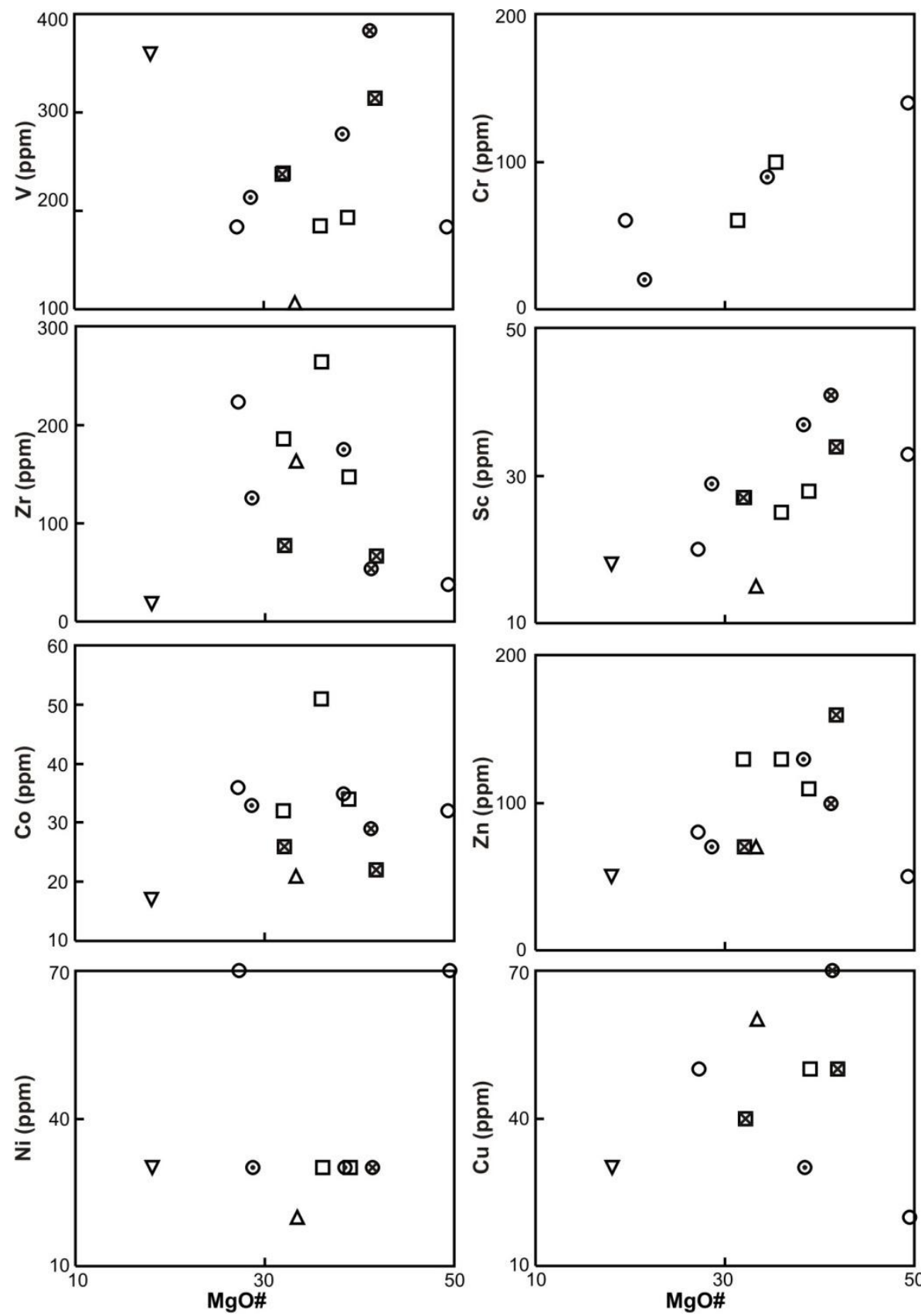

$\bigcirc$ Metabasitos (FXA) $\otimes$ Metabasito (FXV) $\odot$ Metabasitos (FXA - A)

$\square$ Meta-intermediárias (FXA) $\bigotimes$ Meta-intermediárias (FXV)

$\Delta$ Estilpnomelano-muscovita-albita-anfibólio-quartzo xisto $\nabla$ Epidosito

Figura 12.5. Variação do $\mathrm{Mg \#} \mathrm{[100*(MgO/MgO+FeO})]$, com correlação negativa do Co, $\mathrm{Zr}$ e Cr; positiva do $\mathrm{V}$, Sc e Zn e sem correlação com Cu e Ni. Nota-se ainda que o estilpnomelano-muscovita-albita-anfibolioquartzo xisto e o epidosito distinguem do conjunto dos metabasitos. FXA = rochas da fácies xisto azul; FXV = da fácies xisto verde e FXA - $A=$ da fácies xisto azul com alterações nos conteúdos de sódio e potássio.

No diagrama $\mathrm{FeO}, \mathrm{Na}_{2} \mathrm{O}+\mathrm{K}_{2} \mathrm{O}$ e $\mathrm{MgO}$ (Irvine \& Baragar, 1971), que distingue as tendências cálcio-alcalina e tholeiítica, nota-se uma clar tendência cálcio-alcalina para os metabasitos e metaintermediárias de Jambaló, com somente um metabasito da fácies xisto azul situado no campo da série tholeiítica (Figura 12.6). 


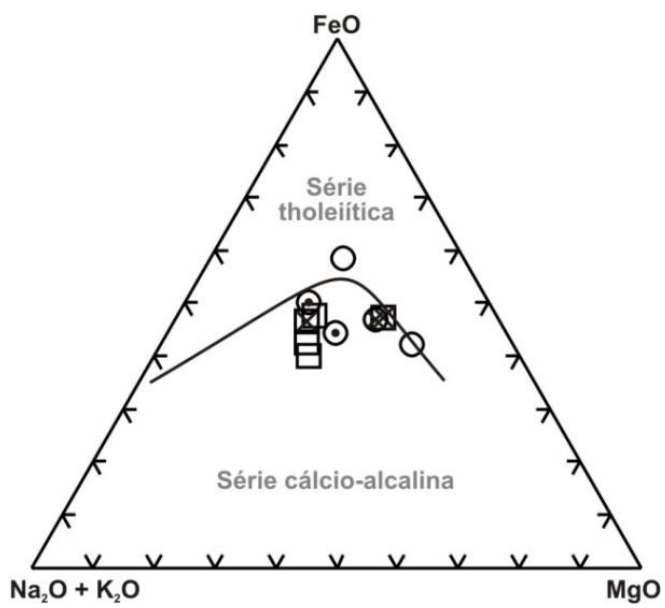

$\bigcirc$ Metabasitos (FXA) $\otimes$ Metabasito (FXV) $\odot$ Metabasitos (FXA - A)

$\square$ Meta-intermediárias (FXA) $\bigotimes$ Meta-intermediárias (FXV)

Figura 12.6. Diagrama $\mathrm{FeO}, \mathrm{Na} 2 \mathrm{O}+\mathrm{K} 2 \mathrm{O}$ e $\mathrm{MgO}$, segundo Irvine e Baragar (1971), que separa as tendências cálcio-alcalinas e tholeiíticas. No diagrama somente uma análise que corresponde a um metabasito da fácies xisto azul esta no campo da série tholeiítica, enquanto as demais análises estão no campo da série cálcio-alcalina. $F X A=$ rochas da fácies xisto azul; $F X V=$ da fácies xisto verde e $F X A-A=$ da fácies xisto azul com alterações nos conteúdos de sódio e potássio.

Essas rochas, quando plotadas no diagrama $\mathrm{Nb} / \mathrm{Y}$ vs $\mathrm{Zr} / \mathrm{TiO}{ }_{2}$ de Winchester \& Floyd, (1977), são classificadas como basalto subalcalino, andesito basáltico e andesito (Figura 12.7), sendo que, somente uma das amostras de metabasito da fácies xisto azul, plota na linha que divide a composição típica de basalto sub-alcalino e basalto alcalino. O epidosito tem composição de basalto subalcalino e distribui-se juntamente com as demais rochas básicas e intermediárias, sugerindo que, apesar da forte alteração hidrotermal que afetou a rocha, não houve variações substanciais nos teores de $\mathrm{Nb}, \mathrm{Y}$ e $\mathrm{Ti}$ e a rocha pode ser considerada como de protolito ígneo ou vulcanoclástico.

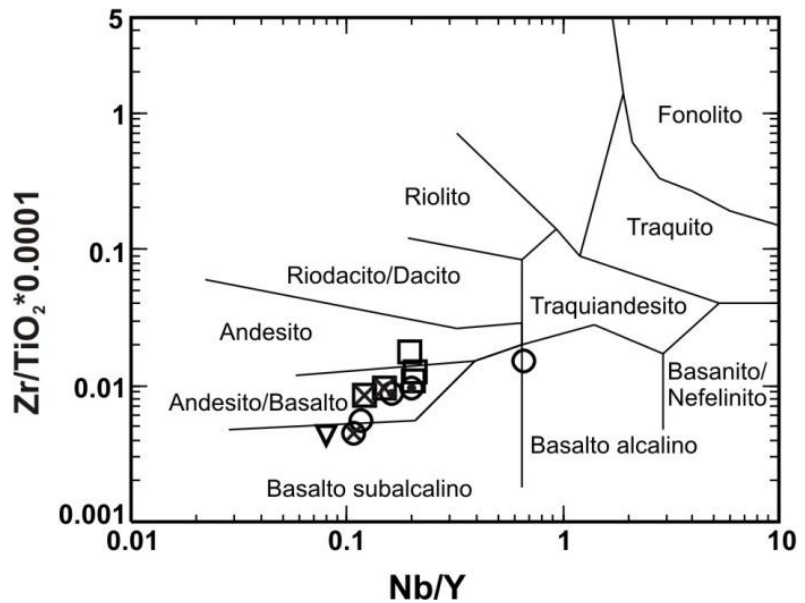

Metabasitos (FXA) $\otimes$ Metabasito (FXV) ○ Metabasitos (FXA - A)

Meta-intermediárias (FXA) $\square$ Meta-intermediárias (FXV) $\nabla$ Epidosito

Figura 12.7. Diagrama $\mathrm{Nb} / \mathrm{Y}$ vs $\mathrm{Zr} / \mathrm{TiO} \mathrm{O}_{2}$ de classificação das rochas vulcânicas (Winchester \& Floyd, 1977), indicando que os protolitos dos xistos azuis e xistos verdes da região de Jambaló foram formados pelo metamorfismo de basaltos subalcalinos, andesitos basálticos e andesitos. FXA = rochas da fácies xisto azul; $F X V=$ da fácies xisto verde e FXA - $A=$ da fácies xisto azul com alterações nos conteúdos de sódio e potássio. 
Essas composições são mais evoluídas que os metabasitos do tipo MORB identificados em Barragán e a associação sugerem que o terreno de Jambaló foi formado num ambiente de arco de ilha.

Nos diagramas de Gill (1981) para rochas intermediárias, nota-se que há uma dispersão dos pontos quando analisado o La em comparação com o Ba (Figura 12.8A). Neste mesmo diagrama nota-se que duas das rochas intermediárias da fácies xisto azul situam-se no campo do N-MORB, enquanto as meta-intermediárias na fácies xisto verde estão no campo do andesito orogênico. Uma amostra meta-intermediária da fácies xisto azul esta na interseção do campo do andesito orogênico com o E-MORB. Esta dispersão de pontos pode ser explicada pela mobilidade do Ba durante os evento metamórficos. No diagrama La vs Th as análises distribuem-se no campo dos andesitos orogênicos (Figura 12.8B), assim como no diagrama La vs Nb, exceto uma amostra da fácies xisto azul, que tem composição de E-MORB (Figura 12.8C).
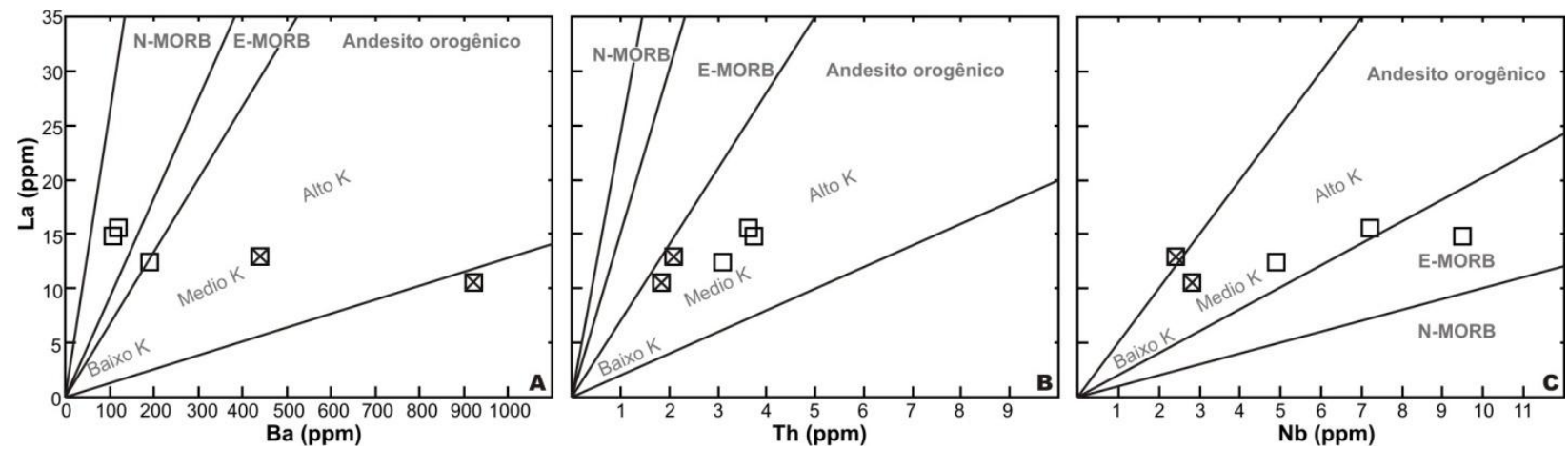

Meta-intermediárias (FXA) $\bigotimes$ Meta-intermediárias (FXV)

Figura 12.8. Diagramas La vs Ba (A), La vs Th (B) e La vs Nb (C) para rochas intermediárias (Gill, 1981), mostrando que as rochas com protolitos intermediários da região Jambaló de correspondem principalmente ao campo do andesito orogênico. $F X A=$ rochas da fácies xisto azul; $F X V=$ da fácies xisto verde e $F X A-A=$ da fácies xisto azul com alterações nos conteúdos de sódio e potássio.

O estado de oxidação do vanádio varia de $3^{+}$a $5^{+}$e, por ser um elemento relativamente incompatível, os magmas podem ter concentrações maiores deste elemento em zonas de subducção, onde o ambiente é relativamente oxidante (Shervais, 1982). No diagrama Ti vs V de discriminação de ambiente tectônico de Shervais (1982), observa-se uma dispersão das amostras analisadas, sendo a maior concentração no campo dos basaltos de back-arc, com algumas das análises no campo dos basaltos de arco (Figura 12.9). Esses dados sugerem fortemente a influência de uma zona de subducção ensimática na geração dos protolitos da região de Jambaló, que devem ter resultado na formação de um arco de ilhas incorporado ao continente no metamorfismo da fácies xisto azul que ocorreu há aproximadamente 66 a $61 \mathrm{Ma}$. As rochas básicas representadas no diagrama de Shervais (1982) mostram variações nos teores de Nb e na razão $\mathrm{Ta} / \mathrm{Yb}$, sendo que correspondem principalmente ao campo dos basaltos de back arc MORB e somente uma análise que corresponde a um metabasito na fácies xisto verde esta no campo do basalto de arco (Figura 12.9) 


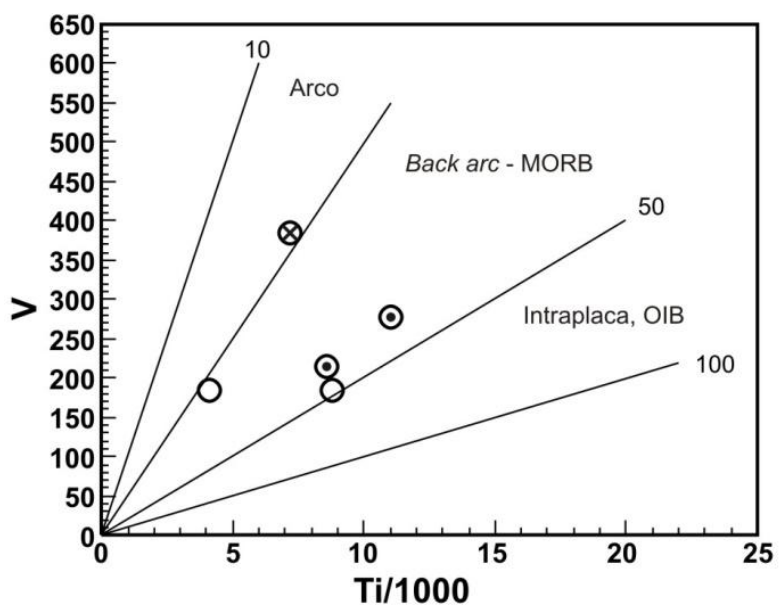

Metabasitos (FXA) $\otimes$ Metabasito (FXV) ○ Metabasitos (FXA - A)

Figura 12.9. Diagrama Ti vs $V$ de discriminação de ambiente tectônico de geração das rochas básicas (Shervais, 1982), indicando que os metabasitos da região de Jambaló correspondem rochas de Back ArcMORB com uma única amostra no campo dos basaltos de arco. FXA = rochas da fácies xisto azul; FXV = da fácies xisto verde e FXA - $A$ = da fácies xisto azul com alterações nos conteúdos de sódio e potássio.

No diagrama Hf-Th-Ta de discriminação de ambiente tectônico de geração de rochas básicas proposto por Wood (1980) as amostras distribuem-se em no campo dos E-MORB e basaltos tholeíticos intraplacas e mostram uma clara tendência evolutiva para os basaltos de arco (Figura 12.10), apesar de dispersões causadas pelo empobrecimento em Hf e/ou enriquecimento em Ta e Th de algumas amostras.

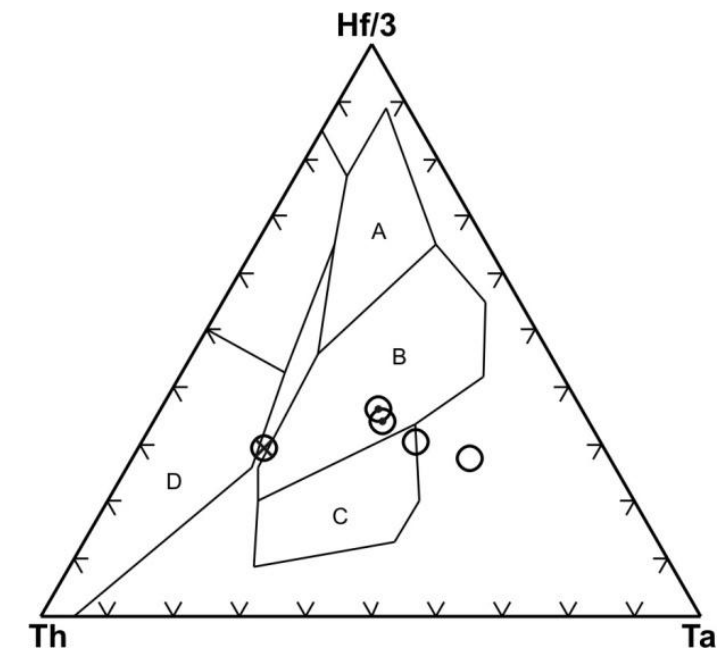

Metabasitos (FXA) $\otimes$ Metabasito (FXV) ○ Metabasitos (FXA - A)

Figura 12.10. Diagrama Hf-Th-Ta de discriminação de ambiente tectônico de geração de rochas básicas (Wood, 1980), no qual se observa a dispersão das análises feitas nos metabasitos da região de Jambaló, mas com tendência a se agruparem nos E-MORB e basaltos tholeiíticos intraplacas. $\boldsymbol{A}=N-M O R B, \boldsymbol{B}=E-$ MORB e basaltos tholeiíticos intraplacas, $\boldsymbol{C}=$ basaltos alcalinos intraplacas e $\boldsymbol{D}=$ basaltos de arco, $F X A=$ rochas da fácies xisto azul; $F X V=$ da fácies xisto verde e $F X A-A=$ da fácies xisto azul com alterações nos conteúdos de sódio e potássio.

As variações dos teores de Ti, $\mathrm{Zr}$ e $\mathrm{Y}$ relacionam-se com a fonte particular de geração do magma ou com a porcentagem de fusão parcial, fatores esses que têm relação com o ambiente tectônico de geração dos magmas, o que permite a distinção dos basaltos intraplaca dos de 
margens convergentes (Pearce, 1982; Pearce \& Norry 1979). No diagrama Zr vs Zr/Y de discriminação de ambiente tectônico de geração de rochas básicas de Pearce \& Norry (1979) as rochas metamórficas da região de Jambaló teriam sido formadas predominantemente em ambientes intraplaca, com gradações para arco de ilhas (Figura 12.11).

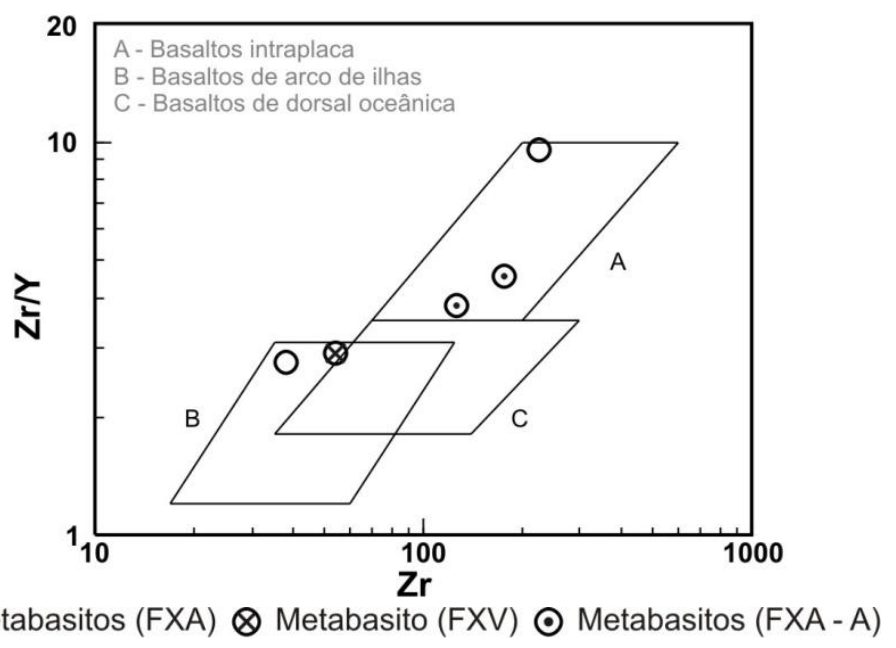

Figura 12.11. Diagrama $Z r$ vs $Z r / Y$ de discriminação de ambiente tectônico de geração de rochas básicas (Pearce \& Norry, 1979), no qual nota-se que os metabasitos analisados correspondem a basaltos de arco de ilhas e intraplaca. $F X A=$ rochas da fácies xisto azul; $F X V=$ da fácies xisto verde e $F X A-A=$ da fácies xisto azul com alterações nos conteúdos de sódio e potássio.

No diagrama de $\mathrm{Nb}-\mathrm{Zr}-\mathrm{Y}$ de Meschede (1986) as rochas plotam nos campos dos basaltos de arco vulcânico e, em menor proporção, no dos basaltos N-MORB com uma única amostra de metabasito da fácies xisto azul no campo do basalto alcalino intraplaca (Figura 12.12).

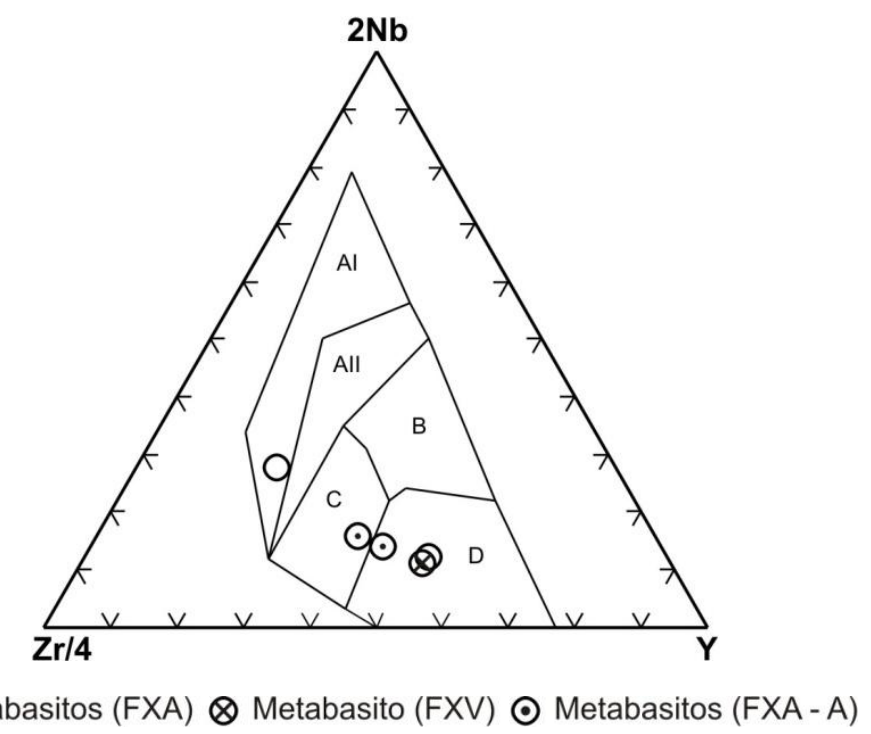

Figura 12.12. Diagrama $\mathrm{Nb}-Z \mathrm{r}-\mathrm{Y}$ de discriminação de ambiente tectônico de geração de rochas básicas (Meschede, 1986) com base no enriquecimento de $\mathrm{Nb}$ se pode observar que as amostras da região de Jambaló inserem-se no campo dos N-MORB com tendência ao campo dos tholeiitos intraplacas e/ou dos basaltos alcalinos intraplaca. $\boldsymbol{A}$,, $\boldsymbol{A l l}=$ campos dos basaltos alcalinos intraplaca; $\boldsymbol{A}$ II, $\boldsymbol{C}=$ campos dos tholeiitos intraplacas; $\boldsymbol{B}=$ campo dos $P$-MORB; $\boldsymbol{D}=$ campo dos $N$-MORB; $\boldsymbol{C}, \boldsymbol{D}=$ campos dos basaltos de arco vulcânico; $F X A=$ rochas da fácies xisto azul; $F X V=$ da fácies xisto verde e $F X A-A=a$ fácies xisto azul com alterações nos conteúdos de sódio e potássio.

No diagrama $\mathrm{Nb} / \mathrm{Yb}$ vs $\mathrm{Th} / \mathrm{Yb}$ (Figura 12.13A) sugerido por Pearce (2008), os metabasitos 
da região de Jambaló apresentam-se relativamente dispersas, com tendência a convergirem para o campo dos N-MORB, mas na área de interação magma-crosta. Somente uma das análises esta na área da série MORB-OIB próximo ao campo dos E-MORB. No diagrama $\mathrm{Nb} / \mathrm{Yb}$ vs $\mathrm{TiO}_{2} / \mathrm{Yb}$ (Figura 12.13B) de Pearce (2008), as análises apresentam-se no campo do N-MORB com tendência ao campo do E-MORB e com uma amostra de metabasito na fácies xisto verde situando-se nas proximidades do campo dos OIB. Estas dispersões podem ser o reflexo de vários fenômenos que tem relação com alterações hidrotermais nos conteúdos de sódio e potássio, assim como a variação do tipo de fácies metamórfica a qual pertence cada uma das amostras analisadas.

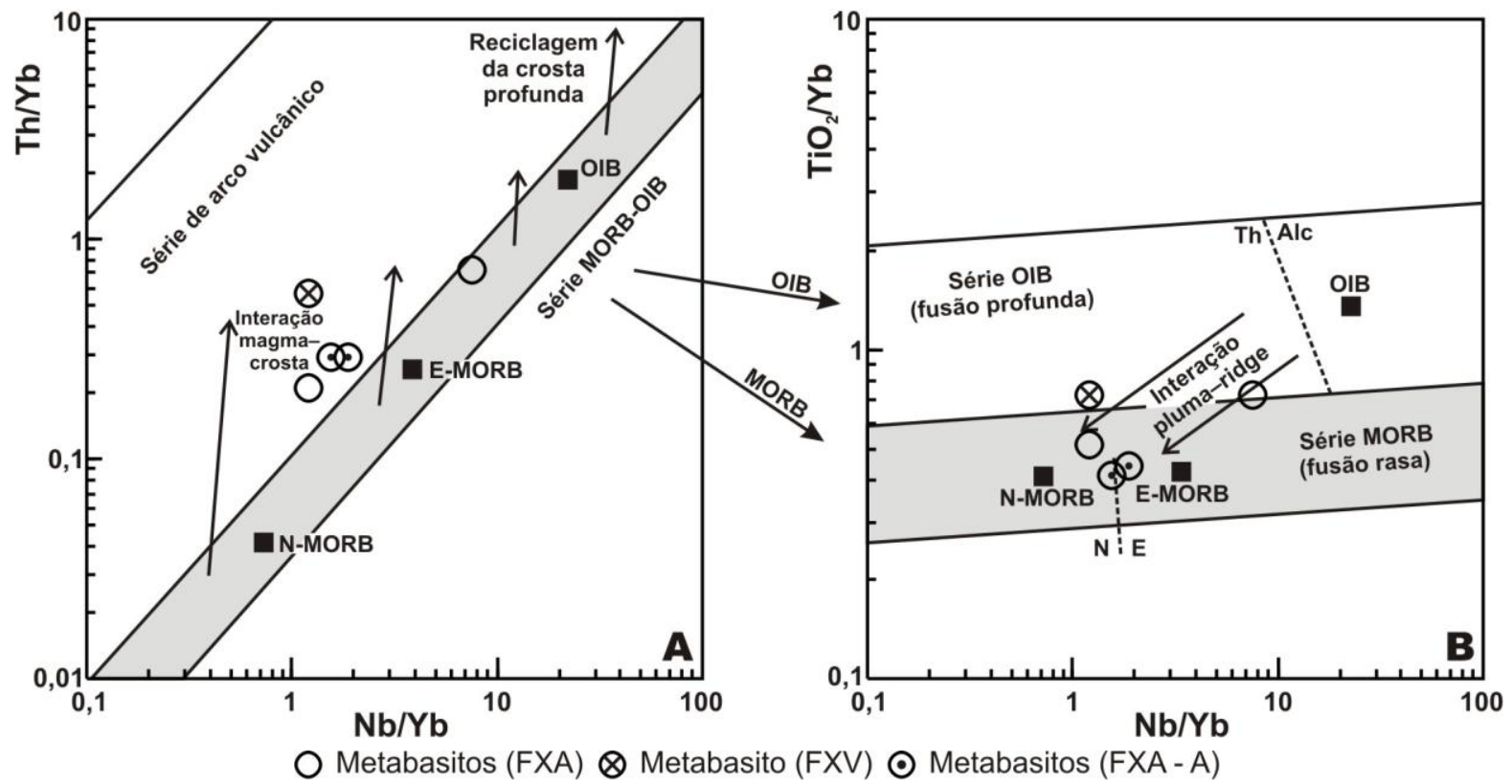

Figura 12.13. Diagramas $\mathrm{Nb} / \mathrm{Yb}$ vs $\mathrm{Th} / \mathrm{Yb}$ (A) e $\mathrm{Nb} / \mathrm{Yb}$ vs $\mathrm{TiO}_{2} / \mathrm{Yb}$ (B) segundo Pearce (2008) no qual apresentam-se as amostras metabásicas da região de Jambaló no campo da série MORB-OIB. Nota-se que no diagrama $\mathrm{Nb} / \mathrm{Yb}$ vs $\mathrm{Th} / \mathrm{Yb}$ as análises distribuem-se no campo da interação magma-crosta e no diagrama $\mathrm{Nb} / \mathrm{Yb}$ vs $\mathrm{TiO}_{2} / \mathrm{Yb}$ as análises situam-se no campo da série dos MORB, com um par de pontos que estão no campo dos OIB. FXA = rochas da fácies xisto azul; $F X V=$ da fácies xisto verde e $F X A-A=$ da fácies xisto azul com alterações nos conteúdos de sódio e potássio.

No diagrama Y-La-Nb de Cabani \& Lacolle (1989), observa-se que as rochas têm composições compatíveis com basaltos de margens convergentes (Figura 12.14), o que é coerente com a formação em arcos de ilhas, como discutido anteriormente, com tendência de variação de basaltos cálcio-alcalinos para basaltos tholeiíticos. Neste diagrama observa-se um comportamento distinto ao obtido com os outros diagramas de discriminação de basaltos, mesmo assim, a tendência geral das rochas basálticas da região de Jambaló, continua na evolução de rochas de tipo E-MORB para N-MORB. 


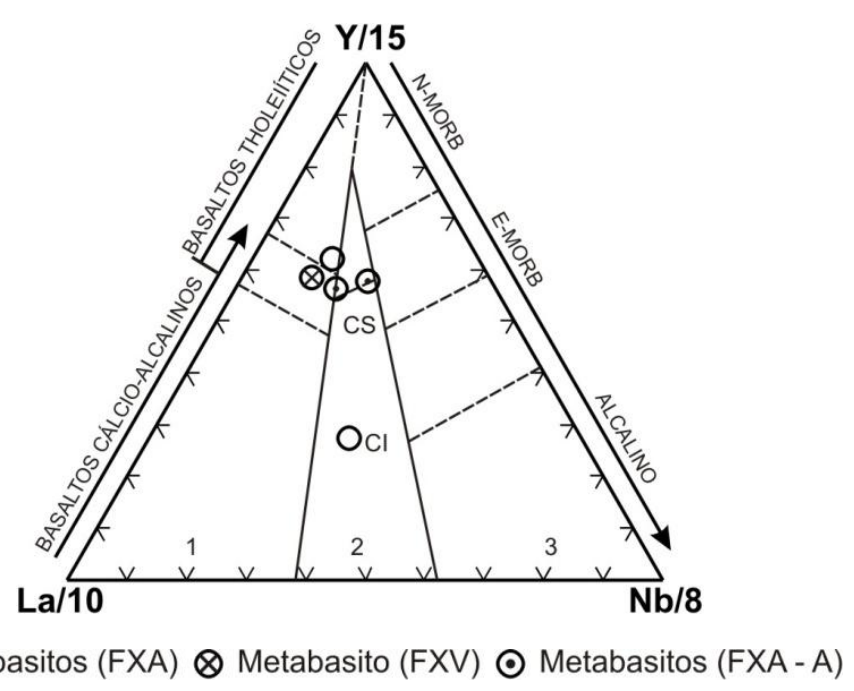

Figura 12.14. No diagrama $Y-L a-N b$ de discriminação de basaltos em ambientes extensionais e compresionais (Cabani \& Lacolle, 1989) aplicado aos metabasitos da região de Jambaló, nota-se que as análises têm tendência de agrupamento no campo dos basaltos tholeiíticos e de E-MORB, com uma amostra no campo da crosta inferior e dos basaltos cálcio-alcalinos. 1 = basaltos de margens convergentes, 2 = magmas não diferenciáveis, mas com possíveis tendências de contaminação, $\mathbf{3}=$ magmas formados em ambientes extensionais, $\mathbf{C l}=$ crosta inferior; $\boldsymbol{C S}=$ crosta superior; $F X A=$ rochas da fácies xisto azul; $F X V=$ da fácies xisto verde e FXA - $A=$ da fácies xisto azul com alterações nos conteúdos de sódio e potássio.

Nos diagramas multi-elementares dos metabasitos e meta-intermediárias da região de Jambaló (Figura 12.15) observam-se variações principalmente nos valores de $\mathrm{Rb}$, Th e $\mathrm{U}$ para os metabasitos, sendo que os da fácies xisto azul sem alteração nos conteúdos de $\mathrm{Na}$ e $\mathrm{K}$ apresentam anomalias negativas de $\mathrm{Ba}, \mathrm{Nb}$ e $\mathrm{Zr}$. As meta-intermediárias tem padrões semelhantes aos dos metabasitos, sugerindo afinidade genética. Um dos metabasitos distingue-se dos demais, com características de MORB.

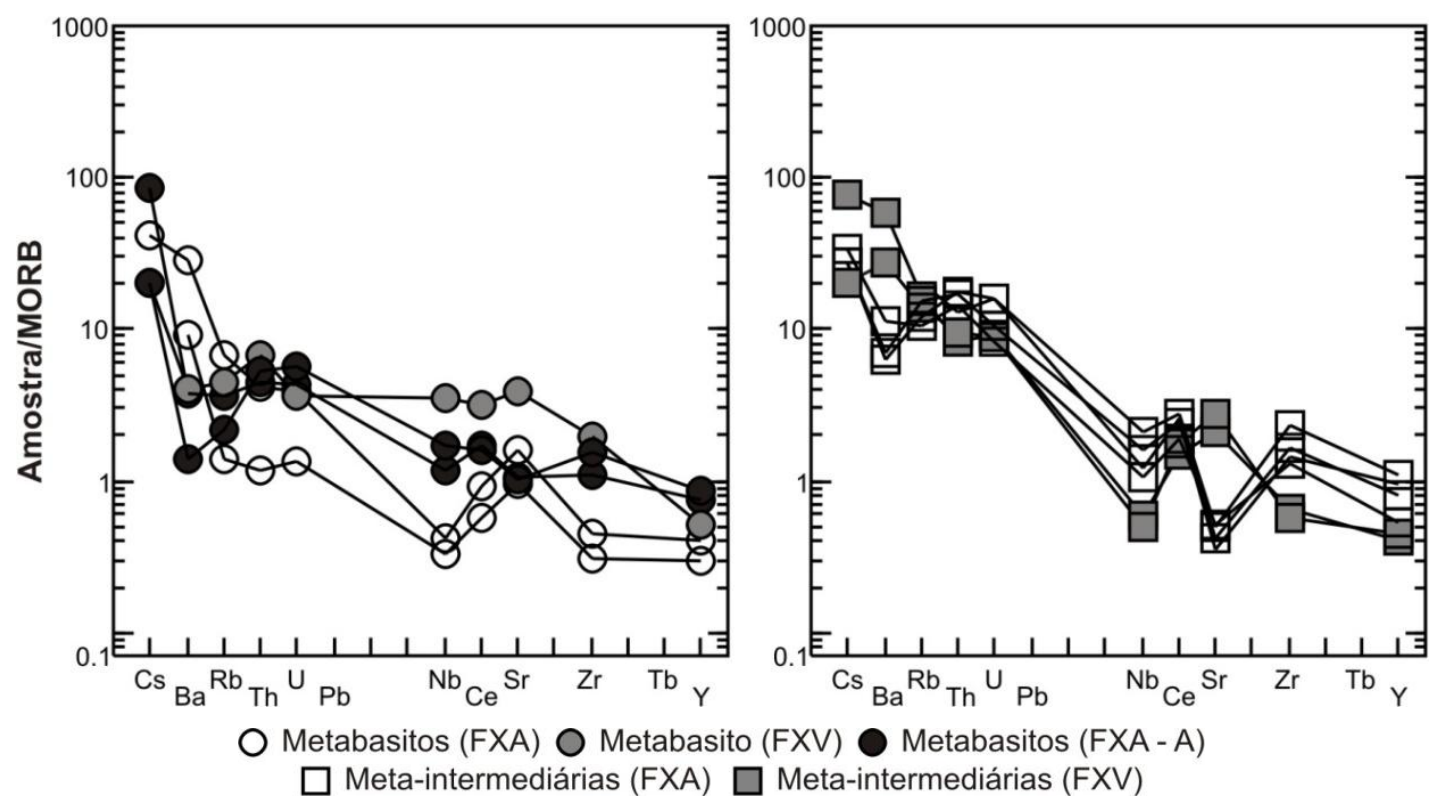

Figura 12.15. Padrões multi-elementos dos metabasitos e das meta-intermediárias da região de Jambaló. $F X A=$ rochas da fácies xisto azul; $F X V=$ da fácies xisto verde e $F X A-A=$ da fácies xisto azul com alterações nos conteúdos de sódio e potássio.

Os padrões das terras raras em relação ao condrito, E-MORB e N-MORB (Figura 12.16) de 
Sun \& McDonough (1989) mostram enriquecimentos de 5 a 70 vezes, com distribuição variando de pouco fracionamento das terras raras leves e pesadas, até com enriquecimentos em terras raras leves, indicativas de processos de diferenciação magmática. Notam-se também anomalias positivas de Eu, em especial nas rochas menos diferenciadas, indicando concentração de plagioclásio na formação dos andesitos basálticos e dos andesitos e, a quase ausência de anomalias levemente positivas de $\mathrm{Ce}$, sugerindo, ao contrário do observado na região de Barragán, menor interação fluido oceânico-rocha, o que pode ser indicativo de formação em ambiente subaéreo.
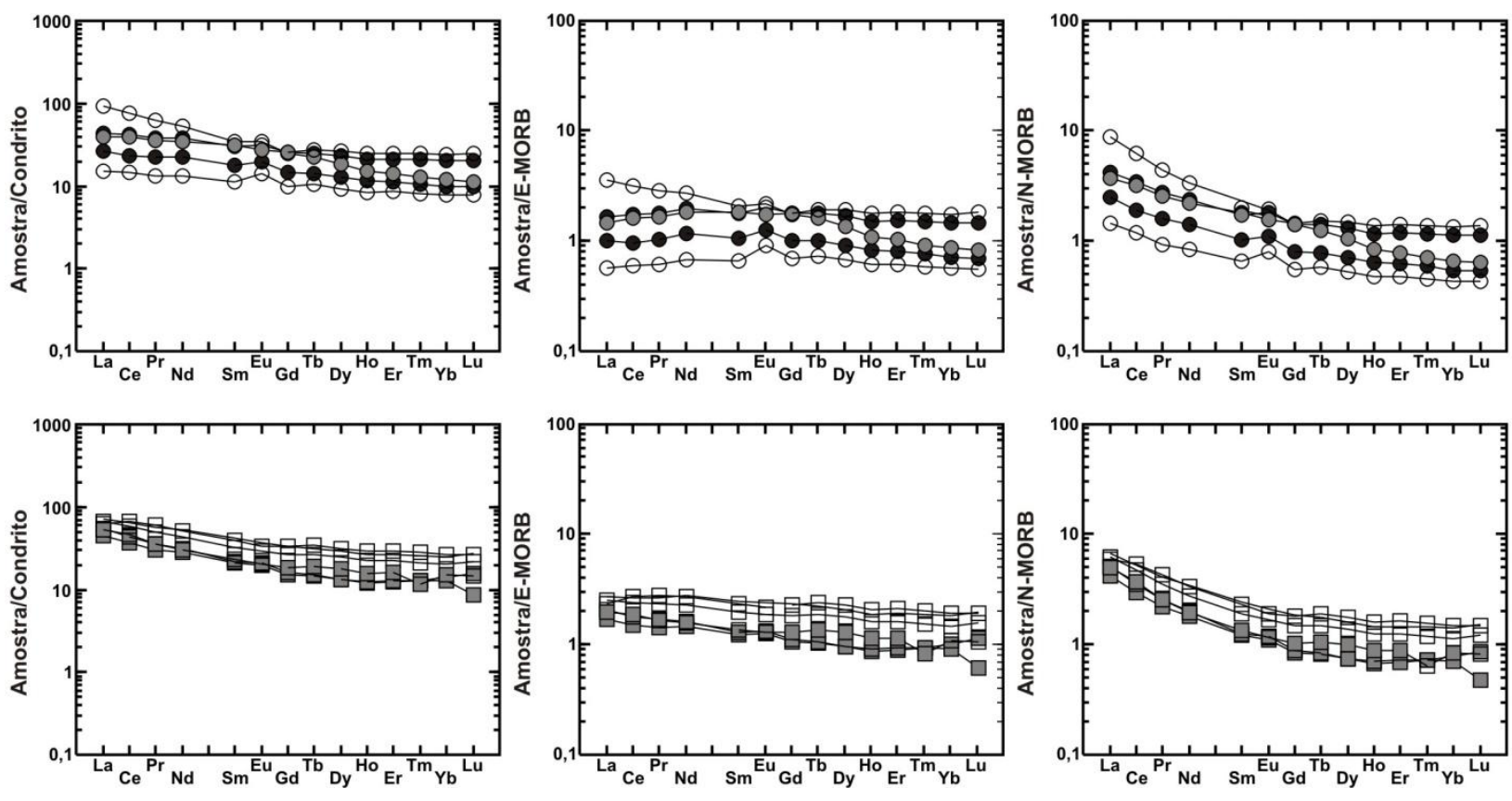

Metabasitos (FXA) $\bigcirc$ Metabasito (FXV) $\bigcirc$ Metabasitos (FXA - A)

$\square$ Meta-intermediárias (FXA) $\square$ Meta-intermediárias (FXV)

Figura 12.16. Padrões de elementos terras raras das amostras da região de Jambaló normalizados ao condrito (esquerda), E-MORB (centro) e N-MORB (direita). FXA = rochas da fácies xisto azul; $F X V=$ da fácies xisto verde e $F X A-A=$ da fácies xisto azul com alterações nos conteúdos de sódio e potássio.

Mesmo com a pouca quantidade de análises da região de Jambaló, pode-se sugerir que o conjunto das rochas corresponde a uma seqüência metavulcânica com metabasitos e metaintermediárias formadas a em ambiente orogênicos, com algumas rochas ainda com características de N-MORB, indicando que subducção deve ter sido ensimática, chegando gerar andesitos em arcos de ilhas. As dispersões químicas de diversos elementos são também sugestivas de alterações hidrotermais, potencialmente relacionadas predominantemente ao cisalhamento que gerou os xistos verdes, durante a exumação dos xistos azuis. 


\section{GEOQUÍMICA DA REGIÃO DE BARRAGÁN}

Da região de Barragán, foram analisadas 11 amostras de metabasitos, cinco (5) das quais da fácies anfibolito e seis (6) da fácies xisto azul. Tal qual verificado em Jambaló, as texturas e mineralogia dos protolitos foram totalmente substituídas pelas metamórficas, dificultando a identificação das rochas originais. As análises completas de geoquímica estão disponíveis no Anexo VI.

No diagrama de Miyashiro (1975), que discrimina as amostras que sofreram alterações nos conteúdos de sódio e potássio (Figura 13.1A), nota-se que somente um dos metabasitos da fácies anfibolito pode ser considerado como sofreu alterações hidrotermais de fundo oceânico (espilitização) ou sin-metamórfica, mas há uma tendência evolutiva o conjunto das amostras que sugere alterações mais fracas em pelo menos outras duas amostras.

No diagrama de Pearce (1982), modificado por Juliani \& McReath (1993), nota-se que todas as amostras têm composição compatível com líquidos basálticos de diversos ambientes tectônicos modernos (Figura 13.1B).

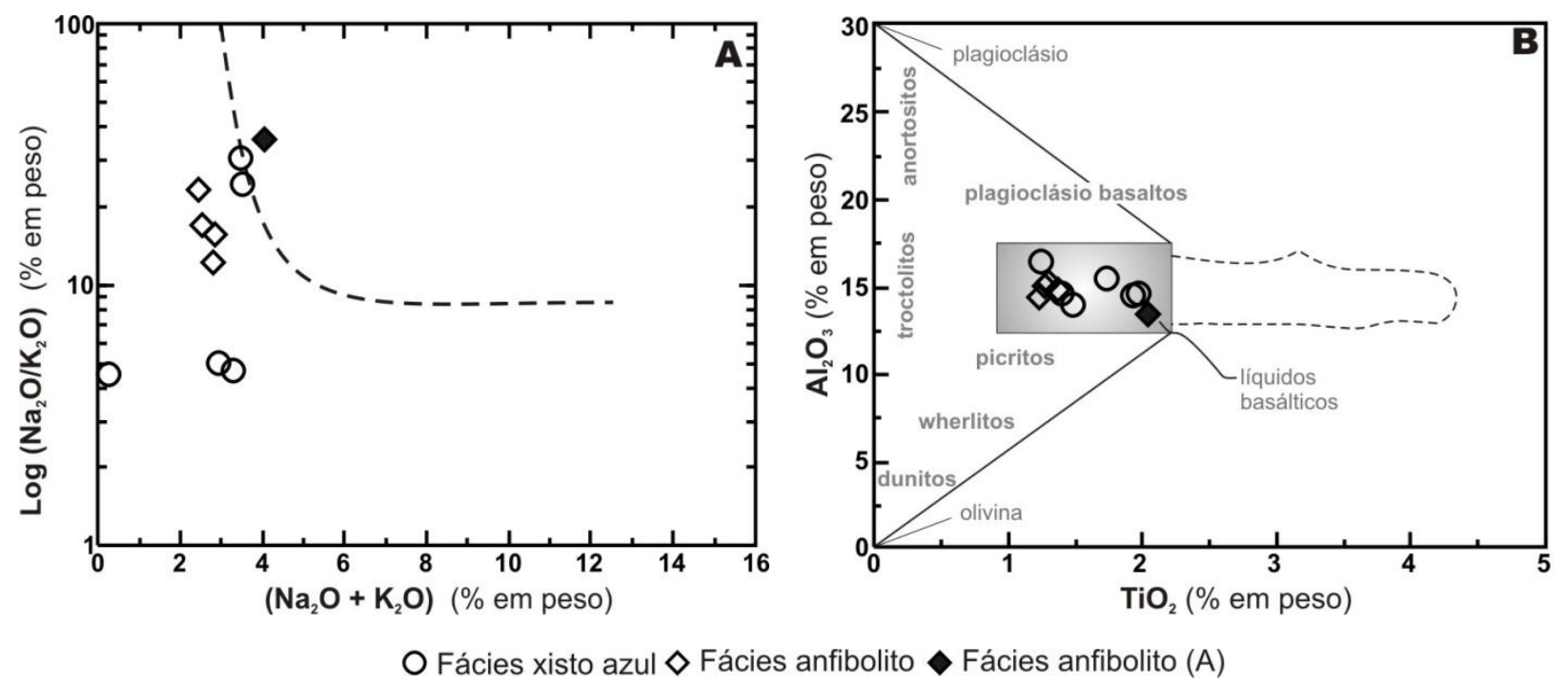

Figura 13.1. Diagrama indicativo de alterações nos conteúdos de sódio e potássio (A), acima acima da curva tracejada (Miyashiro 1975) e de composições compatíveis com líquidos basálticos (B), segundo Pearce (1982), modificado por Juliani \& McReath (1993). O losango preenchido corresponde à rocha que sofreu aumento nos teores de álcalis.

Quando as análises são plotadas no diagrama TAS (total alcalis vs silica), segundo LeMaitre et al. (2002), nota-se que as rochas da fácies xisto azul e da fácies anfibolito da região de Barragán correspondem a basaltos (Figura 13.2) e são subalcalinas, segundo a divisão de Irvine \& Baragar (1971). 


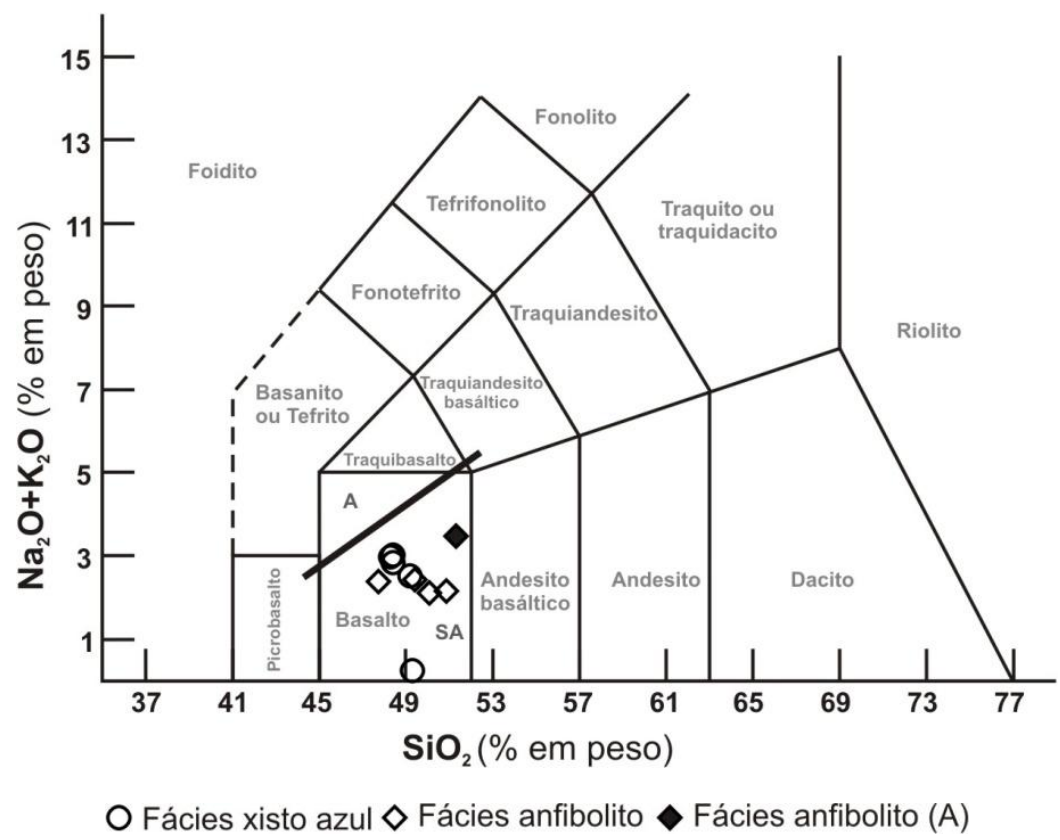

Figura 13.2. Diagrama TAS (total álcalis vs sílica), segundo LeMaitre et al. (2002), para as rochas da região de Barragán, classificadas como basaltos subalcalinos (SA), segundo Irvine \& Baragar (1971). (A) refere-se à amostra da fácies anfibolito com alterações nos conteúdos de sódio e potássio.

Os dados obtidos sugerem que as variações observadas em diversos elementos químicos não são apenas produto de diferenciação magmática, mas também são produto de lixiviação, concentração residual ou metassomatismo durante os eventos metamórficos, como pode ser observado na Figura 13.3, que relaciona o $\mathrm{Zr}$ com Ba, $\mathrm{Sr}, \mathrm{K}_{2} \mathrm{O}$ e $\mathrm{CaO}$.
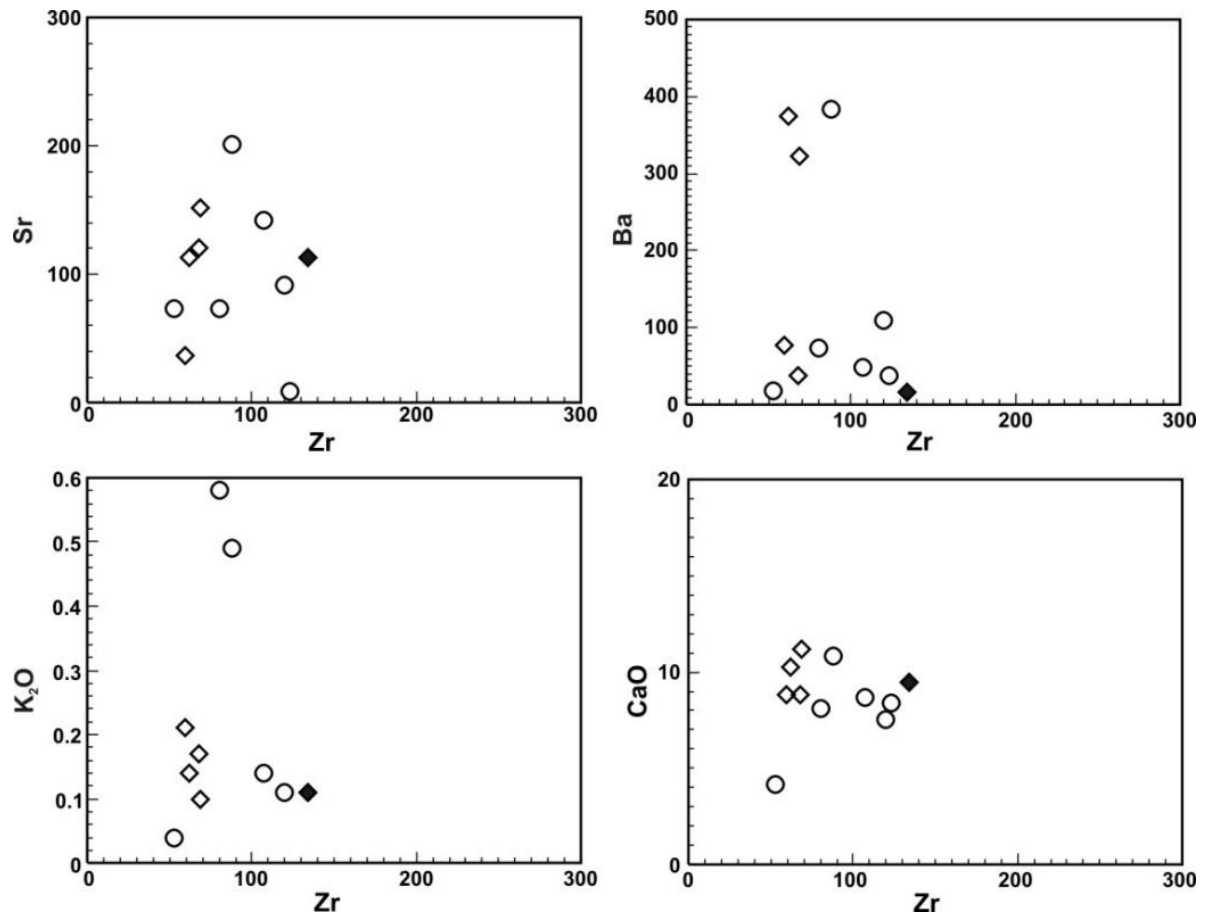

O Fácies xisto azul $\diamond$ Fácies anfibolito $\diamond$ Fácies anfibolito $(A)$

Figura 13.3. Diagramas de comparação de $\mathrm{Zr}$ vs $\mathrm{Ba}$; $\mathrm{Sr} ; \mathrm{K}_{2} \mathrm{O}$ e $\mathrm{CaO}$, mostrando o comportamento dos elementos móveis e sugerindo diversos processos geológicos que afetaram a mobilidade destes. 
Nos diagramas da Figura 13.4 (\#Mg vs óxidos) é possível observar uma correlação

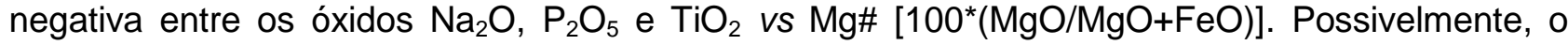
enriquecimento de $\mathrm{Na}_{2} \mathrm{O}$ deve-se a um evento pós-magmático, possivelmente uma espilitização. $\mathrm{A}$ correlação negativa entre o $\mathrm{CaO}$ e $\mathrm{Mg \#} \mathrm{nas} \mathrm{amostras} \mathrm{da} \mathrm{fácies} \mathrm{xisto} \mathrm{azul} \mathrm{pode} \mathrm{indicar} \mathrm{que,}$ possivelmente, existiu uma co-precipitação de plagioclásio cálcico e minerais ferro-magnesianos, entretanto a correlação negativa pode indicar que o controle da composição do líquido residual foi feito apenas pela precipitação de minerais ferro-magnesianos. Também se notam as correlações negativas apresentadas na comparação do \#Mg com o restante dos óxidos, com exceção do $\mathrm{Al}_{2} \mathrm{O}_{3}$ e o $\mathrm{MnO}$, que apresentam uma correlação linear a levemente positiva. $\mathrm{O} \mathrm{K}_{2} \mathrm{O}$ por sua vez, apresenta-se muito disperso e não parece definir nenhum padrão de correlação, indicando a ação de alterações hidrotermais na geração da rocha.

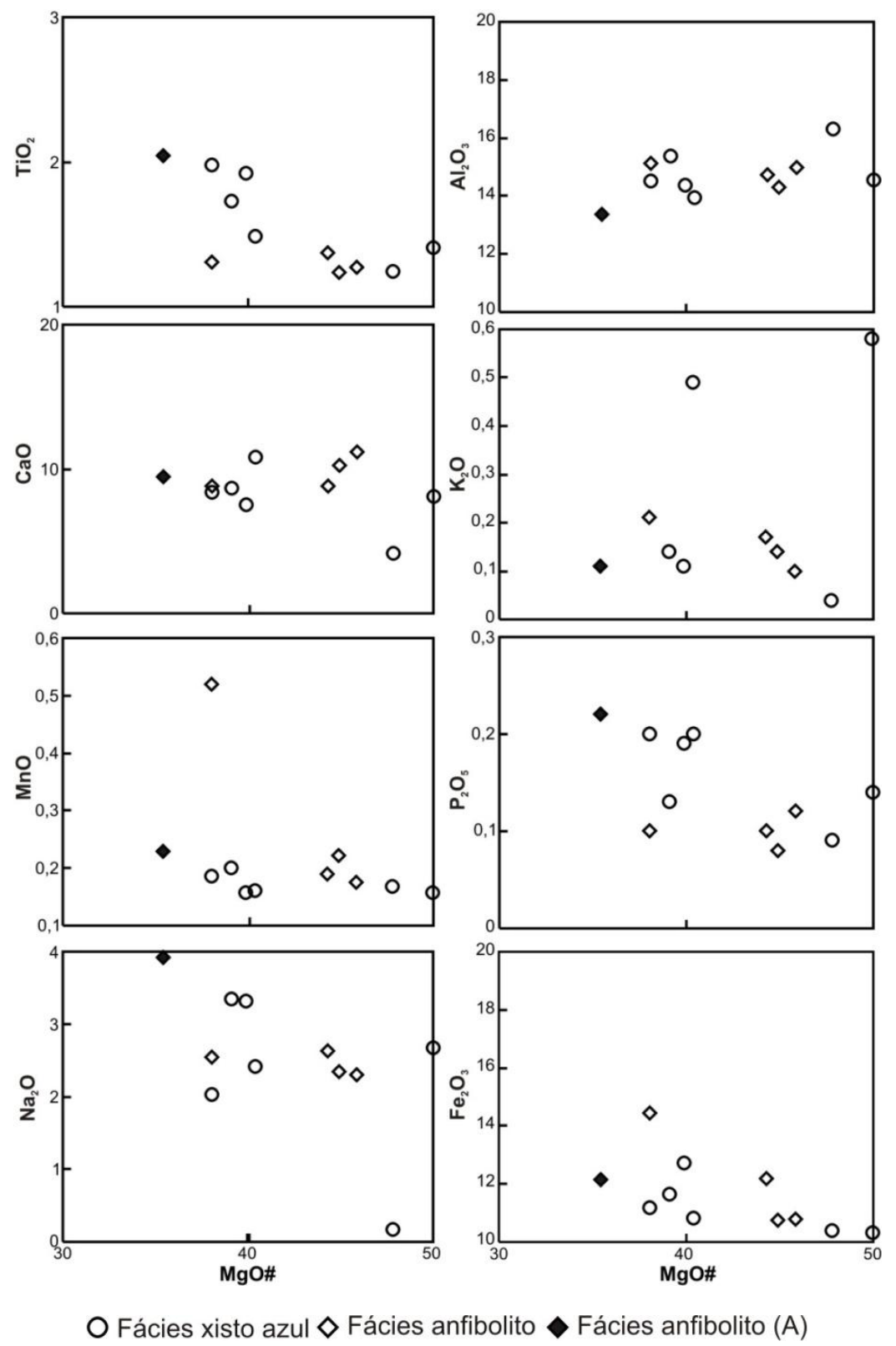

Figura 13.4. Comparação do \#Mg [100*(MgO/MgO+FeO)] com outros óxidos, apresentando uma correlação negativa com $\mathrm{TiO}_{2}, \mathrm{CaO}, \mathrm{K}_{2} \mathrm{O}$ e $\mathrm{P}_{2} \mathrm{O}_{5}$, e positiva com $\mathrm{Al}_{2} \mathrm{O}_{3}$ e o $\mathrm{Na}_{2} \mathrm{O}$ e ausente com $\mathrm{MnO}$ e $\mathrm{Fe}_{2} \mathrm{O}_{3}$. 
Nota-se, entretanto, que $\circ \mathrm{Mg}$, quando comparado com $\circ \mathrm{Zr}$, mostra uma correlação negativa, com dispersão relativamente pequena, sugerindo que seu teor não foi afetado pelas alterações hidrotermais, podendo então ser esse comportamento produto de diferenciação magmática (Figura 13.5). O mesmo pode se observado em relação ao $\mathrm{Ni}$ e ao $\mathrm{Cr}$, cujos teores apresentam uma correlação positiva com o Mg (Figura 13.5). O V e o Co apresentam uma correlação negativa e o Sc e o Zn mostram-se levemente negativos, enquanto o $\mathrm{Cu}$ apresenta uma correlação negativa. Estas correlações junto às dispersões das análises observadas em vários dos diagramas da Figura 13.5 sugerem que o conjunto de rochas tenha sido afetado por alterações hidrotermais assim como processos de diferenciação magmática.

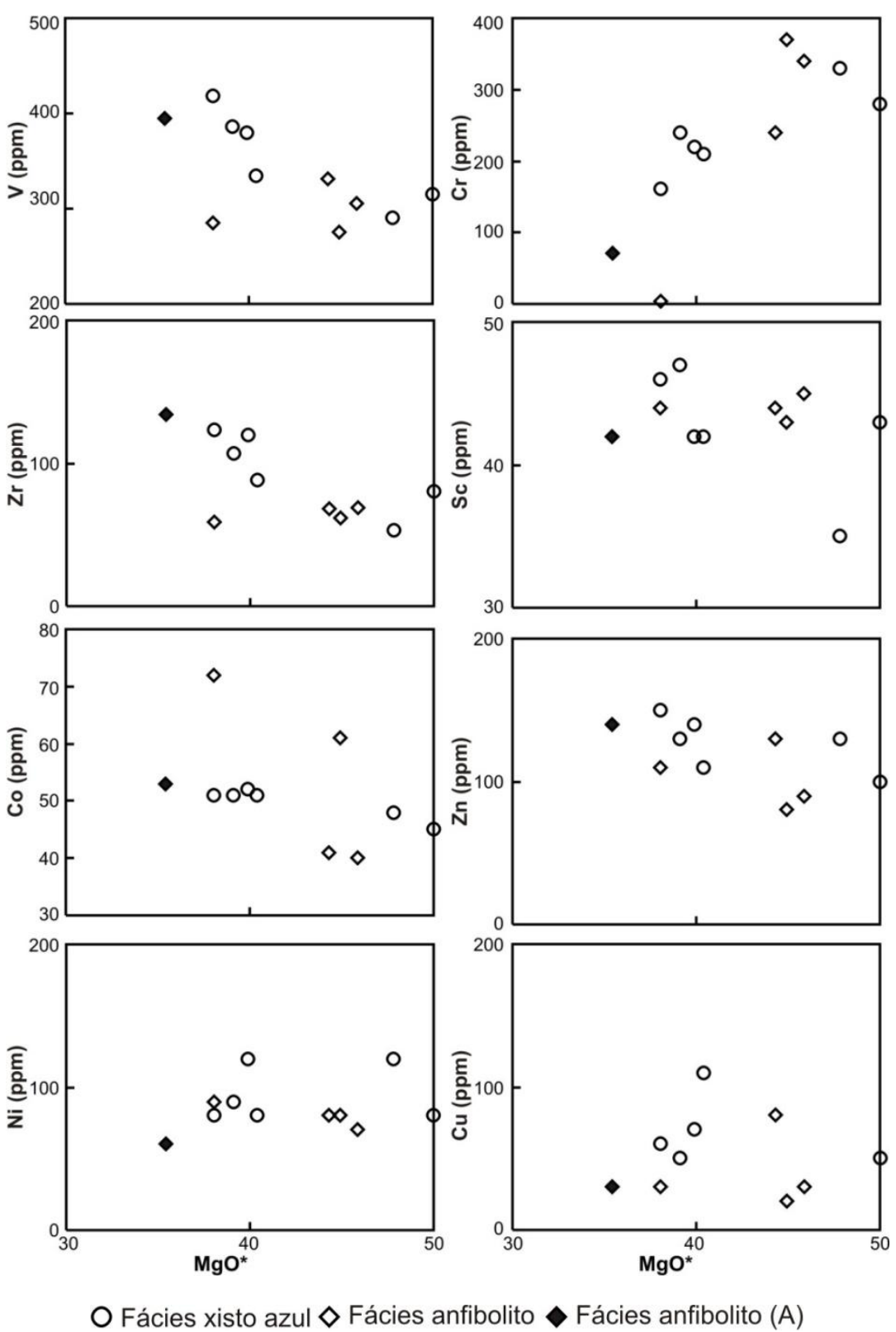

Figura 13.5. Comparação do \#Mg [100* $(\mathrm{MgO} / \mathrm{MgO}+\mathrm{FeO})]$ com outros elementos apresentando correlação negativa com todos os elementos ( $\mathrm{Zr}, \mathrm{Ni}, \mathrm{Cr}, \mathrm{V}, \mathrm{Sc}, \mathrm{Co}$ e $\mathrm{Zn}$ ) com exceção do Cu que mostra-se em correlação positiva com o \#Mg.

No diagrama $\mathrm{FeO}, \mathrm{Na}_{2} \mathrm{O}+\mathrm{K}_{2} \mathrm{O}$ e $\mathrm{MgO}$ que separa as tendências cálcio-alcalinas e tholeiíticas 
(Irvine \& Baragar, 1971) nota-se que todos os metabasitos da fácies xisto azul distribuem-se no campo da série tholeiítica (Figura 13.6).

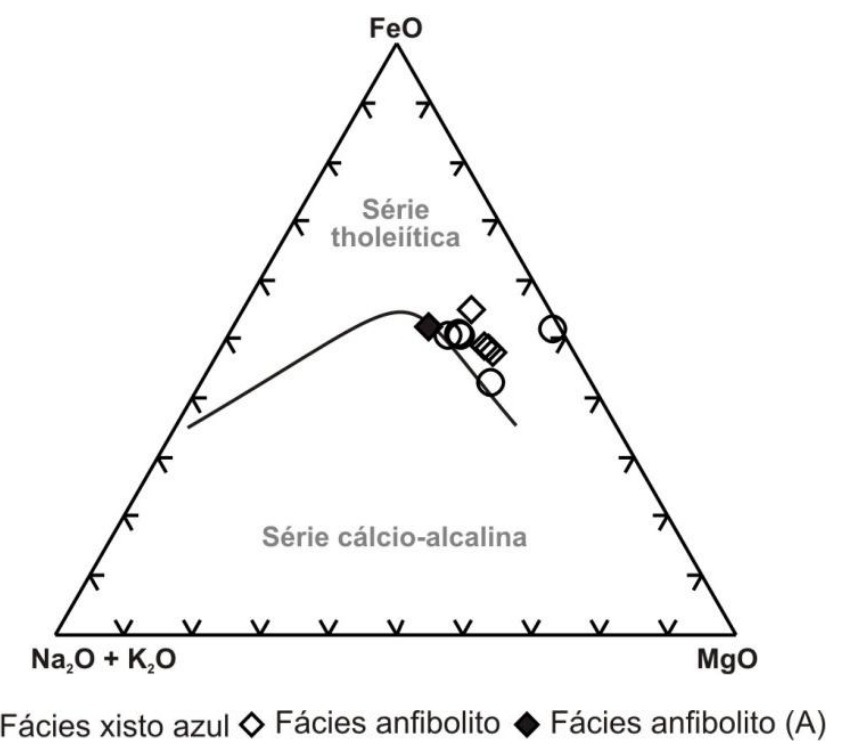

Figura 13.6. Diagrama $\mathrm{FeO}, \mathrm{Na}_{2} \mathrm{O}+\mathrm{K}_{2} \mathrm{O}$ e $\mathrm{MgO}$ segundo Irvine \& Baragar (1971) que distingue as tendências cálcio-alcalinas e tholeíticas. No diagrama todas as análises correspondem ao campo da série. No diagrama a fácies anfibolito (A) refere-se à amostra com alterações nos conteúdos de sódio e potássio.

Essas rochas, quando classificadas no digrama $\mathrm{Nb} / \mathrm{Y}$ vs $\mathrm{Zr} / \mathrm{TiO}_{2}$ de Winchester \& Floyd (1977), são identificadas como basaltos transicionais entre os subalcalinos e os andesitos basálticos (Figura 13.7). Entretanto destaca-se que os anfibolitos têm a razão $\mathrm{Nb} / \mathrm{Y}$ menor que as rochas da fácies xisto azul, sugerindo que pode ter havido mobilidade relativa de $\mathrm{Y}$ ou Nb durante o evento metamórfico.

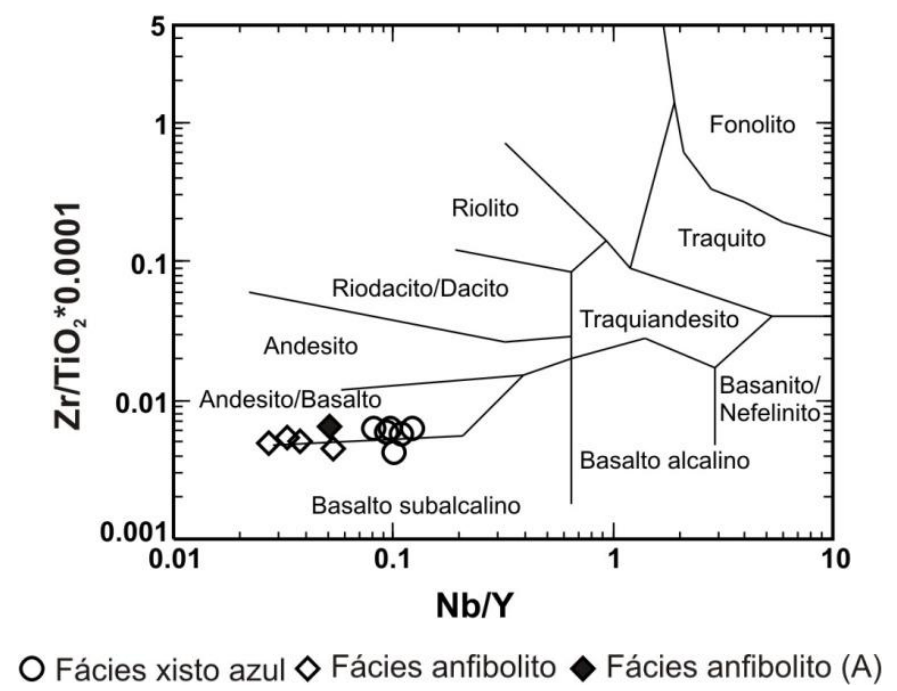

Figura 13.7. Classificação das rochas metabásicas de Barragán, segundo a proposta de Winchester \& Floyd (1977), onde se destaca o agrupamento diferenciado das rochas das fácies anfibolito e xisto azul, e sua composição transicional entre basaltos subalcalinos e andesito basáltico. No diagrama a fácies anfibolito $(A)$ refere-se à amostra com alterações nos conteúdos de sódio e potássio. 
Mediante o uso do diagrama Ti vs $\mathrm{V}$ de discriminação de ambiente tectônico de Shervais (1982) os metabasitos de Barragán mostram afinidade com basaltos formados em back-arc ou MORB (Figura 13.8).

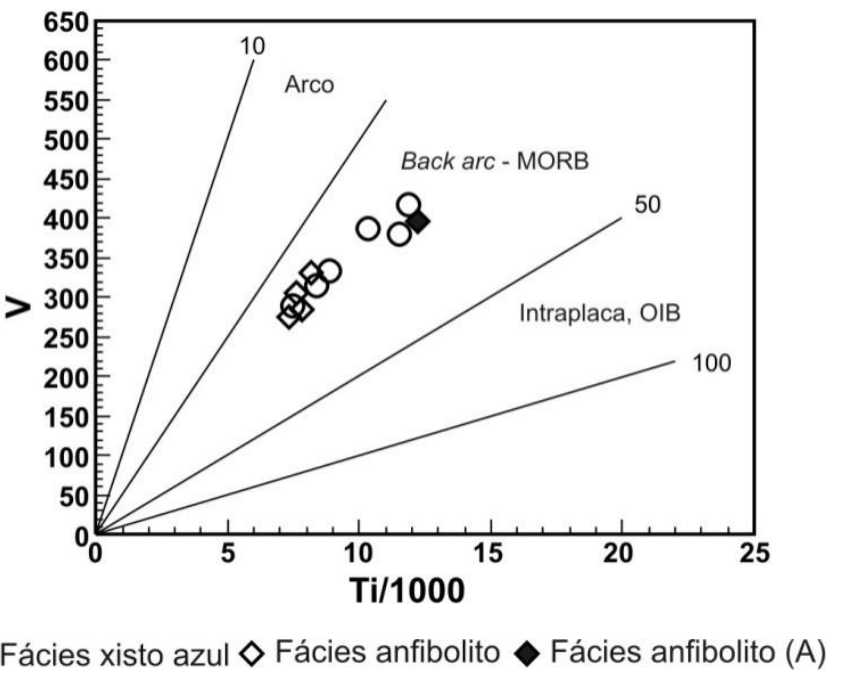

Figura 13.8. Diagrama Ti vs $V$ de discriminação de ambiente tectônico de geração das rochas básicas (Shervais, 1982), indicando que os metabasitos de Barragán têm composições semelhantes a basaltos formados em MORB ou em bacias de back arc. No diagrama a fácies anfibolito (A) refere-se à amostra com alterações nos conteúdos de sódio e potássio.

No diagrama Hf-Th-Ta (Figura 13.9) proposto por Wood (1980) as amostras pertencentes à fácies xisto azul agrupam-se no campo dos basaltos E-MORB ou dos tholeiíticos intraplacas, mas a maioria das rochas da fácies anfibolito mostram fortes variações nos teores de $\mathrm{Hf}$ e $\mathrm{Ta}$ (Figura 13.9), sugerindo forte mobilidade desses elementos, possivelmente durante 0 desenvolvimento da zona de cisalhamento que resultou no retrometamorfismo dos xistos azuis para as rochas da fácies anfibolito.

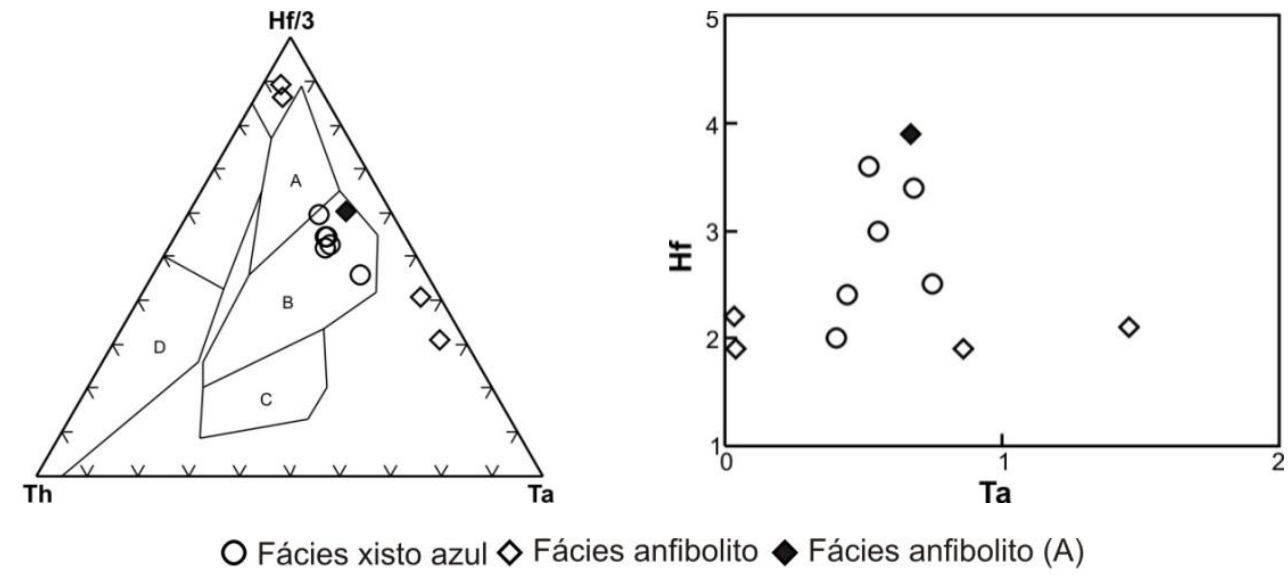

Figura 13.9. Diagrama Hf-Th-Ta (esquerda) de discriminação de ambiente tectônico de geração de rochas básicas (Wood, 1980), mostrando que os metabasitos de Barragán podem ter sido formados em ambientes de E-MORB ou tholeiito intraplaca, mas também nota-se que há uma dispersão muito forte das análises da das rochas na fácies anfibolito. No diagrama Hf vs Ta observa-se dispersão das análises das amostras da fácies anfibolito, enquanto as amostras da fácies xisto azul apresentam uma correlação positiva. Nos diagramas: $\boldsymbol{A}=N-M O R B, \boldsymbol{B}=E-M O R B$ e basaltos tholeiíticos intraplacas, $\boldsymbol{C}=$ basaltos alcalinos intraplacas e $\boldsymbol{D}=$ basaltos de arco e a fácies anfibolito $(A)$ refere-se à amostra com alterações nos conteúdos de sódio e potássio. 
Os teores de $\mathrm{Ti}, \mathrm{Y}$ e $\mathrm{Zr}$ têm relação com a fonte de geração magmática ou com a porcentagem de fusão parcial, o que pode ser relacionado com o ambiente tectônico de geração dos magmas basálticos, permitindo a distinção entre os de intraplaca e os de margens convergentes (Pearce \& Norry 1979; Pearce, 1982). No diagrama Zr vs Zr/Y (Figura 13.10) proposto por Pearce \& Norry (1979), observa-se que os protolitos das rochas metamórficas da fácies xisto azul e anfibolito da região de Barragán correspondem a basaltos formados em dorsais oceânicas, mas também plotam no campo dos basaltos de arco de ilhas. Em especial, nota-se novamente que as rochas da fácies anfibolito apresentam uma maior dispersão, possivelmente devida às alterações hidrotermais/metassomáticas associadas ao cisalhamento.

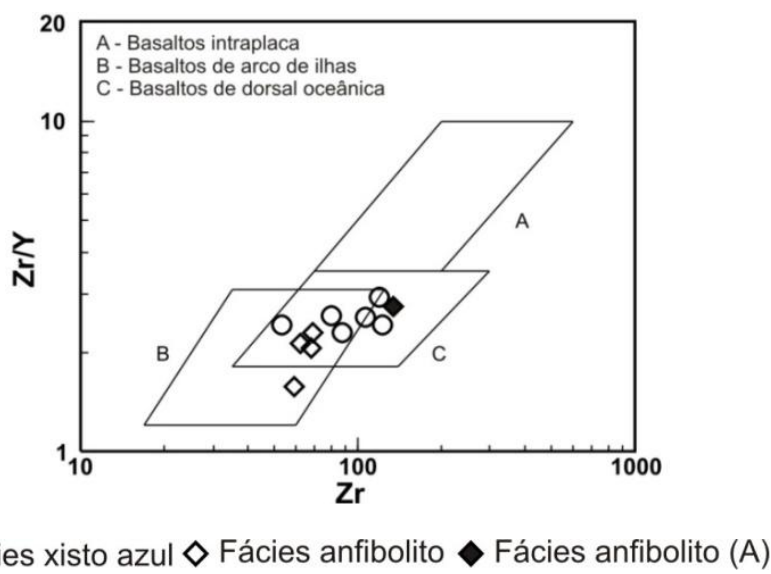

Figura 13.10. Diagramas $\mathrm{Zr}$ vs $\mathrm{Zr} / \mathrm{Y}$ de discriminação de ambiente tectônico de geração de rochas basálticas (Pearce \& Norry, 1979), indicando que os protolitos das rochas da região de Barragán foram possivelmente geradas em ambientes de dorsal oceânica (MORB). No diagrama a fácies anfibolito (A) refere-se à amostra com alterações nos conteúdos de sódio e potássio.

Quando usado o diagrama Nb-Zr-Y (Figura 13.11) proposto por Meschede (1986), as amostras da região de Barragán correspondem a N-MORB, mas que também podem ser de arco vulcânico.

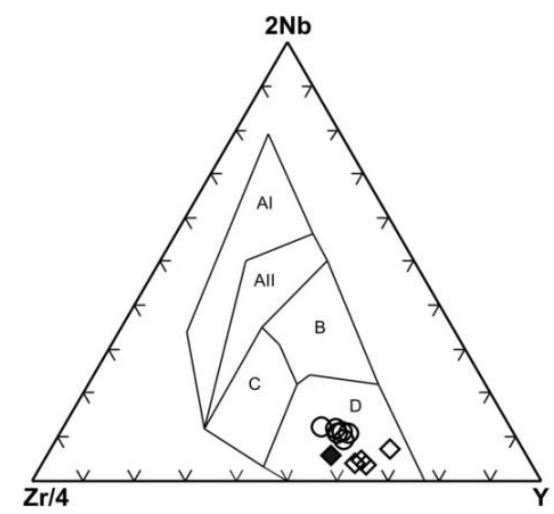

O Fácies xisto azul $\diamond$ Fácies anfibolito $\diamond$ Fácies anfibolito $(\mathrm{A})$

Figura 13.11. Diagrama $\mathrm{Nb}-\mathrm{Zr}-\mathrm{Y}$ de discriminação de ambiente tectônico de geração de rochas basálticas (Meschede, 1986) com base no enriquecimento de $\mathrm{Nb}$, no qual se observa que as análises da região de Barragán entram no campo dos N-MORB. No diagrama, Al, All = campos dos basaltos alcalinos intraplaca; $\boldsymbol{A l l}, \boldsymbol{C}=$ campos dos tholeiitos intraplacas; $\boldsymbol{B}=$ campo dos $P-M O R B ; \boldsymbol{D}=$ campo dos $N$-MORB; $\boldsymbol{C}, \boldsymbol{D}=$ campos dos basaltos de arco vulcânico e, fácies anfibolito $(A)$ refere-se à amostra com alterações nos conteúdos de sódio e potássio. 
No diagrama Y-La-Nb discriminam-se basaltos gerados em ambientes extensionais e compresionais (Cabani \& Lacolle, 1989) e nele pode-se observar que as rochas de Barragán distribuem-se entre os campos dos basaltos formados em ambientes extensionais e de margens. Entretanto, as rochas da fácies xisto azul mostram um tendência em direção ao campo dos basaltos de zonas extensionais, enquanto que os da fácies anfibolito são mais enriquecidos em $Y$ e em La, o que aproxima mais sua composição dos basaltos formados em margens convergentes (Figura 13.12). Esse comportamento, em especial pelo enriquecimento em La, pode ser atribuído às alterações hidrotermais durante o cisalhamento. Para os xistos azuis, a tendência de formação em N-MORB é mais favorecida, e as rochas da fácies anfibolito podem, alternativamente, ter se formado em níveis crustais mais rasos que os xistos azuis.

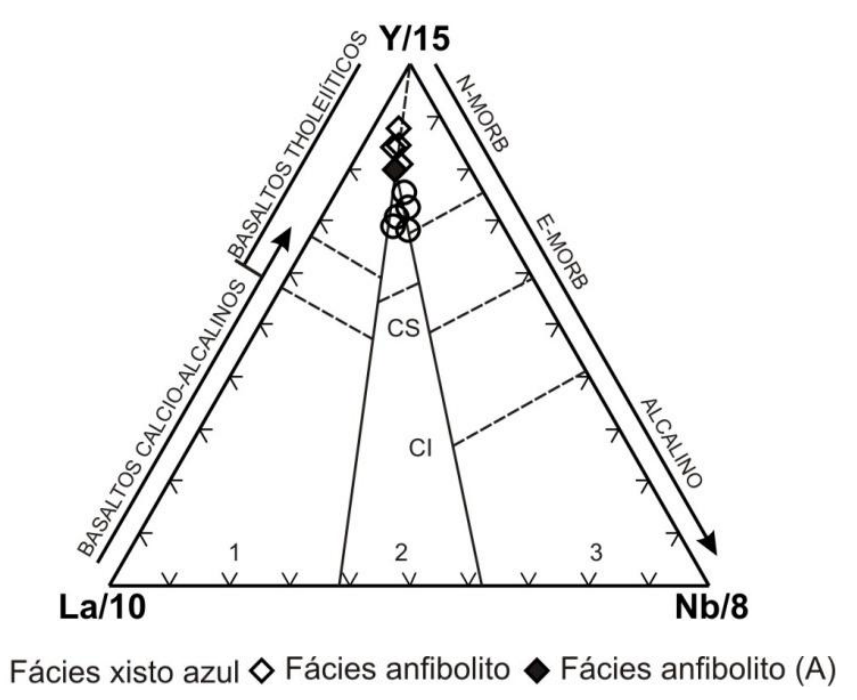

Figura 13.12. Diagrama $Y-L a-N b$ de discriminação de basaltos em ambientes extensionais e compresionais (Cabani \& Lacolle, 1989), no qual se pode observar que as análises das rochas da fácies anfibolito estão mais perto da área dos basaltos tholeiíticos e as amostras da fácies xisto azul estão no campo dos mesmos basaltos com uma tendência evolutiva proveniente dos E-MORB em sentido N-MORB. $\mathbf{1}$ = basaltos de margens convergentes, $\mathbf{2}$ = magmas não diferenciáveis, mas com possíveis tendências de contaminação, $\mathbf{3}$ = magmas formados em ambientes extensionais, $\mathbf{C l}=$ crosta inferior e $\mathbf{C S}=$ crosta superior e fácies anfibolito $(A)$ refere-se à amostra com alterações nos conteúdos de sódio e potássio

Diagrama $\mathrm{Nb} / \mathrm{Yb}$ vs Th/Yb (Figura 13.13A), sugerido por Pearce (2008), as rochas metabásicas da região de Barragán separam-se em dois grupos as rochas da fácies xisto azul e as da fácies anfibolito, ambas no campo dos $\mathrm{N}$-MORB. Já no diagrama $\mathrm{Nb} / \mathrm{Yb}$ vs $\mathrm{TiO}_{2} / \mathrm{Yb}$ (Figura 13.13B) proposto por Pearce (2008), as análises também distinguem-se segundo a fácies metamórfica, mas igualmente no campo do N-MORB com tendência ao campo do E-MORB para o caso das rochas na fácies xisto azul. Estas separações possivelmente correspondam aos diferentes níveis crustais nos quais as rochas metamórficas da região de Barragán foram geradas. 


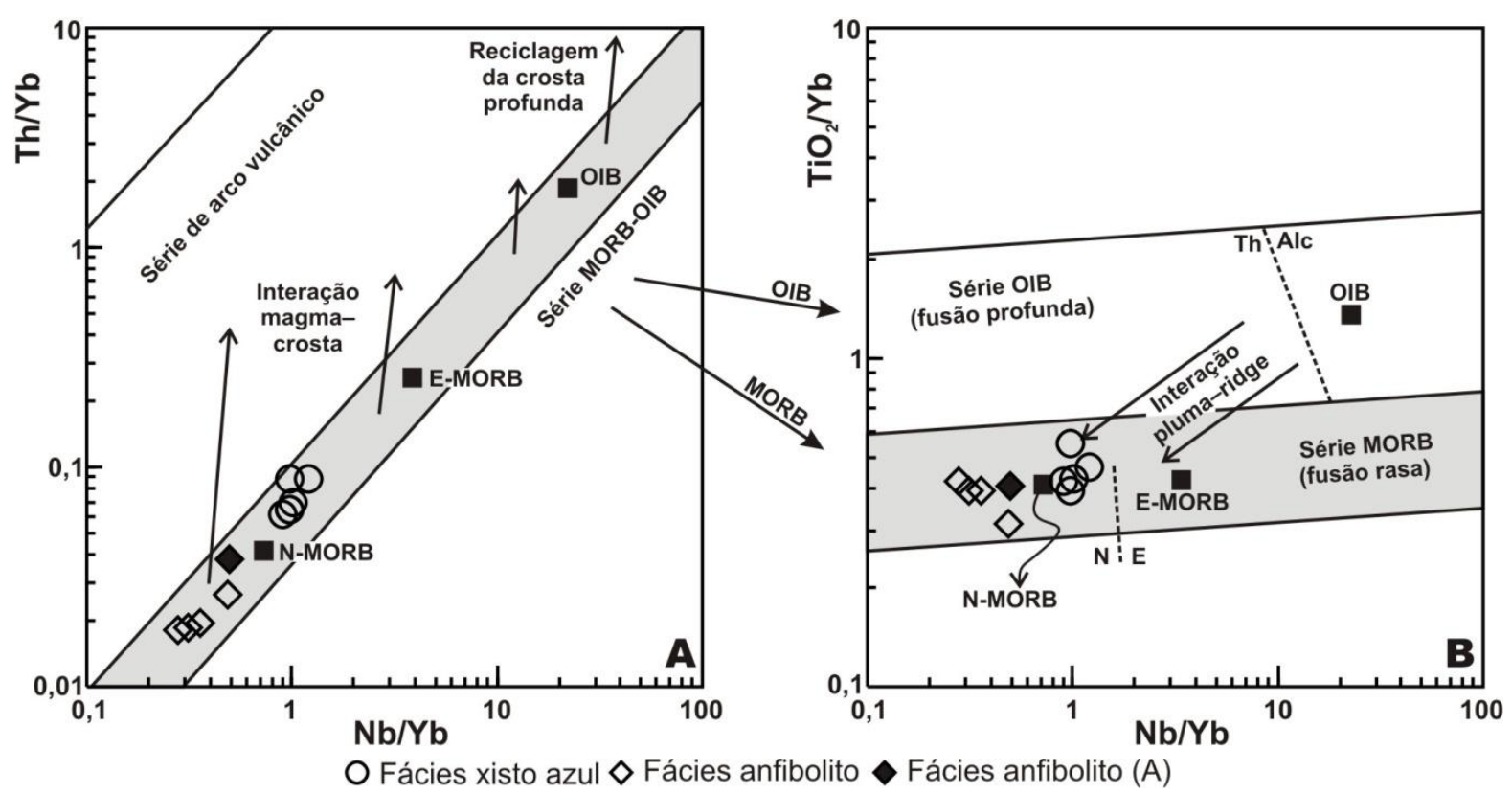

Figura 13.13. Diagramas $\mathrm{Nb} / \mathrm{Yb}$ vs $\mathrm{Th} / \mathrm{Yb}$ (esquerda) e $\mathrm{Nb} / \mathrm{Yb}$ vs $\mathrm{TiO}_{2} / \mathrm{Yb}$ (direita) segundo Pearce (2008) no qual apresentam-se as amostras de metabásicas da região de Barragán distribuem-se no campo da série MORB-OIB, sendo que todas elas concentram-se no campo dos N-MORB, embora separadas pela fácies metamórfica a qual elas pertencem, seja xisto azul ou anfibolito. No diagrama a fácies anfibolito (A) refere-se à amostra com alterações nos conteúdos de sódio e potássio.

Com estas considerações, nota-se uma clara afinidade das rochas analisadas da região de Barragán com os basaltos de tipo MORB, tanto nas amostras da fácies xisto azul quanto nas da fácies anfibolito. Com estas argumentações, fica reforçada a idéia de que um mesmo bloco funcionou como protolito da associação, com variações nas condições de metamorfismo como produto de diferentes níveis crustais aos quais foram submetidas às rochas.

Nos diagramas multi-elementares dos metabasitos da região de Barragán (Figura 13.14) observa-se variação principalmente no valor de $\mathrm{Sr}$ para as rochas metabásicas da fácies xisto azul, com uma única amostra que tem uma forte anomalia negativa de Sr. O restante das amostras apresentam anomalias negativas de Th e Ba e anomalias positivas de $\mathrm{U}$ e Cs. No caso das amostras da fácies anfibolito apresenta-se uma amostra que tem sofrido alterações nos conteúdos de $\mathrm{Na}$ e $\mathrm{K}$ e mostra uma anomalias negativas de Cs, Rb, Th e Sr. Entretanto, para a mesma amostra observam-se anomalias positivas de $\mathrm{Ba}$, levemente de $\mathrm{U}$ e $\mathrm{Ce}$. $\mathrm{O}$ resto das amostras da fácies anfibolito apresentam anomalias negativas de $\mathrm{Th}, \mathrm{Nb}$, levemente de $\mathrm{Zr}$ e da $\mathrm{Ba}$ com exceção e uma amostra que apresenta anomalia positiva deste último elemento. As rochas desta fácies também apresentam anomalias positivas de U, Ce, Sr e Cs. 


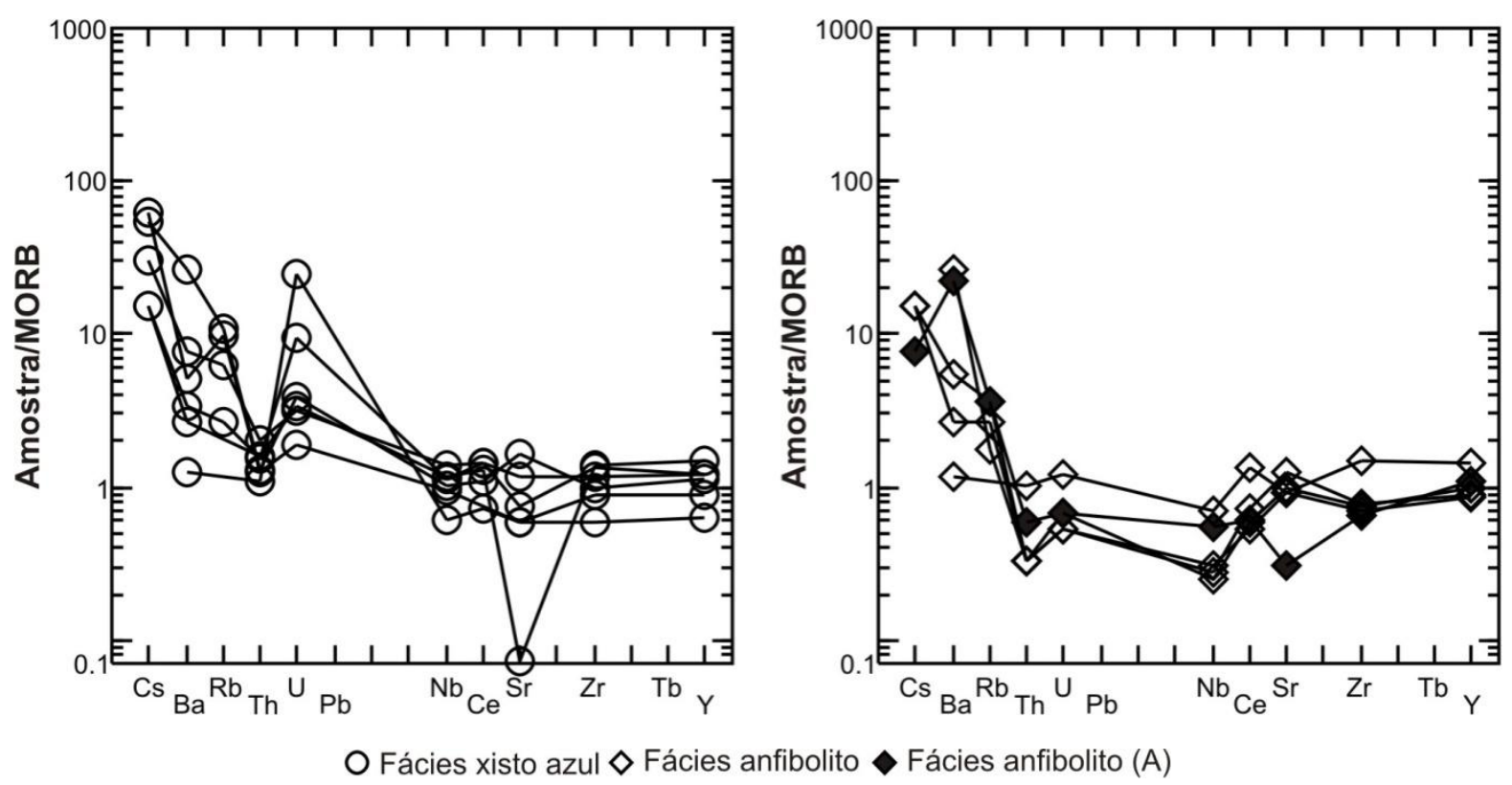

Figura 13.14. Padrões químicos dos metabasitos na fácies xisto azul e anfibolito da região de Barragán. No diagrama a fácies anfibolito $(A)$ refere-se à amostra com alterações nos conteúdos de sódio e potássio.

Os padrões das terras raras em relação ao condrito, E-MORB e N-MORB de Sun \& McDonough (1989) mostram anomalias negativas principalmente nas terras raras leves em relação ao E-MORB, com distribuição variando de pouco fracionamento das terras raras leves e pesadas, até com enriquecimentos em terras raras leves, principalmente quando normalizados com o N-MORB, indicativas de processos de diferenciação magmática (Figura 13.15). Notam-se também anomalias positivas de $\mathrm{Eu}$, em especial nas rochas menos diferenciadas, indicando concentração de plagioclásio na formação dos andesitos basálticos e dos andesitos e, a quase ausência de anomalias de $\mathrm{Ce}$, sugerindo menor interação fluido oceânico-rocha, o que pode ser indicativo de formação em ambiente subaéreo.
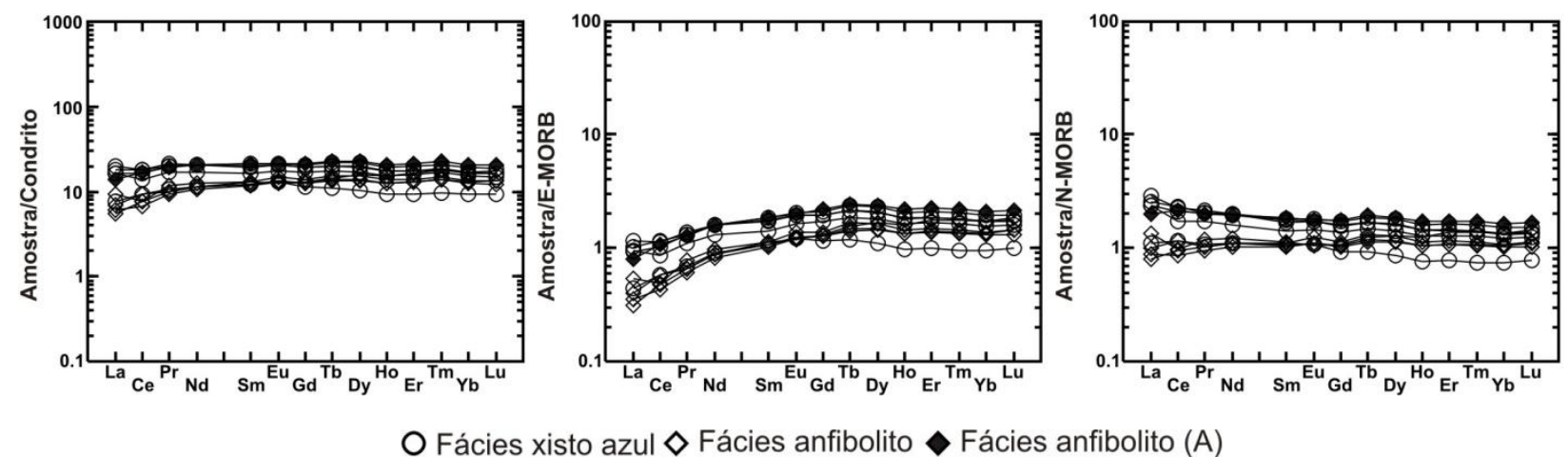

Figura 13.15. Diagramas multi-elementares mostrando padrões de elementos terras raras das amostras da região de Barragán normalizados ao condrito (esquerda), E-MORB (centro) e N-MORB (direita). No diagrama a fácies anfibolito $(A)$ refere-se à amostra com alterações nos conteúdos de sódio e potássio. 


\section{GEOCRONOLOGIA ${ }^{40}$ AR $/{ }^{39}$ AR DA REGIÃO DE JAMBALÓ}

São poucos os dados geocronológicos prévios dessa região, todos feitos pelo método KAr, o qual não é muito apropriado para datação desses tipos de rochas, já que as perdas ou excessos de argônio não podem ser determinados e nem tampouco a complexa história das micas brancas pode ser discriminada (Dallmayer \& Takasu, 1992; Clauer \& Chauduri, 1999).

Segundo Orrego et al. (1980b), a idade mínima do metamorfismo foi obtida por análise de rocha total pelo método $\mathrm{K}-\mathrm{Ar}$, resultando em $125 \pm 15$ Ma. Já a datação do glaucofânio pelo mesmo método resultou em idades de $104 \pm 14 \mathrm{Ma}$ e $217 \pm 10 \mathrm{Ma}$, tendo sido a primeira interpretada como sendo a idade mínima do metamorfismo na fácies xisto azul e a segunda como devida a excesso de argônio (De Souza et al., 1984).

As análises ${ }^{40} \mathrm{Ar} /{ }^{39} \mathrm{Ar}$ feitas neste estudo resultaram em boas idades em um intervalo entre 59 e $63 \mathrm{Ma}$, mas algumas das análises não se mostraram de boa qualidade, principalmente em função pouca quantidade de amostra disponível, pelos teores de $\mathrm{K}_{2} \mathrm{O}$ em paragonita abaixo de $0,5 \%$ e, possivelmente pelo intercrescimento de fengita e paragonita.

Embora nos espectros apareçam referenciada a mica branca como muscovita, da região de Jambaló foram datados paragonita e fengita de sete (7) amostras da fácies xisto azul.

A seguir são apresentados e avaliados os resultados obtidos:

O espectro obtido para a paragonita da amostra 129C, a qual está composta por glaucofânio + albita + paragonita + calcita + clorita + quartzo, apresenta-se como a melhor idade obtida para o conjunto das rochas da fácies xisto azul, com idade plateau de 66,9 $\pm 0,2 \mathrm{Ma}$ (Figura 14.1). O espectro é plano, mas o significado de algumas idades mais antigas ( $80 \mathrm{Ma}$ ) nas fases iniciais de aquecimento não pôde ser seguramente esclarecido, podendo ser devido a excesso de argônio ou heranças de eventos metamórficos mais antigos.

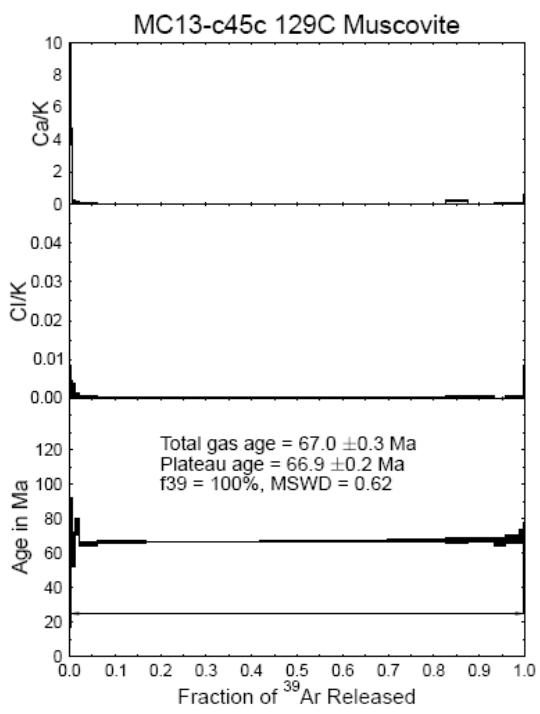

Figura 14.1. Espectro de argônio obtido para a amostra 129 C mostrando uma idade de plateau de $66,9 \pm 0,2$ Ma. 
Pode ser observado nos diferentes espectros obtidos para as amostras da região de Jambaló, que a razão $\mathrm{Ca} / \mathrm{K}$ apresenta variação em cada um deles, sendo que alcançam valores da ordem de 30 como no caso do espectro MC13-c46b da amostra 121B. Estas variações da razão $\mathrm{Ca} / \mathrm{K}$ não foram resolvidos na presente pesquisa, mas algumas possibilidades para explicálas podem ter relação com a existência do solvus $\mathrm{Ca}-\mathrm{Na}-\mathrm{K}$ entre as micas brancas margaritamuscovita (e.g. Guidotti et al., 1994; Feenstra, 1996), o intercrescimento de fengita-paragonita ou vice-versa (e.g. Ahn et al., 1985; Drits et al., 2007) ou substituições entre micas cálcicas passando por sódicas até chegar em composições mais potássicas (e.g. Okuyama, 1985). De fato fica claro que a mica analisada não corresponde unicamente a paragonita ou fengita como foi observado nas análises de química mineral, e que estudos mais detalhados em concentrados deste mineral deveriam ser feitos com o intuito de entender o processo que da origem a estas variações. Também não pode ser descartada que a presença de fases cálcicas como epidoto e titanita inclusa na mica e de caráter microcristalino possam ter alguma influência nas variações da razão $\mathrm{Ca} / \mathrm{K}$.

O estudo da paragonita da amostra 124F, composta por glaucofânio + albita + paragonita + calcita + clorita + titanita + quartzo, resultou em três espectros, um deles com razão $\mathrm{Ca} / \mathrm{K}$ de $\sim 3$ (espectro MC13-c41b). As idades obtidas nesta amostra se sobrepõem no erro e variam entre 61,8 e $62,9 \mathrm{Ma}$ (Figura 14.2).
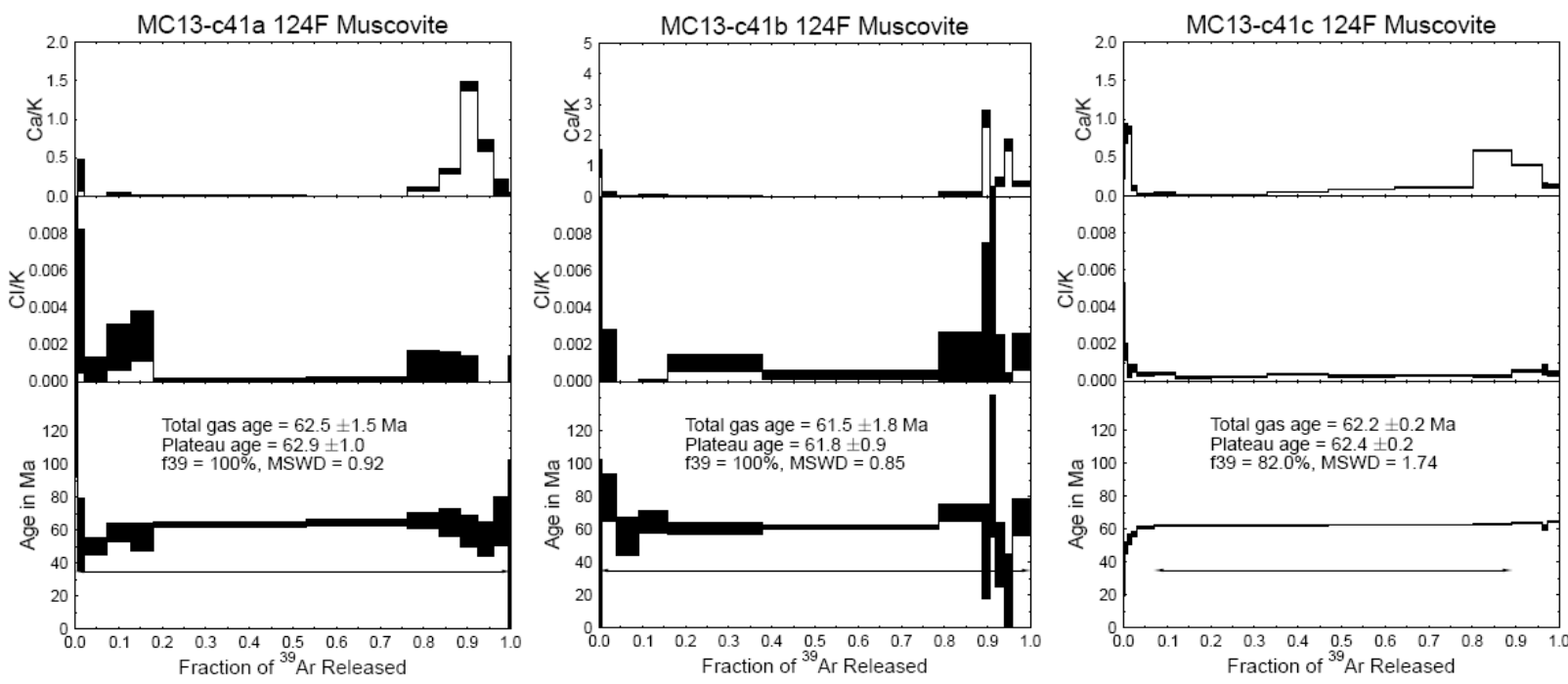

Figura 14.2. Espectros de argônio obtidos para a paragonita da amostra 124F mostrando umas idades plateau que variam entre 61,8 e 62,9 Ma.

Para a amostra 124G, composta por glaucofânio + paragonita + calcita + clorita + quartzo, foi analisada também paragonita e podem-se notar dois espectros (MC13-c37b e MC13-c37c) com idades entre $62,3 \pm 1,1$ e 63,0 \pm 0,3 Ma (Figura 14.3). No outro espectro (MC13-c37a) os primeiros steps têm indicações de excesso de argônio, o equilíbrio é alcançado nas porções intermediárias os steps finais têm razões $\mathrm{Ca} / \mathrm{K}$ na ordem de 4 nos dois primeiros espectros (MC13-c37b e MC13-c37c) e < 1 no último espectro (MC13-c37a), esse resultando em um erro 
maior e em idade de $54,5 \pm 1,6 \mathrm{Ma}$ (Figura 14.3).
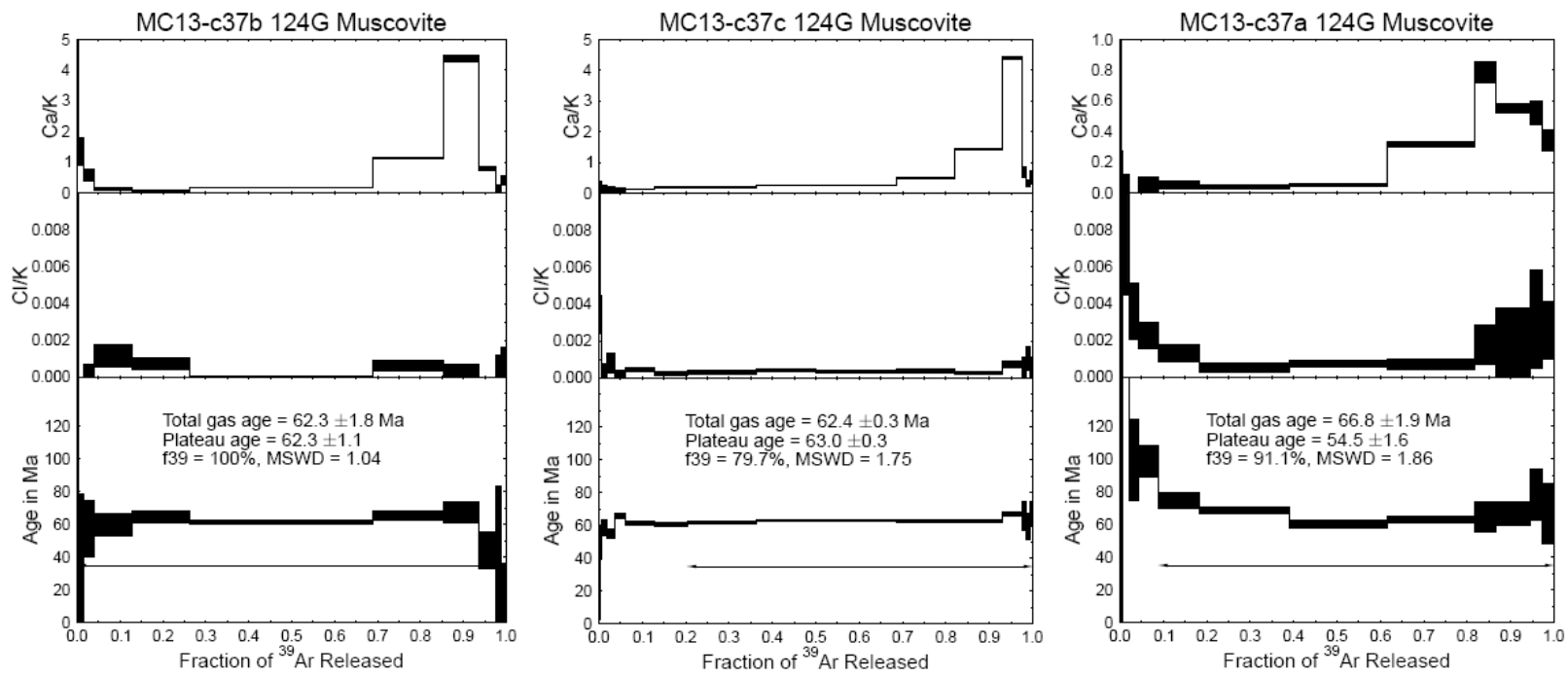

Figura 14.3. Espectros de argônio obtidos em paragonita da amostra 124G, no qual se observam idades plateau da ordem de 62,3 $\pm 1,1,63,0 \pm 0,3$ Ma e 54,5 $\pm 1,6 \mathrm{Ma}$.

As determinações foram obtidas em fengita da amostra a 124J, embora haja coexistência com paragonita nesta amostra e este composta por fengita + glaucofânio + albita + calcita + clorita \pm paragonita + quartzo, resultaram num espectro cujos últimos steps mostram $\mathrm{Ca} / \mathrm{K}$ de $\sim 3$ e a idade plateau obtida é de $67,5 \pm 1,1 \mathrm{Ma}$ (Figura 14.4).

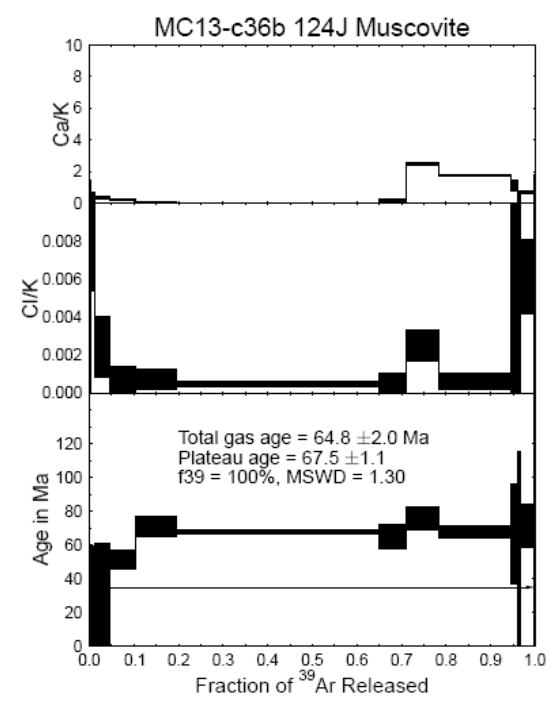

Figura 14.4. Espectro de argônio obtido em fengita da amostra $124 \mathrm{~J}$ com idade plateau de $67,5 \pm 1,1 \mathrm{Ma}$.

Os espectros das análises obtidas em paragonita da amostra 121B, composta por glaucofânio + paragonita + calcita + clorita + quartzo, apresentam as mais altas razões $\mathrm{Ca} / \mathrm{K}$, principalmente no último step (MC13-c46a), da ordem de 7. Em outro espectro (MC13-c46b) a razão $\mathrm{Ca} / \mathrm{K}$ alcança valores da ordem de 30. Dois dos espectros (MC13-c46a e MC13-c46b) apresentam também os maiores intervalos de erro, sendo que no MC13-c46a a idade plateau obtida é de $63,2 \pm 4,4$ e no MC13-c46b o valor obtido é 74,0 $\pm 28,5 \mathrm{Ma}$. O espectro MC13-c46c apresenta-se com um erro menor em uma idade plateau de 67,8 $\pm 1,1 \mathrm{Ma}$. Na Figura 14.5 
apresentam-se os três espectros obtidos para a amostra 121B.
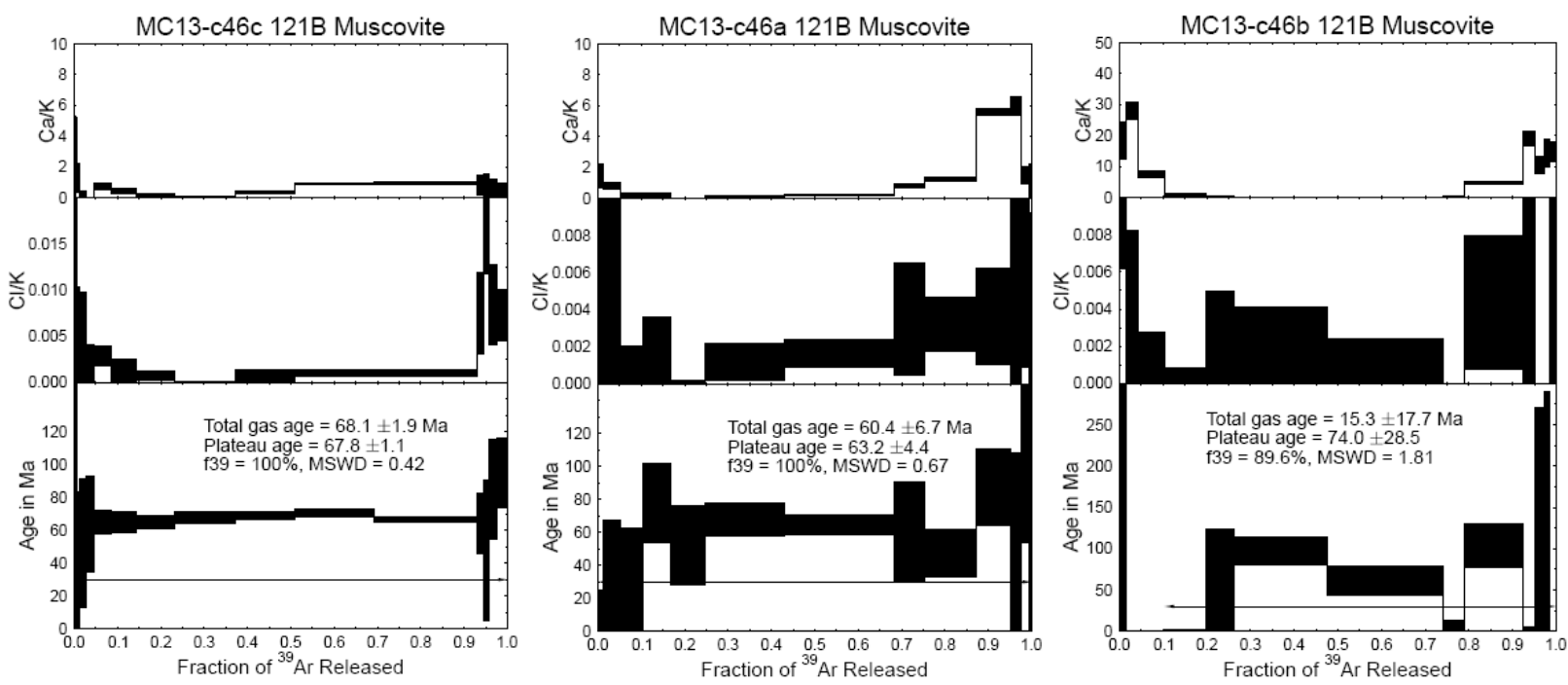

Figura 14.5. Espectros de argônio obtidos para a paragonita da amostra $121 \mathrm{~B}$ no qual se obtiveram idades plateau com um amplo intervalo de erros para dois deles, sendo as idades de 63,2 $\pm 4,4 \mathrm{Ma}$ (espectro do centro) e $74 \pm 28,5 \mathrm{Ma}$ (espectro da direita). No espectro da esquerda a idade plateau é de 67,8 $\pm 1,1 \mathrm{Ma}$.

Da amostra 123A, composta por glaucofânio + epidoto/clinozoisita + paragonita + quartzo, foi analisada paragonita e apresenta um espectro (MC13-c44c) com uma razão $\mathrm{Ca} / \mathrm{K}$ da ordem de $\sim 1,5$ e uma idade plateau de 66,0 $\pm 0,7 \mathrm{Ma}$ (Figura 14.6). Os outros dois espectros (MC13-c44a e MC13-c44b) mostram idades plateau de 67,1 $\pm 2,7$ e 83,1 $\pm 10,6$ Ma respectivamente, com uma razão $\mathrm{Ca} / \mathrm{K}$ da ordem de 6 para o espectro MC13-c44a.
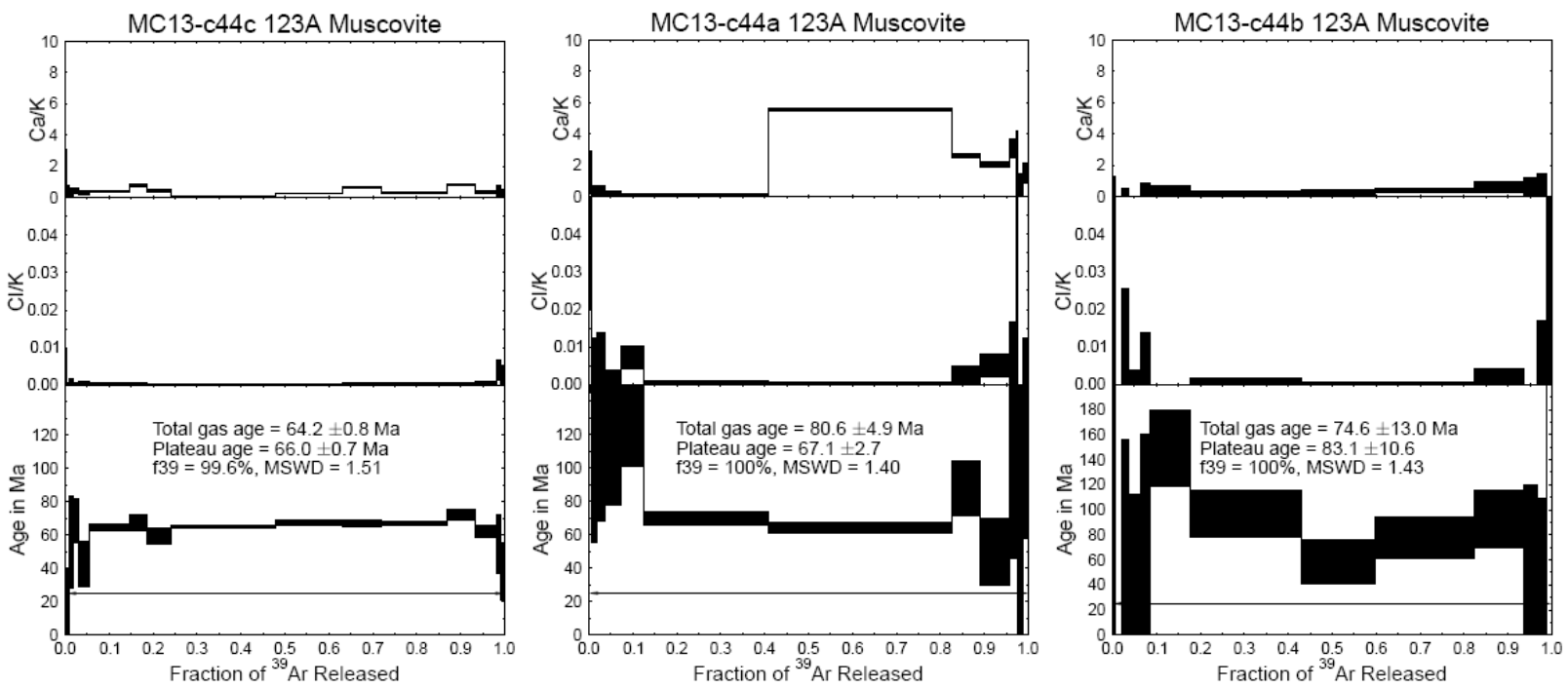

Figura 14.6. Espectros de argônio obtidos para a paragonita da amostra 123A no qual se obtiveram idades plateau com um amplo intervalo de erros para dois deles, sendo as idades de 67,1 $\pm 2,7 \mathrm{Ma}$ (espectro do centro) e 83,1 $\pm 10,6 \mathrm{Ma}$ (espectro da direita). No espectro da esquerda a idade plateau é de $66 \pm 0,7 \mathrm{Ma}$.

A amostra da fácies xisto azul, considerada como transicional para a fácies xisto verde (125M), composta por glaucofânio + albita + paragonita + calcita + clorita, resultou em idades plateau em paragonita com os espectros MC13-c40a e MC13-c40c de 54,7 $\pm 8,9$ e 63,5 $\pm 1,3 \mathrm{Ma}$ 
respectivamente (Figura 14.7), sendo que o espectro MC13-c40c apresenta uma razão da ordem de 2.
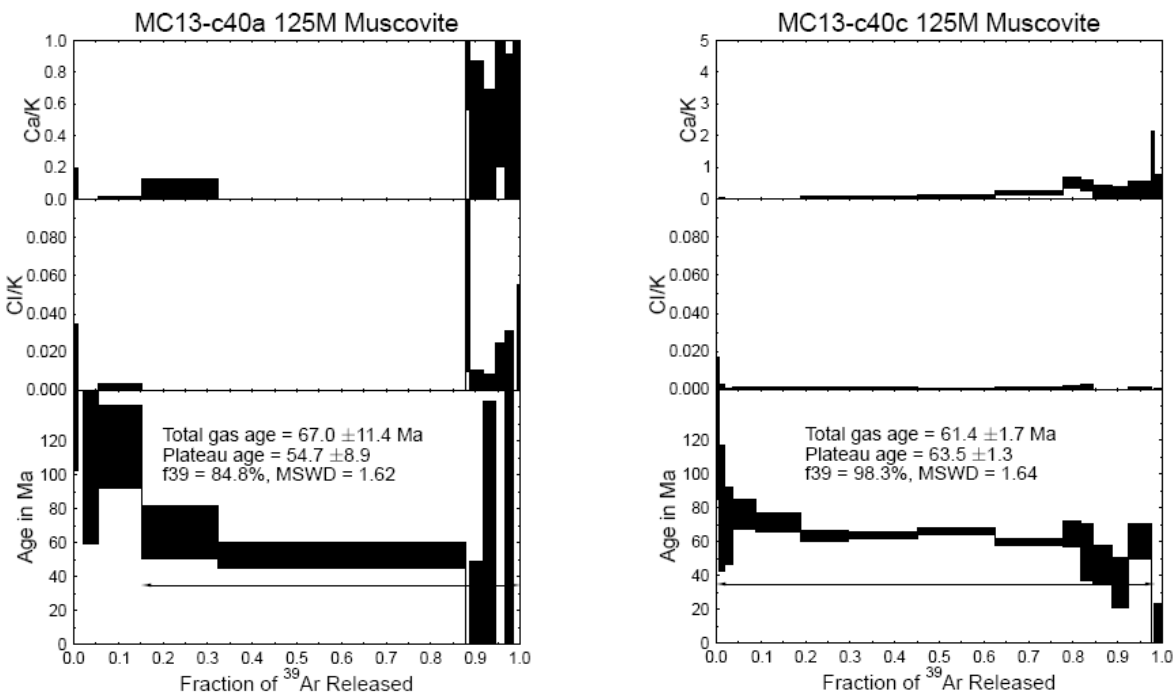

Figura 14.7. Espectros de argônio obtidos para a amostra $125 \mathrm{M}$ mostrando idades plateau de $54,7 \pm 8,9 \mathrm{Ma}$ e $63,5 \pm 1,3 \mathrm{Ma}$.

Na Tabela 14.1 apresenta-se o resumo dos resultados das análises ${ }^{40} \mathrm{Ar} /{ }^{39} \mathrm{Ar}$ feitas nas amostras da região de Jambaló, juntamente com alguns comentários.

Tabela 14.1. Resultados ${ }^{40} \mathrm{Ar} /{ }^{39} \mathrm{Ar}$ das amostras analisadas da região de Jambaló.

\begin{tabular}{|c|c|c|c|c|c|}
\hline $\begin{array}{c}\text { Numero de } \\
\text { irradiação }\end{array}$ & Amostra & Fácies & $\begin{array}{l}\text { Gás total } \\
\text { idade (Ma) }\end{array}$ & $\begin{array}{c}\text { Idade plateau } \\
\text { (Ma) }\end{array}$ & Comentários* $^{\star}$ \\
\hline$c 45 c$ & 129C & Xisto azul & $67,0 \pm 0,3$ & $66,9 \pm 0,2$ & Espectro plano \\
\hline c41a & $124 F$ & Xisto azul & $62,5 \pm 1,5$ & $62,9 \pm 1,0$ & Alto Ca a alta T: Ep, Act? \\
\hline$c 41 b$ & $124 F$ & Xisto azul & $61,5 \pm 1,8$ & $61,8 \pm 0,9$ & Spikes de alto Ca: Ep, Act? \\
\hline c41c & $124 F$ & Xisto azul & $62,2 \pm 0,2$ & $62,4 \pm 0,2$ & Espectro plano, últimos steps com Ca alto \\
\hline c37b & $124 G$ & Xisto azul & $62,3 \pm 1,8$ & $62,3 \pm 1,1$ & Últimos steps com Ca muito alto: Ep, Act? \\
\hline $\mathrm{c} 37 \mathrm{c}$ & $124 G$ & Xisto azul & $62,4 \pm 0,3$ & $63,0 \pm 0,3$ & Últimos steps com Ca muito alto: Ep, Act? \\
\hline c37a & $124 G$ & Xisto azul & $66,8 \pm 1,9$ & $54,5 \pm 1,6$ & Muito Ca para Ms: alto $\mathrm{Ca}$ a alta $\mathrm{T}$ \\
\hline c36b & 124J & Xisto azul & $64,8 \pm 2,0$ & $67,5 \pm 1,1$ & Últimos steps com Ca muito alto: Ep, Act? \\
\hline c46c & 121B & Xisto azul & $68,1 \pm 1,9$ & $67,8 \pm 1,1$ & Últimos steps com Ca muito alto: Ep, Act? \\
\hline$c 46 a$ & 121B & Xisto azul & $60,4 \pm 6,7$ & $63,2 \pm 4,4$ & Ca alto: Ep, Act \\
\hline $\mathrm{c} 46 \mathrm{~b}$ & 121B & Xisto azul & $15,3 \pm 17,7$ & $74,0 \pm 28,5$ & Amostra não suficiente, provavelmente $\mathrm{Pg}$ \\
\hline c44c & 123A & Xisto azul & $64,2 \pm 0,8$ & $66,0 \pm 0,7$ & Últimos steps com Ca muito alto: Ep, Act? \\
\hline c44a & $123 A$ & Xisto azul & $80,6 \pm 4,9$ & $67,1 \pm 2,7$ & Alguns steps com Ca muito alto: Ep, Act? \\
\hline $\mathrm{c} 44 \mathrm{~b}$ & $123 A$ & Xisto azul & $74,6 \pm 13,0$ & $83,1 \pm 10,6$ & Amostra não suficiente \\
\hline $\mathrm{c} 40 \mathrm{a}$ & $125 M$ & Xisto azul & $67,0 \pm 11,4$ & $54,7 \pm 8,9$ & Amostra não suficiente, Alto $\mathrm{Ca}$ a alta $\mathrm{T}$ \\
\hline c40c & $125 M$ & Xisto azul & $61,4 \pm 1,7$ & $63,5 \pm 1,3$ & Últimos steps com Ca muito alto: Ep, Act? \\
\hline
\end{tabular}

$\mathrm{Ep}=$ epidoto, $\mathrm{Act}=$ actinolita, $\mathrm{Pg}=$ paragonita e $\mathrm{T}=$ temperatura. ${ }^{*}$ Os comentários feitos pelo técnico do laboratório analítico.

O conjunto dos dados ${ }^{40} \mathrm{Ar} /{ }^{39} \mathrm{Ar}$ mostram que o metamorfismo da fácies xisto azul de Jambaló têm idade predominante anterior, mas possivelmente muito próxima a $63 \mathrm{Ma}$. Entretanto, há também indicações de possíveis idades até mais antigas que a $71 \mathrm{Ma}$, apesar do melhor intervalo situar-se entre 66 e $61 \mathrm{Ma}$ (Maastritchtiano-Daniano), o que posiciona a a exumação dos xistos azuis de Jambaló no final do Cretáceo até o início do Terciário, pois considerando que as micas das rochas da fácies xisto azul datadas na região de Jambaló são principalmente paragonita e em menor proporção fengita e estas pertencem à foliação milonítica a idade mínima 
do metamorfismo seria, como mencionado, um pouco mais antigo, já que as idades apresentadas para as rochas desta área estariam representando o evento de exumação que tem relação direta com a geração de foliação milonítica.

Geocronologicamente, o metamorfismo da fácies xisto azul da região de Jambaló não tem correlação com o conjunto de rochas de Barragán (ver discussão da idade no capitulo 15) e poderia corresponder a um evento isolado de geração de metamorfismo de alta pressão. 


\section{GEOCRONOLOGIA ${ }^{40} \mathrm{Ar} /{ }^{39} \mathrm{Ar}$ DA REGIÃO DE BARRAGÁN}

Da região de Barragán foi selecionado para geocronologia Ar-Ar em muscovita apenas um metapelito metamorfisado na fácies xisto verde (amostra 190B), que ocorre associado aos xistos azuis.

Foram analisados três grãos de muscovita da amostra, cujos resultados são apresentados na Tabela 15.1.

Tabela 15.1. Resultados ${ }^{40} \mathrm{Ar}{ }^{39} \mathrm{Ar}$ das amostras analisadas da região de Barragán.

\begin{tabular}{|c|c|c|c|c|c|}
\hline $\begin{array}{l}\text { Numero de } \\
\text { irradiação }\end{array}$ & Amostra & Fácies & $\begin{array}{l}\text { Gás total } \\
\text { idade (Ma) }\end{array}$ & $\begin{array}{c}\text { Idade plateau } \\
\text { (Ma) }\end{array}$ & Comentários \\
\hline$c 42 b$ & 190B & Xisto verde & $117,2 \pm 1,6$ & $120,1 \pm 1,0$ & Espectro plano \\
\hline c42c & 190B & Xisto verde & $120,7 \pm 0,3$ & $120,8 \pm 0,3$ & Espectro plano \\
\hline c42a & 190B & Xisto verde & $107,0 \pm 7,0$ & $119,4 \pm 3,8$ & $\begin{array}{l}\text { Todo o gás liberado em um step, spikes de } \\
\text { alto } \mathrm{Ca}\end{array}$ \\
\hline
\end{tabular}

As idades plateau dos espectros foram definidas por mais de $70 \%$ do argônio liberado (Figura 15.1). Em geral a mica analisada apresenta razões $\mathrm{Ca} / \mathrm{K}$ e $\mathrm{Cl} / \mathrm{K}$ relativamente homogêneas e as variações menores observadas foram interpretadas como relacionadas a inclusões. As idades plateau obtidas são aptianas e as três análises se sobrepõem no erro, com $119,4 \pm 3,8 \mathrm{Ma}, 120,1 \pm 1,0 \mathrm{Ma}$ e 120,7 $\pm 0,3 \mathrm{Ma}$. Um dos espectros apresenta spikes de alto Ca com idades mais antigas ( 150 Ma) que possivelmente relacionadas com excesso de argônio.
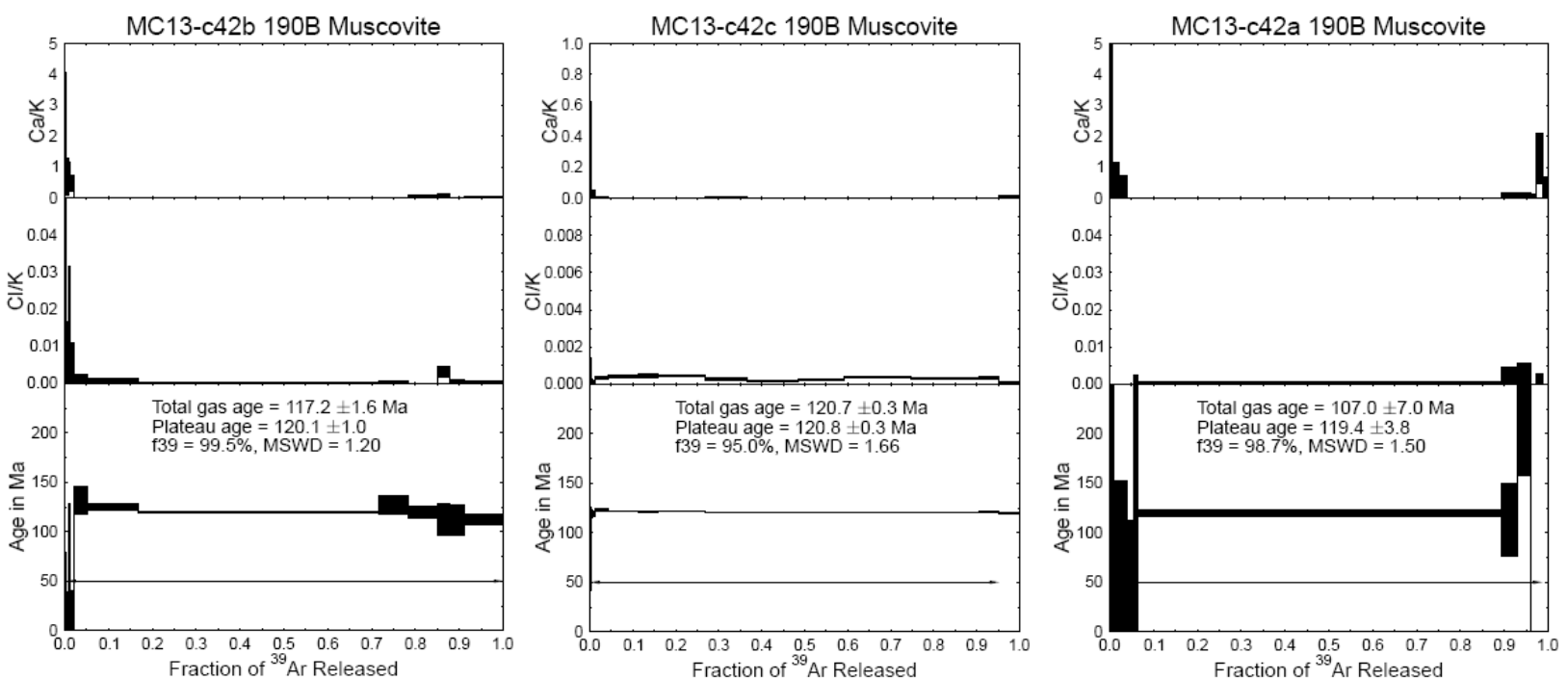

Figura 15.1. Espectros de argônio obtidos para a amostra 190B, resultando em idades plateau aptianas.

Considerando que: a) o xisto cuja muscovita foi datada tem foliação milonítica; b) a presença na região de xistos com andaluzita sob a forma de porfiroblastos sub- e idioblásticos tardios a pós-deformacionais orientados na foliação milonítica; c) que os cristais de andaluzita têm inclusões de granada, indicando a existência de um evento de descompressão associado ao evento de milonitização; d) as temperaturas de fechamento do sistema $\mathrm{Ar}$-Ar nas micas brancas ao redor de 325 a $375{ }^{\circ} \mathrm{C}$, definidas por McDougall \& Harrison (1999) e; f) que o pico térmico alcançado pelas rochas se deu durante o metamorfismo na fácies xisto verde que sucedeu o 
metamorfismo da fácies xisto azul, pode-se definir que a idade de 120 Ma corresponde a uma idade mínima para o evento de alta pressão, pois representa, em essência, o evento de exumação associado ao desenvolvimento da foliação milonítica. Considerando-se um período mínimo para exumação dos xistos azuis de 20 Ma (e.g. Schulmann et al., 2004; Agard et al., 2006) até 2,5 Ma (e.g. Mihalynuk et al., 2004), é possível supor que o evento de alta pressão e baixa temperatura na região de Barragán ocorreu entre 125 e 150 Ma. 


\section{DISCUSSÃO E CONCLUSÕES DO METAMORFISMO DAS ÁREAS DE ESTUDO}

\subsection{Jambaló}

Um evento de metamorfismo de contato poderia estar indicado pelos agregados de cristais radiados de estilpnomelano e dos epidositos em veios. Este metamorfismo termal é claramente posterior ao regional, mas ocorre localizadamente na parte noroeste da área de estudo, é bem visível nas rochas não foliadas, distintas daquelas com dobras intrafoliais prévias à milonitização, mas a geocronologia não indicou nenhuma influência deste evento no conjunto de rochas de Jambaló. $\mathrm{O}$ estilpnomelano em arranjo radiado, as $S_{i}$ em alguns grãos de plagioclásio e o crescimento de cristais de clinozoisita em forma desordenada podem ter sido gerados, eventualmente, pela intrusão de pequenos corpos graníticos, subjacentes ao nível atual de erosão, já que os mesmos não foram observados em campo, exceto na porção noroeste da área. Em sendo de metamorfismo de contato, sua intensidade seria compatível com a fácies albitaepidoto hornfels. O metamorfismo de contato não foi intenso ou generalizado, pois afetou muito pouco o sistema isotópico $\mathrm{Ar}-\mathrm{Ar}$, que raramente mostra indício de rejuvenescimentos. Esse evento também não fica evidente nos zonamentos químicos dos minerais, especialmente nos perfis da granada, que mostram um equilíbrio metaestável incompatível com o esperado para rochas afetadas por um evento intenso de metamorfismo de contato.

Como discutido na síntese bibliográfica fundamental, há dois tipos de trajetórias metamórficas relacionadas com a formação dos xistos azuis (Ernst, 1988). Uma delas, a do Tipo Alpino, tem sentido horário, o que faz com os xistos azuis e os eclogitos sejam substituídos por xistos verdes e anfibolitos durante o metamorfismo retrógrado. Este tipo de metamorfismo com alta razão $\mathrm{P}-\mathrm{T}$ forma-se em zonas de subducção, na qual se segue uma descompressão quase isotermal, provocada pela exumação rápida em regimes compressionais e com forte erosão. Segundo Ernst (1972) isto pode ser causado pela colisão de um arco de ilhas ou por um fragmento de crosta continental com o continente, resultando em rápido soerguimento e denudação dos xistos azuis. Alternativamente este tipo de trajetória pode ser explicado pelo aumento de pressão causado nas rochas supracrustais acumuladas no prisma acrescionário de uma fossa em forte subsidência, o que faz com que haja inserção dos sedimentos sob a crosta continental, seguida pela exumação em zonas de cavalgamentos, acentuada pela presença de um bloco da crosta superposto aos sedimentos durante a colisão (Platt, 1987).

O segundo tipo, chamado de Franciscano, caracteriza-se por uma trajetória retrometamórfica quase coincidente com a trajetória do metamorfismo progressivo. Este tipo de trajetória é formado em terrenos que são resfriados durante a exumação, devido ao soerguimento crustal relativamente lento, o que possibilita a transferência da energia térmica das cunhas tectônicas de rochas de alta razão P-T zonas de mélanges para as encaixantes mais frias (Cloos, 1982). A Figura 16.1 apresenta os diferentes tipos de trajetória segundo Ernst (1988). 


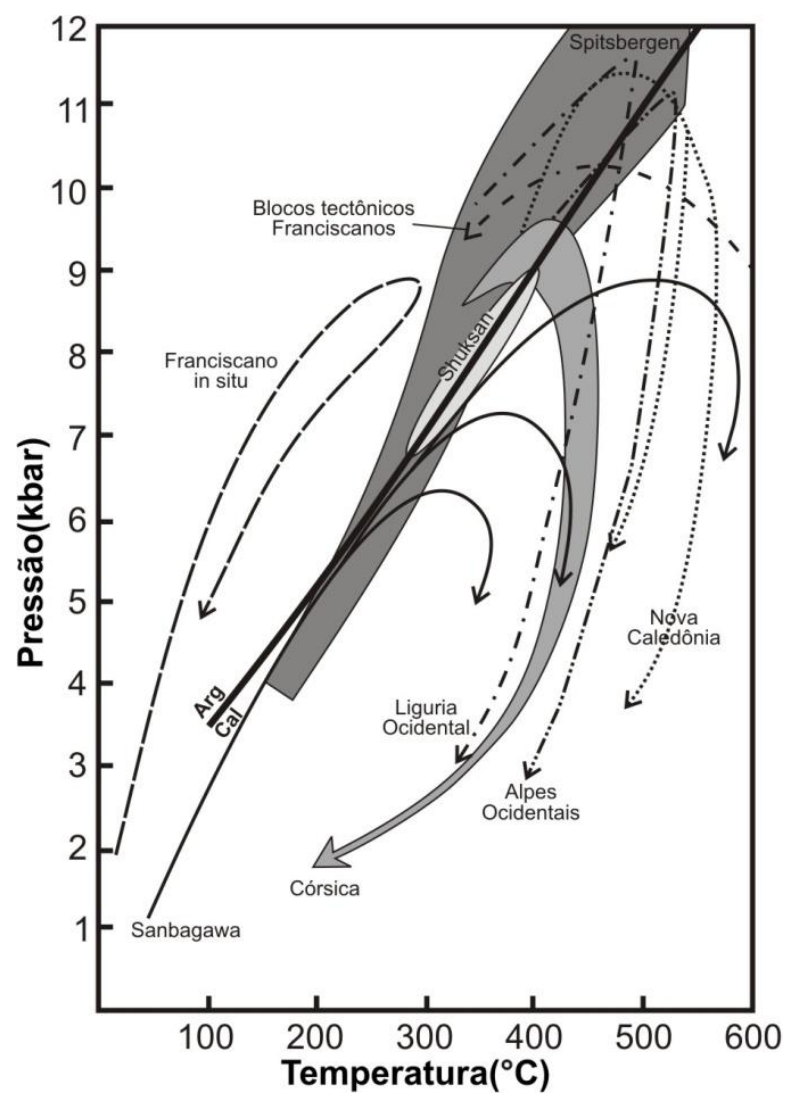

Figura 16.1. Diferentes tipos de trajetórias metamórficas de xistos azuis em zonas de subducção segundo Ernst (1988). A linha da estabilidade arogonito (Arg) - calcita (Cal) segundo Johhannes \& Puhan (1971).

É importante notar que os diferentes tipos e modelos derivados da interpretação das trajetórias metamórficas estão associados sempre com zonas de subducção, mas sua evolução pode relacionar-se com o desenvolvimento do metamorfismo de soterramento e com a colisão tectônica (Platt, 1987), com ofiolitos (Ernst, 1972) e com a formação de eclogitos (Spear, 1995).

Especialmente na área de Jambaló, a presença de glaucofânio e fengita, é possível inferirse que os mica glaucofânio e os glaucofânio micaxistos com transformações para rochas da fácies xisto verde mostrando um aumento na temperatura, permite inferir que o metamorfismo foi do Tipo Alpino. Entretanto, o ambiente cordilheirano de formação das rochas da fácies xisto azul de Jambaló, indicaria a existência de uma trajetória metamórfica do semelhante ao do Tipo Franciscano. Estes aspectos contraditórios sugerem que os xistos azuis de Jambaló podem ter se formado em um regime metamórfico com uma trajetória de gradiente $\mathrm{P}-\mathrm{T}$ intermediários entre o regime Alpino e Franciscano, o que possivelmente constitui um modelo de formação para xistos azuis de tipo Andino.

O conjunto de rochas da fácies xisto azul de Jambaló, experimentou uma intensa deformação milonítica mais tardia, que pode estar relacionada à exumação dos terrenos em zonas de cavalgamentos e mais possivelmente à colisão dos terrenos que conformam a Cordilheira Ocidental dos Andes colombianos (e.g. rochas vulcânicas oceânicas mesozóicas). A deformação associada ao evento de subducção é evidenciada pelas foliações internas em vários minerais, 
pelos microlitons de glaucofânio e por alguns arcos poligonais abandonados, que atualmente apresentam-se como cristais independentes que foram submetidos à deformação em estado dúctil e agora se observa somente uma leve extinção ondulante. Há também neste evento de alta pressão a cristalização de glaucofânio radiado, indicativo de um regime aproximadamente estático, o que sugere que houve ainda um pequeno aumento da temperatura antes do início da exumação dos terrenos que foram submetidos às condições de metamorfismo de alta razão $P / T$. Depois se seguiu-se uma queda na pressão, dada pelo início da exumação, acompanhada por leves aumentos na temperatura, como indicado pela ocorrência de epidoto e clinozoisita, e pelas relíquias de glaucofânio preservado incluso em alguns cristais de quartzo em rochas da transicionais para a fácies xisto verde, o que permitiu sua preservação por estar isolado das reações com outros minerais adjacentes. Isto é evidenciado quando se observa o glaucofânio não incluso no quartzo, que apresenta uma borda de reação, com geração de clorita e de anfibólios sódico-cálcicos e cálcicos. Na continuidade do processo de retrometamorfismo torna-se muito intenso, resultando na formação dos clorita-plagioclásio xistos (xistos verdes), os quais representariam a etapa final da transformação dos mica-glaucofânio e os glaucofânio micaxistos. Nesta fase, a deformação vincula-se com um evento de cisalhamento muito intenso, o que favoreceu os reequilíbrios metamórficos pela quebra dos minerais e pela introdução de fluidos metamórficos hidratados. Segundo esta evolução, parece ser muito plausível associar-se o evento do metamorfismo retrógrado à exumação, que deve ter-se dado em zonas de cavalgamentos. No processo de exumação, é importante ressaltar também que pequenas lascas do manto foram arrancadas e colocadas em contato tectônico com as rochas da fácies xisto azul, e que atualmente são rochas ultramáficas intensamente serpentinizadas.

Em termos estruturais foram identificadas dois fabrics associados à geração das rochas de alta razão $\mathrm{P} / \mathrm{T}$, uma delas evidenciada na foliação pretérita observada em alguns cristais de glaucofânio e definida pelas inclusões de quartzo e mica orientadas e dobradas, e outra dada pela foliação milonítica, que destruiu e orientou os cristais de glaucofânio.

As reações metamórficas são indicativas das condições metamórficas e tectônicas as quais as rochas foram submetidas e é o reflexo da disponibilidade das fases presentes nos diferentes sistemas. Naturalmente, nem sempre é possível a determinação de todas as reações que ocorrem dentro de um evento metamórfico, pois muitas delas são tão intensas que obliteram toda evidência da existência de outras. Dentro dos mica-glaucofânio e glaucofânio micaxistos, pode-se determinar que algumas reações metamórficas aconteceram, embora elas não sejam completas, pois os restos de glaucofânio observados fazem pensar que no processo retrometamórfico a quantidade de água que entrou no sistema pelas zonas de cisalhamento não foi suficiente para completar as transformações dos minerais, ou que a velocidade da exumação foi muito rápida, impossibilitando a transformação retrometamórfica completa durante a 
exumação. Mesmo assim, considerando-se as descrições de Spear (1995) uma das reações de transformação dos xistos azuis em xistos verdes pode ser:

glaucofânio + zoisita (ou epidoto) + quartzo $+\mathrm{H}_{2} \mathrm{O}=$ albita + clorita + actinolita

O fato de terem parte das rochas da fácies xisto verde ainda relíquias de glaucofânio, indicaria, neste contexto, a reação não foi completada.

Muito embora a presença de prehnita não tenha sido confirmada, a pumpellyita encontrada pode sugerir que estas rochas puderam eventualmente alcançar a fácies prehnita-pumpellyita ( 200 a $300^{\circ} \mathrm{C}$ e $<1$ a $4 \mathrm{~kb}$ ). Na amostra $121 \mathrm{C}$ a pumpellyita é pós-cinemática e foi formada no metamorfismo retrógrado, o que corrobora sua relação com a exumação das rochas da área de Jambaló e com o modelo proposto.

A prehnita e a pumpellyita ocorrem com epidoto + clorita e outros minerais da fácies xisto verde baixa, incluindo actinolita, albita, estilpnomelano, mica branca, titanita e calcita ou lawsonita + albita e outras fases típicas da fácies xisto azul (Best, 2003), mas a prehnita não é estável na associação de mais alto grau da fácies prehnita-pumpellyita, na qual coexistem actinolita + pumpellyita + clorita + epidoto. Com o aumento da temperatura esses dois minerais reagem com clorita e quartzo para gerar epidoto + actinolita, mas em rochas pobres em clorita e quartzo a prehnita-pumpellyita permanecem estáveis quase até os $400{ }^{\circ} \mathrm{C}$ na fácies xisto verde (Best, 2003), o que reforça a interpretação acima.

De acordo com os tipos A (colisionais) e B (cordilheiranos) de xistos azuis apresentados por Maruyama (1995), Maruyama, et al., (1996), as rochas da região de Jambaló corresponderiam ao tipo $\mathrm{B}$, mas mesmo que muitas das características apresentadas na nesta classificação (Tabela 4.1), sejam atendidas pelas rochas do estudo, tem algumas características eu correspondem aos xistos azuis de tipo A (e.g. magmatismo bimodal dos protolitos), o que sugere que mesmo sendo um complexo de subducção, não e possível encaixar as rochas da região de Jambaló em um único tipo ou modelo de geração, reforçando a idéia de um processo de geração de xistos azuis tipicamente desta porção dos Andes. Além disso, considerando que a exumação ocorre por três processos: erosão, falhas normais e encurtamento dúctil (ductile thinning) (Ring, et al., 1999), é possível pensar que as rochas de alta razão $\mathrm{P} / \mathrm{T}$ de Jambaló foram afetadas por todos estes processos, embora não tenham sido observadas as relações de campo entre os diferentes litotipos.

Considerando que a cordilheira ocidental da Colômbia é formada por rochas vulcânicas, de idade principalmente cretácica, que eventualmente sofreram os efeitos de uma colisão com uma margem continental durante este período geológico, seria possível sugerir uma conexão entre a acresção de domínios de origem oceânico (evolução de arco vulcânico para plateau oceânico) e a evolução das rochas da região de Jambaló. 
O possível processo de geração e exumação das rochas da fácies xisto azul da região de Jambaló é apresentado na Figura 16.2.
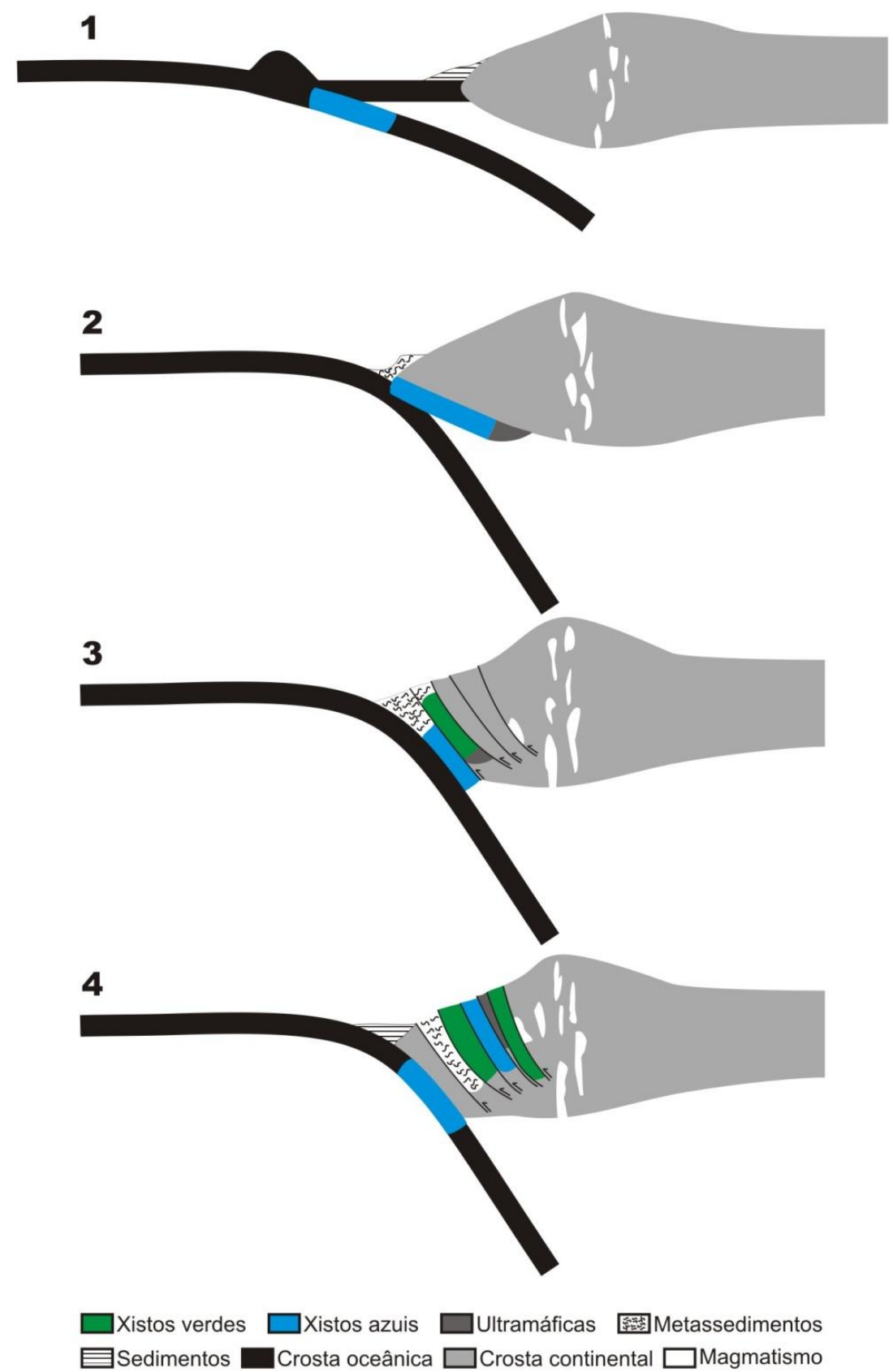

Figura 16.2. Esquema de evolução tectônica (geração e exumação) das rochas na fácies xisto azul da região de Jambaló. No estágio 1 mostra-se a subducção de um arco de ilhas sob uma placa oceânica. No estágio 2 observa-se a quebra e abandono de um fragmento placa subductada e conseqüente mudança no ângulo de subducção. No estágio $\mathbf{3}$ os fragmentos de crosta que foram metamorfisados em fácies xisto azul começam a serem incorporados na crosta continental através de falhas geradas pelo alivio das tensões na crosta continental e no estágio 4 mostram-se os xistos azuis colocados na crosta continental e com transformações para rochas da fácies xisto verde, assim como a presença de pequenas lascas de rochas ultramáficas arrancadas pelo durante o processo de exumação.

Na Figura 16.2, sugere-se que o metamorfismo da fácies xisto azul da região de Jambaló foram gerados a partir da subducção de um arco de ilhas sob outra placa oceânica. Em um estágio posterior a placa oceânica quebra e sofre uma mudança no ângulo de subducção que faz 
com que o bloco que estava sendo metamorfizado na fácies xisto azul comece um processo de incorporação na crosta continental a partir de falhas geradas pelo relaxamento da crosta. Neste processo, fragmentos de rochas ultramáficas são arrancados e levados junto com as rochas de alta pressão que seriam colocadas na crosta continental. Entretanto, os sedimentos acumulados na fossa são submetidos a metamorfismo como parte do prisma acresção. Estes metassedimentos são juntamente colocados com as rochas da fácies xisto azul. No processo de colocação, o bloco inicial em fácies xisto azul sofre aquecimento que faz com que as rochas se transformassem em rochas da fácies xisto verde sobrando assim somente pequenas lentes de rochas de alta razão $\mathrm{P} / \mathrm{T}$ preservadas. Toda esta seqüência de eventos pode ser acompanhada por magmatismo associado. Em termos gerais, a região de Jambaló pode corresponder a uma zona de colisão das rochas vulcânicas oceânicas mesozóicas (Figura 4.4).

Pelas análises geoquímicas das rochas encontradas na região de Jambaló, é possível determinar que os seus protolitos correspondem a rochas básicas que evoluíram para rochas de arco vulcânico e têm associados materiais típicos de precipitação em fundos oceânicos.

Pelos dados geocronológicos obtidos da região de Jambaló, sugere-se que estas rochas correspondam à zona de sutura das rochas vulcânicas oceânicas Mesozóicas com o flanco ocidental da Cordilheira Central, considerando que o choque deste bloco foi quem contribuiu com o processo de geração das rochas da fácies xisto azul. Esta hipótese é reforçada pela geoquímica, que apresenta as rocas de Jambaló como de arco vulcânico.

\subsection{Barragán}

Considerando a petrografia, química mineral, geoquímica e geocronologia $\mathrm{Ar}-\mathrm{Ar}$ surgem algumas idéias sobre as condições de metamorfismo progressivo e retrógrado deu origem a associação de rochas de alta pressão do conjunto de litotipos da região de Barragán, assim como o possível ambiente de geração dos protolitos.

Com os dados petrográficos obtidos mostram o desenvolvimento da foliação metamórfica assim como a milonítica observada na maioria das amostras, sendo que estas duas foliações são fortes indicadoras de eventos tectono-metamórficos, um de caráter regional seguido e outro por cisalhamento, possivelmente relacionado com cavalgamentos e com a exumação das rochas de alta razão $\mathrm{P} / \mathrm{T}$.

Na região de Barragán observam-se poucos veios hidrotermais e mesmo atividade ígnea, razão pela qual as rochas desta área não se apresentam afetadas por metamorfismo térmico, muito embora a presença de andaluzita idioblástica e subidioblástica em um metapelito sugira a presença de rochas ígneas félsicas que não afloram ou não foram encontradas na região de estudo.

Os protolitos das rochas desta região correspondem principalmente a rochas básicas, como indicado pela petrografia, a química mineral e a geoquímica, sendo que com esta última 
ferramenta determinou-se que os protolitos das rochas metamórficas de Barragán correspondem a basaltos de tipo MORB. O modelo de geração e exumação proposto para a região de Barragán e apresentado na Figura 16.3.

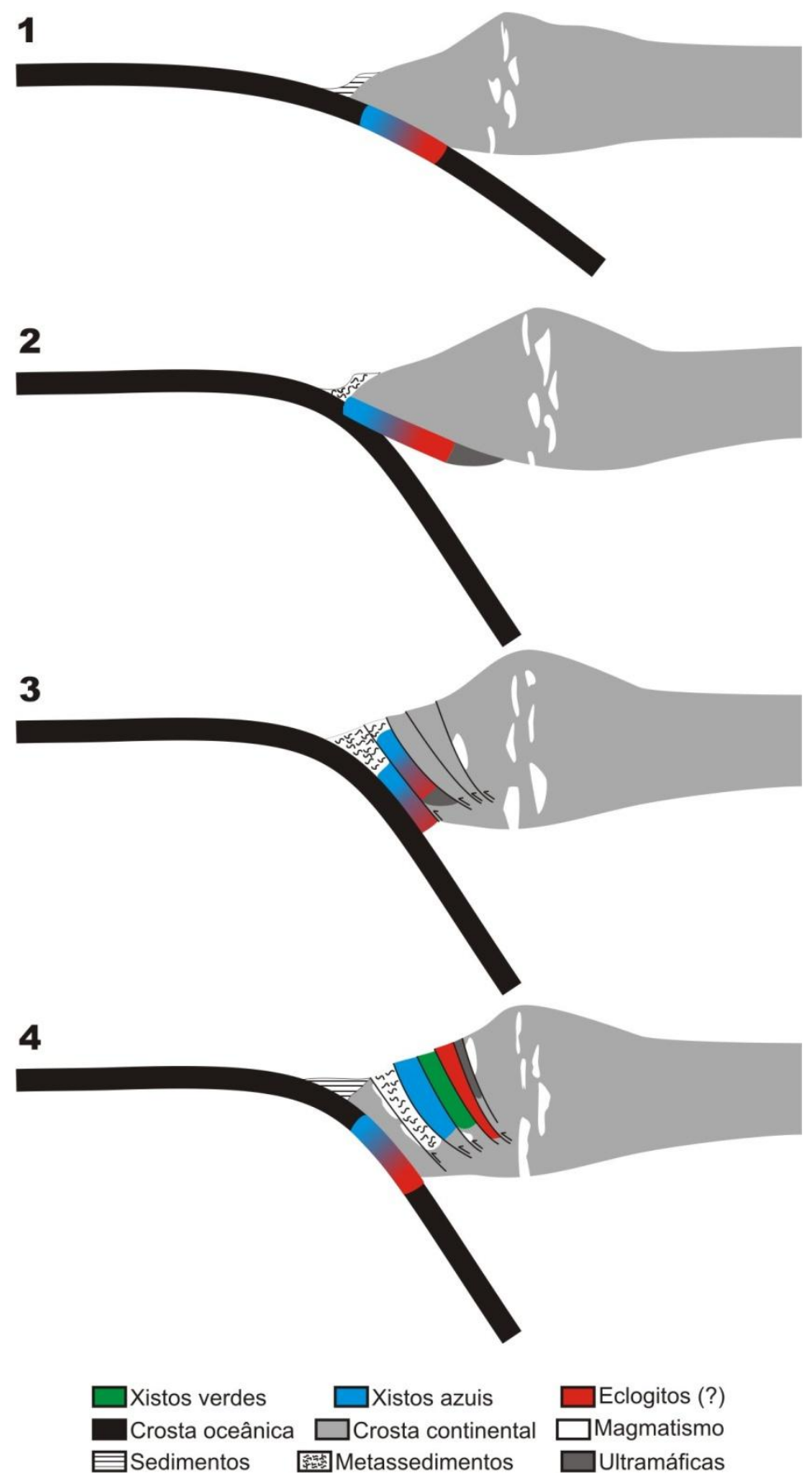

Figura 16.3. Esquema de evolução tectônica (geração e exumação) das rochas de alta pressão da região de Barragán. No estágio 1 mostra-se a subducção de uma placa oceânica sob uma placa continental. No estágio 2 observa-se a quebra e abandono de um fragmento placa subductada e conseqüente mudança no ângulo de subducção. No estágio 3 os fragmentos de crosta que foram metamorfisados em fácies xisto azul e possível eclogito começam a serem incorporados na crosta continental através de falhas geradas pelo alivio das tensões na crosta continental e no estágio 4 mostram-se os xistos azuis e possíveis eclogitos colocados na crosta continental e com transformações para rochas da fácies xisto verde, assim como a presença de pequenas lascas de rochas ultramáficas arrancadas pelo durante o processo de exumação. 
O modelo de geração e exumação proposto para a região de Barragán (Figura 16.3) não apresenta muitas diferenças com o proposto para a região de Jambaló. A principal diferença é na subducção uma placa oceânica sem arcos de ilhas sob uma placa continental, já que os protolitos das rochas de alta pressão desta região são basaltos de tipo MORB. Neste caso, o estágio inicial começou com a subducção, seguido pela quebra e fragmentação da placa subductada, que foi metamorfisada na fácies xisto azul e, possivelmente, eclogito. Logo depois esta placa subductada teve o ângulo de subducção alterado e o bloco metamorfisado em fácies de alta pressão foram gradativamente incorporadas tectonicamente na crosta continental. Neste processo, lascas de rochas ultramáficas foram arrastadas e colocadas em contato tectônico com as rochas de alta pressão. As rochas de alta pressão sofreram um aquecimento que resultou na sua transformação gradativa para xisto verdes, assim como os possíveis eclogitos, resultando em corpos lenticulares, dentro dos quais se preservaram parcialmente os xistos azuis. As rochas sedimentares acumuladas na fossa foram também submetidas a metamorfismo no prisma de acresção e foram justapostas tectônicamente com o restante dos litotipos. O magmatismo associado à subducção pode eventualmente ter gerado metamorfismo de contato, como evidenciado em xistos com andaluzita.

Comparando com os modelos de evolução propostos, sugere-se que as rochas da região de Barragán tenham sido também geradas em regimes tectônicos intermediários entre o Franciscano e o Alpino, ou dos tipos A e B. Estes aspectos reforçam a hipótese da existência de um metamorfismo de fácies xisto azul que poderia ser tentativamente nomeado como do tipo Andino. 


\section{REFERÊNCIAS BIBLIOGRÁFICAS}

ADAMS, C. J., GRAHAM, I. J., JOHNSTON, M. R., 1999. Age and isotopic characterization of geological terranes in Marlbourough Schist, Nelson/Marlborough, New Zealand. New Zealand Journal of Geology \& Geophysics 42, 33-55.

ADAMS, C. J., MAAS, R., 2004. Age/isotopic characterization of the Waipapa Group in Northland and Auckland, New Zealand, and implications for the status of the Waipapa Terrane. New Zealand Journal of Geology \& Geophysics 47, 173-187.

AGARD, P., MONIÉ, P., GERBER, W., OMRANI, J., MOLINARO, M., LABROUSSE, L., VRIELYNCK, B., MEYER, B., JOLIVET, L., YAMATO, P., 2006. Transient, syn-obduction exhumation of Zagros blueschists inferred from P-T-d-t and kinematic constraints: implications for wedge dynamics. Geophysical Research Abstracts 8, 02912.

AHN, J.H., PEACOR, D.R., ESSENE, E.J., 1985. Coexisting paragonite-phengite in blueschist eclogite: a TEM study. American Mineralogist 70, 1193-1204.

ARMBRUSTER, T., BONAZZI, P., AKASAKA, M., BERMANEC, V., CHOPIN, C., GIERÉ, R., HEUSSASSBICHLER, S., LIEBSCHER, A., MENCHETTI, S., PAN, Y., PASERO, M., 2006. Recommended nomenclature of epidote-group minerals. European Journal of Mineralogy 18, 551-567.

ASPDEN, J.A., BONILLA, W., DUQUE, P., 1995. The El Oro metamorphic complex, Ecuador: geology and economic mineral deposits. Overseas Geology and Mineral Resources 67. British Geological Survey Publication, Nottingham, $63 \mathrm{p}$.

ASPDEN, J.A., McCOURT W.J., 1986. Mesozoic oceanic terrane in the Central Andes of Colombia. Geology 14, 415-418.

AVE-LALLEMANT, H.G., 1996. Displacement partitioning and arc-parallel extension: example from the southeastern Caribbean Plate Margin. In: BEBOUT, G.E., SCHOLL, D.W., KIRBY, S.H., PLATT, J.P. (Eds.), Subduction top to bottom. American Geophysical Union, Geophysical Monograph 96, 113-118.

BANERJEE, N.R., GILLIS, K.M., MUEHLENBACHS, K., 2000. Discovery of epidosites in a modern oceanic setting, the Tonga forearc. Geology 28, 151-154.

BECCALUVA, L., OHNENSTETTER, D., OHNESTETTER, M., 1979. Geochemical discrimination between ocean-floor and island-arc-tholeites: application to some ophiolites. Canadian Journal of Earth Sciences 16, 1874-1882.

BERMAN, R.G., 1988. Internally consistent thermodynamic data for minerals in the system $\mathrm{Na}_{2} \mathrm{O}-\mathrm{K}_{2} \mathrm{O}-\mathrm{CaO}-$ $\mathrm{MgO}-\mathrm{FeO}-\mathrm{Fe}_{2} \mathrm{O}_{3}-\mathrm{Al}_{2} \mathrm{O}_{3}-\mathrm{SiO}_{2}-\mathrm{TiO}_{2}-\mathrm{H}_{2} \mathrm{O}-\mathrm{CO}_{2}$. Journal of Petrology 29, 445-522.

BERMAN, R.G., 1991. Thermobarometry using multi-equilibrium calculations: a new technique, with petrological applications. The Canadian Mineralogist 29, 833-855.

BEST, M.G., 2003. Igneous and metamorphic petrology. 2nd edition. Blackwell Publishing Company. 729p.

BETTISON-VARGA, L., VARGA, R.J., SCHIFFMAN, P., 1992. Relation between ore-forming hydrothermal systems and extensional deformation in the Solea Graben spreading center, Troodos Ophiolite, Cyprus. Geology 20, 987-990.

BOSCH, D., GABRIELE, P., LAPIERRE, H., MALFERE, J-L., JAILLARD, E., 2002. Geodynamic significance of the Raspas Metamorphic Complex (SW Ecuador): geochemical and isotopic constraints. Tectonophysics 345, 83-102.

BOURGOIS, J., TOUSSAINT, J.F., GONZALEZ, H., AZEMA, J., CALLE, B., DESMET, A., MURCIA, L.A., ACEVEDO, A.P., PARRA, E., TOURNON, J., 1987. Geological history of the Cretaceous ophiolitic complexes of northwestern South America (Colombian Andes). Tectonophysics 143, 307-327. 
BOWES, D.R., 1989. The encyclopedia of igneous and metamorphic petrology. Van Nostrand Reinhold, pp. 184-187.

BROWN, T.H., BERMAN, R., PERKINS E.H., 1988. Ge0-Calc; software package for calculation and display of pressure-temperature-composition phase diagrams using an IBM or compatible personal computer. Computers and Geosciences 14, 279-289.

BROWN, T.H., BERMAN, R., PERKINS E.H., 1989. PTA-SYSTEM; a Ge0-Calc software package for the calculation and display of activity-temperature-pressure phase diagrams. American Mineralogist 74, 485487.

BUCHER, K., FREY, M., 1994. Petrogenesis of metamorphic rocks. Springer-Verlag, $318 \mathrm{p}$.

CABANIS, B., LECOLLE, M., 1989. Le diagramme La/10-Y715-Nb/8: on outil por la discrimination fes séries volcaniques et la mise en évidence des processus de mélange et/ou de contamination crustale. Comptes Rendus Academies Scieces Paris, Serie II, 2023-2029.

CASTELLI D., CONNOLLY, J.A.D., FRANCESCHI, G., 1997. VERTEXVIEW: an interactive program to analyze and plot petrological phase diagrams. Computers and Geosciences 23, 883-888.

CLAUER, N., CHAUDURI, S., 1999. Isotopic dating of very low-grade meta-sedimentary and meta-volcanic rocks. Methods and techniques. In: Frey, M., Robinson, D. (ed), Low-Grade Metamorphism. BlackwellScience. 202-226.

CLOOS, M., 1982. Flow melanges: numerical modeling and geologic constraints on their origin in the Franciscan subduction complex, California. Geological Society of America Bulletin 93, 330-344.

COLEMAN, R.G., 1972. Blueschist metamorphism and plate tectonics. Report of the Session. International Geological Congress, 24. Anais..., USGS, v. 2, 19-26

CONNOLLY, J.A.D., 1990. Multivariable phase diagrams; an algorithm based on generalized thermodynamics. American Journal of Science 290, 666-718.

COOMBS, D.S., NAKAMURA, Y., VUAGNAT, M., 1976. Pumpellyite-actinolite facies schists of the Taveyanne Formation near Loeche, Valais, Switzerland. Journal of Petrology 17, 440-471.

CORTESOGNO, L., LUCCHETTI, G., SPADEA, P., 1984. Pumpellyite in low-grade metamorphic rocks from Ligurian and Lucanian Apennines, Maritime Alps and Calabria (Italy). Contributions to Mineralogy and Petrology 85, 14-24.

DAHL, P. S., 1996. The effects of compositionon retentivity of argon and oxigen in hornblende and related amphiboles: A field-tested empirical model. Geochemica et Cosmochemica Acta 60, 3687-3700.

DALLMAYER R. A., TAKASU, A., 1992. ${ }^{40} \mathrm{Ar} /{ }^{39} \mathrm{Ar}$ ages of detrital muscovite and whole-rock slate/phyllite, Narragansett Basin, RI-MA, USA: implications for rejuvenation during very low-grade metamorphism. Contributions to Mineralogy and Petrology 110, 515-527.

DE CAPITANI, C., BROWN, T.H., 1987. The computation of chemical equilibrium in complex systems containing non-ideal solutions. Geochimica et Cosmochimica Acta 51, 2639-2652.

DE SOUZA, H.A.F., ESPINOSA, A., DELALOYE, M., 1984. K-Ar ages of basic rocks in the Patia Valley, southwest Colombia. Tectonophysics 107, 135-145.

DEER, W.A., HOWIE, R.A., ZUSSMAN, J., 1986. Rock-Forming Minerals, vol 1B, Disilicates and Ring Silicates .vol 1B. Longman Scientific \& Technical, England. 629 pp.

DEER, W.A., HOWIE, R.A., ZUSSMAN, J., 1992. An introduction to the rock-forming minerals. Longman Scientific \& Technical. USA. $696 p$. 
DESMONS, J., SMULIKOWSKI, W., 2007. A systematic nomenclature for metamorphic rocks: 4. High P/T metmorphic rocks. Recommendations by the IUGS Subcommission on the Systematics of Metamorphic Rocks. Recommendations, web version.

DICKIN, A. P., 1995. Radiogenic Isotope Geology. Cambridge University Press. 490 p.

DONG, H.L., HALL, C.M., PEACOR, D.R., HALLIDAY, A.N., 1995. Mechanisms of argon retention in clays revealed by laser ${ }^{40} \mathrm{Ar}^{-39} \mathrm{Ar}$ dating. Science $267,355-359$.

DRAPER, G., LEWIS J.F., 1991. Metamorphic belts of central Hispaniola. In: MANN, P., DRAPER, G., LEWIS, J.F., (Eds.), Geologic development of the North American-Caribbean plate boundary in Hispaniola: Geological Society of America Special Paper 262, 29-45.

DRITS, V.A., LINDGREEN, H., SAKHAROV, B.A., JAKOBSEN, H.J., FALLICK, A.E., SALYN, A.L., DAINYAK, L.G., ZVIAGINA, B.B., BARFOD, D.N., 2007. Formation and transformation of mixed-layer minerals by Tertiary intrusives in Cretaceous mudstones, West Greenland. Clays and Clay Minerals 55, 260-283.

DROOP, G.T.R., 1987. A general equation for estimating $\mathrm{Fe}^{3+}$ concentrations in ferromagnesian silicates and oxides from microprobe analyses, using stoichiometric criteria. - Mineralogical Magazine 51, 431435.

EL SHAZLY, A.K., 1994. Petrology of lawsonite-, pumpellyite- and sodic amphibole-bearing metabasites from north-east Oman. Journal of Metamorphic Geology 12, 23-48.

ERNST, W.G., 1972. Ocurrence and mineralogic evolution of blueschist belts with time. American Journal of Science 272, 657-668.

ERNST, W.G., 1988. Tectonic history of subduction zones inferred from retrograde blueschit P-T paths. Geology 16, 1081-1084.

ESKOLA, P., 1939. Die metamorphen Gesteine. In: Barth, T.F.W., Correns, C.W., Eskola, P. (Eds.), Die Entstehung der Gesteine; Ein Lehrbuch der Petrogenese. Springer, Berlin, pp. 263-407.

ESQUIVEL, J., FLOREZ, D., NUÑEZ, A., 1981. Anfibolitas granatíferas, esquistos anfibólicos y rocas máficas - ultramáficas al Este de Buga - Palmira, Valle, Colombia. Resúmenes, III Congreso Colombiano de Geología, Medellín, 40-41.

FAURE, G., 1986. Principles of Isotope geology. John Wiley \& Sons. 589 p.

FEENSTRA, A., 1996. An EMP and TEM-AEM study of margarite, muscovite and paragonite in polymetamorphic metabauxites of Naxos (Cyclades, Greece) and the implications of fine-scale mica interlayering and multiple mica generations. Journal of Petrology 37, 201-233.

FEININGER, T., 1980. Eclogite and related high-pressure regional metamorphic rocks from the Andes of Ecuador. Journal of Petrology 21, 107-140.

FEININGER, T., 1982. Glaucophane schist in the Andes at Jambaló, Colombia. The Canadian Mineralogist 20, 41-47.

FEININGER, T., BARRERO, D., CASTRO, N., 1972. Geología de los departamentos de Antioquia y Caldas (Sub zona IIB): Boletín Geológico INGEOMINAS 20(2), 173 p.

FITZHERBERT, J. A., CLARKE, G. L., POWELL, R., 2003. Lawsonite-Omphacite-Bearing Metabasites of the Pam Peninsula, NE New Caledonia: Evidence for Disrupted Blueschist- to Eclogite-Facies Conditions. Journal of Petrology 44, 1805-1831. 
FORERO-SUÁREZ, A., 1991. Distribución de las rocas del Devónico en los Andes Colombianos. En: Suarez, R(ed). Trabajos presentados en la reunión del Proyecto 193, Siluro-Devonian of Latin America. La Paz, Bolivia. Revista Técnica de Yacimientos Petrolíferos Fiscales Bolivianos 12, 101-111.

FYFE, W.S., TURNER, F.J., 1966. Reappraisal of the metamorphic fácies concept. Contributions to Mineralogy and Petrology 12, 354-364.

GILL, J.B., 1981. Orogenic andesites and plate tectonics. Springer Verlag, Berlin. 390 p.

GIUNTA, G., BECCALUVA, L., COLTORTI, M., SIENA, F., VACCARO, C., 2002. The southern margin of the Caribbean Plate in Venezuela: tectono-magmatic setting of the ophiolitic units and kinematic evolution. Lithos 63, 19-40.

GONZÁLEZ, H., 1980. Geología de las planchas 167 (Sonsón) y 187 (Salamina). Boletín Geológico INGEOMINAS 23, $174 \mathrm{p}$.

GONZÁLEZ, H., 1997. Metagabros y eclogitas asociadas en el área de Barragán, departamento del Valle, Colombia. Geología Colombiana 22, 151-170.

GROTJOHANN, H., McCOURT, W., 1981. Resultados de los trabajos corrientes en la cartografía geológica regional del departamento del Valle (Cordillera Central). Resúmenes, III Congreso Colombiano de Geología, Medellín, 3-4.

GUIDOTTI, C. V., SASSI, F. P., SASSI, R., BLENCOE, J. G., 1994. The effects of ferromagnesian components on the paragonite-muscovite solvus: a semiquantitative analysis based on chemical data for natural paragonite-muscovite pairs. Journal of Metamorphic Geology 12, 779-788.

HALL, C.M., HIGUERAS, P.L., KESLER, S.E., LUNAR, R., DONG, H.L., HALLIDAY, A.N., 1997. Dating of alteration episodes related to mercury mineralization in the Almaden district, Spain. Earth and Planetary Sciences Letters 148, 287-298.

HEY M. H., 1954. A new review of the chlorites. Mineralogical Magazine 30, 277-292.

HIBBARD, 1995. Petrography to petrogenesis. Prentice Hall. USA. 335p.

HUNZIKER, J. C., 1986. The evolution of illite to muscovite; an example of the behaviour of isotopes in lowgrade metamorphic terrains. Chemical Geology 57, 31-40.

IRVINE, T.N., BARAGAR, W.R.A., 1971. A guide to the chemical classification of the common volcanic rocks. Canadian Journal of Earth Sciences 8, 523-548.

JAILLARD, E., SOLER, P., CARLIER, G., MOURIER, T., 1990. Geodynamic evolution of the Northern and Central Andes during early and middle Mesozoic times: a Tethyan model. Journal of the Geological Society of London 147, 1009-1022.

JOHHANNES, W., PUHAN, D., 1971. The calcite-aragonite transition, reinvestigated. Contributions to Mineralogy and Petrology 31, 28-38.

JULIANI, C., McREATH, I., 1993. Petroquímica de metabasitos: metodologia para identificação de alterações magmáticas e pós-magmáticas. Revista Geologia, Ciência \& Técnica, Centro Paulista de Estudos Geológicos - CEPEGE, 10, 50-96.

KERR, A.C., MARRINER, G.F., TARNEY J., NIVIA, A., SAUNDERS, A.D., THIRLWALL, M.F., SINTON, C.W., 1997. Cretaceous basaltic terranes in westen Colombia: elemental, chronological and $\mathrm{Sr}-\mathrm{Nd}$ isotopic contraints on petrogenesis. Journal of Petrology 38, 677-702.

KRETZ, R., 1983. Symbols for rock-forming minerals. American Mineralogist 68, 277-279.

LAVIS, S., PEARCE. J.A., KERR, A.C., NIU, Y., 2005. Recycling in Subduction Zones: Evidence from 
blueschists and eclogites from NW China. Geophysical Research Abstracts 7, 07584.

LE MAITRE, R.W., STRECKEISEN, A., ZANETTIN, B., LE BAS, M.J., BONIN, B., BATEMAN, P., BELLIENI, G., DUDEK, A., EFREMOVA, S., KELLER, J., LAMEYRE, J., SABINE, P.A., SCHMID, R., SORENSEN, H., WOOLLEY, A.R., 2002. Igneous rocks: a classification and glossary of terms. Recommendations of the International Union of Geological Sciences Subcommission on the Systematics of Igneous Rocks. 2 ed.Cambridge University Press, United Kingdom. 236 p.

LEAKE, B. E., WOOLLEY, A. R., BIRCH, W. D., BURKE, E. A. J., FERRARIS, G., GRICE, J. D., HAWTHORNE, F. C., KISCH, H. J., KRIVOVICHEV, V. G., SCHUMACHER, J. C., STEPHENSON, N. C. N., WHITTAKER, E. J. W., 2004. Nomenclature of amphiboles: additions and revisions to the International Mineralogical Association's amphibole nomenclature. Mineralogical Magazine 68, 209-215.

LEAKE, B.E., WOOLLEY, A.R., ARPS, C.E.S., BIRCH, W.D., GILBERT, M.C., GRICE, J.D., HAWTHORNE, F.C., KATO, A., KISCH, H.J., KRIVOVICHEV, V.G., LINTHOUT, K., LAIRD, J., MANDARINO, J.A., MARESCH, W.V., NICKEL, E.H., ROCK, N.M.S., SCHUMACHER, J.C., SMITH, D.C., STEPHENSON, N.C.N., UNGARETTI, L., WHITTAKER, E.J.W., YOUZHI, G., 1997. Nomenclature of amphiboles: report of the subcommittee on amphiboles of the International Mineralogical Association, commission on new minerals and mineral names. Canadian Mineralogist 35, 219-246.

LITHERLAND, M., ASPDEN, J.A., EGUEEZ, A., 1993. The geotectonic evolution of Ecuador in the Phanerozoic. In: ISAG 93; International Symposium on Andean Geodynamics; Extended Abstracts, pp. 215-218.

MAEKAWA, H., SHOZUI, M., ISHII, T., FRYER, P., PEARCE, J.A., 1993. Blueschist metamorphism in an active subduction zone, Nature, 364, 520-523.

MARUYAMA, S., 1995. Blueschist of the world and their exhumation model. Bochumer geologische und geotechnische Arbeiten 44, 104-108.

MARUYAMA, S., LIOU, J.G., TERABAYASHI, M., 1996. Blueschists and eclogites of the world and their exhumation. International Geology Review 38, 485-594.

MAYA M., GONZÁLEZ, H., 1995. Unidades litodémicas en la Cordillera Central de Colombia. Boletín Geológico INGEOMINAS 35, 43-57.

MAYA, M., 2001. Distribución, facies y edad de las rocas metamórficas en Colombia. Informe I-2426. INGEOMINAS, $57 \mathrm{p}$.

McCOURT, W.J., 1984. The geology of the central Cordillera in the departments of Valle del Cauca, Quindio and NW Tolima (Sheets 243, 261, 262, 280 Y 300). INGEOMINAS - Misión Británica, Informe interno.

McCOURT, W.J., FEININGER, T., 1984. High pressure metamorphic rocks in the Central Cordillera of Colombia. British Geological Survey Reprint Series 84, 28-35.

MCDOUGALL, I., HARRISON, T. M., 1999. Geochronology and thermochronology by the Ar/Ar method. Oxford University Press. $269 \mathrm{p}$.

MCLENNAN, S. M., HEMMING, S., MCDANIEL, D. K., HANSON, G. N., 1993. Geochemical approaches to sedimentation, provenance and tectonics. Geological Society of America, Special Paper 284, 21-40.

MEGARD, F., 1987. Cordilleran Andes and Marginal Andes: A review of andean geology North of the Arica elbow (18ㅇ). American Geophysical Union Monography 18, 71-95.

MESCHEDE, M., 1986. A method of discriminating between different types of mid-ocean ridge basalts and continental tholeiites with the Nb-Zr-Y diagram. Chemical Geology 56, 207-218. 
MIHALYNUK, M.G., ERDMER, P., GHENT, E.D., CORDEY, F., ARCHIBALD, D.A., FRIEDMAN, R.M., JOHANNSON, G.G., 2004. Coherent French Range blueschist: Subduction to exhumation in <2.5 m.y.?. Geological Society of America Bulletin 116, 910-922.

MIYASHIRO, A., 1957. The chemistry, optics and genesis of the alkali amphiboles. Journal of the Faculty of Science, University of Tokyo, Section II, 11, 57-83.

MIYASHIRO, A., 1961. Evolution of metamorphic belts. Journal of Petrology 2, 277-311.

MIYASHIRO, A., 1975. Tholeiitic and calc-alkalic series in relation to the behaviors of titanium, vanadium, chromium, and nickel. American Journal of Science 275, 265-277.

MOJICA, J., ARÉVALO, O. J., BLANCO, M., CAICEDO, H., ESPINOSA, A., 2001. Geología del Flanco Occidental de la Cordillera Central entre Salento, Génova y Caicedonia, Quindío - Valle, Colombia. VIII Congreso Colombiano de Geología, Memorias (CD).

MOSQUERA, D., 1978. Geología del Cuadrángulo K-8. Informe interno. INGEOMINAS, 1-78.

MOSQUERA, D., NUÑEZ, A., VESGA, J., 1982. Mapa geológico de la Plancha 244 -lbagué-, Escala 1:100.000. INGEOMINAS.

MURCIA, A, CEPEDA, H., 1991a. Mapa geológico de la Plancha 410 -La Unión-, Escala 1:100.000. INGEOMINAS.

MURCIA, A, CEPEDA, H., 1991b. Mapa geológico de la Plancha 429 -Pasto-, Escala 1:100.000. INGEOMINAS.

NEHLIG, P., JUTEAU, T., BENDEL, V., COTTEN, J., 1994. The root zones of oceanic hydrothermal systems; constraints from the Samail Ophiolite (Oman). Journal of Geophysical Research, B, Solid Earth and Planets 99, 4703-4713.

NELSON, W., 1957. Contribution to the Geology of the Central and Western Cordillera of Colombia in the Sector Between Ibague and Cali. Leidse Geologische Mededelingen 22, 1-75.

NESSE, W.D., 1991. Introduction to optical mineralogy. $3^{\text {rd }}$ edition. Oxford University Press. USA. 349 p.

NOBLE, S.R., ASPDEN, J.A., JEMIELITA, R., 1997. Northern Andes Crustal Evolution: New U-Pb geochronological constraints from Ecuador. Geological Society of America Bulletin 109, 789-798.

NÚNEZ, A., MURILLO, A., 1978. Esquistos de glaucofana en el municipio de Pijao, Quindio (Colombia). Congreso Colombiano de Geología, 2, Bogotá, Resúmenes..., pp. 1-18.

OKAY, A.I., 1980. Mineralogy, petrology and phase relations of glaucophane-lawsonite zone blueschists from the Tavşanli region, Northwest Turkey. Contributions to Mineralogy and Petrology 72, 243-255.

OKUYAMA, K.Y., 1985. Margarite-paragonite-muscovite assemblages from the low-grade metapelites of the Tono metamorphic aureole, Kitakami Mountains, Northeast Japan. Journal of the Japanese Association of Mineralogists, Petrologists and Economic Geologists 80, 515-525.

ORREGO, A., CEPEDA, H., RODRIGUEZ, G., 1980. Esquistos Glaucofánicos en el área de Jambaló, Cauca (Colombia). Geología Norandina 1, 5-10.

ORREGO, A., LEON, L.,PADILLA, L, ACEVEDO, A.P., MARULANDA, N., 1993. Mapa geológico de la Plancha 364 - Timbío; Escala 1:100.000. INGEOMINAS.

ORREGO, A., PARÍS, G., 1991. Mapa geológico del Cuadrángulo N-6 Popayán; Informe interno. Escala 1:100.000, INGEOMINAS. 
ORREGO, A., RESTREPO J.J., TOUSSAINT J.F., LINARES, E., 1980b. Datación de un esquisto sericítico de Jambaló, Cauca. Publicación Especial - Geología Universidad Nacional 25, 133-134.

PASSCHIER, C. W., TROUW, R. A, 1996. Microtectonics. Springer. 288p.

PEARCE, J. A, 1982. Trace element characteristics of lavas from destructive plate boundaries. In: Thorpe, R. S. (ed) Andesites. John Wiley \& Sons. 525-548.

PEARCE, J. A, NORRY, 1979. Petrogenetic implications of $\mathrm{Ti}, \mathrm{Zr}, \mathrm{Y}$ and $\mathrm{Nb}$ variations in volcanic rocks. Contributions to Mineralogy and Petrology 69, 33-47.

PEARCE, J.A., 2008. Geochemical fingerprinting of oceanic basalts with applications to ophiolite classification and the search for Archean oceanic crust. Lithos 100, 14-48.

PEARCE, J.A., CANN, J.R., 1973. Tectonic setting of basic volcanic rocks determinated using trace element analysis. Earth and Planetary Sciences Letters 19, 290-300.

PETTKE, T., HALLIDAY, A.N., HALL, C.M., REA, D.K., 2000. Dust production and deposition in Asia and the north Pacific Ocean over the past 12 Myr. Earth and Planetary Science Letters 178, 397-413.

PLATT, J.P., 1987. The uplift of high-pressure-low-temperature metamorphic rocks. Philosophical Transactions of the Royal Society of London A321, 87-103.

POWELL, R. \& HOLLAND. T.J.B., 1985. An internally consistent thermodynamic dataset with uncertainties and correlations: I Methods and worked example. Journal of Metamorphic Geology, 1: 327-342.

POWELL, R. \& HOLLAND. T.J.B., 1988. An internally consistent thermodynamic dataset with uncertainties and correlations: III Applications to geobarometry, worked examples and a computer program. Journal of Metamorphic Geology, 6: 173-204.

RESTREPO, J.J., TOUSSAINT, J.F., 1975. Edades radiométricas de algunas rocas de Antioquia, Colombia. Publicación Especial de Geología, Universidad Nacional Medellín 6, 1-24.

RESTREPO, J.J., TOUSSAINT, J.F., 1982. Metamorfismos superpuestos en la Cordillera Central de Colombia: V Congreso Latinoamericano de Geología, Argentina. Actas 3, 505-512.

RESTREPO, J.J., TOUSSAINT, J.F., 1984. Unidades Litológicas de los Alrededores de Medellín: Primera Conferencia de Riesgos Geológicos del Valle de Aburrá, Medellín, 25 p.

RESTREPO, J.J., TOUSSAINT, J.F., 1988. Terranes and continental accretion in the Colombian Andes. Episodes 11, 189-193.

RICHARDSON, C.J., CANN, J.R., RICHARDS, H.G., COWAN, J.G., 1987. Metal-depleted root zones of the Troodos ore-forming hydrothermal systems, Cyprus. Earth and Planetary Science Letters 84, 243-253.

RING, U., BRANDON, M.T., WILLET, S.D., LISTER, G.S., 1999. Exhumation processes. In: RING, U., BRANDON, M.T., WILLET, S.D., LISTER, G.S. (eds) Exhumation Processes: Normal Faulting, Ductile Flow and Erosion. Geological Society, London, Special Publications 154, 1-27.

RUBATTO, D., 2002. Zircon trace element geochemistry: partitioning with garnet and the link between U-Pb ages and metamorphism. Chemical Geology 184, 123-138.

SCHIFFMAN, P., SMITH, B.M., VARGA, R.J., MOORES, E.M., 1987. Geometry, conditions and timing of offaxis hydrothermal metamorphism and ore-deposition in the Solea Graben. Nature 325, 423-425.

SCHMID, R., FETTES, D., HARTE, B., DAVIS, E., DESMONS, J., 2007. A systematic nomenclature for metamorphic rocks: 1. How to name a metamorphic rock. Recommendations by the IUGS Subcommission on the Systematics of Metamorphic Rocks. Recommendations, web version. 
SCHULMANN, K., FARYAD, S.W., LEXA, O., 2004. Evolutionary Model for exhumation of the Meliata Blueschists, Western Carpathians (Slovakia). Geolines 17, 81.

SHAU, Y.H., FEATHER, M.E., ESSENE, E.J., PEACOR, D.R., 1991. Genesis and solvus relations of submicroscopically intergrown paragonite and phengite in a blueschist from Northern California. Contributions to Mineralogy and Petrology 106, 367-378.

SHERVAIS, J. W., 1982. Ti-V plots and the petrogenesis of modern and ophiolitic lavas. Earth and Planetary Science Letters 59, 101-118.

SMITH, C.A., SISSON, V.B., AVÉ-LALLEMANT, H.G., COPELAND, P., 1999. Two contrasting pressuretemperature-time paths in the Villa de Cura blueschist belt, Venezuela: Possible evidence for Late Cretaceous initiation of subduction in the Caribbean. Geological Society of America Bulletin 111, 831848.

SORENSEN, S.S., 1986. Petrologic and geochemical comparison of the blueschist and greenschist units of the Catalina Schist terrane, southern California. In: Evans, B.W., Brown, E.H. (eds). Blueschists and Eclogites. Geological Society of America Memoir 164, 59-75.

SPEAR, F.S., 1989. Petrologic determination of metamorphic pressure-temperature-time paths. In: Spear, F.S., Peacock, S.M., 1989. Metamorphic Pressure-temperature-time paths. Short Course in Geology, American Geophysical Union, Washington D.C., 1-55 p.

SPEAR, F.S., 1995. Metamorphic phase equilibria and pressure-temperature-time paths. Mineralogical Society of America, $799 \mathrm{p}$.

SPRY, A., 1969. Metamorphic textures. Pergamon Press. Great Britain. 350 p.

SUN, S., McDONOUGH, W. F., 1989. Chemical and isotopic systematics of oceanic basalts: implications for mantle composition and processes. In: Saunder, A. D., Norry, M. J. (Eds), Magmatism in the Ocean Basins. Geological Society Special Publication 42, 313-345.

TISCHENDORF, G., 1997. On Li-bearing micas: estimating Li from electron microprobe analyses and an improved diagram for graphical representation. Mineralogical Magazine 61, 809-834.

TOUSSAINT, J.F., 1993. Evolución Geológica de Colombia, Precámbrico-Paleozoico. Universidad Nacional de Colombia. Medellín, 229 p.

TOUSSAINT, J.F., 1996. Evolución Geológica de Colombia. Cretácico. Universidad Nacional de Colombia. Medellín. 277 p.

TOUSSAINT, J.F., RESTREPO, J.J., 1978. Edad cretácea de una anfibolita granatífera de Pijao, Quindío. Publicación Especial Geológica, Universidad Nacional Medellín 17, 1-2.

TRÖGER, W.E., 1979. Optical determination of rock-forming minerals. Part I determinative tables. Scheweizerbart'sche Verlagsbuschhandlung. Deutchland. $188 \mathrm{p}$.

VERNON, R.H., 2005. A Practical Guide to Rock Microstructure. Cambridge University Press. UK. 552 p.

VILLA, I., 1997. Isotopic Closure. Terra Nova 10, 42-47.

VINASCO, C. J., CORDANI, U.G., WEBER, M., PELAEZ, C., 2006. Geochronological, isotopic, and geochemical data from Permo-Triassic granitic gneisses. Journal of South American Earth Sciences 21, 355-371.

VINASCO, C., 2001. A utilização da metodologia ${ }^{40} \mathrm{Ar}-{ }^{39} \mathrm{Ar}$ para o estudo de reativações tectônicas em zonas de cisalhamento. Paradigma - o falhamento de Romeral nos Andes Centrais da Colômbia. Dissertação de mestrado. Universidade de São Paulo, São Paulo, SP. 112 p. 
WEBER, M.B.I., TARNEY, J., KEMPTON, P.D. KENT R.W., 2002. Crustal make-up of the northern Andes: evidence based on deep crustal xenolith suites, Mercaderes, SW Colombia. Tectonophysics 345, 49-82.

WILSON, M., 1989. Igneous Petrogenesis. Seventh reprinted. Chapman \& Hall. 467p

WINCHESTER, J. A, FLOYD, P. A, 1977. Geochemical discrimination of different magma series and their differentiation products using inmobile element. Chemical Geology 20, 325-343.

WINCHESTER, J.A., MAX, M.D., 1989. Tectonic setting discrimination in clastic sequences; an example from the late Proterozoic Erris Group, NW Ireland. Precambrian Research 45, 191-201.

WOOD, D. A., 1980. The application of a Th-Hf-Ta diagram to problems of tectonomagmatic classification and to the stablishing the nature of crustal contamination of basaltica lavas of British tertiary volcanic province. Earth and Planetary Science Letters 50, 11-30.

YARDLEY B.W.D., 1989. An introduction to metamorphic petrology. Longman Scientific \& Technical, UK, $248 p$.

ZHANG, R.Y., LIOU, J.G., ZHENG, Y.F., FU, B., 2003. Transition of UHP eclogites to gneissic rocks of lowamphibolite facies during exhumation: evidence from the Dabie terrane, central China. Lithos 70, 269291. 


\section{ANEXOS}

I. Mapa esquemático da região de Jambaló

II. Mapa esquemático da região de Barragán

III. Análises de química mineral selecionadas da região de Jambaló

IV. Análises de química mineral selecionadas da região de Barragán

V. Análises geoquímicas completas das amostras da região de Jambaló

VI. Análises geoquímicas completas das amostras da região de Barragán 
ANEXOS I e II. Mapas esquemáticos das regiões de Jambaló e Barragán 


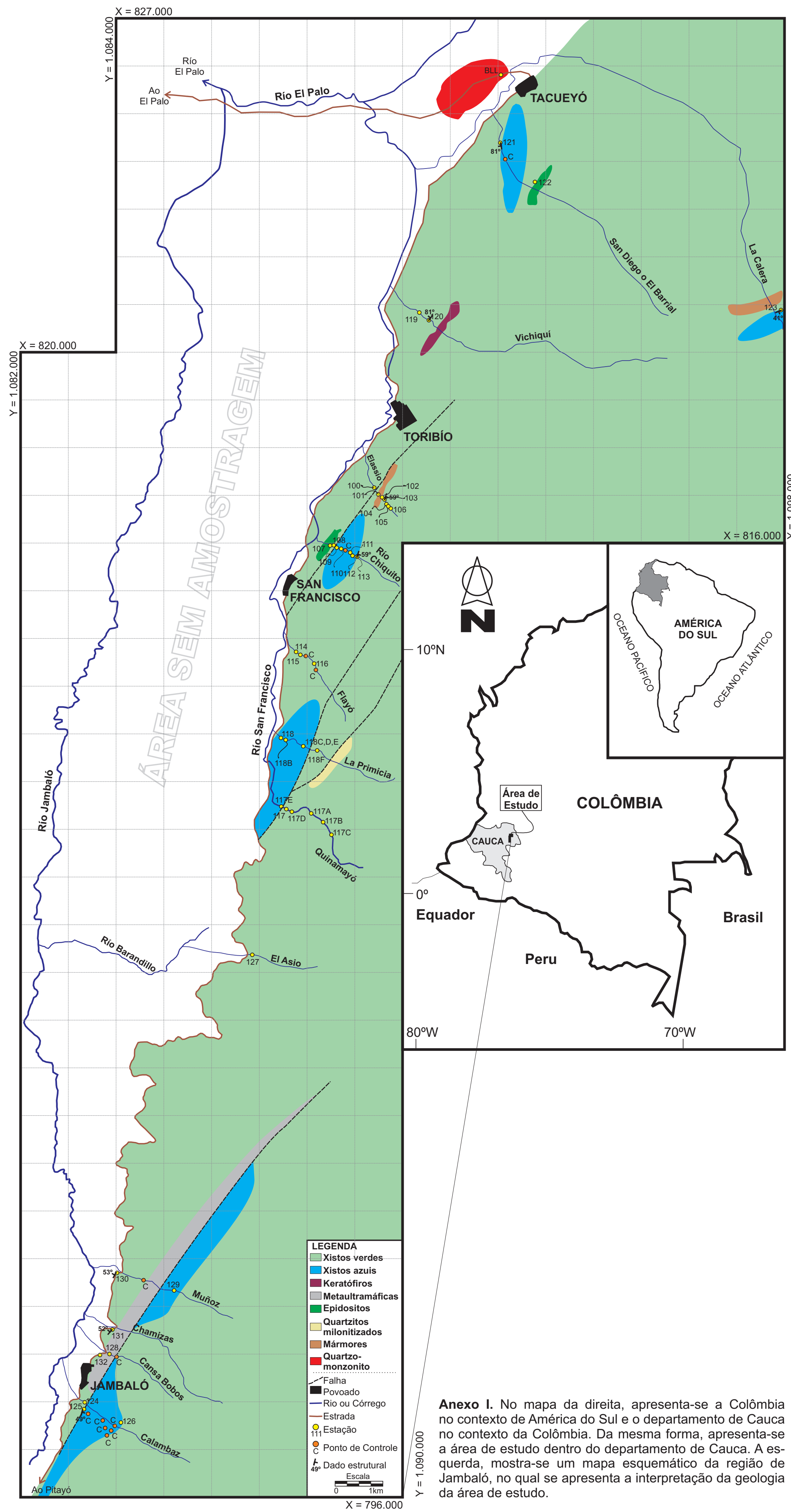




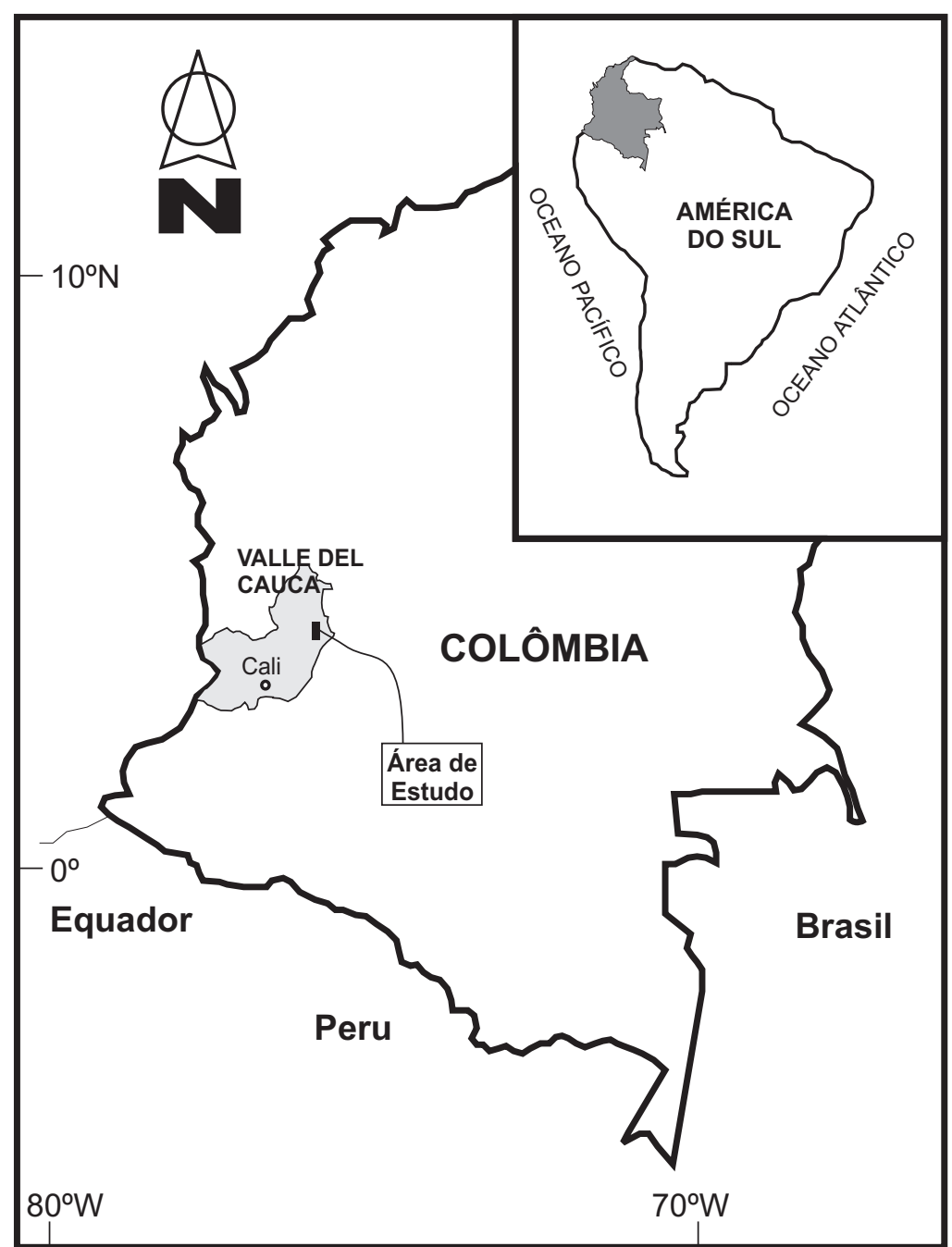

Anexo II. No mapa da esquerda, apresenta-se a Colômbia no contexto de América do Sul e o departamento de Valle del Cauca no contexto da Colômbia. Da mesma forma, apresenta-se a área de estudo dentro do departamento de Valle del Cauca. À direita, mostra-se um mapa esquemático da região de Barragán, no qual se apresenta a interpretação da geologia da área de estudo.

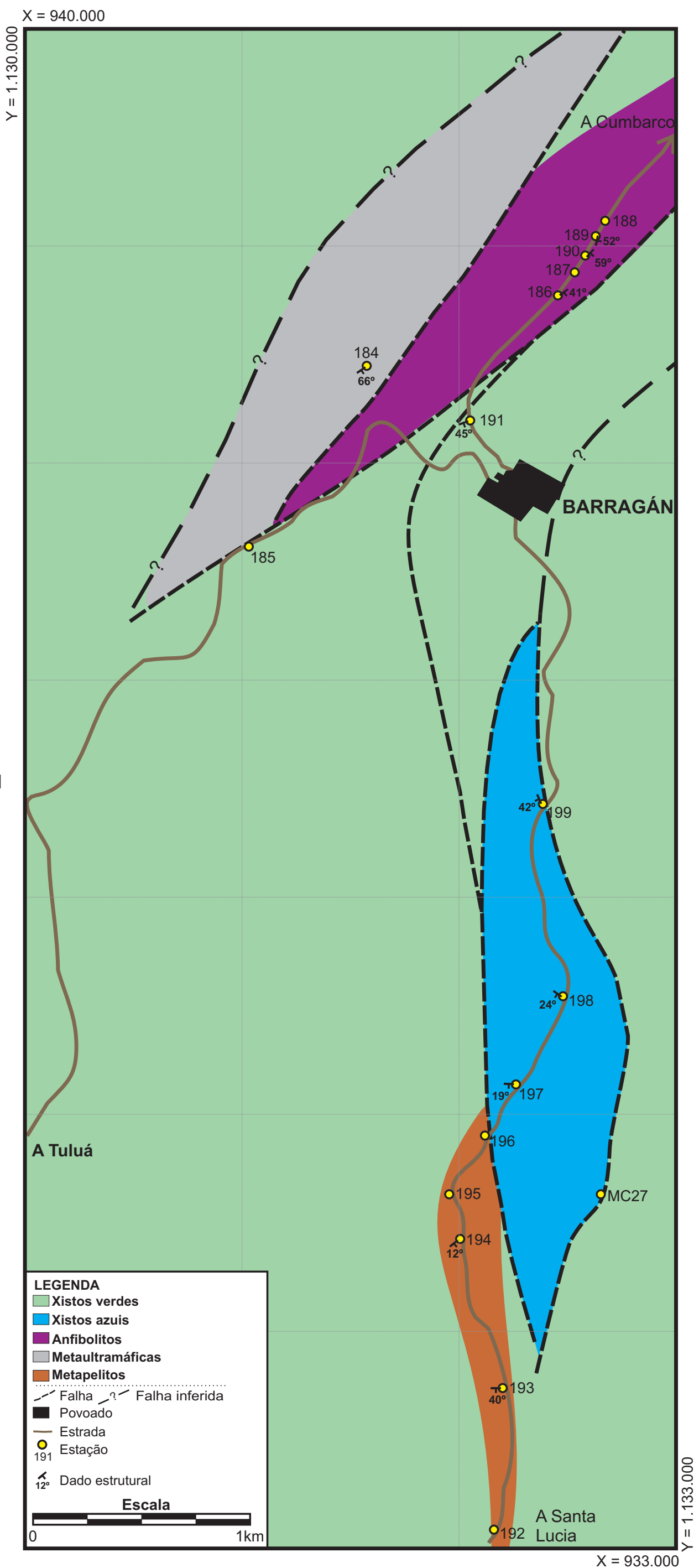


ANEXO III. Análises de química mineral selecionadas da região de Jambaló 
Analıses de quimıca mıneral de antıbolıo selecıonados da regıao de Jambalo

\begin{tabular}{|c|c|c|c|c|c|c|c|c|c|c|c|c|c|c|c|c|c|c|}
\hline Amostra & 107 & 107 & 107 & 107 & 107 & 107 & 107 & 107 & 107 & 107 & 107 & 107 & 107 & 107 & 107 & 107 & 107 & 107 \\
\hline Análise & 335 & 336 & 337 & 338 & 339 & 340 & 342 & 343 & 344 & 345 & 389 & 390 & 391 & 392 & 393 & 394 & 395 & 396 \\
\hline $\mathrm{SiO2}$ & 51.38 & 52.45 & 52.45 & 51.33 & 53.12 & 53.96 & 51.70 & 51.43 & 47.39 & 51.41 & 52.15 & 53.89 & 53.54 & 49.92 & 47.48 & 51.83 & 53.19 & 53.59 \\
\hline TiO2 & 0.06 & 0.04 & 0.00 & 0.12 & 0.10 & 0.12 & 0.02 & 0.08 & 0.29 & 0.02 & 0.00 & 0.12 & 0.08 & 0.04 & 0.35 & 0.00 & 0.08 & 0.08 \\
\hline $\mathrm{Al} 2 \mathrm{O} 3$ & 2.57 & 3.13 & 4.21 & 5.54 & 2.87 & 2.79 & 5.37 & 4.86 & 9.95 & 4.09 & 3.51 & 1.72 & 5.35 & 5.17 & 9.70 & 3.40 & 3.06 & 2.73 \\
\hline $\mathrm{FeO}$ & 18.10 & 19.60 & 18.10 & 17.20 & 18.33 & 16.28 & 18.32 & 18.31 & 19.18 & 17.83 & 18.40 & 17.12 & 16.76 & 19.77 & 19.29 & 19.67 & 18.76 & 19.16 \\
\hline MnO & 0.35 & 0.48 & 0.46 & 0.47 & 0.52 & 0.32 & 0.39 & 0.53 & 0.36 & 0.42 & 0.46 & 0.41 & 0.37 & 0.52 & 0.46 & 0.47 & 0.50 & 0.49 \\
\hline MgO & 12.59 & 11.20 & 11.55 & 11.35 & 12.29 & 12.30 & 11.03 & 11.05 & 9.03 & 11.98 & 11.37 & 12.80 & 11.83 & 11.41 & 8.48 & 11.13 & 11.41 & 11.30 \\
\hline $\mathrm{CaO}$ & 10.06 & 7.68 & 7.89 & 7.38 & 8.44 & 9.65 & 7.48 & 7.93 & 7.04 & 9.81 & 8.28 & 10.47 & 7.23 & 7.59 & 6.92 & 8.06 & 7.31 & 7.84 \\
\hline $\mathrm{Na} 2 \mathrm{O}$ & 1.79 & 2.62 & 2.85 & 3.22 & 2.45 & 1.90 & 3.14 & 2.85 & 4.20 & 1.86 & 2.81 & 1.15 & 3.30 & 2.36 & 4.33 & 2.67 & 3.01 & 2.71 \\
\hline K2O & 0.21 & 0.17 & 0.16 & 0.16 & 0.13 & 0.14 & 0.16 & 0.18 & 0.30 & 0.17 & 0.20 & 0.08 & 0.10 & 0.15 & 0.29 & 0.14 & 0.10 & 0.14 \\
\hline$F$ & 0.17 & 0.06 & 0.09 & 0.19 & 0.09 & 0.03 & 0.00 & 0.10 & 0.10 & 0.44 & 0.17 & 0.10 & 0.00 & 0.22 & 0.23 & 0.00 & 0.00 & 0.00 \\
\hline $\mathrm{Cl}$ & 0.00 & 0.00 & 0.02 & 0.00 & 0.00 & 0.00 & 0.00 & 0.01 & 0.00 & 0.02 & 0.00 & 0.00 & 0.00 & 0.01 & 0.02 & 0.02 & 0.00 & 0.01 \\
\hline TOTAL & 97.28 & 97.41 & 97.78 & 96.95 & 98.33 & 97.48 & 97.60 & 97.31 & 97.84 & 98.05 & 97.34 & 97.85 & 98.56 & 97.15 & 97.53 & 97.40 & 97.42 & 98.06 \\
\hline O_F_Cl & 0.07 & 0.03 & 0.04 & 0.08 & 0.04 & 0.01 & 0.00 & 0.04 & 0.04 & 0.19 & 0.07 & 0.04 & 0.00 & 0.10 & 0.10 & 0.01 & 0.00 & 0.00 \\
\hline O_F- & 0.07 & 0.02 & 0.04 & 0.08 & 0.04 & 0.01 & 0.00 & 0.04 & 0.04 & 0.18 & 0.07 & 0.04 & 0.00 & 0.09 & 0.10 & 0.00 & 0.00 & 0.00 \\
\hline O_Cl & 0.00 & 0.00 & 0.00 & 0.00 & 0.00 & 0.00 & 0.00 & 0.00 & 0.00 & 0.00 & 0.00 & 0.00 & 0.00 & 0.00 & 0.00 & 0.00 & 0.00 & 0.00 \\
\hline $\mathrm{H} \overline{2} \mathrm{O}$ & 0.00 & 0.00 & 0.00 & 0.00 & 0.00 & 0.00 & 0.00 & 0.00 & 0.00 & 0.00 & 0.00 & 0.00 & 0.00 & 0.00 & 0.00 & 0.00 & 0.00 & 0.00 \\
\hline CTOTAL & 97.21 & 97.38 & 97.74 & 96.87 & 98.29 & 97.47 & 97.60 & 97.27 & 97.80 & 97.86 & 97.27 & 97.81 & 98.56 & 97.05 & 97.43 & 97.39 & 97.42 & 98.06 \\
\hline Si & 7.53 & 7.61 & 7.56 & 7.45 & 7.62 & 7.83 & 7.46 & 7.48 & 6.91 & 7.48 & 7.62 & 7.81 & 7.58 & 7.21 & 6.99 & 7.55 & 7.69 & 7.73 \\
\hline Al & 0.44 & 0.40 & 0.44 & 0.56 & 0.38 & 0.17 & 0.54 & 0.53 & 1.09 & 0.52 & 0.38 & 0.19 & 0.42 & 0.79 & 1.01 & 0.45 & 0.32 & 0.27 \\
\hline Fe3 & 0.02 & 0.00 & 0.00 & 0.00 & 0.00 & 0.00 & 0.00 & 0.00 & 0.00 & 0.00 & 0.00 & 0.00 & 0.00 & 0.00 & 0.00 & 0.00 & 0.00 & 0.00 \\
\hline $\mathrm{Ti}$ & 0.00 & 0.00 & 0.00 & 0.00 & 0.00 & 0.00 & 0.00 & 0.00 & 0.00 & 0.00 & 0.00 & 0.00 & 0.00 & 0.00 & 0.00 & 0.00 & 0.00 & 0.00 \\
\hline SUM_T & 8.00 & 8.00 & 8.00 & 8.00 & 8.00 & 8.00 & 8.00 & 8.00 & 8.00 & 8.00 & 8.00 & 8.00 & 8.00 & 8.00 & 8.00 & 8.00 & 8.00 & 8.00 \\
\hline Cal & 0.00 & 0.14 & 0.28 & 0.39 & 0.10 & 0.31 & 0.37 & 0.31 & 0.62 & 0.18 & 0.22 & 0.10 & 0.47 & 0.09 & 0.67 & 0.13 & 0.21 & 0.19 \\
\hline $\mathrm{CCr}$ & 0.00 & 0.00 & 0.00 & 0.00 & 0.00 & 0.00 & 0.00 & 0.00 & 0.00 & 0.00 & 0.00 & 0.00 & 0.00 & 0.00 & 0.00 & 0.00 & 0.00 & 0.00 \\
\hline CFe3 & 0.74 & 1.09 & 0.89 & 0.91 & 0.96 & 0.27 & 0.95 & 0.90 & 0.96 & 0.72 & 0.74 & 0.48 & 0.82 & 1.66 & 0.80 & 1.03 & 0.97 & 0.86 \\
\hline Cti & 0.01 & 0.00 & 0.00 & 0.01 & 0.01 & 0.01 & 0.00 & 0.01 & 0.03 & 0.00 & 0.00 & 0.01 & 0.01 & 0.00 & 0.04 & 0.00 & 0.01 & 0.01 \\
\hline $\mathrm{CMg}$ & 2.75 & 2.42 & 2.48 & 2.45 & 2.63 & 2.66 & 2.37 & 2.39 & 1.96 & 2.60 & 2.48 & 2.77 & 2.50 & 2.46 & 1.86 & 2.42 & 2.46 & 2.43 \\
\hline CFe2 & 1.46 & 1.28 & 1.29 & 1.18 & 1.23 & 1.71 & 1.26 & 1.33 & 1.38 & 1.45 & 1.51 & 1.59 & 1.16 & 0.73 & 1.58 & 1.37 & 1.30 & 1.45 \\
\hline $\mathrm{CMn}$ & 0.04 & 0.06 & 0.06 & 0.06 & 0.06 & 0.04 & 0.05 & 0.07 & 0.05 & 0.05 & 0.06 & 0.05 & 0.04 & 0.06 & 0.06 & 0.06 & 0.06 & 0.06 \\
\hline Cca & 0.00 & 0.00 & 0.00 & 0.00 & 0.00 & 0.00 & 0.00 & 0.00 & 0.00 & 0.00 & 0.00 & 0.00 & 0.00 & 0.00 & 0.00 & 0.00 & 0.00 & 0.00 \\
\hline SUM_C & 5.00 & 5.00 & 5.00 & 5.00 & 5.00 & 5.00 & 5.00 & 5.00 & 5.00 & 5.00 & 5.00 & 5.00 & 5.00 & 5.00 & 5.00 & 5.00 & 5.00 & 5.00 \\
\hline $\mathrm{BMg}^{-}$ & 0.00 & 0.00 & 0.00 & 0.00 & 0.00 & 0.00 & 0.00 & 0.00 & 0.00 & 0.00 & 0.00 & 0.00 & 0.00 & 0.00 & 0.00 & 0.00 & 0.00 & 0.00 \\
\hline BFe2 & 0.00 & 0.00 & 0.00 & 0.00 & 0.00 & 0.00 & 0.00 & 0.00 & 0.00 & 0.00 & 0.00 & 0.00 & 0.00 & 0.00 & 0.00 & 0.00 & 0.00 & 0.00 \\
\hline BMn & 0.00 & 0.00 & 0.00 & 0.00 & 0.00 & 0.00 & 0.00 & 0.00 & 0.00 & 0.00 & 0.00 & 0.00 & 0.00 & 0.00 & 0.00 & 0.00 & 0.00 & 0.00 \\
\hline $\mathrm{BCa}$ & 1.58 & 1.19 & 1.22 & 1.15 & 1.30 & 1.50 & 1.16 & 1.24 & 1.10 & 1.53 & 1.30 & 1.63 & 1.10 & 1.17 & 1.09 & 1.26 & 1.13 & 1.21 \\
\hline $\mathrm{BNa}$ & 0.42 & 0.74 & 0.78 & 0.85 & 0.68 & 0.50 & 0.85 & 0.77 & 0.90 & 0.47 & 0.70 & 0.32 & 0.90 & 0.66 & 0.91 & 0.74 & 0.84 & 0.76 \\
\hline SUM_B & 2.00 & 1.93 & 2.00 & 2.00 & 1.98 & 2.00 & 2.00 & 2.00 & 2.00 & 2.00 & 2.00 & 1.95 & 2.00 & 1.84 & 2.00 & 2.00 & 1.98 & 1.97 \\
\hline $\mathrm{ACa}^{-}$ & 0.00 & 0.00 & 0.00 & 0.00 & 0.00 & 0.00 & 0.00 & 0.00 & 0.00 & 0.00 & 0.00 & 0.00 & 0.00 & 0.00 & 0.00 & 0.00 & 0.00 & 0.00 \\
\hline $\mathrm{ANa}$ & 0.09 & 0.00 & 0.02 & 0.05 & 0.00 & 0.04 & 0.03 & 0.04 & 0.29 & 0.05 & 0.09 & 0.00 & 0.00 & 0.00 & 0.33 & 0.01 & 0.00 & 0.00 \\
\hline AK & 0.04 & 0.03 & 0.03 & 0.03 & 0.03 & 0.03 & 0.03 & 0.03 & 0.06 & 0.03 & 0.04 & 0.02 & 0.02 & 0.03 & 0.06 & 0.03 & 0.02 & 0.03 \\
\hline SUM_A & 0.13 & 0.03 & 0.05 & 0.08 & 0.03 & 0.06 & 0.06 & 0.07 & 0.34 & 0.09 & 0.13 & 0.02 & 0.02 & 0.03 & 0.38 & 0.04 & 0.02 & 0.03 \\
\hline SUM_CAT & 15.13 & 14.96 & 15.05 & 15.08 & 15.00 & 15.06 & 15.06 & 15.07 & 15.34 & 15.09 & 15.13 & 14.96 & 15.02 & 14.86 & 15.38 & 15.04 & 14.99 & 15.00 \\
\hline $\mathrm{CCl}^{-}$ & 0.00 & 0.00 & 0.01 & 0.00 & 0.00 & 0.00 & 0.00 & 0.00 & 0.00 & 0.00 & 0.00 & 0.00 & 0.00 & 0.00 & 0.00 & 0.00 & 0.00 & 0.00 \\
\hline CF & 0.08 & 0.03 & 0.04 & 0.09 & 0.04 & 0.02 & 0.00 & 0.05 & 0.05 & 0.20 & 0.08 & 0.05 & 0.00 & 0.10 & 0.11 & 0.00 & 0.00 & 0.00 \\
\hline
\end{tabular}


Analıses de quimıca mıneral de antıbolıo selecıonados da regıao de Jambalo

\begin{tabular}{|c|c|c|c|c|c|c|c|c|c|c|c|c|c|c|c|c|c|c|}
\hline Amostra & $123 \mathrm{~A}$ & $123 \mathrm{~A}$ & $123 \mathrm{~A}$ & $123 \mathrm{~A}$ & $123 \mathrm{~A}$ & $123 \mathrm{~A}$ & $123 \mathrm{~A}$ & $123 \mathrm{~A}$ & $123 \mathrm{~A}$ & $123 \mathrm{~A}$ & $123 \mathrm{~A}$ & $123 \mathrm{~A}$ & $123 \mathrm{~A}$ & $123 \mathrm{~A}$ & $123 \mathrm{~A}$ & $123 \mathrm{~A}$ & $123 \mathrm{~A}$ & 123A \\
\hline Análise & 001 & 005 & 002 & 003 & 004 & 006 & 007 & 008 & 009 & 010 & 011 & 012 & 013 & 014 & 015 & 016 & 017 & 018 \\
\hline SiO2 & 56.29 & 55.95 & 55.64 & 56.03 & 55.70 & 54.63 & 53.83 & 55.38 & 55.87 & 57.05 & 53.19 & 55.18 & 53.90 & 57.16 & 57.19 & 55.79 & 56.91 & 55.90 \\
\hline TiO2 & 0.06 & 0.00 & 0.10 & 0.00 & 0.16 & 0.08 & 0.21 & 0.14 & 0.10 & 0.02 & 5.71 & 0.00 & 0.08 & 0.02 & 0.20 & 0.02 & 0.00 & 0.06 \\
\hline Al2O3 & 11.44 & 9.39 & 11.08 & 11.43 & 8.95 & 8.27 & 8.88 & 9.24 & 10.62 & 11.20 & 10.48 & 10.09 & 8.28 & 11.32 & 11.57 & 11.11 & 10.96 & 10.15 \\
\hline $\mathrm{FeO}$ & 11.18 & 13.62 & 11.90 & 11.06 & 14.29 & 15.43 & 15.03 & 13.51 & 11.89 & 10.35 & 10.75 & 12.08 & 15.36 & 10.65 & 10.56 & 11.85 & 11.45 & 11.79 \\
\hline MnO & 0.10 & 0.11 & 0.09 & 0.06 & 0.08 & 0.13 & 0.13 & 0.17 & 0.07 & 0.10 & 0.04 & 0.10 & 0.16 & 0.09 & 0.12 & 0.07 & 0.07 & 0.11 \\
\hline MgO & 10.44 & 10.11 & 10.10 & 10.19 & 10.50 & 10.05 & 9.75 & 10.52 & 10.66 & 10.37 & 9.38 & 10.60 & 9.97 & 10.39 & 10.23 & 10.45 & 10.53 & 10.65 \\
\hline $\mathrm{CaO}$ & 0.78 & 0.76 & 0.85 & 0.52 & 0.86 & 0.95 & 1.23 & 1.20 & 1.06 & 0.49 & 0.57 & 1.43 & 1.13 & 0.61 & 0.62 & 1.13 & 0.70 & 1.41 \\
\hline $\mathrm{Na} 2 \mathrm{O}$ & 7.11 & 6.81 & 7.01 & 6.98 & 6.81 & 6.72 & 6.47 & 6.72 & 6.84 & 7.15 & 6.47 & 6.73 & 6.78 & 7.04 & 6.94 & 6.72 & 6.94 & 6.60 \\
\hline K2O & 0.00 & 0.02 & 0.03 & 0.00 & 0.01 & 0.01 & 0.01 & 0.05 & 0.03 & 0.01 & 0.01 & 0.03 & 0.04 & 0.02 & 0.02 & 0.01 & 0.03 & 0.01 \\
\hline F & 0.00 & 0.00 & 0.04 & 0.00 & 0.00 & 0.03 & 0.11 & 0.21 & 0.17 & 0.14 & 0.00 & 0.00 & 0.14 & 0.00 & 0.09 & 0.00 & 0.14 & 0.04 \\
\hline $\mathrm{Cl}$ & 0.00 & 0.00 & 0.01 & 0.00 & 0.01 & 0.00 & 0.00 & 0.00 & 0.01 & 0.00 & 0.00 & 0.02 & 0.00 & 0.01 & 0.00 & 0.00 & 0.01 & 0.00 \\
\hline TOTAL & 97.38 & 96.77 & 96.84 & 96.28 & 97.37 & 96.31 & 95.65 & 97.11 & 97.31 & 96.86 & 96.59 & 96.25 & 95.83 & 97.30 & 97.54 & 97.15 & 97.73 & 96.70 \\
\hline O_F_Cl & 0.00 & 0.00 & 0.02 & 0.00 & 0.00 & 0.01 & 0.05 & 0.09 & 0.07 & 0.06 & 0.00 & 0.00 & 0.06 & 0.00 & 0.04 & 0.00 & 0.06 & 0.01 \\
\hline O_F & 0.00 & 0.00 & 0.01 & 0.00 & 0.00 & 0.01 & 0.05 & 0.09 & 0.07 & 0.06 & 0.00 & 0.00 & 0.06 & 0.00 & 0.04 & 0.00 & 0.06 & 0.01 \\
\hline $\mathrm{O}^{-} \mathrm{Cl}$ & 0.00 & 0.00 & 0.00 & 0.00 & 0.00 & 0.00 & 0.00 & 0.00 & 0.00 & 0.00 & 0.00 & 0.00 & 0.00 & 0.00 & 0.00 & 0.00 & 0.00 & 0.00 \\
\hline $\mathrm{H} 2 \mathrm{O}$ & 0.00 & 0.00 & 0.00 & 0.00 & 0.00 & 0.00 & 0.00 & 0.00 & 0.00 & 0.00 & 0.00 & 0.00 & 0.00 & 0.00 & 0.00 & 0.00 & 0.00 & 0.00 \\
\hline CTOTAL & 97.38 & 96.77 & 96.82 & 96.28 & 97.37 & 96.30 & 95.60 & 97.02 & 97.24 & 96.80 & 96.59 & 96.25 & 95.77 & 97.30 & 97.50 & 97.15 & 97.67 & 96.69 \\
\hline $\mathrm{Si}$ & 7.72 & 7.77 & 7.71 & 7.75 & 7.70 & 7.68 & 7.64 & 7.70 & 7.70 & 7.85 & 7.45 & 7.71 & 7.65 & 7.82 & 7.81 & 7.68 & 7.78 & 7.75 \\
\hline Al & 0.28 & 0.23 & 0.29 & 0.25 & 0.30 & 0.32 & 0.36 & 0.30 & 0.30 & 0.15 & 0.55 & 0.29 & 0.35 & 0.18 & 0.19 & 0.32 & 0.22 & 0.25 \\
\hline $\mathrm{Fe} 3$ & 0.00 & 0.00 & 0.00 & 0.00 & 0.00 & 0.00 & 0.00 & 0.00 & 0.00 & 0.00 & 0.00 & 0.00 & 0.00 & 0.00 & 0.00 & 0.00 & 0.00 & 0.00 \\
\hline $\mathrm{Ti}$ & 0.00 & 0.00 & 0.00 & 0.00 & 0.00 & 0.00 & 0.00 & 0.00 & 0.00 & 0.00 & 0.00 & 0.00 & 0.00 & 0.00 & 0.00 & 0.00 & 0.00 & 0.00 \\
\hline SUM_T & 8.00 & 8.00 & 8.00 & 8.00 & 8.00 & 8.00 & 8.00 & 8.00 & 8.00 & 8.00 & 8.00 & 8.00 & 8.00 & 8.00 & 8.00 & 8.00 & 8.00 & 8.00 \\
\hline $\mathrm{Cal}^{-}$ & 1.57 & 1.31 & 1.52 & 1.61 & 1.16 & 1.05 & 1.12 & 1.22 & 1.42 & 1.67 & 1.18 & 1.37 & 1.04 & 1.65 & 1.68 & 1.48 & 1.54 & 1.41 \\
\hline $\mathrm{CCr}$ & 0.00 & 0.00 & 0.00 & 0.00 & 0.00 & 0.00 & 0.00 & 0.00 & 0.00 & 0.00 & 0.00 & 0.00 & 0.00 & 0.00 & 0.00 & 0.00 & 0.00 & 0.00 \\
\hline CFe3 & 0.58 & 0.85 & 0.62 & 0.61 & 1.03 & 1.13 & 1.05 & 0.88 & 0.72 & 0.42 & 0.24 & 0.67 & 1.07 & 0.48 & 0.45 & 0.71 & 0.64 & 0.63 \\
\hline $\mathrm{Cti}$ & 0.01 & 0.00 & 0.01 & 0.00 & 0.02 & 0.01 & 0.02 & 0.01 & 0.01 & 0.00 & 0.60 & 0.00 & 0.01 & 0.00 & 0.02 & 0.00 & 0.00 & 0.01 \\
\hline CMg & 2.13 & 2.10 & 2.09 & 2.10 & 2.17 & 2.11 & 2.06 & 2.18 & 2.19 & 2.13 & 1.96 & 2.21 & 2.11 & 2.12 & 2.08 & 2.14 & 2.15 & 2.20 \\
\hline CFe2 & 0.70 & 0.73 & 0.76 & 0.67 & 0.62 & 0.69 & 0.74 & 0.69 & 0.66 & 0.77 & 1.02 & 0.74 & 0.75 & 0.74 & 0.76 & 0.66 & 0.67 & 0.74 \\
\hline CMn & 0.01 & 0.01 & 0.01 & 0.01 & 0.01 & 0.02 & 0.02 & 0.02 & 0.01 & 0.01 & 0.00 & 0.01 & 0.02 & 0.01 & 0.01 & 0.01 & 0.01 & 0.01 \\
\hline Cca & 0.00 & 0.00 & 0.00 & 0.00 & 0.00 & 0.00 & 0.00 & 0.00 & 0.00 & 0.00 & 0.00 & 0.00 & 0.00 & 0.00 & 0.00 & 0.00 & 0.00 & 0.00 \\
\hline SUM_C & 5.00 & 5.00 & 5.00 & 5.00 & 5.00 & 5.00 & 5.00 & 5.00 & 5.00 & 5.00 & 5.00 & 5.00 & 5.00 & 5.00 & 5.00 & 5.00 & 5.00 & 5.00 \\
\hline $\mathrm{BMg}^{-}$ & 0.00 & 0.00 & 0.00 & 0.00 & 0.00 & 0.00 & 0.00 & 0.00 & 0.00 & 0.00 & 0.00 & 0.00 & 0.00 & 0.00 & 0.00 & 0.00 & 0.00 & 0.00 \\
\hline BFe2 & 0.00 & 0.00 & 0.00 & 0.00 & 0.00 & 0.00 & 0.00 & 0.00 & 0.00 & 0.00 & 0.00 & 0.00 & 0.00 & 0.00 & 0.00 & 0.00 & 0.00 & 0.00 \\
\hline $\mathrm{BMn}$ & 0.00 & 0.00 & 0.00 & 0.00 & 0.00 & 0.00 & 0.00 & 0.00 & 0.00 & 0.00 & 0.00 & 0.00 & 0.00 & 0.00 & 0.00 & 0.00 & 0.00 & 0.00 \\
\hline $\mathrm{BCa}$ & 0.11 & 0.11 & 0.13 & 0.08 & 0.13 & 0.14 & 0.19 & 0.18 & 0.16 & 0.07 & 0.09 & 0.21 & 0.17 & 0.09 & 0.09 & 0.17 & 0.10 & 0.21 \\
\hline $\mathrm{BNa}$ & 1.89 & 1.83 & 1.87 & 1.87 & 1.83 & 1.83 & 1.78 & 1.81 & 1.83 & 1.91 & 1.76 & 1.79 & 1.83 & 1.87 & 1.84 & 1.79 & 1.84 & 1.78 \\
\hline SUM_B & 2.00 & 1.95 & 2.00 & 1.95 & 1.95 & 1.98 & 1.97 & 1.99 & 1.98 & 1.98 & 1.84 & 2.00 & 2.00 & 1.96 & 1.93 & 1.96 & 1.94 & 1.98 \\
\hline $\mathrm{ACa}^{-}$ & 0.00 & 0.00 & 0.00 & 0.00 & 0.00 & 0.00 & 0.00 & 0.00 & 0.00 & 0.00 & 0.00 & 0.00 & 0.00 & 0.00 & 0.00 & 0.00 & 0.00 & 0.00 \\
\hline $\mathrm{ANa}$ & 0.00 & 0.00 & 0.01 & 0.00 & 0.00 & 0.00 & 0.00 & 0.00 & 0.00 & 0.00 & 0.00 & 0.04 & 0.04 & 0.00 & 0.00 & 0.00 & 0.00 & 0.00 \\
\hline AK & 0.00 & 0.00 & 0.01 & 0.00 & 0.00 & 0.00 & 0.00 & 0.01 & 0.00 & 0.00 & 0.00 & 0.01 & 0.01 & 0.00 & 0.00 & 0.00 & 0.01 & 0.00 \\
\hline SUM_A & 0.00 & 0.00 & 0.02 & 0.00 & 0.00 & 0.00 & 0.00 & 0.01 & 0.00 & 0.00 & 0.00 & 0.04 & 0.05 & 0.00 & 0.00 & 0.00 & 0.01 & 0.00 \\
\hline SUM CAT & 15.00 & 14.95 & 15.02 & 14.95 & 14.95 & 14.98 & 14.97 & 15.00 & 14.99 & 14.98 & 14.85 & 15.04 & 15.05 & 14.96 & 14.93 & 14.96 & 14.95 & 14.99 \\
\hline $\mathrm{CCl}^{-}$ & 0.00 & 0.00 & 0.00 & 0.00 & 0.00 & 0.00 & 0.00 & 0.00 & 0.00 & 0.00 & 0.00 & 0.00 & 0.00 & 0.00 & 0.00 & 0.00 & 0.00 & 0.00 \\
\hline $\mathrm{CF}$ & 0.00 & 0.00 & 0.02 & 0.00 & 0.00 & 0.01 & 0.05 & 0.09 & 0.08 & 0.06 & 0.00 & 0.00 & 0.06 & 0.00 & 0.04 & 0.00 & 0.06 & 0.02 \\
\hline
\end{tabular}


Analıses de quimıca mıneral de antıbolıo selecıonados da regıao de Jambalo

\begin{tabular}{|c|c|c|c|c|c|c|c|c|c|c|c|c|c|c|c|c|c|c|}
\hline $123 A$ & $123 \mathrm{~A}$ & $123 \mathrm{~A}$ & $123 \mathrm{~A}$ & $123 \mathrm{~A}$ & $123 \mathrm{~A}$ & $123 \mathrm{~A}$ & $123 \mathrm{~A}$ & $123 A$ & $123 \mathrm{~A}$ & $123 A$ & $123 \mathrm{~A}$ & $123 \mathrm{~A}$ & $123 \mathrm{~A}$ & $123 \mathrm{~A}$ & $123 \mathrm{~A}$ & $123 \mathrm{~A}$ & $123 \mathrm{~A}$ & $123 \mathrm{~A}$ \\
\hline 019 & 020 & 021 & 022 & 023 & 024 & 025 & 026 & 027 & 028 & 029 & 030 & 031 & 032 & 033 & 034 & 035 & 036 & 037 \\
\hline 54.91 & 55.98 & 56.96 & 54.88 & 56.78 & 54.94 & 55.09 & 55.61 & 56.27 & 55.82 & 56.52 & 55.31 & 54.69 & 56.42 & 55.25 & 55.75 & 57.87 & 55.24 & 55.01 \\
\hline 0.06 & 0.00 & 0.06 & 0.04 & 0.08 & 0.23 & 0.17 & 0.06 & 0.02 & 0.08 & 0.04 & 0.00 & 0.25 & 0.00 & 0.21 & 0.02 & 0.20 & 0.04 & 0.12 \\
\hline 10.04 & 10.68 & 11.17 & 9.57 & 10.40 & 7.74 & 8.05 & 7.37 & 10.36 & 11.13 & 11.53 & 10.60 & 10.36 & 10.46 & 8.02 & 10.67 & 11.61 & 11.11 & 7.98 \\
\hline 12.96 & 12.06 & 10.71 & 12.17 & 12.24 & 15.51 & 14.33 & 15.42 & 12.24 & 11.64 & 10.32 & 11.85 & 11.54 & 12.66 & 14.81 & 12.44 & 10.24 & 11.22 & 15.51 \\
\hline 0.16 & 0.08 & 0.05 & 0.15 & 0.06 & 0.10 & 0.12 & 0.11 & 0.08 & 0.10 & 0.08 & 0.08 & 0.14 & 0.10 & 0.08 & 0.11 & 0.03 & 0.06 & 0.10 \\
\hline 10.30 & 10.14 & 10.23 & 11.35 & 10.40 & 9.96 & 10.19 & 10.60 & 10.32 & 10.09 & 10.18 & 10.51 & 10.61 & 10.07 & 10.22 & 10.05 & 10.40 & 10.23 & 10.24 \\
\hline 1.32 & 0.74 & 0.45 & 2.51 & 0.62 & 1.05 & 0.79 & 0.92 & 1.10 & 0.97 & 0.32 & 1.41 & 2.40 & 0.88 & 0.86 & 1.00 & 0.41 & 0.50 & 1.11 \\
\hline 6.48 & 6.83 & 7.08 & 5.90 & 7.05 & 6.75 & 6.89 & 6.82 & 6.75 & 6.83 & 7.26 & 6.61 & 5.96 & 6.57 & 6.72 & 6.88 & 7.12 & 7.08 & 6.65 \\
\hline 0.01 & 0.01 & 0.01 & 0.03 & 0.01 & 0.01 & 0.03 & 0.02 & 0.03 & 0.00 & 0.00 & 0.02 & 0.04 & 0.01 & 0.02 & 0.04 & 0.02 & 0.01 & 0.03 \\
\hline 0.10 & 0.10 & 0.00 & 0.00 & 0.07 & 0.00 & 0.03 & 0.05 & 0.18 & 0.03 & 0.13 & 0.15 & 0.18 & 0.17 & 0.10 & 0.03 & 0.11 & 0.00 & 0.07 \\
\hline 0.01 & 0.00 & 0.00 & 0.00 & 0.00 & 0.01 & 0.02 & 0.00 & 0.01 & 0.00 & 0.00 & 0.00 & 0.00 & 0.00 & 0.00 & 0.00 & 0.02 & 0.00 & 0.01 \\
\hline 96.34 & 96.61 & 96.73 & 96.60 & 97.70 & 96.32 & 95.71 & 96.96 & 97.35 & 96.69 & 96.38 & 96.54 & 96.15 & 97.35 & 96.29 & 97.00 & 98.04 & 97.48 & 96.81 \\
\hline 0.05 & 0.04 & 0.00 & 0.00 & 0.03 & 0.00 & 0.02 & 0.02 & 0.08 & 0.01 & 0.06 & 0.06 & 0.07 & 0.07 & 0.04 & 0.01 & 0.05 & 0.00 & 0.03 \\
\hline 0.04 & 0.04 & 0.00 & 0.00 & 0.03 & 0.00 & 0.01 & 0.02 & 0.07 & 0.01 & 0.06 & 0.06 & 0.07 & 0.07 & 0.04 & 0.01 & 0.05 & 0.00 & 0.03 \\
\hline 0.00 & 0.00 & 0.00 & 0.00 & 0.00 & 0.00 & 0.00 & 0.00 & 0.00 & 0.00 & 0.00 & 0.00 & 0.00 & 0.00 & 0.00 & 0.00 & 0.00 & 0.00 & 0.00 \\
\hline 0.00 & 0.00 & 0.00 & 0.00 & 0.00 & 0.00 & 0.00 & 0.00 & 0.00 & 0.00 & 0.00 & 0.00 & 0.00 & 0.00 & 0.00 & 0.00 & 0.00 & 0.00 & 0.00 \\
\hline 96.29 & 96.57 & 96.73 & 96.60 & 97.67 & 96.32 & 95.69 & 96.94 & 97.27 & 96.68 & 96.32 & 96.48 & 96.08 & 97.28 & 96.25 & 96.99 & 97.99 & 97.48 & 96.78 \\
\hline 7.67 & 7.76 & 7.84 & 7.64 & 7.78 & 7.75 & 7.79 & 7.76 & 7.77 & 7.73 & 7.82 & 7.70 & 7.67 & 7.77 & 7.76 & 7.73 & 7.85 & 7.83 & 7.71 \\
\hline 0.33 & 0.24 & 0.16 & 0.36 & 0.22 & 0.25 & 0.21 & 0.24 & 0.23 & 0.27 & 0.18 & 0.30 & 0.33 & 0.23 & 0.24 & 0.28 & 0.15 & 0.17 & 0.30 \\
\hline 0.00 & 0.00 & 0.00 & 0.00 & 0.00 & 0.00 & 0.00 & 0.00 & 0.00 & 0.00 & 0.00 & 0.00 & 0.00 & 0.00 & 0.00 & 0.00 & 0.00 & 0.00 & 0.00 \\
\hline 0.00 & 0.00 & 0.00 & 0.00 & 0.00 & 0.00 & 0.00 & 0.00 & 0.00 & 0.00 & 0.00 & 0.00 & 0.00 & 0.00 & 0.00 & 0.00 & 0.00 & 0.00 & 0.00 \\
\hline 8.00 & 8.00 & 8.00 & 8.00 & 8.00 & 8.00 & 8.00 & 8.00 & 8.00 & 8.00 & 8.00 & 8.00 & 8.00 & 8.00 & 8.00 & 8.00 & 8.00 & 8.00 & 8.00 \\
\hline 1.32 & 1.50 & 1.65 & 1.21 & 1.46 & 1.04 & 1.13 & 0.98 & 1.45 & 1.55 & 1.69 & 1.43 & 1.38 & 1.46 & 1.09 & 1.47 & 1.71 & 1.62 & 1.02 \\
\hline 0.00 & 0.00 & 0.00 & 0.00 & 0.00 & 0.00 & 0.00 & 0.00 & 0.00 & 0.00 & 0.00 & 0.00 & 0.00 & 0.00 & 0.00 & 0.00 & 0.00 & 0.00 & 0.00 \\
\hline 0.85 & 0.69 & 0.47 & 0.80 & 0.69 & 0.99 & 0.92 & 1.13 & 0.64 & 0.58 & 0.44 & 0.67 & 0.54 & 0.75 & 1.01 & 0.65 & 0.40 & 0.52 & 1.11 \\
\hline 0.01 & 0.00 & 0.01 & 0.00 & 0.01 & 0.03 & 0.02 & 0.01 & 0.00 & 0.01 & 0.00 & 0.00 & 0.03 & 0.00 & 0.02 & 0.00 & 0.02 & 0.00 & 0.01 \\
\hline 2.14 & 2.09 & 2.10 & 2.35 & 2.12 & 2.10 & 2.15 & 2.21 & 2.12 & 2.08 & 2.10 & 2.18 & 2.22 & 2.07 & 2.14 & 2.08 & 2.10 & 2.09 & 2.14 \\
\hline 0.66 & 0.71 & 0.77 & 0.62 & 0.71 & 0.84 & 0.77 & 0.68 & 0.78 & 0.77 & 0.75 & 0.71 & 0.81 & 0.71 & 0.73 & 0.79 & 0.76 & 0.76 & 0.71 \\
\hline 0.02 & 0.01 & 0.01 & 0.02 & 0.01 & 0.01 & 0.02 & 0.01 & 0.01 & 0.01 & 0.01 & 0.01 & 0.02 & 0.01 & 0.01 & 0.01 & 0.00 & 0.01 & 0.01 \\
\hline 0.00 & 0.00 & 0.00 & 0.00 & 0.00 & 0.00 & 0.00 & 0.00 & 0.00 & 0.00 & 0.00 & 0.00 & 0.00 & 0.00 & 0.00 & 0.00 & 0.00 & 0.00 & 0.00 \\
\hline 5.00 & 5.00 & 5.00 & 5.00 & 5.00 & 5.00 & 5.00 & 5.00 & 5.00 & 5.00 & 5.00 & 5.00 & 5.00 & 5.00 & 5.00 & 5.00 & 5.00 & 5.00 & 5.00 \\
\hline 0.00 & 0.00 & 0.00 & 0.00 & 0.00 & 0.00 & 0.00 & 0.00 & 0.00 & 0.00 & 0.00 & 0.00 & 0.00 & 0.00 & 0.00 & 0.00 & 0.00 & 0.00 & 0.00 \\
\hline 0.00 & 0.00 & 0.00 & 0.00 & 0.00 & 0.00 & 0.00 & 0.00 & 0.00 & 0.00 & 0.00 & 0.00 & 0.00 & 0.00 & 0.00 & 0.00 & 0.00 & 0.00 & 0.00 \\
\hline 0.00 & 0.00 & 0.00 & 0.00 & 0.00 & 0.00 & 0.00 & 0.00 & 0.00 & 0.00 & 0.00 & 0.00 & 0.00 & 0.00 & 0.00 & 0.00 & 0.00 & 0.00 & 0.00 \\
\hline 0.20 & 0.11 & 0.07 & 0.38 & 0.09 & 0.16 & 0.12 & 0.14 & 0.16 & 0.14 & 0.05 & 0.21 & 0.36 & 0.13 & 0.13 & 0.15 & 0.06 & 0.07 & 0.17 \\
\hline 1.76 & 1.84 & 1.89 & 1.59 & 1.87 & 1.84 & 1.88 & 1.85 & 1.81 & 1.84 & 1.95 & 1.78 & 1.62 & 1.75 & 1.83 & 1.85 & 1.87 & 1.88 & 1.81 \\
\hline 1.95 & 1.95 & 1.96 & 1.97 & 1.96 & 2.00 & 2.00 & 1.98 & 1.97 & 1.98 & 1.99 & 1.99 & 1.98 & 1.88 & 1.96 & 2.00 & 1.93 & 1.95 & 1.97 \\
\hline 0.00 & 0.00 & 0.00 & 0.00 & 0.00 & 0.00 & 0.00 & 0.00 & 0.00 & 0.00 & 0.00 & 0.00 & 0.00 & 0.00 & 0.00 & 0.00 & 0.00 & 0.00 & 0.00 \\
\hline 0.00 & 0.00 & 0.00 & 0.00 & 0.00 & 0.01 & 0.01 & 0.00 & 0.00 & 0.00 & 0.00 & 0.00 & 0.00 & 0.00 & 0.00 & 0.00 & 0.00 & 0.00 & 0.00 \\
\hline 0.00 & 0.00 & 0.00 & 0.01 & 0.00 & 0.00 & 0.01 & 0.00 & 0.01 & 0.00 & 0.00 & 0.00 & 0.01 & 0.00 & 0.00 & 0.01 & 0.00 & 0.00 & 0.01 \\
\hline 0.00 & 0.00 & 0.00 & 0.01 & 0.00 & 0.01 & 0.01 & 0.00 & 0.01 & 0.00 & 0.00 & 0.00 & 0.01 & 0.00 & 0.00 & 0.01 & 0.00 & 0.00 & 0.01 \\
\hline 14.95 & 14.95 & 14.96 & 14.97 & 14.96 & 15.01 & 15.01 & 14.99 & 14.98 & 14.98 & 14.99 & 15.00 & 14.99 & 14.89 & 14.96 & 15.00 & 14.94 & 14.95 & 14.98 \\
\hline 0.00 & 0.00 & 0.00 & 0.00 & 0.00 & 0.00 & 0.00 & 0.00 & 0.00 & 0.00 & 0.00 & 0.00 & 0.00 & 0.00 & 0.00 & 0.00 & 0.01 & 0.00 & 0.00 \\
\hline 0.05 & 0.05 & 0.00 & 0.00 & 0.03 & 0.00 & 0.02 & 0.02 & 0.08 & 0.01 & 0.06 & 0.07 & 0.08 & 0.08 & 0.04 & 0.01 & 0.05 & 0.00 & 0.03 \\
\hline
\end{tabular}


Analıses de quimıca mıneral de antıbolıo selecıonados da regiao de Jambalo

\begin{tabular}{|c|c|c|c|c|c|c|c|c|c|c|}
\hline Amostra & 124 & 124 & 124 & 124 & 124 & 124 & 124 & 124 & 124 & 124 \\
\hline Análise & 266 & 267 & 268 & 269 & 270 & 271 & 272 & 273 & 274 & 275 \\
\hline SiO2 & 59.38 & 58.84 & 57.95 & 58.33 & 56.01 & 57.42 & 58.43 & 58.65 & 58.83 & $\overline{57.91}$ \\
\hline TiO2 & 0.01 & 0.01 & 0.12 & 0.04 & 0.04 & 0.11 & 0.00 & 0.02 & 0.03 & 0.06 \\
\hline $\mathrm{Al} 2 \mathrm{O} 3$ & 11.18 & 10.89 & 10.58 & 10.80 & 10.24 & 10.19 & 10.17 & 9.88 & 10.72 & 10.66 \\
\hline $\mathrm{FeO}$ & 13.24 & 13.47 & 14.16 & 14.19 & 15.31 & 14.58 & 13.51 & 14.01 & 12.88 & 13.89 \\
\hline MnO & 0.09 & 0.21 & 0.22 & 0.18 & 0.27 & 0.21 & 0.11 & 0.18 & 0.18 & 0.24 \\
\hline $\mathrm{MgO}$ & 8.72 & 8.70 & 8.59 & 8.30 & 7.62 & 8.28 & 7.61 & 8.69 & 8.43 & 8.23 \\
\hline $\mathrm{CaO}$ & 0.55 & 0.54 & 0.91 & 0.91 & 1.70 & 1.05 & 0.22 & 0.43 & 0.30 & 0.88 \\
\hline $\mathrm{Na2O}$ & 7.20 & 7.03 & 7.13 & 6.88 & 6.63 & 6.58 & 7.17 & 7.07 & 6.91 & 6.62 \\
\hline K2O & 0.01 & 0.01 & 0.02 & 0.02 & 0.03 & 0.03 & 0.01 & 0.00 & 0.00 & 0.03 \\
\hline $\mathbf{F}$ & 0.00 & 0.00 & 0.00 & 0.03 & 0.05 & 0.00 & 0.00 & 0.02 & 0.00 & 0.05 \\
\hline $\mathrm{Cl}$ & 0.00 & 0.00 & 0.00 & 0.00 & 0.00 & 0.00 & 0.00 & 0.00 & 0.00 & 0.00 \\
\hline TOTAL & 100.38 & 99.70 & 99.67 & 99.67 & 97.89 & 98.45 & 97.23 & 98.95 & 98.28 & 98.56 \\
\hline O_F_Cl & 0.00 & 0.00 & 0.00 & 0.01 & 0.02 & 0.00 & 0.00 & 0.01 & 0.00 & 0.02 \\
\hline O_F- & 0.00 & 0.00 & 0.00 & 0.01 & 0.02 & 0.00 & 0.00 & 0.01 & 0.00 & 0.02 \\
\hline O_Cl & 0.00 & 0.00 & 0.00 & 0.00 & 0.00 & 0.00 & 0.00 & 0.00 & 0.00 & 0.00 \\
\hline $\mathrm{H} 2 \mathrm{O}$ & 0.00 & 0.00 & 0.00 & 0.00 & 0.00 & 0.00 & 0.00 & 0.00 & 0.00 & 0.00 \\
\hline CTOTAL & 100.38 & 99.70 & 99.67 & 99.66 & 97.87 & 98.45 & 97.23 & 98.94 & 98.28 & 98.54 \\
\hline Si & 7.98 & 7.96 & 7.90 & 7.94 & 7.87 & 7.92 & 8.16 & 8.02 & 8.05 & 7.96 \\
\hline Al & 0.02 & 0.04 & 0.10 & 0.06 & 0.13 & 0.08 & 0.00 & 0.00 & 0.00 & 0.04 \\
\hline $\mathrm{Fe} 3$ & 0.00 & 0.00 & 0.00 & 0.00 & 0.00 & 0.00 & 0.00 & 0.00 & 0.00 & 0.00 \\
\hline $\mathrm{Ti}$ & 0.00 & 0.00 & 0.00 & 0.00 & 0.00 & 0.00 & 0.00 & 0.00 & 0.00 & 0.00 \\
\hline SUM_T & 8.00 & 8.00 & 8.00 & 8.00 & 8.00 & 8.00 & 8.16 & 8.02 & 8.05 & 8.00 \\
\hline Cal & 1.75 & 1.70 & 1.60 & 1.68 & 1.57 & 1.58 & 1.67 & 1.59 & 1.73 & 1.68 \\
\hline $\mathrm{CCr}$ & 0.00 & 0.00 & 0.00 & 0.00 & 0.00 & 0.00 & 0.00 & 0.00 & 0.00 & 0.00 \\
\hline CFe3 & 0.22 & 0.34 & 0.32 & 0.29 & 0.23 & 0.40 & 0.01 & 0.38 & 0.24 & 0.32 \\
\hline Cti & 0.00 & 0.00 & 0.01 & 0.00 & 0.00 & 0.01 & 0.00 & 0.00 & 0.00 & 0.01 \\
\hline CMg & 1.75 & 1.76 & 1.75 & 1.68 & 1.60 & 1.70 & 1.58 & 1.77 & 1.72 & 1.69 \\
\hline CFe2 & 1.27 & 1.19 & 1.30 & 1.33 & 1.57 & 1.28 & 1.57 & 1.22 & 1.24 & 1.28 \\
\hline CMn & 0.01 & 0.02 & 0.03 & 0.02 & 0.03 & 0.03 & 0.01 & 0.02 & 0.02 & 0.03 \\
\hline Cca & 0.00 & 0.00 & 0.00 & 0.00 & 0.00 & 0.00 & 0.03 & 0.02 & 0.04 & 0.00 \\
\hline SUM_C & 5.00 & 5.00 & 5.00 & 5.00 & 5.00 & 5.00 & 4.88 & 5.00 & 4.99 & 5.00 \\
\hline $\mathrm{BMg}^{-}$ & 0.00 & 0.00 & 0.00 & 0.00 & 0.00 & 0.00 & 0.00 & 0.00 & 0.00 & 0.00 \\
\hline BFe2 & 0.00 & 0.00 & 0.00 & 0.00 & 0.00 & 0.00 & 0.00 & 0.00 & 0.00 & 0.00 \\
\hline BMn & 0.00 & 0.00 & 0.00 & 0.00 & 0.00 & 0.00 & 0.00 & 0.00 & 0.00 & 0.00 \\
\hline $\mathrm{BCa}$ & 0.08 & 0.08 & 0.13 & 0.13 & 0.26 & 0.16 & 0.00 & 0.05 & 0.00 & 0.13 \\
\hline $\mathrm{BNa}$ & 1.88 & 1.84 & 1.87 & 1.82 & 1.75 & 1.76 & 1.94 & 1.87 & 1.84 & 1.76 \\
\hline SUM_B & 1.96 & 1.92 & 2.00 & 1.95 & 2.00 & 1.92 & 1.94 & 1.92 & 1.84 & 1.89 \\
\hline $\mathrm{ACa}^{-}$ & 0.00 & 0.00 & 0.00 & 0.00 & 0.00 & 0.00 & 0.00 & 0.00 & 0.00 & 0.00 \\
\hline $\mathrm{ANa}$ & 0.00 & 0.00 & 0.02 & 0.00 & 0.06 & 0.00 & 0.00 & 0.00 & 0.00 & 0.00 \\
\hline AK & 0.00 & 0.00 & 0.00 & 0.00 & 0.01 & 0.01 & 0.00 & 0.00 & 0.00 & 0.01 \\
\hline SUM_A & 0.00 & 0.00 & 0.02 & 0.00 & 0.07 & 0.01 & 0.00 & 0.00 & 0.00 & 0.01 \\
\hline SUM_CAT & 14.96 & 14.92 & 15.02 & 14.95 & 15.07 & 14.92 & 14.98 & 14.94 & 14.88 & 14.90 \\
\hline $\mathrm{CCl}^{-}$ & 0.00 & 0.00 & 0.00 & 0.00 & 0.00 & 0.00 & 0.00 & 0.00 & 0.00 & 0.00 \\
\hline CF & 0.00 & 0.00 & 0.00 & 0.02 & 0.02 & 0.00 & 0.00 & 0.01 & 0.00 & 0.02 \\
\hline
\end{tabular}


Analıses de quimıca mıneral de antıbolıo selecıonados da regıao de Jambalo

\begin{tabular}{|c|c|c|c|c|c|c|c|c|c|c|c|c|c|c|c|c|c|c|}
\hline Amostra & $124 \mathrm{~J}$ & $124 \mathrm{~J}$ & $124 \mathrm{~J}$ & $124 \mathrm{~J}$ & $124 J$ & $124 J$ & $124 \mathrm{~J}$ & $124 \mathrm{~J}$ & $124 \mathrm{~J}$ & $124 \mathrm{~J}$ & $124 \mathrm{~J}$ & $124 \mathrm{~J}$ & $124 \mathrm{~J}$ & $124 \mathrm{~J}$ & $124 \mathrm{~J}$ & $124 \mathrm{~J}$ & $124 \mathrm{~J}$ & 124J \\
\hline Análise & 081 & 082 & 083 & 084 & 085 & 086 & 087 & 088 & 089 & 090 & 091 & 092 & 093 & 094 & 095 & 096 & 097 & 098 \\
\hline $\mathrm{SiO2}$ & 56.90 & 56.59 & 55.11 & 55.00 & 56.51 & 56.16 & 56.40 & 56.30 & 56.71 & 56.77 & 56.39 & 56.99 & 56.84 & 57.56 & 56.33 & 58.03 & 55.40 & 56.77 \\
\hline TiO2 & 0.06 & 0.10 & 0.19 & 0.33 & 0.00 & 0.04 & 0.14 & 0.04 & 0.02 & 0.04 & 0.00 & 0.00 & 0.10 & 0.04 & 0.02 & 0.04 & 0.00 & 0.08 \\
\hline Al2O3 & 12.53 & 11.08 & 10.05 & 9.75 & 11.68 & 12.71 & 11.59 & 11.92 & 12.12 & 10.62 & 12.47 & 11.59 & 11.96 & 12.33 & 11.70 & 12.64 & 12.12 & 11.14 \\
\hline $\mathrm{FeO}$ & 12.17 & 14.29 & 16.02 & 16.00 & 12.91 & 12.41 & 12.88 & 13.42 & 13.73 & 15.43 & 13.29 & 15.03 & 14.15 & 11.96 & 14.00 & 12.42 & 12.18 & 13.51 \\
\hline MnO & 0.22 & 0.21 & 0.25 & 0.27 & 0.28 & 0.20 & 0.23 & 0.36 & 0.25 & 0.22 & 0.26 & 0.21 & 0.33 & 0.22 & 0.23 & 0.21 & 0.31 & 0.20 \\
\hline MgO & 8.48 & 8.24 & 8.35 & 8.35 & 8.64 & 8.19 & 8.73 & 8.45 & 8.07 & 7.77 & 8.15 & 7.67 & 8.30 & 8.50 & 8.10 & 8.57 & 8.29 & 8.53 \\
\hline $\mathrm{CaO}$ & 0.55 & 0.54 & 0.84 & 0.92 & 0.79 & 0.65 & 0.57 & 0.95 & 0.47 & 0.43 & 0.55 & 0.39 & 0.79 & 0.44 & 0.51 & 0.23 & 0.55 & 0.88 \\
\hline $\mathrm{Na} 2 \mathrm{O}$ & 7.09 & 6.94 & 6.79 & 6.67 & 6.86 & 7.10 & 7.01 & 6.91 & 7.06 & 7.10 & 7.16 & 6.97 & 7.09 & 6.95 & 7.05 & 7.27 & 7.02 & 6.82 \\
\hline K2O & 0.00 & 0.03 & 0.03 & 0.02 & 0.02 & 0.00 & 0.03 & 0.01 & 0.03 & 0.01 & 0.00 & 0.01 & 0.00 & 0.00 & 0.01 & 0.00 & 0.01 & 0.01 \\
\hline F & 0.13 & 0.00 & 0.13 & 0.18 & 0.00 & 0.06 & 0.10 & 0.02 & 0.07 & 0.05 & 0.04 & 0.00 & 0.15 & 0.00 & 0.00 & 0.07 & 0.14 & 0.04 \\
\hline $\mathrm{Cl}$ & 0.00 & 0.00 & 0.00 & 0.02 & 0.00 & 0.00 & 0.00 & 0.00 & 0.02 & 0.00 & 0.00 & 0.00 & 0.00 & 0.00 & 0.01 & 0.01 & 0.01 & 0.01 \\
\hline TOTAL & 98.12 & 98.03 & 97.75 & 97.51 & 97.69 & 97.53 & 97.66 & 98.39 & 98.55 & 98.43 & 98.30 & 98.87 & 99.70 & 97.99 & 97.95 & 99.47 & 96.03 & 97.99 \\
\hline $\mathrm{O} F \mathrm{Cl}$ & 0.05 & 0.00 & 0.05 & 0.08 & 0.00 & 0.03 & 0.04 & 0.01 & 0.04 & 0.02 & 0.02 & 0.00 & 0.06 & 0.00 & 0.00 & 0.03 & 0.06 & 0.02 \\
\hline $\mathrm{OF}$ & 0.05 & 0.00 & 0.05 & 0.07 & 0.00 & 0.03 & 0.04 & 0.01 & 0.03 & 0.02 & 0.02 & 0.00 & 0.06 & 0.00 & 0.00 & 0.03 & 0.06 & 0.02 \\
\hline $\mathrm{O}^{-} \mathrm{Cl}$ & 0.00 & 0.00 & 0.00 & 0.00 & 0.00 & 0.00 & 0.00 & 0.00 & 0.00 & 0.00 & 0.00 & 0.00 & 0.00 & 0.00 & 0.00 & 0.00 & 0.00 & 0.00 \\
\hline $\mathrm{H} 2 \mathrm{O}$ & 0.00 & 0.00 & 0.00 & 0.00 & 0.00 & 0.00 & 0.00 & 0.00 & 0.00 & 0.00 & 0.00 & 0.00 & 0.00 & 0.00 & 0.00 & 0.00 & 0.00 & 0.00 \\
\hline CTOTAL & 98.07 & 98.03 & 97.70 & 97.43 & 97.69 & 97.50 & 97.62 & 98.38 & 98.51 & 98.41 & 98.28 & 98.87 & 99.64 & 97.99 & 97.95 & 99.44 & 95.97 & 97.97 \\
\hline $\mathrm{Si}$ & 7.81 & 7.82 & 7.69 & 7.71 & 7.80 & 7.77 & 7.79 & 7.75 & 7.78 & 7.85 & 7.75 & 7.81 & 7.74 & 7.88 & 7.78 & 7.84 & 7.79 & 7.84 \\
\hline Al & 0.19 & 0.18 & 0.31 & 0.29 & 0.20 & 0.23 & 0.21 & 0.26 & 0.22 & 0.15 & 0.25 & 0.19 & 0.26 & 0.12 & 0.22 & 0.16 & 0.21 & 0.16 \\
\hline $\mathrm{Fe} 3$ & 0.00 & 0.00 & 0.00 & 0.00 & 0.00 & 0.00 & 0.00 & 0.00 & 0.00 & 0.00 & 0.00 & 0.00 & 0.00 & 0.00 & 0.00 & 0.00 & 0.00 & 0.00 \\
\hline $\mathrm{Ti}$ & 0.00 & 0.00 & 0.00 & 0.00 & 0.00 & 0.00 & 0.00 & 0.00 & 0.00 & 0.00 & 0.00 & 0.00 & 0.00 & 0.00 & 0.00 & 0.00 & 0.00 & 0.00 \\
\hline SUM_T & 8.00 & 8.00 & 8.00 & 8.00 & 8.00 & 8.00 & 8.00 & 8.00 & 8.00 & 8.00 & 8.00 & 8.00 & 8.00 & 8.00 & 8.00 & 8.00 & 8.00 & 8.00 \\
\hline $\mathrm{Cal}$ & 1.84 & 1.62 & 1.34 & 1.32 & 1.70 & 1.85 & 1.68 & 1.68 & 1.74 & 1.58 & 1.77 & 1.69 & 1.66 & 1.87 & 1.69 & 1.85 & 1.79 & 1.65 \\
\hline $\mathrm{CCr}$ & 0.00 & 0.00 & 0.00 & 0.00 & 0.00 & 0.00 & 0.00 & 0.00 & 0.00 & 0.00 & 0.00 & 0.00 & 0.00 & 0.00 & 0.00 & 0.00 & 0.00 & 0.00 \\
\hline $\mathrm{CFe} 3$ & 0.29 & 0.52 & 0.83 & 0.82 & 0.43 & 0.27 & 0.46 & 0.45 & 0.45 & 0.52 & 0.41 & 0.53 & 0.48 & 0.27 & 0.49 & 0.34 & 0.34 & 0.40 \\
\hline $\mathrm{Cti}$ & 0.01 & 0.01 & 0.02 & 0.03 & 0.00 & 0.00 & 0.01 & 0.00 & 0.00 & 0.00 & 0.00 & 0.00 & 0.01 & 0.00 & 0.00 & 0.00 & 0.00 & 0.01 \\
\hline CMg & 1.74 & 1.70 & 1.74 & 1.75 & 1.78 & 1.69 & 1.80 & 1.73 & 1.65 & 1.60 & 1.67 & 1.57 & 1.69 & 1.73 & 1.67 & 1.72 & 1.74 & 1.76 \\
\hline CFe2 & 1.10 & 1.13 & 1.04 & 1.06 & 1.06 & 1.17 & 1.03 & 1.10 & 1.13 & 1.27 & 1.12 & 1.19 & 1.13 & 1.10 & 1.13 & 1.06 & 1.10 & 1.16 \\
\hline CMn & 0.03 & 0.03 & 0.03 & 0.03 & 0.03 & 0.02 & 0.03 & 0.04 & 0.03 & 0.03 & 0.03 & 0.02 & 0.04 & 0.03 & 0.03 & 0.02 & 0.04 & 0.02 \\
\hline Cca & 0.00 & 0.00 & 0.00 & 0.00 & 0.00 & 0.00 & 0.00 & 0.00 & 0.00 & 0.00 & 0.00 & 0.00 & 0.00 & 0.00 & 0.00 & 0.00 & 0.00 & 0.00 \\
\hline SUM_C & 5.00 & 5.00 & 5.00 & 5.00 & 5.00 & 5.00 & 5.00 & 5.00 & 5.00 & 5.00 & 5.00 & 5.00 & 5.00 & 5.00 & 5.00 & 5.00 & 5.00 & 5.00 \\
\hline $\mathrm{BMg}^{-}$ & 0.00 & 0.00 & 0.00 & 0.00 & 0.00 & 0.00 & 0.00 & 0.00 & 0.00 & 0.00 & 0.00 & 0.00 & 0.00 & 0.00 & 0.00 & 0.00 & 0.00 & 0.00 \\
\hline BFe2 & 0.00 & 0.00 & 0.00 & 0.00 & 0.00 & 0.00 & 0.00 & 0.00 & 0.00 & 0.00 & 0.00 & 0.00 & 0.00 & 0.00 & 0.00 & 0.00 & 0.00 & 0.00 \\
\hline $\mathrm{BMn}$ & 0.00 & 0.00 & 0.00 & 0.00 & 0.00 & 0.00 & 0.00 & 0.00 & 0.00 & 0.00 & 0.00 & 0.00 & 0.00 & 0.00 & 0.00 & 0.00 & 0.00 & 0.00 \\
\hline $\mathrm{BCa}$ & 0.08 & 0.08 & 0.13 & 0.14 & 0.12 & 0.10 & 0.08 & 0.14 & 0.07 & 0.06 & 0.08 & 0.06 & 0.12 & 0.07 & 0.08 & 0.03 & 0.08 & 0.13 \\
\hline $\mathrm{BNa}$ & 1.89 & 1.86 & 1.84 & 1.81 & 1.84 & 1.90 & 1.88 & 1.84 & 1.88 & 1.91 & 1.91 & 1.85 & 1.87 & 1.85 & 1.89 & 1.90 & 1.91 & 1.83 \\
\hline SUM B & 1.97 & 1.94 & 1.96 & 1.95 & 1.95 & 2.00 & 1.96 & 1.98 & 1.95 & 1.97 & 1.99 & 1.91 & 1.99 & 1.91 & 1.96 & 1.94 & 2.00 & 1.96 \\
\hline $\mathrm{ACa}^{-}$ & 0.00 & 0.00 & 0.00 & 0.00 & 0.00 & 0.00 & 0.00 & 0.00 & 0.00 & 0.00 & 0.00 & 0.00 & 0.00 & 0.00 & 0.00 & 0.00 & 0.00 & 0.00 \\
\hline $\mathrm{ANa}$ & 0.00 & 0.00 & 0.00 & 0.00 & 0.00 & 0.00 & 0.00 & 0.00 & 0.00 & 0.00 & 0.00 & 0.00 & 0.00 & 0.00 & 0.00 & 0.00 & 0.00 & 0.00 \\
\hline AK & 0.00 & 0.01 & 0.01 & 0.00 & 0.00 & 0.00 & 0.01 & 0.00 & 0.01 & 0.00 & 0.00 & 0.00 & 0.00 & 0.00 & 0.00 & 0.00 & 0.00 & 0.00 \\
\hline SUM_A & 0.00 & 0.01 & 0.01 & 0.00 & 0.00 & 0.00 & 0.01 & 0.00 & 0.01 & 0.00 & 0.00 & 0.00 & 0.00 & 0.00 & 0.00 & 0.00 & 0.00 & 0.00 \\
\hline SUM CAT & 14.97 & 14.94 & 14.97 & 14.95 & 14.96 & 15.00 & 14.97 & 14.98 & 14.95 & 14.97 & 14.99 & 14.91 & 14.99 & 14.91 & 14.97 & 14.94 & 15.00 & 14.96 \\
\hline $\mathrm{CCl}^{-}$ & 0.00 & 0.00 & 0.00 & 0.00 & 0.00 & 0.00 & 0.00 & 0.00 & 0.00 & 0.00 & 0.00 & 0.00 & 0.00 & 0.00 & 0.00 & 0.00 & 0.00 & 0.00 \\
\hline $\mathrm{CF}$ & 0.06 & 0.00 & 0.06 & 0.08 & 0.00 & 0.03 & 0.05 & 0.01 & 0.03 & 0.02 & 0.02 & 0.00 & 0.06 & 0.00 & 0.00 & 0.03 & 0.06 & 0.02 \\
\hline
\end{tabular}


Analıses de quimıca mıneral de antıbolıo selecıonados da regıao de Jambalo

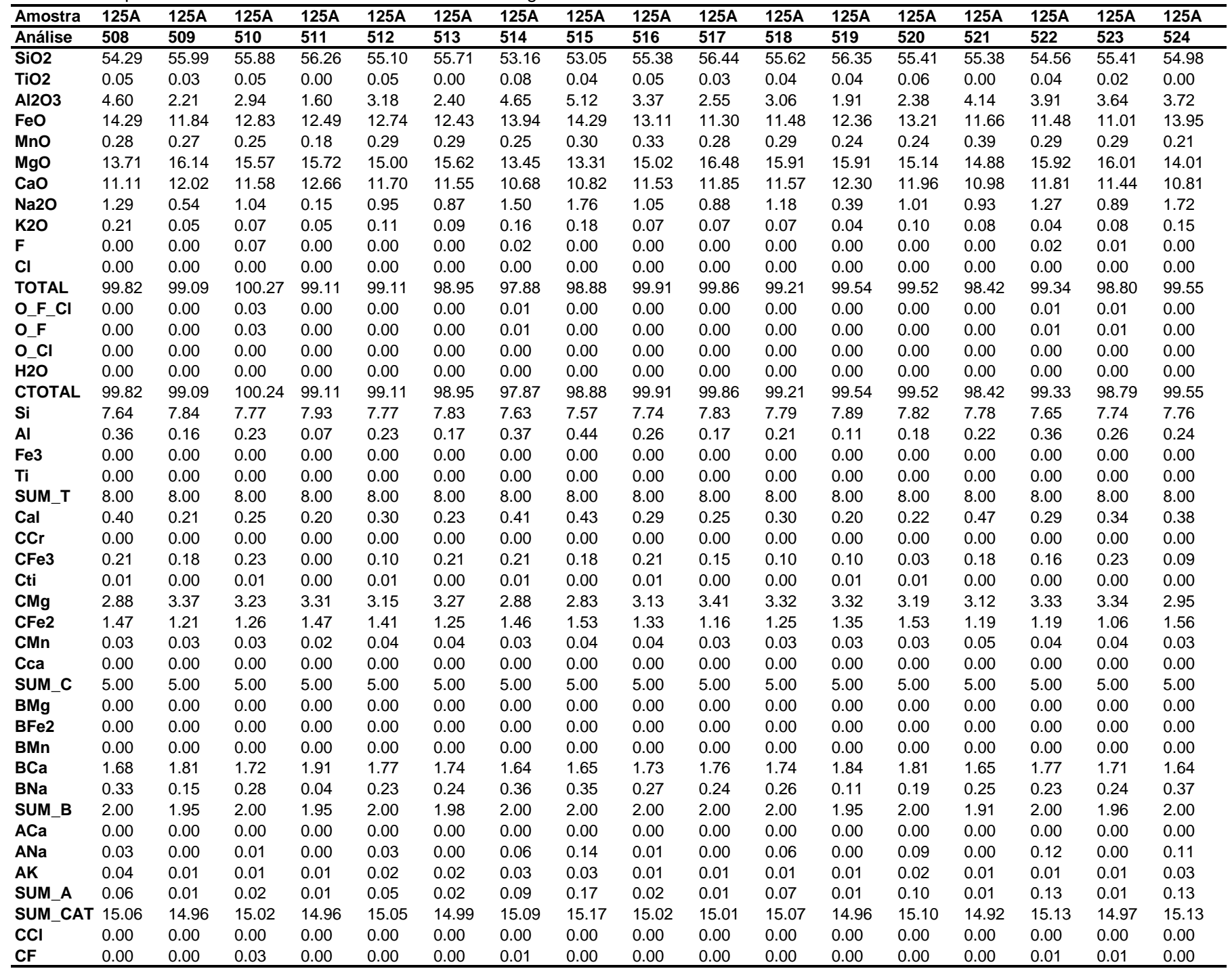


Analıses de quimıca mıneral de antıbolıo selecıonados da regiao de Jambalo

\begin{tabular}{|c|c|c|c|c|c|c|c|c|c|c|c|c|c|c|c|c|c|c|}
\hline Amostra & $125 \mathrm{M}$ & $125 \mathrm{M}$ & $125 \mathrm{M}$ & $125 \mathrm{M}$ & $125 \mathrm{M}$ & $125 M$ & $125 M$ & $125 \mathrm{M}$ & $125 \mathrm{M}$ & $125 \mathrm{M}$ & $125 \mathrm{M}$ & $125 \mathrm{M}$ & $125 \mathrm{M}$ & $125 \mathrm{M}$ & $125 \mathrm{M}$ & $125 \mathrm{M}$ & $125 \mathrm{M}$ & $125 \mathrm{M}$ \\
\hline Análise & 310 & 311 & 312 & 313 & 314 & 315 & 316 & 317 & 318 & 319 & 320 & 321 & 322 & 323 & 324 & 325 & 326 & 327 \\
\hline $\mathrm{SiO2}$ & 55.77 & 56.60 & 57.14 & 58.44 & 58.04 & 57.81 & 55.47 & 54.76 & 55.99 & 54.97 & 55.46 & 56.50 & 56.82 & 56.32 & 55.49 & 55.84 & 54.76 & 58.72 \\
\hline TiO2 & 0.14 & 0.10 & 0.06 & 0.16 & 0.00 & 0.00 & 0.06 & 0.15 & 0.00 & 2.58 & 0.19 & 0.17 & 0.02 & 0.10 & 0.00 & 0.00 & 3.35 & 0.06 \\
\hline Al2O3 & 10.17 & 9.50 & 9.71 & 11.15 & 11.02 & 11.17 & 5.76 & 9.35 & 9.34 & 6.40 & 8.54 & 9.47 & 9.53 & 8.46 & 8.73 & 9.16 & 9.44 & 11.56 \\
\hline $\mathrm{FeO}$ & 14.42 & 14.51 & 13.58 & 11.37 & 10.85 & 10.57 & 14.69 & 14.67 & 13.84 & 9.67 & 16.11 & 15.07 & 14.52 & 16.45 & 15.68 & 14.99 & 13.60 & 9.80 \\
\hline MnO & 0.24 & 0.20 & 0.23 & 0.24 & 0.21 & 0.28 & 0.29 & 0.20 & 0.24 & 0.18 & 0.17 & 0.16 & 0.15 & 0.15 & 0.22 & 0.21 & 0.19 & 0.22 \\
\hline MgO & 9.27 & 9.29 & 9.57 & 9.91 & 10.47 & 10.26 & 12.02 & 9.02 & 9.53 & 11.58 & 9.00 & 8.99 & 9.53 & 8.89 & 8.96 & 9.03 & 9.43 & 10.58 \\
\hline $\mathrm{CaO}$ & 1.02 & 0.66 & 0.65 & 0.39 & 0.19 & 0.41 & 4.96 & 0.92 & 0.97 & 7.33 & 0.66 & 0.58 & 0.53 & 0.59 & 0.75 & 0.86 & 0.70 & 0.24 \\
\hline $\mathrm{Na} 2 \mathrm{O}$ & 6.89 & 6.86 & 6.97 & 6.96 & 7.35 & 7.21 & 4.64 & 6.71 & 6.47 & 3.89 & 6.99 & 6.83 & 6.89 & 6.91 & 6.75 & 6.68 & 6.62 & 7.05 \\
\hline K2O & 0.01 & 0.02 & 0.02 & 0.00 & 0.00 & 0.00 & 0.05 & 0.02 & 0.01 & 0.06 & 0.00 & 0.01 & 0.00 & 0.02 & 0.01 & 0.01 & 0.02 & 0.00 \\
\hline F & 0.03 & 0.00 & 0.00 & 0.00 & 0.00 & 0.00 & 0.04 & 0.03 & 0.00 & 0.26 & 0.25 & 0.00 & 0.00 & 0.00 & 0.00 & 0.21 & 0.00 & 0.00 \\
\hline Cl & 0.00 & 0.01 & 0.02 & 0.00 & 0.01 & 0.01 & 0.01 & 0.01 & 0.00 & 0.01 & 0.00 & 0.01 & 0.00 & 0.00 & 0.00 & 0.01 & 0.02 & 0.02 \\
\hline TOTAL & 97.95 & 97.74 & 97.94 & 98.61 & 98.13 & 97.73 & 97.98 & 95.83 & 96.39 & 96.93 & 97.36 & 97.80 & 97.99 & 97.88 & 96.59 & 97.01 & 98.13 & 98.24 \\
\hline O_F_Cl & 0.01 & 0.00 & 0.00 & 0.00 & 0.00 & 0.00 & 0.02 & 0.01 & 0.00 & 0.11 & 0.10 & 0.00 & 0.00 & 0.00 & 0.00 & 0.09 & 0.00 & 0.00 \\
\hline $\mathrm{OF}$ & 0.01 & 0.00 & 0.00 & 0.00 & 0.00 & 0.00 & 0.02 & 0.01 & 0.00 & 0.11 & 0.10 & 0.00 & 0.00 & 0.00 & 0.00 & 0.09 & 0.00 & 0.00 \\
\hline $\mathrm{O}^{-} \mathrm{Cl}$ & 0.00 & 0.00 & 0.00 & 0.00 & 0.00 & 0.00 & 0.00 & 0.00 & 0.00 & 0.00 & 0.00 & 0.00 & 0.00 & 0.00 & 0.00 & 0.00 & 0.00 & 0.00 \\
\hline $\mathrm{H} 2 \mathrm{O}$ & 0.00 & 0.00 & 0.00 & 0.00 & 0.00 & 0.00 & 0.00 & 0.00 & 0.00 & 0.00 & 0.00 & 0.00 & 0.00 & 0.00 & 0.00 & 0.00 & 0.00 & 0.00 \\
\hline CTOTAL & 97.94 & 97.74 & 97.94 & 98.61 & 98.13 & 97.73 & 97.96 & 95.82 & 96.39 & 96.82 & 97.26 & 97.80 & 97.99 & 97.88 & 96.59 & 96.92 & 98.13 & 98.24 \\
\hline $\mathrm{Si}$ & 7.72 & 7.83 & 7.87 & 7.90 & 7.87 & 7.88 & 7.78 & 7.76 & 7.83 & 7.94 & 7.78 & 7.82 & 7.81 & 7.83 & 7.81 & 7.82 & 7.57 & 7.91 \\
\hline Al & 0.28 & 0.17 & 0.13 & 0.10 & 0.13 & 0.12 & 0.22 & 0.24 & 0.17 & 0.06 & 0.22 & 0.18 & 0.19 & 0.17 & 0.20 & 0.18 & 0.43 & 0.09 \\
\hline $\mathrm{Fe} 3$ & 0.00 & 0.00 & 0.00 & 0.00 & 0.00 & 0.00 & 0.00 & 0.00 & 0.00 & 0.00 & 0.00 & 0.00 & 0.00 & 0.00 & 0.00 & 0.00 & 0.00 & 0.00 \\
\hline $\mathrm{Ti}$ & 0.00 & 0.00 & 0.00 & 0.00 & 0.00 & 0.00 & 0.00 & 0.00 & 0.00 & 0.00 & 0.00 & 0.00 & 0.00 & 0.00 & 0.00 & 0.00 & 0.00 & 0.00 \\
\hline SUM_T & 8.00 & 8.00 & 8.00 & 8.00 & 8.00 & 8.00 & 8.00 & 8.00 & 8.00 & 8.00 & 8.00 & 8.00 & 8.00 & 8.00 & 8.00 & 8.00 & 8.00 & 8.00 \\
\hline $\mathrm{Cal}^{-}$ & 1.38 & 1.37 & 1.44 & 1.67 & 1.63 & 1.68 & 0.73 & 1.32 & 1.37 & 1.03 & 1.19 & 1.36 & 1.36 & 1.22 & 1.25 & 1.33 & 1.11 & 1.74 \\
\hline $\mathrm{CCr}$ & 0.00 & 0.00 & 0.00 & 0.00 & 0.00 & 0.00 & 0.00 & 0.00 & 0.00 & 0.00 & 0.00 & 0.00 & 0.00 & 0.00 & 0.00 & 0.00 & 0.00 & 0.00 \\
\hline CFe3 & 0.72 & 0.74 & 0.63 & 0.46 & 0.51 & 0.42 & 0.73 & 0.77 & 0.76 & 0.00 & 0.89 & 0.77 & 0.83 & 0.89 & 0.88 & 0.77 & 0.63 & 0.43 \\
\hline $\mathrm{Cti}$ & 0.01 & 0.01 & 0.01 & 0.02 & 0.00 & 0.00 & 0.01 & 0.02 & 0.00 & 0.28 & 0.02 & 0.02 & 0.00 & 0.01 & 0.00 & 0.00 & 0.35 & 0.01 \\
\hline CMg & 1.91 & 1.91 & 1.96 & 2.00 & 2.12 & 2.09 & 2.51 & 1.90 & 1.99 & 2.50 & 1.88 & 1.86 & 1.95 & 1.84 & 1.88 & 1.89 & 1.95 & 2.13 \\
\hline CFe2 & 0.95 & 0.94 & 0.94 & 0.83 & 0.72 & 0.79 & 0.99 & 0.97 & 0.86 & 1.17 & 1.00 & 0.97 & 0.84 & 1.02 & 0.97 & 0.99 & 0.94 & 0.67 \\
\hline CMn & 0.03 & 0.02 & 0.03 & 0.03 & 0.02 & 0.03 & 0.03 & 0.02 & 0.03 & 0.02 & 0.02 & 0.02 & 0.02 & 0.02 & 0.03 & 0.03 & 0.02 & 0.03 \\
\hline Cca & 0.00 & 0.00 & 0.00 & 0.00 & 0.00 & 0.00 & 0.00 & 0.00 & 0.00 & 0.00 & 0.00 & 0.00 & 0.00 & 0.00 & 0.00 & 0.00 & 0.00 & 0.00 \\
\hline SUM_C & 5.00 & 5.00 & 5.00 & 5.00 & 5.00 & 5.00 & 5.00 & 5.00 & 5.00 & 5.00 & 5.00 & 5.00 & 5.00 & 5.00 & 5.00 & 5.00 & 5.00 & 5.00 \\
\hline $\mathrm{BMg}^{-}$ & 0.00 & 0.00 & 0.00 & 0.00 & 0.00 & 0.00 & 0.00 & 0.00 & 0.00 & 0.00 & 0.00 & 0.00 & 0.00 & 0.00 & 0.00 & 0.00 & 0.00 & 0.00 \\
\hline BFe2 & 0.00 & 0.00 & 0.00 & 0.00 & 0.00 & 0.00 & 0.00 & 0.00 & 0.00 & 0.00 & 0.00 & 0.00 & 0.00 & 0.00 & 0.00 & 0.00 & 0.00 & 0.00 \\
\hline $\mathrm{BMn}$ & 0.00 & 0.00 & 0.00 & 0.00 & 0.00 & 0.00 & 0.00 & 0.00 & 0.00 & 0.00 & 0.00 & 0.00 & 0.00 & 0.00 & 0.00 & 0.00 & 0.00 & 0.00 \\
\hline $\mathrm{BCa}$ & 0.15 & 0.10 & 0.10 & 0.06 & 0.03 & 0.06 & 0.75 & 0.14 & 0.15 & 1.14 & 0.10 & 0.09 & 0.08 & 0.09 & 0.11 & 0.13 & 0.10 & 0.03 \\
\hline $\mathrm{BNa}$ & 1.85 & 1.84 & 1.86 & 1.83 & 1.93 & 1.91 & 1.26 & 1.84 & 1.75 & 0.87 & 1.90 & 1.83 & 1.84 & 1.86 & 1.84 & 1.82 & 1.78 & 1.84 \\
\hline SUM B & 2.00 & 1.94 & 1.96 & 1.88 & 1.96 & 1.97 & 2.00 & 1.98 & 1.90 & 2.00 & 2.00 & 1.92 & 1.92 & 1.95 & 1.95 & 1.95 & 1.88 & 1.88 \\
\hline $\mathrm{ACa}^{-}$ & 0.00 & 0.00 & 0.00 & 0.00 & 0.00 & 0.00 & 0.00 & 0.00 & 0.00 & 0.00 & 0.00 & 0.00 & 0.00 & 0.00 & 0.00 & 0.00 & 0.00 & 0.00 \\
\hline $\mathrm{ANa}$ & 0.00 & 0.00 & 0.00 & 0.00 & 0.00 & 0.00 & 0.01 & 0.00 & 0.00 & 0.22 & 0.00 & 0.00 & 0.00 & 0.00 & 0.00 & 0.00 & 0.00 & 0.00 \\
\hline AK & 0.00 & 0.00 & 0.00 & 0.00 & 0.00 & 0.00 & 0.01 & 0.00 & 0.00 & 0.01 & 0.00 & 0.00 & 0.00 & 0.00 & 0.00 & 0.00 & 0.00 & 0.00 \\
\hline SUM A & 0.00 & 0.00 & 0.00 & 0.00 & 0.00 & 0.00 & 0.02 & 0.00 & 0.00 & 0.23 & 0.00 & 0.00 & 0.00 & 0.00 & 0.00 & 0.00 & 0.00 & 0.00 \\
\hline SUM CAT & 15.00 & 14.94 & 14.96 & 14.88 & 14.96 & 14.97 & 15.02 & 14.99 & 14.90 & 15.23 & 15.00 & 14.92 & 14.92 & 14.95 & 14.96 & 14.95 & 14.88 & 14.88 \\
\hline $\mathrm{CCl}^{-}$ & 0.00 & 0.00 & 0.00 & 0.00 & 0.00 & 0.00 & 0.00 & 0.00 & 0.00 & 0.00 & 0.00 & 0.00 & 0.00 & 0.00 & 0.00 & 0.00 & 0.01 & 0.00 \\
\hline $\mathrm{CF}$ & 0.02 & 0.00 & 0.00 & 0.00 & 0.00 & 0.00 & 0.02 & 0.01 & 0.00 & 0.12 & 0.11 & 0.00 & 0.00 & 0.00 & 0.00 & 0.09 & 0.00 & 0.00 \\
\hline
\end{tabular}


Analıses de quimıca mıneral de antıbolıo selecıonados da regıao de Jambalo

\begin{tabular}{|c|c|c|c|c|c|c|c|c|c|c|c|c|c|c|c|c|c|c|}
\hline Amostra & 129A & 129A & 129A & 129A & 129A & 129A & 129A & 129A & 129A & 129A & 129A & 129A & $129 \mathrm{~A}$ & 129A & 129A & 129A & 129A & 129A \\
\hline Análise & 047 & 048 & 049 & 050 & 051 & 052 & 053 & 054 & 055 & 056 & 057 & 058 & 059 & 060 & 061 & 062 & 063 & 064 \\
\hline SiO2 & 55.79 & 55.65 & 54.46 & 56.16 & 55.27 & 55.40 & 55.00 & 56.66 & 56.25 & 56.18 & 55.53 & 56.61 & 55.26 & 57.29 & 56.78 & 55.93 & 54.60 & 55.96 \\
\hline TiO2 & 0.00 & 0.04 & 0.04 & 0.13 & 0.15 & 0.00 & 0.17 & 0.06 & 0.19 & 0.12 & 0.06 & 0.00 & 0.00 & 0.00 & 0.00 & 0.06 & 0.06 & 0.06 \\
\hline $\mathrm{Al} 2 \mathrm{O} 3$ & 8.48 & 12.17 & 12.68 & 12.27 & 10.42 & 12.43 & 10.31 & 12.37 & 12.50 & 12.66 & 12.28 & 10.91 & 8.93 & 10.95 & 12.50 & 12.81 & 8.75 & 12.73 \\
\hline $\mathrm{FeO}$ & 17.30 & 13.94 & 14.65 & 13.71 & 14.98 & 14.26 & 15.95 & 13.95 & 14.05 & 13.89 & 14.20 & 14.58 & 18.54 & 12.94 & 13.60 & 13.38 & 18.51 & 14.10 \\
\hline MnO & 0.06 & 0.04 & 0.07 & 0.05 & 0.10 & 0.02 & 0.04 & 0.00 & 0.02 & 0.03 & 0.04 & 0.04 & 0.00 & 0.00 & 0.05 & 0.03 & 0.06 & 0.04 \\
\hline MgO & 7.92 & 7.61 & 7.69 & 7.84 & 8.75 & 7.60 & 8.29 & 7.88 & 7.72 & 7.63 & 7.58 & 8.15 & 6.77 & 9.00 & 7.90 & 8.19 & 7.10 & 7.60 \\
\hline $\mathrm{CaO}$ & 0.16 & 0.66 & 1.07 & 0.27 & 0.51 & 0.62 & 0.65 & 0.23 & 0.46 & 0.67 & 0.57 & 0.12 & 0.17 & 0.08 & 0.24 & 0.32 & 0.40 & 0.57 \\
\hline $\mathrm{Na} 2 \mathrm{O}$ & 7.11 & 6.97 & 6.89 & 7.31 & 7.03 & 7.10 & 6.94 & 7.04 & 7.19 & 7.08 & 7.05 & 7.17 & 7.11 & 7.38 & 7.41 & 4.47 & 7.23 & 7.03 \\
\hline K2O & 0.00 & 0.02 & 0.04 & 0.01 & 0.04 & 0.03 & 0.01 & 0.11 & 0.05 & 0.01 & 0.01 & 0.01 & 0.00 & 0.01 & 0.01 & 0.78 & 0.02 & 0.02 \\
\hline$F$ & 0.10 & 0.21 & 0.31 & 0.00 & 0.13 & 0.00 & 0.23 & 0.33 & 0.18 & 0.00 & 0.00 & 0.00 & 0.00 & 0.14 & 0.00 & 0.00 & 0.00 & 0.00 \\
\hline $\mathrm{Cl}$ & 0.02 & 0.00 & 0.00 & 0.00 & 0.01 & 0.01 & 0.00 & 0.00 & 0.00 & 0.01 & 0.01 & 0.00 & 0.00 & 0.00 & 0.01 & 0.00 & 0.02 & 0.02 \\
\hline TOTAL & 96.93 & 97.29 & 97.89 & 97.76 & 97.38 & 97.47 & 97.57 & 98.62 & 98.61 & 98.28 & 97.32 & 97.59 & 96.77 & 97.77 & 98.49 & 95.95 & 96.74 & 98.10 \\
\hline O_F_Cl & 0.04 & 0.09 & 0.13 & 0.00 & 0.06 & 0.00 & 0.09 & 0.14 & 0.07 & 0.00 & 0.00 & 0.00 & 0.00 & 0.06 & 0.00 & 0.00 & 0.00 & 0.00 \\
\hline O_F- & 0.04 & 0.09 & 0.13 & 0.00 & 0.06 & 0.00 & 0.09 & 0.14 & 0.07 & 0.00 & 0.00 & 0.00 & 0.00 & 0.06 & 0.00 & 0.00 & 0.00 & 0.00 \\
\hline O_Cl & 0.00 & 0.00 & 0.00 & 0.00 & 0.00 & 0.00 & 0.00 & 0.00 & 0.00 & 0.00 & 0.00 & 0.00 & 0.00 & 0.00 & 0.00 & 0.00 & 0.00 & 0.00 \\
\hline $\mathrm{H} 2 \mathrm{O}$ & 0.00 & 0.00 & 0.00 & 0.00 & 0.00 & 0.00 & 0.00 & 0.00 & 0.00 & 0.00 & 0.00 & 0.00 & 0.00 & 0.00 & 0.00 & 0.00 & 0.00 & 0.00 \\
\hline CTOTAL & 96.89 & 97.20 & 97.76 & 97.76 & 97.32 & 97.47 & 97.48 & 98.48 & 98.54 & 98.28 & 97.32 & 97.59 & 96.77 & 97.71 & 98.49 & 95.95 & 96.74 & 98.10 \\
\hline Si & 7.87 & 7.78 & 7.60 & 7.78 & 7.70 & 7.72 & 7.69 & 7.78 & 7.75 & 7.75 & 7.74 & 7.84 & 7.86 & 7.89 & 7.79 & 7.70 & 7.79 & 7.73 \\
\hline Al & 0.13 & 0.22 & 0.40 & 0.23 & 0.30 & 0.28 & 0.31 & 0.22 & 0.25 & 0.25 & 0.26 & 0.16 & 0.14 & 0.11 & 0.21 & 0.31 & 0.21 & 0.27 \\
\hline $\mathrm{Fe} 3$ & 0.00 & 0.00 & 0.00 & 0.00 & 0.00 & 0.00 & 0.00 & 0.00 & 0.00 & 0.00 & 0.00 & 0.00 & 0.00 & 0.00 & 0.00 & 0.00 & 0.00 & 0.00 \\
\hline $\mathrm{Ti}$ & 0.00 & 0.00 & 0.00 & 0.00 & 0.00 & 0.00 & 0.00 & 0.00 & 0.00 & 0.00 & 0.00 & 0.00 & 0.00 & 0.00 & 0.00 & 0.00 & 0.00 & 0.00 \\
\hline SUM_T & 8.00 & 8.00 & 8.00 & 8.00 & 8.00 & 8.00 & 8.00 & 8.00 & 8.00 & 8.00 & 8.00 & 8.00 & 8.00 & 8.00 & 8.00 & 8.00 & 8.00 & 8.00 \\
\hline Cal & 1.28 & 1.78 & 1.68 & 1.78 & 1.41 & 1.76 & 1.39 & 1.78 & 1.78 & 1.81 & 1.76 & 1.62 & 1.36 & 1.66 & 1.82 & 1.77 & 1.27 & 1.80 \\
\hline $\mathrm{CCr}$ & 0.00 & 0.00 & 0.00 & 0.00 & 0.00 & 0.00 & 0.00 & 0.00 & 0.00 & 0.00 & 0.00 & 0.00 & 0.00 & 0.00 & 0.00 & 0.00 & 0.00 & 0.00 \\
\hline CFe3 & 0.85 & 0.35 & 0.53 & 0.38 & 0.80 & 0.42 & 0.81 & 0.47 & 0.37 & 0.32 & 0.41 & 0.57 & 0.77 & 0.46 & 0.35 & 1.10 & 0.80 & 0.41 \\
\hline Cti & 0.00 & 0.00 & 0.00 & 0.01 & 0.02 & 0.00 & 0.02 & 0.01 & 0.02 & 0.01 & 0.01 & 0.00 & 0.00 & 0.00 & 0.00 & 0.01 & 0.01 & 0.01 \\
\hline $\mathrm{CMg}$ & 1.67 & 1.59 & 1.60 & 1.62 & 1.82 & 1.58 & 1.73 & 1.61 & 1.59 & 1.57 & 1.58 & 1.68 & 1.44 & 1.85 & 1.62 & 1.68 & 1.51 & 1.56 \\
\hline CFe2 & 1.19 & 1.28 & 1.19 & 1.21 & 0.95 & 1.25 & 1.05 & 1.13 & 1.25 & 1.29 & 1.25 & 1.12 & 1.44 & 1.04 & 1.21 & 0.44 & 1.41 & 1.22 \\
\hline CMn & 0.01 & 0.00 & 0.01 & 0.01 & 0.01 & 0.00 & 0.00 & 0.00 & 0.00 & 0.00 & 0.01 & 0.01 & 0.00 & 0.00 & 0.01 & 0.00 & 0.01 & 0.01 \\
\hline Cca & 0.00 & 0.00 & 0.00 & 0.00 & 0.00 & 0.00 & 0.00 & 0.00 & 0.00 & 0.00 & 0.00 & 0.00 & 0.00 & 0.00 & 0.00 & 0.00 & 0.00 & 0.00 \\
\hline SUM_C & 5.00 & 5.00 & 5.00 & 5.00 & 5.00 & 5.00 & 5.00 & 5.00 & 5.00 & 5.00 & 5.00 & 5.00 & 5.00 & 5.00 & 5.00 & 5.00 & 5.00 & 5.00 \\
\hline $\mathrm{BMg}^{-}$ & 0.00 & 0.00 & 0.00 & 0.00 & 0.00 & 0.00 & 0.00 & 0.00 & 0.00 & 0.00 & 0.00 & 0.00 & 0.00 & 0.00 & 0.00 & 0.00 & 0.00 & 0.00 \\
\hline BFe2 & 0.00 & 0.00 & 0.00 & 0.00 & 0.00 & 0.00 & 0.00 & 0.00 & 0.00 & 0.00 & 0.00 & 0.00 & 0.00 & 0.00 & 0.00 & 0.00 & 0.00 & 0.00 \\
\hline BMn & 0.00 & 0.00 & 0.00 & 0.00 & 0.00 & 0.00 & 0.00 & 0.00 & 0.00 & 0.00 & 0.00 & 0.00 & 0.00 & 0.00 & 0.00 & 0.00 & 0.00 & 0.00 \\
\hline $\mathrm{BCa}$ & 0.03 & 0.10 & 0.16 & 0.04 & 0.08 & 0.09 & 0.10 & 0.03 & 0.07 & 0.10 & 0.09 & 0.02 & 0.03 & 0.01 & 0.04 & 0.05 & 0.06 & 0.08 \\
\hline $\mathrm{BNa}$ & 1.95 & 1.89 & 1.84 & 1.96 & 1.90 & 1.91 & 1.88 & 1.87 & 1.92 & 1.90 & 1.91 & 1.93 & 1.96 & 1.97 & 1.97 & 1.19 & 1.94 & 1.88 \\
\hline SUM_B & 1.97 & 1.99 & 2.00 & 2.00 & 1.98 & 2.00 & 1.98 & 1.91 & 1.99 & 1.99 & 1.99 & 1.95 & 1.99 & 1.98 & 2.00 & 1.24 & 2.00 & 1.97 \\
\hline $\mathrm{ACa}^{-}$ & 0.00 & 0.00 & 0.00 & 0.00 & 0.00 & 0.00 & 0.00 & 0.00 & 0.00 & 0.00 & 0.00 & 0.00 & 0.00 & 0.00 & 0.00 & 0.00 & 0.00 & 0.00 \\
\hline $\mathrm{ANa}$ & 0.00 & 0.00 & 0.02 & 0.00 & 0.00 & 0.01 & 0.00 & 0.00 & 0.00 & 0.00 & 0.00 & 0.00 & 0.00 & 0.00 & 0.01 & 0.00 & 0.06 & 0.00 \\
\hline AK & 0.00 & 0.00 & 0.01 & 0.00 & 0.01 & 0.01 & 0.00 & 0.02 & 0.01 & 0.00 & 0.00 & 0.00 & 0.00 & 0.00 & 0.00 & 0.14 & 0.00 & 0.00 \\
\hline SUM_A & 0.00 & 0.00 & 0.03 & 0.01 & 0.01 & 0.02 & 0.00 & 0.02 & 0.01 & 0.00 & 0.00 & 0.00 & 0.00 & 0.00 & 0.01 & 0.14 & 0.07 & 0.00 \\
\hline SUM_CAT & 14.97 & 14.99 & 15.03 & 15.01 & 14.98 & 15.02 & 14.98 & 14.93 & 15.00 & 15.00 & 14.99 & 14.95 & 14.99 & 14.98 & 15.01 & 14.38 & 15.07 & 14.97 \\
\hline $\mathrm{CCl}^{-}$ & 0.00 & 0.00 & 0.00 & 0.00 & 0.00 & 0.00 & 0.00 & 0.00 & 0.00 & 0.00 & 0.00 & 0.00 & 0.00 & 0.00 & 0.00 & 0.00 & 0.00 & 0.00 \\
\hline CF & 0.04 & 0.09 & 0.14 & 0.00 & 0.06 & 0.00 & 0.10 & 0.14 & 0.08 & 0.00 & 0.00 & 0.00 & 0.00 & 0.06 & 0.00 & 0.00 & 0.00 & 0.00 \\
\hline
\end{tabular}




\begin{tabular}{|c|c|c|c|c|c|c|c|c|c|c|c|c|c|c|c|c|}
\hline Amostra & & & & & & & & 118 & & & & & & & & \\
\hline Análise & 456 & 457 & 458 & 459 & 460 & 461 & 462 & 463 & 479 & 480 & 481 & 482 & 483 & 484 & 485 & 486 \\
\hline SiO2 & 26.10 & 26.85 & 26.35 & 26.56 & 26.71 & 26.64 & 26.59 & 26.09 & 26.22 & 25.81 & 26.40 & 26.60 & 26.09 & 26.67 & 26.19 & 26.50 \\
\hline TiO2 & 0.00 & 0.06 & 0.00 & 0.00 & 0.24 & 0.08 & 0.02 & 0.00 & 0.08 & 0.00 & 0.02 & 0.02 & 0.09 & 0.02 & 0.06 & 0.00 \\
\hline $\mathrm{Al} 2 \mathrm{O} 3$ & 20.13 & 20.47 & 20.10 & 20.54 & 20.57 & 20.42 & 20.52 & 20.64 & 20.53 & 20.04 & 20.72 & 20.40 & 20.37 & 20.59 & 20.21 & 20.54 \\
\hline Cr2O3 & 0.00 & 0.00 & 0.00 & 0.00 & 0.00 & 0.00 & 0.00 & 0.00 & 0.00 & 0.00 & 0.00 & 0.00 & 0.00 & 0.00 & 0.00 & 0.00 \\
\hline $\mathrm{FeO}$ & 22.79 & 23.28 & 23.77 & 23.61 & 22.98 & 23.79 & 24.30 & 23.95 & 23.50 & 25.43 & 23.31 & 23.15 & 23.00 & 22.94 & 26.40 & 24.22 \\
\hline $\mathrm{Fe} 2 \mathrm{O} 3$ & 0.00 & 0.00 & 0.00 & 0.00 & 0.00 & 0.00 & 0.00 & 0.00 & 0.00 & 0.00 & 0.00 & 0.00 & 0.00 & 0.00 & 0.00 & 0.00 \\
\hline $\mathrm{MnO}$ & 0.09 & 0.25 & 0.24 & 0.18 & 0.19 & 0.25 & 0.29 & 0.24 & 0.20 & 0.34 & 0.23 & 0.20 & 0.16 & 0.21 & 0.43 & 0.29 \\
\hline $\mathrm{MgO}$ & 17.31 & 16.77 & 16.38 & 16.72 & 16.69 & 15.90 & 16.19 & 15.74 & 16.58 & 15.59 & 15.62 & 16.78 & 16.72 & 16.62 & 15.35 & 16.04 \\
\hline $\mathrm{CaO}$ & 0.01 & 0.00 & 0.01 & 0.00 & 0.05 & 0.01 & 0.04 & 0.05 & 0.04 & 0.03 & 0.03 & 0.03 & 0.05 & 0.05 & 0.02 & 0.02 \\
\hline $\mathrm{Na} 2 \mathrm{O}$ & 0.02 & 0.02 & 0.02 & 0.00 & 0.01 & 0.00 & 0.00 & 0.01 & 0.01 & 0.00 & 0.00 & 0.02 & 0.01 & 0.03 & 0.01 & 0.00 \\
\hline K2O & 0.02 & 0.00 & 0.01 & 0.02 & 0.00 & 0.03 & 0.03 & 0.01 & 0.01 & 0.01 & 0.01 & 0.00 & 0.00 & 0.01 & 0.01 & 0.01 \\
\hline $\mathbf{F}$ & 0.07 & 0.00 & 0.00 & 0.10 & 0.00 & 0.11 & 0.02 & 0.02 & 0.00 & 0.00 & 0.08 & 0.00 & 0.00 & 0.00 & 0.00 & 0.19 \\
\hline $\mathrm{Cl}$ & 0.00 & 0.03 & 0.01 & 0.00 & 0.02 & 0.02 & 0.01 & 0.01 & 0.01 & 0.03 & 0.02 & 0.00 & 0.01 & 0.01 & 0.02 & 0.03 \\
\hline $\mathrm{H} 2 \mathrm{O}$ & 0.00 & 0.00 & 0.00 & 0.00 & 0.00 & 0.00 & 0.00 & 0.00 & 0.00 & 0.00 & 0.00 & 0.00 & 0.00 & 0.00 & 0.00 & 0.00 \\
\hline TOTAL & 86.53 & 87.72 & 86.89 & 87.73 & 87.47 & 87.25 & 88.01 & 86.75 & 87.18 & 87.26 & 86.46 & 87.20 & 86.51 & 87.15 & 88.69 & 87.83 \\
\hline O_F_Cl & 0.03 & 0.01 & 0.00 & 0.04 & 0.00 & 0.05 & 0.01 & 0.01 & 0.00 & 0.01 & 0.04 & 0.00 & 0.00 & 0.00 & 0.00 & 0.09 \\
\hline O_F & 0.03 & 0.00 & 0.00 & 0.04 & 0.00 & 0.05 & 0.01 & 0.01 & 0.00 & 0.00 & 0.03 & 0.00 & 0.00 & 0.00 & 0.00 & 0.08 \\
\hline O_Cl & 0.00 & 0.01 & 0.00 & 0.00 & 0.00 & 0.00 & 0.00 & 0.00 & 0.00 & 0.01 & 0.00 & 0.00 & 0.00 & 0.00 & 0.00 & 0.01 \\
\hline CTOTAL & 86.50 & 87.71 & 86.89 & 87.69 & 87.47 & 87.20 & 88.00 & 86.74 & 87.18 & 87.25 & 86.42 & 87.20 & 86.51 & 87.15 & 88.69 & 87.74 \\
\hline Si & 5.70 & 5.78 & 5.76 & 5.74 & 5.76 & 5.79 & 5.74 & 5.71 & 5.70 & 5.68 & 5.78 & 5.76 & 5.70 & 5.77 & 5.69 & 5.75 \\
\hline AllV & 2.30 & 2.22 & 2.25 & 2.26 & 2.24 & 2.21 & 2.26 & 2.29 & 2.30 & 2.33 & 2.22 & 2.24 & 2.30 & 2.23 & 2.31 & 2.25 \\
\hline SUM_T & 8.00 & 8.00 & 8.00 & 8.00 & 8.00 & 8.00 & 8.00 & 8.00 & 8.00 & 8.00 & 8.00 & 8.00 & 8.00 & 8.00 & 8.00 & 8.00 \\
\hline AIVI $^{-}$ & 2.88 & 2.97 & 2.92 & 2.96 & 2.98 & 3.02 & 2.96 & 3.04 & 2.95 & 2.86 & 3.12 & 2.96 & 2.94 & 3.02 & 2.85 & 2.99 \\
\hline $\mathrm{Ti}$ & 0.00 & 0.01 & 0.00 & 0.00 & 0.04 & 0.01 & 0.00 & 0.00 & 0.01 & 0.00 & 0.00 & 0.00 & 0.02 & 0.00 & 0.01 & 0.00 \\
\hline $\mathrm{Fe} 3$ & 0.00 & 0.00 & 0.00 & 0.00 & 0.00 & 0.00 & 0.00 & 0.00 & 0.00 & 0.00 & 0.00 & 0.00 & 0.00 & 0.00 & 0.00 & 0.00 \\
\hline $\mathrm{Fe} 2$ & 4.16 & 4.19 & 4.34 & 4.27 & 4.15 & 4.33 & 4.39 & 4.39 & 4.27 & 4.68 & 4.27 & 4.19 & 4.20 & 4.15 & 4.80 & 4.39 \\
\hline $\mathrm{Cr}$ & 0.00 & 0.00 & 0.00 & 0.00 & 0.00 & 0.00 & 0.00 & 0.00 & 0.00 & 0.00 & 0.00 & 0.00 & 0.00 & 0.00 & 0.00 & 0.00 \\
\hline Mn & 0.02 & 0.05 & 0.05 & 0.03 & 0.03 & 0.05 & 0.05 & 0.05 & 0.04 & 0.06 & 0.04 & 0.04 & 0.03 & 0.04 & 0.08 & 0.05 \\
\hline $\mathbf{M g}$ & 5.64 & 5.38 & 5.33 & 5.38 & 5.36 & 5.16 & 5.21 & 5.14 & 5.37 & 5.11 & 5.10 & 5.42 & 5.45 & 5.36 & 4.97 & 5.18 \\
\hline $\mathrm{Ca}$ & 0.00 & 0.00 & 0.00 & 0.00 & 0.01 & 0.00 & 0.01 & 0.01 & 0.01 & 0.01 & 0.01 & 0.01 & 0.01 & 0.01 & 0.00 & 0.00 \\
\hline $\mathrm{Na}$ & 0.01 & 0.01 & 0.01 & 0.00 & 0.01 & 0.00 & 0.00 & 0.00 & 0.00 & 0.00 & 0.00 & 0.01 & 0.00 & 0.01 & 0.01 & 0.00 \\
\hline K & 0.01 & 0.00 & 0.00 & 0.00 & 0.00 & 0.01 & 0.01 & 0.00 & 0.00 & 0.00 & 0.00 & 0.00 & 0.00 & 0.00 & 0.00 & 0.00 \\
\hline CATIONS & 20.71 & 20.61 & 20.66 & 20.65 & 20.59 & 20.57 & 20.64 & 20.62 & 20.66 & 20.72 & 20.54 & 20.63 & 20.65 & 20.60 & 20.72 & 20.62 \\
\hline CF & 0.09 & 0.00 & 0.00 & 0.13 & 0.00 & 0.16 & 0.03 & 0.03 & 0.00 & 0.00 & 0.12 & 0.00 & 0.00 & 0.00 & 0.00 & 0.27 \\
\hline CCL & 0.00 & 0.02 & 0.01 & 0.00 & 0.01 & 0.01 & 0.01 & 0.01 & 0.01 & 0.02 & 0.02 & 0.00 & 0.01 & 0.01 & 0.02 & 0.02 \\
\hline $\mathrm{OH}$ & 0.00 & 0.00 & 0.00 & 0.00 & 0.00 & 0.00 & 0.00 & 0.00 & 0.00 & 0.00 & 0.00 & 0.00 & 0.00 & 0.00 & 0.00 & 0.00 \\
\hline 0 & 36.00 & 36.00 & 36.00 & 36.00 & 36.00 & 36.00 & 36.00 & 36.00 & 36.00 & 36.00 & 36.00 & 36.00 & 36.00 & 36.00 & 36.00 & 36.00 \\
\hline Fe_FeMg & 0.42 & 0.44 & 0.45 & 0.44 & 0.44 & 0.46 & 0.46 & 0.46 & 0.44 & 0.48 & 0.46 & 0.44 & 0.44 & 0.44 & 0.49 & 0.46 \\
\hline Mg_FeMg & 0.58 & 0.56 & 0.55 & 0.56 & 0.56 & 0.54 & 0.54 & 0.54 & 0.56 & 0.52 & 0.54 & 0.56 & 0.56 & 0.56 & 0.51 & 0.54 \\
\hline Amostra & & & & & & 123A & & & & & & & & & & \\
\hline Análise & 235 & 235 & 236 & 236 & 237 & 237 & 238 & 238 & 239 & 239 & 240 & 240 & & & & \\
\hline $\mathrm{SiO} 2$ & 26.03 & 26.03 & 27.08 & 27.08 & 26.79 & 26.79 & 26.78 & 26.78 & 26.12 & 26.12 & 26.29 & 26.29 & & & & \\
\hline TiO2 & 0.08 & 0.08 & 0.04 & 0.04 & 0.00 & 0.00 & 0.04 & 0.04 & 0.04 & 0.04 & 0.04 & 0.04 & & & & \\
\hline $\mathrm{Al} 2 \mathrm{O} 3$ & 19.58 & 19.58 & 19.48 & 19.48 & 19.71 & 19.71 & 20.04 & 20.04 & 20.41 & 20.41 & 20.41 & 20.41 & & & & \\
\hline Cr2O3 & 0.00 & 0.00 & 0.00 & 0.00 & 0.00 & 0.00 & 0.00 & 0.00 & 0.00 & 0.00 & 0.00 & 0.00 & & & & \\
\hline $\mathrm{FeO}$ & 19.30 & 19.30 & 18.77 & 18.77 & 19.56 & 19.56 & 19.34 & 19.34 & 19.53 & 19.53 & 19.55 & 19.55 & & & & \\
\hline $\mathrm{Fe} 2 \mathrm{O} 3$ & 0.00 & 0.00 & 0.00 & 0.00 & 0.00 & 0.00 & 0.00 & 0.00 & 0.00 & 0.00 & 0.00 & 0.00 & & & & \\
\hline MnO & 0.23 & 0.23 & 0.20 & 0.20 & 0.14 & 0.14 & 0.14 & 0.14 & 0.16 & 0.16 & 0.19 & 0.19 & & & & \\
\hline $\mathrm{MgO}$ & 19.49 & 19.49 & 19.68 & 19.68 & 19.15 & 19.15 & 19.65 & 19.65 & 19.68 & 19.68 & 19.17 & 19.17 & & & & \\
\hline $\mathrm{CaO}$ & 0.01 & 0.01 & 0.01 & 0.01 & 0.03 & 0.03 & 0.02 & 0.02 & 0.02 & 0.02 & 0.00 & 0.00 & & & & \\
\hline $\mathrm{Na} 2 \mathrm{O}$ & 0.00 & 0.00 & 0.02 & 0.02 & 0.01 & 0.01 & 0.03 & 0.03 & 0.02 & 0.02 & 0.02 & 0.02 & & & & \\
\hline K2O & 0.00 & 0.00 & 0.00 & 0.00 & 0.01 & 0.01 & 0.02 & 0.02 & 0.01 & 0.01 & 0.05 & 0.05 & & & & \\
\hline F & 0.00 & 0.00 & 0.01 & 0.01 & 0.04 & 0.04 & 0.00 & 0.00 & 0.00 & 0.00 & 0.00 & 0.00 & & & & \\
\hline $\mathrm{Cl}$ & 0.00 & 0.00 & 0.00 & 0.00 & 0.00 & 0.00 & 0.00 & 0.00 & 0.00 & 0.00 & 0.00 & 0.01 & & & & \\
\hline $\mathrm{H} 2 \mathrm{O}$ & 0.00 & 0.00 & 0.00 & 0.00 & 0.00 & 0.00 & 0.00 & 0.00 & 0.00 & 0.00 & 0.00 & 0.00 & & & & \\
\hline TOTAL & 84.71 & 84.71 & 85.28 & 85.28 & 85.44 & 85.44 & 86.05 & 86.05 & 85.98 & 85.98 & 85.71 & 85.71 & & & & \\
\hline O_F_Cl & 0.00 & 0.00 & 0.00 & 0.00 & 0.02 & 0.02 & 0.00 & 0.00 & 0.00 & 0.00 & 0.00 & 0.00 & & & & \\
\hline O_F & 0.00 & 0.00 & 0.00 & 0.00 & 0.02 & 0.02 & 0.00 & 0.00 & 0.00 & 0.00 & 0.00 & 0.00 & & & & \\
\hline $\mathrm{O}^{-} \mathrm{Cl}$ & 0.00 & 0.00 & 0.00 & 0.00 & 0.00 & 0.00 & 0.00 & 0.00 & 0.00 & 0.00 & 0.00 & 0.00 & & & & \\
\hline CT̄OTAL & 84.71 & 84.71 & 85.28 & 85.28 & 85.42 & 85.42 & 86.05 & 86.05 & 85.98 & 85.98 & 85.71 & 85.71 & & & & \\
\hline $\mathrm{Si}$ & 5.71 & 5.71 & 5.87 & 5.87 & 5.82 & 5.82 & 5.77 & 5.77 & 5.64 & 5.64 & 5.70 & 5.70 & & & & \\
\hline AlIV & 2.29 & 2.29 & 2.14 & 2.14 & 2.18 & 2.18 & 2.24 & 2.24 & 2.36 & 2.36 & 2.30 & 2.30 & & & & \\
\hline SUM_T & 8.00 & 8.00 & 8.00 & 8.00 & 8.00 & 8.00 & 8.00 & 8.00 & 8.00 & 8.00 & 8.00 & 8.00 & & & & \\
\hline $\mathrm{AlVI}^{-}$ & 2.77 & 2.77 & 2.83 & 2.83 & 2.86 & 2.86 & 2.85 & 2.85 & 2.84 & 2.84 & 2.90 & 2.90 & & & & \\
\hline $\mathrm{Ti}$ & 0.01 & 0.01 & 0.01 & 0.01 & 0.00 & 0.00 & 0.01 & 0.01 & 0.01 & 0.01 & 0.01 & 0.01 & & & & \\
\hline $\mathrm{Fe} 3$ & 0.00 & 0.00 & 0.00 & 0.00 & 0.00 & 0.00 & 0.00 & 0.00 & 0.00 & 0.00 & 0.00 & 0.00 & & & & \\
\hline $\mathrm{Fe} 2$ & 3.54 & 3.54 & 3.40 & 3.40 & 3.55 & 3.55 & 3.48 & 3.48 & 3.53 & 3.53 & 3.54 & 3.54 & & & & \\
\hline $\mathrm{Cr}$ & 0.00 & 0.00 & 0.00 & 0.00 & 0.00 & 0.00 & 0.00 & 0.00 & 0.00 & 0.00 & 0.00 & 0.00 & & & & \\
\hline$M n$ & 0.04 & 0.04 & 0.04 & 0.04 & 0.03 & 0.03 & 0.03 & 0.03 & 0.03 & 0.03 & 0.03 & 0.03 & & & & \\
\hline Mg & 6.38 & 6.38 & 6.36 & 6.36 & 6.20 & 6.20 & 6.31 & 6.31 & 6.34 & 6.34 & 6.19 & 6.19 & & & & \\
\hline $\mathrm{Ca}$ & 0.00 & 0.00 & 0.00 & 0.00 & 0.01 & 0.01 & 0.01 & 0.01 & 0.00 & 0.00 & 0.00 & 0.00 & & & & \\
\hline $\mathrm{Na}$ & 0.00 & 0.00 & 0.01 & 0.01 & 0.01 & 0.01 & 0.01 & 0.01 & 0.01 & 0.01 & 0.01 & 0.01 & & & & \\
\hline $\mathrm{K}$ & 0.00 & 0.00 & 0.00 & 0.00 & 0.00 & 0.00 & 0.01 & 0.01 & 0.00 & 0.00 & 0.01 & 0.01 & & & & \\
\hline CATIONS & 20.74 & 20.74 & 20.64 & 20.64 & 20.66 & 20.66 & 20.69 & 20.69 & 20.75 & 20.75 & 20.70 & 20.70 & & & & \\
\hline CF & 0.00 & 0.00 & 0.01 & 0.01 & 0.05 & 0.05 & 0.00 & 0.00 & 0.00 & 0.00 & 0.00 & 0.00 & & & & \\
\hline CCL & 0.00 & 0.00 & 0.00 & 0.00 & 0.00 & 0.00 & 0.00 & 0.00 & 0.00 & 0.00 & 0.00 & 0.00 & & & & \\
\hline $\mathrm{OH}$ & 0.00 & 0.00 & 0.00 & 0.00 & 0.00 & 0.00 & 0.00 & 0.00 & 0.00 & 0.00 & 0.00 & 0.00 & & & & \\
\hline 0 & 36.00 & 36.00 & 36.00 & 36.00 & 36.00 & 36.00 & 36.00 & 36.00 & 36.00 & 36.00 & 36.00 & 36.00 & & & & \\
\hline $\mathrm{Fe} F \mathrm{FeMg}$ & 0.36 & 0.36 & 0.35 & 0.35 & 0.36 & 0.36 & 0.36 & 0.36 & 0.36 & 0.36 & 0.36 & 0.36 & & & & \\
\hline $\mathrm{Mg} \mathrm{FeMg}$ & 0.64 & 0.64 & 0.65 & 0.65 & 0.64 & 0.64 & 0.64 & 0.64 & 0.64 & 0.64 & 0.64 & 0.64 & & & & \\
\hline
\end{tabular}


Analıses de quimıca mıneral de clorıta selecıonados da regiao de Jambalo

\begin{tabular}{|c|c|c|c|c|c|c|c|c|c|c|c|c|c|c|}
\hline Amostra & & & & 124D & & & & & & & 124F & & & \\
\hline Análise & 551 & 552 & 553 & 554 & 555 & 556 & 557 & & 269 & 270 & 271 & 272 & 273 & 274 \\
\hline SiO2 & 28.08 & 27.60 & 27.68 & 27.52 & 27.46 & 27.65 & 27.55 & & 25.56 & 26.53 & 26.86 & 26.38 & 26.74 & 26.15 \\
\hline TiO2 & 0.02 & 0.08 & 0.05 & 0.05 & 0.04 & 0.01 & 0.03 & & 0.04 & 0.04 & 0.05 & 0.05 & 0.02 & 0.04 \\
\hline $\mathrm{Al} 2 \mathrm{O} 3$ & 19.64 & 19.39 & 19.70 & 20.10 & 20.09 & 19.83 & 19.15 & & 20.29 & 20.83 & 20.42 & 20.45 & 20.80 & 21.40 \\
\hline Cr2O3 & 0.00 & 0.00 & 0.00 & 0.00 & 0.00 & 0.00 & 0.00 & & 0.00 & 0.00 & 0.00 & 0.00 & 0.00 & 0.00 \\
\hline $\mathrm{FeO}$ & 22.00 & 21.84 & 21.86 & 21.34 & 21.22 & 21.16 & 21.45 & & 24.21 & 24.40 & 24.31 & 24.86 & 24.89 & 25.20 \\
\hline $\mathrm{Fe} 2 \mathrm{O} 3$ & 0.00 & 0.00 & 0.00 & 0.00 & 0.00 & 0.00 & 0.00 & & 0.00 & 0.00 & 0.00 & 0.00 & 0.00 & 0.00 \\
\hline MnO & 0.30 & 0.35 & 0.31 & 0.30 & 0.35 & 0.36 & 0.35 & & 0.27 & 0.22 & 0.25 & 0.22 & 0.27 & 0.30 \\
\hline $\mathrm{MgO}$ & 18.78 & 18.00 & 18.57 & 18.00 & 17.91 & 18.65 & 18.09 & & 16.42 & 16.25 & 16.67 & 16.34 & 16.09 & 15.92 \\
\hline $\mathrm{CaO}$ & 0.04 & 0.03 & 0.02 & 0.01 & 0.03 & 0.04 & 0.04 & & 0.00 & 0.00 & 0.03 & 0.04 & 0.01 & 0.04 \\
\hline $\mathrm{Na2O}$ & 0.72 & 0.00 & 0.00 & 0.00 & 0.01 & 0.00 & 0.22 & & 0.00 & 0.01 & 0.00 & 0.01 & 0.01 & 0.00 \\
\hline K2O & 0.00 & 0.00 & 0.00 & 0.01 & 0.00 & 0.01 & 0.00 & & 0.00 & 0.00 & 0.00 & 0.00 & 0.00 & 0.00 \\
\hline F & 0.07 & 0.02 & 0.04 & 0.03 & 0.06 & 0.05 & 0.03 & & 0.04 & 0.04 & 0.03 & 0.06 & 0.04 & 0.02 \\
\hline $\mathrm{Cl}$ & 0.00 & 0.00 & 0.00 & 0.00 & 0.00 & 0.00 & 0.00 & & 0.00 & 0.00 & 0.00 & 0.00 & 0.00 & 0.00 \\
\hline H2O & 0.00 & 0.00 & 0.00 & 0.00 & 0.00 & 0.00 & 0.00 & & 0.00 & 0.00 & 0.00 & 0.00 & 0.00 & 0.00 \\
\hline TOTAL & 89.64 & 87.29 & 88.23 & 87.37 & 87.15 & 87.75 & 86.89 & & 86.82 & 88.31 & 88.62 & 88.41 & 88.87 & 89.06 \\
\hline O_F_Cl & 0.03 & 0.01 & 0.02 & 0.01 & 0.03 & 0.02 & 0.01 & & 0.02 & 0.02 & 0.01 & 0.02 & 0.02 & 0.01 \\
\hline O_F & 0.03 & 0.01 & 0.02 & 0.01 & 0.03 & 0.02 & 0.01 & & 0.02 & 0.02 & 0.01 & 0.02 & 0.02 & 0.01 \\
\hline O_Cl & 0.00 & 0.00 & 0.00 & 0.00 & 0.00 & 0.00 & 0.00 & & 0.00 & 0.00 & 0.00 & 0.00 & 0.00 & 0.00 \\
\hline CTOTAL & 89.61 & 87.28 & 88.21 & 87.36 & 87.12 & 87.73 & 86.88 & & 86.80 & 88.29 & 88.61 & 88.39 & 88.85 & 89.05 \\
\hline Si & 5.89 & 5.93 & 5.88 & 5.89 & 5.89 & 5.89 & 5.94 & & 5.62 & 5.71 & 5.76 & 5.69 & 5.73 & 5.61 \\
\hline AllV & 2.11 & 2.07 & 2.12 & 2.11 & 2.11 & 2.11 & 2.06 & & 2.39 & 2.29 & 2.24 & 2.31 & 2.27 & 2.40 \\
\hline SUM_T & 8.00 & 8.00 & 8.00 & 8.00 & 8.00 & 8.00 & 8.00 & & 8.00 & 8.00 & 8.00 & 8.00 & 8.00 & 8.00 \\
\hline AIVI & 2.74 & 2.83 & 2.81 & 2.95 & 2.96 & 2.86 & 2.81 & & 2.86 & 2.99 & 2.91 & 2.89 & 2.98 & 3.01 \\
\hline $\mathrm{Ti}$ & 0.00 & 0.01 & 0.01 & 0.01 & 0.01 & 0.00 & 0.00 & & 0.01 & 0.01 & 0.01 & 0.01 & 0.00 & 0.01 \\
\hline $\mathrm{Fe} 3$ & 0.00 & 0.00 & 0.00 & 0.00 & 0.00 & 0.00 & 0.00 & & 0.00 & 0.00 & 0.00 & 0.00 & 0.00 & 0.00 \\
\hline $\mathrm{Fe} 2$ & 3.86 & 3.92 & 3.88 & 3.82 & 3.81 & 3.77 & 3.87 & & 4.45 & 4.39 & 4.36 & 4.49 & 4.46 & 4.52 \\
\hline $\mathrm{Cr}$ & 0.00 & 0.00 & 0.00 & 0.00 & 0.00 & 0.00 & 0.00 & & 0.00 & 0.00 & 0.00 & 0.00 & 0.00 & 0.00 \\
\hline Mn & 0.05 & 0.06 & 0.06 & 0.05 & 0.06 & 0.06 & 0.06 & & 0.05 & 0.04 & 0.05 & 0.04 & 0.05 & 0.06 \\
\hline Mg & 5.87 & 5.76 & 5.88 & 5.74 & 5.72 & 5.92 & 5.82 & & 5.38 & 5.21 & 5.33 & 5.26 & 5.14 & 5.09 \\
\hline $\mathrm{Ca}$ & 0.01 & 0.01 & 0.01 & 0.00 & 0.01 & 0.01 & 0.01 & & 0.00 & 0.00 & 0.01 & 0.01 & 0.00 & 0.01 \\
\hline $\mathrm{Na}$ & 0.29 & 0.00 & 0.00 & 0.00 & 0.00 & 0.00 & 0.09 & & 0.00 & 0.01 & 0.00 & 0.00 & 0.01 & 0.00 \\
\hline K & 0.00 & 0.00 & 0.00 & 0.00 & 0.00 & 0.00 & 0.00 & & 0.00 & 0.00 & 0.00 & 0.00 & 0.00 & 0.00 \\
\hline CATIONS & 20.83 & 20.60 & 20.64 & 20.57 & 20.57 & 20.62 & 20.66 & & 20.75 & 20.64 & 20.65 & 20.69 & 20.64 & 20.68 \\
\hline CF & 0.09 & 0.02 & 0.06 & 0.05 & 0.08 & 0.06 & 0.04 & & 0.06 & 0.05 & 0.04 & 0.08 & 0.05 & 0.03 \\
\hline CCL & 0.00 & 0.00 & 0.00 & 0.00 & 0.00 & 0.00 & 0.00 & & 0.00 & 0.00 & 0.00 & 0.00 & 0.00 & 0.00 \\
\hline $\mathrm{OH}$ & 0.00 & 0.00 & 0.00 & 0.00 & 0.00 & 0.00 & 0.00 & & 0.00 & 0.00 & 0.00 & 0.00 & 0.00 & 0.00 \\
\hline 0 & 36.00 & 36.00 & 36.00 & 36.00 & 36.00 & 36.00 & 36.00 & & 36.00 & 36.00 & 36.00 & 36.00 & 36.00 & 36.00 \\
\hline Fe_FeMg & 0.40 & 0.41 & 0.40 & 0.40 & 0.40 & 0.39 & 0.40 & & 0.45 & 0.46 & 0.45 & 0.46 & 0.46 & 0.47 \\
\hline Mg_FeMg & 0.60 & 0.59 & 0.60 & 0.60 & 0.60 & 0.61 & 0.60 & & 0.55 & 0.54 & 0.55 & 0.54 & 0.54 & 0.53 \\
\hline Amostra & & & $124 G$ & & & & & & & $124 \mathrm{H}$ & & & & \\
\hline Análise & 359 & 360 & 361 & 362 & 363 & & 2 & 7 & 8 & 91 & 92 & 94 & 95 & 96 \\
\hline $\mathrm{SiO} 2$ & 26.37 & 25.97 & 26.32 & 26.48 & 26.50 & & 26.11 & 26.95 & 29.49 & 27.08 & 27.31 & 29.27 & 29.84 & 27.39 \\
\hline TiO2 & 0.06 & 0.06 & 0.03 & 0.07 & 0.05 & & 0.00 & 0.02 & 0.01 & 0.02 & 0.02 & 0.04 & 0.04 & 0.04 \\
\hline $\mathrm{Al} 203$ & 20.10 & 20.69 & 20.85 & 20.68 & 20.91 & & 20.27 & 20.53 & 21.05 & 20.30 & 21.01 & 19.50 & 19.17 & 19.80 \\
\hline Cr2O3 & 0.00 & 0.00 & 0.00 & 0.00 & 0.00 & & 0.00 & 0.00 & 0.00 & 0.00 & 0.00 & 0.00 & 0.00 & 0.00 \\
\hline $\mathrm{FeO}$ & 25.57 & 25.72 & 26.00 & 25.69 & 25.56 & & 26.18 & 27.43 & 23.70 & 24.95 & 24.95 & 23.89 & 23.68 & 25.25 \\
\hline $\mathrm{Fe} 2 \mathrm{O} 3$ & 0.00 & 0.00 & 0.00 & 0.00 & 0.00 & & 0.00 & 0.00 & 0.00 & 0.00 & 0.00 & 0.00 & 0.00 & 0.00 \\
\hline MnO & 0.27 & 0.27 & 0.29 & 0.35 & 0.32 & & 0.42 & 0.37 & 0.31 & 0.40 & 0.37 & 0.38 & 0.29 & 0.37 \\
\hline $\mathrm{MgO}$ & 15.93 & 15.99 & 5.40 & 15.95 & 16.30 & & 14.79 & 14.43 & 12.17 & 15.64 & 16.11 & 14.07 & 13.62 & 14.68 \\
\hline $\mathrm{CaO}$ & 0.01 & 0.00 & 0.02 & 0.02 & 0.00 & & 0.03 & 0.06 & 0.16 & 0.05 & 0.03 & 0.52 & 0.54 & 0.12 \\
\hline $\mathrm{Na2O}$ & 0.03 & 0.00 & 0.00 & 0.02 & 0.04 & & 0.01 & 0.02 & 0.04 & 0.00 & 0.01 & 0.09 & 0.08 & 0.02 \\
\hline K2O & 0.00 & 0.00 & 0.00 & 0.02 & 0.00 & & 0.02 & 0.04 & 0.36 & 0.02 & 0.00 & 0.14 & 0.16 & 0.07 \\
\hline$F$ & 0.03 & 0.01 & 0.03 & 0.01 & 0.04 & & 0.03 & 0.06 & 0.22 & 0.00 & 0.10 & 0.01 & 0.03 & 0.00 \\
\hline $\mathrm{Cl}$ & 0.00 & 0.00 & 0.00 & 0.00 & 0.00 & & 0.00 & 0.00 & 0.00 & 0.00 & 0.00 & 0.00 & 0.00 & 0.00 \\
\hline $\mathrm{H} 2 \mathrm{O}$ & 0.00 & 0.00 & 0.00 & 0.00 & 0.00 & & 0.00 & 0.00 & 0.00 & 0.00 & 0.00 & 0.00 & 0.00 & 0.00 \\
\hline TOTAL & 88.37 & 88.70 & 78.93 & 89.29 & 89.71 & & 87.84 & 89.90 & 87.49 & 88.45 & 89.90 & 87.90 & 87.44 & 87.74 \\
\hline O_F_Cl & 0.01 & 0.00 & 0.01 & 0.01 & 0.02 & & 0.01 & 0.02 & 0.09 & 0.00 & 0.04 & 0.00 & 0.01 & 0.00 \\
\hline O_F & 0.01 & 0.00 & 0.01 & 0.01 & 0.02 & & 0.01 & 0.02 & 0.09 & 0.00 & 0.04 & 0.00 & 0.01 & 0.00 \\
\hline O_Cl & 0.00 & 0.00 & 0.00 & 0.00 & 0.00 & & 0.00 & 0.00 & 0.00 & 0.00 & 0.00 & 0.00 & 0.00 & 0.00 \\
\hline CTOTAL & 88.36 & 88.70 & 78.92 & 89.28 & 89.69 & & 87.83 & 89.88 & 87.40 & 88.45 & 89.86 & 87.90 & 87.43 & 87.74 \\
\hline Si & 5.72 & 5.61 & 6.38 & 5.68 & 5.65 & & 5.72 & 5.78 & 6.34 & 5.83 & 5.78 & 6.28 & 6.42 & 5.96 \\
\hline AlIV & 2.28 & 2.39 & 1.62 & 2.32 & 2.35 & & 2.28 & 2.22 & 1.66 & 2.17 & 2.22 & 1.72 & 1.58 & 2.05 \\
\hline SUM_T & 8.00 & 8.00 & 8.00 & 8.00 & 8.00 & & 8.00 & 8.00 & 8.00 & 8.00 & 8.00 & 8.00 & 8.00 & 8.00 \\
\hline AIVI $^{-}$ & 2.85 & 2.88 & 4.33 & 2.90 & 2.90 & & 2.95 & 2.97 & 3.67 & 2.98 & 3.02 & 3.21 & 3.28 & 3.03 \\
\hline $\mathrm{Ti}$ & 0.01 & 0.01 & 0.01 & 0.01 & 0.01 & & 0.00 & 0.00 & 0.00 & 0.00 & 0.00 & 0.01 & 0.01 & 0.01 \\
\hline $\mathrm{Fe} 3$ & 0.00 & 0.00 & 0.00 & 0.00 & 0.00 & & 0.00 & 0.00 & 0.00 & 0.00 & 0.00 & 0.00 & 0.00 & 0.00 \\
\hline Fe2 & 4.64 & 4.65 & 5.27 & 4.61 & 4.56 & & 4.80 & 4.92 & 4.26 & 4.49 & 4.42 & 4.29 & 4.26 & 4.59 \\
\hline $\mathrm{Cr}$ & 0.00 & 0.00 & 0.00 & 0.00 & 0.00 & & 0.00 & 0.00 & 0.00 & 0.00 & 0.00 & 0.00 & 0.00 & 0.00 \\
\hline Mn & 0.05 & 0.05 & 0.06 & 0.06 & 0.06 & & 0.08 & 0.07 & 0.06 & 0.07 & 0.07 & 0.07 & 0.05 & 0.07 \\
\hline Mg & 5.15 & 5.15 & 1.95 & 5.10 & 5.18 & & 4.83 & 4.62 & 3.90 & 5.02 & 5.08 & 4.50 & 4.37 & 4.76 \\
\hline $\mathrm{Ca}$ & 0.00 & 0.00 & 0.00 & 0.00 & 0.00 & & 0.01 & 0.01 & 0.04 & 0.01 & 0.01 & 0.12 & 0.12 & 0.03 \\
\hline $\mathrm{Na}$ & 0.01 & 0.00 & 0.00 & 0.01 & 0.01 & & 0.00 & 0.01 & 0.02 & 0.00 & 0.01 & 0.04 & 0.03 & 0.01 \\
\hline $\mathrm{K}$ & 0.00 & 0.00 & 0.00 & 0.00 & 0.00 & & 0.00 & 0.01 & 0.10 & 0.01 & 0.00 & 0.04 & 0.04 & 0.02 \\
\hline CATIONS & 20.71 & 20.74 & 19.63 & 20.70 & 20.72 & & 20.66 & 20.62 & 20.04 & 20.59 & 20.59 & 20.27 & 20.17 & 20.51 \\
\hline CF & 0.04 & 0.01 & 0.04 & 0.02 & 0.06 & & 0.04 & 0.08 & 0.29 & 0.00 & 0.14 & 0.01 & 0.04 & 0.00 \\
\hline CCL & 0.00 & 0.00 & 0.00 & 0.00 & 0.00 & & 0.00 & 0.00 & 0.00 & 0.00 & 0.00 & 0.00 & 0.00 & 0.00 \\
\hline $\mathrm{OH}$ & 0.00 & 0.00 & 0.00 & 0.00 & 0.00 & & 0.00 & 0.00 & 0.00 & 0.00 & 0.00 & 0.00 & 0.00 & 0.00 \\
\hline 0 & 36.00 & 36.00 & 36.00 & 36.00 & 36.00 & & 36.00 & 36.00 & 36.00 & 36.00 & 36.00 & 36.00 & 36.00 & 36.00 \\
\hline $\mathrm{Fe} \_\mathrm{FeMg}$ & 0.47 & 0.47 & 0.73 & 0.47 & 0.47 & & 0.50 & 0.52 & 0.52 & 0.47 & 0.46 & 0.49 & 0.49 & 0.49 \\
\hline $\mathrm{Mg} \mathrm{FeMg}$ & 0.53 & 0.53 & 0.27 & 0.53 & 0.53 & & 0.50 & 0.48 & 0.48 & 0.53 & 0.54 & 0.51 & 0.51 & 0.51 \\
\hline
\end{tabular}




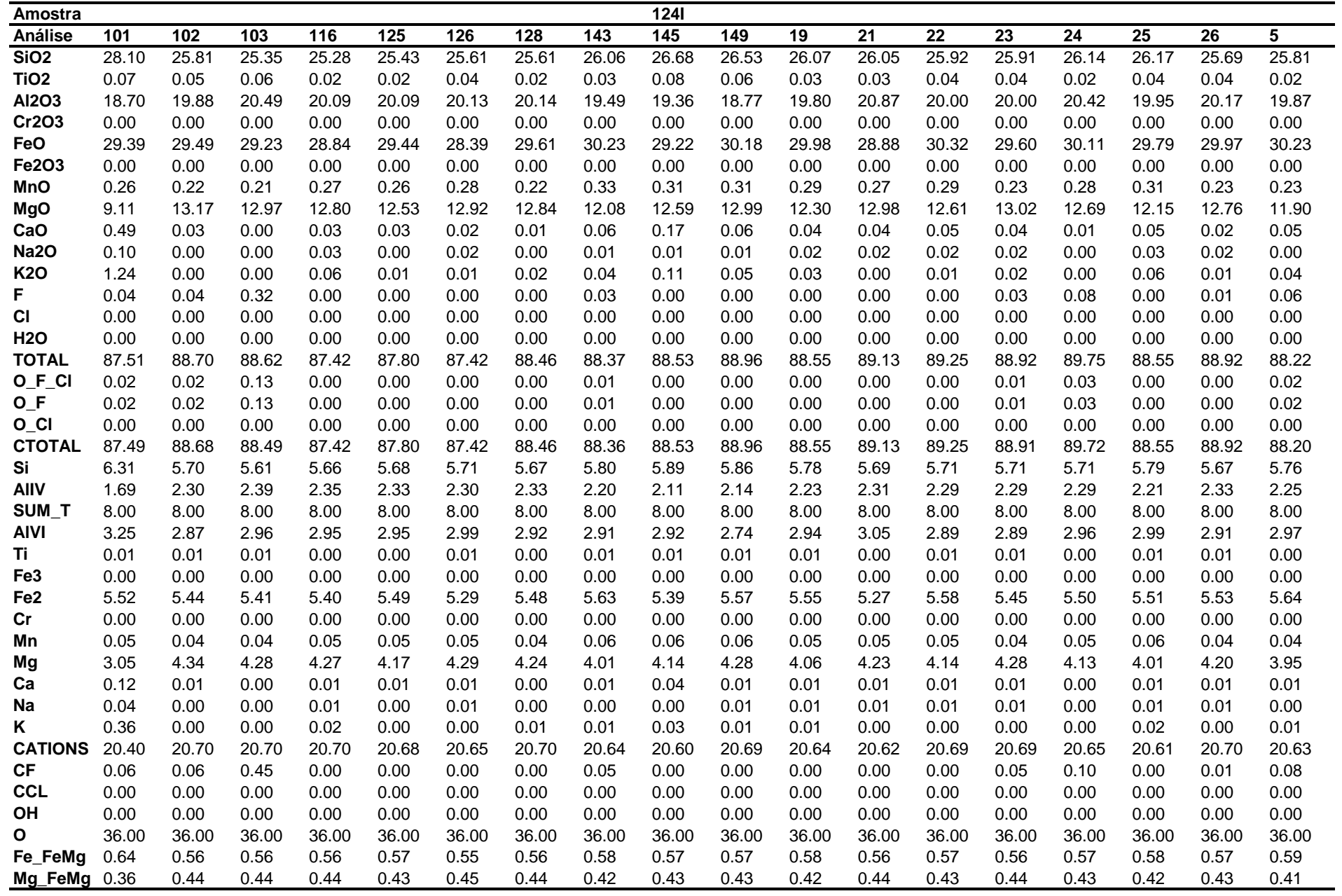

\begin{tabular}{|c|c|c|c|c|c|c|c|c|c|c|c|c|c|c|c|c|c|}
\hline \multicolumn{9}{|l|}{ Amostra } & \multicolumn{9}{|l|}{$124 \mathrm{~J}$} \\
\hline Análise & 122 & 123 & 124 & 220 & 221 & 222 & 223 & 224 & 225 & 226 & 227 & 228 & 229 & 230 & 231 & 232 & 233 \\
\hline $\mathrm{SiO} 2$ & 25.91 & 25.71 & 25.85 & 25.78 & 25.84 & 25.70 & 25.63 & 25.70 & 25.83 & 25.67 & 25.87 & 26.02 & 26.48 & 26.07 & 25.87 & 25.93 & 25.78 \\
\hline TiO2 & 0.02 & 0.00 & 0.00 & 0.11 & 0.08 & 0.08 & 0.07 & 0.19 & 0.06 & 0.00 & 0.04 & 0.09 & 0.00 & 0.08 & 0.06 & 0.06 & 0.15 \\
\hline $\mathrm{Al} 2 \mathrm{O} 3$ & 20.08 & 19.77 & 19.57 & 19.83 & 19.72 & 19.83 & 19.71 & 19.76 & 19.54 & 19.87 & 20.24 & 20.02 & 20.04 & 19.86 & 20.21 & 19.64 & 19.99 \\
\hline Cr2O3 & 0.00 & 0.00 & 0.00 & 0.00 & 0.00 & 0.00 & 0.00 & 0.00 & 0.00 & 0.00 & 0.00 & 0.00 & 0.00 & 0.00 & 0.00 & 0.00 & 0.00 \\
\hline $\mathrm{FeO}$ & 25.30 & 24.34 & 24.68 & 25.11 & 25.00 & 24.88 & 24.62 & 24.60 & 24.76 & 24.65 & 23.87 & 24.56 & 22.99 & 24.10 & 24.26 & 24.57 & 24.83 \\
\hline $\mathrm{Fe} 2 \mathrm{O} 3$ & 0.00 & 0.00 & 0.00 & 0.00 & 0.00 & 0.00 & 0.00 & 0.00 & 0.00 & 0.00 & 0.00 & 0.00 & 0.00 & 0.00 & 0.00 & 0.00 & 0.00 \\
\hline MnO & 0.32 & 0.29 & 0.35 & 0.37 & 0.34 & 0.36 & 0.37 & 0.35 & 0.33 & 0.34 & 0.35 & 0.25 & 0.30 & 0.30 & 0.32 & 0.30 & 0.30 \\
\hline $\mathrm{MgO}$ & 16.16 & 16.25 & 16.46 & 16.00 & 16.32 & 16.57 & 16.46 & 16.42 & 16.20 & 16.40 & 16.40 & 16.34 & 15.84 & 16.24 & 16.53 & 16.35 & 16.44 \\
\hline $\mathrm{CaO}$ & 0.01 & 0.03 & 0.01 & 0.02 & 0.02 & 0.01 & 0.02 & 0.01 & 0.02 & 0.01 & 0.01 & 0.04 & 0.05 & 0.00 & 0.00 & 0.05 & 0.02 \\
\hline $\mathrm{Na2O}$ & 0.00 & 0.02 & 0.03 & 0.00 & 0.02 & 0.04 & 0.00 & 0.02 & 0.00 & 0.01 & 0.01 & 0.03 & 0.50 & 0.00 & 0.01 & 0.03 & 0.01 \\
\hline K2O & 0.00 & 0.00 & 0.01 & 0.01 & 0.00 & 0.00 & 0.00 & 0.01 & 0.02 & 0.01 & 0.01 & 0.00 & 0.00 & 0.01 & 0.00 & 0.00 & 0.01 \\
\hline $\mathbf{F}$ & 0.01 & 0.03 & 0.00 & 0.04 & 0.09 & 0.13 & 0.00 & 0.00 & 0.00 & 0.00 & 0.00 & 0.00 & 0.00 & 0.03 & 0.30 & 0.12 & 0.01 \\
\hline $\mathrm{Cl}$ & 0.00 & 0.00 & 0.01 & 0.02 & 0.01 & 0.00 & 0.01 & 0.00 & 0.01 & 0.01 & 0.00 & 0.03 & 0.00 & 0.01 & 0.00 & 0.00 & 0.00 \\
\hline $\mathrm{H} 2 \mathrm{O}$ & 0.00 & 0.00 & 0.00 & 0.00 & 0.00 & 0.00 & 0.00 & 0.00 & 0.00 & 0.00 & 0.00 & 0.00 & 0.00 & 0.00 & 0.00 & 0.00 & 0.00 \\
\hline TOTAL & 87.81 & 86.43 & 86.95 & 87.27 & 87.43 & 87.60 & 86.88 & 87.06 & 86.75 & 86.97 & 86.79 & 87.37 & 86.20 & 86.69 & 87.57 & 87.03 & 87.54 \\
\hline O_F_Cl & 0.00 & 0.01 & 0.00 & 0.02 & 0.04 & 0.05 & 0.00 & 0.00 & 0.00 & 0.00 & 0.00 & 0.01 & 0.00 & 0.01 & 0.13 & 0.05 & 0.00 \\
\hline O_F & 0.00 & 0.01 & 0.00 & 0.02 & 0.04 & 0.05 & 0.00 & 0.00 & 0.00 & 0.00 & 0.00 & 0.00 & 0.00 & 0.01 & 0.13 & 0.05 & 0.00 \\
\hline O_Cl & 0.00 & 0.00 & 0.00 & 0.00 & 0.00 & 0.00 & 0.00 & 0.00 & 0.00 & 0.00 & 0.00 & 0.01 & 0.00 & 0.00 & 0.00 & 0.00 & 0.00 \\
\hline CT̄OTAL & 87.81 & 86.42 & 86.95 & 87.25 & 87.39 & 87.55 & 86.88 & 87.06 & 86.75 & 86.97 & 86.79 & 87.36 & 86.20 & 86.68 & 87.44 & 86.98 & 87.54 \\
\hline Si & 5.65 & 5.68 & 5.69 & 5.66 & 5.67 & 5.63 & 5.65 & 5.65 & 5.70 & 5.65 & 5.67 & 5.68 & 5.82 & 5.73 & 5.65 & 5.70 & 5.63 \\
\hline AlIV & 2.35 & 2.32 & 2.31 & 2.34 & 2.33 & 2.37 & 2.36 & 2.35 & 2.30 & 2.35 & 2.33 & 2.32 & 2.18 & 2.27 & 2.35 & 2.30 & 2.37 \\
\hline SUM_T & 8.00 & 8.00 & 8.00 & 8.00 & 8.00 & 8.00 & 8.00 & 8.00 & 8.00 & 8.00 & 8.00 & 8.00 & 8.00 & 8.00 & 8.00 & 8.00 & 8.00 \\
\hline AIVI & 2.82 & 2.83 & 2.76 & 2.80 & 2.76 & 2.74 & 2.76 & 2.76 & 2.78 & 2.79 & 2.90 & 2.83 & 3.00 & 2.87 & 2.85 & 2.78 & 2.78 \\
\hline $\mathrm{Ti}$ & 0.00 & 0.00 & 0.00 & 0.02 & 0.01 & 0.01 & 0.01 & 0.03 & 0.01 & 0.00 & 0.01 & 0.02 & 0.00 & 0.01 & 0.01 & 0.01 & 0.02 \\
\hline $\mathrm{Fe} 3$ & 0.00 & 0.00 & 0.00 & 0.00 & 0.00 & 0.00 & 0.00 & 0.00 & 0.00 & 0.00 & 0.00 & 0.00 & 0.00 & 0.00 & 0.00 & 0.00 & 0.00 \\
\hline $\mathrm{Fe} 2$ & 4.62 & 4.50 & 4.54 & 4.61 & 4.59 & 4.56 & 4.53 & 4.52 & 4.57 & 4.54 & 4.38 & 4.49 & 4.22 & 4.43 & 4.43 & 4.52 & 4.54 \\
\hline $\mathrm{Cr}$ & 0.00 & 0.00 & 0.00 & 0.00 & 0.00 & 0.00 & 0.00 & 0.00 & 0.00 & 0.00 & 0.00 & 0.00 & 0.00 & 0.00 & 0.00 & 0.00 & 0.00 \\
\hline Mn & 0.06 & 0.05 & 0.06 & 0.07 & 0.06 & 0.07 & 0.07 & 0.07 & 0.06 & 0.06 & 0.07 & 0.05 & 0.06 & 0.06 & 0.06 & 0.06 & 0.06 \\
\hline Mg & 5.26 & 5.35 & 5.40 & 5.24 & 5.34 & 5.41 & 5.40 & 5.38 & 5.33 & 5.38 & 5.36 & 5.32 & 5.19 & 5.32 & 5.38 & 5.36 & 5.36 \\
\hline $\mathrm{Ca}$ & 0.00 & 0.01 & 0.00 & 0.00 & 0.00 & 0.00 & 0.00 & 0.00 & 0.00 & 0.00 & 0.00 & 0.01 & 0.01 & 0.00 & 0.00 & 0.01 & 0.01 \\
\hline $\mathrm{Na}$ & 0.00 & 0.01 & 0.01 & 0.00 & 0.01 & 0.02 & 0.00 & 0.01 & 0.00 & 0.01 & 0.00 & 0.01 & 0.21 & 0.00 & 0.01 & 0.01 & 0.01 \\
\hline K & 0.00 & 0.00 & 0.00 & 0.00 & 0.00 & 0.00 & 0.00 & 0.00 & 0.01 & 0.00 & 0.00 & 0.00 & 0.00 & 0.00 & 0.00 & 0.00 & 0.00 \\
\hline CATIONS & 20.75 & 20.74 & 20.78 & 20.74 & 20.77 & 20.80 & 20.78 & 20.77 & 20.75 & 20.78 & 20.70 & 20.72 & 20.69 & 20.68 & 20.74 & 20.75 & 20.77 \\
\hline CF & 0.01 & 0.04 & 0.00 & 0.06 & 0.12 & 0.17 & 0.00 & 0.00 & 0.00 & 0.00 & 0.00 & 0.00 & 0.00 & 0.04 & 0.42 & 0.16 & 0.01 \\
\hline CCL & 0.00 & 0.00 & 0.01 & 0.02 & 0.01 & 0.00 & 0.01 & 0.00 & 0.00 & 0.01 & 0.00 & 0.02 & 0.00 & 0.01 & 0.00 & 0.00 & 0.00 \\
\hline $\mathrm{OH}$ & 0.00 & 0.00 & 0.00 & 0.00 & 0.00 & 0.00 & 0.00 & 0.00 & 0.00 & 0.00 & 0.00 & 0.00 & 0.00 & 0.00 & 0.00 & 0.00 & 0.00 \\
\hline 0 & 36.00 & 36.00 & 36.00 & 36.00 & 36.00 & 36.00 & 36.00 & 36.00 & 36.00 & 36.00 & 36.00 & 36.00 & 36.00 & 36.00 & 36.00 & 36.00 & 36.00 \\
\hline $\mathrm{Fe} \_\mathrm{FeMg}$ & 0.47 & 0.46 & 0.46 & 0.47 & 0.46 & 0.46 & 0.46 & 0.46 & 0.46 & 0.46 & 0.45 & 0.46 & 0.45 & 0.45 & 0.45 & 0.46 & 0.46 \\
\hline Mg_FeMg & 0.53 & 0.54 & 0.54 & 0.53 & 0.54 & 0.54 & 0.54 & 0.54 & 0.54 & 0.54 & 0.55 & 0.54 & 0.55 & 0.55 & 0.55 & 0.54 & 0.54 \\
\hline
\end{tabular}




\begin{tabular}{|c|c|c|c|c|c|c|c|}
\hline Amostra & & & & 125D & & & \\
\hline Análise & 259 & 260 & 261 & 262 & 263 & 264 & 265 \\
\hline SiO2 & 26.80 & 27.28 & 26.64 & 26.38 & 26.68 & 27.34 & 27.16 \\
\hline TiO2 & 0.05 & 0.04 & 0.04 & 0.05 & 0.01 & 0.05 & 0.02 \\
\hline Al2O3 & 20.48 & 21.00 & 20.51 & 20.62 & 20.96 & 21.26 & 20.61 \\
\hline Cr2O3 & 0.00 & 0.00 & 0.00 & 0.00 & 0.00 & 0.00 & 0.00 \\
\hline $\mathrm{FeO}$ & 24.79 & 23.44 & 24.00 & 24.99 & 24.58 & 21.18 & 24.41 \\
\hline $\mathrm{Fe} 2 \mathrm{O} 3$ & 0.00 & 0.00 & 0.00 & 0.00 & 0.00 & 0.00 & 0.00 \\
\hline MnO & 0.27 & 0.23 & 0.26 & 0.28 & 0.22 & 0.31 & 0.27 \\
\hline $\mathrm{MgO}$ & 16.35 & 16.32 & 16.84 & 15.93 & 16.33 & 18.00 & 17.92 \\
\hline $\mathrm{CaO}$ & 0.04 & 0.12 & 0.05 & 0.09 & 0.08 & 0.08 & 0.10 \\
\hline $\mathrm{Na} 2 \mathrm{O}$ & 0.00 & 0.92 & 0.00 & 0.14 & 0.00 & 0.15 & 0.00 \\
\hline K2O & 0.00 & 0.00 & 0.00 & 0.02 & 0.01 & 0.01 & 0.00 \\
\hline $\mathbf{F}$ & 0.02 & 0.05 & 0.03 & 0.05 & 0.00 & 0.00 & 0.03 \\
\hline Cl & 0.00 & 0.00 & 0.00 & 0.00 & 0.00 & 0.00 & 0.00 \\
\hline $\mathrm{H} 2 \mathrm{O}$ & 0.00 & 0.00 & 0.00 & 0.00 & 0.00 & 0.00 & 0.00 \\
\hline TOTAL & 88.80 & 89.38 & 88.37 & 88.54 & 88.86 & 88.36 & 90.52 \\
\hline O_F_Cl & 0.01 & 0.02 & 0.01 & 0.02 & 0.00 & 0.00 & 0.01 \\
\hline O_F & 0.01 & 0.02 & 0.01 & 0.02 & 0.00 & 0.00 & 0.01 \\
\hline O_Cl & 0.00 & 0.00 & 0.00 & 0.00 & 0.00 & 0.00 & 0.00 \\
\hline CTOTAL & 88.79 & 89.36 & 88.36 & 88.52 & 88.86 & 88.36 & 90.51 \\
\hline Si & 5.75 & 5.78 & 5.72 & 5.69 & 5.71 & 5.77 & 5.70 \\
\hline AllV & 2.25 & 2.22 & 2.28 & 2.31 & 2.29 & 2.23 & 2.30 \\
\hline SUM_T & 8.00 & 8.00 & 8.00 & 8.00 & 8.00 & 8.00 & 8.00 \\
\hline AIVI & 2.92 & 3.02 & 2.91 & 2.93 & 2.99 & 3.06 & 2.79 \\
\hline $\mathrm{Ti}$ & 0.01 & 0.01 & 0.01 & 0.01 & 0.00 & 0.01 & 0.00 \\
\hline $\mathrm{Fe} 3$ & 0.00 & 0.00 & 0.00 & 0.00 & 0.00 & 0.00 & 0.00 \\
\hline $\mathrm{Fe} 2$ & 4.45 & 4.15 & 4.31 & 4.51 & 4.40 & 3.74 & 4.28 \\
\hline $\mathrm{Cr}$ & 0.00 & 0.00 & 0.00 & 0.00 & 0.00 & 0.00 & 0.00 \\
\hline Mn & 0.05 & 0.04 & 0.05 & 0.05 & 0.04 & 0.06 & 0.05 \\
\hline Mg & 5.23 & 5.16 & 5.39 & 5.12 & 5.21 & 5.66 & 5.60 \\
\hline $\mathrm{Ca}$ & 0.01 & 0.03 & 0.01 & 0.02 & 0.02 & 0.02 & 0.02 \\
\hline $\mathrm{Na}$ & 0.00 & 0.38 & 0.00 & 0.06 & 0.00 & 0.06 & 0.00 \\
\hline K & 0.00 & 0.00 & 0.00 & 0.01 & 0.00 & 0.00 & 0.00 \\
\hline CATIONS & 20.65 & 20.78 & 20.67 & 20.71 & 20.65 & 20.60 & 20.75 \\
\hline CF & 0.02 & 0.07 & 0.04 & 0.07 & 0.00 & 0.00 & 0.03 \\
\hline CCL & 0.00 & 0.00 & 0.00 & 0.00 & 0.00 & 0.00 & 0.00 \\
\hline $\mathrm{OH}$ & 0.00 & 0.00 & 0.00 & 0.00 & 0.00 & 0.00 & 0.00 \\
\hline 0 & 36.00 & 36.00 & 36.00 & 36.00 & 36.00 & 36.00 & 36.00 \\
\hline $\mathrm{Fe}$ FeMg & 0.46 & 0.45 & 0.44 & 0.47 & 0.46 & 0.40 & 0.43 \\
\hline Mg_FeMg & 0.54 & 0.55 & 0.56 & 0.53 & 0.54 & 0.60 & 0.57 \\
\hline
\end{tabular}

\begin{tabular}{|c|c|c|c|c|c|c|c|c|}
\hline \multicolumn{9}{|c|}{$125 \mathrm{H}$} \\
\hline 131 & 132 & 133 & 134 & 135 & 76 & 78 & 80 & 82 \\
\hline 25.94 & 25.33 & 25.26 & 25.19 & 24.93 & 25.33 & 25.64 & 25.38 & 25.21 \\
\hline 0.06 & 0.07 & 0.05 & 0.05 & 0.04 & 0.07 & 0.04 & 0.06 & 0.05 \\
\hline 20.39 & 20.78 & 20.33 & 20.69 & 20.45 & 20.83 & 20.12 & 19.98 & 20.47 \\
\hline 0.00 & 0.00 & 0.00 & 0.00 & 0.00 & 0.00 & 0.00 & 0.00 & 0.00 \\
\hline 30.87 & 32.05 & 32.15 & 31.35 & 33.20 & 32.23 & 32.09 & 32.29 & 33.31 \\
\hline 0.00 & 0.00 & 0.00 & 0.00 & 0.00 & 0.00 & 0.00 & 0.00 & 0.00 \\
\hline 0.23 & 0.27 & 0.33 & 0.28 & 0.32 & 0.25 & 0.29 & 0.20 & 0.42 \\
\hline 10.68 & 10.54 & 10.62 & 10.57 & 9.25 & 10.11 & 9.48 & 10.21 & 8.67 \\
\hline 0.04 & 0.03 & 0.03 & 0.03 & 0.08 & 0.02 & 0.13 & 0.01 & 0.05 \\
\hline 0.00 & 0.58 & 0.00 & 1.52 & 0.00 & 0.02 & 0.00 & 0.00 & 0.01 \\
\hline 0.03 & 0.00 & 0.00 & 0.01 & 0.02 & 0.04 & 0.03 & 0.01 & 0.01 \\
\hline 0.04 & 0.10 & 0.03 & 0.05 & 0.03 & 0.05 & 0.07 & 0.04 & 0.02 \\
\hline 0.00 & 0.00 & 0.00 & 0.00 & 0.00 & 0.00 & 0.00 & 0.00 & 0.00 \\
\hline 0.00 & 0.00 & 0.00 & 0.00 & 0.00 & 0.00 & 0.00 & 0.00 & 0.00 \\
\hline 88.27 & 89.74 & 88.79 & 89.73 & 88.32 & 88.94 & 87.88 & 88.17 & 88.22 \\
\hline 0.02 & 0.04 & 0.01 & 0.02 & 0.01 & 0.02 & 0.03 & 0.02 & 0.01 \\
\hline 0.02 & 0.04 & 0.01 & 0.02 & 0.01 & 0.02 & 0.03 & 0.02 & 0.01 \\
\hline 0.00 & 0.00 & 0.00 & 0.00 & 0.00 & 0.00 & 0.00 & 0.00 & 0.00 \\
\hline 88.25 & 89.70 & 88.78 & 89.71 & 88.31 & 88.92 & 87.85 & 88.15 & 88.21 \\
\hline 5.79 & 5.61 & 5.65 & 5.59 & 5.65 & 5.66 & 5.80 & 5.72 & 5.72 \\
\hline 2.22 & 2.39 & 2.35 & 2.41 & 2.35 & 2.35 & 2.2 & 2.28 & 2.29 \\
\hline 8.00 & 8.00 & 8.00 & 8.00 & 8.00 & 8.00 & 8.00 & 8.00 & 8.00 \\
\hline 3.14 & 3.04 & 3.01 & 2.99 & 3.11 & 3.13 & 3.15 & 3.03 & 3.18 \\
\hline 0.01 & 0.01 & 0.01 & 0.01 & 0.01 & 0.01 & 0.01 & 0.01 & 0.01 \\
\hline 0.00 & 0.00 & 0.00 & 0.00 & 0.00 & 0.00 & 0.0 & 0.00 & 0.00 \\
\hline 5.76 & 5.94 & 6.02 & 5.81 & 6.29 & 6.02 & 6.07 & 6.09 & 6.32 \\
\hline 0.00 & 0.00 & 0.00 & 0.00 & 0.00 & 0.00 & 0.00 & 0.00 & 0.00 \\
\hline 0.04 & 0.05 & 0.06 & 0.05 & 0.06 & 0.05 & 0.06 & 0.04 & 0.08 \\
\hline 3.55 & 3.48 & 3.54 & 3.49 & 3.12 & 3.37 & 3.2 & 3.43 & 2.93 \\
\hline 0.01 & 0.01 & 0.01 & 0.01 & 0.02 & 0.01 & 0.03 & 0.00 & 0.01 \\
\hline 0.00 & 0.25 & 0.00 & 0.65 & 0.00 & 0.01 & 0.00 & 0.00 & 0.00 \\
\hline 0.01 & 0.00 & 0.00 & 0.00 & 0.01 & 0.01 & 0.01 & 0.00 & 0.00 \\
\hline 20.52 & 20.78 & 20.65 & 21.02 & 20.61 & 20.60 & 20.52 & 20.61 & 20.54 \\
\hline 0.06 & 0.14 & 0.04 & 0.07 & 0.05 & 0.07 & 0.10 & 0.05 & 0.03 \\
\hline 0.00 & 0.00 & 0.00 & 0.00 & 0.00 & 0.00 & 0.00 & 0.00 & 0.00 \\
\hline 0.00 & 0.00 & 0.00 & 0.00 & 0.00 & 0.00 & 0.00 & 0.00 & 0.00 \\
\hline 36.00 & 36.00 & 36.00 & 36.00 & 36.00 & 36.00 & 36.00 & 36.00 & 36.00 \\
\hline 0.62 & 0.63 & 0.63 & 0.62 & 0.67 & 0.64 & 0.66 & 0.64 & 0.68 \\
\hline 0.38 & 0.37 & 0.37 & 0.38 & 0.33 & 0.36 & 0.34 & 0.36 & 0.32 \\
\hline
\end{tabular}

\begin{tabular}{lllllll}
\hline Amostra & & & $\mathbf{1 2 5}$ & & & \\
\hline Análise & $\mathbf{3 9 2}$ & $\mathbf{3 9 3}$ & $\mathbf{3 9 4}$ & $\mathbf{3 9 5}$ & $\mathbf{3 9 6}$ & $\mathbf{3 9 7}$ \\
SiO2 & 27.51 & 26.88 & 27.24 & 26.91 & 26.90 & 27.00 \\
TiO2 & 0.02 & 0.05 & 0.04 & 0.05 & 0.01 & 0.04 \\
Al2O3 & 20.86 & 20.68 & 20.96 & 20.31 & 20.55 & 20.71 \\
Cr2O3 & 0.00 & 0.00 & 0.00 & 0.00 & 0.00 & 0.00 \\
FeO & 22.29 & 22.16 & 22.81 & 22.83 & 22.36 & 22.09 \\
Fe2O3 & 0.00 & 0.00 & 0.00 & 0.00 & 0.00 & 0.00 \\
MnO & 0.22 & 0.22 & 0.30 & 0.42 & 0.24 & 0.23 \\
MgO & 17.95 & 18.48 & 17.83 & 17.16 & 17.94 & 18.30 \\
CaO & 0.08 & 0.03 & 0.05 & 0.16 & 0.04 & 0.02 \\
Na2O & 0.02 & 0.01 & 0.00 & 0.05 & 0.02 & 0.03 \\
K2O & 0.01 & 0.00 & 0.00 & 0.04 & 0.01 & 0.00 \\
F & 0.01 & 0.02 & 0.07 & 0.04 & 0.04 & 0.00 \\
CI & 0.00 & 0.00 & 0.00 & 0.00 & 0.00 & 0.00 \\
H2O & 0.00 & 0.00 & 0.00 & 0.00 & 0.00 & 0.00 \\
TOTAL & 88.98 & 88.52 & 89.29 & 87.97 & 88.10 & 88.40 \\
O_F_CI & 0.01 & 0.01 & 0.03 & 0.02 & 0.02 & 0.00 \\
O_F & 0.01 & 0.01 & 0.03 & 0.02 & 0.02 & 0.00 \\
O_CI & 0.00 & 0.00 & 0.00 & 0.00 & 0.00 & 0.00 \\
CTOTAL & 88.97 & 88.51 & 89.26 & 87.95 & 88.08 & 88.40 \\
Si & 5.80 & 5.70 & 5.74 & 5.78 & 5.74 & 5.73 \\
AllV & 2.20 & 2.30 & 2.26 & 2.22 & 2.26 & 2.27 \\
SUM_T & 8.00 & 8.00 & 8.00 & 8.00 & 8.00 & 8.00 \\
AIVI & 2.97 & 2.87 & 2.95 & 2.91 & 2.91 & 2.91 \\
Ti & 0.00 & 0.01 & 0.01 & 0.01 & 0.00 & 0.01 \\
Fe3 & 0.00 & 0.00 & 0.00 & 0.00 & 0.00 & 0.00 \\
Fe2 & 3.93 & 3.93 & 4.02 & 4.10 & 3.99 & 3.92 \\
Cr & 0.00 & 0.00 & 0.00 & 0.00 & 0.00 & 0.00 \\
Mn & 0.04 & 0.04 & 0.05 & 0.08 & 0.04 & 0.04 \\
Mg & 5.64 & 5.84 & 5.60 & 5.49 & 5.71 & 5.79 \\
Ca & 0.02 & 0.01 & 0.01 & 0.04 & 0.01 & 0.01 \\
Na & 0.01 & 0.00 & 0.00 & 0.02 & 0.01 & 0.01 \\
K & 0.00 & 0.00 & 0.00 & 0.01 & 0.00 & 0.00 \\
CATIONS & 20.61 & 20.70 & 20.64 & 20.66 & 20.67 & 20.68 \\
CF & 0.02 & 0.03 & 0.09 & 0.06 & 0.05 & 0.00 \\
CCL & 0.00 & 0.00 & 0.00 & 0.00 & 0.00 & 0.00 \\
OH & 0.00 & 0.00 & 0.00 & 0.00 & 0.00 & 0.00 \\
O & 36.00 & 36.00 & 36.00 & 36.00 & 36.00 & 36.00 \\
Fe_FeMg & 0.41 & 0.40 & 0.42 & 0.43 & 0.41 & 0.40 \\
Mg_FeMg & 0.59 & 0.60 & 0.58 & 0.57 & 0.59 & 0.60 \\
& & & & & & \\
Fr & &
\end{tabular}

\begin{tabular}{|c|c|c|c|c|c|c|c|c|c|c|}
\hline \multicolumn{11}{|c|}{$129 \mathrm{~A}$} \\
\hline 205 & 205 & 206 & 206 & 207 & 207 & 208 & 208 & 209 & 209 & 210 \\
\hline 26.10 & 26.10 & 25.75 & 25.75 & 26.01 & 26.01 & 26.26 & 26.26 & 25.85 & 25.85 & 26.04 \\
\hline 0.02 & 0.02 & 0.00 & 0.00 & 0.02 & 0.02 & 0.11 & 0.11 & 0.02 & 0.02 & 0.06 \\
\hline 19.68 & 19.68 & 19.59 & 19.59 & 19.48 & 19.48 & 19.84 & 19.84 & 19.51 & 19.51 & 19.99 \\
\hline 0.00 & 0.00 & 0.00 & 0.00 & 0.00 & 0.00 & 0.00 & 0.00 & 0.00 & 0.00 & 0.00 \\
\hline 22.16 & 22.16 & 22.06 & 22.06 & 23.35 & 23.35 & 22.77 & 22.77 & 23.19 & 23.19 & 24.14 \\
\hline 0.00 & 0.00 & 0.00 & 0.00 & 0.00 & 0.00 & 0.00 & 0.00 & 0.00 & 0.00 & 0.00 \\
\hline 0.07 & 0.07 & 0.09 & 0.09 & 0.06 & 0.06 & 0.08 & 0.08 & 0.06 & 0.06 & 0.10 \\
\hline 18.34 & 18.34 & 17.77 & 17.77 & 17.40 & 17.40 & 17.07 & 17.07 & 17.12 & 17.12 & 16.98 \\
\hline 0.01 & 0.01 & 0.04 & 0.04 & 0.01 & 0.01 & 0.00 & 0.00 & 0.00 & 0.00 & 0.00 \\
\hline 0.04 & 0.04 & 0.00 & 0.00 & 0.00 & 0.00 & 0.00 & 0.00 & 0.00 & 0.00 & 0.00 \\
\hline 0.01 & 0.01 & 0.00 & 0.00 & 0.01 & 0.01 & 0.02 & 0.02 & 0.00 & 0.00 & 0.01 \\
\hline 0.03 & 0.03 & 0.10 & 0.10 & 0.22 & 0.22 & 0.19 & 0.19 & 0.02 & 0.02 & 0.00 \\
\hline 0.00 & 0.01 & 0.00 & 0.00 & 0.00 & 0.00 & 0.00 & 0.01 & 0.00 & 0.00 & 0.00 \\
\hline 0.00 & 0.00 & 0.00 & 0.00 & 0.00 & 0.00 & 0.00 & 0.00 & 0.00 & 0.00 & 0.00 \\
\hline 86.45 & 86.46 & 85.39 & 85.39 & 86.55 & 86.55 & 86.33 & 86.34 & 85.76 & 85.76 & 87.31 \\
\hline 0.01 & 0.02 & 0.04 & 0.04 & 0.09 & 0.09 & 0.08 & 0.08 & 0.01 & 0.01 & 0.00 \\
\hline 0.01 & 0.01 & 0.04 & 0.04 & 0.09 & 0.09 & 0.08 & 0.08 & 0.01 & 0.01 & 0.00 \\
\hline 0.00 & 0.00 & 0.00 & 0.00 & 0.00 & 0.00 & 0.00 & 0.00 & 0.00 & 0.00 & 0.00 \\
\hline 86.44 & 86.44 & 85.35 & 85.35 & 86.46 & 86.46 & 86.25 & 86.26 & 85.75 & 85.75 & 87.31 \\
\hline 5.69 & 5.69 & 5.69 & 5.69 & 5.71 & 5.71 & 5.75 & 5.75 & 5.71 & 5.71 & 5.67 \\
\hline 2.31 & 2.31 & 2.31 & 2.31 & 2.29 & 2.29 & 2.25 & 2.25 & 2.29 & 2.29 & 2.33 \\
\hline 8.00 & 8.00 & 8.00 & 8.00 & 8.00 & 8.00 & 8.00 & 8.00 & 8.00 & 8.00 & 8.00 \\
\hline 2.74 & 2.74 & 2.79 & 2.79 & 2.75 & 2.75 & 2.87 & 2.87 & 2.79 & 2.79 & 2.80 \\
\hline 0.00 & 0.00 & 0.00 & 0.00 & 0.00 & 0.00 & 0.02 & 0.02 & 0.00 & 0.00 & 0.01 \\
\hline 0.00 & 0.00 & 0.00 & 0.00 & 0.00 & 0.00 & 0.00 & 0.00 & 0.00 & 0.00 & 0.00 \\
\hline 4.04 & 4.04 & 4.08 & 4.08 & 4.29 & 4.29 & 4.17 & 4.17 & 4.29 & 4.29 & 4.40 \\
\hline 0.00 & 0.00 & 0.00 & 0.00 & 0.00 & 0.00 & 0.00 & 0.00 & 0.00 & 0.00 & 0.00 \\
\hline 0.01 & 0.01 & 0.02 & 0.02 & 0.01 & 0.01 & 0.02 & 0.02 & 0.01 & 0.01 & 0.02 \\
\hline 5.96 & 5.96 & 5.86 & 5.86 & 5.70 & 5.70 & 5.58 & 5.58 & 5.64 & 5.64 & 5.52 \\
\hline 0.00 & 0.00 & 0.01 & 0.01 & 0.00 & 0.00 & 0.00 & 0.00 & 0.00 & 0.00 & 0.00 \\
\hline 0.02 & 0.02 & 0.00 & 0.00 & 0.00 & 0.00 & 0.00 & 0.00 & 0.00 & 0.00 & 0.00 \\
\hline 0.00 & 0.00 & 0.00 & 0.00 & 0.00 & 0.00 & 0.01 & 0.01 & 0.00 & 0.00 & 0.00 \\
\hline 20.78 & 20.78 & 20.75 & 20.75 & 20.76 & 20.76 & 20.66 & 20.66 & 20.74 & 20.74 & 20.75 \\
\hline 0.05 & 0.05 & 0.14 & 0.14 & 0.30 & 0.30 & 0.26 & 0.26 & 0.02 & 0.02 & 0.00 \\
\hline 0.00 & 0.01 & 0.00 & 0.00 & 0.00 & 0.00 & 0.00 & 0.00 & 0.00 & 0.00 & 0.00 \\
\hline 0.00 & 0.00 & 0.00 & 0.00 & 0.00 & 0.00 & 0.00 & 0.00 & 0.00 & 0.00 & 0.00 \\
\hline 36.00 & 36.00 & 36.00 & 36.00 & 36.00 & 36.00 & 36.00 & 36.00 & 36.00 & 36.00 & 36.00 \\
\hline 0.40 & 0.40 & 0.41 & 0.41 & 0.43 & 0.43 & 0.43 & 0.43 & 0.43 & 0.43 & 0.44 \\
\hline 0.60 & 0.60 & 0.59 & 0.59 & 0.57 & 0.57 & 0.57 & 0.57 & 0.57 & 0.57 & 0.56 \\
\hline
\end{tabular}




\begin{tabular}{|c|c|c|c|c|c|c|c|c|c|}
\hline Amostra & & & & & $107 C$ & & & & \\
\hline Análise & 201 & 202 & 203 & 204 & 205 & 206 & 207 & 209 & 210 \\
\hline SiO2 & 27.63 & 29.47 & 26.84 & 26.40 & 27.86 & 26.57 & 26.87 & 26.58 & 26.94 \\
\hline TiO2 & 0.04 & 0.16 & 0.03 & 0.00 & 0.02 & 0.02 & 0.01 & 0.04 & 0.00 \\
\hline Al2O3 & 18.68 & 19.04 & 19.12 & 18.59 & 18.25 & 19.56 & 19.24 & 18.96 & 18.57 \\
\hline $\mathrm{Cr} 2 \mathrm{O} 3$ & 0.00 & 0.00 & 0.00 & 0.00 & 0.00 & 0.00 & 0.00 & 0.00 & 0.00 \\
\hline $\mathrm{FeO}$ & 28.71 & 27.66 & 28.39 & 28.38 & 28.60 & 27.00 & 28.76 & 28.14 & 28.56 \\
\hline $\mathrm{Fe} 2 \mathrm{O} 3$ & 0.00 & 0.00 & 0.00 & 0.00 & 0.00 & 0.00 & 0.00 & 0.00 & 0.00 \\
\hline $\mathrm{MnO}$ & 0.71 & 0.61 & 0.69 & 0.77 & 0.70 & 0.76 & 0.68 & 0.69 & 0.72 \\
\hline MgO & 14.01 & 12.99 & 14.23 & 14.36 & 13.89 & 14.94 & 14.52 & 14.26 & 13.88 \\
\hline $\mathrm{CaO}$ & 0.07 & 0.04 & 0.03 & 0.02 & 0.09 & 0.03 & 0.01 & 0.03 & 0.05 \\
\hline $\mathrm{Na} 2 \mathrm{O}$ & 0.02 & 0.01 & 0.02 & 0.01 & 0.03 & 0.01 & 0.02 & 0.03 & 0.02 \\
\hline K2O & 0.11 & 1.57 & 0.01 & 0.02 & 0.08 & 0.02 & 0.01 & 0.02 & 0.02 \\
\hline$F$ & 0.07 & 0.06 & 0.04 & 0.09 & 0.06 & 0.04 & 0.05 & 0.00 & 0.04 \\
\hline $\mathrm{Cl}$ & 0.00 & 0.00 & 0.00 & 0.00 & 0.00 & 0.00 & 0.00 & 0.00 & 0.00 \\
\hline $\mathrm{H} 2 \mathrm{O}$ & 0.00 & 0.00 & 0.00 & 0.00 & 0.00 & 0.00 & 0.00 & 0.00 & 0.00 \\
\hline TOTAL & 90.02 & 91.61 & 89.41 & 88.63 & 89.58 & 88.95 & 90.16 & 88.73 & 88.79 \\
\hline O_F_Cl & 0.03 & 0.03 & 0.02 & 0.04 & 0.02 & 0.02 & 0.02 & 0.00 & 0.02 \\
\hline $\mathrm{O}_{-}^{-} \mathrm{F}$ & 0.03 & 0.03 & 0.02 & 0.04 & 0.02 & 0.02 & 0.02 & 0.00 & 0.02 \\
\hline O_Cl & 0.00 & 0.00 & 0.00 & 0.00 & 0.00 & 0.00 & 0.00 & 0.00 & 0.00 \\
\hline CT̄OTAL & 89.99 & 91.58 & 89.39 & 88.59 & 89.56 & 88.93 & 90.14 & 88.73 & 88.77 \\
\hline $\mathrm{Si}$ & 5.98 & 6.24 & 5.85 & 5.82 & 6.06 & 5.78 & 5.81 & 5.83 & 5.92 \\
\hline AllV & 2.02 & 1.76 & 2.15 & 2.18 & 1.94 & 2.22 & 2.19 & 2.17 & 2.08 \\
\hline SUM_T & 8.00 & 8.00 & 8.00 & 8.00 & 8.00 & 8.00 & 8.00 & 8.00 & 8.00 \\
\hline AIVI & 2.74 & 2.99 & 2.75 & 2.65 & 2.73 & 2.79 & 2.71 & 2.73 & 2.72 \\
\hline $\mathrm{Ti}$ & 0.01 & 0.03 & 0.01 & 0.00 & 0.00 & 0.00 & 0.00 & 0.01 & 0.00 \\
\hline $\mathrm{Fe} 3$ & 0.00 & 0.00 & 0.00 & 0.00 & 0.00 & 0.00 & 0.00 & 0.00 & 0.00 \\
\hline Fe2 & 5.20 & 4.90 & 5.17 & 5.23 & 5.20 & 4.91 & 5.20 & 5.16 & 5.25 \\
\hline $\mathrm{Cr}$ & 0.00 & 0.00 & 0.00 & 0.00 & 0.00 & 0.00 & 0.00 & 0.00 & 0.00 \\
\hline Mn & 0.13 & 0.11 & 0.13 & 0.14 & 0.13 & 0.14 & 0.12 & 0.13 & 0.13 \\
\hline Mg & 4.52 & 4.10 & 4.62 & 4.72 & 4.50 & 4.85 & 4.68 & 4.66 & 4.55 \\
\hline $\mathrm{Ca}$ & 0.02 & 0.01 & 0.01 & 0.01 & 0.02 & 0.01 & 0.00 & 0.01 & 0.01 \\
\hline $\mathrm{Na}$ & 0.01 & 0.01 & 0.01 & 0.01 & 0.01 & 0.00 & 0.01 & 0.01 & 0.01 \\
\hline K & 0.03 & 0.43 & 0.00 & 0.01 & 0.02 & 0.00 & 0.00 & 0.01 & 0.00 \\
\hline CATIONS & 20.65 & 20.57 & 20.69 & 20.76 & 20.62 & 20.71 & 20.73 & 20.71 & 20.68 \\
\hline CF & 0.10 & 0.09 & 0.05 & 0.12 & 0.08 & 0.06 & 0.06 & 0.00 & 0.05 \\
\hline CCL & 0.00 & 0.00 & 0.00 & 0.00 & 0.00 & 0.00 & 0.00 & 0.00 & 0.00 \\
\hline $\mathrm{OH}$ & 0.00 & 0.00 & 0.00 & 0.00 & 0.00 & 0.00 & 0.00 & 0.00 & 0.00 \\
\hline 0 & 36.00 & 36.00 & 36.00 & 36.00 & 36.00 & 36.00 & 36.00 & 36.00 & 36.00 \\
\hline Fe_FeMg & 0.53 & 0.54 & 0.53 & 0.53 & 0.54 & 0.50 & 0.53 & 0.53 & 0.54 \\
\hline $\mathrm{Mg}^{-} \mathrm{FeMg}$ & 0.47 & 0.46 & 0.47 & 0.47 & 0.46 & 0.50 & 0.47 & 0.47 & 0.46 \\
\hline
\end{tabular}

\begin{tabular}{llllllll}
\hline & & $\mathbf{1 0 8}$ & & & $\mathbf{4 6 1}$ \\
\hline $\mathbf{4 5 6}$ & $\mathbf{4 5 7}$ & $\mathbf{4 5 8}$ & $\mathbf{4 5 9}$ & $\mathbf{4 6 0}$ & $\mathbf{4 6 1}$ & $\mathbf{4 6 2}$ & $\mathbf{4 6 3}$ \\
\hline 26.10 & 26.85 & 26.35 & 26.56 & 26.77 & 26.64 & 25.59 & 26.09 \\
0.00 & 0.06 & 0.00 & 0.00 & 0.24 & 0.08 & 0.02 & 0.00 \\
20.13 & 20.47 & 20.10 & 20.54 & 20.57 & 20.42 & 20.52 & 20.64 \\
0.00 & 0.00 & 0.00 & 0.00 & 0.00 & 0.00 & 0.00 & 0.00 \\
22.79 & 23.28 & 23.77 & 23.61 & 22.98 & 23.79 & 24.30 & 23.95 \\
0.00 & 0.00 & 0.00 & 0.00 & 0.00 & 0.00 & 0.00 & 0.00 \\
0.09 & 0.25 & 0.24 & 0.18 & 0.19 & 0.25 & 0.29 & 0.24 \\
17.31 & 16.77 & 16.38 & 16.72 & 16.69 & 15.90 & 16.19 & 15.74 \\
0.01 & 0.00 & 0.01 & 0.00 & 0.05 & 0.01 & 0.04 & 0.05 \\
0.02 & 0.02 & 0.02 & 0.00 & 0.01 & 0.00 & 0.00 & 0.01 \\
0.02 & 0.00 & 0.01 & 0.02 & 0.00 & 0.03 & 0.03 & 0.01 \\
0.07 & 0.00 & 0.00 & 0.10 & 0.00 & 0.11 & 0.02 & 0.02 \\
0.00 & 0.00 & 0.00 & 0.00 & 0.00 & 0.00 & 0.00 & 0.00 \\
0.00 & 0.00 & 0.00 & 0.00 & 0.00 & 0.00 & 0.00 & 0.00 \\
86.53 & 87.69 & 86.87 & 87.72 & 87.51 & 87.23 & 87.00 & 86.74 \\
0.03 & 0.00 & 0.00 & 0.04 & 0.00 & 0.05 & 0.01 & 0.01 \\
0.03 & 0.00 & 0.00 & 0.04 & 0.00 & 0.05 & 0.01 & 0.01 \\
0.00 & 0.00 & 0.00 & 0.00 & 0.00 & 0.00 & 0.00 & 0.00 \\
86.50 & 87.69 & 86.87 & 87.68 & 87.51 & 87.18 & 86.99 & 86.73 \\
5.70 & 5.78 & 5.76 & 5.74 & 5.77 & 5.79 & 5.61 & 5.71 \\
2.30 & 2.22 & 2.25 & 2.26 & 2.23 & 2.21 & 2.39 & 2.29 \\
8.00 & 8.00 & 8.00 & 8.00 & 8.00 & 8.00 & 8.00 & 8.00 \\
2.88 & 2.97 & 2.92 & 2.96 & 2.99 & 3.02 & 2.91 & 3.04 \\
0.00 & 0.01 & 0.00 & 0.00 & 0.04 & 0.01 & 0.00 & 0.00 \\
0.00 & 0.00 & 0.00 & 0.00 & 0.00 & 0.00 & 0.00 & 0.00 \\
4.16 & 4.19 & 4.34 & 4.27 & 4.14 & 4.33 & 4.46 & 4.39 \\
0.00 & 0.00 & 0.00 & 0.00 & 0.00 & 0.00 & 0.00 & 0.00 \\
0.02 & 0.05 & 0.05 & 0.03 & 0.03 & 0.05 & 0.05 & 0.05 \\
5.64 & 5.38 & 5.33 & 5.38 & 5.36 & 5.16 & 5.29 & 5.14 \\
0.00 & 0.00 & 0.00 & 0.00 & 0.01 & 0.00 & 0.01 & 0.01 \\
0.01 & 0.01 & 0.01 & 0.00 & 0.01 & 0.00 & 0.00 & 0.00 \\
0.01 & 0.00 & 0.00 & 0.00 & 0.00 & 0.01 & 0.01 & 0.00 \\
20.71 & 20.61 & 20.66 & 20.65 & 20.58 & 20.57 & 20.73 & 20.62 \\
0.09 & 0.00 & 0.00 & 0.13 & 0.00 & 0.16 & 0.03 & 0.03 \\
0.00 & 0.00 & 0.00 & 0.00 & 0.00 & 0.00 & 0.00 & 0.00 \\
0.00 & 0.00 & 0.00 & 0.00 & 0.00 & 0.00 & 0.00 & 0.00 \\
36.00 & 36.00 & 36.00 & 36.00 & 36.00 & 36.00 & 36.00 & 36.00 \\
0.42 & 0.44 & 0.45 & 0.44 & 0.44 & 0.46 & 0.46 & 0.46 \\
0.58 & 0.56 & 0.55 & 0.56 & 0.56 & 0.54 & 0.54 & 0.54 \\
\hline & & & & & & & \\
\hline & & & &
\end{tabular}

\begin{tabular}{|c|c|c|c|c|c|c|c|c|c|}
\hline \multirow{2}{*}{$\frac{\text { Amostra }}{\text { Análise }}$} & \multicolumn{9}{|c|}{$113 \mathrm{~F}$} \\
\hline & 585 & 586 & 587 & 588 & 589 & 618 & 619 & 620 & 621 \\
\hline$\overline{\mathrm{SiO} 2}$ & 26.18 & 25.97 & 26.08 & 26.87 & 25.91 & 26.27 & 26.05 & 26.02 & 25.94 \\
\hline TiO2 & 0.01 & 0.02 & 0.00 & 0.00 & 0.03 & 0.01 & 0.00 & 0.01 & 0.00 \\
\hline Al2O3 & 19.60 & 18.77 & 19.61 & 20.28 & 19.93 & 19.99 & 19.52 & 19.67 & 19.50 \\
\hline $\mathrm{Cr} 2 \mathrm{O} 3$ & 0.00 & 0.00 & 0.00 & 0.00 & 0.00 & 0.00 & 0.00 & 0.00 & 0.00 \\
\hline $\mathrm{FeO}$ & 31.13 & 31.30 & 31.30 & 31.44 & 31.19 & 31.45 & 30.93 & 30.76 & 30.96 \\
\hline $\mathrm{Fe} 2 \mathrm{O} 3$ & 0.00 & 0.00 & 0.00 & 0.00 & 0.00 & 0.00 & 0.00 & 0.00 & 0.00 \\
\hline MnO & 0.69 & 0.81 & 0.76 & 0.71 & 0.61 & 0.66 & 0.62 & 0.58 & 0.44 \\
\hline MgO & 11.21 & 11.23 & 10.77 & 10.69 & 10.83 & 10.87 & 11.05 & 10.90 & 11.28 \\
\hline $\mathrm{CaO}$ & 0.05 & 0.04 & 0.06 & 0.06 & 0.04 & 0.03 & 0.03 & 0.03 & 0.02 \\
\hline $\mathrm{Na} 2 \mathrm{O}$ & 0.15 & 0.00 & 0.05 & 0.00 & 0.69 & 0.21 & 0.00 & 0.18 & 0.00 \\
\hline K2O & 0.00 & 0.00 & 0.01 & 0.00 & 0.01 & 0.02 & 0.00 & 0.01 & 0.00 \\
\hline $\mathbf{F}$ & 0.03 & 0.06 & 0.06 & 0.03 & 0.05 & 0.06 & 0.08 & 0.04 & 0.05 \\
\hline $\mathrm{Cl}$ & 0.00 & 0.00 & 0.00 & 0.00 & 0.00 & 0.00 & 0.00 & 0.00 & 0.00 \\
\hline $\mathrm{H} 2 \mathrm{O}$ & 0.00 & 0.00 & 0.00 & 0.00 & 0.00 & 0.00 & 0.00 & 0.00 & 0.00 \\
\hline TOTAL & 89.03 & 88.18 & 88.70 & 90.07 & 89.29 & 89.56 & 88.28 & 88.21 & 88.18 \\
\hline O_F_Cl & 0.01 & 0.02 & 0.03 & 0.01 & 0.02 & 0.02 & 0.04 & 0.02 & 0.02 \\
\hline O_F & 0.01 & 0.02 & 0.03 & 0.01 & 0.02 & 0.02 & 0.04 & 0.02 & 0.02 \\
\hline O_Cl & 0.00 & 0.00 & 0.00 & 0.00 & 0.00 & 0.00 & 0.00 & 0.00 & 0.00 \\
\hline CTOTAL & 89.02 & 88.16 & 88.67 & 90.06 & 89.27 & 89.54 & 88.24 & 88.19 & 88.16 \\
\hline $\mathrm{Si}$ & 5.82 & 5.85 & 5.83 & 5.88 & 5.75 & 5.81 & 5.83 & 5.83 & 5.81 \\
\hline AllV & 2.18 & 2.15 & 2.18 & 2.12 & 2.25 & 2.19 & 2.17 & 2.17 & 2.19 \\
\hline SUM_T & 8.00 & 8.00 & 8.00 & 8.00 & 8.00 & 8.00 & 8.00 & 8.00 & 8.00 \\
\hline AIVI & 2.94 & 2.82 & 2.98 & 3.11 & 2.97 & 3.01 & 2.98 & 3.01 & 2.96 \\
\hline $\mathrm{Ti}$ & 0.00 & 0.00 & 0.00 & 0.00 & 0.01 & 0.00 & 0.00 & 0.00 & 0.00 \\
\hline $\mathrm{Fe} 3$ & 0.00 & 0.00 & 0.00 & 0.00 & 0.00 & 0.00 & 0.00 & 0.00 & 0.00 \\
\hline $\mathrm{Fe} 2$ & 5.78 & 5.89 & 5.85 & 5.76 & 5.79 & 5.81 & 5.79 & 5.76 & 5.80 \\
\hline $\mathrm{Cr}$ & 0.00 & 0.00 & 0.00 & 0.00 & 0.00 & 0.00 & 0.00 & 0.00 & 0.00 \\
\hline Mn & 0.13 & 0.15 & 0.14 & 0.13 & 0.12 & 0.12 & 0.12 & 0.11 & 0.08 \\
\hline Mg & 3.71 & 3.77 & 3.59 & 3.49 & 3.59 & 3.58 & 3.69 & 3.64 & 3.77 \\
\hline $\mathrm{Ca}$ & 0.01 & 0.01 & 0.02 & 0.01 & 0.01 & 0.01 & 0.01 & 0.01 & 0.00 \\
\hline $\mathrm{Na}$ & 0.06 & 0.00 & 0.02 & 0.00 & 0.30 & 0.09 & 0.00 & 0.08 & 0.00 \\
\hline K & 0.00 & 0.00 & 0.00 & 0.00 & 0.0 & 0.0 & 0.00 & 0.00 & 0.00 \\
\hline CATIONS & 20.64 & 20.65 & 20.60 & 20.50 & 20.78 & 20.63 & 20.59 & 20.61 & 20.61 \\
\hline CF & 0.04 & 0.08 & 0.09 & 0.04 & 0.07 & 0.08 & 0.12 & 0.06 & 0.07 \\
\hline CCL & 0.00 & 0.00 & 0.00 & 0.00 & 0.00 & 0.00 & 0.00 & 0.00 & 0.00 \\
\hline $\mathrm{OH}$ & 0.00 & 0.00 & 0.00 & 0.00 & 0.00 & 0.00 & 0.00 & 0.00 & 0.00 \\
\hline 0 & 36.00 & 36.00 & 36.00 & 36.00 & 36.00 & 36.00 & 36.00 & 36.00 & 36.00 \\
\hline Fe_FeMg & 0.61 & 0.61 & 0.62 & 0.62 & 0.62 & 0.62 & 0.61 & 0.61 & 0.61 \\
\hline $\mathrm{Mg}$ & 0.39 & 0.39 & 0.38 & 0.38 & 0.38 & 0.38 & 0.39 & 0.39 & 0.39 \\
\hline
\end{tabular}

\begin{tabular}{llllllll}
\hline & & & $\mathbf{1 2 5 A}$ & & & & \\
\hline $\mathbf{5 2 9}$ & $\mathbf{5 3 0}$ & $\mathbf{5 3 1}$ & $\mathbf{5 3 2}$ & $\mathbf{5 3 3}$ & $\mathbf{5 3 4}$ & $\mathbf{5 3 5}$ & $\mathbf{5 3 6}$ \\
\hline 27.93 & 28.72 & 29.03 & 27.18 & 26.97 & 27.09 & 27.80 & 27.85 \\
0.04 & 0.07 & 0.04 & 0.00 & 0.02 & 0.02 & 0.00 & 0.00 \\
19.72 & 20.39 & 20.47 & 20.10 & 19.94 & 19.86 & 21.37 & 20.54 \\
0.00 & 0.00 & 0.00 & 0.00 & 0.00 & 0.00 & 0.00 & 0.00 \\
24.23 & 23.73 & 23.81 & 23.72 & 23.88 & 23.87 & 23.97 & 23.04 \\
0.00 & 0.00 & 0.00 & 0.00 & 0.00 & 0.00 & 0.00 & 0.00 \\
0.28 & 0.34 & 0.27 & 0.26 & 0.25 & 0.27 & 0.30 & 0.28 \\
16.68 & 16.77 & 16.94 & 16.32 & 16.34 & 16.41 & 15.89 & 15.22 \\
0.10 & 0.10 & 0.14 & 0.16 & 0.14 & 0.16 & 0.10 & 0.11 \\
0.00 & 0.00 & 0.00 & 0.00 & 0.08 & 0.00 & 0.00 & 0.00 \\
0.02 & 0.04 & 0.09 & 0.03 & 0.02 & 0.02 & 0.01 & 0.00 \\
0.00 & 0.00 & 0.00 & 0.01 & 0.03 & 0.00 & 0.01 & 0.00 \\
0.00 & 0.00 & 0.00 & 0.00 & 0.00 & 0.00 & 0.00 & 0.00 \\
0.00 & 0.00 & 0.00 & 0.00 & 0.00 & 0.00 & 0.00 & 0.00 \\
88.98 & 90.16 & 90.79 & 87.77 & 87.67 & 87.69 & 89.44 & 87.03 \\
0.00 & 0.00 & 0.00 & 0.00 & 0.01 & 0.00 & 0.01 & 0.00 \\
0.00 & 0.00 & 0.00 & 0.00 & 0.01 & 0.00 & 0.01 & 0.00 \\
0.00 & 0.00 & 0.00 & 0.00 & 0.00 & 0.00 & 0.00 & 0.00 \\
88.98 & 90.16 & 90.79 & 87.77 & 87.66 & 87.69 & 89.43 & 87.03 \\
5.94 & 6.00 & 6.02 & 5.86 & 5.84 & 5.86 & 5.86 & 6.01 \\
2.06 & 2.00 & 1.98 & 2.14 & 2.16 & 2.14 & 2.14 & 1.99 \\
8.00 & 8.00 & 8.00 & 8.00 & 8.00 & 8.00 & 8.00 & 8.00 \\
2.89 & 3.01 & 3.02 & 2.97 & 2.92 & 2.91 & 3.17 & 3.24 \\
0.01 & 0.01 & 0.01 & 0.00 & 0.00 & 0.00 & 0.00 & 0.00 \\
0.00 & 0.00 & 0.00 & 0.00 & 0.00 & 0.00 & 0.00 & 0.00 \\
4.31 & 4.14 & 4.13 & 4.28 & 4.32 & 4.32 & 4.23 & 4.16 \\
0.00 & 0.00 & 0.00 & 0.00 & 0.00 & 0.00 & 0.00 & 0.00 \\
0.05 & 0.06 & 0.05 & 0.05 & 0.05 & 0.05 & 0.05 & 0.05 \\
5.29 & 5.22 & 5.23 & 5.25 & 5.27 & 5.29 & 5.00 & 4.90 \\
0.02 & 0.02 & 0.03 & 0.04 & 0.03 & 0.04 & 0.02 & 0.03 \\
0.00 & 0.00 & 0.00 & 0.00 & 0.03 & 0.00 & 0.00 & 0.00 \\
0.01 & 0.01 & 0.03 & 0.01 & 0.00 & 0.01 & 0.00 & 0.00 \\
20.58 & 20.48 & 20.48 & 20.58 & 20.63 & 20.61 & 20.47 & 20.37 \\
0.00 & 0.00 & 0.00 & 0.01 & 0.05 & 0.00 & 0.02 & 0.00 \\
0.00 & 0.00 & 0.00 & 0.00 & 0.00 & 0.00 & 0.00 & 0.00 \\
0.00 & 0.00 & 0.00 & 0.00 & 0.00 & 0.00 & 0.00 & 0.00 \\
36.00 & 36.00 & 36.00 & 36.00 & 36.00 & 36.00 & 36.00 & 36.00 \\
0.45 & 0.44 & 0.44 & 0.45 & 0.45 & 0.45 & 0.46 & 0.46 \\
0.55 & 0.56 & 0.56 & 0.55 & 0.55 & 0.55 & 0.54 & 0.54
\end{tabular}




\begin{tabular}{|c|c|c|c|c|c|c|c|c|c|c|c|c|c|c|c|c|c|c|}
\hline Amostra & $113 \mathrm{~F}$ & $113 \mathrm{~F}$ & $113 \mathrm{~F}$ & $113 \mathrm{~F}$ & $113 \mathrm{~F}$ & $113 \mathrm{~F}$ & $113 \mathrm{~F}$ & $113 \mathrm{~F}$ & $113 \mathrm{~F}$ & $113 \mathrm{~F}$ & $113 \mathrm{~F}$ & $113 \mathrm{~F}$ & $113 \mathrm{~F}$ & $113 \mathrm{~F}$ & $113 \mathrm{~F}$ & $113 \mathrm{~F}$ & $113 \mathrm{~F}$ & $113 \mathrm{~F}$ \\
\hline Análise & 573 & 574 & 575 & 576 & 577 & 578 & 579 & 580 & 581 & 582 & 583 & 584 & 604 & 605 & 606 & 607 & 608 & 609 \\
\hline SiO2 & 38.03 & 38.41 & 37.72 & 38.16 & 38.05 & 38.14 & 37.85 & 37.86 & 37.90 & 37.83 & 37.94 & 38.04 & 37.21 & 37.09 & 37.23 & 37.11 & 36.93 & 36.72 \\
\hline TiO2 & 0.12 & 0.09 & 0.12 & 0.10 & 0.09 & 0.15 & 0.14 & 0.13 & 0.15 & 0.05 & 0.12 & 0.17 & 0.12 & 0.11 & 0.16 & 0.15 & 0.15 & 0.17 \\
\hline Al2O3 & 21.36 & 20.99 & 21.11 & 21.25 & 21.26 & 21.38 & 21.08 & 21.29 & 20.90 & 21.17 & 20.98 & 21.26 & 21.80 & 21.46 & 21.47 & 21.82 & 21.55 & 21.43 \\
\hline $\mathrm{Cr} 2 \mathrm{O} 3$ & 0.00 & 0.00 & 0.00 & 0.00 & 0.00 & 0.00 & 0.00 & 0.00 & 0.00 & 0.00 & 0.00 & 0.00 & 0.00 & 0.00 & 0.00 & 0.00 & 0.00 & 0.00 \\
\hline $\mathrm{FeO}$ & 27.13 & 25.24 & 27.24 & 25.74 & 26.06 & 24.30 & 24.34 & 24.11 & 23.82 & 23.05 & 23.99 & 25.04 & 26.51 & 25.98 & 24.96 & 25.46 & 24.78 & 23.60 \\
\hline $\mathrm{Fe} 2 \mathrm{O} 3$ & 0.00 & 0.00 & 0.00 & 0.00 & 0.00 & 0.00 & 0.00 & 0.00 & 0.00 & 0.00 & 0.00 & 0.00 & 0.00 & 0.00 & 0.00 & 0.00 & 0.00 & 0.00 \\
\hline MnO & 4.30 & 4.95 & 5.17 & 6.77 & 6.98 & 8.53 & 9.26 & 9.41 & 8.96 & 10.65 & 9.79 & 7.69 & 5.75 & 6.92 & 7.55 & 8.01 & 8.85 & 10.03 \\
\hline MgO & 0.47 & 0.86 & 0.80 & 0.76 & 0.81 & 0.89 & 0.66 & 0.71 & 0.80 & 0.44 & 0.81 & 0.87 & 0.96 & 1.32 & 1.25 & 1.16 & 1.72 & 0.94 \\
\hline $\mathrm{CaO}$ & 9.70 & 10.97 & 8.80 & 8.25 & 8.04 & 8.19 & 7.52 & 7.47 & 7.80 & 8.30 & 7.42 & 8.11 & 8.77 & 7.98 & 8.00 & 7.92 & 7.40 & 7.42 \\
\hline $\mathrm{Na} 2 \mathrm{O}$ & 0.16 & 0.00 & 0.40 & 0.00 & 0.41 & 0.00 & 0.00 & 0.00 & 0.02 & 0.00 & 0.00 & 0.00 & 0.01 & 0.26 & 0.19 & 0.11 & 0.23 & 0.00 \\
\hline $\mathbf{F}$ & 0.00 & 0.00 & 0.00 & 0.00 & 0.00 & 0.00 & 0.00 & 0.00 & 0.00 & 0.00 & 0.00 & 0.00 & 0.00 & 0.00 & 0.00 & 0.00 & 0.00 & 0.00 \\
\hline Cl & 0.00 & 0.00 & 0.00 & 0.00 & 0.00 & 0.00 & 0.00 & 0.00 & 0.00 & 0.00 & 0.00 & 0.00 & 0.00 & 0.00 & 0.00 & 0.00 & 0.00 & 0.00 \\
\hline TOTAL & 101.26 & 101.51 & 101.34 & 101.03 & 101.71 & 101.58 & 100.86 & 100.96 & 100.35 & 101.49 & 101.05 & 101.17 & 101.12 & 101.12 & 100.80 & 101.73 & 101.61 & 100.31 \\
\hline FeOCALC & 27.13 & 25.24 & 27.24 & 25.74 & 26.06 & 24.30 & 24.34 & 24.11 & 23.82 & 23.05 & 23.99 & 25.04 & 26.51 & 25.98 & 24.96 & 25.46 & 24.78 & 23.60 \\
\hline Fe2O3CALC & 0.00 & 0.00 & 0.00 & 0.00 & 0.00 & 0.00 & 0.00 & 0.00 & 0.00 & 0.00 & 0.00 & 0.00 & 0.00 & 0.00 & 0.00 & 0.00 & 0.00 & 0.00 \\
\hline TOTALCALC & 101.26 & 101.51 & 101.34 & 101.03 & 101.71 & 101.58 & 100.86 & 100.96 & 100.35 & 101.49 & 101.05 & 101.17 & 101.12 & 101.12 & 100.80 & 101.73 & 101.61 & 100.31 \\
\hline O_F_CL & 0.00 & 0.00 & 0.00 & 0.00 & 0.00 & 0.00 & 0.00 & 0.00 & 0.00 & 0.00 & 0.00 & 0.00 & 0.00 & 0.00 & 0.00 & 0.00 & 0.00 & 0.00 \\
\hline CTTOTAL & 101.26 & 101.51 & 101.34 & 101.03 & 101.71 & 101.58 & 100.86 & 100.96 & 100.35 & 101.49 & 101.05 & 101.17 & 101.12 & 101.12 & 100.80 & 101.73 & 101.61 & 100.31 \\
\hline Tsi & 3.01 & 3.03 & 2.98 & 3.04 & 3.00 & 3.02 & 3.03 & 3.02 & 3.04 & 3.01 & 3.03 & 3.02 & 2.95 & 2.94 & 2.96 & 2.93 & 2.91 & 2.95 \\
\hline TAI & 0.00 & 0.00 & 0.02 & 0.00 & 0.00 & 0.00 & 0.00 & 0.00 & 0.00 & 0.00 & 0.00 & 0.00 & 0.05 & 0.06 & 0.04 & 0.07 & 0.09 & 0.05 \\
\hline SUM_T & 3.01 & 3.03 & 3.00 & 3.04 & 3.00 & 3.02 & 3.03 & 3.02 & 3.04 & 3.01 & 3.03 & 3.02 & 3.00 & 3.00 & 3.00 & 3.00 & 3.00 & 3.00 \\
\hline AIVI & 1.99 & 1.95 & 1.95 & 1.99 & 1.97 & 1.99 & 1.99 & 2.00 & 1.97 & 1.98 & 1.97 & 1.99 & 1.99 & 1.94 & 1.97 & 1.95 & 1.91 & 1.97 \\
\hline $\mathrm{Fe} 3$ & 0.00 & 0.00 & 0.00 & 0.00 & 0.00 & 0.00 & 0.00 & 0.00 & 0.00 & 0.00 & 0.00 & 0.00 & 0.00 & 0.00 & 0.00 & 0.00 & 0.00 & 0.00 \\
\hline $\mathrm{Ti}$ & 0.01 & 0.01 & 0.01 & 0.01 & 0.01 & 0.01 & 0.01 & 0.01 & 0.01 & 0.00 & 0.01 & 0.01 & 0.01 & 0.01 & 0.01 & 0.01 & 0.01 & 0.01 \\
\hline $\mathrm{Cr}$ & 0.00 & 0.00 & 0.00 & 0.00 & 0.00 & 0.00 & 0.00 & 0.00 & 0.00 & 0.00 & 0.00 & 0.00 & 0.00 & 0.00 & 0.00 & 0.00 & 0.00 & 0.00 \\
\hline SUM_A & 2.00 & 1.95 & 1.95 & 2.00 & 1.98 & 2.00 & 1.99 & 2.01 & 1.98 & 1.99 & 1.98 & 2.00 & 2.00 & 1.94 & 1.98 & 1.96 & 1.92 & 1.98 \\
\hline $\mathrm{Fe} 2$ & 1.80 & 1.66 & 1.80 & 1.71 & 1.72 & 1.61 & 1.63 & 1.61 & 1.60 & 1.53 & 1.60 & 1.67 & 1.76 & 1.72 & 1.66 & 1.68 & 1.63 & 1.58 \\
\hline Mg & 0.06 & 0.10 & 0.09 & 0.09 & 0.10 & 0.11 & 0.08 & 0.08 & 0.10 & 0.05 & 0.10 & 0.10 & 0.11 & 0.16 & 0.15 & 0.14 & 0.20 & 0.11 \\
\hline Mn & 0.29 & 0.33 & 0.35 & 0.46 & 0.47 & 0.57 & 0.63 & 0.64 & 0.61 & 0.72 & 0.66 & 0.52 & 0.39 & 0.46 & 0.51 & 0.54 & 0.59 & 0.68 \\
\hline $\mathrm{Ca}$ & 0.82 & 0.93 & 0.75 & 0.70 & 0.68 & 0.70 & 0.64 & 0.64 & 0.67 & 0.71 & 0.63 & 0.69 & 0.75 & 0.68 & 0.68 & 0.67 & 0.62 & 0.64 \\
\hline $\mathrm{Na}$ & 0.02 & 0.00 & 0.06 & 0.00 & 0.06 & 0.00 & 0.00 & 0.00 & 0.00 & 0.00 & 0.00 & 0.00 & 0.00 & 0.04 & 0.03 & 0.02 & 0.04 & 0.00 \\
\hline SUM_B & 2.99 & 3.02 & 3.05 & 2.96 & 3.02 & 2.98 & 2.98 & 2.97 & 2.98 & 3.01 & 2.99 & 2.98 & 3.00 & 3.06 & 3.02 & 3.04 & 3.08 & 3.02 \\
\hline SUM_CAT & 8.00 & 8.00 & 8.00 & 8.00 & 8.00 & 8.00 & 8.00 & 8.00 & 8.00 & 8.00 & 8.00 & 8.00 & 8.00 & 8.00 & 8.00 & 8.00 & 8.00 & 8.00 \\
\hline 0 & 12.00 & 12.00 & 12.00 & 12.00 & 12.00 & 12.00 & 12.00 & 12.00 & 12.00 & 12.00 & 12.00 & 12.00 & 12.00 & 12.00 & 12.00 & 12.00 & 12.00 & 12.00 \\
\hline CF & 0.00 & 0.00 & 0.00 & 0.00 & 0.00 & 0.00 & 0.00 & 0.00 & 0.00 & 0.00 & 0.00 & 0.00 & 0.00 & 0.00 & 0.00 & 0.00 & 0.00 & 0.00 \\
\hline $\mathrm{CCL}$ & 0.00 & 0.00 & 0.00 & 0.00 & 0.00 & 0.00 & 0.00 & 0.00 & 0.00 & 0.00 & 0.00 & 0.00 & 0.00 & 0.00 & 0.00 & 0.00 & 0.00 & 0.00 \\
\hline Alm & 0.00 & 55.07 & 0.00 & 57.82 & 0.00 & 53.98 & 54.66 & 54.22 & 53.70 & 50.94 & 53.49 & 55.94 & 58.53 & 0.00 & 0.00 & 0.00 & 0.00 & 52.52 \\
\hline Adr & 0.00 & 0.00 & 0.00 & 0.00 & 0.00 & 0.00 & 0.00 & 0.00 & 0.00 & 0.00 & 0.00 & 0.00 & 0.00 & 0.00 & 0.00 & 0.00 & 0.00 & 0.00 \\
\hline Grs & 0.00 & 30.65 & 0.00 & 23.75 & 0.00 & 23.31 & 21.62 & 21.53 & 22.52 & 23.49 & 21.20 & 23.21 & 24.80 & 0.00 & 0.00 & 0.00 & 0.00 & 21.14 \\
\hline Рyp & 0.00 & 3.35 & 0.00 & 3.03 & 0.00 & 3.52 & 2.65 & 2.83 & 3.22 & 1.75 & 3.20 & 3.46 & 3.77 & 0.00 & 0.00 & 0.00 & 0.00 & 3.73 \\
\hline Sps & 0.00 & 10.93 & 0.00 & 15.41 & 0.00 & 19.19 & 21.07 & 21.43 & 20.46 & 23.82 & 22.11 & 17.39 & 12.85 & 0.00 & 0.00 & 0.00 & 0.00 & 22.61 \\
\hline Uvr & 0.00 & 0.00 & 0.00 & 0.00 & 0.00 & 0.00 & 0.00 & 0.00 & 0.00 & 0.00 & 0.00 & 0.00 & 0.00 & 0.00 & 0.00 & 0.00 & 0.00 & 0.00 \\
\hline XCaGrt & 0.28 & 0.31 & 0.25 & 0.24 & 0.23 & 0.23 & 0.22 & 0.22 & 0.23 & 0.24 & 0.21 & 0.23 & 0.25 & 0.22 & 0.23 & 0.22 & 0.21 & 0.21 \\
\hline XFeGrt & 0.61 & 0.55 & 0.60 & 0.58 & 0.58 & 0.54 & 0.55 & 0.54 & 0.54 & 0.51 & 0.54 & 0.56 & 0.59 & 0.57 & 0.55 & 0.56 & 0.54 & 0.53 \\
\hline XMgGrt & 0.02 & 0.03 & 0.03 & 0.03 & 0.03 & 0.04 & 0.03 & 0.03 & 0.03 & 0.02 & 0.03 & 0.04 & 0.04 & 0.05 & 0.05 & 0.05 & 0.07 & 0.04 \\
\hline $\mathrm{Fe}$ MgGrt & 32.67 & 16.47 & 19.15 & 19.04 & 17.89 & 15.32 & 20.61 & 19.16 & 16.65 & 28.93 & 16.68 & 16.17 & 15.57 & 11.03 & 11.20 & 12.35 & 8.08 & 14.02 \\
\hline
\end{tabular}




\begin{tabular}{|c|c|c|c|c|c|c|c|c|c|c|c|c|c|c|c|c|c|c|}
\hline Amostra & 118 & 118 & 118 & 118 & 118 & 118 & 118 & 118 & 118 & 118 & 118 & 118 & 118 & 118 & 118 & 118 & 118 & 118 \\
\hline Análise & 529 & 530 & 531 & 532 & 533 & 534 & 535 & 536 & 537 & 538 & 539 & 540 & 541 & 542 & 543 & 544 & 545 & 546 \\
\hline SiO2 & 37.87 & 38.12 & 37.42 & 37.40 & 38.03 & 37.93 & 37.93 & 37.85 & 37.81 & 37.63 & 37.43 & 37.74 & 37.80 & 37.53 & 37.49 & 37.81 & 37.79 & 37.88 \\
\hline TiO2 & 0.08 & 0.06 & 0.23 & 0.17 & 0.02 & 0.08 & 0.11 & 0.02 & 0.00 & 0.15 & 0.15 & 0.09 & 0.19 & 0.08 & 0.02 & 0.08 & 0.06 & 0.06 \\
\hline $\mathrm{Al} 2 \mathrm{O3}$ & 21.84 & 21.70 & 21.59 & 21.65 & 21.67 & 21.84 & 21.54 & 21.40 & 21.49 & 21.59 & 21.51 & 21.42 & 21.37 & 21.57 & 21.76 & 21.75 & 21.63 & 21.89 \\
\hline $\mathrm{FeO}$ & 23.67 & 23.71 & 21.26 & 20.76 & 19.54 & 18.40 & 17.46 & 19.68 & 19.90 & 18.72 & 19.52 & 19.77 & 20.28 & 20.62 & 21.10 & 22.94 & 23.93 & 23.75 \\
\hline Cr2O3 & 0.00 & 0.03 & 0.00 & 0.08 & 0.04 & 0.03 & 0.02 & 0.00 & 0.00 & 0.02 & 0.00 & 0.00 & 0.00 & 0.04 & 0.02 & 0.00 & 0.04 & 0.02 \\
\hline MnO & 4.18 & 5.18 & 7.61 & 8.90 & 9.28 & 11.03 & 11.27 & 11.13 & 10.90 & 10.94 & 10.70 & 10.71 & 9.08 & 8.64 & 7.81 & 6.14 & 4.92 & 4.18 \\
\hline $\mathrm{MgO}$ & 1.13 & 1.08 & 0.80 & 0.80 & 0.74 & 0.69 & 0.59 & 0.72 & 0.73 & 0.69 & 0.68 & 0.72 & 0.74 & 0.79 & 0.91 & 1.04 & 1.12 & 1.14 \\
\hline Y2O3 & 0.06 & 0.00 & 0.03 & 0.06 & 0.12 & 0.18 & 0.19 & 0.12 & 0.12 & 0.21 & 0.11 & 0.14 & 0.12 & 0.11 & 0.09 & 0.03 & 0.06 & 0.04 \\
\hline $\mathrm{CaO}$ & 11.28 & 10.46 & 11.14 & 10.06 & 10.71 & 10.30 & 10.92 & 10.05 & 9.05 & 10.25 & 10.20 & 9.65 & 10.04 & 10.06 & 10.22 & 10.17 & 10.53 & 11.33 \\
\hline TOTAL & 100.11 & 100.30 & 100.07 & 99.79 & 100.11 & 100.44 & 100.01 & 100.96 & 100.00 & 100.18 & 100.29 & 100.25 & 99.60 & 99.41 & 99.40 & 99.97 & 100.03 & 100.26 \\
\hline FeOCALC & 23.67 & 23.71 & 21.26 & 20.76 & 19.54 & 18.40 & 17.46 & 19.68 & 19.90 & 18.72 & 19.52 & 19.77 & 20.28 & 20.62 & 21.10 & 22.94 & 23.93 & 23.75 \\
\hline Fe2O3CALC & 0.00 & 0.00 & 0.00 & 0.00 & 0.00 & 0.00 & 0.00 & 0.00 & 0.00 & 0.00 & 0.00 & 0.00 & 0.00 & 0.00 & 0.00 & 0.00 & 0.00 & 0.00 \\
\hline TOTALCALC & 100.11 & 100.30 & 100.07 & 99.79 & 100.11 & 100.44 & 100.01 & 100.96 & 100.00 & 100.18 & 100.29 & 100.25 & 99.60 & 99.41 & 99.40 & 99.97 & 100.03 & 100.26 \\
\hline TSi & 3.01 & 3.03 & 2.98 & 2.99 & 3.03 & 3.02 & 3.03 & 3.00 & 3.03 & 3.01 & 2.99 & 3.02 & 3.04 & 3.02 & 3.01 & 3.02 & 3.01 & 3.00 \\
\hline Tal & 0.00 & 0.00 & 0.02 & 0.01 & 0.00 & 0.00 & 0.00 & 0.00 & 0.00 & 0.00 & 0.01 & 0.00 & 0.00 & 0.00 & 0.00 & 0.00 & 0.00 & 0.00 \\
\hline SUM_T & 3.01 & 3.03 & 3.00 & 3.00 & 3.03 & 3.02 & 3.03 & 3.00 & 3.03 & 3.01 & 3.00 & 3.02 & 3.04 & 3.02 & 3.01 & 3.02 & 3.01 & 3.00 \\
\hline AIVI & 2.04 & 2.03 & 2.01 & 2.03 & 2.03 & 2.05 & 2.03 & 2.00 & 2.03 & 2.03 & 2.01 & 2.02 & 2.02 & 2.04 & 2.06 & 2.04 & 2.03 & 2.04 \\
\hline $\mathrm{Fe} 3$ & 0.00 & 0.00 & 0.00 & 0.00 & 0.00 & 0.00 & 0.00 & 0.00 & 0.00 & 0.00 & 0.00 & 0.00 & 0.00 & 0.00 & 0.00 & 0.00 & 0.00 & 0.00 \\
\hline $\mathrm{Ti}$ & 0.01 & 0.00 & 0.01 & 0.01 & 0.00 & 0.00 & 0.01 & 0.00 & 0.00 & 0.01 & 0.01 & 0.01 & 0.01 & 0.01 & 0.00 & 0.00 & 0.00 & 0.00 \\
\hline $\mathrm{Cr}$ & 0.00 & 0.00 & 0.00 & 0.01 & 0.00 & 0.00 & 0.00 & 0.00 & 0.00 & 0.00 & 0.00 & 0.00 & 0.00 & 0.00 & 0.00 & 0.00 & 0.00 & 0.00 \\
\hline SUM_A & 2.05 & 2.03 & 2.02 & 2.05 & 2.04 & 2.05 & 2.04 & 2.00 & 2.03 & 2.04 & 2.02 & 2.02 & 2.03 & 2.05 & 2.06 & 2.05 & 2.03 & 2.05 \\
\hline $\mathrm{Fe} 2$ & 1.57 & 1.57 & 1.42 & 1.39 & 1.30 & 1.22 & 1.17 & 1.31 & 1.34 & 1.25 & 1.30 & 1.32 & 1.36 & 1.39 & 1.42 & 1.53 & 1.59 & 1.57 \\
\hline Mg & 0.13 & 0.13 & 0.10 & 0.10 & 0.09 & 0.08 & 0.07 & 0.09 & 0.09 & 0.08 & 0.08 & 0.09 & 0.09 & 0.10 & 0.11 & 0.12 & 0.13 & 0.13 \\
\hline Mn & 0.28 & 0.35 & 0.51 & 0.60 & 0.63 & 0.74 & 0.76 & 0.75 & 0.74 & 0.74 & 0.72 & 0.73 & 0.62 & 0.59 & 0.53 & 0.42 & 0.33 & 0.28 \\
\hline $\mathrm{Ca}$ & 0.96 & 0.89 & 0.95 & 0.86 & 0.92 & 0.88 & 0.94 & 0.86 & 0.78 & 0.88 & 0.87 & 0.83 & 0.86 & 0.87 & 0.88 & 0.87 & 0.90 & 0.96 \\
\hline $\mathrm{Na}$ & 0.00 & 0.00 & 0.00 & 0.00 & 0.00 & 0.00 & 0.00 & 0.00 & 0.00 & 0.00 & 0.00 & 0.00 & 0.00 & 0.00 & 0.00 & 0.00 & 0.00 & 0.00 \\
\hline SUM_B & 2.95 & 2.94 & 2.98 & 2.95 & 2.93 & 2.93 & 2.93 & 2.99 & 2.94 & 2.95 & 2.98 & 2.96 & 2.93 & 2.94 & 2.93 & 2.94 & 2.96 & 2.95 \\
\hline SUM_CAT & 8.00 & 8.00 & 8.00 & 8.00 & 8.00 & 8.00 & 8.00 & 8.00 & 8.00 & 8.00 & 8.00 & 8.00 & 8.00 & 8.00 & 8.00 & 8.00 & 8.00 & 8.00 \\
\hline 0 & 12.00 & 12.00 & 12.00 & 12.00 & 12.00 & 12.00 & 12.00 & 12.00 & 12.00 & 12.00 & 12.00 & 12.00 & 12.00 & 12.00 & 12.00 & 12.00 & 12.00 & 12.00 \\
\hline CF & 0.00 & 0.00 & 0.00 & 0.00 & 0.00 & 0.00 & 0.00 & 0.00 & 0.00 & 0.00 & 0.00 & 0.00 & 0.00 & 0.00 & 0.00 & 0.00 & 0.00 & 0.00 \\
\hline $\mathrm{CCl}$ & 0.00 & 0.00 & 0.00 & 0.00 & 0.00 & 0.00 & 0.00 & 0.00 & 0.00 & 0.00 & 0.00 & 0.00 & 0.00 & 0.00 & 0.00 & 0.00 & 0.00 & 0.00 \\
\hline Alm & 53.35 & 53.54 & 47.59 & 47.10 & 44.43 & 41.82 & 39.76 & 43.63 & 45.41 & 42.39 & 43.73 & 44.67 & 46.45 & 47.21 & 48.26 & 52.08 & 53.89 & 53.35 \\
\hline Adr & 0.00 & 0.00 & 0.00 & 0.00 & 0.00 & 0.00 & 0.00 & 0.00 & 0.00 & 0.00 & 0.00 & 0.00 & 0.00 & 0.00 & 0.00 & 0.00 & 0.00 & 0.00 \\
\hline Grs & 32.57 & 30.19 & 31.95 & 29.00 & 31.07 & 29.90 & 31.80 & 28.54 & 26.45 & 29.69 & 29.25 & 27.92 & 29.45 & 29.40 & 29.90 & 29.59 & 30.29 & 32.53 \\
\hline Pyp & 4.53 & 4.34 & 3.21 & 3.22 & 3.01 & 2.79 & 2.38 & 2.83 & 2.97 & 2.77 & 2.73 & 2.91 & 3.04 & 3.24 & 3.70 & 4.21 & 4.48 & 4.56 \\
\hline Sps & 9.55 & 11.86 & 17.25 & 20.45 & 21.37 & 25.39 & 26.00 & 24.99 & 25.18 & 25.09 & 24.28 & 24.50 & 21.06 & 20.04 & 18.09 & 14.12 & 11.23 & 9.51 \\
\hline Uvr & 0.00 & 0.08 & 0.00 & 0.23 & 0.13 & 0.10 & 0.06 & 0.00 & 0.00 & 0.06 & 0.01 & 0.00 & 0.00 & 0.12 & 0.05 & 0.00 & 0.11 & 0.06 \\
\hline XCaGrt & 0.33 & 0.30 & 0.32 & 0.29 & 0.31 & 0.30 & 0.32 & 0.29 & 0.26 & 0.30 & 0.29 & 0.28 & 0.30 & 0.30 & 0.30 & 0.30 & 0.30 & 0.33 \\
\hline XFeGrt & 0.53 & 0.54 & 0.48 & 0.47 & 0.44 & 0.42 & 0.40 & 0.44 & 0.45 & 0.42 & 0.44 & 0.45 & 0.47 & 0.47 & 0.48 & 0.52 & 0.54 & 0.53 \\
\hline XMgGrt & 0.05 & 0.04 & 0.03 & 0.03 & 0.03 & 0.03 & 0.02 & 0.03 & 0.03 & 0.03 & 0.03 & 0.03 & 0.03 & 0.03 & 0.04 & 0.04 & 0.05 & 0.05 \\
\hline $\mathrm{Fe}$ MgGrt & 11.73 & 12.39 & 14.92 & 14.63 & 14.81 & 14.93 & 16.67 & 15.37 & 15.35 & 15.26 & 16.09 & 15.37 & 15.30 & 14.59 & 12.99 & 12.34 & 12.07 & 11.75 \\
\hline
\end{tabular}




\begin{tabular}{|c|c|c|c|c|c|c|c|c|c|c|c|c|c|c|c|c|c|c|}
\hline Amostra & 121B & 121B & 121B & 121B & 121B & 121B & 121B & 121B & 121B & 121B & 121B & 121B & 121B & 121B & 121B & 121B & 121B & 121B \\
\hline Análise & 279 & 280 & 281 & 282 & 283 & 284 & 285 & 286 & 287 & 288 & 289 & 290 & 291 & 292 & 293 & 294 & 295 & 296 \\
\hline SiO2 & 38.11 & 38.10 & 37.96 & 37.71 & 37.77 & 38.14 & 37.67 & 38.01 & 37.78 & 37.96 & 37.94 & 37.87 & 37.86 & 37.84 & 37.75 & 37.52 & 37.75 & 37.68 \\
\hline TiO2 & 0.16 & 0.13 & 0.13 & 0.09 & 0.09 & 0.22 & 0.18 & 0.09 & 0.10 & 0.13 & 0.10 & 0.06 & 0.12 & 0.16 & 0.15 & 0.04 & 0.13 & 0.20 \\
\hline $\mathrm{Al} 2 \mathrm{O} 3$ & 21.40 & 21.35 & 21.42 & 21.43 & 21.51 & 21.32 & 21.37 & 21.43 & 21.55 & 21.51 & 21.28 & 21.45 & 21.37 & 21.20 & 21.28 & 21.06 & 21.23 & 20.83 \\
\hline Cr2O3 & 0.00 & 0.00 & 0.00 & 0.00 & 0.00 & 0.00 & 0.00 & 0.00 & 0.00 & 0.00 & 0.00 & 0.00 & 0.00 & 0.00 & 0.00 & 0.00 & 0.00 & 0.00 \\
\hline $\mathrm{FeO}$ & 27.23 & 27.19 & 26.15 & 26.64 & 26.70 & 24.61 & 23.52 & 26.27 & 27.41 & 27.10 & 25.85 & 27.07 & 27.05 & 24.81 & 22.71 & 21.57 & 19.21 & 19.03 \\
\hline $\mathrm{Fe} 2 \mathrm{O} 3$ & 0.00 & 0.00 & 0.00 & 0.00 & 0.00 & 0.00 & 0.00 & 0.00 & 0.00 & 0.00 & 0.00 & 0.00 & 0.00 & 0.00 & 0.00 & 0.00 & 0.00 & 0.00 \\
\hline MnO & 3.47 & 2.77 & 3.51 & 4.51 & 3.15 & 4.93 & 5.65 & 3.61 & 2.65 & 2.39 & 3.92 & 3.39 & 3.18 & 4.68 & 8.32 & 11.99 & 12.89 & 12.42 \\
\hline MgO & 0.90 & 0.96 & 0.91 & 0.90 & 1.05 & 0.83 & 0.73 & 0.92 & 1.00 & 0.96 & 0.84 & 0.89 & 0.96 & 0.77 & 0.72 & 0.67 & 0.55 & 0.51 \\
\hline $\mathrm{CaO}$ & 9.98 & 10.20 & 10.80 & 9.51 & 10.57 & 11.12 & 11.35 & 10.55 & 10.20 & 10.76 & 10.62 & 10.09 & 10.09 & 11.13 & 9.60 & 7.38 & 8.75 & 9.03 \\
\hline $\mathrm{Na2O}$ & 0.01 & 0.02 & 0.01 & 0.01 & 0.03 & 0.01 & 0.02 & 0.00 & 0.04 & 0.02 & 0.02 & 0.00 & 0.00 & 0.01 & 0.02 & 0.00 & 0.03 & 0.03 \\
\hline$F$ & 0.00 & 0.00 & 0.00 & 0.00 & 0.00 & 0.00 & 0.00 & 0.00 & 0.00 & 0.00 & 0.00 & 0.00 & 0.00 & 0.00 & 0.00 & 0.00 & 0.00 & 0.00 \\
\hline $\mathrm{Cl}$ & 0.00 & 0.00 & 0.00 & 0.00 & 0.00 & 0.00 & 0.00 & 0.00 & 0.00 & 0.00 & 0.00 & 0.00 & 0.00 & 0.00 & 0.00 & 0.00 & 0.00 & 0.00 \\
\hline TOTAL & 101.25 & 100.72 & 100.89 & 100.80 & 100.87 & 101.16 & 100.50 & 100.88 & 100.73 & 100.85 & 100.58 & 100.81 & 100.63 & 100.60 & 100.55 & 100.23 & 100.54 & 99.72 \\
\hline FeOCALC & 27.23 & 27.19 & 26.15 & 26.64 & 26.70 & 24.61 & 23.52 & 26.27 & 27.41 & 27.10 & 25.85 & 27.07 & 27.05 & 24.81 & 22.71 & 21.57 & 19.21 & 19.03 \\
\hline Fe2O3CALC & 0.00 & 0.00 & 0.00 & 0.00 & 0.00 & 0.00 & 0.00 & 0.00 & 0.00 & 0.00 & 0.00 & 0.00 & 0.00 & 0.00 & 0.00 & 0.00 & 0.00 & 0.00 \\
\hline TOTALCALC & 101.25 & 100.72 & 100.89 & 100.80 & 100.87 & 101.16 & 100.50 & 100.88 & 100.73 & 100.85 & 100.58 & 100.81 & 100.63 & 100.60 & 100.55 & 100.23 & 100.54 & 99.72 \\
\hline O_F_Cl & 0.00 & 0.00 & 0.00 & 0.00 & 0.00 & 0.00 & 0.00 & 0.00 & 0.00 & 0.00 & 0.00 & 0.00 & 0.00 & 0.00 & 0.00 & 0.00 & 0.00 & 0.00 \\
\hline ст̄OTAL & 101.25 & 100.72 & 100.89 & 100.80 & 100.87 & 101.16 & 100.50 & 100.88 & 100.73 & 100.85 & 100.58 & 100.81 & 100.63 & 100.60 & 100.55 & 100.23 & 100.54 & 99.72 \\
\hline TSi & 3.01 & 3.02 & 3.01 & 3.00 & 2.99 & 3.01 & 2.99 & 3.01 & 3.00 & 3.00 & 3.01 & 3.01 & 3.01 & 3.01 & 3.01 & 3.02 & 3.02 & 3.04 \\
\hline Tal & 0.00 & 0.00 & 0.00 & 0.00 & 0.01 & 0.00 & 0.01 & 0.00 & 0.00 & 0.00 & 0.00 & 0.00 & 0.00 & 0.00 & 0.00 & 0.00 & 0.00 & 0.00 \\
\hline SUM_T & 3.01 & 3.02 & 3.01 & 3.00 & 3.00 & 3.01 & 3.00 & 3.01 & 3.00 & 3.00 & 3.01 & 3.01 & 3.01 & 3.01 & 3.01 & 3.02 & 3.02 & 3.04 \\
\hline AIVI & 1.99 & 2.00 & 2.00 & 2.00 & 1.99 & 1.98 & 1.99 & 2.00 & 2.01 & 2.01 & 1.99 & 2.00 & 2.00 & 1.98 & 2.00 & 2.00 & 2.00 & 1.98 \\
\hline $\mathrm{Fe} 3$ & 0.00 & 0.00 & 0.00 & 0.00 & 0.00 & 0.00 & 0.00 & 0.00 & 0.00 & 0.00 & 0.00 & 0.00 & 0.00 & 0.00 & 0.00 & 0.00 & 0.00 & 0.00 \\
\hline $\mathrm{Ti}$ & 0.01 & 0.01 & 0.01 & 0.01 & 0.01 & 0.01 & 0.01 & 0.01 & 0.01 & 0.01 & 0.01 & 0.00 & 0.01 & 0.01 & 0.01 & 0.00 & 0.01 & 0.01 \\
\hline $\mathrm{Cr}$ & 0.00 & 0.00 & 0.00 & 0.00 & 0.00 & 0.00 & 0.00 & 0.00 & 0.00 & 0.00 & 0.00 & 0.00 & 0.00 & 0.00 & 0.00 & 0.00 & 0.00 & 0.00 \\
\hline SUM_A & 2.00 & 2.00 & 2.01 & 2.01 & 2.00 & 2.00 & 2.00 & 2.01 & 2.02 & 2.01 & 2.00 & 2.01 & 2.01 & 1.99 & 2.01 & 2.00 & 2.01 & 1.99 \\
\hline $\mathrm{Fe} 2$ & 1.80 & 1.80 & 1.73 & 1.77 & 1.77 & 1.63 & 1.56 & 1.74 & 1.82 & 1.79 & 1.72 & 1.80 & 1.80 & 1.65 & 1.51 & 1.45 & 1.28 & 1.28 \\
\hline Mg & 0.11 & 0.11 & 0.11 & 0.11 & 0.12 & 0.10 & 0.09 & 0.11 & 0.12 & 0.11 & 0.10 & 0.11 & 0.11 & 0.09 & 0.09 & 0.08 & 0.07 & 0.06 \\
\hline Mn & 0.23 & 0.19 & 0.24 & 0.30 & 0.21 & 0.33 & 0.38 & 0.24 & 0.18 & 0.16 & 0.26 & 0.23 & 0.21 & 0.32 & 0.56 & 0.82 & 0.87 & 0.85 \\
\hline $\mathrm{Ca}$ & 0.85 & 0.87 & 0.92 & 0.81 & 0.90 & 0.94 & 0.97 & 0.90 & 0.87 & 0.91 & 0.90 & 0.86 & 0.86 & 0.95 & 0.82 & 0.64 & 0.75 & 0.78 \\
\hline $\mathrm{Na}$ & 0.00 & 0.00 & 0.00 & 0.00 & 0.00 & 0.00 & 0.00 & 0.00 & 0.01 & 0.00 & 0.00 & 0.00 & 0.00 & 0.00 & 0.00 & 0.00 & 0.00 & 0.00 \\
\hline SUM_B & 2.99 & 2.97 & 2.99 & 2.99 & 3.00 & 2.99 & 3.00 & 2.99 & 2.99 & 2.98 & 2.99 & 2.99 & 2.99 & 3.00 & 2.98 & 2.98 & 2.98 & 2.98 \\
\hline SUM_CAT & 8.00 & 8.00 & 8.00 & 8.00 & 8.00 & 8.00 & 8.00 & 8.00 & 8.00 & 8.00 & 8.00 & 8.00 & 8.00 & 8.00 & 8.00 & 8.00 & 8.00 & 8.00 \\
\hline 0 & 12.00 & 12.00 & 12.00 & 12.00 & 12.00 & 12.00 & 12.00 & 12.00 & 12.00 & 12.00 & 12.00 & 12.00 & 12.00 & 12.00 & 12.00 & 12.00 & 12.00 & 12.00 \\
\hline CF & 0.00 & 0.00 & 0.00 & 0.00 & 0.00 & 0.00 & 0.00 & 0.00 & 0.00 & 0.00 & 0.00 & 0.00 & 0.00 & 0.00 & 0.00 & 0.00 & 0.00 & 0.00 \\
\hline CCL & 0.00 & 0.00 & 0.00 & 0.00 & 0.00 & 0.00 & 0.00 & 0.00 & 0.00 & 0.00 & 0.00 & 0.00 & 0.00 & 0.00 & 0.00 & 0.00 & 0.00 & 0.00 \\
\hline Alm & 60.32 & 60.68 & 57.88 & 59.20 & 58.87 & 54.28 & 52.10 & 58.29 & 60.88 & 60.12 & 57.48 & 60.14 & 60.23 & 54.90 & 50.74 & 48.63 & 43.16 & 43.09 \\
\hline Adr & 0.00 & 0.00 & 0.00 & 0.00 & 0.00 & 0.00 & 0.00 & 0.00 & 0.00 & 0.00 & 0.00 & 0.00 & 0.00 & 0.00 & 0.00 & 0.00 & 0.00 & 0.00 \\
\hline Grs & 28.32 & 29.16 & 30.61 & 27.06 & 29.84 & 31.42 & 32.22 & 29.98 & 29.01 & 30.59 & 30.26 & 28.71 & 28.79 & 31.54 & 27.48 & 21.30 & 25.19 & 26.21 \\
\hline Pyp & 3.55 & 3.82 & 3.59 & 3.57 & 4.12 & 3.26 & 2.88 & 3.63 & 3.97 & 3.81 & 3.35 & 3.51 & 3.79 & 3.03 & 2.88 & 2.69 & 2.21 & 2.07 \\
\hline Sps & 7.78 & 6.25 & 7.86 & 10.15 & 7.04 & 11.00 & 12.68 & 8.10 & 5.96 & 5.38 & 8.83 & 7.63 & 7.17 & 10.50 & 18.82 & 27.39 & 29.31 & 28.49 \\
\hline Uvr & 0.00 & 0.00 & 0.00 & 0.00 & 0.00 & 0.00 & 0.00 & 0.00 & 0.00 & 0.00 & 0.00 & 0.00 & 0.00 & 0.00 & 0.00 & 0.00 & 0.00 & 0.00 \\
\hline XCaGrt & 0.28 & 0.29 & 0.31 & 0.27 & 0.30 & 0.31 & 0.32 & 0.30 & 0.29 & 0.31 & 0.30 & 0.29 & 0.29 & 0.32 & 0.28 & 0.21 & 0.25 & 0.26 \\
\hline XFeGrt & 0.60 & 0.61 & 0.58 & 0.59 & 0.59 & 0.54 & 0.52 & 0.58 & 0.61 & 0.60 & 0.58 & 0.60 & 0.60 & 0.55 & 0.51 & 0.49 & 0.43 & 0.43 \\
\hline XMgGrt & 0.04 & 0.04 & 0.04 & 0.04 & 0.04 & 0.03 & 0.03 & 0.04 & 0.04 & 0.04 & 0.03 & 0.04 & 0.04 & 0.03 & 0.03 & 0.03 & 0.02 & 0.02 \\
\hline Fe_MgGrt & 16.99 & 15.83 & 16.18 & 16.55 & 14.25 & 16.58 & 18.16 & 15.96 & 15.27 & 15.74 & 17.18 & 17.11 & 15.91 & 18.11 & 17.61 & 18.14 & 19.46 & 20.68 \\
\hline
\end{tabular}




\begin{tabular}{|c|c|c|c|c|c|c|c|c|c|c|c|c|c|c|c|c|c|c|}
\hline Amostra & 124J & $124 \mathrm{~J}$ & $124 \mathrm{~J}$ & 124J & $124 \mathrm{~J}$ & $124 \mathrm{~J}$ & $124 \mathrm{~J}$ & $124 \mathrm{~J}$ & $124 \mathrm{~J}$ & $124 \mathrm{~J}$ & $124 \mathrm{~J}$ & $124 \mathrm{~J}$ & $124 \mathrm{~J}$ & $124 \mathrm{~J}$ & $124 \mathrm{~J}$ & $124 \mathrm{~J}$ & $124 \mathrm{~J}$ & $124 \mathrm{~J}$ \\
\hline Análise & 249 & 250 & 251 & 252 & 253 & 254 & 255 & 256 & 257 & 258 & 259 & 260 & 261 & 262 & 263 & 264 & 265 & 266 \\
\hline $\mathrm{SiO2}$ & 37.88 & 37.88 & 37.65 & 37.38 & 37.98 & 37.43 & 37.71 & 37.16 & 37.72 & 37.97 & 38.00 & 38.15 & 37.66 & 38.13 & 37.87 & 37.99 & 37.75 & 37.50 \\
\hline TiO2 & 0.11 & 0.02 & 0.11 & 0.28 & 0.15 & 0.26 & 0.21 & 0.02 & 0.17 & 0.15 & 0.08 & 0.09 & 0.11 & 0.11 & 0.22 & 0.15 & 0.06 & 0.08 \\
\hline $\mathrm{Al} 2 \mathrm{O} 3$ & 21.39 & 21.67 & 21.49 & 21.17 & 21.93 & 21.54 & 21.70 & 21.68 & 21.57 & 21.76 & 21.63 & 21.78 & 21.57 & 21.66 & 21.44 & 21.55 & 21.58 & 21.43 \\
\hline $\mathrm{FeO}$ & 18.53 & 17.87 & 17.12 & 15.03 & 13.97 & 13.67 & 14.98 & 17.39 & 17.98 & 18.57 & 18.76 & 17.84 & 16.38 & 15.87 & 17.46 & 16.82 & 18.27 & 17.74 \\
\hline Cr2O3 & 0.01 & 0.00 & 0.00 & 0.02 & 0.00 & 0.02 & 0.00 & 0.03 & 0.01 & 0.06 & 0.00 & 0.02 & 0.00 & 0.02 & 0.02 & 0.03 & 0.02 & 0.00 \\
\hline MnO & 10.88 & 12.74 & 12.35 & 17.17 & 16.80 & 17.32 & 15.51 & 12.54 & 11.85 & 11.69 & 12.17 & 11.82 & 14.48 & 14.29 & 13.48 & 12.23 & 11.29 & 11.38 \\
\hline MgO & 0.62 & 0.60 & 0.56 & 0.47 & 0.44 & 0.40 & 0.47 & 0.55 & 0.64 & 0.64 & 0.66 & 0.62 & 0.48 & 0.47 & 0.61 & 0.54 & 0.61 & 0.63 \\
\hline Y2O3 & 0.10 & 0.01 & 0.10 & 0.15 & 0.14 & 0.12 & 0.16 & 0.09 & 0.10 & 0.10 & 0.10 & 0.02 & 0.13 & 0.12 & 0.11 & 0.14 & 0.03 & 0.11 \\
\hline $\mathrm{CaO}$ & 10.94 & 9.81 & 10.44 & 9.03 & 9.29 & 9.51 & 9.88 & 10.28 & 9.96 & 9.91 & 9.80 & 9.94 & 10.11 & 10.11 & 9.20 & 10.85 & 10.77 & 10.79 \\
\hline TOTAL & 100.45 & 100.59 & 99.81 & 100.69 & 100.69 & 100.26 & 100.61 & 99.72 & 99.98 & 100.86 & 101.20 & 100.28 & 100.93 & 100.78 & 100.41 & 100.29 & 100.37 & 99.64 \\
\hline FeOCALC & 18.53 & 17.87 & 17.12 & 15.03 & 13.97 & 13.67 & 14.98 & 17.39 & 17.98 & 18.57 & 18.76 & 17.84 & 16.38 & 15.87 & 17.46 & 16.82 & 18.27 & 17.74 \\
\hline Fe2O3CALC & 0.00 & 0.00 & 0.00 & 0.00 & 0.00 & 0.00 & 0.00 & 0.00 & 0.00 & 0.00 & 0.00 & 0.00 & 0.00 & 0.00 & 0.00 & 0.00 & 0.00 & 0.00 \\
\hline TOTALCALC & 100.44 & 100.59 & 99.81 & 100.67 & 100.69 & 100.24 & 100.61 & 99.69 & 99.97 & 100.80 & 101.20 & 100.26 & 100.93 & 100.76 & 100.39 & 100.27 & 100.35 & 99.64 \\
\hline TSi & 6.03 & 6.03 & 6.03 & 5.98 & 6.05 & 6.00 & 6.01 & 5.96 & 6.04 & 6.03 & 6.02 & 6.08 & 5.99 & 6.06 & 6.05 & 6.06 & 6.01 & 6.02 \\
\hline Tal & 0.00 & 0.00 & 0.00 & 0.02 & 0.00 & 0.01 & 0.00 & 0.04 & 0.00 & 0.00 & 0.00 & 0.00 & 0.02 & 0.00 & 0.00 & 0.00 & 0.00 & 0.00 \\
\hline SUM_T & 6.03 & 6.03 & 6.03 & 6.00 & 6.05 & 6.00 & 6.01 & 6.00 & 6.04 & 6.03 & 6.02 & 6.08 & 6.00 & 6.06 & 6.05 & 6.06 & 6.01 & 6.02 \\
\hline AIVI & 4.01 & 4.06 & 4.06 & 3.97 & 4.11 & 4.06 & 4.08 & 4.06 & 4.07 & 4.07 & 4.03 & 4.09 & 4.02 & 4.06 & 4.04 & 4.05 & 4.05 & 4.05 \\
\hline $\mathrm{Fe} 3$ & 0.00 & 0.00 & 0.00 & 0.00 & 0.00 & 0.00 & 0.00 & 0.00 & 0.00 & 0.00 & 0.00 & 0.00 & 0.00 & 0.00 & 0.00 & 0.00 & 0.00 & 0.00 \\
\hline $\mathrm{Ti}$ & 0.01 & 0.00 & 0.01 & 0.03 & 0.02 & 0.03 & 0.03 & 0.00 & 0.02 & 0.02 & 0.01 & 0.01 & 0.01 & 0.01 & 0.03 & 0.02 & 0.01 & 0.01 \\
\hline $\mathrm{Cr}$ & 0.00 & 0.00 & 0.00 & 0.00 & 0.00 & 0.00 & 0.00 & 0.00 & 0.00 & 0.01 & 0.00 & 0.00 & 0.00 & 0.00 & 0.00 & 0.00 & 0.00 & 0.00 \\
\hline SUM_A & 4.03 & 4.06 & 4.07 & 4.00 & 4.13 & 4.09 & 4.10 & 4.07 & 4.09 & 4.10 & 4.04 & 4.10 & 4.04 & 4.07 & 4.07 & 4.07 & 4.05 & 4.06 \\
\hline $\mathrm{Fe} 2$ & 2.47 & 2.38 & 2.30 & 2.01 & 1.86 & 1.83 & 2.00 & 2.33 & 2.41 & 2.47 & 2.49 & 2.38 & 2.18 & 2.11 & 2.34 & 2.24 & 2.43 & 2.38 \\
\hline Mg & 0.15 & 0.14 & 0.13 & 0.11 & 0.10 & 0.10 & 0.11 & 0.13 & 0.15 & 0.15 & 0.16 & 0.15 & 0.12 & 0.11 & 0.15 & 0.13 & 0.15 & 0.15 \\
\hline Mn & 1.47 & 1.72 & 1.68 & 2.33 & 2.27 & 2.35 & 2.09 & 1.70 & 1.61 & 1.57 & 1.63 & 1.60 & 1.95 & 1.92 & 1.83 & 1.65 & 1.52 & 1.55 \\
\hline $\mathrm{Ca}$ & 1.87 & 1.67 & 1.79 & 1.55 & 1.59 & 1.63 & 1.69 & 1.77 & 1.71 & 1.69 & 1.66 & 1.70 & 1.72 & 1.72 & 1.58 & 1.85 & 1.84 & 1.85 \\
\hline $\mathrm{Na}$ & 0.00 & 0.00 & 0.00 & 0.00 & 0.00 & 0.00 & 0.00 & 0.00 & 0.00 & 0.00 & 0.00 & 0.00 & 0.00 & 0.00 & 0.00 & 0.00 & 0.00 & 0.00 \\
\hline SUM_B & 5.95 & 5.91 & 5.90 & 6.00 & 5.82 & 5.91 & 5.89 & 5.94 & 5.87 & 5.88 & 5.94 & 5.82 & 5.96 & 5.87 & 5.88 & 5.88 & 5.94 & 5.93 \\
\hline SUM_CAT & 16.00 & 16.00 & 16.00 & 16.00 & 16.00 & 16.00 & 16.00 & 16.00 & 16.00 & 16.00 & 16.00 & 16.00 & 16.00 & 16.00 & 16.00 & 16.00 & 16.00 & 16.00 \\
\hline 0 & 24.00 & 24.00 & 24.00 & 24.00 & 24.00 & 24.00 & 24.00 & 24.00 & 24.00 & 24.00 & 24.00 & 24.00 & 24.00 & 24.00 & 24.00 & 24.00 & 24.00 & 24.00 \\
\hline CF & 0.00 & 0.00 & 0.00 & 0.00 & 0.00 & 0.00 & 0.00 & 0.00 & 0.00 & 0.00 & 0.00 & 0.00 & 0.00 & 0.00 & 0.00 & 0.00 & 0.00 & 0.00 \\
\hline CCL & 0.00 & 0.00 & 0.00 & 0.00 & 0.00 & 0.00 & 0.00 & 0.00 & 0.00 & 0.00 & 0.00 & 0.00 & 0.00 & 0.00 & 0.00 & 0.00 & 0.00 & 0.00 \\
\hline Alm & 41.49 & 40.23 & 38.91 & 33.53 & 32.00 & 31.00 & 33.90 & 39.32 & 40.98 & 41.98 & 41.85 & 40.87 & 36.51 & 35.96 & 39.71 & 38.17 & 40.96 & 40.14 \\
\hline Adr & 0.00 & 0.00 & 0.00 & 0.00 & 0.00 & 0.00 & 0.00 & 0.00 & 0.00 & 0.00 & 0.00 & 0.00 & 0.00 & 0.00 & 0.00 & 0.00 & 0.00 & 0.00 \\
\hline Grs & 31.34 & 28.31 & 30.39 & 25.75 & 27.27 & 27.57 & 28.65 & 29.68 & 29.06 & 28.49 & 28.01 & 29.13 & 28.88 & 29.30 & 26.74 & 31.46 & 30.90 & 31.26 \\
\hline Pyp & 2.46 & 2.42 & 2.27 & 1.86 & 1.78 & 1.61 & 1.89 & 2.20 & 2.59 & 2.59 & 2.64 & 2.53 & 1.92 & 1.90 & 2.47 & 2.18 & 2.44 & 2.53 \\
\hline Sps & 24.67 & 29.05 & 28.42 & 38.79 & 38.96 & 39.77 & 35.56 & 28.71 & 27.35 & 26.76 & 27.50 & 27.42 & 32.69 & 32.79 & 31.03 & 28.10 & 25.64 & 26.07 \\
\hline Uvr & 0.03 & 0.00 & 0.00 & 0.06 & 0.00 & 0.06 & 0.00 & 0.09 & 0.03 & 0.19 & 0.00 & 0.06 & 0.00 & 0.05 & 0.05 & 0.08 & 0.05 & 0.00 \\
\hline XCaGrt & 0.31 & 0.28 & 0.30 & 0.26 & 0.27 & 0.28 & 0.29 & 0.30 & 0.29 & 0.29 & 0.28 & 0.29 & 0.29 & 0.29 & 0.27 & 0.32 & 0.31 & 0.31 \\
\hline XFeGrt & 0.42 & 0.40 & 0.39 & 0.34 & 0.32 & 0.31 & 0.34 & 0.39 & 0.41 & 0.42 & 0.42 & 0.41 & 0.37 & 0.36 & 0.40 & 0.38 & 0.41 & 0.40 \\
\hline XMgGrt & 0.03 & 0.02 & 0.02 & 0.02 & 0.02 & 0.02 & 0.02 & 0.02 & 0.03 & 0.03 & 0.03 & 0.03 & 0.02 & 0.02 & 0.03 & 0.02 & 0.02 & 0.03 \\
\hline Fe_MgGrt & 16.90 & 16.62 & 17.13 & 18.12 & 18.08 & 19.27 & 17.98 & 17.81 & 15.84 & 16.22 & 15.83 & 16.18 & 18.93 & 18.84 & 16.10 & 17.52 & 16.77 & 15.87 \\
\hline
\end{tabular}


Analıses de quimıca mıneral de mıca selecıonados da regiao de Jambalo

\begin{tabular}{|c|c|c|c|c|c|c|c|c|c|c|c|c|c|c|c|c|c|c|}
\hline Amostra & 118 & 118 & 118 & 118 & 118 & 118 & 118 & 118 & 118 & 118 & 118 & 118 & 118 & 118 & 118 & 118 & 118 & 118 \\
\hline Análise & 432 & 433 & 434 & 435 & 436 & 437 & 438 & 439 & 440 & 441 & 442 & 443 & 444 & 445 & 446 & 447 & 448 & 449 \\
\hline $\mathrm{SiO2}$ & 49.23 & 48.07 & 49.02 & 47.73 & 48.93 & 47.80 & 47.87 & 47.08 & 46.96 & 50.91 & 49.86 & 47.85 & 50.16 & 50.34 & 49.77 & 49.98 & 50.16 & 49.37 \\
\hline TiO2 & 0.04 & 0.08 & 0.12 & 0.00 & 0.00 & 0.20 & 0.16 & 0.00 & 0.12 & 0.16 & 0.16 & 0.16 & 0.16 & 0.22 & 0.16 & 0.32 & 0.20 & 0.02 \\
\hline $\mathrm{Al} 2 \mathrm{O} 3$ & 33.59 & 36.42 & 33.58 & 39.01 & 32.74 & 36.94 & 35.49 & 36.94 & 38.41 & 26.41 & 27.42 & 33.86 & 27.58 & 27.46 & 28.01 & 27.66 & 27.85 & 27.35 \\
\hline Cr2O3 & 0.00 & 0.00 & 0.00 & 0.00 & 0.00 & 0.00 & 0.00 & 0.00 & 0.00 & 0.00 & 0.00 & 0.00 & 0.00 & 0.00 & 0.00 & 0.00 & 0.00 & 0.00 \\
\hline $\mathrm{FeO}$ & 1.50 & 0.79 & 1.50 & 0.29 & 1.51 & 0.69 & 0.84 & 0.70 & 0.34 & 2.53 & 1.95 & 1.29 & 2.42 & 2.29 & 2.69 & 2.47 & 2.18 & 2.25 \\
\hline $\mathrm{Fe} 2 \mathrm{O} 3$ & 0.00 & 0.00 & 0.00 & 0.00 & 0.00 & 0.00 & 0.00 & 0.00 & 0.00 & 0.00 & 0.00 & 0.00 & 0.00 & 0.00 & 0.00 & 0.00 & 0.00 & 0.00 \\
\hline MnO & 0.00 & 0.02 & 0.01 & 0.01 & 0.00 & 0.01 & 0.02 & 0.00 & 0.03 & 0.01 & 0.04 & 0.00 & 0.00 & 0.01 & 0.02 & 0.03 & 0.02 & 0.03 \\
\hline $\mathrm{MgO}$ & 1.52 & 0.67 & 1.50 & 0.21 & 1.74 & 0.61 & 0.96 & 0.41 & 0.15 & 3.15 & 3.20 & 1.39 & 2.86 & 3.15 & 2.86 & 3.10 & 2.88 & 2.93 \\
\hline $\mathrm{CaO}$ & 0.06 & 0.10 & 0.09 & 0.14 & 0.07 & 0.10 & 0.04 & 0.09 & 0.05 & 0.00 & 0.01 & 0.04 & 0.00 & 0.00 & 0.00 & 0.01 & 0.03 & 0.00 \\
\hline $\mathrm{Na2O}$ & 2.87 & 4.52 & 2.62 & 5.42 & 2.32 & 4.60 & 3.88 & 4.63 & 5.90 & 0.35 & 0.29 & 3.35 & 0.39 & 0.39 & 0.37 & 0.43 & 0.39 & 0.29 \\
\hline K2O & 5.46 & 3.05 & 5.72 & 1.06 & 6.38 & 2.60 & 3.65 & 2.80 & 0.64 & 10.35 & 10.41 & 5.46 & 10.38 & 10.30 & 10.20 & 10.28 & 10.51 & 10.07 \\
\hline $\mathrm{Cl}$ & 0.01 & 0.00 & 0.00 & 0.01 & 0.01 & 0.00 & 0.01 & 0.00 & 0.00 & 0.00 & 0.00 & 0.00 & 0.01 & 0.00 & 0.01 & 0.00 & 0.03 & 0.00 \\
\hline $\mathbf{F}$ & 0.00 & 0.00 & 0.00 & 0.16 & 0.04 & 0.11 & 0.04 & 0.00 & 0.00 & 0.05 & 0.05 & 0.15 & 0.04 & 0.00 & 0.00 & 0.00 & 0.09 & 0.04 \\
\hline $\mathrm{BaO}$ & 0.08 & 0.05 & 0.13 & 0.07 & 0.13 & 0.00 & 0.14 & 0.05 & 0.05 & 0.24 & 0.28 & 0.22 & 0.27 & 0.35 & 0.23 & 0.24 & 0.48 & 0.20 \\
\hline $\mathrm{H} 2 \mathrm{O}$ & 0.00 & 0.00 & 0.00 & 0.00 & 0.00 & 0.00 & 0.00 & 0.00 & 0.00 & 0.00 & 0.00 & 0.00 & 0.00 & 0.00 & 0.00 & 0.00 & 0.00 & 0.00 \\
\hline TOTAL & 94.36 & 93.76 & 94.28 & 94.11 & 93.88 & 93.66 & 93.09 & 92.70 & 92.64 & 94.18 & 93.66 & 93.76 & 94.25 & 94.51 & 94.32 & 94.50 & 94.80 & 92.55 \\
\hline O_F_Cl & 0.00 & 0.00 & 0.00 & 0.07 & 0.02 & 0.05 & 0.02 & 0.00 & 0.00 & 0.02 & 0.02 & 0.06 & 0.02 & 0.00 & 0.00 & 0.00 & 0.04 & 0.02 \\
\hline CTOTAL & 94.36 & 93.76 & 94.28 & 94.04 & 93.86 & 93.61 & 93.07 & 92.70 & 92.64 & 94.16 & 93.64 & 93.70 & 94.23 & 94.51 & 94.32 & 94.50 & 94.76 & 92.53 \\
\hline Si & 6.45 & 6.27 & 6.44 & 6.14 & 6.48 & 6.22 & 6.30 & 6.20 & 6.12 & 6.89 & 6.78 & 6.35 & 6.78 & 6.78 & 6.73 & 6.74 & 6.76 & 6.78 \\
\hline AlIV & 1.55 & 1.73 & 1.56 & 1.86 & 1.52 & 1.78 & 1.70 & 1.80 & 1.88 & 1.11 & 1.23 & 1.65 & 1.22 & 1.22 & 1.27 & 1.26 & 1.24 & 1.22 \\
\hline SUM_T & 8.00 & 8.00 & 8.00 & 8.00 & 8.00 & 8.00 & 8.00 & 8.00 & 8.00 & 8.00 & 8.00 & 8.00 & 8.00 & 8.00 & 8.00 & 8.00 & 8.00 & 8.00 \\
\hline AIVI & 3.64 & 3.86 & 3.64 & 4.04 & 3.59 & 3.89 & 3.81 & 3.93 & 4.02 & 3.10 & 3.16 & 3.64 & 3.17 & 3.14 & 3.18 & 3.13 & 3.18 & 3.20 \\
\hline $\mathrm{Ti}$ & 0.00 & 0.01 & 0.01 & 0.00 & 0.00 & 0.02 & 0.02 & 0.00 & 0.01 & 0.02 & 0.02 & 0.02 & 0.02 & 0.02 & 0.02 & 0.03 & 0.02 & 0.00 \\
\hline $\mathrm{Fe} 3$ & 0.00 & 0.00 & 0.00 & 0.00 & 0.00 & 0.00 & 0.00 & 0.00 & 0.00 & 0.00 & 0.00 & 0.00 & 0.00 & 0.00 & 0.00 & 0.00 & 0.00 & 0.00 \\
\hline $\mathrm{Fe} 2$ & 0.17 & 0.09 & 0.17 & 0.03 & 0.17 & 0.08 & 0.09 & 0.08 & 0.04 & 0.29 & 0.22 & 0.14 & 0.27 & 0.26 & 0.30 & 0.28 & 0.25 & 0.26 \\
\hline $\mathrm{Cr}$ & 0.00 & 0.00 & 0.00 & 0.00 & 0.00 & 0.00 & 0.00 & 0.00 & 0.00 & 0.00 & 0.00 & 0.00 & 0.00 & 0.00 & 0.00 & 0.00 & 0.00 & 0.00 \\
\hline Mn & 0.00 & 0.00 & 0.00 & 0.00 & 0.00 & 0.00 & 0.00 & 0.00 & 0.00 & 0.00 & 0.00 & 0.00 & 0.00 & 0.00 & 0.00 & 0.00 & 0.00 & 0.00 \\
\hline Mg & 0.30 & 0.13 & 0.29 & 0.04 & 0.34 & 0.12 & 0.19 & 0.08 & 0.03 & 0.64 & 0.65 & 0.28 & 0.58 & 0.63 & 0.58 & 0.62 & 0.58 & 0.60 \\
\hline $\mathrm{Ca}$ & 0.01 & 0.01 & 0.01 & 0.02 & 0.01 & 0.01 & 0.01 & 0.01 & 0.01 & 0.00 & 0.00 & 0.01 & 0.00 & 0.00 & 0.00 & 0.00 & 0.00 & 0.00 \\
\hline $\mathrm{Na}$ & 0.73 & 1.14 & 0.67 & 1.35 & 0.60 & 1.16 & 0.99 & 1.18 & 1.49 & 0.09 & 0.08 & 0.86 & 0.10 & 0.10 & 0.10 & 0.11 & 0.10 & 0.08 \\
\hline K & 0.91 & 0.51 & 0.96 & 0.17 & 1.08 & 0.43 & 0.61 & 0.47 & 0.11 & 1.79 & 1.80 & 0.92 & 1.79 & 1.77 & 1.76 & 1.77 & 1.81 & 1.76 \\
\hline CATIONS & 13.76 & 13.75 & 13.75 & 13.66 & 13.79 & 13.71 & 13.71 & 13.75 & 13.71 & 13.91 & 13.93 & 13.86 & 13.93 & 13.93 & 13.94 & 13.95 & 13.94 & 13.91 \\
\hline CF & 0.00 & 0.00 & 0.00 & 0.13 & 0.04 & 0.09 & 0.03 & 0.00 & 0.00 & 0.04 & 0.05 & 0.13 & 0.03 & 0.00 & 0.00 & 0.00 & 0.07 & 0.03 \\
\hline $\mathrm{CCl}$ & 0.00 & 0.00 & 0.00 & 0.01 & 0.01 & 0.00 & 0.01 & 0.00 & 0.00 & 0.00 & 0.00 & 0.00 & 0.01 & 0.00 & 0.00 & 0.00 & 0.01 & 0.00 \\
\hline $\mathrm{OH}$ & 0.00 & 0.00 & 0.00 & 0.00 & 0.00 & 0.00 & 0.00 & 0.00 & 0.00 & 0.00 & 0.00 & 0.00 & 0.00 & 0.00 & 0.00 & 0.00 & 0.00 & 0.00 \\
\hline 0 & 24.00 & 24.00 & 24.00 & 24.00 & 24.00 & 24.00 & 24.00 & 24.00 & 24.00 & 24.00 & 24.00 & 24.00 & 24.00 & 24.00 & 24.00 & 24.00 & 24.00 & 24.00 \\
\hline Fe_FeMg & 0.36 & 0.40 & 0.36 & 0.43 & 0.33 & 0.39 & 0.33 & 0.49 & 0.55 & 0.31 & 0.25 & 0.34 & 0.32 & 0.29 & 0.35 & 0.31 & 0.30 & 0.30 \\
\hline Mg_FeMg & 0.64 & 0.60 & 0.64 & 0.57 & 0.67 & 0.61 & 0.67 & 0.51 & 0.45 & 0.69 & 0.75 & 0.66 & 0.68 & 0.71 & 0.65 & 0.69 & 0.70 & 0.70 \\
\hline
\end{tabular}

\begin{tabular}{|c|c|c|c|c|c|c|c|c|c|c|c|c|}
\hline Amostra & 121B & 121B & 121B & 121B & 121B & 121B & 121B & 121B & 121B & 121B & 121B & 121B \\
\hline Análise & 303 & 304 & 305 & 306 & 307 & 308 & 309 & 310 & 311 & 312 & 313 & 314 \\
\hline SiO2 & 49.67 & 48.11 & 49.13 & 48.19 & 49.17 & 48.49 & 49.21 & 48.16 & 49.30 & 48.20 & 48.80 & 48.20 \\
\hline TiO2 & 0.06 & 0.06 & 0.06 & 0.01 & 0.07 & 0.02 & 0.03 & 0.06 & 0.02 & 0.03 & 0.06 & 0.04 \\
\hline $\mathrm{Al} 2 \mathrm{O3}$ & 40.02 & 40.25 & 40.27 & 40.89 & 40.13 & 40.35 & 40.09 & 40.36 & 40.14 & 40.79 & 40.45 & 40.85 \\
\hline Cr2O3 & 0.00 & 0.00 & 0.00 & 0.00 & 0.00 & 0.00 & 0.00 & 0.00 & 0.00 & 0.00 & 0.00 & 0.00 \\
\hline $\mathrm{FeO}$ & 0.76 & 0.79 & 0.63 & 0.66 & 0.68 & 0.66 & 0.63 & 0.41 & 0.52 & 0.56 & 0.56 & 0.64 \\
\hline $\mathrm{Fe} 2 \mathrm{O} 3$ & 0.00 & 0.00 & 0.00 & 0.00 & 0.00 & 0.00 & 0.00 & 0.00 & 0.00 & 0.00 & 0.00 & 0.00 \\
\hline MnO & 0.03 & 0.06 & 0.02 & 0.05 & 0.02 & 0.04 & 0.06 & 0.05 & 0.06 & 0.04 & 0.08 & 0.05 \\
\hline $\mathrm{MgO}$ & 0.23 & 0.24 & 0.18 & 0.15 & 0.21 & 0.23 & 0.24 & 0.16 & 0.13 & 0.19 & 0.20 & 0.20 \\
\hline $\mathrm{CaO}$ & 0.05 & 0.05 & 0.04 & 0.05 & 0.05 & 0.06 & 0.06 & 0.08 & 0.04 & 0.03 & 0.05 & 0.07 \\
\hline $\mathrm{Na2O}$ & 7.25 & 5.76 & 7.38 & 5.52 & 7.51 & 5.66 & 7.25 & 5.78 & 7.43 & 5.81 & 7.81 & 5.49 \\
\hline K2O & 0.72 & 0.66 & 0.47 & 0.40 & 0.67 & 0.69 & 0.91 & 0.47 & 0.51 & 0.32 & 0.25 & 0.69 \\
\hline $\mathrm{Cl}$ & 0.00 & 0.00 & 0.00 & 0.00 & 0.00 & 0.00 & 0.00 & 0.00 & 0.00 & 0.00 & 0.00 & 0.00 \\
\hline $\mathbf{F}$ & 0.00 & 0.00 & 0.00 & 0.00 & 0.00 & 0.00 & 0.00 & 0.00 & 0.00 & 0.00 & 0.00 & 0.00 \\
\hline $\mathrm{BaO}$ & 0.00 & 0.00 & 0.00 & 0.00 & 0.00 & 0.00 & 0.00 & 0.00 & 0.00 & 0.00 & 0.00 & 0.00 \\
\hline $\mathrm{H} 2 \mathrm{O}$ & 0.00 & 0.00 & 0.00 & 0.00 & 0.00 & 0.00 & 0.00 & 0.00 & 0.00 & 0.00 & 0.00 & 0.00 \\
\hline TOTAL & 98.78 & 95.98 & 98.19 & 95.91 & 98.50 & 96.21 & 98.49 & 95.51 & 98.15 & 95.96 & 98.26 & 96.22 \\
\hline O_F_Cl & 0.00 & 0.00 & 0.00 & 0.00 & 0.00 & 0.00 & 0.00 & 0.00 & 0.00 & 0.00 & 0.00 & 0.00 \\
\hline CTOTAL & 98.78 & 95.98 & 98.19 & 95.91 & 98.50 & 96.21 & 98.49 & 95.51 & 98.15 & 95.96 & 98.26 & 96.22 \\
\hline Si & 6.11 & 6.06 & 6.08 & 6.05 & 6.08 & 6.09 & 6.08 & 6.08 & 6.10 & 6.05 & 6.04 & 6.05 \\
\hline AllV & 1.89 & 1.94 & 1.92 & 1.95 & 1.92 & 1.91 & 1.92 & 1.92 & 1.90 & 1.95 & 1.96 & 1.95 \\
\hline SUM_T & 8.00 & 8.00 & 8.00 & 8.00 & 8.00 & 8.00 & 8.00 & 8.00 & 8.00 & 8.00 & 8.00 & 8.00 \\
\hline $\mathrm{AIVI}^{-}$ & 3.92 & 4.03 & 3.94 & 4.10 & 3.92 & 4.05 & 3.92 & 4.07 & 3.95 & 4.08 & 3.93 & 4.08 \\
\hline $\mathrm{Ti}$ & 0.01 & 0.01 & 0.01 & 0.00 & 0.01 & 0.00 & 0.00 & 0.01 & 0.00 & 0.00 & 0.01 & 0.00 \\
\hline $\mathrm{Fe} 3$ & 0.00 & 0.00 & 0.00 & 0.00 & 0.00 & 0.00 & 0.00 & 0.00 & 0.00 & 0.00 & 0.00 & 0.00 \\
\hline $\mathrm{Fe} 2$ & 0.08 & 0.08 & 0.07 & 0.07 & 0.07 & 0.07 & 0.07 & 0.04 & 0.05 & 0.06 & 0.06 & 0.07 \\
\hline $\mathrm{Cr}$ & 0.00 & 0.00 & 0.00 & 0.00 & 0.00 & 0.00 & 0.00 & 0.00 & 0.00 & 0.00 & 0.00 & 0.00 \\
\hline Mn & 0.00 & 0.01 & 0.00 & 0.01 & 0.00 & 0.00 & 0.01 & 0.01 & 0.01 & 0.00 & 0.01 & 0.01 \\
\hline Mg & 0.04 & 0.05 & 0.03 & 0.03 & 0.04 & 0.04 & 0.05 & 0.03 & 0.03 & 0.04 & 0.04 & 0.04 \\
\hline $\mathrm{Ca}$ & 0.01 & 0.01 & 0.01 & 0.01 & 0.01 & 0.01 & 0.01 & 0.01 & 0.01 & 0.00 & 0.01 & 0.01 \\
\hline $\mathrm{Na}$ & 1.73 & 1.41 & 1.77 & 1.35 & 1.80 & 1.38 & 1.74 & 1.41 & 1.78 & 1.42 & 1.87 & 1.33 \\
\hline K & 0.11 & 0.11 & 0.08 & 0.06 & 0.11 & 0.11 & 0.14 & 0.08 & 0.08 & 0.05 & 0.04 & 0.11 \\
\hline CATIONS & 13.89 & 13.70 & 13.90 & 13.62 & 13.94 & 13.66 & 13.93 & 13.66 & 13.90 & 13.65 & 13.96 & 13.65 \\
\hline CF & 0.00 & 0.00 & 0.00 & 0.00 & 0.00 & 0.00 & 0.00 & 0.00 & 0.00 & 0.00 & 0.00 & 0.00 \\
\hline $\mathrm{CCl}$ & 0.00 & 0.00 & 0.00 & 0.00 & 0.00 & 0.00 & 0.00 & 0.00 & 0.00 & 0.00 & 0.00 & 0.00 \\
\hline $\mathrm{OH}$ & 0.00 & 0.00 & 0.00 & 0.00 & 0.00 & 0.00 & 0.00 & 0.00 & 0.00 & 0.00 & 0.00 & 0.00 \\
\hline 0 & 24.00 & 24.00 & 24.00 & 24.00 & 24.00 & 24.00 & 24.00 & 24.00 & 24.00 & 24.00 & 24.00 & 24.00 \\
\hline Fe_FeMg & 0.66 & 0.65 & 0.67 & 0.72 & 0.65 & 0.61 & 0.59 & 0.59 & 0.68 & 0.62 & 0.61 & 0.64 \\
\hline Mg_FeMg & 0.34 & 0.35 & 0.33 & 0.28 & 0.35 & 0.39 & 0.41 & 0.41 & 0.32 & 0.38 & 0.39 & 0.36 \\
\hline
\end{tabular}


Analıses de quimıca mıneral de mıca selecıonados da regiao de Jambalo

\begin{tabular}{|c|c|c|c|c|c|c|c|c|c|c|c|c|c|c|c|c|c|c|}
\hline Amostra & $123 \mathrm{~A}$ & $123 \mathrm{~A}$ & $123 \mathrm{~A}$ & $123 \mathrm{~A}$ & $123 \mathrm{~A}$ & $123 A$ & $123 A$ & $123 A$ & $123 A$ & $123 A$ & $123 \mathrm{~A}$ & $123 A$ & $123 A$ & $123 A$ & $123 A$ & $123 \mathrm{~A}$ & $123 \mathrm{~A}$ & $123 A$ \\
\hline Análise & 108 & 109 & 110 & 111 & 153 & 154 & 155 & 156 & 157 & 158 & 159 & 160 & 161 & 162 & 163 & 164 & 165 & 166 \\
\hline SiO2 & 46.28 & 46.94 & 46.49 & 45.50 & 46.31 & 46.20 & 46.47 & 45.95 & 45.68 & 45.92 & 47.28 & 46.30 & 46.94 & 46.03 & 45.87 & 46.71 & 57.51 & 58.81 \\
\hline TiO2 & 0.08 & 0.00 & 0.02 & 0.14 & 0.04 & 0.10 & 0.00 & 0.00 & 0.04 & 0.06 & 0.18 & 0.02 & 0.00 & 0.04 & 0.00 & 0.00 & 0.00 & 0.08 \\
\hline $\mathrm{Al} 2 \mathrm{O} 3$ & 37.29 & 37.49 & 37.14 & 36.77 & 37.09 & 37.32 & 37.57 & 37.43 & 37.50 & 37.03 & 32.15 & 37.75 & 38.23 & 37.47 & 37.79 & 37.53 & 10.20 & 9.86 \\
\hline $\mathrm{Cr} 2 \mathrm{O} 3$ & 0.00 & 0.00 & 0.00 & 0.00 & 0.00 & 0.00 & 0.00 & 0.00 & 0.00 & 0.00 & 0.00 & 0.00 & 0.00 & 0.00 & 0.00 & 0.00 & 0.00 & 0.00 \\
\hline $\mathrm{FeO}$ & 0.80 & 0.68 & 0.83 & 0.72 & 0.96 & 1.05 & 0.78 & 0.49 & 0.68 & 0.82 & 2.28 & 0.75 & 0.71 & 0.87 & 0.85 & 0.73 & 10.75 & 10.39 \\
\hline $\mathrm{Fe} 2 \mathrm{O} 3$ & 0.00 & 0.00 & 0.00 & 0.00 & 0.00 & 0.00 & 0.00 & 0.00 & 0.00 & 0.00 & 0.00 & 0.00 & 0.00 & 0.00 & 0.00 & 0.00 & 0.00 & 0.00 \\
\hline MnO & 0.00 & 0.00 & 0.00 & 0.00 & 0.04 & 0.01 & 0.00 & 0.00 & 0.01 & 0.00 & 0.01 & 0.01 & 0.00 & 0.01 & 0.00 & 0.00 & 0.05 & 0.08 \\
\hline MgO & 0.32 & 0.23 & 0.27 & 0.32 & 0.33 & 0.29 & 0.29 & 0.25 & 0.26 & 0.29 & 1.60 & 0.30 & 0.17 & 0.27 & 0.17 & 0.28 & 10.68 & 10.56 \\
\hline $\mathrm{CaO}$ & 0.05 & 0.06 & 0.07 & 0.06 & 0.07 & 0.07 & 0.05 & 0.09 & 0.09 & 0.08 & 0.08 & 0.06 & 0.09 & 0.07 & 0.04 & 0.08 & 0.01 & 0.00 \\
\hline $\mathrm{Na2O}$ & 6.94 & 7.31 & 7.00 & 7.08 & 6.81 & 6.44 & 6.58 & 6.77 & 6.71 & 6.88 & 3.00 & 7.00 & 6.89 & 7.11 & 7.47 & 7.15 & 0.04 & 0.02 \\
\hline K2O & 0.90 & 0.86 & 0.59 & 0.91 & 0.78 & 0.93 & 0.92 & 0.73 & 0.74 & 0.97 & 5.65 & 0.73 & 0.48 & 0.91 & 0.40 & 0.84 & 6.49 & 6.35 \\
\hline Cl & 0.00 & 0.01 & 0.01 & 0.00 & 0.00 & 0.00 & 0.00 & 0.00 & 0.00 & 0.00 & 0.01 & 0.00 & 0.01 & 0.01 & 0.01 & 0.01 & 0.00 & 0.00 \\
\hline $\mathbf{F}$ & 0.00 & 0.00 & 0.00 & 0.04 & 0.00 & 0.00 & 0.00 & 0.00 & 0.00 & 0.00 & 0.01 & 0.08 & 0.00 & 0.23 & 0.34 & 0.00 & 0.20 & 0.26 \\
\hline $\mathrm{BaO}$ & 0.00 & 0.00 & 0.00 & 0.00 & 0.00 & 0.00 & 0.00 & 0.00 & 0.00 & 0.00 & 0.00 & 0.00 & 0.00 & 0.00 & 0.00 & 0.00 & 0.00 & 0.00 \\
\hline $\mathrm{H} 2 \mathrm{O}$ & 0.00 & 0.00 & 0.00 & 0.00 & 0.00 & 0.00 & 0.00 & 0.00 & 0.00 & 0.00 & 0.00 & 0.00 & 0.00 & 0.00 & 0.00 & 0.00 & 0.00 & 0.00 \\
\hline TOTAL & 92.66 & 93.56 & 92.43 & 91.52 & 92.43 & 92.41 & 92.66 & 91.71 & 91.71 & 92.05 & 92.26 & 93.00 & 93.52 & 93.02 & 92.94 & 93.33 & 95.93 & 96.40 \\
\hline O_F_Cl & 0.00 & 0.00 & 0.00 & 0.02 & 0.00 & 0.00 & 0.00 & 0.00 & 0.00 & 0.00 & 0.01 & 0.03 & 0.00 & 0.10 & 0.14 & 0.00 & 0.08 & 0.11 \\
\hline CT̄OTAL & 92.66 & 93.56 & 92.43 & 91.52 & 92.43 & 92.41 & 92.66 & 91.71 & 91.71 & 92.05 & 92.26 & 93.00 & 93.52 & 93.02 & 92.94 & 93.33 & 95.93 & 96.40 \\
\hline Si & 6.09 & 6.12 & 6.12 & 6.07 & 6.11 & 6.09 & 6.10 & 6.09 & 6.06 & 6.09 & 6.40 & 6.07 & 6.10 & 6.06 & 6.04 & 6.10 & 7.80 & 7.90 \\
\hline AllV & 1.91 & 1.88 & 1.88 & 1.93 & 1.89 & 1.91 & 1.90 & 1.91 & 1.94 & 1.91 & 1.60 & 1.93 & 1.90 & 1.94 & 1.96 & 1.90 & 0.20 & 0.10 \\
\hline SUM_T & 8.00 & 8.00 & 8.00 & 8.00 & 8.00 & 8.00 & 8.00 & 8.00 & 8.00 & 8.00 & 8.00 & 8.00 & 8.00 & 8.00 & 8.00 & 8.00 & 8.00 & 8.00 \\
\hline AIVI $^{-}$ & 3.87 & 3.87 & 3.88 & 3.86 & 3.87 & 3.89 & 3.92 & 3.93 & 3.92 & 3.87 & 3.52 & 3.90 & 3.94 & 3.87 & 3.90 & 3.88 & 1.43 & 1.46 \\
\hline $\mathrm{Ti}$ & 0.01 & 0.00 & 0.00 & 0.01 & 0.00 & 0.01 & 0.00 & 0.00 & 0.00 & 0.01 & 0.02 & 0.00 & 0.00 & 0.00 & 0.00 & 0.00 & 0.00 & 0.01 \\
\hline $\mathrm{Fe} 3$ & 0.00 & 0.00 & 0.00 & 0.00 & 0.00 & 0.00 & 0.00 & 0.00 & 0.00 & 0.00 & 0.00 & 0.00 & 0.00 & 0.00 & 0.00 & 0.00 & 0.00 & 0.00 \\
\hline $\mathrm{Fe} 2$ & 0.09 & 0.07 & 0.09 & 0.08 & 0.11 & 0.12 & 0.09 & 0.06 & 0.08 & 0.09 & 0.26 & 0.08 & 0.08 & 0.10 & 0.09 & 0.08 & 1.22 & 1.17 \\
\hline $\mathrm{Cr}$ & 0.00 & 0.00 & 0.00 & 0.00 & 0.00 & 0.00 & 0.00 & 0.00 & 0.00 & 0.00 & 0.00 & 0.00 & 0.00 & 0.00 & 0.00 & 0.00 & 0.00 & 0.00 \\
\hline Mn & 0.00 & 0.00 & 0.00 & 0.00 & 0.01 & 0.00 & 0.00 & 0.00 & 0.00 & 0.00 & 0.00 & 0.00 & 0.00 & 0.00 & 0.00 & 0.00 & 0.01 & 0.01 \\
\hline Mg & 0.06 & 0.05 & 0.05 & 0.06 & 0.07 & 0.06 & 0.06 & 0.05 & 0.05 & 0.06 & 0.32 & 0.06 & 0.03 & 0.05 & 0.03 & 0.06 & 2.16 & 2.12 \\
\hline $\mathrm{Ca}$ & 0.01 & 0.01 & 0.01 & 0.01 & 0.01 & 0.01 & 0.01 & 0.01 & 0.01 & 0.01 & 0.01 & 0.01 & 0.01 & 0.01 & 0.01 & 0.01 & 0.00 & 0.00 \\
\hline $\mathrm{Na}$ & 1.77 & 1.85 & 1.79 & 1.83 & 1.74 & 1.65 & 1.68 & 1.74 & 1.73 & 1.77 & 0.79 & 1.78 & 1.74 & 1.82 & 1.91 & 1.81 & 0.01 & 0.01 \\
\hline K & 0.15 & 0.14 & 0.10 & 0.15 & 0.13 & 0.16 & 0.15 & 0.12 & 0.13 & 0.17 & 0.98 & 0.12 & 0.08 & 0.15 & 0.07 & 0.14 & 1.12 & 1.09 \\
\hline CATIONS & 13.96 & 13.99 & 13.93 & 14.01 & 13.93 & 13.89 & 13.90 & 13.91 & 13.92 & 13.97 & 13.90 & 13.96 & 13.88 & 14.01 & 14.01 & 13.98 & 13.95 & 13.86 \\
\hline CF & 0.00 & 0.00 & 0.00 & 0.04 & 0.00 & 0.00 & 0.00 & 0.00 & 0.00 & 0.00 & 0.01 & 0.06 & 0.00 & 0.19 & 0.28 & 0.00 & 0.17 & 0.22 \\
\hline $\mathrm{CCl}$ & 0.00 & 0.00 & 0.00 & 0.00 & 0.00 & 0.00 & 0.00 & 0.00 & 0.00 & 0.00 & 0.01 & 0.00 & 0.00 & 0.00 & 0.00 & 0.00 & 0.00 & 0.00 \\
\hline $\mathrm{OH}$ & 0.00 & 0.00 & 0.00 & 0.00 & 0.00 & 0.00 & 0.00 & 0.00 & 0.00 & 0.00 & 0.00 & 0.00 & 0.00 & 0.00 & 0.00 & 0.00 & 0.00 & 0.00 \\
\hline 0 & 24.00 & 24.00 & 24.00 & 24.00 & 24.00 & 24.00 & 24.00 & 24.00 & 24.00 & 24.00 & 24.00 & 24.00 & 24.00 & 24.00 & 24.00 & 24.00 & 24.00 & 24.00 \\
\hline $\mathrm{Fe} \_\mathrm{FeMg}$ & 0.58 & 0.62 & 0.63 & 0.56 & 0.62 & 0.67 & 0.60 & 0.52 & 0.60 & 0.61 & 0.44 & 0.58 & 0.71 & 0.64 & 0.74 & 0.59 & 0.36 & 0.36 \\
\hline $\mathrm{Mg}^{-} \mathrm{FeMg}$ & 0.42 & 0.38 & 0.37 & 0.44 & 0.38 & 0.33 & 0.40 & 0.48 & 0.40 & 0.39 & 0.56 & 0.42 & 0.29 & 0.36 & 0.26 & 0.41 & 0.64 & 0.64 \\
\hline
\end{tabular}

\begin{tabular}{|c|c|c|c|c|c|c|c|c|c|c|c|c|c|c|c|c|c|c|}
\hline Amostra & $124 \mathrm{~J}$ & $124 \mathrm{~J}$ & $124 \mathrm{~J}$ & $124 \mathrm{~J}$ & $124 \mathrm{~J}$ & $124 \mathrm{~J}$ & $124 \mathrm{~J}$ & $124 \mathrm{~J}$ & $124 \mathrm{~J}$ & $124 \mathrm{~J}$ & $124 \mathrm{~J}$ & $124 \mathrm{~J}$ & $124 \mathrm{~J}$ & $124 \mathrm{~J}$ & $124 \mathrm{~J}$ & $124 \mathrm{~J}$ & $124 \mathrm{~J}$ & $124 \mathrm{~J}$ \\
\hline Análise & 113 & 114 & 115 & 116 & 117 & 118 & 119 & 120 & 121 & 125 & 126 & 127 & 128 & 129 & 130 & 131 & 132 & 133 \\
\hline$\overline{\mathrm{SiO} 2}$ & 44.91 & 46.14 & 46.16 & 46.16 & 45.97 & 46.28 & 47.47 & 48.48 & 44.71 & 47.20 & 45.76 & 45.69 & 45.16 & 46.39 & 46.29 & 46.47 & 50.31 & 49.75 \\
\hline TiO2 & 0.16 & 0.14 & 0.04 & 0.04 & 0.06 & 0.04 & 0.20 & 0.22 & 0.04 & 0.04 & 0.18 & 0.00 & 0.14 & 0.06 & 0.04 & 0.04 & 0.22 & 0.06 \\
\hline Al2O3 & 29.97 & 33.34 & 38.11 & 37.80 & 37.89 & 38.08 & 30.99 & 27.54 & 37.09 & 36.80 & 36.90 & 37.48 & 37.29 & 37.86 & 33.50 & 38.20 & 27.78 & 25.54 \\
\hline $\mathrm{Cr} 2 \mathrm{O} 3$ & 0.00 & 0.00 & 0.00 & 0.00 & 0.00 & 0.00 & 0.00 & 0.00 & 0.00 & 0.00 & 0.00 & 0.00 & 0.00 & 0.00 & 0.00 & 0.00 & 0.00 & 0.00 \\
\hline $\mathrm{FeO}$ & 4.52 & 2.42 & 0.59 & 0.49 & 0.54 & 0.43 & 2.23 & 3.55 & 0.65 & 1.21 & 0.68 & 0.40 & 0.51 & 0.39 & 1.56 & 0.44 & 3.28 & 4.65 \\
\hline $\mathrm{Fe} 2 \mathrm{O} 3$ & 0.00 & 0.00 & 0.00 & 0.00 & 0.00 & 0.00 & 0.00 & 0.00 & 0.00 & 0.00 & 0.00 & 0.00 & 0.00 & 0.00 & 0.00 & 0.00 & 0.00 & 0.00 \\
\hline $\mathrm{MnO}$ & 0.05 & 0.02 & 0.02 & 0.00 & 0.01 & 0.01 & 0.03 & 0.00 & 0.00 & 0.00 & 0.01 & 0.00 & 0.04 & 0.00 & 0.00 & 0.00 & 0.05 & 0.07 \\
\hline MgO & 2.92 & 1.27 & 0.18 & 0.15 & 0.18 & 0.26 & 1.82 & 2.85 & 0.22 & 0.55 & 0.39 & 0.25 & 0.23 & 0.21 & 1.09 & 0.16 & 2.70 & 3.23 \\
\hline $\mathrm{CaO}$ & 0.04 & 0.04 & 0.04 & 0.05 & 0.05 & 0.04 & 0.03 & 0.00 & 0.06 & 0.06 & 0.06 & 0.08 & 0.22 & 0.04 & 0.07 & 0.04 & 0.00 & 0.07 \\
\hline $\mathrm{Na2O}$ & 3.30 & 4.40 & 7.39 & 7.65 & 7.38 & 7.12 & 3.11 & 0.59 & 7.32 & 6.22 & 6.86 & 7.18 & 7.54 & 7.30 & 4.79 & 7.48 & 0.46 & 1.20 \\
\hline K2O & 5.85 & 5.01 & 0.72 & 0.43 & 0.63 & 0.82 & 6.41 & 9.69 & 0.88 & 2.35 & 1.53 & 0.92 & 0.75 & 0.81 & 4.04 & 0.54 & 9.93 & 8.53 \\
\hline Cl & 0.03 & 0.00 & 0.00 & 0.01 & 0.00 & 0.00 & 0.00 & 0.00 & 0.00 & 0.00 & 0.00 & 0.00 & 0.01 & 0.01 & 0.00 & 0.01 & 0.00 & 0.00 \\
\hline $\mathbf{F}$ & 0.05 & 0.00 & 0.00 & 0.00 & 0.00 & 0.00 & 0.26 & 0.21 & 0.00 & 0.00 & 0.09 & 0.08 & 0.07 & 0.00 & 0.00 & 0.10 & 0.00 & 0.00 \\
\hline $\mathrm{BaO}$ & 0.00 & 0.00 & 0.00 & 0.00 & 0.00 & 0.00 & 0.00 & 0.00 & 0.00 & 0.00 & 0.00 & 0.00 & 0.00 & 0.00 & 0.00 & 0.00 & 0.00 & 0.00 \\
\hline $\mathrm{H} 2 \mathrm{O}$ & 0.00 & 0.00 & 0.00 & 0.00 & 0.00 & 0.00 & 0.00 & 0.00 & 0.00 & 0.00 & 0.00 & 0.00 & 0.00 & 0.00 & 0.00 & 0.00 & 0.00 & 0.00 \\
\hline TOTAL & 91.79 & 92.77 & 93.26 & 92.78 & 92.72 & 93.10 & 92.54 & 93.14 & 90.97 & 94.43 & 92.44 & 92.06 & 91.95 & 93.07 & 91.38 & 93.48 & 94.74 & 93.10 \\
\hline O_F_Cl & 0.03 & 0.00 & 0.00 & 0.00 & 0.00 & 0.00 & 0.11 & 0.09 & 0.00 & 0.00 & 0.04 & 0.03 & 0.03 & 0.00 & 0.00 & 0.04 & 0.00 & 0.00 \\
\hline CT̄OTAL & 91.79 & 92.77 & 93.26 & 92.78 & 92.72 & 93.10 & 92.54 & 93.14 & 90.97 & 94.43 & 92.44 & 92.06 & 91.95 & 93.07 & 91.38 & 93.48 & 94.74 & 93.10 \\
\hline $\mathrm{Si}$ & 6.25 & 6.23 & 6.04 & 6.06 & 6.04 & 6.05 & 6.46 & 6.67 & 6.01 & 6.15 & 6.07 & 6.06 & 6.01 & 6.07 & 6.28 & 6.06 & 6.76 & 6.83 \\
\hline AllV & 1.76 & 1.77 & 1.96 & 1.94 & 1.96 & 1.95 & 1.54 & 1.33 & 1.99 & 1.85 & 1.93 & 1.94 & 1.99 & 1.93 & 1.72 & 1.94 & 1.24 & 1.17 \\
\hline SUM_T & 8.00 & 8.00 & 8.00 & 8.00 & 8.00 & 8.00 & 8.00 & 8.00 & 8.00 & 8.00 & 8.00 & 8.00 & 8.00 & 8.00 & 8.00 & 8.00 & 8.00 & 8.00 \\
\hline $\mathrm{AIVI}^{-}$ & 3.15 & 3.54 & 3.91 & 3.90 & 3.91 & 3.92 & 3.42 & 3.13 & 3.88 & 3.79 & 3.83 & 3.91 & 3.86 & 3.91 & 3.64 & 3.92 & 3.16 & 2.96 \\
\hline $\mathrm{Ti}$ & 0.02 & 0.01 & 0.00 & 0.00 & 0.01 & 0.00 & 0.02 & 0.02 & 0.00 & 0.00 & 0.02 & 0.00 & 0.01 & 0.01 & 0.00 & 0.00 & 0.02 & 0.01 \\
\hline $\mathrm{Fe} 3$ & 0.00 & 0.00 & 0.00 & 0.00 & 0.00 & 0.00 & 0.00 & 0.00 & 0.00 & 0.00 & 0.00 & 0.00 & 0.00 & 0.00 & 0.00 & 0.00 & 0.00 & 0.00 \\
\hline $\mathrm{Fe} 2$ & 0.53 & 0.27 & 0.06 & 0.05 & 0.06 & 0.05 & 0.25 & 0.41 & 0.07 & 0.13 & 0.08 & 0.04 & 0.06 & 0.04 & 0.18 & 0.05 & 0.37 & 0.53 \\
\hline $\mathrm{Cr}$ & 0.00 & 0.00 & 0.00 & 0.00 & 0.00 & 0.00 & 0.00 & 0.00 & 0.00 & 0.00 & 0.00 & 0.00 & 0.00 & 0.00 & 0.00 & 0.00 & 0.00 & 0.00 \\
\hline Mn & 0.01 & 0.00 & 0.00 & 0.00 & 0.00 & 0.00 & 0.00 & 0.00 & 0.00 & 0.00 & 0.00 & 0.00 & 0.01 & 0.00 & 0.00 & 0.00 & 0.01 & 0.01 \\
\hline Mg & 0.61 & 0.26 & 0.04 & 0.03 & 0.04 & 0.05 & 0.37 & 0.58 & 0.04 & 0.11 & 0.08 & 0.05 & 0.05 & 0.04 & 0.22 & 0.03 & 0.54 & 0.66 \\
\hline $\mathrm{Ca}$ & 0.01 & 0.01 & 0.01 & 0.01 & 0.01 & 0.01 & 0.00 & 0.00 & 0.01 & 0.01 & 0.01 & 0.01 & 0.03 & 0.01 & 0.01 & 0.01 & 0.00 & 0.01 \\
\hline $\mathrm{Na}$ & 0.89 & 1.15 & 1.87 & 1.95 & 1.88 & 1.81 & 0.82 & 0.16 & 1.91 & 1.57 & 1.76 & 1.84 & 1.95 & 1.85 & 1.26 & 1.89 & 0.12 & 0.32 \\
\hline $\mathrm{K}$ & 1.04 & 0.86 & 0.12 & 0.07 & 0.11 & 0.14 & 1.11 & 1.70 & 0.15 & 0.39 & 0.26 & 0.16 & 0.13 & 0.14 & 0.70 & 0.09 & 1.70 & 1.50 \\
\hline CATIONS & 14.24 & 14.10 & 14.01 & 14.02 & 14.00 & 13.97 & 14.00 & 14.00 & 14.07 & 14.00 & 14.03 & 14.01 & 14.08 & 13.99 & 14.01 & 13.99 & 13.92 & 14.00 \\
\hline CF & 0.04 & 0.00 & 0.00 & 0.00 & 0.00 & 0.00 & 0.23 & 0.18 & 0.00 & 0.00 & 0.07 & 0.06 & 0.06 & 0.00 & 0.00 & 0.08 & 0.00 & 0.00 \\
\hline CCI & 0.02 & 0.00 & 0.00 & 0.00 & 0.00 & 0.00 & 0.00 & 0.00 & 0.00 & 0.00 & 0.00 & 0.00 & 0.01 & 0.00 & 0.00 & 0.00 & 0.00 & 0.00 \\
\hline $\mathrm{OH}$ & 0.00 & 0.00 & 0.00 & 0.00 & 0.00 & 0.00 & 0.00 & 0.00 & 0.00 & 0.00 & 0.00 & 0.00 & 0.00 & 0.00 & 0.00 & 0.00 & 0.00 & 0.00 \\
\hline 0 & 24.00 & 24.00 & 24.00 & 24.00 & 24.00 & 24.00 & 24.00 & 24.00 & 24.00 & 24.00 & 24.00 & 24.00 & 24.00 & 24.00 & 24.00 & 24.00 & 24.00 & 24.00 \\
\hline $\mathrm{Fe} \_\mathrm{FeMg}$ & 0.47 & 0.52 & 0.65 & 0.65 & 0.62 & 0.48 & 0.41 & 0.41 & 0.62 & 0.55 & 0.49 & 0.47 & 0.55 & 0.51 & 0.45 & 0.60 & 0.41 & 0.45 \\
\hline $\mathrm{Mg}^{-} \mathrm{FeMg}$ & 0.53 & 0.48 & 0.35 & 0.35 & 0.38 & 0.52 & 0.59 & 0.59 & 0.38 & 0.45 & 0.51 & 0.53 & 0.45 & 0.49 & 0.55 & 0.40 & 0.59 & 0.55 \\
\hline
\end{tabular}




\begin{tabular}{|c|c|c|c|c|c|c|c|c|c|c|c|c|c|c|c|c|c|c|}
\hline Amostra & 129A & 129A & 129A & 129A & 129A & 129A & 129A & 129A & 129A & 129A & 129A & 129A & 129A & 129A & 129A & 129A & 129A & 129A \\
\hline Análise & 183 & 184 & 185 & 186 & 187 & 188 & 189 & 190 & 191 & 192 & 193 & 194 & 195 & 196 & 197 & 198 & 200 & 201 \\
\hline $\mathrm{SiO2}$ & 46.69 & 46.74 & 46.73 & 47.15 & 46.21 & 48.69 & 46.15 & 46.07 & 46.68 & 46.05 & 45.70 & 47.00 & 46.93 & 46.63 & 46.55 & 46.42 & 45.87 & 46.17 \\
\hline TiO2 & 0.00 & 0.00 & 0.00 & 0.12 & 0.02 & 0.02 & 0.10 & 0.10 & 0.04 & 0.12 & 0.00 & 0.00 & 0.16 & 0.02 & 0.00 & 0.10 & 0.20 & 0.02 \\
\hline $\mathrm{Al} 2 \mathrm{O3}$ & 38.53 & 38.85 & 38.33 & 38.43 & 38.41 & 35.44 & 38.31 & 37.83 & 38.68 & 38.10 & 37.50 & 38.39 & 38.66 & 38.06 & 37.90 & 37.73 & 37.39 & 38.07 \\
\hline Cr2O3 & 0.00 & 0.00 & 0.00 & 0.00 & 0.00 & 0.00 & 0.00 & 0.00 & 0.00 & 0.00 & 0.00 & 0.00 & 0.00 & 0.00 & 0.00 & 0.00 & 0.00 & 0.00 \\
\hline $\mathrm{FeO}$ & 0.76 & 0.68 & 0.84 & 0.77 & 0.81 & 0.93 & 0.63 & 0.70 & 0.69 & 0.49 & 0.89 & 0.55 & 0.63 & 0.87 & 0.87 & 1.05 & 0.95 & 0.72 \\
\hline $\mathrm{Fe} 2 \mathrm{O} 3$ & 0.00 & 0.00 & 0.00 & 0.00 & 0.00 & 0.00 & 0.00 & 0.00 & 0.00 & 0.00 & 0.00 & 0.00 & 0.00 & 0.00 & 0.00 & 0.00 & 0.00 & 0.00 \\
\hline MnO & 0.01 & 0.02 & 0.00 & 0.04 & 0.00 & 0.00 & 0.00 & 0.01 & 0.01 & 0.00 & 0.02 & 0.01 & 0.00 & 0.02 & 0.00 & 0.00 & 0.01 & 0.00 \\
\hline MgO & 0.15 & 0.10 & 0.15 & 0.13 & 0.11 & 0.24 & 0.21 & 0.21 & 0.15 & 0.16 & 0.32 & 0.20 & 0.26 & 0.14 & 0.25 & 0.25 & 0.20 & 0.20 \\
\hline $\mathrm{CaO}$ & 0.02 & 0.04 & 0.07 & 0.05 & 0.03 & 0.03 & 0.03 & 0.03 & 0.02 & 0.04 & 0.01 & 0.04 & 0.03 & 0.02 & 0.03 & 0.00 & 0.03 & 0.03 \\
\hline $\mathrm{Na} 2 \mathrm{O}$ & 7.36 & 7.62 & 7.38 & 7.19 & 7.12 & 8.12 & 7.54 & 7.45 & 7.67 & 7.20 & 7.41 & 7.33 & 7.17 & 7.68 & 7.81 & 7.66 & 7.42 & 7.40 \\
\hline K2O & 0.42 & 0.42 & 0.43 & 0.50 & 0.31 & 0.36 & 0.52 & 0.45 & 0.32 & 0.40 & 0.42 & 0.58 & 0.72 & 0.31 & 0.31 & 0.42 & 0.50 & 0.53 \\
\hline $\mathrm{Cl}$ & 0.00 & 0.00 & 0.00 & 0.00 & 0.01 & 0.01 & 0.00 & 0.02 & 0.00 & 0.02 & 0.00 & 0.00 & 0.00 & 0.01 & 0.00 & 0.01 & 0.01 & 0.01 \\
\hline $\mathbf{F}$ & 0.00 & 0.03 & 0.08 & 0.00 & 0.00 & 0.15 & 0.00 & 0.00 & 0.05 & 0.00 & 0.00 & 0.12 & 0.03 & 0.00 & 0.00 & 0.00 & 0.00 & 0.00 \\
\hline $\mathrm{BaO}$ & 0.06 & 0.00 & 0.00 & 0.03 & 0.00 & 0.09 & 0.00 & 0.00 & 0.00 & 0.05 & 0.00 & 0.00 & 0.00 & 0.11 & 0.00 & 0.01 & 0.00 & 0.04 \\
\hline $\mathrm{H} 2 \mathrm{O}$ & 0.00 & 0.00 & 0.00 & 0.00 & 0.00 & 0.00 & 0.00 & 0.00 & 0.00 & 0.00 & 0.00 & 0.00 & 0.00 & 0.00 & 0.00 & 0.00 & 0.00 & 0.00 \\
\hline TOTAL & 93.98 & 94.49 & 94.01 & 94.41 & 93.03 & 94.09 & 93.48 & 92.86 & 94.30 & 92.61 & 92.29 & 94.22 & 94.58 & 93.86 & 93.72 & 93.65 & 92.57 & 93.19 \\
\hline O_F_Cl & 0.00 & 0.01 & 0.04 & 0.00 & 0.00 & 0.07 & 0.00 & 0.00 & 0.02 & 0.00 & 0.00 & 0.05 & 0.01 & 0.00 & 0.00 & 0.00 & 0.00 & 0.00 \\
\hline CTOTAL & 93.98 & 94.48 & 93.97 & 94.41 & 93.03 & 94.02 & 93.48 & 92.86 & 94.28 & 92.61 & 92.29 & 94.17 & 94.57 & 93.86 & 93.72 & 93.65 & 92.57 & 93.19 \\
\hline Si & 6.05 & 6.03 & 6.06 & 6.08 & 6.04 & 6.32 & 6.02 & 6.05 & 6.03 & 6.05 & 6.04 & 6.08 & 6.04 & 6.06 & 6.06 & 6.06 & 6.05 & 6.04 \\
\hline AllV & 1.95 & 1.97 & 1.94 & 1.92 & 1.96 & 1.68 & 1.98 & 1.95 & 1.97 & 1.95 & 1.96 & 1.92 & 1.96 & 1.94 & 1.94 & 1.95 & 1.95 & 1.96 \\
\hline SUM_T & 8.00 & 8.00 & 8.00 & 8.00 & 8.00 & 8.00 & 8.00 & 8.00 & 8.00 & 8.00 & 8.00 & 8.00 & 8.00 & 8.00 & 8.00 & 8.00 & 8.00 & 8.00 \\
\hline AIVI $^{-}$ & 3.93 & 3.93 & 3.91 & 3.91 & 3.95 & 3.75 & 3.90 & 3.89 & 3.92 & 3.94 & 3.88 & 3.92 & 3.91 & 3.89 & 3.87 & 3.85 & 3.86 & 3.91 \\
\hline $\mathrm{Ti}$ & 0.00 & 0.00 & 0.00 & 0.01 & 0.00 & 0.00 & 0.01 & 0.01 & 0.00 & 0.01 & 0.00 & 0.00 & 0.02 & 0.00 & 0.00 & 0.01 & 0.02 & 0.00 \\
\hline $\mathrm{Fe} 3$ & 0.00 & 0.00 & 0.00 & 0.00 & 0.00 & 0.00 & 0.00 & 0.00 & 0.00 & 0.00 & 0.00 & 0.00 & 0.00 & 0.00 & 0.00 & 0.00 & 0.00 & 0.00 \\
\hline Fe2 & 0.08 & 0.07 & 0.09 & 0.08 & 0.09 & 0.10 & 0.07 & 0.08 & 0.07 & 0.05 & 0.10 & 0.06 & 0.07 & 0.09 & 0.10 & 0.12 & 0.10 & 0.08 \\
\hline $\mathrm{Cr}$ & 0.00 & 0.00 & 0.00 & 0.00 & 0.00 & 0.00 & 0.00 & 0.00 & 0.00 & 0.00 & 0.00 & 0.00 & 0.00 & 0.00 & 0.00 & 0.00 & 0.00 & 0.00 \\
\hline Mn & 0.00 & 0.00 & 0.00 & 0.00 & 0.00 & 0.00 & 0.00 & 0.00 & 0.00 & 0.00 & 0.00 & 0.00 & 0.00 & 0.00 & 0.00 & 0.00 & 0.00 & 0.00 \\
\hline Mg & 0.03 & 0.02 & 0.03 & 0.03 & 0.02 & 0.05 & 0.04 & 0.04 & 0.03 & 0.03 & 0.06 & 0.04 & 0.05 & 0.03 & 0.05 & 0.05 & 0.04 & 0.04 \\
\hline $\mathrm{Ca}$ & 0.00 & 0.01 & 0.01 & 0.01 & 0.00 & 0.01 & 0.00 & 0.00 & 0.00 & 0.01 & 0.00 & 0.01 & 0.00 & 0.00 & 0.00 & 0.00 & 0.00 & 0.00 \\
\hline $\mathrm{Na}$ & 1.85 & 1.90 & 1.86 & 1.80 & 1.80 & 2.05 & 1.91 & 1.90 & 1.92 & 1.83 & 1.90 & 1.84 & 1.79 & 1.94 & 1.97 & 1.94 & 1.90 & 1.88 \\
\hline K & 0.07 & 0.07 & 0.07 & 0.08 & 0.05 & 0.06 & 0.09 & 0.08 & 0.05 & 0.07 & 0.07 & 0.10 & 0.12 & 0.05 & 0.05 & 0.07 & 0.09 & 0.09 \\
\hline CATIONS & 13.96 & 14.00 & 13.97 & 13.92 & 13.92 & 14.01 & 14.02 & 14.00 & 14.00 & 13.94 & 14.02 & 13.96 & 13.95 & 14.00 & 14.04 & 14.03 & 14.01 & 14.00 \\
\hline CF & 0.00 & 0.02 & 0.07 & 0.00 & 0.00 & 0.13 & 0.00 & 0.00 & 0.04 & 0.00 & 0.00 & 0.10 & 0.02 & 0.00 & 0.00 & 0.00 & 0.00 & 0.00 \\
\hline $\mathrm{CCl}$ & 0.00 & 0.00 & 0.00 & 0.00 & 0.00 & 0.00 & 0.00 & 0.01 & 0.00 & 0.01 & 0.00 & 0.00 & 0.00 & 0.00 & 0.00 & 0.01 & 0.01 & 0.00 \\
\hline $\mathrm{OH}$ & 0.00 & 0.00 & 0.00 & 0.00 & 0.00 & 0.00 & 0.00 & 0.00 & 0.00 & 0.00 & 0.00 & 0.00 & 0.00 & 0.00 & 0.00 & 0.00 & 0.00 & 0.00 \\
\hline 0 & 24.00 & 24.00 & 24.00 & 24.00 & 24.00 & 24.00 & 24.00 & 24.00 & 24.00 & 24.00 & 24.00 & 24.00 & 24.00 & 24.00 & 24.00 & 24.00 & 24.00 & 24.00 \\
\hline Fe_FeMg & 0.75 & 0.78 & 0.77 & 0.77 & 0.80 & 0.69 & 0.63 & 0.65 & 0.73 & 0.63 & 0.60 & 0.60 & 0.57 & 0.78 & 0.66 & 0.70 & 0.73 & 0.67 \\
\hline Mg_FeMg & 0.25 & 0.22 & 0.23 & 0.23 & 0.20 & 0.31 & 0.37 & 0.35 & 0.27 & 0.37 & 0.40 & 0.40 & 0.43 & 0.22 & 0.34 & 0.30 & 0.27 & 0.33 \\
\hline
\end{tabular}


ANEXO IV. Análises de química mineral selecionadas da região de Barragán 
Análises de química mineral de anfibólio selecionados da região de Barraqán

\begin{tabular}{|c|c|c|c|c|c|c|c|c|c|c|c|c|c|c|c|c|}
\hline Amostra & 187A & 187A & 187A & 187A & 187A & 187A & 187A & 187A & 187A & 187A & 187A & 187A & 187A & 187A & 187A & 187A \\
\hline Análise & 653 & 654 & 655 & 656 & 657 & 658 & 659 & 660 & 661 & 662 & 663 & 664 & 665 & 666 & 667 & 668 \\
\hline SiO2 & 50.46 & 50.52 & 49.99 & 49.81 & 49.86 & 49.78 & 48.66 & 48.79 & 49.10 & 48.45 & 48.62 & 48.89 & 49.82 & 47.81 & 48.30 & 48.15 \\
\hline TiO2 & 0.34 & 0.33 & 0.31 & 0.41 & 0.37 & 0.45 & 0.57 & 0.49 & 0.44 & 0.53 & 0.42 & 0.41 & 0.34 & 0.50 & 0.46 & 0.39 \\
\hline Al2O3 & 11.92 & 11.82 & 11.96 & 11.95 & 12.09 & 12.36 & 12.98 & 13.43 & 12.69 & 13.22 & 13.19 & 12.45 & 12.07 & 13.61 & 13.65 & 12.94 \\
\hline $\mathrm{FeO}$ & 10.87 & 10.80 & 10.70 & 10.88 & 11.13 & 10.93 & 10.98 & 11.47 & 10.96 & 11.36 & 11.62 & 11.15 & 10.99 & 11.51 & 11.64 & 11.96 \\
\hline $\mathrm{Cr} 2 \mathrm{O} 3$ & 0.00 & 0.00 & 0.00 & 0.00 & 0.00 & 0.00 & 0.00 & 0.00 & 0.00 & 0.00 & 0.00 & 0.00 & 0.00 & 0.00 & 0.00 & 0.00 \\
\hline MnO & 0.09 & 0.09 & 0.14 & 0.08 & 0.09 & 0.10 & 0.06 & 0.10 & 0.13 & 0.09 & 0.13 & 0.08 & 0.09 & 0.02 & 0.12 & 0.11 \\
\hline MgO & 13.36 & 13.31 & 13.04 & 13.00 & 12.94 & 13.04 & 13.06 & 12.36 & 12.52 & 12.42 & 12.22 & 12.76 & 13.04 & 11.85 & 11.98 & 12.29 \\
\hline $\mathrm{CaO}$ & 9.03 & 8.96 & 9.17 & 9.02 & 9.04 & 9.15 & 9.11 & 9.10 & 9.11 & 9.12 & 9.75 & 9.23 & 8.83 & 9.01 & 9.21 & 9.75 \\
\hline $\mathrm{Na2O}$ & 3.06 & 2.93 & 3.10 & 2.68 & 2.92 & 2.88 & 7.42 & 3.16 & 3.62 & 3.29 & 3.07 & 2.66 & 3.20 & 3.41 & 3.30 & 2.74 \\
\hline K2O & 0.13 & 0.17 & 0.14 & 0.12 & 0.16 & 0.15 & 0.16 & 0.11 & 0.15 & 0.14 & 0.13 & 0.16 & 0.16 & 0.15 & 0.12 & 0.11 \\
\hline $\mathbf{F}$ & 0.00 & 0.00 & 0.00 & 0.00 & 0.00 & 0.00 & 0.00 & 0.00 & 0.00 & 0.00 & 0.00 & 0.00 & 0.00 & 0.00 & 0.00 & 0.00 \\
\hline Cl & 0.00 & 0.00 & 0.00 & 0.00 & 0.00 & 0.00 & 0.00 & 0.00 & 0.00 & 0.00 & 0.00 & 0.00 & 0.00 & 0.00 & 0.00 & 0.00 \\
\hline TOTAL & 99.26 & 98.92 & 98.55 & 97.95 & 98.60 & 98.83 & 103.00 & 99.01 & 98.71 & 98.61 & 99.15 & 97.78 & 98.52 & 97.88 & 98.78 & 98.43 \\
\hline O_F_Cl & 0.00 & 0.00 & 0.00 & 0.00 & 0.00 & 0.00 & 0.00 & 0.00 & 0.00 & 0.00 & 0.00 & 0.00 & 0.00 & 0.00 & 0.00 & 0.00 \\
\hline O_F- & 0.00 & 0.00 & 0.00 & 0.00 & 0.00 & 0.00 & 0.00 & 0.00 & 0.00 & 0.00 & 0.00 & 0.00 & 0.00 & 0.00 & 0.00 & 0.00 \\
\hline O_Cl & 0.00 & 0.00 & 0.00 & 0.00 & 0.00 & 0.00 & 0.00 & 0.00 & 0.00 & 0.00 & 0.00 & 0.00 & 0.00 & 0.00 & 0.00 & 0.00 \\
\hline $\mathrm{H} 2 \mathrm{O}$ & & 0.00 & 0.00 & 0.00 & 0.00 & 0.00 & 0.00 & 0.00 & 0.00 & 0.00 & 0.00 & 0.00 & 0.00 & 0.00 & 0.00 & 0.00 \\
\hline CTOTAL & & 98.92 & 98.55 & 97.95 & 98.60 & 98.83 & 103.00 & 99.01 & 98.71 & 98.61 & 99.15 & 97.78 & 98.52 & 97.88 & 98.78 & 98.43 \\
\hline $\mathrm{Si}$ & 6.99 & 7.02 & 7.00 & 6.98 & 6.97 & 6.93 & 6.80 & 6.82 & 6.92 & 6.81 & 6.83 & 6.89 & 6.97 & 6.79 & 6.80 & 6.80 \\
\hline Al & 1.01 & 0.99 & 1.00 & 1.02 & 1.03 & 1.07 & 1.20 & 1.19 & 1.09 & 1.19 & 1.17 & 1.11 & 1.04 & 1.21 & 1.21 & 1.20 \\
\hline $\mathrm{Fe} 3$ & 0.00 & 0.00 & 0.00 & 0.00 & 0.00 & 0.00 & 0.00 & 0.00 & 0.00 & 0.00 & 0.00 & 0.00 & 0.00 & 0.00 & 0.00 & 0.00 \\
\hline $\mathrm{Ti}$ & 0.00 & 0.00 & 0.00 & 0.00 & 0.00 & 0.00 & 0.00 & 0.00 & 0.00 & 0.00 & 0.00 & 0.00 & 0.00 & 0.00 & 0.00 & 0.00 \\
\hline SUM_T & 8.00 & 8.00 & 8.00 & 8.00 & 8.00 & 8.00 & 8.00 & 8.00 & 8.00 & 8.00 & 8.00 & 8.00 & 8.00 & 8.00 & 8.00 & 8.00 \\
\hline Cal & 0.94 & 0.95 & 0.97 & 0.95 & 0.96 & 0.96 & 0.93 & 1.02 & 1.02 & 1.00 & 1.01 & 0.95 & 0.95 & 1.07 & 1.06 & 0.95 \\
\hline $\mathrm{CCr}$ & 0.00 & 0.00 & 0.00 & 0.00 & 0.00 & 0.00 & 0.00 & 0.00 & 0.00 & 0.00 & 0.00 & 0.00 & 0.00 & 0.00 & 0.00 & 0.00 \\
\hline CFe3 & 0.48 & 0.48 & 0.34 & 0.52 & 0.47 & 0.48 & 0.00 & 0.46 & 0.21 & 0.41 & 0.27 & 0.53 & 0.47 & 0.33 & 0.35 & 0.46 \\
\hline Cti & 0.04 & 0.03 & 0.03 & 0.04 & 0.04 & 0.05 & 0.06 & 0.05 & 0.05 & 0.06 & 0.05 & 0.04 & 0.04 & 0.05 & 0.05 & 0.04 \\
\hline $\mathrm{CMg}$ & 2.76 & 2.75 & 2.72 & 2.72 & 2.70 & 2.71 & 2.72 & 2.57 & 2.63 & 2.60 & 2.56 & 2.68 & 2.72 & 2.51 & 2.51 & 2.59 \\
\hline CFe2 & 0.78 & 0.77 & 0.91 & 0.76 & 0.83 & 0.80 & 1.28 & 0.88 & 1.08 & 0.92 & 1.09 & 0.78 & 0.81 & 1.04 & 1.02 & 0.96 \\
\hline $\mathrm{CMn}$ & 0.01 & 0.01 & 0.02 & 0.01 & 0.01 & 0.01 & 0.01 & 0.01 & 0.02 & 0.01 & 0.02 & 0.01 & 0.01 & 0.00 & 0.01 & 0.01 \\
\hline Cca & 0.00 & 0.00 & 0.00 & 0.00 & 0.00 & 0.00 & 0.00 & 0.00 & 0.00 & 0.00 & 0.00 & 0.00 & 0.00 & 0.00 & 0.00 & 0.00 \\
\hline SUM_C & 5.00 & 5.00 & 5.00 & 5.00 & 5.00 & 5.00 & 5.00 & 5.00 & 5.00 & 5.00 & 5.00 & 5.00 & 5.00 & 5.00 & 5.00 & 5.00 \\
\hline BMg & 0.00 & 0.00 & 0.00 & 0.00 & 0.00 & 0.00 & 0.00 & 0.00 & 0.00 & 0.00 & 0.00 & 0.00 & 0.00 & 0.00 & 0.00 & 0.00 \\
\hline BFe2 & 0.00 & 0.00 & 0.00 & 0.00 & 0.00 & 0.00 & 0.00 & 0.00 & 0.00 & 0.00 & 0.00 & 0.00 & 0.00 & 0.00 & 0.00 & 0.00 \\
\hline BMn & 0.00 & 0.00 & 0.00 & 0.00 & 0.00 & 0.00 & 0.00 & 0.00 & 0.00 & 0.00 & 0.00 & 0.00 & 0.00 & 0.00 & 0.00 & 0.00 \\
\hline $\mathrm{BCa}$ & 1.34 & 1.33 & 1.38 & 1.35 & 1.35 & 1.37 & 1.36 & 1.36 & 1.38 & 1.37 & 1.47 & 1.39 & 1.32 & 1.37 & 1.39 & 1.47 \\
\hline $\mathrm{BNa}$ & 0.66 & 0.67 & 0.62 & 0.65 & 0.65 & 0.63 & 0.64 & 0.64 & 0.63 & 0.63 & 0.53 & 0.61 & 0.68 & 0.63 & 0.61 & 0.53 \\
\hline SUM_B & 2.00 & 2.00 & 2.00 & 2.00 & 2.00 & 2.00 & 2.00 & 2.00 & 2.00 & 2.00 & 2.00 & 2.00 & 2.00 & 2.00 & 2.00 & 2.00 \\
\hline $\mathrm{ACa}$ & 0.00 & 0.00 & 0.00 & 0.00 & 0.00 & 0.00 & 0.00 & 0.00 & 0.00 & 0.00 & 0.00 & 0.00 & 0.00 & 0.00 & 0.00 & 0.00 \\
\hline ANa & 0.16 & 0.12 & 0.22 & 0.08 & 0.15 & 0.14 & 1.37 & 0.22 & 0.36 & 0.27 & 0.30 & 0.12 & 0.19 & 0.31 & 0.29 & 0.22 \\
\hline AK & 0.02 & 0.03 & 0.03 & 0.02 & 0.03 & 0.03 & 0.03 & 0.02 & 0.03 & 0.03 & 0.02 & 0.03 & 0.03 & 0.03 & 0.02 & 0.02 \\
\hline SUM_A & 0.19 & 0.15 & 0.24 & 0.10 & 0.17 & 0.17 & 1.40 & 0.24 & 0.39 & 0.30 & 0.33 & 0.15 & 0.22 & 0.34 & 0.31 & 0.24 \\
\hline SUM_CAT & 15.19 & 15.15 & 15.24 & 15.10 & 15.17 & 15.17 & 16.40 & 15.24 & 15.39 & 15.30 & 15.33 & 15.15 & 15.22 & 15.34 & 15.31 & 15.24 \\
\hline $\mathrm{CCl}^{-}$ & 0.00 & 0.00 & 0.00 & 0.00 & 0.00 & 0.00 & 0.00 & 0.00 & 0.00 & 0.00 & 0.00 & 0.00 & 0.00 & 0.00 & 0.00 & 0.00 \\
\hline CF & 0.00 & 0.00 & 0.00 & 0.00 & 0.00 & 0.00 & 0.00 & 0.00 & 0.00 & 0.00 & 0.00 & 0.00 & 0.00 & 0.00 & 0.00 & 0.00 \\
\hline $\mathrm{OH}$ & 0.00 & 0.00 & 0.00 & 0.00 & 0.00 & 0.00 & 0.00 & 0.00 & 0.00 & 0.00 & 0.00 & 0.00 & 0.00 & 0.00 & 0.00 & 0.00 \\
\hline SUM_OXY & 23.00 & 23.00 & 23.00 & 23.00 & 23.00 & 23.00 & 23.31 & 23.00 & 23.00 & 23.00 & 23.00 & 23.00 & 23.00 & 23.00 & 23.00 & 23.00 \\
\hline
\end{tabular}


Análises de química mineral de anfibólio selecionados da região de Barraqán

\begin{tabular}{|c|c|c|c|c|c|c|c|c|c|c|c|c|c|c|c|c|c|c|}
\hline Amostra & 187B & 187B & 187B & 187B & 187B & 187B & 187B & 187B & 187B & 187B & 187B & 187B & 187B & 187B & 187B & 187B & 187B & 187B \\
\hline Análise & 28 & 29 & 30 & 32 & 33 & 34 & 35 & 36 & 39 & 53 & 54 & 55 & 56 & 57 & 70 & 71 & 72 & 73 \\
\hline SiO2 & 45.72 & 48.05 & 48.80 & 48.56 & 47.50 & 47.12 & 46.59 & 47.34 & 45.42 & 46.93 & 46.49 & 47.36 & 46.74 & 46.61 & 47.93 & 46.92 & 46.28 & 47.69 \\
\hline TiO2 & 0.46 & 0.52 & 0.32 & 0.52 & 0.46 & 0.38 & 0.35 & 0.24 & 0.32 & 0.31 & 0.33 & 0.51 & 0.44 & 0.43 & 0.30 & 0.48 & 0.49 & 0.33 \\
\hline Al2O3 & 12.93 & 12.66 & 11.66 & 11.89 & 13.02 & 12.09 & 11.16 & 11.19 & 14.56 & 12.67 & 13.48 & 13.25 & 13.37 & 12.63 & 10.77 & 13.30 & 13.16 & 11.60 \\
\hline $\mathrm{FeO}$ & 13.53 & 11.70 & 11.27 & 11.74 & 12.35 & 11.85 & 12.39 & 12.54 & 13.57 & 12.78 & 12.22 & 12.50 & 12.52 & 12.58 & 14.28 & 12.86 & 12.13 & 12.85 \\
\hline $\mathrm{Cr} 2 \mathrm{O} 3$ & 0.00 & 0.00 & 0.00 & 0.00 & 0.00 & 0.00 & 0.00 & 0.00 & 0.00 & 0.00 & 0.00 & 0.00 & 0.00 & 0.00 & 0.00 & 0.00 & 0.00 & 0.00 \\
\hline MnO & 0.14 & 0.15 & 0.13 & 0.06 & 0.14 & 0.15 & 0.10 & 0.20 & 0.04 & 0.10 & 0.06 & 0.13 & 0.06 & 0.18 & 0.23 & 0.16 & 0.16 & 0.14 \\
\hline MgO & 12.13 & 12.64 & 13.33 & 13.10 & 12.15 & 12.80 & 13.11 & 13.00 & 10.84 & 11.88 & 12.43 & 12.40 & 12.45 & 12.44 & 12.05 & 11.61 & 12.61 & 12.22 \\
\hline $\mathrm{CaO}$ & 11.52 & 9.19 & 9.11 & 9.33 & 9.29 & 10.22 & 10.96 & 10.87 & 10.29 & 10.70 & 9.62 & 9.59 & 9.80 & 9.70 & 11.10 & 9.37 & 9.57 & 10.02 \\
\hline $\mathrm{Na2O}$ & 1.97 & 3.05 & 2.75 & 3.01 & 2.75 & 2.53 & 1.97 & 2.12 & 2.46 & 2.20 & 3.09 & 2.98 & 2.94 & 2.75 & 1.76 & 2.90 & 2.76 & 2.35 \\
\hline K2O & 0.17 & 0.17 & 0.13 & 0.10 & 0.13 & 0.16 & 0.14 & 0.12 & 0.15 & 0.19 & 0.12 & 0.12 & 0.15 & 0.13 & 0.07 & 0.12 & 0.10 & 0.08 \\
\hline $\mathbf{F}$ & 0.00 & 0.00 & 0.09 & 0.03 & 0.03 & 0.00 & 0.00 & 0.14 & 0.00 & 0.03 & 0.03 & 0.00 & 0.20 & 0.00 & 0.00 & 0.09 & 0.00 & 0.00 \\
\hline $\mathrm{Cl}$ & 0.00 & 0.00 & 0.00 & 0.00 & 0.00 & 0.00 & 0.00 & 0.00 & 0.00 & 0.00 & 0.00 & 0.00 & 0.00 & 0.00 & 0.00 & 0.00 & 0.00 & 0.00 \\
\hline TOTAL & 98.56 & 98.12 & 97.59 & 98.33 & 97.82 & 97.29 & 96.77 & 97.76 & 97.64 & 97.79 & 97.86 & 98.85 & 98.67 & 97.43 & 98.47 & 97.80 & 97.26 & 97.29 \\
\hline O_F_Cl & 0.00 & 0.00 & 0.04 & 0.01 & 0.01 & 0.00 & 0.00 & 0.06 & 0.00 & 0.01 & 0.01 & 0.00 & 0.09 & 0.00 & 0.00 & 0.04 & 0.00 & 0.00 \\
\hline O_F- & 0.00 & 0.00 & 0.04 & 0.01 & 0.01 & 0.00 & 0.00 & 0.06 & 0.00 & 0.01 & 0.01 & 0.00 & 0.09 & 0.00 & 0.00 & 0.04 & 0.00 & 0.00 \\
\hline O_Cl & 0.00 & 0.00 & 0.00 & 0.00 & 0.00 & 0.00 & 0.00 & 0.00 & 0.00 & 0.00 & 0.00 & 0.00 & 0.00 & 0.00 & 0.00 & 0.00 & 0.00 & 0.00 \\
\hline $\mathrm{H} 2 \mathrm{O}$ & 0.00 & 0.00 & 0.00 & 0.00 & 0.00 & 0.00 & 0.00 & 0.00 & 0.00 & 0.00 & 0.00 & 0.00 & 0.00 & 0.00 & 0.00 & 0.00 & 0.00 & 0.00 \\
\hline CTOTAL & 98.56 & 98.12 & 97.55 & 98.32 & 97.81 & 97.29 & 96.77 & 97.70 & 97.64 & 97.78 & 97.85 & 98.85 & 98.58 & 97.43 & 98.47 & 97.76 & 97.26 & 97.29 \\
\hline Si & 6.55 & 6.78 & 6.88 & 6.84 & 6.73 & 6.75 & 6.73 & 6.78 & 6.54 & 6.74 & 6.61 & 6.66 & 6.61 & 6.66 & 6.85 & 6.69 & 6.60 & 6.84 \\
\hline Al & 1.45 & 1.22 & 1.12 & 1.16 & 1.27 & 1.25 & 1.27 & 1.22 & 1.46 & 1.26 & 1.39 & 1.34 & 1.39 & 1.34 & 1.15 & 1.31 & 1.41 & 1.16 \\
\hline $\mathrm{Fe} 3$ & 0.00 & 0.00 & 0.00 & 0.00 & 0.00 & 0.00 & 0.00 & 0.00 & 0.00 & 0.00 & 0.00 & 0.00 & 0.00 & 0.00 & 0.00 & 0.00 & 0.00 & 0.00 \\
\hline $\mathrm{Ti}$ & 0.00 & 0.00 & 0.00 & 0.00 & 0.00 & 0.00 & 0.00 & 0.00 & 0.00 & 0.00 & 0.00 & 0.00 & 0.00 & 0.00 & 0.00 & 0.00 & 0.00 & 0.00 \\
\hline SUM_T & 8.00 & 8.00 & 8.00 & 8.00 & 8.00 & 8.00 & 8.00 & 8.00 & 8.00 & 8.00 & 8.00 & 8.00 & 8.00 & 8.00 & 8.00 & 8.00 & 8.00 & 8.00 \\
\hline Cal & 0.73 & 0.89 & 0.82 & 0.81 & 0.90 & 0.79 & 0.63 & 0.67 & 1.00 & 0.88 & 0.87 & 0.86 & 0.84 & 0.78 & 0.67 & 0.93 & 0.80 & 0.80 \\
\hline $\mathrm{CCr}$ & 0.00 & 0.00 & 0.00 & 0.00 & 0.00 & 0.00 & 0.00 & 0.00 & 0.00 & 0.00 & 0.00 & 0.00 & 0.00 & 0.00 & 0.00 & 0.00 & 0.00 & 0.00 \\
\hline CFe3 & 0.52 & 0.57 & 0.70 & 0.60 & 0.67 & 0.51 & 0.59 & 0.55 & 0.51 & 0.38 & 0.64 & 0.64 & 0.65 & 0.72 & 0.52 & 0.59 & 0.79 & 0.55 \\
\hline Cti & 0.05 & 0.06 & 0.03 & 0.06 & 0.05 & 0.04 & 0.04 & 0.03 & 0.04 & 0.03 & 0.04 & 0.05 & 0.05 & 0.05 & 0.03 & 0.05 & 0.05 & 0.04 \\
\hline $\mathrm{CMg}$ & 2.59 & 2.66 & 2.80 & 2.75 & 2.57 & 2.73 & 2.82 & 2.78 & 2.33 & 2.54 & 2.63 & 2.60 & 2.63 & 2.65 & 2.57 & 2.47 & 2.68 & 2.61 \\
\hline CFe2 & 1.10 & 0.81 & 0.63 & 0.79 & 0.80 & 0.91 & 0.91 & 0.96 & 1.13 & 1.15 & 0.81 & 0.83 & 0.83 & 0.78 & 1.19 & 0.94 & 0.65 & 0.99 \\
\hline CMn & 0.02 & 0.02 & 0.02 & 0.01 & 0.02 & 0.02 & 0.01 & 0.03 & 0.01 & 0.01 & 0.01 & 0.02 & 0.01 & 0.02 & 0.03 & 0.02 & 0.02 & 0.02 \\
\hline Cca & 0.00 & 0.00 & 0.00 & 0.00 & 0.00 & 0.00 & 0.00 & 0.00 & 0.00 & 0.00 & 0.00 & 0.00 & 0.00 & 0.00 & 0.00 & 0.00 & 0.00 & 0.00 \\
\hline SUM_C & 5.00 & 5.00 & 5.00 & 5.00 & 5.00 & 5.00 & 5.00 & 5.00 & 5.00 & 5.00 & 5.00 & 5.00 & 5.00 & 5.00 & 5.00 & 5.00 & 5.00 & 5.00 \\
\hline BMg & 0.00 & 0.00 & 0.00 & 0.00 & 0.00 & 0.00 & 0.00 & 0.00 & 0.00 & 0.00 & 0.00 & 0.00 & 0.00 & 0.00 & 0.00 & 0.00 & 0.00 & 0.00 \\
\hline BFe2 & 0.00 & 0.00 & 0.00 & 0.00 & 0.00 & 0.00 & 0.00 & 0.00 & 0.00 & 0.00 & 0.00 & 0.00 & 0.00 & 0.00 & 0.00 & 0.00 & 0.00 & 0.00 \\
\hline BMn & 0.00 & 0.00 & 0.00 & 0.00 & 0.00 & 0.00 & 0.00 & 0.00 & 0.00 & 0.00 & 0.00 & 0.00 & 0.00 & 0.00 & 0.00 & 0.00 & 0.00 & 0.00 \\
\hline $\mathrm{BCa}$ & 1.77 & 1.39 & 1.38 & 1.41 & 1.41 & 1.57 & 1.70 & 1.67 & 1.59 & 1.65 & 1.47 & 1.45 & 1.49 & 1.48 & 1.70 & 1.43 & 1.46 & 1.54 \\
\hline $\mathrm{BNa}$ & 0.23 & 0.61 & 0.62 & 0.59 & 0.59 & 0.43 & 0.30 & 0.33 & 0.41 & 0.36 & 0.53 & 0.55 & 0.52 & 0.52 & 0.30 & 0.57 & 0.54 & 0.46 \\
\hline SUM_B & 2.00 & 2.00 & 2.00 & 2.00 & 2.00 & 2.00 & 2.00 & 2.00 & 2.00 & 2.00 & 2.00 & 2.00 & 2.00 & 2.00 & 2.00 & 2.00 & 2.00 & 2.00 \\
\hline $\mathrm{ACa}^{-}$ & 0.00 & 0.00 & 0.00 & 0.00 & 0.00 & 0.00 & 0.00 & 0.00 & 0.00 & 0.00 & 0.00 & 0.00 & 0.00 & 0.00 & 0.00 & 0.00 & 0.00 & 0.00 \\
\hline $\mathrm{ANa}$ & 0.31 & 0.23 & 0.13 & 0.23 & 0.17 & 0.27 & 0.25 & 0.26 & 0.27 & 0.26 & 0.32 & 0.26 & 0.29 & 0.24 & 0.19 & 0.23 & 0.23 & 0.19 \\
\hline AK & 0.03 & 0.03 & 0.02 & 0.02 & 0.02 & 0.03 & 0.03 & 0.02 & 0.03 & 0.03 & 0.02 & 0.02 & 0.03 & 0.02 & 0.01 & 0.02 & 0.02 & 0.02 \\
\hline SUM_A & 0.34 & 0.26 & 0.15 & 0.25 & 0.19 & 0.30 & 0.28 & 0.28 & 0.30 & 0.29 & 0.34 & 0.28 & 0.32 & 0.27 & 0.20 & 0.25 & 0.24 & 0.21 \\
\hline SUM_CAT & 15.34 & 15.26 & 15.15 & 15.25 & 15.19 & 15.30 & 15.28 & 15.28 & 15.30 & 15.29 & 15.34 & 15.28 & 15.32 & 15.27 & 15.20 & 15.25 & 15.24 & 15.21 \\
\hline $\mathrm{CCl}^{-}$ & 0.00 & 0.00 & 0.00 & 0.00 & 0.00 & 0.00 & 0.00 & 0.00 & 0.00 & 0.00 & 0.00 & 0.00 & 0.00 & 0.00 & 0.00 & 0.00 & 0.00 & 0.00 \\
\hline $\mathrm{CF}$ & 0.00 & 0.00 & 0.04 & 0.01 & 0.01 & 0.00 & 0.00 & 0.07 & 0.00 & 0.01 & 0.01 & 0.00 & 0.09 & 0.00 & 0.00 & 0.04 & 0.00 & 0.00 \\
\hline $\mathrm{OH}$ & 0.00 & 0.00 & 0.00 & 0.00 & 0.00 & 0.00 & 0.00 & 0.00 & 0.00 & 0.00 & 0.00 & 0.00 & 0.00 & 0.00 & 0.00 & 0.00 & 0.00 & 0.00 \\
\hline SUM_OXY & 23.00 & 23.00 & 23.00 & 23.00 & 23.00 & 23.00 & 23.00 & 23.00 & 23.00 & 23.00 & 23.00 & 23.00 & 23.00 & 23.00 & 23.00 & 23.00 & 23.00 & 23.00 \\
\hline
\end{tabular}


Análises de química mineral de anfibólio selecionados da reqião de Barraqán

\begin{tabular}{|c|c|c|c|c|c|c|c|c|c|c|c|c|c|c|c|c|c|c|}
\hline Amostra & 188 & 188 & 188 & 188 & 188 & 188 & 188 & 188 & 188 & 188 & 188 & 188 & 188 & 188 & 188 & 188 & 188 & 188 \\
\hline Análise & 129 & 130 & 131 & 132 & 133 & 134 & 135 & 136 & 137 & 138 & 89 & 90 & 91 & 92 & 93 & 94 & 95 & 96 \\
\hline $\mathrm{SiO2}$ & 46.05 & 45.76 & 45.12 & 45.37 & 46.26 & 45.86 & 45.04 & 44.91 & 45.79 & 45.62 & 49.81 & 50.78 & 49.68 & 52.19 & 48.13 & 46.27 & 50.04 & 46.05 \\
\hline TiO2 & 0.31 & 0.45 & 0.36 & 0.50 & 0.34 & 0.40 & 0.36 & 0.41 & 0.40 & 0.41 & 0.18 & 0.19 & 0.25 & 0.10 & 0.13 & 0.46 & 0.19 & 0.35 \\
\hline Al2O3 & 11.90 & 12.75 & 11.94 & 12.01 & 11.33 & 11.82 & 10.70 & 11.89 & 11.49 & 11.37 & 6.64 & 5.27 & 6.72 & 2.99 & 8.14 & 12.02 & 7.55 & 12.17 \\
\hline $\mathrm{FeO}$ & 15.84 & 16.08 & 15.68 & 15.07 & 15.73 & 15.94 & 16.19 & 16.68 & 16.10 & 15.85 & 15.91 & 16.60 & 16.88 & 18.19 & 16.07 & 16.16 & 17.01 & 16.31 \\
\hline $\mathrm{Cr} 2 \mathrm{O} 3$ & 0.00 & 0.00 & 0.00 & 0.00 & 0.00 & 0.00 & 0.00 & 0.00 & 0.00 & 0.00 & 0.00 & 0.00 & 0.00 & 0.00 & 0.00 & 0.00 & 0.00 & 0.00 \\
\hline MnO & 0.17 & 0.14 & 0.07 & 0.12 & 0.23 & 0.18 & 0.11 & 0.19 & 0.10 & 0.09 & 0.13 & 0.20 & 0.13 & 0.29 & 0.04 & 0.16 & 0.21 & 0.09 \\
\hline MgO & 10.92 & 10.26 & 11.36 & 11.04 & 10.81 & 10.90 & 10.58 & 10.40 & 10.86 & 10.71 & 12.38 & 11.91 & 11.67 & 11.46 & 11.96 & 10.86 & 11.22 & 10.22 \\
\hline $\mathrm{CaO}$ & 10.53 & 9.63 & 11.50 & 10.78 & 11.12 & 11.69 & 12.04 & 12.08 & 11.87 & 10.63 & 12.26 & 11.90 & 11.83 & 12.05 & 11.91 & 10.12 & 10.78 & 11.26 \\
\hline $\mathrm{Na2O}$ & 2.20 & 2.46 & 1.96 & 2.10 & 1.89 & 1.54 & 1.66 & 1.76 & 1.66 & 2.19 & 1.10 & 1.02 & 1.13 & 0.54 & 1.17 & 2.41 & 1.65 & 1.91 \\
\hline K2O & 0.14 & 0.19 & 0.17 & 0.15 & 0.16 & 0.14 & 0.12 & 0.21 & 0.18 & 0.14 & 0.06 & 0.07 & 0.06 & 0.04 & 0.09 & 0.18 & 0.14 & 0.17 \\
\hline $\mathbf{F}$ & 0.06 & 0.00 & 0.00 & 0.00 & 0.00 & 0.00 & 0.12 & 0.00 & 0.00 & 0.00 & 0.00 & 0.07 & 0.00 & 0.00 & 0.29 & 0.00 & 0.00 & 0.17 \\
\hline $\mathrm{Cl}$ & 0.00 & 0.00 & 0.00 & 0.00 & 0.00 & 0.00 & 0.00 & 0.00 & 0.00 & 0.00 & 0.00 & 0.00 & 0.00 & 0.00 & 0.00 & 0.00 & 0.00 & 0.00 \\
\hline TOTAL & 98.13 & 97.72 & 98.14 & 97.13 & 97.86 & 98.47 & 96.92 & 98.52 & 98.44 & 97.00 & 98.46 & 98.03 & 98.34 & 97.84 & 97.93 & 98.64 & 98.79 & 98.69 \\
\hline O_F_Cl & 0.02 & 0.00 & 0.00 & 0.00 & 0.00 & 0.00 & 0.05 & 0.00 & 0.00 & 0.00 & 0.00 & 0.03 & 0.00 & 0.00 & 0.12 & 0.00 & 0.00 & 0.07 \\
\hline O_F & 0.02 & 0.00 & 0.00 & 0.00 & 0.00 & 0.00 & 0.05 & 0.00 & 0.00 & 0.00 & 0.00 & 0.03 & 0.00 & 0.00 & 0.12 & 0.00 & 0.00 & 0.07 \\
\hline O_Cl & 0.00 & 0.00 & 0.00 & 0.00 & 0.00 & 0.00 & 0.00 & 0.00 & 0.00 & 0.00 & 0.00 & 0.00 & 0.00 & 0.00 & 0.00 & 0.00 & 0.00 & 0.00 \\
\hline $\mathrm{H} 2 \mathrm{O}$ & 0.00 & 0.00 & 0.00 & 0.00 & 0.00 & 0.00 & 0.00 & 0.00 & 0.00 & 0.00 & 0.00 & 0.00 & 0.00 & 0.00 & 0.00 & 0.00 & 0.00 & 0.00 \\
\hline CTOTAL & 98.11 & 97.72 & 98.14 & 97.13 & 97.86 & 98.47 & 96.87 & 98.52 & 98.44 & 97.00 & 98.46 & 98.00 & 98.34 & 97.84 & 97.81 & 98.64 & 98.79 & 98.62 \\
\hline Si & 6.65 & 6.61 & 6.55 & 6.62 & 6.73 & 6.64 & 6.71 & 6.57 & 6.66 & 6.69 & 7.22 & 7.42 & 7.22 & 7.68 & 7.02 & 6.64 & 7.21 & 6.68 \\
\hline Al & 1.35 & 1.39 & 1.45 & 1.38 & 1.27 & 1.36 & 1.30 & 1.43 & 1.34 & 1.31 & 0.78 & 0.58 & 0.78 & 0.32 & 0.98 & 1.36 & 0.79 & 1.32 \\
\hline $\mathrm{Fe} 3$ & 0.00 & 0.00 & 0.00 & 0.00 & 0.00 & 0.00 & 0.00 & 0.00 & 0.00 & 0.00 & 0.00 & 0.00 & 0.00 & 0.00 & 0.00 & 0.00 & 0.00 & 0.00 \\
\hline $\mathrm{Ti}$ & 0.00 & 0.00 & 0.00 & 0.00 & 0.00 & 0.00 & 0.00 & 0.00 & 0.00 & 0.00 & 0.00 & 0.00 & 0.00 & 0.00 & 0.00 & 0.00 & 0.00 & 0.00 \\
\hline SUM_T & 8.00 & 8.00 & 8.00 & 8.00 & 8.00 & 8.00 & 8.00 & 8.00 & 8.00 & 8.00 & 8.00 & 8.00 & 8.00 & 8.00 & 8.00 & 8.00 & 8.00 & 8.00 \\
\hline Cal & 0.68 & 0.78 & 0.59 & 0.69 & 0.67 & 0.65 & 0.58 & 0.62 & 0.63 & 0.66 & 0.36 & 0.33 & 0.38 & 0.20 & 0.42 & 0.67 & 0.49 & 0.76 \\
\hline $\mathrm{CCr}$ & 0.00 & 0.00 & 0.00 & 0.00 & 0.00 & 0.00 & 0.00 & 0.00 & 0.00 & 0.00 & 0.00 & 0.00 & 0.00 & 0.00 & 0.00 & 0.00 & 0.00 & 0.00 \\
\hline CFe3 & 0.69 & 0.80 & 0.62 & 0.58 & 0.49 & 0.54 & 0.29 & 0.39 & 0.42 & 0.57 & 0.25 & 0.17 & 0.33 & 0.14 & 0.46 & 0.78 & 0.44 & 0.41 \\
\hline Cti & 0.03 & 0.05 & 0.04 & 0.06 & 0.04 & 0.04 & 0.04 & 0.05 & 0.04 & 0.05 & 0.02 & 0.02 & 0.03 & 0.01 & 0.01 & 0.05 & 0.02 & 0.04 \\
\hline $\mathrm{CMg}$ & 2.35 & 2.21 & 2.46 & 2.40 & 2.35 & 2.35 & 2.35 & 2.27 & 2.36 & 2.34 & 2.68 & 2.60 & 2.53 & 2.51 & 2.60 & 2.32 & 2.41 & 2.21 \\
\hline CFe2 & 1.22 & 1.14 & 1.28 & 1.26 & 1.42 & 1.39 & 1.73 & 1.65 & 1.54 & 1.38 & 1.68 & 1.86 & 1.72 & 2.10 & 1.50 & 1.16 & 1.62 & 1.57 \\
\hline CMn & 0.02 & 0.02 & 0.01 & 0.01 & 0.03 & 0.02 & 0.01 & 0.02 & 0.01 & 0.01 & 0.02 & 0.03 & 0.02 & 0.04 & 0.01 & 0.02 & 0.03 & 0.01 \\
\hline Cca & 0.00 & 0.00 & 0.00 & 0.00 & 0.00 & 0.00 & 0.00 & 0.00 & 0.00 & 0.00 & 0.00 & 0.00 & 0.00 & 0.00 & 0.00 & 0.00 & 0.00 & 0.00 \\
\hline SUM C & 5.00 & 5.00 & 5.00 & 5.00 & 5.00 & 5.00 & 5.00 & 5.00 & 5.00 & 5.00 & 5.00 & 5.00 & 5.00 & 5.00 & 5.00 & 5.00 & 5.00 & 5.00 \\
\hline BMg & 0.00 & 0.00 & 0.00 & 0.00 & 0.00 & 0.00 & 0.00 & 0.00 & 0.00 & 0.00 & 0.00 & 0.00 & 0.00 & 0.00 & 0.00 & 0.00 & 0.00 & 0.00 \\
\hline BFe2 & 0.00 & 0.00 & 0.00 & 0.00 & 0.00 & 0.00 & 0.00 & 0.00 & 0.00 & 0.00 & 0.00 & 0.00 & 0.00 & 0.00 & 0.00 & 0.00 & 0.00 & 0.00 \\
\hline BMn & 0.00 & 0.00 & 0.00 & 0.00 & 0.00 & 0.00 & 0.00 & 0.00 & 0.00 & 0.00 & 0.00 & 0.00 & 0.00 & 0.00 & 0.00 & 0.00 & 0.00 & 0.00 \\
\hline $\mathrm{BCa}$ & 1.63 & 1.49 & 1.79 & 1.69 & 1.73 & 1.81 & 1.92 & 1.89 & 1.85 & 1.67 & 1.91 & 1.86 & 1.84 & 1.90 & 1.86 & 1.56 & 1.67 & 1.75 \\
\hline $\mathrm{BNa}$ & 0.37 & 0.51 & 0.21 & 0.31 & 0.27 & 0.19 & 0.08 & 0.11 & 0.15 & 0.33 & 0.10 & 0.14 & 0.16 & 0.10 & 0.14 & 0.44 & 0.34 & 0.25 \\
\hline SUM_B & 2.00 & 2.00 & 2.00 & 2.00 & 2.00 & 2.00 & 2.00 & 2.00 & 2.00 & 2.00 & 2.00 & 2.00 & 2.00 & 2.00 & 2.00 & 2.00 & 2.00 & 2.00 \\
\hline $\mathrm{ACa}^{-}$ & 0.00 & 0.00 & 0.00 & 0.00 & 0.00 & 0.00 & 0.00 & 0.00 & 0.00 & 0.00 & 0.00 & 0.00 & 0.00 & 0.00 & 0.00 & 0.00 & 0.00 & 0.00 \\
\hline $\mathrm{ANa}$ & 0.25 & 0.18 & 0.34 & 0.28 & 0.27 & 0.24 & 0.40 & 0.39 & 0.32 & 0.29 & 0.22 & 0.16 & 0.16 & 0.05 & 0.19 & 0.23 & 0.13 & 0.29 \\
\hline AK & 0.03 & 0.04 & 0.03 & 0.03 & 0.03 & 0.03 & 0.02 & 0.04 & 0.03 & 0.03 & 0.01 & 0.01 & 0.01 & 0.01 & 0.02 & 0.03 & 0.03 & 0.03 \\
\hline SUM_A & 0.28 & 0.22 & 0.37 & 0.31 & 0.29 & 0.27 & 0.43 & 0.43 & 0.35 & 0.32 & 0.23 & 0.17 & 0.17 & 0.06 & 0.21 & 0.26 & 0.15 & 0.32 \\
\hline SUM_CAT & 15.28 & 15.22 & 15.37 & 15.31 & 15.29 & 15.27 & 15.43 & 15.43 & 15.35 & 15.32 & 15.23 & 15.17 & 15.17 & 15.06 & 15.21 & 15.26 & 15.15 & 15.32 \\
\hline $\mathrm{CCl}^{-}$ & 0.00 & 0.00 & 0.00 & 0.00 & 0.00 & 0.00 & 0.00 & 0.00 & 0.00 & 0.00 & 0.00 & 0.00 & 0.00 & 0.00 & 0.00 & 0.00 & 0.00 & 0.00 \\
\hline CF & 0.03 & 0.00 & 0.00 & 0.00 & 0.00 & 0.00 & 0.05 & 0.00 & 0.00 & 0.00 & 0.00 & 0.03 & 0.00 & 0.00 & 0.13 & 0.00 & 0.00 & 0.08 \\
\hline $\mathrm{OH}$ & 0.00 & 0.00 & 0.00 & 0.00 & 0.00 & 0.00 & 0.00 & 0.00 & 0.00 & 0.00 & 0.00 & 0.00 & 0.00 & 0.00 & 0.00 & 0.00 & 0.00 & 0.00 \\
\hline SUM OXY & 23.00 & 23.00 & 23.00 & 23.00 & 23.00 & 23.00 & 23.00 & 23.00 & 23.00 & 23.00 & 23.00 & 23.00 & 23.00 & 23.00 & 23.00 & 23.00 & 23.00 & 23.00 \\
\hline
\end{tabular}


Análises de química mineral de anfibólio selecionados da reqião de Barraqán

\begin{tabular}{|c|c|c|c|c|c|c|c|c|c|c|c|c|c|c|c|c|c|c|}
\hline Amostra & 189 & 189 & 189 & 189 & 189 & 189 & 189 & 189 & 189 & 189 & 189A & 189A & 189A & 189A & 189A & 189A & 189A & 189A \\
\hline Análise & 689 & 691 & 692 & 693 & 698 & 699 & 700 & 701 & 702 & 703 & 753 & 754 & 755 & 756 & 757 & 758 & 759 & 760 \\
\hline SiO2 & 48.14 & 49.75 & 48.14 & 48.38 & 48.19 & 48.80 & 46.90 & 46.61 & 47.59 & 47.49 & 47.90 & 47.86 & 48.05 & 48.44 & 48.20 & 48.08 & 47.36 & 46.39 \\
\hline TiO2 & 0.48 & 0.29 & 0.45 & 0.47 & 0.44 & 0.36 & 0.47 & 0.31 & 0.47 & 0.50 & 0.43 & 0.41 & 0.39 & 0.36 & 0.34 & 0.33 & 0.49 & 0.30 \\
\hline Al2O3 & 13.77 & 9.92 & 13.66 & 13.42 & 13.58 & 13.22 & 13.74 & 12.31 & 13.59 & 13.54 & 13.07 & 13.84 & 13.36 & 12.67 & 12.84 & 12.54 & 14.12 & 13.02 \\
\hline $\mathrm{FeO}$ & 11.72 & 14.00 & 11.75 & 11.57 & 11.82 & 11.50 & 14.52 & 16.50 & 14.02 & 12.82 & 13.32 & 12.73 & 13.02 & 12.63 & 12.98 & 12.94 & 12.10 & 14.92 \\
\hline Cr2O3 & 0.00 & 0.00 & 0.00 & 0.00 & 0.00 & 0.00 & 0.00 & 0.00 & 0.00 & 0.00 & 0.00 & 0.00 & 0.00 & 0.00 & 0.00 & 0.00 & 0.00 & 0.00 \\
\hline MnO & 0.12 & 0.20 & 0.04 & 0.07 & 0.08 & 0.05 & 0.19 & 0.41 & 0.30 & 0.16 & 0.15 & 0.10 & 0.10 & 0.16 & 0.16 & 0.17 & 0.15 & 0.27 \\
\hline MgO & 12.44 & 12.98 & 12.28 & 12.53 & 12.70 & 12.55 & 10.36 & 9.95 & 10.40 & 11.88 & 11.78 & 12.13 & 12.15 & 11.92 & 12.25 & 11.95 & 11.95 & 10.64 \\
\hline $\mathrm{CaO}$ & 8.89 & 9.65 & & 8.85 & 8.94 & 9.05 & 9.25 & 10.96 & 9.06 & 9.06 & 9.78 & 9.86 & 9.66 & 9.97 & 10.33 & 10.49 & 9.36 & 10.78 \\
\hline $\mathrm{Na2O}$ & 3.19 & 2.06 & 2.71 & 4.41 & 3.25 & 3.42 & 2.73 & 6.17 & 2.52 & 2.95 & 3.02 & 2.51 & 3.01 & 2.52 & 4.92 & 2.09 & 3.53 & 1.72 \\
\hline K2O & 0.16 & 0.11 & 0.19 & 0.17 & 0.16 & 0.17 & 0.18 & 0.19 & 0.21 & 0.20 & 0.15 & 0.15 & 0.17 & 0.16 & 0.14 & 0.15 & 0.18 & 0.19 \\
\hline $\mathbf{F}$ & 0.00 & 0.00 & 0.00 & 0.00 & 0.00 & 0.00 & 0.00 & 0.00 & 0.00 & 0.00 & 0.00 & 0.00 & 0.00 & 0.00 & 0.00 & 0.00 & 0.00 & 0.02 \\
\hline $\mathrm{Cl}$ & 0.00 & 0.00 & 0.00 & 0.00 & 0.00 & 0.00 & 0.00 & 0.00 & 0.00 & 0.00 & 0.00 & 0.00 & 0.00 & 0.00 & 0.00 & 0.00 & 0.00 & 0.00 \\
\hline TOTAL & 98.92 & 98.95 & 98.20 & 99.87 & 99.16 & 99.11 & 98.34 & 103.41 & 98.15 & 98.60 & 99.60 & 99.57 & 99.90 & 98.84 & 102.14 & 98.73 & 99.25 & 98.25 \\
\hline O_F_Cl & 0.00 & 0.00 & 0.00 & 0.00 & 0.00 & 0.00 & 0.00 & 0.00 & 0.00 & 0.00 & 0.00 & 0.00 & 0.00 & 0.00 & 0.00 & 0.00 & 0.00 & 0.01 \\
\hline O_F & 0.00 & 0.00 & 0.00 & 0.00 & 0.00 & 0.00 & 0.00 & 0.00 & 0.00 & 0.00 & 0.00 & 0.00 & 0.00 & 0.00 & 0.00 & 0.00 & 0.00 & 0.01 \\
\hline O_Cl & 0.00 & 0.00 & 0.00 & 0.00 & 0.00 & 0.00 & 0.00 & 0.00 & 0.00 & 0.00 & 0.00 & 0.00 & 0.00 & 0.00 & 0.00 & 0.00 & 0.00 & 0.00 \\
\hline $\mathrm{H} 2 \mathrm{O}$ & 0.00 & 0.00 & 0.00 & 0.00 & 0.00 & 0.00 & 0.00 & 0.00 & 0.00 & 0.00 & 0.00 & 0.00 & 0.00 & 0.00 & 0.00 & 0.00 & 0.00 & 0.00 \\
\hline CTOTAL & 98.92 & 98.95 & 98.20 & 99.87 & 99.16 & 99.11 & 98.34 & 103.41 & 98.15 & 98.60 & 99.60 & 99.57 & 99.90 & 98.84 & 102.14 & 98.73 & 99.25 & 98.24 \\
\hline Si & 6.72 & 6.96 & 6.75 & 6.77 & 6.71 & 6.82 & 6.69 & 6.71 & 6.77 & 6.68 & 6.74 & 6.67 & 6.71 & 6.84 & 6.75 & 6.80 & 6.66 & 6.66 \\
\hline Al & 1.28 & 1.04 & 1.25 & 1.23 & 1.29 & 1.18 & 1.31 & 1.29 & 1.23 & 1.32 & 1.26 & 1.33 & 1.29 & 1.16 & 1.25 & 1.20 & 1.34 & 1.34 \\
\hline $\mathrm{Fe} 3$ & 0.00 & 0.00 & 0.00 & 0.00 & 0.00 & 0.00 & 0.00 & 0.00 & 0.00 & 0.00 & 0.00 & 0.00 & 0.00 & 0.00 & 0.00 & 0.00 & 0.00 & 0.00 \\
\hline $\mathrm{Ti}$ & 0.00 & 0.00 & 0.00 & 0.00 & 0.00 & 0.00 & 0.00 & 0.00 & 0.00 & 0.00 & 0.00 & 0.00 & 0.00 & 0.00 & 0.00 & 0.00 & 0.00 & 0.00 \\
\hline SUM_T & 8.00 & 8.00 & 8.00 & 8.00 & 8.00 & 8.00 & 8.00 & 8.00 & 8.00 & 8.00 & 8.00 & 8.00 & 8.00 & 8.00 & 8.00 & 8.00 & 8.00 & 8.00 \\
\hline Cal & 0.98 & 0.60 & 1.00 & 0.98 & 0.93 & 1.00 & 0.99 & 0.80 & 1.04 & 0.93 & 0.90 & 0.94 & 0.90 & 0.94 & 0.87 & 0.89 & 1.00 & 0.87 \\
\hline $\mathrm{CCr}$ & 0.00 & 0.00 & 0.00 & 0.00 & 0.00 & 0.00 & 0.00 & 0.00 & 0.00 & 0.00 & 0.00 & 0.00 & 0.00 & 0.00 & 0.00 & 0.00 & 0.00 & 0.00 \\
\hline CFe3 & 0.65 & 0.90 & 0.68 & 0.28 & 0.69 & 0.44 & 0.61 & 0.00 & 0.60 & 0.71 & 0.47 & 0.65 & 0.58 & 0.41 & 0.00 & 0.46 & 0.42 & 0.58 \\
\hline Cti & 0.05 & 0.03 & 0.05 & 0.05 & 0.05 & 0.04 & 0.05 & 0.03 & 0.05 & 0.05 & 0.05 & 0.04 & 0.04 & 0.04 & 0.04 & 0.04 & 0.05 & 0.03 \\
\hline CMg & 2.59 & 2.71 & 2.57 & 2.61 & 2.64 & 2.62 & 2.20 & 2.14 & 2.20 & 2.49 & 2.47 & 2.52 & 2.53 & 2.51 & 2.56 & 2.52 & 2.51 & 2.28 \\
\hline CFe2 & 0.72 & 0.73 & 0.70 & 1.07 & 0.68 & 0.91 & 1.13 & 1.99 & 1.07 & 0.80 & 1.09 & 0.83 & 0.94 & 1.08 & 1.52 & 1.08 & 1.01 & 1.22 \\
\hline CMn & 0.01 & 0.02 & 0.00 & 0.01 & 0.01 & 0.01 & 0.02 & 0.05 & 0.04 & 0.02 & 0.02 & 0.01 & 0.01 & 0.02 & 0.02 & 0.02 & 0.02 & 0.03 \\
\hline Cca & 0.00 & 0.00 & 0.00 & 0.00 & 0.00 & 0.00 & 0.00 & 0.00 & 0.00 & 0.00 & 0.00 & 0.00 & 0.00 & 0.00 & 0.00 & 0.00 & 0.00 & 0.00 \\
\hline SUM_C & 5.00 & 5.00 & 5.00 & 5.00 & 5.00 & 5.00 & 5.00 & 5.00 & 5.00 & 5.00 & 5.00 & 5.00 & 5.00 & 5.00 & 5.00 & 5.00 & 5.00 & 5.00 \\
\hline $\mathrm{BMg}^{-}$ & 0.00 & 0.00 & 0.00 & 0.00 & 0.00 & 0.00 & 0.00 & 0.00 & 0.00 & 0.00 & 0.00 & 0.00 & 0.00 & 0.00 & 0.00 & 0.00 & 0.00 & 0.00 \\
\hline BFe2 & 0.00 & 0.00 & 0.00 & 0.00 & 0.00 & 0.00 & 0.00 & 0.00 & 0.00 & 0.00 & 0.00 & 0.00 & 0.00 & 0.00 & 0.00 & 0.00 & 0.00 & 0.00 \\
\hline BMn & 0.00 & 0.00 & 0.00 & 0.00 & 0.00 & 0.00 & 0.00 & 0.00 & 0.00 & 0.00 & 0.00 & 0.00 & 0.00 & 0.00 & 0.00 & 0.00 & 0.00 & 0.00 \\
\hline $\mathrm{BCa}$ & 1.33 & 1.45 & 1.35 & 1.33 & 1.33 & 1.36 & 1.41 & 1.69 & 1.38 & 1.37 & 1.47 & 1.47 & 1.45 & 1.51 & 1.55 & 1.59 & 1.41 & 1.66 \\
\hline $\mathrm{BNa}$ & 0.67 & 0.55 & 0.65 & 0.67 & 0.67 & 0.65 & 0.59 & 0.31 & 0.62 & 0.63 & 0.53 & 0.53 & 0.56 & 0.49 & 0.45 & 0.41 & 0.59 & 0.34 \\
\hline SUM_B & 2.00 & 2.00 & 2.00 & 2.00 & 2.00 & 2.00 & 2.00 & 2.00 & 2.00 & 2.00 & 2.00 & 2.00 & 2.00 & 2.00 & 2.00 & 2.00 & 2.00 & 2.00 \\
\hline $\mathrm{ACa}$ & 0.00 & 0.00 & 0.00 & 0.00 & 0.00 & 0.00 & 0.00 & 0.00 & 0.00 & 0.00 & 0.00 & 0.00 & 0.00 & 0.00 & 0.00 & 0.00 & 0.00 & 0.00 \\
\hline $\mathrm{ANa}$ & 0.19 & 0.01 & 0.09 & 0.52 & 0.21 & 0.28 & 0.17 & 1.41 & 0.08 & 0.17 & 0.30 & 0.15 & 0.26 & 0.20 & 0.89 & 0.16 & 0.37 & 0.14 \\
\hline AK & 0.03 & 0.02 & 0.03 & 0.03 & 0.03 & 0.03 & 0.03 & 0.03 & 0.04 & 0.04 & 0.03 & 0.03 & 0.03 & 0.03 & 0.03 & 0.03 & 0.03 & 0.04 \\
\hline SUM_A & 0.22 & 0.03 & 0.12 & 0.55 & 0.24 & 0.31 & 0.20 & 1.45 & 0.11 & 0.21 & 0.32 & 0.18 & 0.29 & 0.23 & 0.91 & 0.19 & 0.41 & 0.17 \\
\hline SUM_CAT & 15.22 & 15.03 & 15.12 & 15.55 & 15.24 & 15.31 & 15.20 & 16.45 & 15.11 & 15.21 & 15.32 & 15.18 & 15.29 & 15.23 & 15.91 & 15.19 & 15.41 & 15.17 \\
\hline $\mathrm{CCl}$ & 0.00 & 0.00 & 0.00 & 0.00 & 0.00 & 0.00 & 0.00 & 0.00 & 0.00 & 0.00 & 0.00 & 0.00 & 0.00 & 0.00 & 0.00 & 0.00 & 0.00 & 0.00 \\
\hline CF & 0.00 & 0.00 & 0.00 & 0.00 & 0.00 & 0.00 & 0.00 & 0.00 & 0.00 & 0.00 & 0.00 & 0.00 & 0.00 & 0.00 & 0.00 & 0.00 & 0.00 & 0.01 \\
\hline $\mathrm{OH}$ & 0.00 & 0.00 & 0.00 & 0.00 & 0.00 & 0.00 & 0.00 & 0.00 & 0.00 & 0.00 & 0.00 & 0.00 & 0.00 & 0.00 & 0.00 & 0.00 & 0.00 & 0.00 \\
\hline SUM_OXY & 23.00 & 23.00 & 23.00 & 23.00 & 23.00 & 23.00 & 23.00 & 23.35 & 23.00 & 23.00 & 23.00 & 23.00 & 23.00 & 23.00 & 23.07 & 23.00 & 23.00 & 23.00 \\
\hline
\end{tabular}


Análises de química mineral de anfibólio selecionados da região de Barragán

\begin{tabular}{|c|c|c|c|c|c|c|c|c|c|c|c|c|c|c|c|c|c|}
\hline Amostra & 196 & 196 & 196 & 196 & 196 & 196 & 196 & 196D & 196D & 196D & 196D & 196D & 196D & 196D & 196D & 196D & 196D \\
\hline Análise & 187 & 188 & 189 & 190 & 191 & 192 & 193 & 102 & 103 & 104 & 105 & 106 & 107 & 108 & 109 & 110 & 111 \\
\hline SiO2 & 58.79 & 58.92 & 58.18 & 58.86 & 58.01 & 58.96 & 59.14 & 58.89 & 58.46 & 58.20 & 59.15 & 58.38 & 58.42 & 58.11 & 58.78 & 58.46 & 58.82 \\
\hline TiO2 & 0.03 & 0.01 & 0.06 & 0.00 & 0.06 & 0.05 & 0.01 & 0.03 & 0.00 & 0.03 & 0.03 & 0.01 & 0.02 & 0.01 & 0.00 & 0.04 & 0.00 \\
\hline Al2O3 & 11.11 & 11.53 & 11.13 & 11.72 & 11.51 & 11.36 & 11.28 & 9.84 & 7.80 & 10.47 & 10.76 & 10.20 & 9.85 & 10.70 & 10.36 & 10.55 & 10.54 \\
\hline $\mathrm{FeO}$ & 9.97 & 10.01 & 10.49 & 10.26 & 10.33 & 9.85 & 10.39 & 11.98 & 12.18 & 12.22 & 11.21 & 12.26 & 12.57 & 11.60 & 12.86 & 11.97 & 11.41 \\
\hline $\mathrm{Cr} 2 \mathrm{O} 3$ & 0.00 & 0.00 & 0.00 & 0.00 & 0.00 & 0.00 & 0.00 & 0.00 & 0.00 & 0.00 & 0.00 & 0.00 & 0.00 & 0.00 & 0.00 & 0.00 & 0.00 \\
\hline $\mathrm{MnO}$ & 0.13 & 0.14 & 0.10 & 0.12 & 0.14 & 0.10 & 0.14 & 0.17 & 0.13 & 0.17 & 0.07 & 0.12 & 0.12 & 0.09 & 0.12 & 0.13 & 0.12 \\
\hline $\mathrm{MgO}$ & 10.91 & 10.90 & 11.02 & 10.51 & 10.68 & 10.99 & 10.35 & 10.45 & 10.38 & 10.41 & 10.19 & 9.92 & 10.19 & 10.79 & 9.29 & 10.38 & 10.25 \\
\hline $\mathrm{CaO}$ & 1.64 & 1.26 & 1.95 & 0.98 & 1.75 & 1.59 & 0.82 & 1.90 & 1.87 & 1.77 & 1.10 & 1.39 & 1.99 & 1.91 & 0.51 & 1.77 & 1.44 \\
\hline $\mathrm{Na} 2 \mathrm{O}$ & 6.88 & 6.93 & 6.70 & 7.10 & 6.81 & 6.68 & 7.18 & 6.37 & 6.65 & 6.57 & 6.92 & 6.58 & 6.59 & 6.53 & 7.22 & 6.77 & 6.90 \\
\hline K2O & 0.03 & 0.00 & 0.04 & 0.01 & 0.02 & 0.00 & 0.02 & 0.01 & 0.01 & 0.03 & 0.01 & 0.01 & 0.02 & 0.01 & 0.02 & 0.02 & 0.02 \\
\hline $\mathbf{F}$ & 0.00 & 0.00 & 0.00 & 0.00 & 0.00 & 0.00 & 0.00 & 0.00 & 0.00 & 0.00 & 0.00 & 0.03 & 0.00 & 0.00 & 0.00 & 0.00 & 0.00 \\
\hline $\mathrm{Cl}$ & 0.00 & 0.00 & 0.00 & 0.00 & 0.00 & 0.00 & 0.00 & 0.00 & 0.00 & 0.00 & 0.00 & 0.00 & 0.00 & 0.00 & 0.00 & 0.00 & 0.00 \\
\hline TOTAL & 99.50 & 99.69 & 99.67 & 99.55 & 99.31 & 99.59 & 99.33 & 99.64 & 97.48 & 99.87 & 99.44 & 98.89 & 99.77 & 99.74 & 99.15 & 100.09 & 99.49 \\
\hline O_F_Cl & 0.00 & 0.00 & 0.00 & 0.00 & 0.00 & 0.00 & 0.00 & 0.00 & 0.00 & 0.00 & 0.00 & 0.01 & 0.00 & 0.00 & 0.00 & 0.00 & 0.00 \\
\hline O_F & 0.00 & 0.00 & 0.00 & 0.00 & 0.00 & 0.00 & 0.00 & 0.00 & 0.00 & 0.00 & 0.00 & 0.01 & 0.00 & 0.00 & 0.00 & 0.00 & 0.00 \\
\hline O_Cl & 0.00 & 0.00 & 0.00 & 0.00 & 0.00 & 0.00 & 0.00 & 0.00 & 0.00 & 0.00 & 0.00 & 0.00 & 0.00 & 0.00 & 0.00 & 0.00 & 0.00 \\
\hline $\mathrm{H} 2 \mathrm{O}$ & 0.00 & 0.00 & 0.00 & 0.00 & 0.00 & 0.00 & 0.00 & 0.00 & 0.00 & 0.00 & 0.00 & 0.00 & 0.00 & 0.00 & 0.00 & 0.00 & 0.00 \\
\hline CTOTAL & 99.50 & 99.69 & 99.67 & 99.55 & 99.31 & 99.59 & 99.33 & 99.64 & 97.48 & 99.87 & 99.44 & 98.88 & 99.77 & 99.74 & 99.15 & 100.09 & 99.49 \\
\hline Si & 7.91 & 7.88 & 7.83 & 7.89 & 7.83 & 7.90 & 7.95 & 7.96 & 8.14 & 7.85 & 7.97 & 7.94 & 7.93 & 7.82 & 7.99 & 7.88 & 7.95 \\
\hline Al & 0.09 & 0.12 & 0.17 & 0.11 & 0.17 & 0.11 & 0.05 & 0.05 & 0.00 & 0.15 & 0.03 & 0.06 & 0.08 & 0.18 & 0.01 & 0.13 & 0.05 \\
\hline $\mathrm{Fe} 3$ & 0.00 & 0.00 & 0.00 & 0.00 & 0.00 & 0.00 & 0.00 & 0.00 & 0.00 & 0.00 & 0.00 & 0.00 & 0.00 & 0.00 & 0.00 & 0.00 & 0.00 \\
\hline $\mathrm{Ti}$ & 0.00 & 0.00 & 0.00 & 0.00 & 0.00 & 0.00 & 0.00 & 0.00 & 0.00 & 0.00 & 0.00 & 0.00 & 0.00 & 0.00 & 0.00 & 0.00 & 0.00 \\
\hline SUM_T & 8.00 & 8.00 & 8.00 & 8.00 & 8.00 & 8.00 & 8.00 & 8.00 & 8.14 & 8.00 & 8.00 & 8.00 & 8.00 & 8.00 & 8.00 & 8.00 & 8.00 \\
\hline $\mathrm{Cal}$ & 1.67 & 1.69 & 1.59 & 1.74 & 1.66 & 1.69 & 1.74 & 1.52 & 1.28 & 1.51 & 1.68 & 1.58 & 1.50 & 1.52 & 1.64 & 1.55 & 1.63 \\
\hline $\mathrm{CCr}$ & 0.00 & 0.00 & 0.00 & 0.00 & 0.00 & 0.00 & 0.00 & 0.00 & 0.00 & 0.00 & 0.00 & 0.00 & 0.00 & 0.00 & 0.00 & 0.00 & 0.00 \\
\hline CFe3 & 0.14 & 0.27 & 0.25 & 0.25 & 0.20 & 0.22 & 0.19 & 0.30 & 0.10 & 0.41 & 0.22 & 0.33 & 0.26 & 0.40 & 0.32 & 0.29 & 0.19 \\
\hline Cti & 0.00 & 0.00 & 0.01 & 0.00 & 0.01 & 0.01 & 0.00 & 0.00 & 0.00 & 0.00 & 0.00 & 0.00 & 0.00 & 0.00 & 0.00 & 0.00 & 0.00 \\
\hline $\mathrm{CMg}$ & 2.19 & 2.17 & 2.21 & 2.10 & 2.15 & 2.19 & 2.08 & 2.10 & 2.15 & 2.09 & 2.05 & 2.01 & 2.06 & 2.17 & 1.88 & 2.09 & 2.07 \\
\hline CFe2 & 0.98 & 0.85 & 0.93 & 0.90 & 0.97 & 0.89 & 0.98 & 1.06 & 1.32 & 0.97 & 1.05 & 1.06 & 1.17 & 0.90 & 1.15 & 1.06 & 1.10 \\
\hline $\mathrm{CMn}$ & 0.02 & 0.02 & 0.01 & 0.01 & 0.02 & 0.01 & 0.02 & 0.02 & 0.02 & 0.02 & 0.01 & 0.01 & 0.01 & 0.01 & 0.01 & 0.01 & 0.01 \\
\hline Cca & 0.00 & 0.00 & 0.00 & 0.00 & 0.00 & 0.00 & 0.00 & 0.00 & 0.14 & 0.00 & 0.00 & 0.00 & 0.00 & 0.00 & 0.00 & 0.00 & 0.00 \\
\hline SUM_C & 5.00 & 5.00 & 5.00 & 5.00 & 5.00 & 5.00 & 5.00 & 5.00 & 5.00 & 5.00 & 5.00 & 5.00 & 5.00 & 5.00 & 5.00 & 5.00 & 5.00 \\
\hline $\mathrm{BMg}^{-}$ & 0.00 & 0.00 & 0.00 & 0.00 & 0.00 & 0.00 & 0.00 & 0.00 & 0.00 & 0.00 & 0.00 & 0.00 & 0.00 & 0.00 & 0.00 & 0.00 & 0.00 \\
\hline BFe2 & 0.00 & 0.00 & 0.00 & 0.00 & 0.00 & 0.00 & 0.00 & 0.00 & 0.00 & 0.00 & 0.00 & 0.00 & 0.00 & 0.00 & 0.00 & 0.00 & 0.00 \\
\hline BMn & 0.00 & 0.00 & 0.00 & 0.00 & 0.00 & 0.00 & 0.00 & 0.00 & 0.00 & 0.00 & 0.00 & 0.00 & 0.00 & 0.00 & 0.00 & 0.00 & 0.00 \\
\hline $\mathrm{BCa}$ & 0.24 & 0.18 & 0.28 & 0.14 & 0.25 & 0.23 & 0.12 & 0.28 & 0.14 & 0.26 & 0.16 & 0.20 & 0.29 & 0.28 & 0.08 & 0.26 & 0.21 \\
\hline $\mathrm{BNa}$ & 1.76 & 1.80 & 1.72 & 1.85 & 1.75 & 1.74 & 1.87 & 1.67 & 1.79 & 1.72 & 1.81 & 1.74 & 1.71 & 1.70 & 1.90 & 1.74 & 1.79 \\
\hline SUM_B & 2.00 & 1.98 & 2.00 & 1.99 & 2.00 & 1.96 & 1.99 & 1.94 & 1.94 & 1.97 & 1.97 & 1.94 & 2.00 & 1.98 & 1.98 & 2.00 & 2.00 \\
\hline $\mathrm{ACa}$ & 0.00 & 0.00 & 0.00 & 0.00 & 0.00 & 0.00 & 0.00 & 0.00 & 0.00 & 0.00 & 0.00 & 0.00 & 0.00 & 0.00 & 0.00 & 0.00 & 0.00 \\
\hline $\mathrm{ANa}$ & 0.03 & 0.00 & 0.03 & 0.00 & 0.04 & 0.00 & 0.00 & 0.00 & 0.00 & 0.00 & 0.00 & 0.00 & 0.02 & 0.00 & 0.00 & 0.03 & 0.02 \\
\hline AK & 0.00 & 0.00 & 0.01 & 0.00 & 0.00 & 0.00 & 0.00 & 0.00 & 0.00 & 0.01 & 0.00 & 0.00 & 0.00 & 0.00 & 0.00 & 0.00 & 0.00 \\
\hline SUM_A & 0.04 & 0.00 & 0.03 & 0.00 & 0.04 & 0.00 & 0.00 & 0.00 & 0.00 & 0.01 & 0.00 & 0.00 & 0.03 & 0.00 & 0.00 & 0.03 & 0.02 \\
\hline SUM_CAT & 15.04 & 14.98 & 15.03 & 14.99 & 15.04 & 14.96 & 14.99 & 14.95 & 15.07 & 14.98 & 14.97 & 14.94 & 15.03 & 14.98 & 14.98 & 15.03 & 15.02 \\
\hline $\mathrm{CCl}$ & 0.00 & 0.00 & 0.00 & 0.00 & 0.00 & 0.00 & 0.00 & 0.00 & 0.00 & 0.00 & 0.00 & 0.00 & 0.00 & 0.00 & 0.00 & 0.00 & 0.00 \\
\hline $\mathrm{CF}$ & 0.00 & 0.00 & 0.00 & 0.00 & 0.00 & 0.00 & 0.00 & 0.00 & 0.00 & 0.00 & 0.00 & 0.01 & 0.00 & 0.00 & 0.00 & 0.00 & 0.00 \\
\hline $\mathrm{OH}$ & 0.00 & 0.00 & 0.00 & 0.00 & 0.00 & 0.00 & 0.00 & 0.00 & 0.00 & 0.00 & 0.00 & 0.00 & 0.00 & 0.00 & 0.00 & 0.00 & 0.00 \\
\hline SUM_OXY & 23 & 23 & 23 & 23 & 23 & 23 & 23 & 23 & 23 & 23 & 23 & 23 & 23 & 23 & 23 & 23 & 23 \\
\hline
\end{tabular}


Análises de química mineral de anfibólio selecionados da região de Barragán

\begin{tabular}{|c|c|c|c|c|c|c|c|c|c|c|}
\hline Amostra & 196D & 196D & 196D & 196D & 196D & 196D & 196D & 196D & 196D & 196D \\
\hline Análise & 131 & 132 & 133 & 134 & 65 & 81 & 82 & 83 & 84 & 85 \\
\hline SiO2 & 58.99 & 57.51 & 57.61 & 58.53 & 57.69 & 58.22 & 58.48 & 57.42 & 57.91 & 58.53 \\
\hline TiO2 & 0.02 & 0.07 & 0.05 & 0.05 & 0.02 & 0.00 & 0.00 & 0.00 & 0.00 & 0.01 \\
\hline Al2O3 & 10.58 & 10.93 & 11.59 & 10.59 & 11.62 & 10.62 & 10.77 & 10.32 & 10.43 & 10.57 \\
\hline $\mathrm{FeO}$ & 11.52 & 11.63 & 11.48 & 11.89 & 11.36 & 12.06 & 12.03 & 12.56 & 11.95 & 12.11 \\
\hline Cr2O3 & 0.00 & 0.00 & 0.00 & 0.00 & 0.00 & 0.00 & 0.00 & 0.00 & 0.00 & 0.00 \\
\hline MnO & 0.12 & 0.14 & 0.15 & 0.13 & 0.13 & 0.10 & 0.14 & 0.13 & 0.13 & 0.11 \\
\hline $\mathrm{MgO}$ & 10.01 & 10.29 & 10.04 & 9.98 & 9.55 & 9.97 & 9.68 & 9.67 & 9.95 & 9.72 \\
\hline $\mathrm{CaO}$ & 1.14 & 2.06 & 1.27 & 1.08 & 1.11 & 1.23 & 0.99 & 1.45 & 1.49 & 1.03 \\
\hline $\mathrm{Na2O}$ & 6.89 & 6.23 & 6.97 & 6.53 & 6.40 & 7.21 & 6.58 & 6.58 & 6.71 & 7.00 \\
\hline K2O & 0.01 & 0.02 & 0.00 & 0.01 & 0.81 & 0.00 & 0.00 & 0.43 & 0.02 & 0.00 \\
\hline $\mathbf{F}$ & 0.00 & 0.00 & 0.00 & 0.00 & 0.00 & 0.00 & 0.00 & 0.01 & 0.00 & 0.00 \\
\hline $\mathrm{Cl}$ & 0.00 & 0.00 & 0.00 & 0.00 & 0.00 & 0.00 & 0.00 & 0.00 & 0.00 & 0.00 \\
\hline TOTAL & 99.27 & 98.87 & 99.16 & 98.79 & 98.67 & 99.40 & 98.68 & 98.56 & 98.59 & 99.07 \\
\hline $\mathrm{O} F \mathrm{Cl}$ & 0.00 & 0.00 & 0.00 & 0.00 & 0.00 & 0.00 & 0.00 & 0.00 & 0.00 & 0.00 \\
\hline O_F & 0.00 & 0.00 & 0.00 & 0.00 & 0.00 & 0.00 & 0.00 & 0.00 & 0.00 & 0.00 \\
\hline O_Cl & 0.00 & 0.00 & 0.00 & 0.00 & 0.00 & 0.00 & 0.00 & 0.00 & 0.00 & 0.00 \\
\hline $\mathrm{H} 2 \mathrm{O}$ & 0.00 & 0.00 & 0.00 & 0.00 & 0.00 & 0.00 & 0.00 & 0.00 & 0.00 & 0.00 \\
\hline CTOTAL & 99.27 & 98.87 & 99.16 & 98.79 & 98.67 & 99.40 & 98.68 & 98.56 & 98.59 & 99.07 \\
\hline $\mathrm{Si}$ & 7.98 & 7.82 & 7.80 & 7.93 & 7.88 & 7.90 & 7.94 & 7.89 & 7.91 & 7.95 \\
\hline Al & 0.02 & 0.18 & 0.20 & 0.07 & 0.12 & 0.10 & 0.06 & 0.11 & 0.09 & 0.05 \\
\hline Fe3 & 0.00 & 0.00 & 0.00 & 0.00 & 0.00 & 0.00 & 0.00 & 0.00 & 0.00 & 0.00 \\
\hline $\mathrm{Ti}$ & 0.00 & 0.00 & 0.00 & 0.00 & 0.00 & 0.00 & 0.00 & 0.00 & 0.00 & 0.00 \\
\hline SUM_T & 8.00 & 8.00 & 8.00 & 8.00 & 8.00 & 8.00 & 8.00 & 8.00 & 8.00 & 8.00 \\
\hline Cal & 1.66 & 1.57 & 1.65 & 1.62 & 1.74 & 1.60 & 1.66 & 1.56 & 1.59 & 1.64 \\
\hline $\mathrm{CCr}$ & 0.00 & 0.00 & 0.00 & 0.00 & 0.00 & 0.00 & 0.00 & 0.00 & 0.00 & 0.00 \\
\hline CFe3 & 0.22 & 0.36 & 0.33 & 0.41 & 0.22 & 0.24 & 0.38 & 0.29 & 0.28 & 0.26 \\
\hline Cti & 0.00 & 0.01 & 0.01 & 0.01 & 0.00 & 0.00 & 0.00 & 0.00 & 0.00 & 0.00 \\
\hline CMg & 2.02 & 2.09 & 2.03 & 2.02 & 1.94 & 2.02 & 1.96 & 1.98 & 2.03 & 1.97 \\
\hline CFe2 & 1.09 & 0.97 & 0.97 & 0.93 & 1.08 & 1.13 & 0.98 & 1.15 & 1.09 & 1.11 \\
\hline CMn & 0.01 & 0.02 & 0.02 & 0.02 & 0.01 & 0.01 & 0.02 & 0.02 & 0.02 & 0.01 \\
\hline Cca & 0.00 & 0.00 & 0.00 & 0.00 & 0.00 & 0.00 & 0.00 & 0.00 & 0.00 & 0.00 \\
\hline SUM_C & 5.00 & 5.00 & 5.00 & 5.00 & 5.00 & 5.00 & 5.00 & 5.00 & 5.00 & 5.00 \\
\hline BMg & 0.00 & 0.00 & 0.00 & 0.00 & 0.00 & 0.00 & 0.00 & 0.00 & 0.00 & 0.00 \\
\hline BFe2 & 0.00 & 0.00 & 0.00 & 0.00 & 0.00 & 0.00 & 0.00 & 0.00 & 0.00 & 0.00 \\
\hline BMn & 0.00 & 0.00 & 0.00 & 0.00 & 0.00 & 0.00 & 0.00 & 0.00 & 0.00 & 0.00 \\
\hline $\mathrm{BCa}$ & 0.17 & 0.30 & 0.19 & 0.16 & 0.16 & 0.18 & 0.14 & 0.21 & 0.22 & 0.15 \\
\hline $\mathrm{BNa}$ & 1.81 & 1.64 & 1.82 & 1.71 & 1.69 & 1.82 & 1.73 & 1.75 & 1.78 & 1.84 \\
\hline SUM_B & 1.97 & 1.94 & 2.00 & 1.87 & 1.86 & 2.00 & 1.88 & 1.97 & 2.00 & 1.99 \\
\hline $\mathrm{ACa}^{-}$ & 0.00 & 0.00 & 0.00 & 0.00 & 0.00 & 0.00 & 0.00 & 0.00 & 0.00 & 0.00 \\
\hline ANa & 0.00 & 0.00 & 0.02 & 0.00 & 0.00 & 0.08 & 0.00 & 0.00 & 0.00 & 0.00 \\
\hline AK & 0.00 & 0.00 & 0.00 & 0.00 & 0.14 & 0.00 & 0.00 & 0.08 & 0.00 & 0.00 \\
\hline SUM_A & 0.00 & 0.00 & 0.02 & 0.00 & 0.14 & 0.08 & 0.00 & 0.08 & 0.00 & 0.00 \\
\hline SUM_CAT & 14.97 & 14.94 & 15.02 & 14.87 & 15.00 & 15.08 & 14.88 & 15.04 & 15.00 & 14.99 \\
\hline $\mathrm{CCl}^{-}$ & 0.00 & 0.00 & 0.00 & 0.00 & 0.00 & 0.00 & 0.00 & 0.00 & 0.00 & 0.00 \\
\hline CF & 0.00 & 0.00 & 0.00 & 0.00 & 0.00 & 0.00 & 0.00 & 0.00 & 0.00 & 0.00 \\
\hline $\mathrm{OH}$ & 0.00 & 0.00 & 0.00 & 0.00 & 0.00 & 0.00 & 0.00 & 0.00 & 0.00 & 0.00 \\
\hline SUM OXY & 23 & 23 & 23 & 23 & 23 & 23 & 23 & 23 & 23 & 23 \\
\hline
\end{tabular}

\begin{tabular}{|c|c|c|c|c|c|c|}
\hline 197 & 197 & 197 & 197 & 197 & 197 & 197 \\
\hline 14 & 15 & 17 & 18 & 19 & 20 & 21 \\
\hline 58.35 & 58.00 & 57.57 & 57.76 & 58.47 & 58.43 & 58.23 \\
\hline 0.00 & 0.02 & 0.00 & 0.02 & 0.02 & 0.00 & 0.01 \\
\hline 11.17 & 10.69 & 9.46 & 9.77 & 11.27 & 10.96 & 10.30 \\
\hline 12.25 & 12.62 & 14.69 & 15.05 & 13.37 & 13.92 & 14.61 \\
\hline 0.00 & 0.00 & 0.00 & 0.00 & 0.00 & 0.00 & 0.00 \\
\hline 0.12 & 0.20 & 0.08 & 0.10 & 0.10 & 0.05 & 0.05 \\
\hline 8.93 & 9.16 & 8.97 & 8.57 & 8.15 & 8.15 & 8.04 \\
\hline 0.84 & 1.58 & 2.34 & 1.66 & 0.25 & 0.49 & 0.85 \\
\hline 6.99 & 6.71 & 6.20 & 6.64 & 7.46 & 7.20 & 7.04 \\
\hline 0.02 & 0.02 & 0.00 & 0.01 & 0.01 & 0.01 & 0.00 \\
\hline 0.00 & 0.00 & 0.02 & 0.00 & 0.00 & 0.00 & 0.00 \\
\hline 0.00 & 0.00 & 0.00 & 0.00 & 0.00 & 0.00 & 0.00 \\
\hline 98.66 & 99.01 & 99.32 & 99.58 & 99.09 & 99.21 & 99.13 \\
\hline 0.00 & 0.00 & 0.01 & 0.00 & 0.00 & 0.00 & 0.00 \\
\hline 0.00 & 0.00 & 0.01 & 0.00 & 0.00 & 0.00 & 0.00 \\
\hline 0.00 & 0.00 & 0.00 & 0.00 & 0.00 & 0.00 & 0.00 \\
\hline 0.00 & 0.00 & 0.00 & 0.00 & 0.00 & 0.00 & 0.00 \\
\hline 98.66 & 99.01 & 99.31 & 99.58 & 99.09 & 99.21 & 99.13 \\
\hline 7.97 & 7.94 & 7.93 & 7.93 & 7.99 & 7.98 & 8.00 \\
\hline 0.03 & 0.06 & 0.08 & 0.07 & 0.01 & 0.02 & 0.00 \\
\hline 0.00 & 0.00 & 0.00 & 0.00 & 0.00 & 0.00 & 0.00 \\
\hline 0.00 & 0.00 & 0.00 & 0.00 & 0.00 & 0.00 & 0.00 \\
\hline 8.00 & 8.00 & 8.00 & 8.00 & 8.00 & 8.00 & 8.00 \\
\hline 1.77 & 1.66 & 1.46 & 1.51 & 1.80 & 1.74 & 1.67 \\
\hline 0.00 & 0.00 & 0.00 & 0.00 & 0.00 & 0.00 & 0.00 \\
\hline 0.16 & 0.15 & 0.27 & 0.31 & 0.16 & 0.22 & 0.21 \\
\hline 0.00 & 0.00 & 0.00 & 0.00 & 0.00 & 0.00 & 0.00 \\
\hline 1.82 & 1.87 & 1.84 & 1.75 & 1.66 & 1.66 & 1.65 \\
\hline 1.24 & 1.30 & 1.42 & 1.42 & 1.37 & 1.37 & 1.47 \\
\hline 0.01 & 0.02 & 0.01 & 0.01 & 0.01 & 0.01 & 0.01 \\
\hline 0.00 & 0.00 & 0.00 & 0.00 & 0.00 & 0.00 & 0.00 \\
\hline 5.00 & 5.00 & 5.00 & 5.00 & 5.00 & 5.00 & 5.00 \\
\hline 0.00 & 0.00 & 0.00 & 0.00 & 0.00 & 0.00 & 0.00 \\
\hline 0.00 & 0.00 & 0.00 & 0.00 & 0.00 & 0.00 & 0.00 \\
\hline 0.00 & 0.00 & 0.00 & 0.00 & 0.00 & 0.00 & 0.00 \\
\hline 0.12 & 0.23 & 0.35 & 0.24 & 0.04 & 0.07 & 0.12 \\
\hline 1.85 & 1.77 & 1.66 & 1.76 & 1.96 & 1.91 & 1.88 \\
\hline 1.97 & 2.00 & 2.00 & 2.00 & 2.00 & 1.98 & 2.00 \\
\hline 0.00 & 0.00 & 0.00 & 0.00 & 0.00 & 0.00 & 0.00 \\
\hline 0.00 & 0.01 & 0.00 & 0.01 & 0.01 & 0.00 & 0.00 \\
\hline 0.00 & 0.00 & 0.00 & 0.00 & 0.00 & 0.00 & 0.00 \\
\hline 0.00 & 0.02 & 0.00 & 0.01 & 0.01 & 0.00 & 0.00 \\
\hline 14.98 & 15.02 & 15.00 & 15.01 & 15.01 & 14.98 & 15.00 \\
\hline 0.00 & 0.00 & 0.00 & 0.00 & 0.00 & 0.00 & 0.00 \\
\hline 0.00 & 0.00 & 0.01 & 0.00 & 0.00 & 0.00 & 0.00 \\
\hline 0.00 & 0.00 & 0.00 & 0.00 & 0.00 & 0.00 & 0.00 \\
\hline 23 & 23 & 23 & 23 & 23 & 23 & 23 \\
\hline
\end{tabular}


Análises de química mineral de anfibólio selecionados da reqião de Barraqán

\begin{tabular}{|c|c|c|c|c|c|c|c|c|c|c|c|c|c|c|c|c|c|}
\hline Amostra & 197 & 197 & 197 & 197 & 197 & 197 & 199 & 199 & 199 & 199 & 199 & 199 & 199 & 199 & 199 & 199 & 199 \\
\hline Análise & 23 & 42 & 43 & 44 & 45 & 47 & 216 & 217 & 218 & 219 & 220 & 221 & 222 & 224 & 225 & 226 & 230 \\
\hline $\mathrm{SiO} 2$ & 58.77 & 58.68 & 58.04 & 57.74 & 57.88 & 58.82 & 56.71 & 58.04 & 56.29 & 56.42 & 57.07 & 56.82 & 57.36 & 57.68 & 56.96 & 57.44 & 56.69 \\
\hline TiO2 & 0.00 & 0.04 & 0.02 & 0.00 & 0.03 & 0.03 & 0.06 & 0.01 & 0.08 & 0.00 & 0.06 & 0.02 & 0.04 & 0.03 & 0.00 & 0.03 & 0.00 \\
\hline $\mathrm{Al} 2 \mathrm{O} 3$ & 10.77 & 10.61 & 10.93 & 8.05 & 11.01 & 10.81 & 11.34 & 11.95 & 11.70 & 11.03 & 8.89 & 8.06 & 10.01 & 10.49 & 10.98 & 10.25 & 10.72 \\
\hline $\mathrm{FeO}$ & 14.53 & 12.65 & 12.82 & 12.15 & 12.67 & 13.76 & 12.18 & 11.08 & 12.80 & 12.10 & 13.55 & 12.58 & 12.61 & 12.40 & 12.04 & 12.25 & 13.12 \\
\hline Cr2O3 & 0.00 & 0.00 & 0.00 & 0.00 & 0.00 & 0.00 & 0.00 & 0.00 & 0.00 & 0.00 & 0.00 & 0.00 & 0.00 & 0.00 & 0.00 & 0.00 & 0.00 \\
\hline MnO & 0.08 & 0.13 & 0.13 & 0.15 & 0.09 & 0.10 & 0.18 & 0.07 & 0.17 & 0.14 & 0.16 & 0.11 & 0.15 & 0.14 & 0.06 & 0.18 & 0.17 \\
\hline $\mathrm{MgO}$ & 8.00 & 8.50 & 8.83 & 11.03 & 9.34 & 8.05 & 9.65 & 9.51 & 9.34 & 10.20 & 9.69 & 11.16 & 9.50 & 9.26 & 9.86 & 9.80 & 9.26 \\
\hline $\mathrm{CaO}$ & 0.64 & 0.96 & 1.20 & 4.09 & 1.45 & 0.22 & 1.71 & 0.89 & 2.00 & 2.10 & 2.03 & 4.34 & 1.47 & 1.05 & 1.46 & 1.96 & 1.56 \\
\hline $\mathrm{Na} 2 \mathrm{O}$ & 7.40 & 6.85 & 6.95 & 5.25 & 6.82 & 7.40 & 6.68 & 7.05 & 6.66 & 6.61 & 6.23 & 5.41 & 6.64 & 6.69 & 6.79 & 6.20 & 6.79 \\
\hline K2O & 0.01 & 0.01 & 0.02 & 0.02 & 0.01 & 0.02 & 0.00 & 0.00 & 0.00 & 0.00 & 0.00 & 0.00 & 0.00 & 0.00 & 0.00 & 0.00 & 0.00 \\
\hline $\mathbf{F}$ & 0.00 & 0.02 & 0.00 & 0.01 & 0.00 & 0.00 & 0.08 & 0.00 & 0.00 & 0.00 & 0.00 & 0.09 & 0.06 & 0.00 & 0.00 & 0.00 & 0.00 \\
\hline Cl & 0.00 & 0.00 & 0.00 & 0.00 & 0.00 & 0.00 & 0.00 & 0.00 & 0.00 & 0.00 & 0.00 & 0.00 & 0.00 & 0.00 & 0.00 & 0.00 & 0.00 \\
\hline TOTAL & 100.18 & 98.45 & 98.92 & 98.48 & 99.29 & 99.21 & 98.60 & 98.59 & 99.05 & 98.60 & 97.68 & 98.59 & 97.83 & 97.73 & 98.17 & 98.11 & 98.31 \\
\hline O_F_Cl & 0.00 & 0.01 & 0.00 & 0.01 & 0.00 & 0.00 & 0.04 & 0.00 & 0.00 & 0.00 & 0.00 & 0.04 & 0.02 & 0.00 & 0.00 & 0.00 & 0.00 \\
\hline O_F & 0.00 & 0.01 & 0.00 & 0.01 & 0.00 & 0.00 & 0.04 & 0.00 & 0.00 & 0.00 & 0.00 & 0.04 & 0.02 & 0.00 & 0.00 & 0.00 & 0.00 \\
\hline O_Cl & 0.00 & 0.00 & 0.00 & 0.00 & 0.00 & 0.00 & 0.00 & 0.00 & 0.00 & 0.00 & 0.00 & 0.00 & 0.00 & 0.00 & 0.00 & 0.00 & 0.00 \\
\hline $\mathrm{H} \overline{2} \mathrm{O}$ & 0.00 & 0.00 & 0.00 & 0.00 & 0.00 & 0.00 & 0.00 & 0.00 & 0.00 & 0.00 & 0.00 & 0.00 & 0.00 & 0.00 & 0.00 & 0.00 & 0.00 \\
\hline CTOTAL & 100.18 & 98.44 & 98.92 & 98.47 & 99.29 & 99.21 & 98.56 & 98.59 & 99.05 & 98.60 & 97.68 & 98.55 & 97.81 & 97.73 & 98.17 & 98.11 & 98.31 \\
\hline Si & 7.99 & 8.07 & 7.95 & 7.99 & 7.88 & 8.04 & 7.77 & 7.89 & 7.71 & 7.73 & 7.94 & 7.89 & 7.93 & 7.95 & 7.82 & 7.90 & 7.82 \\
\hline Al & 0.01 & 0.00 & 0.05 & 0.01 & 0.12 & 0.00 & 0.23 & 0.11 & 0.29 & 0.27 & 0.06 & 0.11 & 0.07 & 0.05 & 0.18 & 0.10 & 0.18 \\
\hline $\mathrm{Fe} 3$ & 0.00 & 0.00 & 0.00 & 0.00 & 0.00 & 0.00 & 0.00 & 0.00 & 0.00 & 0.00 & 0.00 & 0.00 & 0.00 & 0.00 & 0.00 & 0.00 & 0.00 \\
\hline $\mathrm{Ti}$ & 0.00 & 0.00 & 0.00 & 0.00 & 0.00 & 0.00 & 0.00 & 0.00 & 0.00 & 0.00 & 0.00 & 0.00 & 0.00 & 0.00 & 0.00 & 0.00 & 0.00 \\
\hline SUM_T & 8.00 & 8.07 & 8.00 & 8.00 & 8.00 & 8.04 & 8.00 & 8.00 & 8.00 & 8.00 & 8.00 & 8.00 & 8.00 & 8.00 & 8.00 & 8.00 & 8.00 \\
\hline $\mathrm{Cal}^{-}$ & 1.72 & 1.72 & 1.71 & 1.30 & 1.65 & 1.74 & 1.60 & 1.80 & 1.60 & 1.51 & 1.39 & 1.21 & 1.56 & 1.65 & 1.59 & 1.56 & 1.56 \\
\hline $\mathrm{CCr}$ & 0.00 & 0.00 & 0.00 & 0.00 & 0.00 & 0.00 & 0.00 & 0.00 & 0.00 & 0.00 & 0.00 & 0.00 & 0.00 & 0.00 & 0.00 & 0.00 & 0.00 \\
\hline CFe3 & 0.15 & 0.03 & 0.14 & 0.09 & 0.24 & 0.16 & 0.33 & 0.19 & 0.32 & 0.38 & 0.38 & 0.14 & 0.28 & 0.30 & 0.35 & 0.31 & 0.34 \\
\hline Cti & 0.00 & 0.00 & 0.00 & 0.00 & 0.00 & 0.00 & 0.01 & 0.00 & 0.01 & 0.00 & 0.01 & 0.00 & 0.00 & 0.00 & 0.00 & 0.00 & 0.00 \\
\hline CMg & 1.62 & 1.74 & 1.80 & 2.28 & 1.90 & 1.64 & 1.97 & 1.93 & 1.91 & 2.08 & 2.01 & 2.31 & 1.96 & 1.90 & 2.02 & 2.01 & 1.91 \\
\hline CFe2 & 1.50 & 1.43 & 1.33 & 1.32 & 1.20 & 1.42 & 1.07 & 1.07 & 1.15 & 1.01 & 1.20 & 1.32 & 1.17 & 1.13 & 1.03 & 1.10 & 1.17 \\
\hline CMn & 0.01 & 0.02 & 0.02 & 0.02 & 0.01 & 0.01 & 0.02 & 0.01 & 0.02 & 0.02 & 0.02 & 0.01 & 0.02 & 0.02 & 0.01 & 0.02 & 0.02 \\
\hline Cca & 0.00 & 0.07 & 0.00 & 0.00 & 0.00 & 0.03 & 0.00 & 0.00 & 0.00 & 0.00 & 0.00 & 0.00 & 0.00 & 0.00 & 0.00 & 0.00 & 0.00 \\
\hline SUM_C & 5.00 & 5.00 & 5.00 & 5.00 & 5.00 & 5.00 & 5.00 & 5.00 & 5.00 & 5.00 & 5.00 & 5.00 & 5.00 & 5.00 & 5.00 & 5.00 & 5.00 \\
\hline $\mathrm{BMg}$ & 0.00 & 0.00 & 0.00 & 0.00 & 0.00 & 0.00 & 0.00 & 0.00 & 0.00 & 0.00 & 0.00 & 0.00 & 0.00 & 0.00 & 0.00 & 0.00 & 0.00 \\
\hline BFe2 & 0.00 & 0.00 & 0.00 & 0.00 & 0.00 & 0.00 & 0.00 & 0.00 & 0.00 & 0.00 & 0.00 & 0.00 & 0.00 & 0.00 & 0.00 & 0.00 & 0.00 \\
\hline BMn & 0.00 & 0.00 & 0.00 & 0.00 & 0.00 & 0.00 & 0.00 & 0.00 & 0.00 & 0.00 & 0.00 & 0.00 & 0.00 & 0.00 & 0.00 & 0.00 & 0.00 \\
\hline $\mathrm{BCa}$ & 0.09 & 0.08 & 0.18 & 0.61 & 0.21 & 0.00 & 0.25 & 0.13 & 0.29 & 0.31 & 0.30 & 0.65 & 0.22 & 0.16 & 0.22 & 0.29 & 0.23 \\
\hline $\mathrm{BNa}$ & 1.91 & 1.83 & 1.82 & 1.39 & 1.79 & 1.96 & 1.75 & 1.86 & 1.71 & 1.69 & 1.68 & 1.35 & 1.78 & 1.79 & 1.79 & 1.65 & 1.77 \\
\hline SUM_B & 2.00 & 1.90 & 2.00 & 2.00 & 2.00 & 1.96 & 2.00 & 1.99 & 2.00 & 2.00 & 1.98 & 2.00 & 2.00 & 1.94 & 2.00 & 1.94 & 2.00 \\
\hline $\mathrm{ACa}^{-}$ & 0.00 & 0.00 & 0.00 & 0.00 & 0.00 & 0.00 & 0.00 & 0.00 & 0.00 & 0.00 & 0.00 & 0.00 & 0.00 & 0.00 & 0.00 & 0.00 & 0.00 \\
\hline $\mathrm{ANa}$ & 0.04 & 0.00 & 0.02 & 0.01 & 0.01 & 0.00 & 0.03 & 0.00 & 0.06 & 0.07 & 0.00 & 0.10 & 0.00 & 0.00 & 0.02 & 0.00 & 0.05 \\
\hline AK & 0.00 & 0.00 & 0.00 & 0.00 & 0.00 & 0.00 & 0.00 & 0.00 & 0.00 & 0.00 & 0.00 & 0.00 & 0.00 & 0.00 & 0.00 & 0.00 & 0.00 \\
\hline SUM_A & 0.05 & 0.00 & 0.02 & 0.02 & 0.01 & 0.00 & 0.03 & 0.00 & 0.06 & 0.07 & 0.00 & 0.10 & 0.00 & 0.00 & 0.02 & 0.00 & 0.05 \\
\hline SUM_CAT & 15.05 & 14.97 & 15.02 & 15.02 & 15.01 & 15.00 & 15.03 & 14.99 & 15.06 & 15.07 & 14.98 & 15.10 & 15.00 & 14.94 & 15.02 & 14.94 & 15.05 \\
\hline $\mathrm{CCl}^{-}$ & 0.00 & 0.00 & 0.00 & 0.00 & 0.00 & 0.00 & 0.00 & 0.00 & 0.00 & 0.00 & 0.00 & 0.00 & 0.00 & 0.00 & 0.00 & 0.00 & 0.00 \\
\hline CF & 0.00 & 0.01 & 0.00 & 0.01 & 0.00 & 0.00 & 0.04 & 0.00 & 0.00 & 0.00 & 0.00 & 0.04 & 0.03 & 0.00 & 0.00 & 0.00 & 0.00 \\
\hline $\mathrm{OH}$ & 0.00 & 0.00 & 0.00 & 0.00 & 0.00 & 0.00 & 0.00 & 0.00 & 0.00 & 0.00 & 0.00 & 0.00 & 0.00 & 0.00 & 0.00 & 0.00 & 0.00 \\
\hline SUM_OXY & 23 & 23 & 23 & 23 & 23 & 23 & 23 & 23 & 23 & 23 & 23 & 23 & 23 & 23 & 23 & 23 & 23 \\
\hline
\end{tabular}


Análises de química mineral de anfibólio selecionados da reqião de Barraqán

\begin{tabular}{|c|c|c|c|c|c|c|c|c|c|c|c|c|c|c|c|c|c|c|}
\hline 199 & 199 & 199 & 199 & 199 & 199 & 199 & 199 & 199 & 199 & 199 & 199 & 199 & 199 & 199 & 199 & 199 & 199 & 199 \\
\hline 231 & 247 & 248 & 249 & 250 & 259 & 260 & 261 & 262 & 263 & 264 & 265 & 266 & 268 & 269 & 270 & 272 & 279 & 280 \\
\hline$\overline{57.84}$ & 57.73 & 56.51 & 57.13 & 57.48 & 57.46 & 58.48 & 57.79 & 58.17 & 57.80 & 56.76 & 56.52 & 57.60 & 57.12 & 56.84 & 57.38 & 58.92 & 57.85 & 57.61 \\
\hline 0.05 & 0.00 & 0.03 & 0.04 & 0.01 & 0.03 & 0.05 & 0.02 & 0.00 & 0.03 & 0.01 & 0.06 & 0.02 & 0.02 & 0.07 & 0.02 & 0.00 & 0.07 & 0.02 \\
\hline 10.73 & 9.47 & 10.85 & 10.91 & 10.23 & 10.69 & 11.00 & 10.16 & 10.28 & 9.78 & 10.41 & 10.79 & 10.71 & 10.67 & 10.18 & 9.93 & 10.11 & 10.83 & 10.18 \\
\hline 12.56 & 13.38 & 11.36 & 11.91 & 13.54 & 12.66 & 12.62 & 12.49 & 12.35 & 12.60 & 11.83 & 12.78 & 12.42 & 11.27 & 12.44 & 12.92 & 12.45 & 12.64 & 12.77 \\
\hline 0.00 & 0.00 & 0.00 & 0.00 & 0.00 & 0.00 & 0.00 & 0.00 & 0.00 & 0.00 & 0.00 & 0.00 & 0.00 & 0.00 & 0.00 & 0.00 & 0.00 & 0.00 & 0.00 \\
\hline 0.03 & 0.12 & 0.12 & 0.12 & 0.05 & 0.02 & 0.10 & 0.14 & 0.12 & 0.26 & 0.13 & 0.19 & 0.08 & 0.14 & 0.24 & 0.12 & 0.13 & 0.12 & 0.07 \\
\hline 9.28 & 9.23 & 10.18 & 9.84 & 8.97 & 8.97 & 9.08 & 9.55 & 9.30 & 9.76 & 10.07 & 9.10 & 9.25 & 9.90 & 9.58 & 9.22 & 9.15 & 9.06 & 8.96 \\
\hline 1.10 & 1.31 & 2.09 & 1.58 & 0.49 & 1.03 & 0.64 & 1.28 & 0.96 & 1.81 & 1.94 & 1.04 & 0.96 & 1.43 & 1.74 & 1.77 & 1.10 & 0.83 & 0.67 \\
\hline 6.88 & 6.65 & 6.29 & 6.65 & 7.12 & 6.65 & 7.10 & 6.71 & 6.72 & 6.39 & 6.28 & 6.78 & 6.94 & 6.65 & 6.56 & 6.54 & 7.23 & 6.83 & 7.06 \\
\hline 0.00 & 0.00 & 0.00 & 0.00 & 0.00 & 0.00 & 0.00 & 0.00 & 0.00 & 0.00 & 0.00 & 0.00 & 0.00 & 0.00 & 0.00 & 0.00 & 0.00 & 0.00 & 0.00 \\
\hline 0.00 & 0.00 & 0.00 & 0.00 & 0.08 & 0.00 & 0.00 & 0.20 & 0.14 & 0.08 & 0.08 & 0.00 & 0.00 & 0.00 & 0.20 & 0.00 & 0.06 & 0.00 & 0.14 \\
\hline 0.00 & 0.00 & 0.00 & 0.00 & 0.00 & 0.00 & 0.00 & 0.00 & 0.00 & 0.00 & 0.00 & 0.00 & 0.00 & 0.00 & 0.00 & 0.00 & 0.00 & 0.00 & 0.00 \\
\hline 98.46 & 97.87 & 97.42 & 98.18 & 97.97 & 97.51 & 99.08 & 98.32 & 98.04 & 98.52 & 97.52 & 97.26 & 97.99 & 97.20 & 97.83 & 97.91 & 99.16 & 98.22 & 97.48 \\
\hline 0.00 & 0.00 & 0.00 & 0.00 & 0.03 & 0.00 & 0.00 & 0.08 & 0.06 & 0.04 & 0.04 & 0.00 & 0.00 & 0.00 & 0.08 & 0.00 & 0.02 & 0.00 & 0.06 \\
\hline 0.00 & 0.00 & 0.00 & 0.00 & 0.03 & 0.00 & 0.00 & 0.08 & 0.06 & 0.04 & 0.04 & 0.00 & 0.00 & 0.00 & 0.08 & 0.00 & 0.02 & 0.00 & 0.06 \\
\hline 0.00 & 0.00 & 0.00 & 0.00 & 0.00 & 0.00 & 0.00 & 0.00 & 0.00 & 0.00 & 0.00 & 0.00 & 0.00 & 0.00 & 0.00 & 0.00 & 0.00 & 0.00 & 0.00 \\
\hline 0.00 & 0.00 & 0.00 & 0.00 & 0.00 & 0.00 & 0.00 & 0.00 & 0.00 & 0.00 & 0.00 & 0.00 & 0.00 & 0.00 & 0.00 & & 0.00 & 0.00 & 0.00 \\
\hline 98.46 & 97.87 & 97.42 & 98.18 & 97.94 & 97.51 & 99.08 & 98.24 & 97.98 & 98.48 & 97.48 & 97.26 & 97.99 & 97.20 & 97.75 & & 99.14 & 98.22 & 97.42 \\
\hline 7.93 & 7.99 & 7.81 & 7.84 & 7.93 & 7.94 & 7.95 & 7.94 & 8.00 & 7.94 & 7.85 & 7.84 & 7.93 & 7.90 & 7.88 & 7.96 & 8.06 & 7.93 & 7.99 \\
\hline 0.08 & 0.01 & 0.19 & 0.16 & 0.07 & 0.06 & 0.05 & 0.06 & 0.00 & 0.06 & 0.15 & 0.16 & 0.07 & 0.10 & 0.12 & 0.04 & 0.00 & 0.07 & 0.01 \\
\hline 0.00 & 0.00 & 0.00 & 0.00 & 0.00 & 0.00 & 0.00 & 0.00 & 0.00 & 0.00 & 0.00 & 0.00 & 0.00 & 0.00 & 0.00 & 0.00 & 0.00 & 0.00 & 0.00 \\
\hline 0.00 & 0.00 & 0.00 & 0.00 & 0.00 & 0.00 & 0.00 & 0.00 & 0.00 & 0.00 & 0.00 & 0.00 & 0.00 & 0.00 & 0.00 & 0.00 & 0.00 & 0.00 & 0.00 \\
\hline 8.00 & 8.00 & 8.00 & 8.00 & 8.00 & 8.00 & 8.00 & 8.00 & 8.00 & 8.00 & 8.00 & 8.00 & 8.00 & 8.00 & 8.00 & 8.00 & 8.06 & 8.00 & 8.00 \\
\hline 1.66 & 1.53 & 1.57 & 1.60 & 1.59 & 1.68 & 1.71 & 1.59 & 1.66 & 1.52 & 1.54 & 1.61 & 1.66 & 1.64 & 1.54 & 1.58 & 1.63 & 1.68 & 1.66 \\
\hline 0.00 & 0.00 & 0.00 & 0.00 & 0.00 & 0.00 & 0.00 & 0.00 & 0.00 & 0.00 & 0.00 & 0.00 & 0.00 & 0.00 & 0.00 & 0.00 & 0.00 & 0.00 & 0.00 \\
\hline 0.26 & 0.31 & 0.31 & 0.32 & 0.44 & 0.28 & 0.28 & 0.30 & 0.27 & 0.30 & 0.35 & 0.40 & 0.28 & 0.25 & 0.28 & 0.17 & 0.00 & 0.32 & 0.25 \\
\hline 0.01 & 0.00 & 0.00 & 0.00 & 0.00 & 0.00 & 0.01 & 0.00 & 0.00 & 0.00 & 0.00 & 0.01 & 0.00 & 0.00 & 0.01 & 0.00 & 0.00 & 0.01 & 0.00 \\
\hline 1.90 & 1.90 & 2.10 & 2.01 & 1.84 & 1.85 & 1.84 & 1.96 & 1.91 & 2.00 & 2.08 & 1.88 & 1.90 & 2.04 & 1.98 & 1.91 & 1.87 & 1.85 & 1.85 \\
\hline 1.18 & 1.24 & 1.00 & 1.05 & 1.12 & 1.18 & 1.16 & 1.14 & 1.15 & 1.15 & 1.02 & 1.08 & 1.15 & 1.05 & 1.16 & 1.32 & 1.42 & 1.13 & 1.23 \\
\hline 0.00 & 0.01 & 0.01 & 0.01 & 0.01 & 0.00 & 0.01 & 0.02 & 0.01 & 0.03 & 0.02 & 0.02 & 0.01 & 0.02 & 0.03 & 0.01 & 0.02 & 0.01 & 0.01 \\
\hline 0.00 & 0.00 & 0.00 & 0.00 & 0.00 & 0.00 & 0.00 & 0.00 & 0.00 & 0.00 & 0.00 & 0.00 & 0.00 & 0.00 & 0.00 & 0.00 & 0.06 & 0.00 & 0.00 \\
\hline 5.00 & 5.00 & 5.00 & 5.00 & 5.00 & 5.00 & 5.00 & 5.00 & 5.00 & 5.00 & 5.00 & 5.00 & 5.00 & 5.00 & 5.00 & 5.00 & 5.00 & 5.00 & 5.00 \\
\hline 0.00 & 0.00 & 0.00 & 0.00 & 0.00 & 0.00 & 0.00 & 0.00 & 0.00 & 0.00 & 0.00 & 0.00 & 0.00 & 0.00 & 0.00 & 0.00 & 0.00 & 0.00 & 0.00 \\
\hline 0.00 & 0.00 & 0.00 & 0.00 & 0.00 & 0.00 & 0.00 & 0.00 & 0.00 & 0.00 & 0.00 & 0.00 & 0.00 & 0.00 & 0.00 & 0.00 & 0.00 & 0.00 & 0.00 \\
\hline 0.00 & 0.00 & 0.00 & 0.00 & 0.00 & 0.00 & 0.00 & 0.00 & 0.00 & 0.00 & 0.00 & 0.00 & 0.00 & 0.00 & 0.00 & 0.00 & 0.00 & 0.00 & 0.00 \\
\hline 0.16 & 0.19 & 0.31 & 0.23 & 0.07 & 0.15 & 0.09 & 0.19 & 0.14 & 0.27 & 0.29 & 0.16 & 0.14 & 0.21 & 0.26 & 0.26 & 0.10 & 0.12 & 0.10 \\
\hline 1.83 & 1.78 & 1.68 & 1.77 & 1.90 & 1.78 & 1.87 & 1.79 & 1.79 & 1.70 & 1.68 & 1.83 & 1.85 & 1.78 & 1.74 & 1.74 & 1.90 & 1.82 & 1.90 \\
\hline 1.99 & 1.98 & 1.99 & 2.00 & 1.98 & 1.94 & 1.96 & 1.98 & 1.93 & 1.97 & 1.97 & 1.98 & 1.99 & 2.00 & 2.00 & 2.00 & 2.00 & 1.94 & 2.00 \\
\hline 0.00 & 0.00 & 0.00 & 0.00 & 0.00 & 0.00 & 0.00 & 0.00 & 0.00 & 0.00 & 0.00 & 0.00 & 0.00 & 0.00 & 0.00 & 0.00 & 0.00 & 0.00 & 0.00 \\
\hline 0.00 & 0.00 & 0.00 & 0.00 & 0.00 & 0.00 & 0.00 & 0.00 & 0.00 & 0.00 & 0.00 & 0.00 & 0.00 & 0.00 & 0.02 & 0.02 & 0.02 & 0.00 & 0.00 \\
\hline 0.00 & 0.00 & 0.00 & 0.00 & 0.00 & 0.00 & 0.00 & 0.00 & 0.00 & 0.00 & 0.00 & 0.00 & 0.00 & 0.00 & 0.00 & 0.00 & 0.00 & 0.00 & 0.00 \\
\hline 0.00 & 0.00 & 0.00 & 0.00 & 0.00 & 0.00 & 0.00 & 0.00 & 0.00 & 0.00 & 0.00 & 0.00 & 0.00 & 0.00 & 0.02 & 0.02 & 0.02 & 0.00 & 0.00 \\
\hline 14.99 & 14.98 & 14.99 & 15.00 & 14.98 & 14.94 & 14.96 & 14.98 & 14.93 & 14.97 & 14.97 & 14.98 & 14.99 & 15.00 & 15.02 & 15.02 & 15.08 & 14.94 & 15.00 \\
\hline 0.00 & 0.00 & 0.00 & 0.00 & 0.00 & 0.00 & 0.00 & 0.00 & 0.00 & 0.00 & 0.00 & 0.00 & 0.00 & 0.00 & 0.00 & 0.00 & 0.00 & 0.00 & 0.00 \\
\hline 0.00 & 0.00 & 0.00 & 0.00 & 0.04 & 0.00 & 0.00 & 0.09 & 0.06 & 0.04 & 0.04 & 0.00 & 0.00 & 0.00 & 0.09 & 0.00 & 0.02 & 0.00 & 0.06 \\
\hline 0.00 & 0.00 & 0.00 & 0.00 & 0.00 & 0.00 & 0.00 & 0.00 & 0.00 & 0.00 & 0.00 & 0.00 & 0.00 & 0.00 & 0.00 & 0.00 & 0.00 & 0.00 & 0.00 \\
\hline 23 & 23 & 23 & 23 & 23 & 23 & 23 & 23 & 23 & 23 & 23 & 23 & 23 & 23 & 23 & 23 & 23 & 23 & 23 \\
\hline
\end{tabular}


Análises de química mineral de clorita selecionados da reqião de Barraqán

\begin{tabular}{|c|c|c|c|c|c|c|c|c|c|}
\hline Amostra & 187B & 189 & 189 & 189 & 189 & $189 \mathrm{~A}$ & $189 \mathrm{~A}$ & $189 \mathrm{~A}$ & $189 \mathrm{~A}$ \\
\hline Análise & 52 & 704 & 705 & 706 & 707 & 763 & 764 & 765 & 766 \\
\hline SiO2 & 26.62 & 26.60 & 25.73 & 26.19 & 26.43 & 25.86 & 26.64 & 25.85 & 25.76 \\
\hline TiO2 & 0.03 & 0.01 & 0.02 & 0.05 & 0.04 & 0.05 & 0.04 & 0.05 & 0.06 \\
\hline Al2O3 & 21.40 & 20.90 & 20.94 & 20.90 & 20.70 & 21.70 & 21.69 & 21.41 & 20.54 \\
\hline $\mathrm{Cr} 2 \mathrm{O} 3$ & 0.00 & 0.00 & 0.00 & 0.00 & 0.00 & 0.00 & 0.00 & 0.00 & 0.00 \\
\hline $\mathrm{FeO}$ & 20.31 & 26.19 & 25.44 & 25.21 & 25.86 & 25.98 & 26.76 & 25.80 & 26.55 \\
\hline $\mathrm{Fe} 2 \mathrm{O} 3$ & 0.00 & 0.00 & 0.00 & 0.00 & 0.00 & 0.00 & 0.00 & 0.00 & 0.00 \\
\hline MnO & 0.19 & 0.56 & 0.54 & 0.49 & 0.51 & 0.39 & 0.48 & 0.42 & 0.44 \\
\hline MgO & 18.90 & 14.38 & 14.85 & 14.69 & 14.58 & 14.93 & 13.57 & 14.49 & 13.06 \\
\hline $\mathrm{CaO}$ & 0.14 & 0.06 & 0.09 & 0.15 & 0.08 & 0.06 & 0.06 & 0.08 & 0.14 \\
\hline $\mathrm{Na2O}$ & 0.01 & 0.08 & 0.05 & 0.00 & 0.00 & 0.00 & 0.00 & 0.24 & 0.00 \\
\hline K2O & 0.02 & 0.00 & 0.01 & 0.01 & 0.00 & 0.00 & 0.01 & 0.01 & 0.02 \\
\hline $\mathbf{F}$ & 0.05 & 0.01 & 0.00 & 0.00 & 0.00 & 0.01 & 0.02 & 0.01 & 0.06 \\
\hline $\mathrm{Cl}$ & 0.00 & 0.00 & 0.00 & 0.00 & 0.00 & 0.00 & 0.00 & 0.00 & 0.00 \\
\hline $\mathrm{H} 2 \mathrm{O}$ & 0.00 & 0.00 & 0.00 & 0.00 & 0.00 & 0.00 & 0.00 & 0.00 & 0.00 \\
\hline TOTAL & 87.66 & 88.79 & 87.68 & 87.70 & 88.19 & 88.97 & 89.27 & 88.37 & 86.63 \\
\hline O_F_Cl & 0.02 & 0.00 & 0.00 & 0.00 & 0.00 & 0.01 & 0.01 & 0.01 & 0.03 \\
\hline O_F & 0.02 & 0.00 & 0.00 & 0.00 & 0.00 & 0.01 & 0.01 & 0.01 & 0.03 \\
\hline O_Cl & 0.00 & 0.00 & 0.00 & 0.00 & 0.00 & 0.00 & 0.00 & 0.00 & 0.00 \\
\hline CTOTAL & 87.64 & 88.79 & 87.68 & 87.70 & 88.19 & 88.96 & 89.26 & 88.36 & 86.60 \\
\hline $\mathrm{Si}$ & 5.46 & 5.55 & 5.44 & 5.51 & 5.55 & 5.38 & 5.54 & 5.42 & 5.54 \\
\hline AllV & 2.54 & 2.45 & 2.56 & 2.49 & 2.45 & 2.62 & 2.47 & 2.58 & 2.46 \\
\hline SUM_T & 8.00 & 8.00 & 8.00 & 8.00 & 8.00 & 8.00 & 8.00 & 8.00 & 8.00 \\
\hline AIVI & 2.62 & 2.69 & 2.65 & 2.70 & 2.67 & 2.70 & 2.84 & 2.71 & 2.75 \\
\hline $\mathrm{Ti}$ & 0.01 & 0.00 & 0.00 & 0.01 & 0.01 & 0.01 & 0.01 & 0.01 & 0.01 \\
\hline Fe3 & 0.00 & 0.00 & 0.00 & 0.00 & 0.00 & 0.00 & 0.00 & 0.00 & 0.00 \\
\hline Fe2 & 3.48 & 4.57 & 4.49 & 4.44 & 4.54 & 4.52 & 4.65 & 4.53 & 4.78 \\
\hline $\mathrm{Cr}$ & 0.00 & 0.00 & 0.00 & 0.00 & 0.00 & 0.00 & 0.00 & 0.00 & 0.00 \\
\hline Mn & 0.03 & 0.10 & 0.10 & 0.09 & 0.09 & 0.07 & 0.08 & 0.08 & 0.08 \\
\hline Mg & 5.78 & 4.48 & 4.68 & 4.61 & 4.56 & 4.63 & 4.20 & 4.53 & 4.19 \\
\hline $\mathrm{Ca}$ & 0.03 & 0.01 & 0.02 & 0.03 & 0.02 & 0.01 & 0.01 & 0.02 & 0.03 \\
\hline $\mathrm{Na}$ & 0.00 & 0.03 & 0.02 & 0.00 & 0.00 & 0.00 & 0.00 & 0.10 & 0.00 \\
\hline K & 0.00 & 0.00 & 0.00 & 0.00 & 0.00 & 0.00 & 0.00 & 0.00 & 0.01 \\
\hline CATIONS & 19.95 & 19.89 & 19.96 & 19.88 & 19.88 & 19.94 & 19.80 & 19.97 & 19.84 \\
\hline CF & 0.07 & 0.02 & 0.00 & 0.00 & 0.00 & 0.02 & 0.03 & 0.02 & 0.09 \\
\hline CCL & 0.00 & 0.00 & 0.00 & 0.00 & 0.00 & 0.00 & 0.00 & 0.00 & 0.00 \\
\hline $\mathrm{OH}$ & 0.00 & 0.00 & 0.00 & 0.00 & 0.00 & 0.00 & 0.00 & 0.00 & 0.00 \\
\hline 0 & 36.00 & 36.00 & 36.00 & 36.00 & 36.00 & 36.00 & 36.00 & 36.00 & 36.00 \\
\hline Fe_FeMg & 0.38 & 0.51 & 0.49 & 0.49 & 0.50 & 0.49 & 0.53 & 0.50 & 0.53 \\
\hline $\mathrm{Mg} F \mathrm{FeMg}$ & 0.62 & 0.49 & 0.51 & 0.51 & 0.50 & 0.51 & 0.47 & 0.50 & 0.47 \\
\hline
\end{tabular}

\begin{tabular}{lllll}
\hline $196 \mathrm{D}$ & $196 \mathrm{D}$ & $196 \mathrm{D}$ & $196 \mathrm{D}$ & $196 \mathrm{D}$ \\
\hline 112 & 113 & 114 & 115 & 116 \\
\hline 27.79 & 28.40 & 28.85 & 28.69 & 28.72 \\
0.01 & 0.01 & 0.00 & 0.00 & 0.01 \\
19.21 & 19.11 & 19.20 & 19.04 & 18.86 \\
0.00 & 0.00 & 0.00 & 0.00 & 0.00 \\
21.47 & 21.72 & 23.58 & 21.20 & 21.94 \\
0.00 & 0.00 & 0.00 & 0.00 & 0.00 \\
0.38 & 0.35 & 0.37 & 0.35 & 0.36 \\
19.00 & 19.02 & 17.81 & 19.28 & 20.21 \\
0.16 & 0.14 & 0.22 & 0.16 & 0.22 \\
0.00 & 0.00 & 0.00 & 0.00 & 0.00 \\
0.02 & 0.01 & 0.01 & 0.00 & 0.00 \\
0.01 & 0.04 & 0.01 & 0.01 & 0.03 \\
0.00 & 0.00 & 0.00 & 0.00 & 0.00 \\
0.00 & 0.00 & 0.00 & 0.00 & 0.00 \\
88.05 & 88.78 & 90.04 & 88.74 & 90.35 \\
0.01 & 0.02 & 0.00 & 0.01 & 0.01 \\
0.01 & 0.02 & 0.00 & 0.01 & 0.01 \\
0.00 & 0.00 & 0.00 & 0.00 & 0.00 \\
88.04 & 88.76 & 90.04 & 88.73 & 90.34 \\
5.71 & 5.78 & 5.83 & 5.82 & 5.75 \\
2.29 & 2.22 & 2.17 & 2.18 & 2.25 \\
8.00 & 8.00 & 8.00 & 8.00 & 8.00 \\
2.35 & 2.36 & 2.41 & 2.37 & 2.20 \\
0.00 & 0.00 & 0.00 & 0.00 & 0.00 \\
0.00 & 0.00 & 0.00 & 0.00 & 0.00 \\
3.69 & 3.70 & 3.99 & 3.60 & 3.68 \\
0.00 & 0.00 & 0.00 & 0.00 & 0.00 \\
0.07 & 0.06 & 0.06 & 0.06 & 0.06 \\
5.82 & 5.77 & 5.37 & 5.83 & 6.03 \\
0.03 & 0.03 & 0.05 & 0.04 & 0.05 \\
0.00 & 0.00 & 0.00 & 0.00 & 0.00 \\
0.01 & 0.00 & 0.00 & 0.00 & 0.00 \\
19.97 & 19.92 & 19.88 & 19.90 & 20.02 \\
0.02 & 0.05 & 0.01 & 0.02 & 0.04 \\
0.00 & 0.00 & 0.00 & 0.00 & 0.00 \\
0.00 & 0.00 & 0.00 & 0.00 & 0.00 \\
36.00 & 36.00 & 36.00 & 36.00 & 36.00 \\
0.39 & 0.39 & 0.43 & 0.38 & 0.38 \\
0.61 & 0.61 & 0.57 & 0.62 & 0.62 \\
\hline & & & & \\
\hline & & \\
0.00 &
\end{tabular}

\begin{tabular}{lllllll}
\hline Amostra & 197 & 197 & 197 & 197 & 197 & 197 \\
\hline
\end{tabular} \begin{tabular}{rllllll}
\hline Análise & 10 & 50 & 51 & 52 & 53 & 54 \\
\hline SiO2 & 27.02 & 28.82 & 27.97 & 28.15 & 28.26 & 27.96 \\
TiO2 & 0.05 & 0.12 & 0.11 & 0.18 & 0.21 & 0.27
\end{tabular}

$\begin{array}{llllllll}\text { TiO2 } & 0.05 & 0.12 & 0.11 & 0.18 & 0.21 & 0.27\end{array}$

$\begin{array}{lllllll}\text { Al2O3 } & 20.26 & 20.90 & 19.77 & 20.10 & 19.89 & 19.83\end{array}$

$\begin{array}{lllllll}\mathrm{Cr} 2 \mathrm{O} 3 & 0.00 & 0.00 & 0.00 & 0.00 & 0.00 & 0.00 \\ \mathrm{FeO} & 24.85 & 22.53 & 22.84 & 22.72 & 22.68 & 22.83\end{array}$

$\begin{array}{lllllll}\mathrm{Fe} 2 \mathrm{O} 3 & 0.00 & 0.00 & 0.00 & 0.00 & 0.00 & 0.00\end{array}$

$\begin{array}{lllllll}\text { MnO } & 0.28 & 0.40 & 0.31 & 0.34 & 0.43 & 0.40\end{array}$

$\begin{array}{lllllll}\text { MgO } & 16.44 & 16.78 & 17.93 & 17.79 & 18.42 & 17.52\end{array}$

$\begin{array}{lllllll}\mathrm{CaO} & 0.11 & 0.08 & 0.01 & 0.03 & 0.05 & 0.03\end{array}$

$\begin{array}{lllllll}\mathrm{Na2O} & 0.01 & 0.02 & 0.03 & 0.01 & 0.01 & 0.00 \\ \mathrm{~K} 2 \mathrm{O} & 0.01 & 0.00 & 0.00 & 0.02 & 0.01 & 0.00\end{array}$

$\begin{array}{lllllll}\mathrm{F} & 0.03 & 0.01 & 0.05 & 0.03 & 0.06 & 0.06\end{array}$

$\begin{array}{lllllll}\text { Cl } & 0.00 & 0.00 & 0.00 & 0.00 & 0.00 & 0.00\end{array}$

$\begin{array}{lllllll}\text { H2O } & 0.00 & 0.00 & 0.00 & 0.00 & 0.00 & 0.00 \\ \text { TOTAL } & 89.06 & 89.64 & 89.01 & 89.38 & 90.01 & 88.90\end{array}$

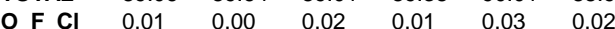

$\begin{array}{lllllll}\text { O_F } & 0.01 & 0.00 & 0.02 & 0.01 & 0.03 & 0.02\end{array}$

$\begin{array}{lllllll}\text { O_Cl } & 0.00 & 0.00 & 0.00 & 0.00 & 0.00 & 0.00\end{array}$

$\begin{array}{lllll}89.64 & 88.99 & 89.37 & 89.98 & 88.88\end{array}$

$\begin{array}{lllllll}\text { Si } & 5.58 & 5.80 & 5.71 & 5.71 & 5.70 & 5.72\end{array}$

$\begin{array}{lllllll}\text { AlIV } & 2.42 & 2.20 & 2.29 & 2.29 & 2.30 & 2.28 \\ \text { SUM T } & 8.00 & 8.00 & 8.00 & 8.00 & 8.00 & 8.00\end{array}$

$\begin{array}{lllllll}\text { AIVI } & 2.51 & 2.76 & 2.46 & 2.52 & 2.42 & 2.49\end{array}$

$\begin{array}{lllllll}\mathrm{Ti} & 0.01 & 0.02 & 0.02 & 0.03 & 0.03 & 0.04\end{array}$

$\begin{array}{lllllll}\text { Fe3 } & 0.00 & 0.00 & 0.00 & 0.00 & 0.00 & 0.00\end{array}$

$\begin{array}{lllllll}\mathrm{Fe} 2 & 4.29 & 3.79 & 3.90 & 3.86 & 3.83 & 3.90 \\ \mathrm{Cr} & 0.00 & 0.00 & 0.00 & 0.00 & 0.00 & 0.00\end{array}$

$\begin{array}{lllllll}\mathrm{Mn} & 0.05 & 0.07 & 0.05 & 0.06 & 0.07 & 0.07\end{array}$

$\begin{array}{lllllll}M g & 5.06 & 5.04 & 5.46 & 5.38 & 5.54 & 5.34\end{array}$

$\begin{array}{lllllll}\mathrm{Ca} & 0.02 & 0.02 & 0.00 & 0.01 & 0.01 & 0.01\end{array}$

$\begin{array}{lllllll}\mathrm{Na} & 0.01 & 0.01 & 0.01 & 0.01 & 0.00 & 0.00\end{array}$

$\begin{array}{llllll}0.00 & 0.00 & 0.00 & 0.01 & 0.00 & 0.00\end{array}$

$\begin{array}{lllllll}\text { CF } & 0.04 & 0.01 & 0.07 & 0.04 & 0.08 & 0.07\end{array}$

$\begin{array}{lllllll}\text { CCL } & 0.00 & 0.00 & 0.00 & 0.00 & 0.00 & 0.00\end{array}$

$\begin{array}{lllllll}\mathrm{OH} & 0.00 & 0.00 & 0.00 & 0.00 & 0.00 & 0.00\end{array}$

\begin{tabular}{lllllll} 
O & 36.00 & 36.00 & 36.00 & 36.00 & 36.00 & 36.00 \\
\hline Fe & 0.46 & 0.43 & 0.42 & 0.42 & 0.41 & 0.42
\end{tabular}

\begin{tabular}{lllllll} 
Mg_FeMg & 0.54 & 0.57 & 0.58 & 0.58 & 0.59 & 0.58 \\
\hline
\end{tabular}

\begin{tabular}{|c|c|c|c|c|c|c|c|c|c|c|}
\hline $197 \mathrm{~A}$ & $197 \mathrm{~A}$ & $197 \mathrm{~A}$ & $197 \mathrm{~A}$ & $197 \mathrm{~A}$ & $197 A$ & $197 \mathrm{~A}$ & $197 \mathrm{~A}$ & 197A & 197A & $197 \mathrm{~A}$ \\
\hline 101 & 110 & 111 & 112 & 118 & 119 & 12 & 120 & 121 & 122 & 126 \\
\hline 27.72 & 27.72 & 28.11 & 28.62 & 27.55 & 27.11 & 27.82 & 27.63 & 28.16 & 28.84 & 27.24 \\
\hline 0.03 & 0.18 & 0.00 & 0.03 & 0.01 & 0.09 & 0.01 & 0.12 & 0.00 & 0.06 & 0.00 \\
\hline 20.48 & 20.30 & 19.85 & 19.39 & 19.65 & 20.29 & 19.75 & 20.13 & 18.94 & 20.01 & 19.68 \\
\hline 0.00 & 0.00 & 0.00 & 0.00 & 0.00 & 0.00 & 0.00 & 0.00 & 0.00 & 0.00 & 0.00 \\
\hline 21.07 & 20.77 & 20.45 & 20.69 & 21.34 & 21.58 & 21.04 & 21.06 & 21.56 & 21.02 & 21.31 \\
\hline 0.00 & 0.00 & 0.00 & 0.00 & 0.00 & 0.00 & 0.00 & 0.00 & 0.00 & 0.00 & 0.00 \\
\hline 0.35 & 0.42 & 0.35 & 0.27 & 0.46 & 0.25 & 0.41 & 0.41 & 0.38 & 0.45 & 0.33 \\
\hline 18.40 & 18.47 & 19.57 & 20.13 & 18.62 & 18.70 & 18.95 & 18.76 & 19.00 & 19.58 & 18.91 \\
\hline 0.03 & 0.03 & 0.01 & 0.02 & 0.02 & 0.02 & 0.03 & 0.07 & 0.07 & 0.03 & 0.06 \\
\hline 0.00 & 0.00 & 0.02 & 0.00 & 0.01 & 0.00 & 0.03 & 0.00 & 0.01 & 0.01 & 0.01 \\
\hline 0.00 & 0.00 & 0.00 & 0.00 & 0.00 & 0.00 & 0.00 & 0.00 & 0.00 & 0.00 & 0.00 \\
\hline 0.15 & 0.00 & 0.15 & 0.13 & 0.00 & 0.00 & 0.18 & 0.00 & 0.20 & 0.10 & 0.10 \\
\hline 0.00 & 0.00 & 0.00 & 0.00 & 0.00 & 0.00 & 0.00 & 0.00 & 0.00 & 0.00 & 0.00 \\
\hline 0.00 & 0.00 & 0.00 & 0.00 & 0.00 & 0.00 & 0.00 & 0.00 & 0.00 & 0.00 & 0.00 \\
\hline 88.22 & 87.88 & 88.52 & 89.27 & 87.66 & 88.05 & 88.20 & 88.18 & 88.32 & 90.10 & 87.63 \\
\hline 0.06 & 0.00 & 0.06 & 0.05 & 0.00 & 0.00 & 0.07 & 0.00 & 0.08 & 0.04 & 0.04 \\
\hline 0.06 & 0.00 & 0.06 & 0.05 & 0.00 & 0.00 & 0.07 & 0.00 & 0.08 & 0.04 & 0.04 \\
\hline 0.00 & 0.00 & 0.00 & 0.00 & 0.00 & 0.00 & 0.00 & 0.00 & 0.00 & 0.00 & 0.00 \\
\hline 88.16 & 87.88 & 88.46 & 89.22 & 87.66 & 88.05 & 88.13 & 88.18 & 88.24 & 90.06 & 87.59 \\
\hline 5.66 & 5.67 & 5.71 & 5.76 & 5.68 & 5.57 & 5.69 & 5.65 & 5.77 & 5.75 & 5.62 \\
\hline 2.34 & 2.33 & 2.29 & 2.24 & 2.32 & 2.44 & 2.31 & 2.36 & 2.23 & 2.25 & 2.38 \\
\hline 8.00 & 8.00 & 8.00 & 8.00 & 8.00 & 8.00 & 8.00 & 8.00 & 8.00 & 8.00 & 8.00 \\
\hline 2.59 & 2.56 & 2.45 & 2.36 & 2.44 & 2.47 & 2.45 & 2.49 & 2.35 & 2.46 & 2.41 \\
\hline 0.00 & 0.03 & 0.00 & 0.00 & 0.00 & 0.01 & 0.00 & 0.02 & 0.00 & 0.01 & 0.00 \\
\hline 0.00 & 0.00 & 0.00 & 0.00 & 0.00 & 0.00 & 0.00 & 0.00 & 0.00 & 0.00 & 0.00 \\
\hline 3.60 & 3.55 & 3.47 & 3.48 & 3.68 & 3.71 & 3.60 & 3.60 & 3.70 & 3.51 & 3.68 \\
\hline 0.00 & 0.00 & 0.00 & 0.00 & 0.00 & 0.00 & 0.00 & 0.00 & 0.00 & 0.00 & 0.00 \\
\hline 0.06 & 0.07 & 0.06 & 0.05 & 0.08 & 0.04 & 0.07 & 0.07 & 0.07 & 0.08 & 0.06 \\
\hline 5.60 & 5.63 & 5.92 & 6.04 & 5.72 & 5.72 & 5.78 & 5.71 & 5.81 & 5.82 & 5.82 \\
\hline 0.01 & 0.01 & 0.00 & 0.00 & 0.01 & 0.00 & 0.01 & 0.02 & 0.01 & 0.01 & 0.01 \\
\hline 0.00 & 0.00 & 0.01 & 0.00 & 0.00 & 0.00 & 0.01 & 0.00 & 0.00 & 0.01 & 0.00 \\
\hline 0.00 & 0.00 & 0.00 & 0.00 & 0.00 & 0.00 & 0.00 & 0.00 & 0.00 & 0.00 & 0.00 \\
\hline 19.86 & 19.85 & 19.92 & 19.93 & 19.93 & 19.96 & 19.93 & 19.91 & 19.94 & 19.88 & 19.98 \\
\hline 0.19 & 0.00 & 0.19 & 0.16 & 0.00 & 0.00 & 0.23 & 0.00 & 0.26 & 0.13 & 0.13 \\
\hline 0.00 & 0.00 & 0.00 & 0.00 & 0.00 & 0.00 & 0.00 & 0.00 & 0.00 & 0.00 & 0.00 \\
\hline 0.00 & 0.00 & 0.00 & 0.00 & 0.00 & 0.00 & 0.00 & 0.00 & 0.00 & 0.00 & 0.00 \\
\hline 36.00 & 36.00 & 36.00 & 36.00 & 36.00 & 36.00 & 36.00 & 36.00 & 36.00 & 36.00 & 36.00 \\
\hline 0.39 & 0.39 & 0.37 & 0.37 & 0.39 & 0.39 & 0.38 & 0.39 & 0.39 & 0.38 & 0.39 \\
\hline 0.61 & 0.61 & 0.63 & 0.63 & 0.61 & 0.61 & 0.62 & 0.61 & 0.61 & 0.62 & 0.61 \\
\hline
\end{tabular}


Análises de química mineral de granada selecionados da região de Barraqán

\begin{tabular}{|c|c|c|c|c|c|c|c|c|c|c|c|c|c|c|c|}
\hline Amostra & $187 A$ & $187 A$ & $187 A$ & $187 A$ & $187 A$ & $187 A$ & $187 A$ & $187 A$ & $187 A$ & $187 A$ & $187 A$ & $187 A$ & $187 A$ & $187 A$ & $187 A$ \\
\hline Análise & 633 & 634 & 635 & 636 & 637 & 638 & 639 & 640 & 641 & 642 & 643 & 644 & 645 & 646 & 647 \\
\hline SiO2 & 38.17 & 37.85 & 37.44 & 37.53 & 37.63 & 37.71 & 37.86 & 37.68 & 37.38 & 37.88 & 37.33 & 37.73 & 37.78 & 37.75 & 38.22 \\
\hline TiO2 & 0.08 & 0.07 & 0.09 & 0.14 & 0.19 & 0.21 & 0.20 & 0.11 & 0.15 & 0.17 & 0.16 & 0.08 & 0.09 & 0.11 & 0.04 \\
\hline $\mathrm{Al} 2 \mathrm{O} 3$ & 22.48 & 22.24 & 22.00 & 22.17 & 22.12 & 22.06 & 22.13 & 21.99 & 22.12 & 22.05 & 22.03 & 27.97 & 22.24 & 22.35 & 22.44 \\
\hline Cr2O3 & 0.00 & 0.00 & 0.00 & 0.00 & 0.00 & 0.00 & 0.00 & 0.00 & 0.00 & 0.00 & 0.00 & 0.00 & 0.00 & 0.00 & 0.00 \\
\hline $\mathrm{FeO}$ & 25.47 & 25.72 & 24.33 & 24.13 & 23.34 & 22.73 & 23.16 & 23.39 & 23.38 & 23.68 & 24.37 & 25.30 & 25.53 & 24.51 & 24.90 \\
\hline $\mathrm{Fe} 2 \mathrm{O} 3$ & 0.00 & 0.00 & 0.00 & 0.00 & 0.00 & 0.00 & 0.00 & 0.00 & 0.00 & 0.00 & 0.00 & 0.00 & 0.00 & 0.00 & 0.00 \\
\hline MnO & 0.81 & 2.97 & 4.06 & 4.73 & 5.24 & 5.25 & 5.44 & 5.63 & 5.47 & 4.90 & 4.28 & 3.90 & 2.56 & 1.40 & 0.73 \\
\hline $\mathrm{MgO}$ & 4.22 & 2.77 & 2.12 & 2.57 & 1.97 & 2.13 & 2.03 & 2.05 & 1.82 & 2.00 & 2.02 & 2.17 & 2.45 & 3.22 & 3.50 \\
\hline $\mathrm{CaO}$ & 11.03 & 10.55 & 10.43 & 10.59 & 10.88 & 11.11 & 10.41 & 10.27 & 10.31 & 10.63 & 10.73 & 10.22 & 10.67 & 11.58 & 11.36 \\
\hline $\mathrm{Na} 2 \mathrm{O}$ & 0.14 & 0.14 & 0.14 & 0.00 & 0.06 & 0.00 & 0.00 & 0.14 & 0.17 & 0.06 & 0.00 & 0.00 & 0.06 & 0.00 & 0.00 \\
\hline$F$ & 0.00 & 0.00 & 0.00 & 0.00 & 0.00 & 0.00 & 0.00 & 0.00 & 0.00 & 0.00 & 0.00 & 0.00 & 0.00 & 0.00 & 0.00 \\
\hline $\mathrm{Cl}$ & 0.00 & 0.00 & 0.00 & 0.00 & 0.00 & 0.00 & 0.00 & 0.00 & 0.00 & 0.00 & 0.00 & 0.00 & 0.00 & 0.00 & 0.00 \\
\hline TOTAL & 102.39 & 102.29 & 100.61 & 101.85 & 101.44 & 101.21 & 101.21 & 101.26 & 100.80 & 101.37 & 100.92 & 107.37 & 101.38 & 100.91 & 101.18 \\
\hline FeOCALC & 25.47 & 25.72 & 24.33 & 24.13 & 23.34 & 22.73 & 23.16 & 23.39 & 23.38 & 23.68 & 24.37 & 25.30 & 25.53 & 24.51 & 24.90 \\
\hline Fe2O3CALC & 0.00 & 0.00 & 0.00 & 0.00 & 0.00 & 0.00 & 0.00 & 0.00 & 0.00 & 0.00 & 0.00 & 0.00 & 0.00 & 0.00 & 0.00 \\
\hline TOTALCALC & 102.39 & 102.29 & 100.61 & 101.85 & 101.44 & 101.21 & 101.21 & 101.26 & 100.80 & 101.37 & 100.92 & 107.37 & 101.38 & 100.91 & 101.18 \\
\hline O F CL & 0.00 & 0.00 & 0.00 & 0.00 & 0.00 & 0.00 & 0.00 & 0.00 & 0.00 & 0.00 & 0.00 & 0.00 & 0.00 & 0.00 & 0.00 \\
\hline СT̄OTAL & 102.39 & 102.29 & 100.61 & 101.85 & 101.44 & 101.21 & 101.21 & 101.26 & 100.80 & 101.37 & 100.92 & 107.37 & 101.38 & 100.91 & 101.18 \\
\hline Tsi & 2.91 & 2.92 & 2.94 & 2.91 & 2.94 & 2.95 & 2.96 & 2.95 & 2.94 & 2.96 & 2.93 & 2.76 & 2.94 & 2.93 & 2.95 \\
\hline TAI & 0.09 & 0.08 & 0.06 & 0.09 & 0.06 & 0.05 & 0.04 & 0.05 & 0.06 & 0.04 & 0.07 & 0.24 & 0.06 & 0.07 & 0.05 \\
\hline SUM_T & 3.00 & 3.00 & 3.00 & 3.00 & 3.00 & 3.00 & 3.00 & 3.00 & 3.00 & 3.00 & 3.00 & 3.00 & 3.00 & 3.00 & 3.00 \\
\hline AIVI $^{-}$ & 1.92 & 1.94 & 1.98 & 1.94 & 1.97 & 1.98 & 2.00 & 1.97 & 1.98 & 1.99 & 1.97 & 2.17 & 1.98 & 1.98 & 2.00 \\
\hline $\mathrm{Fe} 3$ & 0.00 & 0.00 & 0.00 & 0.00 & 0.00 & 0.00 & 0.00 & 0.00 & 0.00 & 0.00 & 0.00 & 0.00 & 0.00 & 0.00 & 0.00 \\
\hline $\mathrm{Ti}$ & 0.01 & 0.00 & 0.01 & 0.01 & 0.01 & 0.01 & 0.01 & 0.01 & 0.01 & 0.01 & 0.01 & 0.01 & 0.01 & 0.01 & 0.00 \\
\hline $\mathrm{Cr}$ & 0.00 & 0.00 & 0.00 & 0.00 & 0.00 & 0.00 & 0.00 & 0.00 & 0.00 & 0.00 & 0.00 & 0.00 & 0.00 & 0.00 & 0.00 \\
\hline SUM_A & 1.93 & 1.94 & 1.98 & 1.95 & 1.98 & 1.99 & 2.01 & 1.98 & 1.99 & 2.00 & 1.98 & 2.17 & 1.99 & 1.98 & 2.00 \\
\hline $\mathrm{Fe} 2$ & 1.62 & 1.66 & 1.60 & 1.57 & 1.52 & 1.49 & 1.52 & 1.53 & 1.54 & 1.55 & 1.60 & 1.55 & 1.66 & 1.59 & 1.61 \\
\hline $\mathrm{Mg}$ & 0.48 & 0.32 & 0.25 & 0.30 & 0.23 & 0.25 & 0.24 & 0.24 & 0.21 & 0.23 & 0.24 & 0.24 & 0.28 & 0.37 & 0.40 \\
\hline Mn & 0.05 & 0.19 & 0.27 & 0.31 & 0.35 & 0.35 & 0.36 & 0.37 & 0.36 & 0.32 & 0.28 & 0.24 & 0.17 & 0.09 & 0.05 \\
\hline $\mathrm{Ca}$ & 0.90 & 0.87 & 0.88 & 0.88 & 0.91 & 0.93 & 0.87 & 0.86 & 0.87 & 0.89 & 0.90 & 0.80 & 0.89 & 0.96 & 0.94 \\
\hline $\mathrm{Na}$ & 0.02 & 0.02 & 0.02 & 0.00 & 0.01 & 0.00 & 0.00 & 0.02 & 0.03 & 0.01 & 0.00 & 0.00 & 0.01 & 0.00 & 0.00 \\
\hline SUM_B & 3.07 & 3.06 & 3.02 & 3.05 & 3.02 & 3.01 & 2.99 & 3.02 & 3.01 & 3.00 & 3.02 & 2.83 & 3.01 & 3.02 & 3.00 \\
\hline SUM_CAT & 8.00 & 8.00 & 8.00 & 8.00 & 8.00 & 8.00 & 8.00 & 8.00 & 8.00 & 8.00 & 8.00 & 8.00 & 8.00 & 8.00 & 8.00 \\
\hline 0 & 12.00 & 12.00 & 12.00 & 12.00 & 12.00 & 12.00 & 12.00 & 12.00 & 12.00 & 12.00 & 12.00 & 12.00 & 12.00 & 12.00 & 12.00 \\
\hline CF & 0.00 & 0.00 & 0.00 & 0.00 & 0.00 & 0.00 & 0.00 & 0.00 & 0.00 & 0.00 & 0.00 & 0.00 & 0.00 & 0.00 & 0.00 \\
\hline CCL & 0.00 & 0.00 & 0.00 & 0.00 & 0.00 & 0.00 & 0.00 & 0.00 & 0.00 & 0.00 & 0.00 & 0.00 & 0.00 & 0.00 & 0.00 \\
\hline Alm & 0.00 & 0.00 & 0.00 & 51.27 & 0.00 & 49.32 & 50.76 & 0.00 & 0.00 & 0.00 & 52.92 & 54.75 & 0.00 & 52.72 & 53.64 \\
\hline Adr & 0.00 & 0.00 & 0.00 & 0.00 & 0.00 & 0.00 & 0.00 & 0.00 & 0.00 & 0.00 & 0.00 & 0.00 & 0.00 & 0.00 & 0.00 \\
\hline Grs & 0.00 & 0.00 & 0.00 & 28.84 & 0.00 & 30.89 & 29.24 & 0.00 & 0.00 & 0.00 & 29.86 & 28.32 & 0.00 & 31.92 & 31.35 \\
\hline Pyp & 0.00 & 0.00 & 0.00 & 9.73 & 0.00 & 8.24 & 7.92 & 0.00 & 0.00 & 0.00 & 7.82 & 8.39 & 0.00 & 12.33 & 13.43 \\
\hline Sps & 0.00 & 0.00 & 0.00 & 10.17 & 0.00 & 11.54 & 12.08 & 0.00 & 0.00 & 0.00 & 9.40 & 8.55 & 0.00 & 3.04 & 1.58 \\
\hline Uvr & 0.00 & 0.00 & 0.00 & 0.00 & 0.00 & 0.00 & 0.00 & 0.00 & 0.00 & 0.00 & 0.00 & 0.00 & 0.00 & 0.00 & 0.00 \\
\hline XCaGrt & 0.30 & 0.29 & 0.29 & 0.29 & 0.30 & 0.31 & 0.29 & 0.29 & 0.29 & 0.30 & 0.30 & 0.28 & 0.30 & 0.32 & 0.31 \\
\hline XFeGrt & 0.53 & 0.55 & 0.53 & 0.51 & 0.51 & 0.49 & 0.51 & 0.51 & 0.52 & 0.52 & 0.53 & 0.55 & 0.55 & 0.53 & 0.54 \\
\hline XMgGrt & 0.16 & 0.11 & 0.08 & 0.10 & 0.08 & 0.08 & 0.08 & 0.08 & 0.07 & 0.08 & 0.08 & 0.08 & 0.10 & 0.12 & 0.13 \\
\hline Fe_MgGrt & 3.39 & 5.21 & 6.45 & 5.27 & 6.62 & 5.99 & 6.42 & 6.40 & 7.22 & 6.64 & 6.78 & 6.53 & 5.85 & 4.28 & 4.00 \\
\hline
\end{tabular}


Análises de química mineral de granada selecionados da região de Barraqán

\begin{tabular}{|c|c|c|c|c|c|c|c|c|c|c|c|c|c|c|c|c|c|}
\hline Amostra & 187B & 187B & 187B & 187B & 187B & 187B & 187B & 187B & 187B & 187B & 187B & 187B & 187B & 187B & 187B & 187B & 187B \\
\hline Análise & 10 & 11 & 12 & 13 & 14 & 15 & 16 & 17 & 58 & 59 & 60 & 61 & 62 & 63 & 64 & 65 & 66 \\
\hline $\mathrm{SiO} 2$ & 37.72 & 37.89 & 37.50 & 37.65 & 30.10 & 38.63 & 38.11 & 37.77 & 38.27 & 36.91 & 38.02 & 37.85 & 37.94 & 38.06 & 38.36 & 38.04 & 37.58 \\
\hline TiO2 & 0.11 & 0.10 & 0.01 & 0.08 & 0.13 & 0.17 & 0.17 & 0.28 & 0.15 & 0.00 & 0.19 & 0.19 & 0.17 & 0.13 & 0.09 & 0.10 & 0.22 \\
\hline $\mathrm{Al} 2 \mathrm{O} 3$ & 21.57 & 21.56 & 21.04 & 21.25 & 21.38 & 21.04 & 21.71 & 21.54 & 21.64 & 21.29 & 21.37 & 21.21 & 21.57 & 21.39 & 21.44 & 21.58 & 21.57 \\
\hline Cr2O3 & 0.00 & 0.00 & 0.00 & 0.00 & 0.00 & 0.00 & 0.00 & 0.00 & 0.00 & 0.00 & 0.00 & 0.00 & 0.00 & 0.00 & 0.00 & 0.00 & 0.00 \\
\hline $\mathrm{FeO}$ & 23.66 & 25.00 & 25.28 & 25.43 & 24.61 & 25.76 & 25.00 & 25.70 & 25.68 & 25.14 & 25.10 & 25.55 & 26.26 & 26.35 & 25.13 & 25.41 & 25.63 \\
\hline $\mathrm{Fe} 2 \mathrm{O} 3$ & 0.00 & 0.00 & 0.00 & 0.00 & 0.00 & 0.00 & 0.00 & 0.00 & 0.00 & 0.00 & 0.00 & 0.00 & 0.00 & 0.00 & 0.00 & 0.00 & 0.00 \\
\hline MnO & 2.50 & 2.65 & 2.52 & 2.46 & 2.21 & 1.85 & 1.58 & 1.51 & 1.73 & 1.87 & 2.12 & 2.31 & 2.51 & 2.29 & 2.13 & 2.00 & 1.10 \\
\hline MgO & 2.32 & 2.14 & 2.14 & 2.33 & 2.40 & 2.54 & 2.73 & 2.80 & 2.38 & 2.38 & 2.30 & 2.25 & 2.09 & 2.07 & 2.09 & 2.14 & 2.91 \\
\hline $\mathrm{Na} 2 \mathrm{O}$ & 0.03 & 0.03 & 0.04 & 0.05 & 0.03 & 0.05 & 0.01 & 0.04 & 0.01 & 0.00 & 0.03 & 0.04 & 0.08 & 0.01 & 0.06 & 0.02 & 0.04 \\
\hline$F$ & 0.00 & 0.00 & 0.00 & 0.00 & 0.00 & 0.00 & 0.00 & 0.00 & 0.00 & 0.00 & 0.00 & 0.00 & 0.00 & 0.00 & 0.00 & 0.00 & 0.00 \\
\hline Cl & 0.00 & 0.00 & 0.00 & 0.00 & 0.00 & 0.00 & 0.00 & 0.00 & 0.00 & 0.00 & 0.00 & 0.00 & 0.00 & 0.00 & 0.00 & 0.00 & 0.00 \\
\hline TOTAL & 99.23 & 100.17 & 99.89 & 100.86 & 92.29 & 101.50 & 100.63 & 100.78 & 101.28 & 99.13 & 100.64 & 100.29 & 101.78 & 101.01 & 100.60 & 100.39 & 100.63 \\
\hline FeOCALC & 23.66 & 25.00 & 25.28 & 25.43 & 24.61 & 25.76 & 25.00 & 25.70 & 25.68 & 25.14 & 25.10 & 25.55 & 26.26 & 26.35 & 25.13 & 25.41 & 25.63 \\
\hline Fe2O3CALC & 0.00 & 0.00 & 0.00 & 0.00 & 0.00 & 0.00 & 0.00 & 0.00 & 0.00 & 0.00 & 0.00 & 0.00 & 0.00 & 0.00 & 0.00 & 0.00 & 0.00 \\
\hline TOTALCALC & 99.23 & 100.17 & 99.89 & 100.86 & 92.29 & 101.50 & 100.63 & 100.78 & 101.28 & 99.13 & 100.64 & 100.29 & 101.78 & 101.01 & 100.60 & 100.39 & 100.63 \\
\hline O_F_CL & 0.00 & 0.00 & 0.00 & 0.00 & 0.00 & 0.00 & 0.00 & 0.00 & 0.00 & 0.00 & 0.00 & 0.00 & 0.00 & 0.00 & 0.00 & 0.00 & 0.00 \\
\hline TAl & 0.01 & 0.01 & 0.03 & 0.05 & 0.43 & 0.00 & 0.02 & 0.05 & 0.02 & 0.06 & 0.02 & 0.01 & 0.05 & 0.01 & 0.00 & 0.01 & 0.06 \\
\hline SUM_T & 3.00 & 3.00 & 3.00 & 3.00 & 3.00 & 3.01 & 3.00 & 3.00 & 3.00 & 3.00 & 3.00 & 3.00 & 3.00 & 3.00 & 3.01 & 3.00 & 3.00 \\
\hline AIVI & 2.01 & 2.00 & 1.93 & 1.91 & 1.72 & 1.93 & 1.98 & 1.94 & 1.97 & 1.93 & 1.96 & 1.96 & 1.93 & 1.97 & 1.98 & 2.00 & 1.92 \\
\hline Fe3 & 0.00 & 0.00 & 0.00 & 0.00 & 0.00 & 0.00 & 0.00 & 0.00 & 0.00 & 0.00 & 0.00 & 0.00 & 0.00 & 0.00 & 0.00 & 0.00 & 0.00 \\
\hline $\mathrm{Ti}$ & 0.01 & 0.01 & 0.00 & 0.01 & 0.01 & 0.01 & 0.01 & 0.02 & 0.01 & 0.00 & 0.01 & 0.01 & 0.01 & 0.01 & 0.01 & 0.01 & 0.01 \\
\hline $\mathrm{Cr}$ & 0.00 & 0.00 & 0.00 & 0.00 & 0.00 & 0.00 & 0.00 & 0.00 & 0.00 & 0.00 & 0.00 & 0.00 & 0.00 & 0.00 & 0.00 & 0.00 & 0.00 \\
\hline SUM_A & 2.02 & 2.00 & 1.93 & 1.92 & 1.73 & 1.94 & 1.99 & 1.95 & 1.98 & 1.93 & 1.97 & 1.97 & 1.94 & 1.97 & 1.99 & 2.00 & 1.94 \\
\hline $\mathrm{Fe} 2$ & 1.57 & 1.65 & 1.68 & 1.67 & 1.76 & 1.68 & 1.64 & 1.68 & 1.68 & 1.67 & 1.65 & 1.69 & 1.71 & 1.73 & 1.65 & 1.67 & 1.68 \\
\hline Mg & 0.27 & 0.25 & 0.25 & 0.27 & 0.31 & 0.29 & 0.32 & 0.33 & 0.28 & 0.28 & 0.27 & 0.27 & 0.24 & 0.24 & 0.25 & 0.25 & 0.34 \\
\hline Mn & 0.17 & 0.18 & 0.17 & 0.16 & 0.16 & 0.12 & 0.10 & 0.10 & 0.11 & 0.13 & 0.14 & 0.15 & 0.17 & 0.15 & 0.14 & 0.13 & 0.07 \\
\hline $\mathrm{Ca}$ & 0.96 & 0.91 & 0.96 & 0.98 & 1.05 & 0.96 & 0.95 & 0.93 & 0.95 & 0.98 & 0.97 & 0.92 & 0.93 & 0.90 & 0.95 & 0.94 & 0.97 \\
\hline $\mathrm{Na}$ & 0.01 & 0.01 & 0.01 & 0.01 & 0.01 & 0.01 & 0.00 & 0.01 & 0.00 & 0.00 & 0.01 & 0.01 & 0.01 & 0.00 & 0.01 & 0.00 & 0.01 \\
\hline SUM_B & 2.98 & 3.00 & 3.07 & 3.08 & 3.27 & 3.06 & 3.01 & 3.05 & 3.02 & 3.07 & 3.03 & 3.03 & 3.06 & 3.03 & 3.00 & 3.00 & 3.06 \\
\hline SUM_CAT & 8.00 & 8.00 & 8.00 & 8.00 & 8.00 & 8.00 & 8.00 & 8.00 & 8.00 & 8.00 & 8.00 & 8.00 & 8.00 & 8.00 & 8.00 & 8.00 & 8.00 \\
\hline 0 & 12.00 & 12.00 & 12.00 & 12.00 & 12.00 & 12.00 & 12.00 & 12.00 & 12.00 & 12.00 & 12.00 & 12.00 & 12.00 & 12.00 & 12.00 & 12.00 & 12.00 \\
\hline CF & 0.00 & 0.00 & 0.00 & 0.00 & 0.00 & 0.00 & 0.00 & 0.00 & 0.00 & 0.00 & 0.00 & 0.00 & 0.00 & 0.00 & 0.00 & 0.00 & 0.00 \\
\hline CCL & 0.00 & 0.00 & 0.00 & 0.00 & 0.00 & 0.00 & 0.00 & 0.00 & 0.00 & 0.00 & 0.00 & 0.00 & 0.00 & 0.00 & 0.00 & 0.00 & 0.00 \\
\hline Alm & 52.71 & 55.05 & 0.00 & 0.00 & 53.68 & 0.00 & 54.37 & 0.00 & 55.43 & 54.59 & 54.36 & 55.62 & 0.00 & 57.17 & 0.00 & 55.80 & 54.71 \\
\hline Pyp & 9.21 & 8.38 & 0.00 & 0.00 & 9.33 & 0.00 & 10.60 & 0.00 & 9.15 & 9.20 & 8.88 & 8.74 & 0.00 & 8.00 & 0.00 & 8.38 & 11.06 \\
\hline Sps & 5.65 & 5.90 & 0.00 & 0.00 & 4.89 & 0.00 & 3.47 & 0.00 & 3.77 & 4.12 & 4.65 & 5.10 & 0.00 & 5.04 & 0.00 & 4.45 & 2.38 \\
\hline Uvr & 0.00 & 0.00 & 0.00 & 0.00 & 0.00 & 0.00 & 0.00 & 0.00 & 0.00 & 0.00 & 0.00 & 0.00 & 0.00 & 0.00 & 0.00 & 0.00 & 0.00 \\
\hline XCaGrt & 0.32 & 0.31 & 0.32 & 0.32 & 0.32 & 0.31 & 0.32 & 0.31 & 0.32 & 0.32 & 0.32 & 0.30 & 0.31 & 0.30 & 0.32 & 0.31 & 0.32 \\
\hline XFeGrt & 0.53 & 0.55 & 0.55 & 0.54 & 0.54 & 0.55 & 0.54 & 0.55 & 0.56 & 0.55 & 0.54 & 0.56 & 0.56 & 0.57 & 0.55 & 0.56 & 0.55 \\
\hline XMgGrt & 0.09 & 0.08 & 0.08 & 0.09 & 0.09 & 0.10 & 0.11 & 0.11 & 0.09 & 0.09 & 0.09 & 0.09 & 0.08 & 0.08 & 0.08 & 0.08 & 0.11 \\
\hline $\mathrm{Fe} \_\mathrm{MgGrt}$ & 5.73 & 6.58 & 6.62 & 6.13 & 5.76 & 5.70 & 5.13 & 5.16 & 6.07 & 5.94 & 6.12 & 6.36 & 7.07 & 7.15 & 6.74 & 6.67 & 4.94 \\
\hline
\end{tabular}


Análises de química mineral de granada selecionados da região de Barragán

\begin{tabular}{|c|c|c|c|c|c|c|c|c|c|c|c|c|c|c|c|c|c|}
\hline Amostra & 188 & 188 & 188 & 188 & 188 & 188 & 188 & 188 & 188 & 188 & 188 & 188 & 188 & 188 & 188 & 188 & 188 \\
\hline Análise & 100 & 101 & 102 & 103 & 119 & 120 & 121 & 122 & 123 & 124 & 82 & 84 & 85 & 86 & 87 & 88 & 98 \\
\hline $\mathrm{SiO2}$ & 37.81 & 37.11 & 37.66 & 38.58 & 38.85 & 38.36 & 37.74 & 37.33 & 37.44 & 37.65 & 37.63 & 37.23 & 37.73 & 37.75 & 37.77 & 38.00 & 37.92 \\
\hline TiO2 & 0.22 & 0.12 & 0.09 & 0.12 & 0.02 & 0.07 & 0.06 & 0.09 & 0.07 & 0.10 & 0.12 & 0.12 & 0.21 & 0.00 & 0.09 & 0.15 & 0.13 \\
\hline Al2O3 & 21.28 & 21.40 & 21.59 & 21.05 & 21.60 & 21.37 & 21.25 & 20.79 & 21.04 & 20.96 & 21.63 & 21.05 & 21.34 & 21.45 & 21.50 & 21.34 & 21.41 \\
\hline $\mathrm{Cr} 2 \mathrm{O} 3$ & 0.00 & 0.00 & 0.00 & 0.00 & 0.00 & 0.00 & 0.00 & 0.00 & 0.00 & 0.00 & 0.00 & 0.00 & 0.00 & 0.00 & 0.00 & 0.00 & 0.00 \\
\hline $\mathrm{FeO}$ & 26.82 & 26.10 & 25.73 & 27.78 & 28.11 & 26.93 & 25.35 & 25.37 & 25.31 & 25.45 & 29.09 & 25.83 & 25.60 & 28.23 & 27.36 & 26.94 & 27.31 \\
\hline $\mathrm{Fe} 2 \mathrm{O} 3$ & 0.00 & 0.00 & 0.00 & 0.00 & 0.00 & 0.00 & 0.00 & 0.00 & 0.00 & 0.00 & 0.00 & 0.00 & 0.00 & 0.00 & 0.00 & 0.00 & 0.00 \\
\hline MnO & 1.55 & 1.61 & 1.75 & 0.61 & 0.15 & 1.12 & 2.39 & 4.04 & 3.79 & 3.12 & 0.30 & 1.85 & 2.64 & 0.25 & 0.17 & 0.11 & 0.19 \\
\hline MgO & 1.76 & 1.57 & 1.52 & 2.05 & 2.75 & 1.89 & 1.66 & 1.24 & 1.32 & 1.28 & 2.77 & 1.57 & 1.59 & 2.78 & 2.77 & 2.98 & 2.92 \\
\hline $\mathrm{CaO}$ & 11.00 & 11.82 & 12.39 & 10.78 & 10.54 & 11.25 & 12.13 & 10.74 & 11.57 & 12.08 & 10.35 & 12.12 & 11.86 & 10.54 & 10.82 & 10.83 & 10.90 \\
\hline $\mathrm{Na} 2 \mathrm{O}$ & 0.00 & 0.02 & 0.01 & 0.04 & 0.02 & 0.02 & 0.02 & 0.03 & 0.03 & 0.04 & 0.05 & 0.01 & 0.02 & 0.01 & 0.06 & 0.08 & 0.02 \\
\hline $\mathbf{F}$ & 0.00 & 0.00 & 0.00 & 0.00 & 0.00 & 0.00 & 0.00 & 0.00 & 0.00 & 0.00 & 0.00 & 0.00 & 0.00 & 0.00 & 0.00 & 0.00 & 0.00 \\
\hline $\mathrm{Cl}$ & 0.00 & 0.00 & 0.00 & 0.00 & 0.00 & 0.00 & 0.00 & 0.00 & 0.00 & 0.00 & 0.00 & 0.00 & 0.00 & 0.00 & 0.00 & 0.00 & 0.00 \\
\hline TOTAL & 100.44 & 99.74 & 100.74 & 101.02 & 102.03 & 101.01 & 100.59 & 99.63 & 100.58 & 100.68 & 101.94 & 99.77 & 100.98 & 100.99 & 100.55 & 100.42 & 100.80 \\
\hline FeOCALC & 26.82 & 26.10 & 25.73 & 27.78 & 28.11 & 26.93 & 25.35 & 25.37 & 25.31 & 25.45 & 29.09 & 25.83 & 25.60 & 28.23 & 27.36 & 26.94 & 27.31 \\
\hline Fe2O3CALC & 0.00 & 0.00 & 0.00 & 0.00 & 0.00 & 0.00 & 0.00 & 0.00 & 0.00 & 0.00 & 0.00 & 0.00 & 0.00 & 0.00 & 0.00 & 0.00 & 0.00 \\
\hline TOTALCALC & 100.44 & 99.74 & 100.74 & 101.02 & 102.03 & 101.01 & 100.59 & 99.63 & 100.58 & 100.68 & 101.94 & 99.77 & 100.98 & 100.99 & 100.55 & 100.42 & 100.80 \\
\hline O_F_CL & 0.00 & 0.00 & 0.00 & 0.00 & 0.00 & 0.00 & 0.00 & 0.00 & 0.00 & 0.00 & 0.00 & 0.00 & 0.00 & 0.00 & 0.00 & 0.00 & 0.00 \\
\hline TAl & 0.01 & 0.05 & 0.04 & 0.00 & 0.00 & 0.00 & 0.03 & 0.01 & 0.04 & 0.03 & 0.08 & 0.04 & 0.04 & 0.05 & 0.04 & 0.02 & 0.04 \\
\hline SUM_T & 3.00 & 3.00 & 3.00 & 3.03 & 3.01 & 3.01 & 3.00 & 3.00 & 3.00 & 3.00 & 3.00 & 3.00 & 3.00 & 3.00 & 3.00 & 3.00 & 3.00 \\
\hline AIVI $^{-}$ & 1.97 & 1.95 & 1.96 & 1.95 & 1.97 & 1.98 & 1.95 & 1.95 & 1.93 & 1.93 & 1.90 & 1.93 & 1.94 & 1.93 & 1.95 & 1.95 & 1.94 \\
\hline $\mathrm{Fe} 3$ & 0.00 & 0.00 & 0.00 & 0.00 & 0.00 & 0.00 & 0.00 & 0.00 & 0.00 & 0.00 & 0.00 & 0.00 & 0.00 & 0.00 & 0.00 & 0.00 & 0.00 \\
\hline $\mathrm{Ti}$ & 0.01 & 0.01 & 0.01 & 0.01 & 0.00 & 0.00 & 0.00 & 0.01 & 0.00 & 0.01 & 0.01 & 0.01 & 0.01 & 0.00 & 0.01 & 0.01 & 0.01 \\
\hline $\mathrm{Cr}$ & 0.00 & 0.00 & 0.00 & 0.00 & 0.00 & 0.00 & 0.00 & 0.00 & 0.00 & 0.00 & 0.00 & 0.00 & 0.00 & 0.00 & 0.00 & 0.00 & 0.00 \\
\hline SUM_A & 1.98 & 1.96 & 1.97 & 1.95 & 1.97 & 1.98 & 1.95 & 1.95 & 1.93 & 1.93 & 1.90 & 1.94 & 1.95 & 1.93 & 1.95 & 1.96 & 1.95 \\
\hline $\mathrm{Fe} 2$ & 1.77 & 1.74 & 1.69 & 1.82 & 1.82 & 1.77 & 1.67 & 1.70 & 1.68 & 1.68 & 1.89 & 1.72 & 1.68 & 1.85 & 1.79 & 1.77 & 1.79 \\
\hline Mg & 0.21 & 0.19 & 0.18 & 0.24 & 0.32 & 0.22 & 0.20 & 0.15 & 0.16 & 0.15 & 0.32 & 0.19 & 0.19 & 0.32 & 0.32 & 0.35 & 0.34 \\
\hline Mn & 0.10 & 0.11 & 0.12 & 0.04 & 0.01 & 0.07 & 0.16 & 0.27 & 0.25 & 0.21 & 0.02 & 0.13 & 0.18 & 0.02 & 0.01 & 0.01 & 0.01 \\
\hline $\mathrm{Ca}$ & 0.93 & 1.01 & 1.04 & 0.91 & 0.87 & 0.95 & 1.02 & 0.92 & 0.98 & 1.02 & 0.86 & 1.03 & 1.00 & 0.88 & 0.91 & 0.91 & 0.91 \\
\hline $\mathrm{Na}$ & 0.00 & 0.00 & 0.00 & 0.01 & 0.00 & 0.00 & 0.00 & 0.01 & 0.01 & 0.01 & 0.01 & 0.00 & 0.00 & 0.00 & 0.01 & 0.01 & 0.00 \\
\hline SUM B & 3.02 & 3.04 & 3.03 & 3.02 & 3.02 & 3.01 & 3.05 & 3.05 & 3.07 & 3.07 & 3.10 & 3.06 & 3.05 & 3.07 & 3.05 & 3.04 & 3.06 \\
\hline SUM_CAT & 8.00 & 8.00 & 8.00 & 8.00 & 8.00 & 8.00 & 8.00 & 8.00 & 8.00 & 8.00 & 8.00 & 8.00 & 8.00 & 8.00 & 8.00 & 8.00 & 8.00 \\
\hline 0 & 12.00 & 12.00 & 12.00 & 12.00 & 12.00 & 12.00 & 12.00 & 12.00 & 12.00 & 12.00 & 12.00 & 12.00 & 12.00 & 12.00 & 12.00 & 12.00 & 12.00 \\
\hline CF & 0.00 & 0.00 & 0.00 & 0.00 & 0.00 & 0.00 & 0.00 & 0.00 & 0.00 & 0.00 & 0.00 & 0.00 & 0.00 & 0.00 & 0.00 & 0.00 & 0.00 \\
\hline CCL & 0.00 & 0.00 & 0.00 & 0.00 & 0.00 & 0.00 & 0.00 & 0.00 & 0.00 & 0.00 & 0.00 & 0.00 & 0.00 & 0.00 & 0.00 & 0.00 & 0.00 \\
\hline Alm & 58.80 & 57.10 & 55.78 & 60.44 & 60.20 & 58.69 & 54.74 & 55.77 & 54.56 & 0.00 & 0.00 & 56.09 & 55.22 & 60.13 & 0.00 & 0.00 & 58.45 \\
\hline Pyp & 6.87 & 6.11 & 5.89 & 7.97 & 10.48 & 7.33 & 6.37 & 4.84 & 5.06 & 0.00 & 0.00 & 6.06 & 6.12 & 10.54 & 0.00 & 0.00 & 11.15 \\
\hline Sps & 3.44 & 3.57 & 3.83 & 1.34 & 0.32 & 2.46 & 5.23 & 8.98 & 8.26 & 0.00 & 0.00 & 4.07 & 5.76 & 0.54 & 0.00 & 0.00 & 0.41 \\
\hline Uvr & 0.00 & 0.00 & 0.00 & 0.00 & 0.00 & 0.00 & 0.00 & 0.00 & 0.00 & 0.00 & 0.00 & 0.00 & 0.00 & 0.00 & 0.00 & 0.00 & 0.00 \\
\hline XCaGrt & 0.31 & 0.33 & 0.34 & 0.30 & 0.29 & 0.31 & 0.34 & 0.30 & 0.32 & 0.33 & 0.28 & 0.34 & 0.33 & 0.29 & 0.30 & 0.30 & 0.30 \\
\hline XFeGrt & 0.59 & 0.57 & 0.56 & 0.61 & 0.60 & 0.59 & 0.55 & 0.56 & 0.55 & 0.55 & 0.61 & 0.56 & 0.55 & 0.60 & 0.59 & 0.58 & 0.59 \\
\hline XMgGrt & 0.07 & 0.06 & 0.06 & 0.08 & 0.11 & 0.07 & 0.06 & 0.05 & 0.05 & 0.05 & 0.10 & 0.06 & 0.06 & 0.11 & 0.11 & 0.12 & 0.11 \\
\hline $\mathrm{Fe}$ MgGrt & 8.57 & 9.33 & 9.45 & 7.60 & 5.74 & 8.00 & 8.57 & 11.48 & 10.81 & 11.13 & 5.90 & 9.23 & 9.00 & 5.70 & 5.54 & 5.08 & 5.24 \\
\hline
\end{tabular}


Análises de química mineral de qranada selecionados da reqião de Barraqán

\begin{tabular}{|c|c|c|c|c|c|c|c|c|c|c|c|c|}
\hline Amostra & 189 & 189 & 189 & 189 & 189 & 189 & 189 & 189 & 189 & 189 & 189 & 189 \\
\hline Análise & 676 & 677 & 679 & 680 & 681 & 682 & 683 & 684 & 685 & 686 & 687 & 688 \\
\hline $\mathrm{SiO2}$ & 37.71 & 37.97 & 38.22 & 37.81 & 38.09 & 37.02 & 38.17 & 37.82 & 37.83 & 37.45 & 37.87 & 38.14 \\
\hline TiO2 & 0.20 & 0.18 & 0.21 & 0.23 & 0.20 & 0.22 & 0.20 & 0.21 & 0.22 & 0.19 & 0.20 & 0.23 \\
\hline Al2O3 & 22.06 & 22.28 & 22.21 & 21.93 & 22.04 & 22.02 & 21.99 & 22.19 & 21.91 & 21.99 & 22.38 & 22.18 \\
\hline Cr2O3 & 0.00 & 0.00 & 0.00 & 0.00 & 0.00 & 0.00 & 0.00 & 0.00 & 0.00 & 0.00 & 0.00 & 0.00 \\
\hline $\mathrm{FeO}$ & 22.01 & 21.78 & 24.71 & 20.73 & 21.05 & 22.35 & 21.14 & 22.68 & 20.99 & 20.67 & 23.05 & 21.06 \\
\hline $\mathrm{Fe} 2 \mathrm{O} 3$ & 0.00 & 0.00 & 0.00 & 0.00 & 0.00 & 0.00 & 0.00 & 0.00 & 0.00 & 0.00 & 0.00 & 0.00 \\
\hline MnO & 5.55 & 5.66 & 2.49 & 7.17 & 7.04 & 5.01 & 6.23 & 4.37 & 7.81 & 8.03 & 4.26 & 6.66 \\
\hline $\mathrm{MgO}$ & 2.18 & 2.40 & 3.19 & 2.22 & 1.57 & 3.10 & 2.66 & 2.50 & 1.82 & 1.80 & 3.38 & 2.80 \\
\hline $\mathrm{CaO}$ & 11.51 & 11.30 & 11.38 & 11.61 & 11.45 & 11.44 & 11.45 & 11.33 & 11.28 & 11.34 & 10.84 & 11.07 \\
\hline $\mathrm{Na} 2 \mathrm{O}$ & 0.00 & 0.00 & 0.00 & 0.13 & 0.00 & 0.00 & 0.02 & 0.02 & 0.05 & 0.06 & 0.15 & 0.00 \\
\hline $\mathbf{F}$ & 0.00 & 0.00 & 0.00 & 0.00 & 0.00 & 0.00 & 0.00 & 0.00 & 0.00 & 0.00 & 0.00 & 0.00 \\
\hline Cl & 0.00 & 0.00 & 0.00 & 0.00 & 0.00 & 0.00 & 0.00 & 0.00 & 0.00 & 0.00 & 0.00 & 0.00 \\
\hline TOTAL & 101.22 & 101.57 & 102.40 & 101.82 & 101.42 & 101.16 & 101.87 & 101.11 & 101.90 & 101.53 & 102.12 & 102.14 \\
\hline FeOCALC & 22.01 & 21.78 & 24.71 & 20.73 & 21.05 & 22.35 & 21.14 & 22.68 & 20.99 & 20.67 & 23.05 & 21.06 \\
\hline Fe2O3CALC & 0.00 & 0.00 & 0.00 & 0.00 & 0.00 & 0.00 & 0.00 & 0.00 & 0.00 & 0.00 & 0.00 & 0.00 \\
\hline TOTALCALC & 101.22 & 101.57 & 102.40 & 101.82 & 101.42 & 101.16 & 101.87 & 101.11 & 101.90 & 101.53 & 102.12 & 102.14 \\
\hline OFCL & 0.00 & 0.00 & 0.00 & 0.00 & 0.00 & 0.00 & 0.00 & 0.00 & 0.00 & 0.00 & 0.00 & 0.00 \\
\hline CTOTAL & 101.22 & 101.57 & 102.40 & 101.82 & 101.42 & 101.16 & 101.87 & 101.11 & 101.90 & 101.53 & 102.12 & 102.14 \\
\hline Tsi & 2.94 & 2.95 & 2.93 & 2.93 & 2.98 & 2.88 & 2.95 & 2.95 & 2.94 & 2.92 & 2.91 & 2.94 \\
\hline TAI & 0.06 & 0.05 & 0.07 & 0.07 & 0.02 & 0.12 & 0.05 & 0.05 & 0.06 & 0.08 & 0.09 & 0.06 \\
\hline SUM $T$ & 3.00 & 3.00 & 3.00 & 3.00 & 3.00 & 3.00 & 3.00 & 3.00 & 3.00 & 3.00 & 3.00 & 3.00 \\
\hline AIVI ${ }^{-}$ & 1.97 & 1.99 & 1.94 & 1.93 & 2.01 & 1.89 & 1.95 & 1.98 & 1.95 & 1.94 & 1.93 & 1.96 \\
\hline $\mathrm{Fe} 3$ & 0.00 & 0.00 & 0.00 & 0.00 & 0.00 & 0.00 & 0.00 & 0.00 & 0.00 & 0.00 & 0.00 & 0.00 \\
\hline $\mathrm{Ti}$ & 0.01 & 0.01 & 0.01 & 0.01 & 0.01 & 0.01 & 0.01 & 0.01 & 0.01 & 0.01 & 0.01 & 0.01 \\
\hline $\mathrm{Cr}$ & 0.00 & 0.00 & 0.00 & 0.00 & 0.00 & 0.00 & 0.00 & 0.00 & 0.00 & 0.00 & 0.00 & 0.00 \\
\hline SUM_A & 1.98 & 2.00 & 1.95 & 1.95 & 2.02 & 1.91 & 1.97 & 2.00 & 1.96 & 1.95 & 1.94 & 1.97 \\
\hline $\mathrm{Fe} 2$ & 1.44 & 1.41 & 1.59 & 1.34 & 1.38 & 1.45 & 1.37 & 1.48 & 1.37 & 1.35 & 1.48 & 1.36 \\
\hline Mg & 0.25 & 0.28 & 0.37 & 0.26 & 0.18 & 0.36 & 0.31 & 0.29 & 0.21 & 0.21 & 0.39 & 0.32 \\
\hline Mn & 0.37 & 0.37 & 0.16 & 0.47 & 0.47 & 0.33 & 0.41 & 0.29 & 0.51 & 0.53 & 0.28 & 0.44 \\
\hline $\mathrm{Ca}$ & 0.96 & 0.94 & 0.94 & 0.96 & 0.96 & 0.95 & 0.95 & 0.95 & 0.94 & 0.95 & 0.89 & 0.92 \\
\hline $\mathrm{Na}$ & 0.00 & 0.00 & 0.00 & 0.02 & 0.00 & 0.00 & 0.00 & 0.00 & 0.01 & 0.01 & 0.02 & 0.00 \\
\hline SUM B & 3.02 & 3.00 & 3.05 & 3.06 & 2.98 & 3.09 & 3.04 & 3.01 & 3.04 & 3.05 & 3.06 & 3.03 \\
\hline SUM_CAT & 8.00 & 8.00 & 8.00 & 8.00 & 8.00 & 8.00 & 8.00 & 8.00 & 8.00 & 8.00 & 8.00 & 8.00 \\
\hline 0 & 12.00 & 12.00 & 12.00 & 12.00 & 12.00 & 12.00 & 12.00 & 12.00 & 12.00 & 12.00 & 12.00 & 12.00 \\
\hline CF & 0.00 & 0.00 & 0.00 & 0.00 & 0.00 & 0.00 & 0.00 & 0.00 & 0.00 & 0.00 & 0.00 & 0.00 \\
\hline CCL & 0.00 & 0.00 & 0.00 & 0.00 & 0.00 & 0.00 & 0.00 & 0.00 & 0.00 & 0.00 & 0.00 & 0.00 \\
\hline Alm & 47.59 & 47.08 & 52.02 & 0.00 & 46.12 & 46.95 & 45.05 & 49.19 & 0.00 & 0.00 & 0.00 & 44.83 \\
\hline Adr & 0.00 & 0.00 & 0.00 & 0.00 & 0.00 & 0.00 & 0.00 & 0.00 & 0.00 & 0.00 & 0.00 & 0.00 \\
\hline Grs & 31.87 & 31.28 & 30.71 & 0.00 & 32.14 & 30.79 & 31.27 & 31.47 & 0.00 & 0.00 & 0.00 & 30.18 \\
\hline Pyp & 8.39 & 9.24 & 11.96 & 0.00 & 6.12 & 11.60 & 10.12 & 9.67 & 0.00 & 0.00 & 0.00 & 10.63 \\
\hline Sps & 12.15 & 12.40 & 5.32 & 0.00 & 15.62 & 10.66 & 13.45 & 9.59 & 0.00 & 0.00 & 0.00 & 14.36 \\
\hline Uvr & 0.00 & 0.00 & 0.00 & 0.00 & 0.00 & 0.00 & 0.00 & 0.00 & 0.00 & 0.00 & 0.00 & 0.00 \\
\hline XCaGrt & 0.32 & 0.31 & 0.31 & 0.32 & 0.32 & 0.31 & 0.31 & 0.32 & 0.31 & 0.31 & 0.29 & 0.30 \\
\hline XFeGrt & 0.48 & 0.47 & 0.52 & 0.44 & 0.46 & 0.47 & 0.45 & 0.49 & 0.45 & 0.44 & 0.49 & 0.45 \\
\hline XMgGrt & 0.08 & 0.09 & 0.12 & 0.09 & 0.06 & 0.12 & 0.10 & 0.10 & 0.07 & 0.07 & 0.13 & 0.11 \\
\hline $\mathrm{Fe}$ MgGrt & 5.68 & 5.09 & 4.35 & 5.23 & 7.52 & 4.05 & 4.45 & 5.08 & 6.47 & 6.46 & 3.82 & 4.22 \\
\hline
\end{tabular}


Análises de química mineral de qranada selecionados da reqião de Barraqán

\begin{tabular}{|c|c|c|c|c|c|c|c|c|c|c|c|c|c|c|c|c|c|}
\hline Amostra & 189A & 189A & 189A & 189A & 189A & 189A & 189A & 189A & 189A & 189A & 189A & 189A & 189A & 189A & 189A & 189A & 189A \\
\hline Análise & 720 & 721 & 722 & 723 & 724 & 725 & 726 & 727 & 728 & 729 & 730 & 731 & 732 & 733 & 734 & 735 & 736 \\
\hline $\mathrm{SiO2}$ & 38.61 & 38.73 & 38.00 & 38.33 & 38.50 & 38.16 & 37.91 & 37.64 & 37.83 & 37.75 & 37.63 & 37.42 & 37.96 & 37.49 & 37.93 & 37.89 & 37.02 \\
\hline TiO2 & 0.16 & 0.12 & 0.11 & 0.08 & 0.20 & 0.18 & 0.14 & 0.13 & 0.14 & 0.11 & 0.12 & 0.14 & 0.13 & 0.11 & 0.18 & 0.13 & 0.12 \\
\hline $\mathrm{Al} 2 \mathrm{O} 3$ & 22.60 & 22.62 & 22.50 & 22.49 & 22.53 & 22.28 & 22.51 & 22.17 & 22.16 & 22.16 & 22.01 & 22.04 & 22.03 & 22.11 & 22.19 & 21.89 & 21.83 \\
\hline $\mathrm{Cr} 2 \mathrm{O} 3$ & 0.00 & 0.00 & 0.00 & 0.00 & 0.00 & 0.00 & 0.00 & 0.00 & 0.00 & 0.00 & 0.00 & 0.00 & 0.00 & 0.00 & 0.00 & 0.00 & 0.00 \\
\hline $\mathrm{FeO}$ & 25.44 & 25.55 & 25.98 & 26.47 & 26.46 & 25.94 & 26.59 & 26.09 & 25.82 & 25.94 & 25.88 & 24.93 & 24.65 & 24.66 & 24.41 & 24.55 & 25.02 \\
\hline $\mathrm{Fe} 2 \mathrm{O} 3$ & 0.00 & 0.00 & 0.00 & 0.00 & 0.00 & 0.00 & 0.00 & 0.00 & 0.00 & 0.00 & 0.00 & 0.00 & 0.00 & 0.00 & 0.00 & 0.00 & 0.00 \\
\hline MnO & 0.52 & 0.47 & 0.75 & 1.14 & 1.44 & 1.59 & 1.82 & 2.75 & 2.83 & 3.21 & 3.62 & 4.17 & 4.61 & 5.13 & 4.99 & 4.92 & 4.74 \\
\hline MgO & 3.63 & 3.41 & 3.31 & 3.01 & 2.88 & 2.94 & 3.17 & 2.06 & 2.60 & 1.99 & 1.92 & 1.73 & 1.87 & 1.71 & 1.72 & 1.70 & 1.77 \\
\hline $\mathrm{Na} 2 \mathrm{O}$ & 0.00 & 0.10 & 0.06 & 0.10 & 0.00 & 0.00 & 0.03 & 0.00 & 0.00 & 0.00 & 0.00 & 0.00 & 0.00 & 0.00 & 0.00 & 0.00 & 0.00 \\
\hline $\mathbf{F}$ & 0.00 & 0.00 & 0.00 & 0.00 & 0.00 & 0.00 & 0.00 & 0.00 & 0.00 & 0.00 & 0.00 & 0.00 & 0.00 & 0.00 & 0.00 & 0.00 & 0.00 \\
\hline $\mathrm{Cl}$ & 0.00 & 0.00 & 0.00 & 0.00 & 0.00 & 0.00 & 0.00 & 0.00 & 0.00 & 0.00 & 0.00 & 0.00 & 0.00 & 0.00 & 0.00 & 0.00 & 0.00 \\
\hline TOTAL & 102.00 & 102.19 & 101.56 & 102.03 & 102.40 & 102.12 & 102.79 & 101.45 & 102.27 & 101.56 & 101.39 & 101.16 & 101.40 & 101.27 & 101.83 & 101.32 & 100.61 \\
\hline FeOCALC & 25.44 & 25.55 & 25.98 & 26.47 & 26.46 & 25.94 & 26.59 & 26.09 & 25.82 & 25.94 & 25.88 & 24.93 & 24.65 & 24.66 & 24.41 & 24.55 & 25.02 \\
\hline Fe2O3CALC & 0.00 & 0.00 & 0.00 & 0.00 & 0.00 & 0.00 & 0.00 & 0.00 & 0.00 & 0.00 & 0.00 & 0.00 & 0.00 & 0.00 & 0.00 & 0.00 & 0.00 \\
\hline TOTALCALC & 102.00 & 102.19 & 101.56 & 102.03 & 102.40 & 102.12 & 102.79 & 101.45 & 102.27 & 101.56 & 101.39 & 101.16 & 101.40 & 101.27 & 101.83 & 101.32 & 100.61 \\
\hline O_F_CL & 0.00 & 0.00 & 0.00 & 0.00 & 0.00 & 0.00 & 0.00 & 0.00 & 0.00 & 0.00 & 0.00 & 0.00 & 0.00 & 0.00 & 0.00 & 0.00 & 0.00 \\
\hline TAl & 0.04 & 0.03 & 0.07 & 0.05 & 0.04 & 0.06 & 0.10 & 0.06 & 0.08 & 0.05 & 0.05 & 0.06 & 0.03 & 0.06 & 0.04 & 0.03 & 0.08 \\
\hline SUM_T & 3.00 & 3.00 & 3.00 & 3.00 & 3.00 & 3.00 & 3.00 & 3.00 & 3.00 & 3.00 & 3.00 & 3.00 & 3.00 & 3.00 & 3.00 & 3.00 & 3.00 \\
\hline AIVI & 2.00 & 2.01 & 1.98 & 2.00 & 2.00 & 1.96 & 1.93 & 1.98 & 1.94 & 1.99 & 1.98 & 1.97 & 2.00 & 1.99 & 2.00 & 2.00 & 1.96 \\
\hline Fe3 & 0.00 & 0.00 & 0.00 & 0.00 & 0.00 & 0.00 & 0.00 & 0.00 & 0.00 & 0.00 & 0.00 & 0.00 & 0.00 & 0.00 & 0.00 & 0.00 & 0.00 \\
\hline $\mathrm{Ti}$ & 0.01 & 0.01 & 0.01 & 0.00 & 0.01 & 0.01 & 0.01 & 0.01 & 0.01 & 0.01 & 0.01 & 0.01 & 0.01 & 0.01 & 0.01 & 0.01 & 0.01 \\
\hline $\mathrm{Cr}$ & 0.00 & 0.00 & 0.00 & 0.00 & 0.00 & 0.00 & 0.00 & 0.00 & 0.00 & 0.00 & 0.00 & 0.00 & 0.00 & 0.00 & 0.00 & 0.00 & 0.00 \\
\hline SUM_A & 2.01 & 2.01 & 1.99 & 2.00 & 2.02 & 1.98 & 1.94 & 1.99 & 1.95 & 1.99 & 1.98 & 1.98 & 2.01 & 1.99 & 2.01 & 2.00 & 1.96 \\
\hline $\mathrm{Fe} 2$ & 1.63 & 1.64 & 1.68 & 1.71 & 1.70 & 1.67 & 1.70 & 1.70 & 1.67 & 1.69 & 1.70 & 1.64 & 1.61 & 1.62 & 1.59 & 1.61 & 1.65 \\
\hline Mg & 0.42 & 0.39 & 0.38 & 0.35 & 0.33 & 0.34 & 0.36 & 0.24 & 0.30 & 0.23 & 0.22 & 0.20 & 0.22 & 0.20 & 0.20 & 0.20 & 0.21 \\
\hline Mn & 0.03 & 0.03 & 0.05 & 0.07 & 0.09 & 0.10 & 0.12 & 0.18 & 0.19 & 0.21 & 0.24 & 0.28 & 0.31 & 0.34 & 0.33 & 0.33 & 0.32 \\
\hline $\mathrm{Ca}$ & 0.91 & 0.92 & 0.90 & 0.86 & 0.86 & 0.91 & 0.87 & 0.89 & 0.90 & 0.87 & 0.86 & 0.90 & 0.85 & 0.85 & 0.87 & 0.86 & 0.86 \\
\hline $\mathrm{Na}$ & 0.00 & 0.01 & 0.01 & 0.02 & 0.00 & 0.00 & 0.00 & 0.00 & 0.00 & 0.00 & 0.00 & 0.00 & 0.00 & 0.00 & 0.00 & 0.00 & 0.00 \\
\hline SUM_B & 2.99 & 2.99 & 3.01 & 3.00 & 2.99 & 3.03 & 3.06 & 3.01 & 3.05 & 3.01 & 3.02 & 3.02 & 2.99 & 3.01 & 2.99 & 3.00 & 3.04 \\
\hline SUM_CAT & 8.00 & 8.00 & 8.00 & 8.00 & 8.00 & 8.00 & 8.00 & 8.00 & 8.00 & 8.00 & 8.00 & 8.00 & 8.00 & 8.00 & 8.00 & 8.00 & 8.00 \\
\hline 0 & 12.00 & 12.00 & 12.00 & 12.00 & 12.00 & 12.00 & 12.00 & 12.00 & 12.00 & 12.00 & 12.00 & 12.00 & 12.00 & 12.00 & 12.00 & 12.00 & 12.00 \\
\hline CF & 0.00 & 0.00 & 0.00 & 0.00 & 0.00 & 0.00 & 0.00 & 0.00 & 0.00 & 0.00 & 0.00 & 0.00 & 0.00 & 0.00 & 0.00 & 0.00 & 0.00 \\
\hline CCL & 0.00 & 0.00 & 0.00 & 0.00 & 0.00 & 0.00 & 0.00 & 0.00 & 0.00 & 0.00 & 0.00 & 0.00 & 0.00 & 0.00 & 0.00 & 0.00 & 0.00 \\
\hline Alm & 54.61 & 0.00 & 0.00 & 0.00 & 57.05 & 55.28 & 55.67 & 56.55 & 54.61 & 56.30 & 56.21 & 54.22 & 54.01 & 53.84 & 53.22 & 53.75 & 54.48 \\
\hline Pyp & 13.90 & 0.00 & 0.00 & 0.00 & 11.07 & 11.16 & 11.82 & 7.96 & 9.82 & 7.68 & 7.43 & 6.69 & 7.28 & 6.64 & 6.67 & 6.63 & 6.87 \\
\hline Sps & 1.12 & 0.00 & 0.00 & 0.00 & 3.15 & 3.43 & 3.86 & 6.03 & 6.07 & 7.06 & 7.97 & 9.18 & 10.24 & 11.35 & 11.01 & 10.92 & 10.46 \\
\hline Uvr & 0.00 & 0.00 & 0.00 & 0.00 & 0.00 & 0.00 & 0.00 & 0.00 & 0.00 & 0.00 & 0.00 & 0.00 & 0.00 & 0.00 & 0.00 & 0.00 & 0.00 \\
\hline XCaGrt & 0.30 & 0.31 & 0.30 & 0.29 & 0.29 & 0.30 & 0.29 & 0.30 & 0.30 & 0.29 & 0.28 & 0.30 & 0.29 & 0.28 & 0.29 & 0.29 & 0.28 \\
\hline XFeGrt & 0.55 & 0.55 & 0.56 & 0.57 & 0.57 & 0.55 & 0.56 & 0.57 & 0.55 & 0.56 & 0.56 & 0.54 & 0.54 & 0.54 & 0.53 & 0.54 & 0.55 \\
\hline XMgGrt & 0.14 & 0.13 & 0.13 & 0.12 & 0.11 & 0.11 & 0.12 & 0.08 & 0.10 & 0.08 & 0.07 & 0.07 & 0.07 & 0.07 & 0.07 & 0.07 & 0.07 \\
\hline $\mathrm{Fe} \_\mathrm{MgGrt}$ & 3.93 & 4.21 & 4.40 & 4.93 & 5.16 & 4.95 & 4.70 & 7.10 & 5.56 & 7.33 & 7.57 & 8.10 & 7.40 & 8.10 & 7.96 & 8.10 & 7.91 \\
\hline
\end{tabular}


Análises de química mineral de mica selecionados da região de Barragán

\begin{tabular}{|c|c|c|c|c|c|c|c|c|c|c|c|c|c|c|c|c|}
\hline Amostra & 196D & 196D & 196D & 196D & 196D & 196D & 196D & 196D & 196D & 196D & 196D & 196D & 196D & 196D & 196D & 196D \\
\hline Análise & 136 & 137 & 138 & 139 & 140 & 141 & 142 & 143 & 144 & 145 & 146 & 147 & 148 & 149 & 150 & 151 \\
\hline $\mathrm{SiO2}$ & 53.57 & 55.64 & 50.70 & 52.46 & 50.96 & 51.83 & 50.37 & 51.55 & 50.72 & 51.57 & 49.69 & 52.30 & 50.27 & 51.71 & 50.41 & 54.81 \\
\hline TiO2 & 0.01 & 0.05 & 0.37 & 0.34 & 0.33 & 0.34 & 0.26 & 0.40 & 0.36 & 0.30 & 0.33 & 0.37 & 0.32 & 0.29 & 0.26 & 0.14 \\
\hline $\mathrm{Al} 2 \mathrm{O} 3$ & 25.58 & 26.11 & 30.62 & 29.00 & 30.73 & 29.27 & 30.07 & 29.54 & 31.66 & 29.59 & 30.45 & 29.84 & 31.05 & 29.22 & 30.54 & 26.04 \\
\hline $\mathrm{Cr} 2 \mathrm{O} 3$ & 0.00 & 0.00 & 0.00 & 0.00 & 0.00 & 0.00 & 0.00 & 0.00 & 0.00 & 0.00 & 0.00 & 0.00 & 0.00 & 0.00 & 0.00 & 0.00 \\
\hline $\mathrm{FeO}$ & 2.68 & 2.66 & 2.70 & 2.64 & 2.66 & 2.55 & 2.71 & 2.65 & 2.74 & 2.62 & 2.69 & 2.62 & 2.72 & 2.66 & 2.70 & 2.84 \\
\hline $\mathrm{Fe} 2 \mathrm{O} 3$ & 0.00 & 0.00 & 0.00 & 0.00 & 0.00 & 0.00 & 0.00 & 0.00 & 0.00 & 0.00 & 0.00 & 0.00 & 0.00 & 0.00 & 0.00 & 0.00 \\
\hline MnO & 0.06 & 0.05 & 0.02 & 0.02 & 0.03 & 0.02 & 0.04 & 0.01 & 0.00 & 0.02 & 0.01 & 0.00 & 0.01 & 0.03 & 0.01 & 0.06 \\
\hline MgO & 4.24 & 4.35 & 2.75 & 3.20 & 2.76 & 2.97 & 2.84 & 2.99 & 2.65 & 2.84 & 2.53 & 2.81 & 2.70 & 2.90 & 2.93 & 4.07 \\
\hline $\mathrm{CaO}$ & 0.00 & 0.04 & 0.00 & 0.00 & 0.00 & 0.00 & 0.01 & 0.00 & 0.04 & 0.00 & 0.00 & 0.00 & 0.01 & 0.00 & 0.04 & 0.06 \\
\hline $\mathrm{Na} 2 \mathrm{O}$ & 0.10 & 0.19 & 0.80 & 0.86 & 0.72 & 1.01 & 0.62 & 0.97 & 0.90 & 1.17 & 0.89 & 1.06 & 0.77 & 0.93 & 0.74 & 0.24 \\
\hline K2O & 7.04 & 10.25 & 6.91 & 9.86 & 6.97 & 9.91 & 6.83 & 9.83 & 6.46 & 9.51 & 7.08 & 9.73 & 6.92 & 9.91 & 6.87 & 10.01 \\
\hline Cl & 0.00 & 0.00 & 0.00 & 0.00 & 0.00 & 0.00 & 0.00 & 0.00 & 0.00 & 0.00 & 0.00 & 0.00 & 0.00 & 0.00 & 0.00 & 0.00 \\
\hline $\mathbf{F}$ & 0.00 & 0.00 & 0.00 & 0.00 & 0.00 & 0.00 & 0.00 & 0.00 & 0.00 & 0.00 & 0.00 & 0.00 & 0.00 & 0.00 & 0.00 & 0.00 \\
\hline $\mathrm{H} 2 \mathrm{O}$ & 0.00 & 0.00 & 0.00 & 0.00 & 0.00 & 0.00 & 0.00 & 0.00 & 0.00 & 0.00 & 0.00 & 0.00 & 0.00 & 0.00 & 0.00 & 0.00 \\
\hline TOTAL & 93.27 & 99.34 & 94.87 & 98.37 & 95.16 & 97.90 & 93.74 & 97.94 & 95.52 & 97.61 & 93.66 & 98.72 & 94.76 & 97.66 & 94.51 & 98.28 \\
\hline O_F_Cl & 0.00 & 0.00 & 0.00 & 0.00 & 0.00 & 0.00 & 0.00 & 0.00 & 0.00 & 0.00 & 0.00 & 0.00 & 0.00 & 0.00 & 0.00 & 0.00 \\
\hline С̄̄OTAL & 93.27 & 99.34 & 94.87 & 98.37 & 95.16 & 97.90 & 93.74 & 97.94 & 95.52 & 97.61 & 93.66 & 98.72 & 94.76 & 97.66 & 94.51 & 98.28 \\
\hline Si & 3.24 & 3.22 & 3.02 & 3.07 & 3.03 & 3.05 & 3.04 & 3.04 & 3.00 & 3.04 & 3.01 & 3.05 & 3.00 & 3.05 & 3.02 & 3.20 \\
\hline AlIV & 1.82 & 1.78 & 2.15 & 2.00 & 2.15 & 2.03 & 2.14 & 2.05 & 2.20 & 2.06 & 2.17 & 2.05 & 2.18 & 2.03 & 2.15 & 1.79 \\
\hline SUM_T & 5.06 & 4.99 & 5.18 & 5.07 & 5.18 & 5.08 & 5.17 & 5.08 & 5.20 & 5.10 & 5.18 & 5.10 & 5.19 & 5.09 & 5.17 & 5.00 \\
\hline AIVI & 0.00 & 0.00 & 0.00 & 0.00 & 0.00 & 0.00 & 0.00 & 0.00 & 0.00 & 0.00 & 0.00 & 0.00 & 0.00 & 0.00 & 0.00 & 0.00 \\
\hline $\mathrm{Ti}$ & 0.00 & 0.00 & 0.02 & 0.02 & 0.02 & 0.02 & 0.01 & 0.02 & 0.02 & 0.01 & 0.02 & 0.02 & 0.02 & 0.01 & 0.01 & 0.01 \\
\hline $\mathrm{Fe} 3$ & 0.00 & 0.00 & 0.00 & 0.00 & 0.00 & 0.00 & 0.00 & 0.00 & 0.00 & 0.00 & 0.00 & 0.00 & 0.00 & 0.00 & 0.00 & 0.00 \\
\hline Fe2 & 0.14 & 0.13 & 0.13 & 0.13 & 0.13 & 0.13 & 0.14 & 0.13 & 0.14 & 0.13 & 0.14 & 0.13 & 0.14 & 0.13 & 0.14 & 0.14 \\
\hline $\mathrm{Cr}$ & 0.00 & 0.00 & 0.00 & 0.00 & 0.00 & 0.00 & 0.00 & 0.00 & 0.00 & 0.00 & 0.00 & 0.00 & 0.00 & 0.00 & 0.00 & 0.00 \\
\hline Mn & 0.00 & 0.00 & 0.00 & 0.00 & 0.00 & 0.00 & 0.00 & 0.00 & 0.00 & 0.00 & 0.00 & 0.00 & 0.00 & 0.00 & 0.00 & 0.00 \\
\hline Mg & 0.38 & 0.37 & 0.25 & 0.28 & 0.24 & 0.26 & 0.26 & 0.26 & 0.23 & 0.25 & 0.23 & 0.24 & 0.24 & 0.26 & 0.26 & 0.36 \\
\hline $\mathrm{Ca}$ & 0.00 & 0.00 & 0.00 & 0.00 & 0.00 & 0.00 & 0.00 & 0.00 & 0.00 & 0.00 & 0.00 & 0.00 & 0.00 & 0.00 & 0.00 & 0.00 \\
\hline $\mathrm{Na}$ & 0.01 & 0.02 & 0.09 & 0.10 & 0.08 & 0.12 & 0.07 & 0.11 & 0.10 & 0.13 & 0.10 & 0.12 & 0.09 & 0.11 & 0.09 & 0.03 \\
\hline K & 0.54 & 0.76 & 0.53 & 0.74 & 0.53 & 0.75 & 0.53 & 0.74 & 0.49 & 0.72 & 0.55 & 0.72 & 0.53 & 0.75 & 0.53 & 0.75 \\
\hline CATIONS & 6.13 & 6.28 & 6.19 & 6.33 & 6.18 & 6.35 & 6.18 & 6.35 & 6.18 & 6.34 & 6.21 & 6.33 & 6.20 & 6.34 & 6.20 & 6.28 \\
\hline CF & 0.00 & 0.00 & 0.00 & 0.00 & 0.00 & 0.00 & 0.00 & 0.00 & 0.00 & 0.00 & 0.00 & 0.00 & 0.00 & 0.00 & 0.00 & 0.00 \\
\hline $\mathrm{CCl}$ & 0.00 & 0.00 & 0.00 & 0.00 & 0.00 & 0.00 & 0.00 & 0.00 & 0.00 & 0.00 & 0.00 & 0.00 & 0.00 & 0.00 & 0.00 & 0.00 \\
\hline $\mathrm{OH}$ & 0.00 & 0.00 & 0.00 & 0.00 & 0.00 & 0.00 & 0.00 & 0.00 & 0.00 & 0.00 & 0.00 & 0.00 & 0.00 & 0.00 & 0.00 & 0.00 \\
\hline 0 & 11.00 & 11.00 & 11.00 & 11.00 & 11.00 & 11.00 & 11.00 & 11.00 & 11.00 & 11.00 & 11.00 & 11.00 & 11.00 & 11.00 & 11.00 & 11.00 \\
\hline $\mathrm{Fe} \_\mathrm{FeMg}$ & 0.26 & 0.26 & 0.35 & 0.32 & 0.35 & 0.33 & 0.35 & 0.33 & 0.37 & 0.34 & 0.37 & 0.34 & 0.36 & 0.34 & 0.34 & 0.28 \\
\hline Mg_FeMg & 0.74 & 0.74 & 0.65 & 0.68 & 0.65 & 0.67 & 0.65 & 0.67 & 0.63 & 0.66 & 0.63 & 0.66 & 0.64 & 0.66 & 0.66 & 0.72 \\
\hline
\end{tabular}


Análises de química mineral de lawsonita selecionados da região de Barragán

\begin{tabular}{|c|c|c|c|c|c|c|c|c|c|c|c|c|c|}
\hline Amostra & 197 & 197 & 197 & 197 & 197 & 197 & 197 & 197 & 197 & 197 & 197 & 197 & 197 \\
\hline Análise & 11 & 12 & 13 & 31 & 32 & 33 & 34 & 35 & 36 & 37 & 38 & 39 & 40 \\
\hline $\mathrm{SiO} 2$ & 41.00 & 38.97 & 41.22 & 40.41 & 39.14 & 40.60 & 39.11 & 40.42 & 39.32 & 41.08 & 39.24 & 39.81 & 39.66 \\
\hline TiO2 & 0.19 & 0.49 & 0.11 & 0.02 & 0.29 & 0.15 & 0.20 & 0.26 & 0.40 & 0.11 & 0.35 & 0.58 & 0.13 \\
\hline Al2O3 & 31.83 & 32.52 & 32.57 & 32.05 & 32.42 & 32.40 & 32.82 & 32.52 & 32.13 & 32.11 & 32.46 & 31.90 & 32.24 \\
\hline V2O3 & 0.00 & 0.00 & 0.00 & 0.00 & 0.00 & 0.00 & 0.00 & 0.00 & 0.00 & 0.00 & 0.00 & 0.00 & 0.00 \\
\hline $\mathrm{Fe} 2 \mathrm{O} 3$ & 0.00 & 0.00 & 0.00 & 0.00 & 0.00 & 0.00 & 0.00 & 0.00 & 0.00 & 0.00 & 0.00 & 0.00 & 0.00 \\
\hline La2O3 & 0.00 & 0.00 & 0.00 & 0.00 & 0.00 & 0.00 & 0.00 & 0.00 & 0.00 & 0.00 & 0.00 & 0.00 & 0.00 \\
\hline $\mathrm{Ce} 2 \mathrm{O} 3$ & 0.00 & 0.00 & 0.00 & 0.00 & 0.00 & 0.00 & 0.00 & 0.00 & 0.00 & 0.00 & 0.00 & 0.00 & 0.00 \\
\hline $\mathrm{Nd2O3}$ & 0.00 & 0.00 & 0.00 & 0.00 & 0.00 & 0.00 & 0.00 & 0.00 & 0.00 & 0.00 & 0.00 & 0.00 & 0.00 \\
\hline MnO & 0.03 & 0.00 & 0.00 & 0.03 & 0.00 & 0.00 & 0.01 & 0.03 & 0.02 & 0.01 & 0.01 & 0.03 & 0.00 \\
\hline MgO & 0.00 & 0.01 & 0.01 & 0.01 & 0.01 & 0.00 & 0.01 & 0.00 & 0.01 & 0.00 & 0.02 & 0.03 & 0.18 \\
\hline $\mathrm{CaO}$ & 17.31 & 17.14 & 17.37 & 17.02 & 17.01 & 17.38 & 17.29 & 17.30 & 17.04 & 17.08 & 16.83 & 17.09 & 16.83 \\
\hline SrO & 0.00 & 0.00 & 0.00 & 0.00 & 0.00 & 0.00 & 0.00 & 0.00 & 0.00 & 0.00 & 0.00 & 0.00 & 0.00 \\
\hline $\mathrm{BaO}$ & 0.00 & 0.00 & 0.00 & 0.00 & 0.00 & 0.00 & 0.00 & 0.00 & 0.00 & 0.00 & 0.00 & 0.00 & 0.00 \\
\hline $\mathrm{Na} 2 \mathrm{O}$ & 0.00 & 0.01 & 0.00 & 0.00 & 0.01 & 0.01 & 0.00 & 0.02 & 0.00 & 0.00 & 0.00 & 0.00 & 0.09 \\
\hline K2O & 0.00 & 0.00 & 0.00 & 0.01 & 0.00 & 0.01 & 0.01 & 0.00 & 0.00 & 0.00 & 0.00 & 0.00 & 0.00 \\
\hline $\mathrm{H} 2 \mathrm{O}$ & 12.29 & 11.69 & 12.36 & 12.12 & 11.74 & 12.17 & 11.73 & 12.12 & 11.79 & 12.32 & 11.77 & 11.94 & 11.89 \\
\hline $\mathbf{F}$ & 0.00 & 0.00 & 0.00 & 0.00 & 0.00 & 0.00 & 0.00 & 0.00 & 0.00 & 0.00 & 0.00 & 0.00 & 0.00 \\
\hline anidra sum & 90.37 & 89.13 & 91.28 & 89.54 & 88.88 & 90.56 & 89.45 & 90.55 & 88.92 & 90.39 & 88.92 & 89.45 & 89.13 \\
\hline hidratada sum & 102.66 & 100.82 & 103.64 & 101.66 & 100.62 & 102.74 & 101.17 & 102.67 & 100.71 & 102.71 & 100.69 & 101.38 & 101.02 \\
\hline Si & 0.68 & 0.65 & 0.69 & 0.67 & 0.65 & 0.68 & 0.65 & 0.67 & 0.65 & 0.68 & 0.65 & 0.66 & 0.66 \\
\hline $\mathrm{Ti}$ & 0.00 & 0.01 & 0.00 & 0.00 & 0.00 & 0.00 & 0.00 & 0.00 & 0.00 & 0.00 & 0.00 & 0.01 & 0.00 \\
\hline Al & 0.62 & 0.64 & 0.64 & 0.63 & 0.64 & 0.64 & 0.64 & 0.64 & 0.63 & 0.63 & 0.64 & 0.63 & 0.63 \\
\hline Fe3+ & 0.00 & 0.00 & 0.00 & 0.00 & 0.00 & 0.00 & 0.00 & 0.00 & 0.00 & 0.00 & 0.00 & 0.00 & 0.00 \\
\hline Mn2+ & 0.00 & 0.00 & 0.00 & 0.00 & 0.00 & 0.00 & 0.00 & 0.00 & 0.00 & 0.00 & 0.00 & 0.00 & 0.00 \\
\hline Mg & 0.00 & 0.00 & 0.00 & 0.00 & 0.00 & 0.00 & 0.00 & 0.00 & 0.00 & 0.00 & 0.00 & 0.00 & 0.00 \\
\hline $\mathrm{Ca}$ & 0.31 & 0.31 & 0.31 & 0.30 & 0.30 & 0.31 & 0.31 & 0.31 & 0.30 & 0.30 & 0.30 & 0.30 & 0.30 \\
\hline $\mathrm{Na}$ & 0.00 & 0.00 & 0.00 & 0.00 & 0.00 & 0.00 & 0.00 & 0.00 & 0.00 & 0.00 & 0.00 & 0.00 & 0.00 \\
\hline K & 0.00 & 0.00 & 0.00 & 0.00 & 0.00 & 0.00 & 0.00 & 0.00 & 0.00 & 0.00 & 0.00 & 0.00 & 0.00 \\
\hline 0 & 2.61 & 2.57 & 2.64 & 2.59 & 2.57 & 2.62 & 2.58 & 2.62 & 2.57 & 2.62 & 2.57 & 2.58 & 2.58 \\
\hline H & 1.36 & 1.30 & 1.37 & 1.35 & 1.30 & 1.35 & 1.30 & 1.35 & 1.31 & 1.37 & 1.31 & 1.33 & 1.32 \\
\hline Si & 2.00 & 2.00 & 2.00 & 2.00 & 2.00 & 2.00 & 2.00 & 2.00 & 2.00 & 2.00 & 2.00 & 2.00 & 2.00 \\
\hline $\mathrm{Ti}$ & 0.01 & 0.02 & 0.00 & 0.00 & 0.01 & 0.01 & 0.01 & 0.01 & 0.02 & 0.00 & 0.01 & 0.02 & 0.00 \\
\hline Al & 1.83 & 1.97 & 1.86 & 1.87 & 1.95 & 1.88 & 1.98 & 1.90 & 1.93 & 1.84 & 1.95 & 1.89 & 1.92 \\
\hline V & 0.00 & 0.00 & 0.00 & 0.00 & 0.00 & 0.00 & 0.00 & 0.00 & 0.00 & 0.00 & 0.00 & 0.00 & 0.00 \\
\hline $\mathrm{Fe} 3+$ & 0.00 & 0.00 & 0.00 & 0.00 & 0.00 & 0.00 & 0.00 & 0.00 & 0.00 & 0.00 & 0.00 & 0.00 & 0.00 \\
\hline Mn2+ & 0.00 & 0.00 & 0.00 & 0.00 & 0.00 & 0.00 & 0.00 & 0.00 & 0.00 & 0.00 & 0.00 & 0.00 & 0.00 \\
\hline Mg & 0.00 & 0.00 & 0.00 & 0.00 & 0.00 & 0.00 & 0.00 & 0.00 & 0.00 & 0.00 & 0.00 & 0.00 & 0.01 \\
\hline $\mathrm{Ca}$ & 0.90 & 0.94 & 0.90 & 0.90 & 0.93 & 0.92 & 0.95 & 0.92 & 0.93 & 0.89 & 0.92 & 0.92 & 0.91 \\
\hline $\mathrm{Sr}$ & 0.00 & 0.00 & 0.00 & 0.00 & 0.00 & 0.00 & 0.00 & 0.00 & 0.00 & 0.00 & 0.00 & 0.00 & 0.00 \\
\hline $\mathrm{Ba}$ & 0.00 & 0.00 & 0.00 & 0.00 & 0.00 & 0.00 & 0.00 & 0.00 & 0.00 & 0.00 & 0.00 & 0.00 & 0.00 \\
\hline $\mathrm{Na}$ & 0.00 & 0.00 & 0.00 & 0.00 & 0.00 & 0.00 & 0.00 & 0.00 & 0.00 & 0.00 & 0.00 & 0.00 & 0.01 \\
\hline K & 0.00 & 0.00 & 0.00 & 0.00 & 0.00 & 0.00 & 0.00 & 0.00 & 0.00 & 0.00 & 0.00 & 0.00 & 0.00 \\
\hline 0 & 7.66 & 7.93 & 7.70 & 7.71 & 7.88 & 7.75 & 7.93 & 7.78 & 7.85 & 7.66 & 7.87 & 7.80 & 7.81 \\
\hline H & 4.00 & 4.00 & 4.00 & 4.00 & 4.00 & 4.00 & 4.00 & 4.00 & 4.00 & 4.00 & 4.00 & 4.00 & 4.00 \\
\hline sum VI site & 1.84 & 1.99 & 1.87 & 1.87 & 1.96 & 1.89 & 1.99 & 1.91 & 1.94 & 1.85 & 1.96 & 1.91 & 1.93 \\
\hline sum VIII site & 0.91 & 0.94 & 0.90 & 0.90 & 0.93 & 0.92 & 0.95 & 0.92 & 0.93 & 0.89 & 0.92 & 0.92 & 0.93 \\
\hline sum O site & 7.66 & 7.93 & 7.70 & 7.71 & 7.88 & 7.75 & 7.93 & 7.78 & 7.85 & 7.66 & 7.87 & 7.80 & 7.81 \\
\hline sum IV + VI & 3.84 & 3.99 & 3.87 & 3.87 & 3.96 & 3.89 & 3.99 & 3.91 & 3.94 & 3.85 & 3.96 & 3.91 & 3.93 \\
\hline Si & 2.09 & 2.02 & 2.08 & 2.08 & 2.03 & 2.06 & 2.02 & 2.06 & 2.04 & 2.09 & 2.03 & 2.05 & 2.05 \\
\hline $\mathrm{Ti}$ & 0.01 & 0.02 & 0.00 & 0.00 & 0.01 & 0.01 & 0.01 & 0.01 & 0.02 & 0.00 & 0.01 & 0.02 & 0.00 \\
\hline Al & 1.91 & 1.98 & 1.93 & 1.94 & 1.98 & 1.94 & 2.00 & 1.95 & 1.96 & 1.92 & 1.98 & 1.94 & 1.96 \\
\hline V & 0.00 & 0.00 & 0.00 & 0.00 & 0.00 & 0.00 & 0.00 & 0.00 & 0.00 & 0.00 & 0.00 & 0.00 & 0.00 \\
\hline Fe3+ & 0.00 & 0.00 & 0.00 & 0.00 & 0.00 & 0.00 & 0.00 & 0.00 & 0.00 & 0.00 & 0.00 & 0.00 & 0.00 \\
\hline Mn2+ & 0.00 & 0.00 & 0.00 & 0.00 & 0.00 & 0.00 & 0.00 & 0.00 & 0.00 & 0.00 & 0.00 & 0.00 & 0.00 \\
\hline Mg & 0.00 & 0.00 & 0.00 & 0.00 & 0.00 & 0.00 & 0.00 & 0.00 & 0.00 & 0.00 & 0.00 & 0.00 & 0.01 \\
\hline $\mathrm{Ca}$ & 0.94 & 0.95 & 0.94 & 0.94 & 0.95 & 0.95 & 0.96 & 0.94 & 0.95 & 0.93 & 0.93 & 0.94 & 0.93 \\
\hline $\mathrm{Sr}$ & 0.00 & 0.00 & 0.00 & 0.00 & 0.00 & 0.00 & 0.00 & 0.00 & 0.00 & 0.00 & 0.00 & 0.00 & 0.00 \\
\hline $\mathrm{Ba}$ & 0.00 & 0.00 & 0.00 & 0.00 & 0.00 & 0.00 & 0.00 & 0.00 & 0.00 & 0.00 & 0.00 & 0.00 & 0.00 \\
\hline $\mathrm{Na}$ & 0.00 & 0.00 & 0.00 & 0.00 & 0.00 & 0.00 & 0.00 & 0.00 & 0.00 & 0.00 & 0.00 & 0.00 & 0.01 \\
\hline K & 0.00 & 0.00 & 0.00 & 0.00 & 0.00 & 0.00 & 0.00 & 0.00 & 0.00 & 0.00 & 0.00 & 0.00 & 0.00 \\
\hline $\mathbf{H}$ & 4.00 & 4.00 & 4.00 & 4.00 & 4.00 & 4.00 & 4.00 & 4.00 & 4.00 & 4.00 & 4.00 & 4.00 & 4.00 \\
\hline sum IV site & 2.09 & 2.02 & 2.08 & 2.08 & 2.03 & 2.06 & 2.02 & 2.06 & 2.04 & 2.09 & 2.03 & 2.05 & 2.05 \\
\hline sum VI site & 1.92 & 2.00 & 1.94 & 1.94 & 1.99 & 1.95 & 2.00 & 1.96 & 1.98 & 1.93 & 2.00 & 1.96 & 1.98 \\
\hline sum VIII site & 0.94 & 0.95 & 0.94 & 0.94 & 0.95 & 0.95 & 0.96 & 0.94 & 0.95 & 0.93 & 0.94 & 0.95 & 0.95 \\
\hline sum IV + VI & 4.01 & 4.02 & 4.01 & 4.02 & 4.02 & 4.01 & 4.02 & 4.02 & 4.02 & 4.02 & 4.03 & 4.01 & 4.03 \\
\hline X(Lws) & 1.00 & 1.00 & 1.00 & 1.00 & 1.00 & 1.00 & 1.00 & 1.00 & 1.00 & 1.00 & 1.00 & 1.00 & 1.00 \\
\hline$x(F e-L w s)$ & 0.00 & 0.00 & 0.00 & 0.00 & 0.00 & 0.00 & 0.00 & 0.00 & 0.00 & 0.00 & 0.00 & 0.00 & 0.00 \\
\hline
\end{tabular}


Análises de química mineral de lawsonita selecionados da região de Barragán

\begin{tabular}{|c|c|c|c|c|c|c|c|c|c|c|c|c|c|c|c|c|c|}
\hline Amostra & 197A & $197 A$ & 197A & $197 A$ & 197A & 197A & $197 A$ & $197 A$ & 197A & $197 A$ & 197A & 197A & 197A & 197A & 197A & 197A & 197A \\
\hline Análise & 11 & 12 & 13 & 31 & 32 & 33 & 34 & 35 & 36 & 37 & 38 & 39 & 40 & 25 & 26 & 27 & 29 \\
\hline SiO2 & 38.46 & 37.65 & 39.84 & 39.90 & 38.88 & 39.17 & 39.14 & 39.13 & 39.81 & 39.26 & 39.64 & 39.74 & 39.72 & 38.92 & 39.28 & 39.19 & 39.65 \\
\hline TiO2 & 0.08 & 0.00 & 0.52 & 0.67 & 1.82 & 0.44 & 0.85 & 0.53 & 0.45 & 0.44 & 0.70 & 0.34 & 0.50 & 0.49 & 0.85 & 0.55 & 0.17 \\
\hline Al2O3 & 31.64 & 31.72 & 31.48 & 31.71 & 30.03 & 31.59 & 31.15 & 31.11 & 31.79 & 31.52 & 30.87 & 31.53 & 31.17 & 31.37 & 31.38 & 31.47 & 31.85 \\
\hline V2O3 & 0.00 & 0.00 & 0.00 & 0.00 & 0.00 & 0.00 & 0.00 & 0.00 & 0.00 & 0.00 & 0.00 & 0.00 & 0.00 & 0.00 & 0.00 & 0.00 & 0.00 \\
\hline $\mathrm{Fe} 2 \mathrm{O} 3$ & 0.30 & 0.34 & 0.53 & 0.33 & 0.31 & 0.30 & 0.38 & 0.44 & 0.30 & 0.24 & 0.37 & 0.36 & 0.44 & 0.43 & 0.36 & 0.29 & 0.23 \\
\hline La2O3 & 0.00 & 0.00 & 0.00 & 0.00 & 0.00 & 0.00 & 0.00 & 0.00 & 0.00 & 0.00 & 0.00 & 0.00 & 0.00 & 0.00 & 0.00 & 0.00 & 0.00 \\
\hline $\mathrm{Ce} 2 \mathrm{O} 3$ & 0.00 & 0.00 & 0.00 & 0.00 & 0.00 & 0.00 & 0.00 & 0.00 & 0.00 & 0.00 & 0.00 & 0.00 & 0.00 & 0.00 & 0.00 & 0.00 & 0.00 \\
\hline $\mathrm{Nd} 2 \mathrm{O} 3$ & 0.00 & 0.00 & 0.00 & 0.00 & 0.00 & 0.00 & 0.00 & 0.00 & 0.00 & 0.00 & 0.00 & 0.00 & 0.00 & 0.00 & 0.00 & 0.00 & 0.00 \\
\hline MnO & 0.00 & 0.00 & 0.08 & 0.00 & 0.04 & 0.01 & 0.04 & 0.01 & 0.02 & 0.00 & 0.00 & 0.01 & 0.01 & 0.03 & 0.03 & 0.02 & 0.06 \\
\hline $\mathrm{MgO}$ & 0.01 & 0.01 & 0.00 & 0.00 & 0.01 & 0.02 & 0.00 & 0.02 & 0.02 & 0.02 & 0.00 & 0.00 & 0.00 & 0.01 & 0.00 & 0.03 & 0.01 \\
\hline $\mathrm{CaO}$ & 18.27 & 17.47 & 17.45 & 17.35 & 17.61 & 17.61 & 17.08 & 16.93 & 17.51 & 17.48 & 17.36 & 17.50 & 17.02 & 17.30 & 17.33 & 17.08 & 17.11 \\
\hline SrO & 0.00 & 0.00 & 0.00 & 0.00 & 0.00 & 0.00 & 0.00 & 0.00 & 0.00 & 0.00 & 0.00 & 0.00 & 0.00 & 0.00 & 0.00 & 0.00 & 0.00 \\
\hline $\mathrm{BaO}$ & 0.00 & 0.00 & 0.00 & 0.00 & 0.00 & 0.00 & 0.00 & 0.00 & 0.00 & 0.00 & 0.00 & 0.00 & 0.00 & 0.00 & 0.00 & 0.00 & 0.00 \\
\hline $\mathrm{Na} 2 \mathrm{O}$ & 0.00 & 0.00 & 0.01 & 0.00 & 0.00 & 0.00 & 0.02 & 0.00 & 0.00 & 0.02 & 0.00 & 0.00 & 0.01 & 0.01 & 0.00 & 0.01 & 0.00 \\
\hline K2O & 0.00 & 0.00 & 0.00 & 0.00 & 0.00 & 0.00 & 0.00 & 0.00 & 0.00 & 0.00 & 0.00 & 0.00 & 0.00 & 0.00 & 0.00 & 0.00 & 0.00 \\
\hline $\mathrm{H} 2 \mathrm{O}$ & 11.53 & 11.29 & 11.95 & 11.97 & 11.66 & 11.74 & 11.74 & 11.73 & 11.94 & 11.77 & 11.89 & 11.92 & 11.91 & 11.67 & 11.78 & 11.75 & 11.89 \\
\hline $\mathbf{F}$ & 0.07 & -0.14 & -0.17 & 0.07 & 0.24 & 0.07 & 0.24 & 0.27 & 0.10 & 0.20 & -0.03 & -0.13 & -0.07 & 0.14 & 0.03 & 0.00 & 0.13 \\
\hline anidra sum & 88.77 & 87.19 & 89.92 & 89.98 & 88.70 & 89.14 & 88.66 & 88.18 & 89.91 & 88.97 & 88.96 & 89.49 & 88.88 & 88.56 & 89.22 & 88.63 & 89.08 \\
\hline hidratada sum & 100.30 ו & 98.48 & 101.87 & 101.95 & 100.36 & 100.88 & 100.40 & 99.91 & 101.85 & 100.75 & 100.85 & 101.40 & 100.79 & 100.23 & 101.00 & 100.39 & 100.97 \\
\hline $\mathrm{Si}$ & 0.64 & 0.63 & 0.66 & 0.66 & 0.65 & 0.65 & 0.65 & 0.65 & 0.66 & 0.65 & 0.66 & 0.66 & 0.66 & 0.65 & 0.65 & 0.65 & 0.66 \\
\hline $\mathrm{Ti}$ & 0.00 & 0.00 & 0.01 & 0.01 & 0.02 & 0.01 & 0.01 & 0.01 & 0.01 & 0.01 & 0.01 & 0.00 & 0.01 & 0.01 & 0.01 & 0.01 & 0.00 \\
\hline Al & 0.62 & 0.62 & 0.62 & 0.62 & 0.59 & 0.62 & 0.61 & 0.61 & 0.62 & 0.62 & 0.61 & 0.62 & 0.61 & 0.62 & 0.62 & 0.62 & 0.62 \\
\hline Fe3+ & 0.00 & 0.00 & 0.01 & 0.00 & 0.00 & 0.00 & 0.00 & 0.01 & 0.00 & 0.00 & 0.00 & 0.00 & 0.01 & 0.01 & 0.00 & 0.00 & 0.00 \\
\hline Mn2+ & 0.00 & 0.00 & 0.00 & 0.00 & 0.00 & 0.00 & 0.00 & 0.00 & 0.00 & 0.00 & 0.00 & 0.00 & 0.00 & 0.00 & 0.00 & 0.00 & 0.00 \\
\hline Mg & 0.00 & 0.00 & 0.00 & 0.00 & 0.00 & 0.00 & 0.00 & 0.00 & 0.00 & 0.00 & 0.00 & 0.00 & 0.00 & 0.00 & 0.00 & 0.00 & 0.00 \\
\hline $\mathrm{Ca}$ & 0.33 & 0.31 & 0.31 & 0.31 & 0.31 & 0.31 & 0.30 & 0.30 & 0.31 & 0.31 & 0.31 & 0.31 & 0.30 & 0.31 & 0.31 & 0.30 & 0.31 \\
\hline $\mathrm{Na}$ & 0.00 & 0.00 & 0.00 & 0.00 & 0.00 & 0.00 & 0.00 & 0.00 & 0.00 & 0.00 & 0.00 & 0.00 & 0.00 & 0.00 & 0.00 & 0.00 & 0.00 \\
\hline $\mathrm{K}$ & 0.00 & 0.00 & 0.00 & 0.00 & 0.00 & 0.00 & 0.00 & 0.00 & 0.00 & 0.00 & 0.00 & 0.00 & 0.00 & 0.00 & 0.00 & 0.00 & 0.00 \\
\hline 0 & 2.55 & 2.50 & 2.59 & 2.59 & 2.54 & 2.56 & 2.55 & 2.54 & 2.59 & 2.56 & 2.56 & 2.58 & 2.56 & 2.55 & 2.57 & 2.56 & 2.57 \\
\hline H & 1.28 & 1.25 & 1.33 & 1.33 & 1.29 & 1.30 & 1.30 & 1.30 & 1.33 & 1.31 & 1.32 & 1.32 & 1.32 & 1.30 & 1.31 & 1.30 & 1.32 \\
\hline Si & 2.00 & 2.00 & 2.00 & 2.00 & 2.00 & 2.00 & 2.00 & 2.00 & 2.00 & 2.00 & 2.00 & 2.00 & 2.00 & 2.00 & 2.00 & 2.00 & 2.00 \\
\hline $\mathrm{Ti}$ & 0.00 & 0.00 & 0.02 & 0.03 & 0.07 & 0.02 & 0.03 & 0.02 & 0.02 & 0.02 & 0.03 & 0.01 & 0.02 & 0.02 & 0.03 & 0.02 & 0.01 \\
\hline Al & 1.94 & 1.99 & 1.86 & 1.87 & 1.82 & 1.90 & 1.88 & 1.87 & 1.88 & 1.89 & 1.84 & 1.87 & 1.85 & 1.90 & 1.88 & 1.89 & 1.89 \\
\hline v & 0.00 & 0.00 & 0.00 & 0.00 & 0.00 & 0.00 & 0.00 & 0.00 & 0.00 & 0.00 & 0.00 & 0.00 & 0.00 & 0.00 & 0.00 & 0.00 & 0.00 \\
\hline Fe3+ & 0.01 & 0.01 & 0.02 & 0.01 & 0.01 & 0.01 & 0.01 & 0.02 & 0.01 & 0.01 & 0.01 & 0.01 & 0.02 & 0.02 & 0.01 & 0.01 & 0.01 \\
\hline Mn2+ & 0.00 & 0.00 & 0.00 & 0.00 & 0.00 & 0.00 & 0.00 & 0.00 & 0.00 & 0.00 & 0.00 & 0.00 & 0.00 & 0.00 & 0.00 & 0.00 & 0.00 \\
\hline Mg & 0.00 & 0.00 & 0.00 & 0.00 & 0.00 & 0.00 & 0.00 & 0.00 & 0.00 & 0.00 & 0.00 & 0.00 & 0.00 & 0.00 & 0.00 & 0.00 & 0.00 \\
\hline $\mathrm{Ca}$ & 1.02 & 0.99 & 0.94 & 0.93 & 0.97 & 0.96 & 0.94 & 0.93 & 0.94 & 0.95 & 0.94 & 0.94 & 0.92 & 0.95 & 0.95 & 0.93 & 0.92 \\
\hline $\mathrm{Sr}$ & 0.00 & 0.00 & 0.00 & 0.00 & 0.00 & 0.00 & 0.00 & 0.00 & 0.00 & 0.00 & 0.00 & 0.00 & 0.00 & 0.00 & 0.00 & 0.00 & 0.00 \\
\hline $\mathrm{Ba}$ & 0.00 & 0.00 & 0.00 & 0.00 & 0.00 & 0.00 & 0.00 & 0.00 & 0.00 & 0.00 & 0.00 & 0.00 & 0.00 & 0.00 & 0.00 & 0.00 & 0.00 \\
\hline $\mathrm{Na}$ & 0.00 & 0.00 & 0.00 & 0.00 & 0.00 & 0.00 & 0.00 & 0.00 & 0.00 & 0.00 & 0.00 & 0.00 & 0.00 & 0.00 & 0.00 & 0.00 & 0.00 \\
\hline $\mathrm{K}$ & 0.00 & 0.00 & 0.00 & 0.00 & 0.00 & 0.00 & 0.00 & 0.00 & 0.00 & 0.00 & 0.00 & 0.00 & 0.00 & 0.00 & 0.00 & 0.00 & 0.00 \\
\hline 0 & 7.95 & 7.99 & 7.80 & 7.81 & 7.86 & 7.87 & 7.84 & 7.81 & 7.82 & 7.84 & 7.77 & 7.80 & 7.76 & 7.87 & 7.86 & 7.83 & 7.79 \\
\hline H & 4.00 & 4.00 & 4.00 & 4.00 & 4.00 & 4.00 & 4.00 & 4.00 & 4.00 & 4.00 & 4.00 & 4.00 & 4.00 & 4.00 & 4.00 & 4.00 & 4.00 \\
\hline sum VI site & 1.96 & 2.00 & 1.90 & 1.91 & 1.90 & 1.93 & 1.92 & 1.91 & 1.91 & 1.92 & 1.88 & 1.90 & 1.89 & 1.94 & 1.93 & 1.93 & 1.91 \\
\hline sum VIII site & 1.02 & 0.99 & 0.94 & 0.93 & 0.97 & 0.96 & 0.94 & 0.93 & 0.94 & 0.96 & 0.94 & 0.94 & 0.92 & 0.95 & 0.95 & 0.94 & 0.93 \\
\hline sum $O$ site & 7.95 & 7.99 & 7.80 & 7.81 & 7.86 & 7.87 & 7.84 & 7.81 & 7.82 & 7.84 & 7.77 & 7.80 & 7.76 & 7.87 & 7.86 & 7.83 & 7.79 \\
\hline sum IV + VI & 3.96 & 4.00 & 3.90 & 3.91 & 3.90 & 3.93 & 3.92 & 3.91 & 3.91 & 3.92 & 3.88 & 3.90 & 3.89 & 3.94 & 3.93 & 3.93 & 3.91 \\
\hline Si & 2.01 & 2.00 & 2.05 & 2.05 & 2.04 & 2.03 & 2.04 & 2.05 & 2.05 & 2.04 & 2.06 & 2.05 & 2.06 & 2.03 & 2.04 & 2.04 & 2.05 \\
\hline $\mathrm{Ti}$ & 0.00 & 0.00 & 0.02 & 0.03 & 0.07 & 0.02 & 0.03 & 0.02 & 0.02 & 0.02 & 0.03 & 0.01 & 0.02 & 0.02 & 0.03 & 0.02 & 0.01 \\
\hline Al & 1.95 & 1.99 & 1.91 & 1.92 & 1.85 & 1.93 & 1.92 & 1.92 & 1.93 & 1.93 & 1.89 & 1.92 & 1.91 & 1.93 & 1.92 & 1.93 & 1.94 \\
\hline V & 0.00 & 0.00 & 0.00 & 0.00 & 0.00 & 0.00 & 0.00 & 0.00 & 0.00 & 0.00 & 0.00 & 0.00 & 0.00 & 0.00 & 0.00 & 0.00 & 0.00 \\
\hline $\mathrm{Fe} 3+$ & 0.01 & 0.01 & 0.02 & 0.01 & 0.01 & 0.01 & 0.02 & 0.02 & 0.01 & 0.01 & 0.01 & 0.01 & 0.02 & 0.02 & 0.01 & 0.01 & 0.01 \\
\hline Mn2+ & 0.00 & 0.00 & 0.00 & 0.00 & 0.00 & 0.00 & 0.00 & 0.00 & 0.00 & 0.00 & 0.00 & 0.00 & 0.00 & 0.00 & 0.00 & 0.00 & 0.00 \\
\hline Mg & 0.00 & 0.00 & 0.00 & 0.00 & 0.00 & 0.00 & 0.00 & 0.00 & 0.00 & 0.00 & 0.00 & 0.00 & 0.00 & 0.00 & 0.00 & 0.00 & 0.00 \\
\hline $\mathrm{Ca}$ & 1.02 & 1.00 & 0.96 & 0.95 & 0.99 & 0.98 & 0.95 & 0.95 & 0.96 & 0.97 & 0.97 & 0.97 & 0.95 & 0.97 & 0.96 & 0.95 & 0.95 \\
\hline $\mathrm{Sr}$ & 0.00 & 0.00 & 0.00 & 0.00 & 0.00 & 0.00 & 0.00 & 0.00 & 0.00 & 0.00 & 0.00 & 0.00 & 0.00 & 0.00 & 0.00 & 0.00 & 0.00 \\
\hline $\mathrm{Ba}$ & 0.00 & 0.00 & 0.00 & 0.00 & 0.00 & 0.00 & 0.00 & 0.00 & 0.00 & 0.00 & 0.00 & 0.00 & 0.00 & 0.00 & 0.00 & 0.00 & 0.00 \\
\hline $\mathrm{Na}$ & 0.00 & 0.00 & 0.00 & 0.00 & 0.00 & 0.00 & 0.00 & 0.00 & 0.00 & 0.00 & 0.00 & 0.00 & 0.00 & 0.00 & 0.00 & 0.00 & 0.00 \\
\hline $\mathrm{K}$ & 0.00 & 0.00 & 0.00 & 0.00 & 0.00 & 0.00 & 0.00 & 0.00 & 0.00 & 0.00 & 0.00 & 0.00 & 0.00 & 0.00 & 0.00 & 0.00 & 0.00 \\
\hline H & 4.00 & 4.00 & 4.00 & 4.00 & 4.00 & 4.00 & 4.00 & 4.00 & 4.00 & 4.00 & 4.00 & 4.00 & 4.00 & 4.00 & 4.00 & 4.00 & 4.00 \\
\hline sum IV site & 2.01 & 2.00 & 2.05 & 2.05 & 2.04 & 2.03 & 2.04 & 2.05 & 2.05 & 2.04 & 2.06 & 2.05 & 2.06 & 2.03 & 2.04 & 2.04 & 2.05 \\
\hline sum VI site & 1.97 & 2.00 & 1.95 & 1.96 & 1.94 & 1.96 & 1.96 & 1.96 & 1.96 & 1.96 & 1.93 & 1.95 & 1.94 & 1.97 & 1.96 & 1.97 & 1.96 \\
\hline sum VIII site & 1.03 & 1.00 & 0.96 & 0.95 & 0.99 & 0.98 & 0.96 & 0.95 & 0.97 & 0.98 & 0.97 & 0.97 & 0.95 & 0.97 & 0.96 & 0.96 & 0.95 \\
\hline sum IV + VI & 3.98 & 4.00 & 4.00 & 4.01 & 3.97 & 4.00 & 4.00 & 4.01 & 4.00 & 4.00 & 3.99 & 4.00 & 4.01 & 4.00 & 4.00 & 4.01 & 4.01 \\
\hline$X($ Lws $)$ & 0.99 & 0.99 & 0.99 & 0.99 & 0.99 & 0.99 & 0.99 & 0.99 & 0.99 & 1.00 & 0.99 & 0.99 & 0.99 & 0.99 & 0.99 & 0.99 & 1.00 \\
\hline X(Fe-Lws) & 0.01 & 0.01 & 0.01 & 0.01 & 0.01 & 0.01 & 0.01 & 0.01 & 0.01 & 0.00 & 0.01 & 0.01 & 0.01 & 0.01 & 0.01 & 0.01 & 0.00 \\
\hline
\end{tabular}


Análises de química mineral de pumpellyita selecionados da reqião de Barraqán

\begin{tabular}{|c|c|c|c|c|c|c|c|c|c|c|}
\hline Amostra & 196D & 196D & 196D & 196D & 196D & 196D & 196D & 196D & 199 & 199 \\
\hline Análise & 232 & 124 & 125 & 126 & 127 & 128 & 129 & 130 & 232 & 246 \\
\hline SiO2 & 37.90 & 38.52 & 38.46 & 38.23 & 38.40 & 38.49 & 38.51 & 38.19 & 37.90 & 37.55 \\
\hline $\mathrm{Al} 2 \mathrm{O3}$ & 25.32 & 25.75 & 25.79 & 25.58 & 25.90 & 25.65 & 25.81 & 25.88 & 25.32 & 25.21 \\
\hline MgO & 3.21 & 3.56 & 3.59 & 3.38 & 3.49 & 3.67 & 3.48 & 3.55 & 3.21 & 3.40 \\
\hline $\mathrm{Na} 2 \mathrm{O}$ & 0.14 & 0.23 & 0.21 & 0.18 & 0.17 & 0.11 & 0.15 & 0.17 & 0.14 & 0.18 \\
\hline V2O3 & 0.00 & 0.00 & 0.00 & 0.00 & 0.00 & 0.00 & 0.00 & 0.00 & 0.00 & 0.00 \\
\hline MnO & 0.36 & 0.54 & 0.68 & 0.55 & 0.62 & 0.52 & 0.75 & 0.63 & 0.36 & 0.55 \\
\hline Cr2O3 & 0.00 & 0.00 & 0.00 & 0.00 & 0.00 & 0.00 & 0.00 & 0.00 & 0.00 & 0.00 \\
\hline $\mathrm{FeO}$ & 3.57 & 3.15 & 3.34 & 3.36 & 2.93 & 2.94 & 3.03 & 2.98 & 3.57 & 3.32 \\
\hline F & 0.00 & 0.03 & 0.00 & 0.00 & 0.00 & 0.07 & 0.01 & 0.01 & 0.00 & 0.30 \\
\hline K2O & 0.00 & 0.00 & 0.00 & 0.00 & 0.02 & 0.02 & 0.00 & 0.02 & 0.00 & 0.00 \\
\hline $\mathrm{CaO}$ & 23.19 & 22.29 & 22.28 & 22.01 & 22.30 & 22.43 & 22.38 & 22.29 & 23.19 & 22.61 \\
\hline SrO & 0.00 & 0.00 & 0.00 & 0.00 & 0.00 & 0.00 & 0.00 & 0.00 & 0.00 & 0.00 \\
\hline $\mathrm{BaO}$ & 0.00 & 0.00 & 0.00 & 0.00 & 0.00 & 0.00 & 0.00 & 0.00 & 0.00 & 0.00 \\
\hline TiO2 & 0.07 & 0.08 & 0.05 & 0.07 & 0.05 & 0.04 & 0.04 & 0.07 & 0.07 & 0.07 \\
\hline SiO2 & 37.90 & 38.52 & 38.46 & 38.23 & 38.40 & 38.49 & 38.51 & 38.19 & 37.90 & 37.55 \\
\hline TiO2 & 0.07 & 0.08 & 0.05 & 0.07 & 0.05 & 0.04 & 0.04 & 0.07 & 0.07 & 0.07 \\
\hline Al2O3 & 25.32 & 25.75 & 25.79 & 25.58 & 25.90 & 25.65 & 25.81 & 25.88 & 25.32 & 25.21 \\
\hline V2O3 & 0.00 & 0.00 & 0.00 & 0.00 & 0.00 & 0.00 & 0.00 & 0.00 & 0.00 & 0.00 \\
\hline Cr2O3 & 0.00 & 0.00 & 0.00 & 0.00 & 0.00 & 0.00 & 0.00 & 0.00 & 0.00 & 0.00 \\
\hline $\mathrm{Fe} 2 \mathrm{O} 3$ & 3.97 & 3.50 & 3.72 & 3.74 & 3.26 & 3.27 & 3.37 & 3.31 & 3.97 & 3.69 \\
\hline MnO & 0.36 & 0.54 & 0.68 & 0.55 & 0.62 & 0.52 & 0.75 & 0.63 & 0.36 & 0.55 \\
\hline MgO & 3.21 & 3.56 & 3.59 & 3.38 & 3.49 & 3.67 & 3.48 & 3.55 & 3.21 & 3.40 \\
\hline $\mathrm{CaO}$ & 23.19 & 22.29 & 22.28 & 22.01 & 22.30 & 22.43 & 22.38 & 22.29 & 23.19 & 22.61 \\
\hline SrO & 0.00 & 0.00 & 0.00 & 0.00 & 0.00 & 0.00 & 0.00 & 0.00 & 0.00 & 0.00 \\
\hline $\mathrm{BaO}$ & 0.00 & 0.00 & 0.00 & 0.00 & 0.00 & 0.00 & 0.00 & 0.00 & 0.00 & 0.00 \\
\hline $\mathrm{Na2O}$ & 0.14 & 0.23 & 0.21 & 0.18 & 0.17 & 0.11 & 0.15 & 0.17 & 0.14 & 0.18 \\
\hline K2O & 0.00 & 0.00 & 0.00 & 0.00 & 0.02 & 0.02 & 0.00 & 0.02 & 0.00 & 0.00 \\
\hline $\mathrm{H} 2 \mathrm{O}$ & 6.63 & 6.74 & 6.73 & 6.69 & 6.72 & 6.73 & 6.74 & 6.68 & 6.63 & 6.57 \\
\hline anidra sum & 94.15 & 94.46 & 94.79 & 93.73 & 94.21 & 94.20 & 94.49 & 94.13 & 94.15 & 93.25 \\
\hline hidratada sum & 100.78 & 101.20 & 101.51 & 100.42 & 100.93 & 100.93 & 101.23 & 100.81 & 100.78 & 99.82 \\
\hline $\mathrm{Si}$ & 0.63 & 0.64 & 0.64 & 0.64 & 0.64 & 0.64 & 0.64 & 0.64 & 0.63 & 0.62 \\
\hline $\mathrm{Ti}$ & 0.00 & 0.00 & 0.00 & 0.00 & 0.00 & 0.00 & 0.00 & 0.00 & 0.00 & 0.00 \\
\hline Al & 0.50 & 0.51 & 0.51 & 0.50 & 0.51 & 0.50 & 0.51 & 0.51 & 0.50 & 0.49 \\
\hline V & 0.00 & 0.00 & 0.00 & 0.00 & 0.00 & 0.00 & 0.00 & 0.00 & 0.00 & 0.00 \\
\hline $\mathrm{Cr}$ & 0.00 & 0.00 & 0.00 & 0.00 & 0.00 & 0.00 & 0.00 & 0.00 & 0.00 & 0.00 \\
\hline Fe3+ & 0.05 & 0.04 & 0.05 & 0.05 & 0.04 & 0.04 & 0.04 & 0.04 & 0.05 & 0.05 \\
\hline Mn2+ & 0.01 & 0.01 & 0.01 & 0.01 & 0.01 & 0.01 & 0.01 & 0.01 & 0.01 & 0.01 \\
\hline Mg & 0.08 & 0.09 & 0.09 & 0.08 & 0.09 & 0.09 & 0.09 & 0.09 & 0.08 & 0.08 \\
\hline $\mathrm{Ca}$ & 0.41 & 0.40 & 0.40 & 0.39 & 0.40 & 0.40 & 0.40 & 0.40 & 0.41 & 0.40 \\
\hline $\mathrm{Na}$ & 0.00 & 0.01 & 0.01 & 0.01 & 0.01 & 0.00 & 0.00 & 0.01 & 0.00 & 0.01 \\
\hline K & 0.00 & 0.00 & 0.00 & 0.00 & 0.00 & 0.00 & 0.00 & 0.00 & 0.00 & 0.00 \\
\hline 0 & 2.58 & 2.60 & 2.61 & 2.58 & 2.60 & 2.60 & 2.60 & 2.59 & 2.58 & 2.56 \\
\hline $\mathrm{OH}$ & 0.74 & 0.75 & 0.75 & 0.74 & 0.75 & 0.75 & 0.75 & 0.74 & 0.74 & 0.73 \\
\hline $\mathrm{Si}$ & 6.00 & 6.00 & 6.00 & 6.00 & 6.00 & 6.00 & 6.00 & 6.00 & 6.00 & 6.00 \\
\hline $\mathrm{Ti}$ & 0.01 & 0.01 & 0.01 & 0.01 & 0.01 & 0.01 & 0.01 & 0.01 & 0.01 & 0.01 \\
\hline Al & 4.72 & 4.73 & 4.74 & 4.73 & 4.77 & 4.71 & 4.74 & 4.79 & 4.72 & 4.75 \\
\hline V & 0.00 & 0.00 & 0.00 & 0.00 & 0.00 & 0.00 & 0.00 & 0.00 & 0.00 & 0.00 \\
\hline $\mathrm{Cr}$ & 0.00 & 0.00 & 0.00 & 0.00 & 0.00 & 0.00 & 0.00 & 0.00 & 0.00 & 0.00 \\
\hline Fe3+ & 0.47 & 0.41 & 0.44 & 0.44 & 0.38 & 0.38 & 0.40 & 0.39 & 0.47 & 0.44 \\
\hline Mn2+ & 0.05 & 0.07 & 0.09 & 0.07 & 0.08 & 0.07 & 0.10 & 0.08 & 0.05 & 0.07 \\
\hline Mg & 0.76 & 0.83 & 0.83 & 0.79 & 0.81 & 0.85 & 0.81 & 0.83 & 0.76 & 0.81 \\
\hline $\mathrm{Ca}$ & 3.93 & 3.72 & 3.72 & 3.70 & 3.73 & 3.75 & 3.74 & 3.75 & 3.93 & 3.87 \\
\hline $\mathrm{Na}$ & 0.04 & 0.07 & 0.06 & 0.05 & 0.05 & 0.03 & 0.05 & 0.05 & 0.04 & 0.05 \\
\hline K & 0.00 & 0.00 & 0.00 & 0.00 & 0.00 & 0.00 & 0.00 & 0.00 & 0.00 & 0.00 \\
\hline 0 & 24.57 & 24.38 & 24.46 & 24.37 & 24.40 & 24.34 & 24.38 & 24.49 & 24.57 & 24.58 \\
\hline H & 7.00 & 7.00 & 7.00 & 7.00 & 7.00 & 7.00 & 7.00 & 7.00 & 7.00 & 7.00 \\
\hline sum VI site & 6.01 & 6.04 & 6.11 & 6.05 & 6.05 & 6.02 & 6.05 & 6.11 & 6.01 & 6.08 \\
\hline sum VIII site & 3.98 & 3.79 & 3.79 & 3.75 & 3.79 & 3.78 & 3.78 & 3.81 & 3.98 & 3.93 \\
\hline sum $O$ site & 31.57 & 31.38 & 31.46 & 31.37 & 31.40 & 31.34 & 31.38 & 31.49 & 31.57 & 31.58 \\
\hline sum cations & 15.99 & 15.83 & 15.90 & 15.80 & 15.84 & 15.81 & 15.83 & 15.92 & 15.99 & 16.01 \\
\hline adj. 0 & 24.59 & 24.63 & 24.62 & 24.68 & 24.64 & 24.64 & 24.64 & 24.62 & 24.59 & 24.57 \\
\hline cations $=16,0$ & $=24.5$ & & & & & & & & & \\
\hline $\mathrm{Si}$ & 6.01 & 6.06 & 6.04 & 6.08 & 6.06 & 6.07 & 6.06 & 6.03 & 6.01 & 6.00 \\
\hline $\mathrm{Ti}$ & 0.01 & 0.01 & 0.01 & 0.01 & 0.01 & 0.01 & 0.01 & 0.01 & 0.01 & 0.01 \\
\hline Al & 4.73 & 4.78 & 4.77 & 4.79 & 4.82 & 4.77 & 4.79 & 4.82 & 4.73 & 4.74 \\
\hline Fe3+ & 0.00 & 0.00 & 0.00 & 0.00 & 0.00 & 0.00 & 0.00 & 0.00 & 0.00 & 0.00 \\
\hline Fe2+ & 0.19 & 0.27 & 0.24 & 0.35 & 0.28 & 0.28 & 0.28 & 0.23 & 0.19 & 0.14 \\
\hline Mn2+ & 0.05 & 0.07 & 0.09 & 0.07 & 0.08 & 0.07 & 0.10 & 0.08 & 0.05 & 0.07 \\
\hline Mg & 0.76 & 0.83 & 0.84 & 0.80 & 0.82 & 0.86 & 0.82 & 0.84 & 0.76 & 0.81 \\
\hline $\mathrm{Ca}$ & 3.94 & 3.76 & 3.75 & 3.75 & 3.77 & 3.79 & 3.78 & 3.77 & 3.94 & 3.87 \\
\hline $\mathrm{Na}$ & 0.04 & 0.07 & 0.06 & 0.05 & 0.05 & 0.03 & 0.05 & 0.05 & 0.04 & 0.05 \\
\hline K & 0.00 & 0.00 & 0.00 & 0.00 & 0.00 & 0.00 & 0.00 & 0.00 & 0.00 & 0.00 \\
\hline 0 & 24.07 & 24.28 & 24.19 & 24.36 & 24.34 & 24.33 & 24.33 & 24.26 & 24.07 & 24.05 \\
\hline H & 7.00 & 7.00 & 7.00 & 7.00 & 7.00 & 7.00 & 7.00 & 7.00 & 7.00 & 7.00 \\
\hline sum VI site & 5.73 & 5.96 & 5.94 & 6.03 & 6.01 & 5.99 & 6.00 & 5.98 & 5.73 & 5.78 \\
\hline sum VIII site & 3.98 & 3.83 & 3.81 & 3.80 & 3.83 & 3.83 & 3.82 & 3.83 & 3.98 & 3.92 \\
\hline $\mathrm{Mg} /(\mathrm{Mg}+\mathrm{Fe} 2+)$ & 0.80 & 0.76 & 0.78 & 0.70 & 0.75 & 0.76 & 0.74 & 0.78 & 0.80 & 0.85 \\
\hline $\mathrm{Fe} /(\mathrm{Mg}+\mathrm{Fe} 2+)$ & 0.20 & 0.24 & 0.22 & 0.30 & 0.25 & 0.24 & 0.26 & 0.22 & 0.20 & 0.15 \\
\hline Al & 0.83 & 0.81 & 0.82 & 0.81 & 0.81 & 0.81 & 0.81 & 0.82 & 0.83 & 0.83 \\
\hline $\mathrm{Fe}$ & 0.03 & 0.05 & 0.04 & 0.06 & 0.05 & 0.05 & 0.05 & 0.04 & 0.03 & 0.03 \\
\hline Mg & 0.13 & 0.14 & 0.14 & 0.13 & 0.14 & 0.15 & 0.14 & 0.14 & 0.13 & 0.14 \\
\hline $\mathrm{Mg} /(\mathrm{Mg}+\mathrm{Fe} 2+)$ & 0.80 & 0.76 & 0.78 & 0.70 & 0.75 & 0.76 & 0.74 & 0.78 & 0.80 & 0.85 \\
\hline $\mathrm{Fe} /(\mathrm{Mg}+\mathrm{Fe} 2+)$ & 0.20 & 0.24 & 0.22 & 0.30 & 0.25 & 0.24 & 0.26 & 0.22 & 0.20 & 0.15 \\
\hline Al-4 & 0.44 & 0.41 & 0.42 & 0.41 & 0.43 & 0.40 & 0.42 & 0.43 & 0.44 & 0.44 \\
\hline $\mathrm{Fe}$ & 0.11 & 0.14 & 0.13 & 0.18 & 0.15 & 0.15 & 0.15 & 0.12 & 0.11 & 0.08 \\
\hline Mg & 0.45 & 0.44 & 0.45 & 0.41 & 0.43 & 0.45 & 0.43 & 0.44 & 0.45 & 0.48 \\
\hline
\end{tabular}


ANEXO V. Análises geoquímicas completas das amostras da região de Jambaló 


\begin{tabular}{|c|c|c|c|c|c|c|c|}
\hline \multirow{2}{*}{$\begin{array}{l}\text { Fácies } \\
\text { Amostra }\end{array}$} & \multicolumn{6}{|c|}{ Xisto verde } & \multirow[b]{2}{*}{$125 \mathrm{M}^{\star \star \star *}$} \\
\hline & $\begin{array}{l}\text { Limite de } \\
\text { detecção }\end{array}$ & $107^{*}$ & 107A & 107B & $109 A^{\star \star *}$ & 114 & \\
\hline$\overline{\mathrm{SiO} 2(\%)}$ & 0.01 & 59.270 & 49.060 & 58.120 & 38.270 & 55.160 & 56.330 \\
\hline TiO2 (\%) & 0.001 & 1.020 & 1.196 & 0.821 & 0.429 & 0.778 & 1.167 \\
\hline Al2O3 (\%) & 0.01 & 15.580 & 16.550 & 16.990 & 17.690 & 16.480 & 17.770 \\
\hline $\mathrm{Fe} 2 \mathrm{O} 3(\mathrm{~T})(\%)$ & 0.01 & 7.080 & 11.520 & 7.780 & 7.830 & 9.120 & 8.140 \\
\hline $\mathrm{MnO}(\%)$ & 0.001 & 0.156 & 0.180 & 0.096 & 0.147 & 0.174 & 0.103 \\
\hline MgO (\%) & 0.01 & 3.180 & 7.290 & 3.310 & 1.550 & 5.910 & 4.680 \\
\hline $\mathrm{CaO}(\%)$ & 0.01 & 2.990 & 6.650 & 4.700 & 20.700 & 4.600 & 1.640 \\
\hline $\mathrm{Na2O}(\%)$ & 0.01 & 6.670 & 3.860 & 3.560 & 2.820 & 1.860 & 5.650 \\
\hline K2O (\%) & 0.01 & 1.590 & 0.510 & 1.190 & 0.550 & 1.360 & 0.650 \\
\hline P2O5 (\%) & 0.01 & 0.340 & 0.130 & 0.140 & 0.030 & 0.160 & 0.130 \\
\hline LOI (\%) & 0.01 & 1.970 & 3.570 & 3.520 & 10.440 & 4.770 & 3.740 \\
\hline Total (\%) & 0.01 & 99.850 & 100.500 & 100.200 & 100.500 & 100.400 & 99.990 \\
\hline $\mathrm{Ba}(\mathrm{ppm})$ & 3 & 988.000 & 458.000 & 921.000 & 285.000 & 440.000 & 191.000 \\
\hline $\mathrm{Rb}(\mathrm{ppm})$ & 1 & 26.000 & 9.000 & 21.000 & 9.000 & 18.000 & 14.000 \\
\hline $\mathrm{Sr}(\mathrm{ppm})$ & 2 & 57.000 & 249.000 & 324.000 & 387.000 & 414.000 & 83.000 \\
\hline Cs (ppm) & 0.1 & 3.000 & 0.600 & 1.100 & 0.500 & 0.300 & 0.500 \\
\hline Ga (ppm) & 1 & 15.000 & 19.000 & 18.000 & 30.000 & 21.000 & 19.000 \\
\hline $\mathrm{TI}$ (ppm) & 0.05 & 0.200 & 0.240 & 0.690 & 0.090 & 0.200 & 0.150 \\
\hline $\mathrm{Ta}(\mathrm{ppm})$ & 0.01 & 0.560 & 0.350 & 0.880 & 0.210 & 0.720 & 1.010 \\
\hline $\mathrm{Nb}$ (ppm) & 0.2 & 5.600 & 2.000 & 2.800 & 0.600 & 2.400 & 4.900 \\
\hline Hf (ppm) & 0.1 & 4.200 & 1.600 & 2.200 & 0.500 & 1.900 & 3.700 \\
\hline $\mathrm{Zr}(\mathrm{ppm})$ & 4 & 164.000 & 54.000 & 78.000 & 19.000 & 67.000 & 147.000 \\
\hline$Y(\mathrm{ppm})$ & 0.5 & 42.400 & 18.600 & 18.700 & 7.100 & 20.100 & 23.800 \\
\hline Th (ppm) & 0.05 & 2.790 & 0.930 & 1.830 & 0.220 & 2.090 & 3.090 \\
\hline$U$ (ppm) & 0.01 & 1.380 & 0.360 & 0.810 & 0.170 & 0.790 & 0.750 \\
\hline $\operatorname{Cr}(\mathrm{ppm})$ & 20 & $<20$ & $<20$ & $<20$ & $<20$ & $<20$ & 100.000 \\
\hline $\mathrm{Ni}(\mathrm{ppm})$ & 20 & 20.000 & 30.000 & $<20$ & 30.000 & $<20$ & 30.000 \\
\hline Co (ppm) & 1 & 21.000 & 29.000 & 26.000 & 17.000 & 22.000 & 34.000 \\
\hline Sc (ppm) & 1 & 15.000 & 41.000 & 27.000 & 18.000 & 34.000 & 28.000 \\
\hline$V(\mathrm{ppm})$ & 5 & 107.000 & 384.000 & 239.000 & 360.000 & 315.000 & 194.000 \\
\hline $\mathrm{Cu}(\mathrm{ppm})$ & 10 & 60.000 & 70.000 & 40.000 & 30.000 & 50.000 & 50.000 \\
\hline $\mathrm{Pb}(\mathrm{ppm})$ & 5 & $<5$ & 8.000 & $<5$ & $<5$ & 20.000 & 5.000 \\
\hline $\mathrm{Zn}(\mathrm{ppm})$ & 30 & 70.000 & 100.000 & 70.000 & 50.000 & 160.000 & 110.000 \\
\hline $\mathrm{Bi}(\mathrm{ppm})$ & 0.1 & $<0.1$ & $<0.1$ & $<0.1$ & $<0.1$ & 0.200 & $<0.1$ \\
\hline Sn (ppm) & 1 & 1.000 & $<1$ & $<1$ & $<1$ & 2.000 & 2.000 \\
\hline $\mathrm{W}$ (ppm) & 0.5 & 76.500 & 71.800 & 228.000 & 57.300 & 189.000 & 171.000 \\
\hline $\operatorname{Be}(\mathrm{ppm})$ & 1 & 2.000 & 1.000 & 1.000 & $<1$ & 1.000 & 1.000 \\
\hline $\mathrm{Ag}(\mathrm{ppm})$ & 0.5 & 0.600 & $<0.5$ & $<0.5$ & $<0.5$ & $<0.5$ & $<0.5$ \\
\hline As $(\mathrm{ppm})$ & 5 & $<5$ & $<5$ & $<5$ & $<5$ & $<5$ & $<5$ \\
\hline La (ppm) & 0.05 & 16.800 & 6.290 & 10.500 & 1.650 & 12.900 & 12.400 \\
\hline $\mathrm{Ce}(\mathrm{ppm})$ & 0.05 & 39.000 & 14.300 & 22.500 & 4.030 & 26.800 & 28.100 \\
\hline $\operatorname{Pr}(\mathrm{ppm})$ & 0.01 & 5.450 & 2.120 & 2.900 & 0.600 & 3.420 & 3.360 \\
\hline $\mathrm{Nd}(\mathrm{ppm})$ & 0.05 & 25.100 & 10.400 & 13.100 & 3.010 & 14.500 & 14.200 \\
\hline Sm (ppm) & 0.01 & 6.420 & 2.710 & 3.190 & 0.860 & 3.300 & 3.510 \\
\hline $\mathrm{Eu}(\mathrm{ppm})$ & 0.005 & 2.150 & 1.130 & 1.130 & 0.446 & 1.210 & 1.180 \\
\hline $\mathrm{Gd}(\mathrm{ppm})$ & 0.01 & 6.820 & 2.960 & 3.140 & 1.060 & 3.280 & 3.810 \\
\hline Tb (ppm) & 0.01 & 1.180 & 0.530 & 0.550 & 0.190 & 0.560 & 0.710 \\
\hline Dy (ppm) & 0.01 & 7.340 & 3.250 & 3.400 & 1.250 & 3.410 & 4.550 \\
\hline Ho (ppm) & 0.01 & 1.480 & 0.650 & 0.680 & 0.260 & 0.710 & 0.890 \\
\hline $\operatorname{Er}(\mathbf{p p m})$ & 0.01 & 4.360 & 1.860 & 2.060 & 0.770 & 2.150 & 2.660 \\
\hline $\operatorname{Tm}(p p m)$ & 0.005 & 0.659 & 0.269 & 0.331 & 0.112 & 0.329 & 0.396 \\
\hline $\mathrm{Yb}(\mathrm{ppm})$ & 0.01 & 4.270 & 1.660 & 2.380 & 0.720 & 2.150 & 2.550 \\
\hline Lu (ppm) & 0.002 & 0.689 & 0.247 & 0.397 & 0.113 & 0.316 & 0.377 \\
\hline Ge (ppm) & 0.5 & 1.300 & 1.600 & 1.300 & 2.000 & 1.300 & 1.600 \\
\hline
\end{tabular}

\begin{tabular}{|c|c|c|c|c|c|}
\hline \multicolumn{6}{|c|}{ Xisto azul } \\
\hline 121B & $121 \mathrm{C}$ & $123 \mathrm{~A}$ & $124 \mathrm{G}$ & $124 \mathrm{~J}$ & $129 \mathrm{~A}$ \\
\hline$\overline{51.740}$ & 50.940 & 50.420 & 56.900 & 52.010 & 51.420 \\
\hline 1.428 & 0.680 & 1.462 & 1.710 & 1.478 & 1.838 \\
\hline 15.590 & 17.670 & 17.760 & 15.620 & 18.060 & 14.410 \\
\hline 9.660 & 6.960 & 9.750 & 9.500 & 8.840 & 9.530 \\
\hline 0.441 & 0.118 & 0.139 & 0.123 & 0.145 & 0.129 \\
\hline 3.490 & 6.130 & 3.270 & 4.020 & 4.480 & 5.330 \\
\hline 5.760 & 8.870 & 11.600 & 2.940 & 3.480 & 3.950 \\
\hline 4.780 & 2.330 & 2.620 & 4.490 & 5.570 & 5.180 \\
\hline 0.310 & 0.130 & 0.350 & 0.830 & 0.690 & 0.160 \\
\hline 0.290 & 0.090 & 0.410 & 0.290 & 0.230 & 0.230 \\
\hline 6.600 & 4.690 & 2.580 & 3.800 & 4.180 & 7.840 \\
\hline 100.100 & 98.610 & 100.400 & 100.200 & 99.150 & 100.000 \\
\hline 66.000 & 154.000 & 71.000 & 119.000 & 108.000 & 25.000 \\
\hline 5.000 & 2.000 & 6.000 & 20.000 & 16.000 & 3.000 \\
\hline 166.000 & 151.000 & 574.000 & 68.000 & 80.000 & 163.000 \\
\hline 1.200 & $<0.1$ & 0.300 & 0.400 & 0.400 & 0.300 \\
\hline 17.000 & 13.000 & 25.000 & 20.000 & 22.000 & 20.000 \\
\hline 0.070 & $<0.05$ & $<0.05$ & 0.140 & 0.120 & $<0.05$ \\
\hline 1.120 & 0.670 & 2.210 & 1.460 & 1.390 & 1.290 \\
\hline 5.300 & 1.600 & 15.400 & 7.200 & 9.500 & 7.700 \\
\hline 3.300 & 1.100 & 4.900 & 4.500 & 6.400 & 4.300 \\
\hline 126.000 & 38.000 & 224.000 & 186.000 & 264.000 & 175.000 \\
\hline 33.000 & 13.800 & 23.500 & 35.800 & 48.600 & 38.400 \\
\hline 1.000 & 0.280 & 1.480 & 3.640 & 3.740 & 1.200 \\
\hline 0.390 & 0.130 & 0.340 & 0.930 & 1.380 & 0.520 \\
\hline 20.000 & 140.000 & 60.000 & $<20$ & 60.000 & 90.000 \\
\hline 30.000 & 70.000 & 70.000 & $<20$ & 30.000 & 30.000 \\
\hline 33.000 & 32.000 & 36.000 & 32.000 & 51.000 & 35.000 \\
\hline 29.000 & 33.000 & 20.000 & 27.000 & 25.000 & 37.000 \\
\hline 214.000 & 184.000 & 184.000 & 238.000 & 185.000 & 278.000 \\
\hline$<10$ & 20.000 & 50.000 & $<10$ & $<10$ & 30.000 \\
\hline$<5$ & $<5$ & $<5$ & $<5$ & $<5$ & $<5$ \\
\hline 70.000 & 50.000 & 80.000 & 130.000 & 130.000 & 130.000 \\
\hline$<0.1$ & $<0.1$ & 0.100 & $<0.1$ & $<0.1$ & $<0.1$ \\
\hline 1.000 & 1.000 & 2.000 & 2.000 & 3.000 & 3.000 \\
\hline 258.000 & 219.000 & 333.000 & 322.000 & 230.000 & 107.000 \\
\hline 1.000 & $<1$ & 1.000 & 2.000 & 2.000 & 1.000 \\
\hline$<0.5$ & $<0.5$ & $<0.5$ & $<0.5$ & $<0.5$ & $<0.5$ \\
\hline 7.000 & $<5$ & $<5$ & $<5$ & $<5$ & $<5$ \\
\hline 10.400 & 3.590 & 22.300 & 15.600 & 14.800 & 9.220 \\
\hline 25.900 & 8.990 & 46.600 & 35.400 & 40.400 & 24.000 \\
\hline 3.620 & 1.240 & 5.860 & 4.710 & 5.650 & 3.380 \\
\hline 17.500 & 6.090 & 24.400 & 20.400 & 24.300 & 16.200 \\
\hline 4.590 & 1.720 & 5.310 & 5.020 & 6.040 & 4.740 \\
\hline 1.830 & 0.817 & 1.980 & 1.700 & 1.950 & 1.580 \\
\hline 5.270 & 2.050 & 5.170 & 5.450 & 6.760 & 5.320 \\
\hline 0.940 & 0.390 & 0.840 & 0.990 & 1.270 & 1.020 \\
\hline 5.920 & 2.380 & 4.740 & 6.230 & 8.010 & 6.740 \\
\hline 1.180 & 0.480 & 0.860 & 1.280 & 1.630 & 1.400 \\
\hline 3.510 & 1.410 & 2.350 & 3.740 & 4.880 & 4.160 \\
\hline 0.532 & 0.207 & 0.327 & 0.542 & 0.721 & 0.631 \\
\hline 3.450 & 1.330 & 2.030 & 3.480 & 4.530 & 4.140 \\
\hline 0.516 & 0.197 & 0.290 & 0.550 & 0.683 & 0.635 \\
\hline 1.200 & 1.600 & 1.400 & 1.300 & 1.300 & 1.100 \\
\hline
\end{tabular}

"estilpnomelano-muscovita-albita-anfibólio-quartzo xisto, ${ }^{* *}$ epidosito, ${ }^{* * *}$ rocha transicional 
ANEXO VI. Análises geoquímicas completas das amostras da região de Barragán 


\begin{tabular}{|c|c|c|c|c|c|c|}
\hline \multicolumn{2}{|l|}{ Fácies } & \multicolumn{5}{|c|}{ Anfibolito } \\
\hline Amostra & $\begin{array}{l}\text { Limite de } \\
\text { detecção }\end{array}$ & 187 & $187 A$ & 187B & 188 & 189 \\
\hline$\overline{\mathrm{SiO} 2(\%)}$ & 0.01 & 47.670 & 50.830 & 50.030 & 51.270 & 49.350 \\
\hline TiO2 (\%) & 0.001 & 1.302 & 1.227 & 1.269 & 2.042 & 1.366 \\
\hline Al2O3 (\%) & 0.01 & 15.120 & 14.320 & 14.970 & 13.390 & 14.720 \\
\hline $\mathrm{Fe} 2 \mathrm{O} 3(\mathrm{~T})(\%)$ & 0.01 & 14.450 & 10.770 & 10.600 & 12.170 & 12.190 \\
\hline $\mathrm{MnO}(\%)$ & 0.001 & 0.519 & 0.222 & 0.176 & 0.230 & 0.190 \\
\hline $\mathrm{MgO}(\%)$ & 0.01 & 7.990 & 7.910 & 8.240 & 6.010 & 8.720 \\
\hline $\mathrm{CaO}(\%)$ & 0.01 & 8.810 & 10.260 & 11.210 & 9.440 & 8.820 \\
\hline $\mathrm{Na} 2 \mathrm{O}(\%)$ & 0.01 & 2.550 & 2.350 & 2.310 & 3.920 & 2.640 \\
\hline K2O (\%) & 0.01 & 0.210 & 0.140 & 0.100 & 0.110 & 0.170 \\
\hline P2O5 (\%) & 0.01 & 0.100 & 0.080 & 0.120 & 0.220 & 0.100 \\
\hline LOI (\%) & 0.01 & 1.400 & 2.080 & 1.230 & 1.150 & 2.050 \\
\hline Total (\%) & 0.01 & 100.100 & 100.200 & 100.300 & 99.960 & 100.300 \\
\hline $\mathrm{Ba}(\mathrm{ppm})$ & 3 & 78.000 & 374.000 & 323.000 & 17.000 & 38.000 \\
\hline $\mathrm{Rb}(\mathrm{ppm})$ & 1 & 4.000 & 2.000 & 4.000 & $<1$ & 3.000 \\
\hline $\operatorname{Sr}(\mathbf{p p m})$ & 2 & 37.000 & 113.000 & 152.000 & 113.000 & 120.000 \\
\hline Cs (ppm) & 0.1 & 0.200 & $<0.1$ & 0.100 & $<0.1$ & 0.200 \\
\hline $\mathrm{Ga}(\mathrm{ppm})$ & 1 & 14.000 & 16.000 & 18.000 & 18.000 & 19.000 \\
\hline $\mathrm{TI}(\mathrm{ppm})$ & 0.05 & 0.060 & $<0.05$ & $<0.05$ & $<0.05$ & $<0.05$ \\
\hline $\mathrm{Ta}(\mathrm{ppm})$ & 0.01 & 1.460 & 0.860 & 0.040 & 0.670 & 0.030 \\
\hline $\mathrm{Nb}$ (ppm) & 0.2 & 2.000 & 1.100 & 1.000 & 2.500 & 0.900 \\
\hline Hf (ppm) & 0.1 & 2.100 & 1.900 & 1.900 & 3.900 & 2.200 \\
\hline $\operatorname{Zr}(\mathrm{ppm})$ & 4 & 59.000 & 62.000 & 69.000 & 134.000 & 68.000 \\
\hline$Y(\mathrm{ppm})$ & 0.5 & 37.500 & 29.200 & 30.300 & 48.800 & 33.200 \\
\hline Th (ppm) & 0.05 & 0.110 & 0.060 & 0.060 & 0.190 & 0.060 \\
\hline $\mathrm{U}(\mathrm{ppm})$ & 0.01 & 0.050 & 0.040 & 0.040 & 0.090 & 0.050 \\
\hline $\operatorname{Cr}(\mathrm{ppm})$ & 20 & 270.000 & 370.000 & 340.000 & 70.000 & 240.000 \\
\hline $\mathrm{Ni}(\mathrm{ppm})$ & 20 & 90.000 & 80.000 & 70.000 & 60.000 & 80.000 \\
\hline Co (ppm) & 1 & 72.000 & 61.000 & 40.000 & 53.000 & 41.000 \\
\hline Sc (ppm) & 1 & 44.000 & 43.000 & 45.000 & 42.000 & 44.000 \\
\hline$V(p p m)$ & 5 & 285.000 & 275.000 & 305.000 & 395.000 & 331.000 \\
\hline $\mathrm{Cu}(\mathrm{ppm})$ & 10 & 30.000 & 20.000 & 30.000 & 30.000 & 80.000 \\
\hline $\mathrm{Pb}(\mathrm{ppm})$ & 5 & $<5$ & $<5$ & $<5$ & $<5$ & $<5$ \\
\hline $\mathrm{Zn}(\mathrm{ppm})$ & 30 & 110.000 & 80.000 & 90.000 & 140.000 & 130.000 \\
\hline $\mathrm{Bi}(\mathrm{ppm})$ & 0.1 & $<0.1$ & 0.400 & $<0.1$ & $<0.1$ & $<0.1$ \\
\hline $\mathrm{Sn}(\mathrm{ppm})$ & 1 & 2.000 & 1.000 & 1.000 & 2.000 & 1.000 \\
\hline $\mathrm{W}(\mathrm{ppm})$ & 0.5 & 208.000 & 230.000 & 2.600 & 137.000 & 1.500 \\
\hline $\mathrm{Be}(\mathrm{ppm})$ & 1 & $<1$ & $<1$ & 1.000 & 1.000 & 1.000 \\
\hline $\mathrm{Ag}(\mathrm{ppm})$ & 0.5 & 0.500 & $<0.5$ & $<0.5$ & $<0.5$ & $<0.5$ \\
\hline As (ppm) & 5 & $<5$ & $<5$ & $<5$ & $<5$ & $<5$ \\
\hline La (ppm) & 0.05 & 3.380 & 2.230 & 2.520 & 5.020 & 1.990 \\
\hline $\mathrm{Ce}(\mathrm{ppm})$ & 0.05 & 7.280 & 6.450 & 6.810 & 16.000 & 7.130 \\
\hline $\operatorname{Pr}(\mathrm{ppm})$ & 0.01 & 1.590 & 1.260 & 1.350 & 2.630 & 1.350 \\
\hline $\mathrm{Nd}(\mathrm{ppm})$ & 0.05 & 8.810 & 7.450 & 8.050 & 14.400 & 8.040 \\
\hline Sm (ppm) & 0.01 & 2.950 & 2.700 & 2.790 & 4.870 & 2.930 \\
\hline $\mathrm{Eu}(\mathrm{ppm})$ & 0.005 & 1.080 & 1.120 & 1.140 & 1.810 & 1.270 \\
\hline Gd (ppm) & 0.01 & 3.950 & 3.790 & 3.860 & 6.520 & 4.150 \\
\hline $\mathrm{Tb}(\mathrm{ppm})$ & 0.01 & 0.830 & 0.760 & 0.790 & 1.300 & 0.890 \\
\hline Dy (ppm) & 0.01 & 5.910 & 5.100 & 5.240 & 8.510 & 5.840 \\
\hline Ho (ppm) & 0.01 & 1.270 & 1.060 & 1.070 & 1.750 & 1.150 \\
\hline $\operatorname{Er}(\mathrm{ppm})$ & 0.01 & 4.060 & 3.170 & 3.240 & 5.190 & 3.440 \\
\hline $\operatorname{Tm}(\mathrm{ppm})$ & 0.005 & 0.635 & 0.482 & 0.495 & 0.787 & 0.514 \\
\hline $\mathrm{Yb}(\mathrm{ppm})$ & 0.01 & 4.140 & 3.100 & 3.210 & 5.020 & 3.270 \\
\hline Lu (ppm) & 0.002 & 0.656 & 0.464 & 0.509 & 0.766 & 0.512 \\
\hline $\mathrm{Ge}(\mathrm{ppm})$ & 0.5 & 1.600 & 1.300 & 1.300 & 1.600 & 1.400 \\
\hline
\end{tabular}

\begin{tabular}{|c|c|c|c|c|c|}
\hline \multicolumn{6}{|c|}{ Xisto azul } \\
\hline 195 & 196 & 196A & $196 \mathrm{D}$ & 197A & 199 \\
\hline 50.000 & 48.370 & 48.420 & 49.140 & 49.240 & 48.250 \\
\hline 1.976 & 1.399 & 1.727 & 1.481 & 1.241 & 1.920 \\
\hline 14.520 & 14.540 & 15.360 & 13.930 & 16.310 & 14.380 \\
\hline 11.180 & 10.320 & 11.670 & 10.820 & 10.410 & 12.730 \\
\hline 0.187 & 0.157 & 0.200 & 0.161 & 0.168 & 0.158 \\
\hline 6.180 & 9.280 & 6.740 & 6.600 & 8.590 & 7.600 \\
\hline 8.410 & 8.100 & 8.650 & 10.810 & 4.190 & 7.550 \\
\hline 2.030 & 2.680 & 3.360 & 2.420 & 0.180 & 3.330 \\
\hline$<0.01$ & 0.580 & 0.140 & 0.490 & 0.040 & 0.110 \\
\hline 0.200 & 0.140 & 0.130 & 0.200 & 0.090 & 0.190 \\
\hline 5.210 & 4.520 & 3.450 & 3.270 & 8.480 & 3.870 \\
\hline 99.910 & 100.100 & 99.840 & 99.320 & 98.930 & 100.100 \\
\hline 38.000 & 73.000 & 49.000 & 383.000 & 18.000 & 110.000 \\
\hline$<1$ & 11.000 & 3.000 & 12.000 & $<1$ & 7.000 \\
\hline 9.000 & 73.000 & 142.000 & 201.000 & 73.000 & 91.000 \\
\hline$<0.1$ & 0.800 & 0.200 & 0.700 & $<0.1$ & 0.400 \\
\hline 21.000 & 17.000 & 21.000 & 18.000 & 18.000 & 19.000 \\
\hline$<0.05$ & 0.070 & 0.060 & 0.090 & $<0.05$ & 0.080 \\
\hline 0.520 & 0.440 & 0.550 & 0.760 & 0.400 & 0.680 \\
\hline 4.200 & 3.400 & 4.100 & 3.600 & 2.200 & 5.000 \\
\hline 3.600 & 2.400 & 3.000 & 2.500 & 2.000 & 3.400 \\
\hline 123.000 & 80.000 & 107.000 & 88.000 & 53.000 & 120.000 \\
\hline 51.000 & 30.900 & 41.900 & 38.300 & 21.900 & 40.800 \\
\hline 0.290 & 0.230 & 0.280 & 0.240 & 0.200 & 0.370 \\
\hline 0.250 & 0.140 & 0.700 & 0.290 & 1.830 & 0.240 \\
\hline 160.000 & 280.000 & 240.000 & 210.000 & 330.000 & 220.000 \\
\hline 80.000 & 80.000 & 90.000 & 80.000 & 120.000 & 120.000 \\
\hline 51.000 & 45.000 & 51.000 & 51.000 & 48.000 & 52.000 \\
\hline 46.000 & 43.000 & 47.000 & 42.000 & 35.000 & 42.000 \\
\hline 418.000 & 315.000 & 386.000 & 334.000 & 290.000 & 380.000 \\
\hline 60.000 & 50.000 & 50.000 & 110.000 & $<10$ & 70.000 \\
\hline$<5$ & $<5$ & $<5$ & $<5$ & 6.000 & $<5$ \\
\hline 150.000 & 100.000 & 130.000 & 110.000 & 130.000 & 140.000 \\
\hline$<0.1$ & $<0.1$ & $<0.1$ & 0.300 & $<0.1$ & $<0.1$ \\
\hline 1.000 & $<1$ & 2.000 & 1.000 & $<1$ & 1.000 \\
\hline 93.700 & 66.300 & 90.100 & 163.000 & 92.800 & 97.300 \\
\hline 2.000 & 1.000 & 1.000 & 1.000 & $<1$ & 1.000 \\
\hline$<0.5$ & $<0.5$ & $<0.5$ & $<0.5$ & $<0.5$ & $<0.5$ \\
\hline 16.000 & $<5$ & $<5$ & $<5$ & $<5$ & $<5$ \\
\hline 5.890 & 4.490 & 7.340 & 5.980 & 2.770 & 6.480 \\
\hline 15.600 & 12.100 & 17.100 & 13.000 & 8.690 & 17.300 \\
\hline 2.690 & 1.880 & 2.860 & 2.290 & 1.420 & 2.720 \\
\hline 14.600 & 9.850 & 14.500 & 11.700 & 8.100 & 14.400 \\
\hline 4.810 & 3.130 & 4.460 & 3.690 & 2.820 & 4.620 \\
\hline 1.850 & 1.270 & 1.760 & 1.490 & 1.100 & 1.770 \\
\hline 6.330 & 4.040 & 5.850 & 5.070 & 3.450 & 5.800 \\
\hline 1.250 & 0.800 & 1.140 & 0.990 & 0.630 & 1.140 \\
\hline 8.170 & 5.230 & 7.390 & 6.420 & 3.900 & 7.350 \\
\hline 1.640 & 1.050 & 1.450 & 1.290 & 0.780 & 1.470 \\
\hline 4.870 & 3.120 & 4.260 & 3.860 & 2.300 & 4.340 \\
\hline 0.730 & 0.463 & 0.639 & 0.589 & 0.342 & 0.652 \\
\hline 4.690 & 2.920 & 4.060 & 3.730 & 2.260 & 4.130 \\
\hline 0.700 & 0.457 & 0.609 & 0.566 & 0.353 & 0.624 \\
\hline 1.900 & 1.500 & 2.000 & 1.700 & 1.400 & 1.900 \\
\hline
\end{tabular}

